FILLIPE AUGUSTO GALETI MAURO

\title{
A Máscara e o espírito \\ Estudo comparado dos retratos jornalísticos de Marcel Proust e Jorge Andrade
}

(versão final)

Dissertação de Mestrado apresentada ao Programa de Pós-Graduação em Estudos Linguísticos, Literários e Tradutológicos em Francês da Faculdade de Filosofia, Letras e Ciências Humanas da Universidade de São Paulo como parte dos requisitos para obtenção do título de Mestre em Literatura Francesa.

Orientador: Prof. Dr. Alexandre Bebiano de Almeida 

Autorizo a reprodução e divulgação total ou parcial deste trabalho, por qualquer meio convencional ou eletrônico, para fins de estudo e pesquisa, desde que citada a fonte. 

MAUR0, Fillipe Augusto Galeti. A Máscara e o espírito: estudo comparado dos retratos jornalísticos de Marcel Proust e Jorge Andrade. Dissertação apresentada à Faculdade de Filosofia, Letras e Ciências Humanas da Universidade de São Paulo para obtenção do título de Mestre em Literatura Francesa.

\section{Aprovado em:}

\section{Banca Examinadora}

Prof. Dr. Instituição:

Julgamento: Assinatura:

Prof. Dr. Instituição:

Julgamento: Assinatura:

Prof. Dr. Instituição:

Julgamento: Assinatura:

Prof. Dr. Instituição:

Julgamento: Assinatura: 

Para meus pais, Gisele e Paulo, e meu irmão, Gabriel. Com amor e gratidão. 



\section{Agradecimentos}

À Fapesp - Fundação de Amparo à Pesquisa do Estado de São Paulo - por seu valoroso auxílio através da Bolsa Regular 2015/16689-3 e da Bolsa de Estágio de Pesquisa no Exterior (BEPE) 2016/17831-0.

A Alexandre Bebiano de Almeida, meu orientador, pela fraterna amizade.

Aos colegas do Laboratório do Manuscrito Literário - Philippe, Yuri, Vivian, Caio, Lúcia e Samira - pela rigorosa leitura de meus textos, pelas proveitosas sugestões e pela paciência nos longos debates.

Ao amigo Etienne Sauthier, pelo entusiasmo de sua amizade, a sempre amável hospedagem em Paris e os sábios conselhos na varanda de Montmartre.

À professora Nathalie Mauriac Dyer e à pesquisadora Pyra Wise, do Institut des Textes Manucrits Modernes da École Normale Supérieure de Paris, pela disponibilidade de seu centro de documentação e os convites para suas jornadas de estudos proustianos.

À professora Olinda Kleiman, pela preciosa acolhida no Centre de Recherches sur les Pays Lusophones da universidade Paris 3 - Sorbonne Nouvelle.

À professora Jacqueline Penjon, pelos sempre alegres (e inusitados) encontros: em Paris, São Paulo ou mesmo no Rio.

Aos professores Jorge de Almeida e Maria Sílvia Betti, pelos conselhos cirúrgicos em meu exame de qualificação. Mas, sobretudo, por pedirem mais coragem, ousadia e personalidade em minha argumentação.

Aos amigos de sempre: Caio, Henrique, Juliana, Ruan e Victor, com o perdão do pedantismo e o reconhecimento de suas alegres palavras de apoio.

Finalmente, a Marília, grande parceira e entusiasta, por buscar ao meu lado um pouco da beleza que há no mundo. 


\section{Resumo}

MAURO, Fillipe Augusto Galeti. A Máscara e o espírito: estudo comparado dos retratos jornalísticos de Marcel Proust e Jorge Andrade. Dissertação apresentada à Faculdade de Filosofia, Letras e Ciências Humanas da Universidade de São Paulo para obtenção do título de Mestre em Literatura Francesa.

Esta dissertação se propõe a comparar o estilo de descrição da figura humana em retratos jornalísticos de Jorge Andrade e de Marcel Proust. 0 primeiro, enquanto repórter na revista Realidade e o segundo enquanto colaborador ocasional de inúmeros jornais e revistas da Belle Époque parisiense. Cada um desses dois escritores não hesitou diante da oportunidade de produzir artigos jornalísticos de forte verve literária sobre intelectuais, artistas e mundanos de suas épocas. A participação de Andrade na revista Realidade ocorre na segunda fase do periódico, entre 1969 e 1972, quando os métodos iniciais de edição de artigos foram reestruturados para contornar a censura do Ato Institucional no 5 (AI-5). Por sua vez, Marcel Proust escreve para publicações que abrem espaço substantivo ao gênero portrait com o intuito de satisfazer a curiosidade de um público-leitor fortemente interessado pelos traços que distinguiriam o artista, o homem de letras ou o indivíduo da alta sociedade. A tônica comum nesses textos não é somente o aprofundamento nos traços sentimentais e psicológicos dos entrevistados, mas também a forte valorização do memorialismo, que se faz notar pelo recurso a experiências pessoais não somente daquele que é retratado, mas também do próprio escritor. Assim, o exercício do gênero retrato literário não apenas os inseriu de modo particular nas tendências da imprensa em seu tempo, mas também contribuiu para a experimentação de uma estética que viriam a consagrar em peças de teatro e romances. A partir da leitura comparada dos dez perfis jornalísticos de Jorge Andrade com uma dúzia de retratos literários selecionados na obra de Marcel Proust, buscamos descrever os fundamentos das formas de representação da realidade que aproximam os dois autores, traçar a maneira como dialogaram com a cultura midiática de suas épocas e testar a hipótese de que o jornalismo pode ter operado à moda de um laboratório estético no momento em que escreveram obras romanescas de maior comprimento e sofisticação: o romance Labirinto, de Andrade, e o ciclo À la recherche du temps perdu, de Proust.

Palavras-chave: retrato literário; Marcel Proust; Jorge Andrade; revista Realidade 


\section{Résumé}

MAURO, Fillipe Augusto Galeti. La Masque et l'esprit : étude comparée des portraits journalistiques de Marcel Proust et Jorge Andrade. Mémoire présentée à la Faculté de Philosophie, Lettres et Sciences Humaines de l'Université de São Paulo en vue de l'obtention du titre de Maître en Littérature Française.

Ce mémoire est une comparaison du style de description de la figure humaine dans des portraits journalistiques de Jorge Andrade et Marcel Proust. Le premier quand il était reporter pour la revue Realidade et le second en tant que chroniqueur occasionnel dans plusieurs journaux de la belle époque parisienne. Ces deux écrivains n'ont jamais hésité à produire des articles journalistiques sur des personnalités intellectuelles, artistiques et mondaines de leurs époques, où on aperçoit d'un fort aspect littéraire. Jorge Andrade est devenu reporter chez Realidade au début d'un tournant de l'hebdomadaire, entre 1969 et 1972, quand les premières méthodes d'édition d'articles venaient d'être restructurées pour éviter la censure de l'Acte Institutionnel n. 5 (AI-5). De l'autre côté, Marcel Proust a publié plusieurs articles dans des journaux intéressés par le genre portrait, essayant par là, de satisfaire la curiosité d'un lectorat appartenant à la haute société. L'aspect commun dans ces textes n'est pas seulement l'approfondissement des sentiments et de la psychologie des interviewés, mais aussi une remarquable valorisation du mémorialisme. Ce trait est perceptible grâce à la lumière que les écrivains jettent sur les expériences personnelles de chaque individu portraituré et sur eux-mêmes. L'exercice du portrait littéraire ne les a pas seulement placés d'une façon particulière dans la tradition de la presse de leurs temps, il a aussi contribué pour qu'une certaine esthétique se développe dans des pièces de théâtre et romans. À travers la lecture comparée des dix profils journalistiques de Jorge Andrade et des douze portraits littéraires de Marcel Proust, on a essayé d'analyser les similarités chez ces deux auteurs dans les représentations de la réalité et enfin de caractériser la façon dont ils ont dialogué avec la culture médiatique de leurs temps ; ainsi que tester l'hypothèse selon laquelle le journalisme a pu être un laboratoire esthétique pour leurs ouvrages : le roman Labirinto, d'Andrade, et le fameux À la recherche du temps perdu de Proust.

Mots clés: portrait littéraire; Marcel Proust; Jorge Andrade; revue Realidade 


\begin{abstract}
MAUR0, Fillipe Augusto Galeti. The Mask and the spirit: comparative study on the journalistic portraits of Marcel Proust and Jorge Andrade. Master thesis defended at the Faculty of Philosophy, Languages and Human Sciences of the University of São Paulo for the award of a Master Degree in French Literature.

This master thesis aims at comparing the style of human disruption in either Jorge Andrade and Marcel Proust's journalistic portraits. The first one, while he held a reporter's post in the magazine Realidade; the second one as an occasional columnist in several newspapers and magazines from the Parisian Belle Époque. Each one of them has never hesitated to produce highly literary, journalistic articles about intellectuals, artists and socialites from their times. Andrade was hired by Realidade in the second phase of this magazine, from 1969 to 1972, when the initial editing methods were restructured in order to avoid the censorship of the Brazilian Military Regime. On the other hand, Marcel Proust wrote articles for newspapers interested in publishing portraits as a way to satisfy their readers' curiosities, mostly related to the characteristics that differed common men from artists, writers and high-society individuals. The main aspect of such texts is not only a deep vision of an interviewee's sentimental or psychological particularities, but also an enormous value placed on memory. That can be noticed through the search for personal experiences of either model and the writers themselves. The habit of writing literary portraits has therefore not only allocated them in the journalistic tradition of their times in a very particular way, but also helped them test the aesthetic forms that would lead to the success of their plays and novels. Through a comparative reading of the ten journalistic profiles of Jorge Andrade and a dozen literary portraits selected from the works of Marcel Proust, we hope to describe the forms of representation of reality of both authors, find the way they interacted with the mediatic culture of their times and test the hypothesis that journalism can be an aesthetic laboratory for writing longer and more sophisticated works, such as the novel Labirinto, by Andrade, and the cycle À la recherche du temps perdu, by Proust.
\end{abstract}

Keywords: literary portrait; Marcel Proust; Jorge Andrade; magazine Realidade 


\section{Nota Bene}

Todas as citações à obra de Marcel Proust foram retiradas da coleção Bibliothèque de la Pléiade. Tomam-se por referência os quatro tomos de À la recherche du temps perdu, organizados por Jean-Yves Tadié entre 1987 e 1989, assim como o volume de artigos críticos Contre Sainte-Beuve, editado por Pierre Clarac e Yves Sandre em 1971. Para a correspondência de Proust, nos fiamos aos 21 volumes organizados por Philip Kolb e publicados pela editora Plon entre 1976 e 1993. Quanto a Jorge Andrade, todos seus perfis jornalísticos foram retirados de volumes originais da revista Realidade. Utilizamos também a edição de 2009 do romance Labirinto, publicado pela editora Amarilys, e a edição de 1970 do ciclo de peças Marta, a árvore e o relógio, da editora Perspectiva. As traduções de excertos, em notas de rodapé, assim como dos retratos de Marcel Proust, em anexo, são de minha própria autoria.

Abreviações utilizadas:

À la recherche du temps perdu

R.T.P.

Contre Sainte-Beuve

C.S.B.

Correspondance de Marcel Proust

Corr.

Revista Realidade

R.R.

Labirinto

Lab.

Marta, a árvore e o relógio

M.A.R. 


\section{SUMÁRIO}

APRESENTAÇÃ

\section{CAPÍTULO 1}

No ninho de Sainte-Beuve

\section{CAPÍTULO 2}

Seres divididos

\section{CAPÍTULO 3}

Torreões e bibliotecas

II. Sobre Jorge Andrade

IV. Obras de apoio teórico e específico

\section{ANEXOS}

Retratos publicados por Jorge Andrade na revista Realidade entre 1969 e 1972 ..........153

No fundo ela é família 155

Duke Lee, o nosso surrealista tipo exportação ....................................................... 165

Marília Pêra, cem mil volts. Mas só no palco. .......................................................... 173

É Clodovil, sim. Alguma coisa contra? ...................................................................... 181

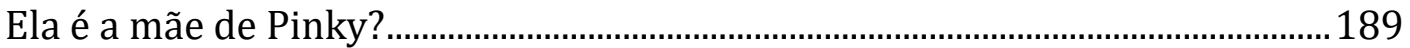


Admirado, odiado, um homem desconhecido: Sir Gilberto Freyre 195

A liberdade será sempre a minha causa......................................................................207

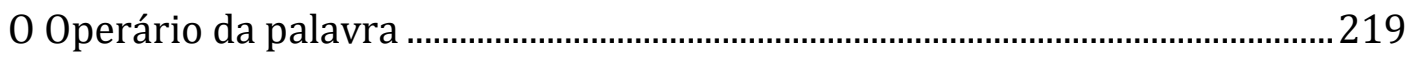

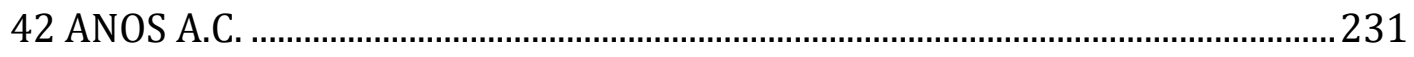

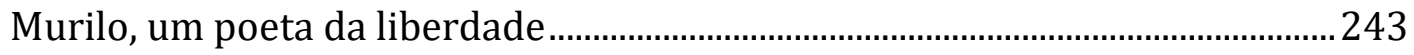

Seleção de retratos literários publicados por Marcel Proust na imprensa parisiense .. 253

Figures parisiennes : Camille Saint-Saëns ………………….....................................25

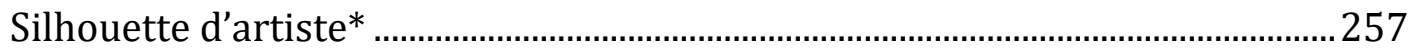

La Personne d'Alphonse Daudet: « CEuvre d'art » ..................................................259

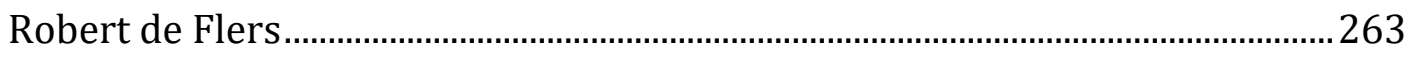

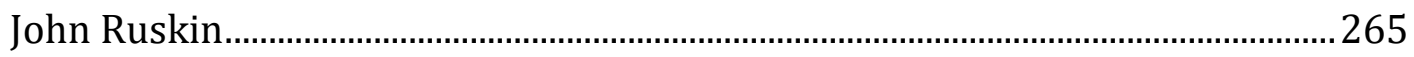

Une miniaturiste du seconde empire: Madame Herbelin......................................267

Le Salon de la Princesse Edmond de Polignac : musique d'aujourd'hui, échos

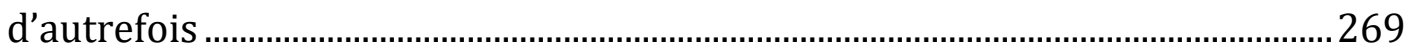

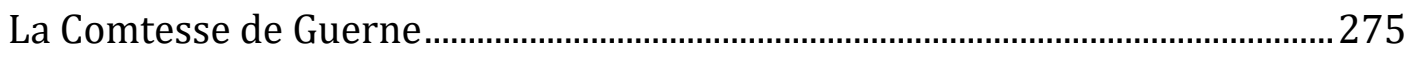

Un Professeur de Beauté......................................................................................2 279

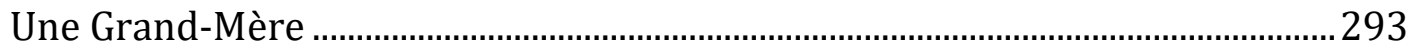

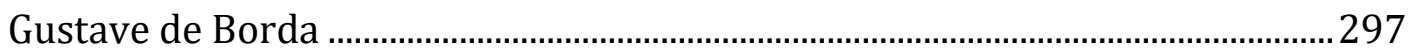

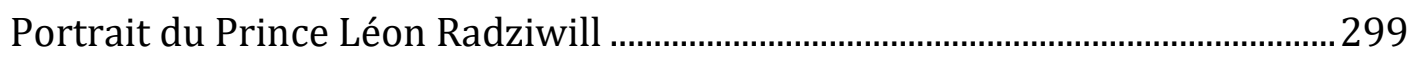

Tradução comentada dos retratos literários selecionados na obra de Marcel Proust... 303

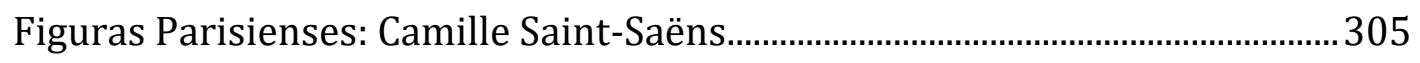

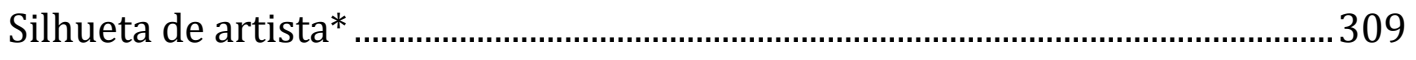

A pessoa de Alphonse Daudet: "obra de arte" ...............................................................313

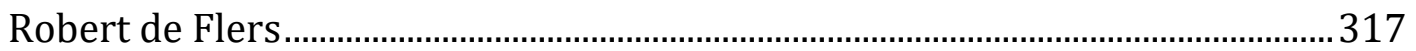

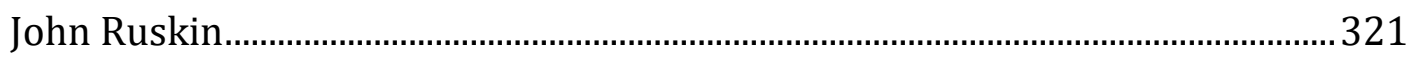

Uma miniaturista do segundo império: madame Herbelin ...................................325

O Salão da princesa Edmond de Polignac: música de hoje, ecos do passado..329

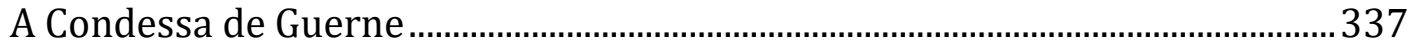

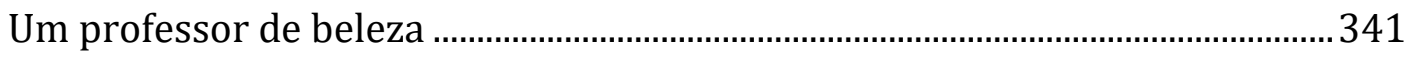

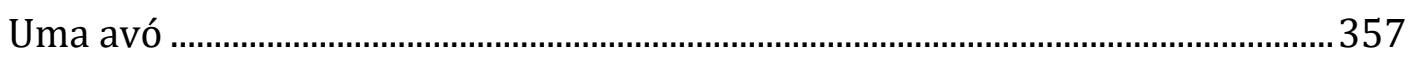

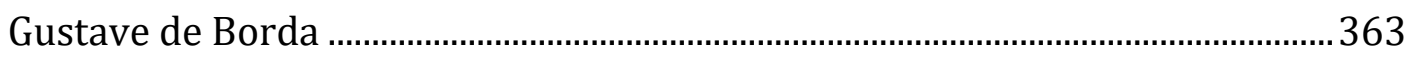

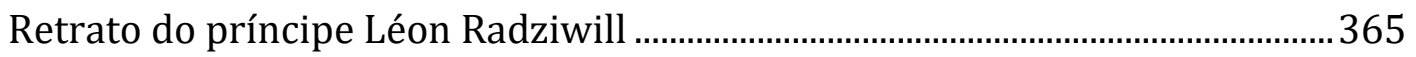


What immortal hand or eye, Could frame thy fearful symmetry?

- William Blake 


\section{Apresentação}

O estilo da obra de Jorge Andrade sempre foi aproximado daquele de Marcel Proust. Talvez devido ao espaço que ocupa em sua dramaturgia a decadência de uma sociedade rural aristocrática e a ascensão da ordem industrial burguesa. Talvez devido ao memorialismo com que constrói suas personagens, sempre as retomando de maneira diversa em pontos distintos de uma mesma narrativa. Talvez devido à comum vocação de alguns de seus heróis, sempre propelidos à carreira artística e intelectual. Talvez porque em 1970 tenha entrelaçado parte de sua obra no ciclo Marta, a árvore e o relógio, adaptando seus enredos para que, em todos, pudéssemos identificar a figura desta heroína e dos dois nada fortuitos signos que sempre a acompanham - a identidade fundamental na qual nos enraizamos e as transformações que sobre ela opera o transcorrer da vida. Em todo caso, a relação nunca superou os ares de vaga hipótese e os anos viram se frutificar estudos comparando Andrade a outros autores - mas jamais a Proust. Nas palavras de uma pesquisadora, a "histeria coletiva, o clima opressivo, a perseguição religiosa e os desenlaces infelizes"1 teriam feito de Vereda da salvação (1964) um exemplar brasileiro do The Crucible (1953) de Arthur Miller². Em outro estudo, por sua vez, A Moratória (1955) se aproximaria do Jardim das Cerejeiras (1904) de Anton Tchekhov, onde os mais velhos "veem o modo de vida ao qual dedicaram suas existências se despedaçar diante de seus olhos" e os mais jovens

\footnotetext{
${ }^{1}$ Cf. AZEVEDO, Elizabeth. Recursos estilísticos na dramaturgia de Jorge Andrade. São Paulo: Edusp, 2014, p. 107.

${ }^{2}$ Mesmo dramaturgo que, em um causo contado inúmeras vezes por Jorge Andrade, lhe aconselhou: "volte para seu país, Jorge, e procure descobrir por que os homens são o que são e não o que gostariam de ser; e escreva sobre a diferença". Cf. SANT'ANNA, Catarina. Metalinguagem e teatro. São Paulo: Perspectiva, 2012, p. 133.
} 
"não conseguem encarar a realidade e vivem na ilusão"3. Mas, no que diz respeito a Proust, a crítica jamais se lançou a qualquer cotejo aprofundado. Nada além da constatação de Terezinha Tagé, para quem os métodos criativos de Jorge Andrade “incorporaram experiências de sua formação pessoal, reelaborando continuamente as marcas de seus ancestrais, homens e mulheres ligados ao cultivo da Terra em sua memória emotiva intensificada pela leitura incorporada de Marcel Proust e Henri Bergson"4. A partir desse ponto, seria natural nos questionarmos onde na obra de Jorge Andrade é mais evidente essa incorporação? De que modo ela ocorre? Como Jorge Andrade concebe o mecanismo estilístico da reelaboração? 0 que esse dramaturgo entenderia como memória emotiva proustiana? Desses importantes questionamentos não restaram ao público mais que as pistas deixadas pelo próprio Jorge Andrade e seus próximos. Alusões quase incidentais, semelhantes a um convite à exploração de um campo recôndito, porém substantivo, do universo criativo desse autor. 0 gracejo da Noêmia de Senhora na boca do lixo ("localizei Balbec e a igrejinha querida de Proust. É linda!"5), algumas passagens do romance Labirinto ("xícara mais encantada que a de Marcel Proust!"6) e a conhecida sugestão do crítico e amigo Sábato Magaldi, para quem o subtítulo desse livro deveria ser "Em busca do pai perdido"7. Coube a Anatol Rosenfeld, enfim, a enunciação mais clara, ainda que hesitante, da suspeita:

No panorama do teatro brasileiro contemporâneo, a obra de Jorge Andrade se distingue pelo equilíbrio, pela firmeza do avanço para uma lucidez crescente que não se deixa contaminar por modismos irracionalistas e anárquicos ou por

\footnotetext{
${ }^{3} C f$. NEVES, Larissa de Oliveira. Jorge Andrade e Anton Tchekhov: uma proposta de pesquisa. Cadernos Letra e Ato, ano 1, n. 1, p. 2.

${ }^{4}$ Cf. TAGÉ, Terezinha. Jornalismo e dramaturgia: o mundo composto de Jorge Andrade. 2010. 122 p. Tese de livre-docência - ECA/USP, pp. 5-6.

${ }^{5}$ M.A.R. p. 294.

${ }^{6}$ Lab., p. 228.

${ }^{7}$ Ibidem, p. 7.
} 
desvarios patológicos. Com frequência transforma o palco em espaço interno da mente de personagens. $O$ destaque dado à memória talvez tenha sido alimentada [sic] pela leitura de Proust. $^{8}$

É dessa presença do estilo proustiano em Jorge Andrade que esse estudo se ocupa. Não em suas peças teatrais, como seria de se imaginar a partir do comentário de Rosenfeld. Mas, sobretudo, em obras menos pesquisadas e quase sempre negligenciadas desse autor onde acreditamos justamente mais vivas certas formas proustianas de representação dos seres - os perfis jornalísticos que publicou entre 1969 e 1972 na revista Realidade e seu único romance, Labirinto, de 1978. Não se trata de ignorar o que há de proustiano na dramaturgia andradina. Sobre ela nos debruçaremos, ainda que de maneira rápida, no terceiro capítulo, quando discutirmos certos procedimentos estilísticos de Labirinto. Sobretudo, nos interessamos pelos textos cuja vocação primeira é o desenho dos seres, o traçado de personalidades, a delimitação de individualidades, por textos que muitas vezes foram incorporados para a construção de uma narrativa memorialista mais sofisticada e longa e desenvolvida em prosa. Ao todo, Jorge Andrade publicou dez perfis jornalísticos, ou, como lhe agradava dizer, dez retratos literários ${ }^{9}:$ No fundo ela é família (a atriz Dercy Gonçalves, outubro de 1969), Duke Lee, o nosso surrealista tipo exportação (o pintor Wesley Duke Lee, maio de 1971), Marília Pêra, cem mil volts. Mas só no palco (a atriz Marília Pera, junho de 1971), É Clodovil sim. Alguma coisa contra? (o estilista Clodovil Hernandes, agosto de 1971), Ela é a mãe de Pinky (a modelo Danuza Leão, setembro de 1971), Sir Gilberto Freyre (o escritor Gilberto Freyre, dezembro de 1971), A Liberdade será sempre a minha causa (o

\footnotetext{
${ }^{8}$ Cf. ROSENFELD, Anatol. Visão do ciclo. In: M.A.R., p. 600.

${ }^{9}$ Terezinha Tagé entrevistou a viúva de Jorge Andrade, senhora Helena Almeida Prado Franco, que lhe declarou que, "segundo seus editores de Realidade, ele era muito solicitado para realizar entrevistas do gênero perfis de personalidades da cultura brasileira, das quais fazia 'retratos', conforme preferia chamar este tipo de textos". Cf. TAGÉ, Terezinha. Op. cit., p. 6.
} 
escritor Érico Veríssimo, fevereiro de 1972), o Operário da palavra (o intelectual Antônio Houaiss, abril de 1972), 42 Anos A.C. (o historiador Sérgio Buarque de Holanda, junho de 1972) e Murilo, um poeta da liberdade (o poeta Murilo Mendes, agosto de 1972). Nossas fontes foram os próprios exemplares originais de Realidade, dado que, uma vez publicados, esses textos jamais foram reeditados em livro e acabaram relegados a arquivos privados. Veremos, de início, como a forma de representar esses tantos (e diversos) personagens da cena social brasileira dos anos 60 e 70 se inscreve de maneira bastante particular no movimento geral do jornalismo daquele tempo. Uma leitura primeira desses retratos de Jorge Andrade tenderia a enquadrá-lo no mesmo rol de autores do New Journalism americano. Mas o toque proustiano na construção da personalidade de seus modelos, com todo o princípio de insegurança ontológica que acarreta a adesão a esse estilo, torna difícil associar a poética desse autor, sem quaisquer ressalvas, ao que nos parece o neorrealismo de jornalistas como Tom Wolfe e Gay Talese. Por sinal, a julgar pela opinião de Brenda M. Boyle, para quem esses autores se diferem de Balzac, por exemplo, porque "tudo que estamos lendo de fato ocorreu" e porque "o factual e o atual foram transmutados em um trabalho com a estrutura, o estilo e a ressonância da ficção, mas que é completamente autêntico"10, mais apropriado seria assim chamá-los realistas radicais. Não é o caso de Jorge Andrade, para quem, como dizemos oportunamente, a lapidação de um perfil jornalístico passa necessariamente por uma intuição, por uma inferência de estados psicológicos impossível de ser comportada pela objetividade e referencialidade que pretendem as escolas americanas de jornalismo de meados do século XX. À certeza de seus

\footnotetext{
${ }^{10} \mathrm{Cf}$. BOYLE, Brenda M. The Vietnam War: topics in contemporary north american literature. Nova York: Bloomsbury, 2014, p. 33.
} 
colegas do norte, Jorge Andrade se contrapõe sempre com um narrador em dúvida, hesitante e inseguro diante de seu modelo.

É nessa altura de nossa argumentação que acreditamos pertinente verificar e isolar no interior de cada um desses perfis andradinos os traços estilísticos proustianos que os constituem. Nesse instante, ainda que de modo inconsciente, a opção de Jorge Andrade pela nomenclatura retrato em detrimento de perfil perde qualquer trivialidade e revela uma coincidência bastante significativa. Proust, antes de voltar-se à construção de seu grande romance e mesmo durante a empreitada da Recherche, foi também autor de inúmeros retratos. No primeiro capítulo, comentamos a evolução do gênero portrait littéraire na literatura francesa e as especificidades da inserção de Proust na tradição jornalística daquele país (o debate Proust - Sainte-Beuve, por exemplo). Mas o que mais nos intriga é como em cada um de seus vários retratos surge uma maneira de pintar o ser humano e a si próprio bastante semelhante àquela que Jorge Andrade, em um contexto geográfico e histórico absolutamente distinto, também empregaria para a redação de sua série de perfis. Poderíamos resumir como a forma bem particular de descrição que Erich Auerbach encontra enraizada já em meados do século XVIII nas Mémoires do Duque de Saint-Simon. Apesar de somar aspectos físicos e psicológicos às descrições de seus personagens sem o planejamento e o cálculo de Proust ou de Andrade, isto é, ainda que sua escrita guarde forte componente de desordenamento, o efeito do estilo de Saint-Simon anteciparia no auge do moralismo francês a complexidade psicológica cara a autores da modernidade. Para Auerbach, Saint-Simon pode até escrever afoito, sem grande rigor, segundo o impetuoso fluxo de suas lembranças, mas devemos à estética que seu apressamento produz as "hibridações" que tanto verificamos nos retratos 
proustianos e, em última instância, andradinos. Mesmo o que veremos como a preocupação em tornar o modelo um "ser especial" já é traço marcante em SaintSimon, e Auerbach afirma que a interpenetração do corpo e da alma, a constante mistura de traços físicos e morais, interiores e exteriores concorre nessas memórias pela construção de um individuum ineffabile. Marcel Proust e Jorge Andrade se alinham, sob esse aspecto, a Saint-Simon quando apregoam o "contraste que opõe o ser interior à aparência exterior", e o resultado disso é a apreensão de uma "essência íntima do conjunto", de uma "individualidade"11. Surpreende a proximidade entre a força literária que Auerbach identifica em SaintSimon e aquela que localizamos no cerne do estilo de um moderno como Proust ou mesmo de um contemporâneo como Andrade: os dois, à semelhança de SaintSimon, "sabem utilizar o fortuito e o particular, a realidade bruta, mesmo sua parcialidade às vezes próxima do absurdo, como ponto de partida para um repentino mergulho nas profundezas da existência humana"12. Selecionamos uma amostra de onze artigos jornalísticos da lavra de Proust para lastrear essa comparação com os retratos de Jorge Andrade. Não raro, a crítica proustiana os lê como crônicas de salão, obituários ou ensaios literários. Mas em seu âmago pulsa o gênero retrato e a tentativa predominante de delinear os contornos de uma personalidade. Nosso estudo contempla Figures parisiennes: Camille Saint-Saëns (sem assinatura, publicado no jornal Le Gaulois em 14 de dezembro de 1895), Silhouette d'artiste (assinado por Marcel Proust e publicado em La Revue d'Art

\footnotetext{
${ }^{11}$ Para a longa reflexão de Erich Auerbach a propósito do estilo de Saint-Simon, ver AUERBACH, Erich. Das unterbrochene Abendessen. In: Mimesis: Dargestellte Wirklichkeit in der abendländischen Literatur. Tübingen: Francke Verlag, 2001, p. 386 sqq.

12 "Gerade das, was die anderen in ihrer menschlichkünstlerischen Wirkung begrenzt, das Anekdotische, Persönliche, allzu Einzelne, vielfach Unbedeutende dessen, was sie berichten, gerade das ist seine Stärke, eben gerade da er allein aus dem beliebig Einzelnen, Unausgewählten, oft bis zum Absurden Persönlichen und Parteiischen unversehens in die Tiefe der menschlichen Existenz hinabstößt". Ibidem, pp. 401-402.
} 
Dramatique em janeiro de 1897), Opinions sur M. Alphonse Daudet: ceuvre d'art (assinado por Marcel Proust e publicado no jornal La Presse em 11 de agosto de 1897), Robert de Flers (sem assinatura, publicado em La Revue d'art dramatique em 20 de janeiro de 1898), John Ruskin (assinado por Marcel Proust e publicado na revista La Chronique des Arts et de la Curiosité em 27 de janeiro de 1900), Une miniaturiste du seconde empire: Madame Herbelin (sem assinatura, publicado na revista La Chronique des Arts et de la Curiosité em 23 de abril de 1904), Le Salon de la Princesse Edmond de Polignac: musique d'aujourd'hui, échos d'autrefois (assinado por Horatio e publicado no jornal Le Figaro em 6 de setembro de 1903), La Comtesse de Guerne (assinado por Écho e publicado no jornal Le Figaro em 7 de maio de 1905), Un professeur de beauté (assinado por Marcel Proust e publicado na revista Les Arts de la Vie em 15 de agosto de 1905), Une grand-mère (assinado por Marcel Proust e publicado no jornal Le Figaro em 23 de julho de 1907), Gustave de Borda (assinado por D. e publicado no jornal Le Figaro em 26 de dezembro de 1907), e, por fim, Portrait du Prince Léon Radziwill (publicado postumamente no primeiro volume dos Cahiers Marcel Proust, em 1927). Todos os retratos que selecionamos foram publicados por Proust ainda em vida e nas páginas de jornais e revistas. Cremos, assim, nos aproximar do que seria a forma mais acabada e menos fragmentária do estilo proustiano. A única exceção é o Portrait du Prince Léon Radziwill, um simples esboço que muito insistimos em manter em nosso corpus de análise não pelo arremate do texto, nosso critério geral, mas pela maneira aberta e até mesmo sistemática com que expõe os pressupostos da representação da figura humana na poética proustiana. Já ao final de nossa argumentação também estudamos o artigo Les Éblouissements, muito mais um ensaio crítico a respeito da antologia de poemas então publicada pela condessa de 
Noailles, amiga do círculo social de Proust, do que um exemplo transparente de retrato literário. No entanto, não só entrevemos ali uma constante tentativa de apreensão da personalidade de Noailles a partir da visão de mundo professada por sua obra como também, nesse texto, estão guardadas importantes chaves para a compreensão da utilidade da experiência de escrita de textos jornalísticos esparsos para a constituição de um romance mais longo e sofisticado.

Esse é o objeto da última seção de nosso estudo. Discutida a maneira particular como Jorge Andrade e Marcel Proust participaram do jornalismo de suas épocas e os recursos descritivos que aproximam o estilo de seus retratos, cabe se questionar de que maneira e em que medida a experiência nas páginas de jornais e revistas contribui para o amadurecimento de práticas narrativas romanescas. Como se inscrevem os pequenos retratos de Proust ao longo de sua Recherche? E como Jorge Andrade se serve dos perfis de Realidade para o enredo de Labirinto? São questões que revelam mais que o ofício genético desses autores. Elas permitem a compreensão do laboratório artístico que pode constituir o jornalismo no processo de formação estética do romancista. Por serem desconsideradas as sutilezas que ocorrem na passagem dos perfis ao romance, Labirinto sempre foi lido como mera obra de memórias, uma simples coleção estilizada de lembranças do dramaturgo Jorge Andrade, uma referência fidedigna dos fatos de sua vida e de sua concepção do mister artístico. Além de ocupar espaço coadjuvante na crítica, o livro se transformou em fonte biográfica, esquecendo-se muitas vezes as diferenças que separam Jorge Andrade do protagonista Jorge, de Labirinto, e omitindo-se assim a imensa (e significativa) distância que há entre um autor e seus personagens. 0 grande dilema que se impõe a essa leitura de Labirinto é que inúmeras passagens do romance são construídas tendo como base a incorporação 
e a modificação dos perfis jornalísticos que, poucos anos antes, publicara em Realidade. E, ao traçar essas modificações, nos damos conta dos esforços criativos desse autor, de seu empenho em figurar a realidade que vivera e dela extrair um personagem. Alguns dados da vida do protagonista Jorge coincidem com a biografia de Jorge Andrade. A questão é entendermos o tratamento que esses dados imediatos da realidade sofrem no processo de escrita realizado pelos autores. 0 recorte, a projeção, o olhar, enfim, que lançam sobre ela. Proust pode nos auxiliar nessa leitura do único romance andradino. Também ele se vale de seus próprios retratos publicados na imprensa da virada do século para a construção de algumas passagens importantes de $\grave{A}$ la recherche du temps perdu. Proust se apropria de metáforas, temas e cenas, as modifica segundo critérios nada casuais e as enxerta ao longo de sua obra romanesca. A trajetória do herói Marcel bebe das vivências de Marcel Proust em seus círculos sociais, mas nem por isso os dois se confundem. Entre os dois, há o trabalho literário e poético, com formas próprias para imitar e transfigurar a vida. Comparando o uso dos retratos desses autores em cada um de seus romances, acreditamos melhor compreender como percebiam o exercício do jornalismo e mesmo como se davam seus procedimentos criativos.

São esses nossos objetivos. Situar Marcel Proust e Jorge Andrade em suas tradições jornalísticas; verificar internamente, no seio de seus retratos, o estilo que os aproxima; e, então, averiguar de que maneira reformam e enxertam esses textos em obras de vocação distinta, em romances do universo da ficção. Trata-se do caminho para a compreensão do que Jorge Andrade possui de proustiano e do que a poética de romances memorialistas como À la recherche du temps perdu e Labirinto deve à prática pregressa ou mesmo concorrente do jornalismo. 


\title{
I. No ninho de Sainte-Beuve
}

\section{A inserção de Marcel Proust e Jorge Andrade em gêneros da imprensa}

\begin{abstract}
Conséquence forcée de la nature des choses de ce temps, le mouvement d'idées qui tend à multiplier les biographies est le même que celui qui multiplie, dans nos expositions, ce nombre fatigant de portraits qui vont chaque jour les envahissant davantage. Portraits ou biographies, en effet, ce sont là les gouttes d'eau de cette mer d'individualité qui monte et qui doit bientôt tout couvrir! ${ }^{1}$
\end{abstract}

Jules Barbey d'Aurevilly fez parte do dilúvio que profecia. E partiram de sua pena diversas "gotas de água" desse tsunami na iminência de engolfar boa parte da produção artística de seu tempo. Autor de inúmeros retratos literários, seu comentário consta justo de uma coletânea desses textos, os Portraits politiques et littéraires de $1898^{2}$, exemplares de um gênero que, de fato, cada vez "invadiu" mais a cena cultural francesa ao longo do século XIX. Embora o retrato literário, como aborda Jacqueline Plantié em seu longo estudo sobre o tema ${ }^{3}$, já fosse bastante difundido nos cercles précieux das cortes francesas do século XVII, especialmente no entourage de aristocráticas salonistas como Mademoiselle de Scudéry e Mademoiselle de Montpensier, é nos oitocentos que esse gênero, para falar uma vez mais como d'Aurevilly, passou a "chover" sob a forma de populares artigos de

\footnotetext{
1 "Consequência inevitável da natureza das coisas nesse momento, o movimento de ideias que tende a multiplicar as biografias é o mesmo que aquele que, em nossas exposições, multiplica esse número cansativo de retratos que, dia após dia, as invade cada vez mais. Retratos ou biografias, como quisermos, são as gotas de água desse mar de individualidade que se avoluma e que, logo mais, tudo cobrirá". Cf. DUFOUR, Hélène. Portraits, en phrases: les recueils de portraits littéraires au XIXe siècle. Paris: Presses Universitaires de France, 1997, p. 9.

2 D'AUREVILLY, Barbey. XIXe Siècle: les azuvres et les hommes. Paris: Alphonse Lemerre, tomo XVI, 1898.

${ }^{3}$ PLANTIÉ, Jacqueline. La mode du portrait littéraire en France (1641-1681). Paris: Honoré Champion, 2016.
} 
jornal e grandes coletâneas reunidas em livro ${ }^{4}$. Hélène Dufour, ao se debruçar sobre o caso das antologias de retratos literários nesse período, nos proporciona a dimensão do fenômeno. Do início do século XIX às primeiras décadas do século XX, ela identificou cerca de cem retratistas na França, cada um, por sua vez, responsável pela publicação de várias séries de antologias, o que a levou a estimar, ainda que sem grande precisão empírica, o total de um "milhão" desses textos 5 . Trata-se talvez de uma hipérbole. Mas nem por isso o volume subjetivamente inferido deixaria de ser relevante. Assim, é da lavra de Dufour o termo portraitomanie (retratomania, a obsessão por retratos) e a autora não se pretende menos categórica ao afirmar que, na história da literatura francesa, o século XIX pode ser chamado de "o século dos retratos"6. É verdade que as classificações atribuídas por esses autores a seus trabalhos não raro variavam. Com frequência associadas ao léxico das artes plásticas ou decorativas, o leitor oitocentista francês encontrava, ao folhear jornais e revistas, de "perfis", "medalhões" e "mármores" a "máscaras" e "camafeus". Mas, a despeito dessas sutilezas categóricas, todos esses textos sempre soam passíveis de serem reduzidos ao denominador comum de "retrato literário", na medida em que, como coloca Jean-Philippe Miraux em sua obra introdutória, neles se constata "uma técnica de escrita precisa e dominada, uma arte da representação, um conhecimento da descrição literária" voltado para “elaborar uma presença, constituir uma personalidade, proporcionar os índices necessários e suficientes para delimitar um personagem único, uma espécie de

\footnotetext{
${ }^{4}$ DUFOUR, Hélène. Ibidem, p. V.

${ }^{5}$ DUFOUR, Hélène. Op. cit., p. VI.

6 Ibidem, p. 2.
} 
individualidade própria cujo nome, vestimenta, traços e partes serão, de alguma maneira, os critérios definitivos e discriminadores"7.

Um gênero literário com a pretensão de definir e discriminar o que particulariza os seres, com pleno florescimento no século XIX. Ora, esses dois aspectos, a pretensão definitiva e o momento histórico de disseminação, servem de indicativo para as importantes questões literárias que o retrato carregava consigo. Se o século XIX é a grande era desse gênero, não se poderia fugir à observação de Miraux de que as escolas realista e naturalista, tão frutíferas na França, foram também seu "reino"8. A autores como Honoré de Balzac, que, no avant-propos de sua Comédie Humaine, propõe a catalogação dos homens em sociedade da mesma forma como a modernização dos métodos científicos fazia avançar a categorização das espécies na natureza ${ }^{9}$, interessou a possibilidade de reunir recursos literários para delinear aquilo que cada indivíduo possuía de particular e único. E, ainda mais do que isso: com um olhar anatomista de quem buscava "a realidade referencial da maneira mais exata e mais verossímil”10. 0 exemplo mais clássico, recuperado pelo filólogo Erich Auerbach para definir o "realismo atmosférico" de

\footnotetext{
7 "L'on constate une technique d'écriture précise et maîtrisée, un art de la représentation, une connaissance de la description littéraire". Cf. MIRAUX, Jean-Philippe. Le Portrait littéraire. Paris: Hachette, 2003, p. 6

8 Ibidem, pp. 98-99.

9 "La Société ne fait-elle pas de l'homme, suivant les milieux où son action se déploie, autant d'hommes différents qu'il y a de variétés en zoologie ? Les différences entre un soldat, un ouvrier, un administrateur, un avocat, un oisif, un savant, un homme d'état, un commerçant, un marin, un poëte, un pauvre, un prêtre, sont, quoique plus difficiles à saisir, aussi considérables que celles qui distinguent le loup, le lion, l'âne, le corbeau, le requin, le veau marin, la brebis, etc" [A sociedade não produz do homem, segundo os ambientes nos quais sua ação se desenrola, tantos tipos de homens quanto há de espécies na zoologia? As diferenças entre um soldado, um trabalhador, um administrador, um advogado, um desocupado, um sábio, um estadista, um comerciante, um marinheiro, um poeta, um pobre, um padre não são, ainda que mais difíceis de se apreender, tão substantivas quanto aquelas que distinguem o lobo, o leão, o asno, o corvo, o tubarão, a foca, a ovelha, etc.]. Cf. BALZAC, Honoré de. La Comédie humaine. Paris : Gallimard, Bibliothèque de la Pléiade, tomo I, 1976, p. 8.

${ }^{10}$ MIRAUX, Jean-Philippe. Op. cit., p.98-99.
} 
Balzac, esse vínculo determinante entre o ser e o meio que habita ${ }^{11}$, é o retrato da personagem Madame Vauquer no romance Le Père Goriot:

Cette pièce est dans tout son lustre au moment où vers sept heures du matin, le chat de madame Vauquer précède sa maîtresse, saute sur les buffets, y flaire le lait que contiennent plusieurs jattes couvertes d'assiettes, et fait entendre son ronron matinal. Bientôt la veuve se montre, attifée de son bonnet de tulle sous lequel pend un tour de faux cheveux mal mis; elle marche en traînassant ses pantoufles grimacées. Sa face vieillotte, grassouillette, du milieu de laquelle sort un nez à bec de perroquet; ses petites mains potelées, sa personne dodue comme un rat d'église, son corsage trop plein et qui flotte, sont en harmonie avec cette salle où suinte le malheur, où s'est blottie la spéculation et dont madame Vauquer respire l'air chaudement fétide sans en être écaurée. Sa figure fraîche comme une première gelée d'automne, ses yeux rides, dont l'expression passe du sourire prescrit aux danseuses à l'amer renfrognement de l'escompteur, enfin toute sa personne explique la pension, comme la pension implique sa personne ${ }^{12}$.

Os esforços de definição e discriminação do retrato literário aqui se servem, para falar como Auerbach, de inúmeros elementos do "espaço vital" do modelo, tais quais "paisagem, habitação, móveis, acessórios, vestuário, corpo, caráter, trato, ideologia, atividade e destino". A mecha de cabelos falsos, sua face envelhecida e rechonchuda e mesmo seu nariz, semelhante a um bico de papagaio, são empregados na representação de Madame Vauquer não para retratá-la de modo próprio ou original, mas sim para caracterizá-la como um tipo "verossímil” de nossa sociedade. Nesse exemplo específico, tem-se a figura da pensionista burguesa. Nas páginas de jornais e revistas, contudo, o mesmo valerá para

\footnotetext{
${ }^{11}$ AUERBACH, Erich. Im Hôtel de la Mole. In: Mimesis: Dargestellte Wirklichkeit in der abendländischen Literatur. Tübingen: Francke Verlag, 2001, p. 441.

12 "Este cômodo vive todo seu esplendor no momento em que, por volta das sete horas da manhã, o gato de madame Vauquer antecede sua dona, salta sobre os bufês, neles fareja o leite que várias tigelas cobertas com pratos contêm e ecoa seu ronronar matinal. Em seguida, a viúva se apresenta, adornada com sua touca rendada sob a qual pende uma mecha de cabelos falsos mal colocada; ela caminha arrastando suas pantufas em petição de miséria. Sua face envelhecida, rechonchuda, de cujo conjunto salta um nariz de bico de papagaio; suas pequeninas mãos inchadas, seu aspecto gordo como um rato de igreja, sua blusa apertada que flutua, eles harmonizam com aquela sala onde se exala desconforto, onde se acomodam intrigas e da qual madame Vauquer respira um ar morno e fétido sem nojo. Sua figura fria como uma primeira geada de outono, seus olhos enrugados, cuja expressão vai do sorriso prescrito a dançarinas à amarga carranca dos agiotas, enfim, toda a sua pessoa explica a pensão, assim como a pensão implica sua pessoa". BALZAC, Honoré de. Op. cit., tomo III, p. 54.
} 
escritores, filósofos, políticos, músicos, mundanos, intelectuais e artistas de modo

geral. Ao apreender os traços particulares de cada modelo, o retratista busca

identificá-lo como representativo de uma categoria social, alocá-lo junto a um

grupo, torná-lo significativo de uma comunidade humana. É bastante significativo

disso o trecho que reproduzimos abaixo, excerto do retrato de Charles Augustin

Sainte-Beuve feito por Émile Zola e publicado na coletânea Marbres et plâtres:

La maison, située rue du Montparnasse, est petite, close et discrète. On dirait un couvent, une retraite mystique, où traînent des vagues parfums voluptueux.

Il y a quelques années [...] je fus chargé de Porter quelques papiers à M. Sainte-Beuve qui écrivait alors la belle notice qu'il a publiée sur M. Littré. La porte s'ouvrit d'une façon douce, et l'on m'introduisit dans un salon obscur où je demeurai seul pendant dix bonnes minutes. Au fond, Il y a un jardin, et les feuilles ne laissaient entrer qu'une lumière tendre et verdâtre.

J'étais poète, en ces heureux temps d'ignorance, et le silence frissonnant de cette pièce, la lumière attendrie me firent rêver que je venais d'être brusquement transporte dans le nid tiède et caché d'un jeune ménage en pleine lune de miel.

Puis, on me fit monter un escalier étroit, et je trouvai l'éminent critique debout au milieu de son cabinet. Je restai au plus une minute, et je vois pourtant encore devant moi son visage blanc aux traits forts et épais ; la forme de la tête est caractéristique, ovoïde et allongée; les yeux, ronds et saillants, ont une expression d'étonnement malicieux, et les lèvres largement taillées annoncent des curiosités et des appétits de poète et d'analyste [...]13.

Com a diferença de, aqui, estarmos diante da imagem de um grande escritor,

uma vez mais o modelo do retrato passa a ser determinado pelo ambiente que

habita (seu espaço vital), tornando-se ao fim uma figura típica. Tudo na cena

13 "Sua residência, situada na rue du Montparnasse, é pequena, reclusa e discreta. Dir-se-ia um convento, um recanto místico, onde se dispersam vagas fragrâncias voluptuosas.

Há alguns anos [...], fui encarregado de levar alguns papeis ao Sr. Sainte-Beuve, que então escrevia a bela nota que publicou sobre o Sr. Littré. A porta foi aberta docemente e fui introduzido em uma sala obscura na qual fiquei a sós por longos dez minutos. Ao fundo, há um jardim, e as folhas deixavam entrar apenas uma iluminação tenra e verdejante.

Eu era poeta nesses alegres tempos de ignorância, e o silêncio arrepiante desse cômodo, sua luz fraca me fizeram imaginar que havia sido transportado para o ninho morno e recôndito de um jovem casal em plena lua de mel.

Então, pediram que eu subisse uma escada estreita, e encontrei o eminente crítico de pé no centro de seu gabinete. Lá fiquei por, no máximo, um minuto, e, no entanto, ainda consigo ver diante de mim seu rosto alvo de traços fortes e espessos; a forma da cabeça é característica, ovoide e alongada; os olhos, arredondados e protuberantes, carregam uma expressão de surpresa maliciosa, e os lábios, bastante grossos, anunciam curiosidades e apetites de poeta e de analista". ZOLA, Émile. OEuvres complètes. Paris: Cercle du livre précieux, 1968, p. 233. 
descrita por Zola converge a uma paisagem idealizada para o trabalho intelectual, na qual os sentidos são poupados e acalmados para favorecer maior potência mental e transcendência. O primeiro parágrafo deixa isso bastante claro, comparando a morada a um "recanto místico". Mais adiante, a porta da residência de Sainte-Beuve se abre com "doçura", dando acesso a um salão "obscuro". Ao fundo, nada mais que um jardim cuja iluminação é "tenra e verdejante". Essa mesma iluminação o leva a sonhar que fora transportado ao "ninho morno e recôndito de um jovem casal em lua de mel". Então, o jovem narrador, visitante encantado, sobe "estreitas escadas" (todos os elementos materiais são sóbrios) e se depara com a imponente figura de Sainte-Beuve. Naqueles "tempos de ignorância", ele "era poeta": com que reverência e cerimônia ele se dirige ao escritor! Tudo que a casa possuía de modesta há de monumental nos traços da face do escritor. 0 "rosto branco de traços fortes e espessos", os "olhos redondos e salientes", plenos de "maliciosa surpresa", e lábios "esculpidos" a anunciar "curiosidades e apetites de poeta e analista". Ora, Zola parece depositar sobre a aparência de Sainte-Beuve a figura de uma escultura, signo importante da expressão de um raciocínio artístico. Ele justifica, com isso, a escolha do título da antologia em que reuniu esse retrato, mármores e gessos. Toda a calma idealizada da casa, semelhante àquela de um templo, favorecendo religiosamente o trabalho intelectual, converge para a confecção de uma grande obra, que é a mente do escritor traduzida nos traços de seu rosto. Mais do que Sainte-Beuve, Zola descreve o tipo ideal de escritor, do qual faz o elogio. Trata-se de um modelo tão característico quanto a velha pensionista burguesa de Balzac.

Os retratos de escritores célebres, como esse de Sainte-Beuve, ganharam tamanha notoriedade na imprensa francesa de meados do século XIX que, segundo 
Marie-Ève Thérenty, estariam até mesmo nas origens do modelo das entrevistas tal qual o conhecemos ainda hoje ${ }^{14}$. Ou, mais especificamente, nas raízes da "interview à la française", que o retratista Adolphe Brisson, buscando distanciar-se das práticas anglo-saxônicas (definidas pelo jornalista Pierre Giffard como mera "máquina de anotações"), afirma não ser apenas o ato de:

rapporter des paroles entendues, mais d'évoquer celui qui parle, de donner l'impression de sa voix, de son geste, de sa physionomie, du milieu où il vous est apparu, et de deviner ce qu'il n'a souvent énoncé qu'à demi, de surprendre le secret de sa pensée. ${ }^{15}$

Uma vez mais surgem palavras do gosto do autor naturalista francês: a busca de fisionomias, vozes ou mesmo gestos que, determinados pelo milieu do retratado (termo que tanto salienta Auerbach ${ }^{16}$ ) criam, através da verossimilhança, uma ilusão de presença, a "evocação daquele que fala". Mas, sem ir além, atendo-se ao que há de pertinente aos retratos literários, que são nosso objeto de estudo, isto é, sem entrar no mérito do gênero jornalístico à parte que se desenvolveu nas fases mais adiantadas do século XIX sob a forma das entrevistas de grandes escritores, convém lembrar que Thérenty percebe mais que apenas razões "oportunistas" na proliferação desses textos, provas de "camaradagem literária”, auxílio mútuo na promoção de autores através de veículos de imprensa.

\footnotetext{
14 "La prolifération de l'interview d'écrivain pourrait en fait s'expliquer par la combinaison de ce modèle anglo-saxon avec l'héritage du portrait littéraire inventé dans les années 1830. Selon les spécialistes, la forme du portrait évoluerait nettement au cours du xixe siècle depuis le parcours biographique jusqu'à l'interview journalistique en passant par les formes aussi très codifiées de la visite à l'écrivain et de l'entretien" [A proliferação das entrevistas de escritores poderia, de fato, ser explicada pela combinação desse modelo anglo-saxônico com a herança do retrato literário inventado na década de 1830. De acordo com especialistas, a forma do retrato teria evoluído nitidamente ao longo do século XIX, do percurso biográfico até a entrevista jornalística, passando pelas formas também bastante codificadas da visita ao escritor e da entrevista]. Cf. THÉRENTY, Marie-Ève. Paroles, paroles, paroles: Du portrait littéraire à l'interview d'écrivain. In BLAISE, Marie; TRIAIRE, Sylvie; e VAILLANT, Alain (orgs.). L'histoire littéraire des écrivains. Paroles vives. Montpellier: Presses universitaires de la Méditerranée, 2009. Disponível online: $<$ http://books.openedition.org/pulm/855> (consultado em 22 de junho de 2017).

15 "relatar as conversas que ouviu, mas de evocar aquele que fala, de dar a impressão de sua voz, de seus gestos, de sua fisionomia, do ambiente no qual ele surgiu e de intuir aquilo que normalmente enunciou apenas pela metade, de surpreender o segredo de seu pensamento". Idem.

${ }^{16}$ AUERBACH, Erich. Op. cit., p. 438.
} 
Um fundo ainda mais relevante de razões que chama "estruturais" se impõe para esse fenômeno. Ela cita "brevidade do retrato, atualidade do gênero, complementaridade com o artigo crítico e a crônica" ${ }^{17}$. E cremos que outros pontos ainda mais estruturais podem ser enumerados...

Ademais da conveniência do retrato literário às correntes de pensamento artístico em voga naquele momento, outro aspecto, como indicamos de início, marcado por natureza sobretudo sociológica, favoreceu a proliferação desse tipo de texto. Seja em sua forma autônoma, como artigos de publicações periódicas, ou integrados a obras de maior envergadura, como romances e novelas. Trata-se do momento histórico em que esse fenômeno se deu e de todas as contingências sociais que o acompanham e que participam da compreensão de seu significado. Por contingências sociais do momento histórico de disseminação do retrato literário, entendam-se os fatores que contribuíram para que esse gênero, diferente de seu predecessor seiscentista, se tornasse um tipo de texto eminentemente popular. 0 aumento dos índices de alfabetização na França, a maior circulação de periódicos e livros nesse país e o projeto de construção de uma memória nacional, calcada em cânones intelectuais, a partir da ascensão do estado moderno burguês, na passagem do século XVIII ao XIX.

\footnotetext{
17 "Il faut donc souligner dès les années 1830 un lien viscéral entre la presse et le portrait littéraire, dû sans doute à des raisons opportunistes (caractère distrayant du portrait, camaraderie littéraire) mais aussi à des raisons structurelles (brièveté du portrait, actualité du genre, complémentarité avec l'article critique et la chronique)"[É preciso, portanto, destacar desde a década de 1830 uma ligação visceral entre a imprensa e o retrato literário, por causa, sem dúvida, de razões oportunistas (caráter de distração do retrato, camaradagem literária), mas também por conta de razões estruturais (brevidade do retrato, atualidade do gênero, complementaridade com o artigo crítico e a crônica)]. Cf. THÉRENTY, Marie-Ève. Op. cit.
} 
Como demonstra o artigo de François Furet e Wladimir Sachs ${ }^{18}$, a Revolução Francesa legou ao século XIX um país mais alfabetizado que aquele sob o Antigo Regime. Os historiadores pautam seus cálculos na variação da quantidade de assinaturas em atas de casamento, o que poderia ser denunciado como um critério fraco para se aferir índices de alfabetização. Mas que, no entanto, a julgar pela prioridade atribuída à aprendizagem da leitura frente à escrita naquele momento, tanto na formação escolar quanto na doméstica, acaba por demonstrar que a população francesa avançava em seu acesso ao universo das letras. Como afirmam os autores, "a capacidade de assinar é um indicador intermediário de alfabetização, entre o domínio da leitura e da escrita, incluindo menos pessoas que aqueles capazes de escrever, e mais que aqueles que sabem ler"19. Ainda do ponto de vista metodológico, some-se a essas constatações o fato de que os dados de que dispuseram os autores são em sua maioria rurais, levando a pressupor que o fenômeno de aumento dos índices de alfabetização, já elevado no campo na virada do século XVIII ao XIX, teria sido ainda mais intenso nos principais centros urbanos, sobretudo em uma cidade que não figura nas sondagens, a capital Paris. Em todo caso, a conclusão de Furet e Sachs é de que o século XIX se inaugura em meio a uma "aceleração da tendência de alfabetização em vários departamentos retardatários" e de que, "à exceção de desvios locais, a Revolução Francesa, longe de haver contrariado esse esforço, parece tê-lo favorecido"20.

\footnotetext{
18 FURET, François; SACHS, Wladimir. La croissance de l'alphabétisation en France (XVIIIe-XIXe siècle). Annales. Économies, Sociétés, Civilisations, vol. 29, n. 3, 1974. pp. 714-737. Disponível online: <www.persee.fr/doc/ahess_0395-2649_1974_num_29_3_293505> (consultado em 22 de junho de 2017).

19 "la capacité à signer est un indicateur d'alphabétisation intermédiaire entre la maîtrise de la lecture et celle de l'écriture incluant moins de gens que ceux qui sont capables d'écrire mais plus que ceux qui savent lire". Cf. Ibidem, p. 716.

${ }^{20}$ É o que demonstra a série de três mapas que os autores lograram produzir, comparando homens e mulheres nos intervalos de recenseamento de 1686-1690/1786-1790, 1786-1790/1816-1820 e 1816-1820/1866. Neste último período, a maior parte das regiões consideradas apresenta
} 
O segundo fator que citamos, qual seja a maior circulação de periódicos e livros na França a partir do século XIX, parece ser consequência direta do primeiro. Com um leitorado mais amplo, cresce também a demanda por leitura e sua conseguinte oferta. E o retrato literário, pela dimensão breve de seus textos e pelas temáticas sobre as quais se debruçava - figuras públicas e tipos sociais de grande repercussão e interesse -, revelou-se apropriado ao conteúdo de jornais e revistas. Louis Charlet e Robert Ranc estimam em Histoire générale de la presse française as proporções do aumento da circulação de periódicos na França como reverberação de uma tendência ainda mais forte, que era a de crescente alfabetização da população francesa e sua inclusão na esfera pública de debates e interlocução a partir da Revolução Francesa. Segundo os autores, nas primeiras décadas do século XIX, "uma tiragem de cinco mil exemplares representa para um jornal um sucesso considerável"21. 0 número parece modesto, mas ganha contornos robustos se interpretado à luz de perspectiva histórica, tomado num tempo em que os métodos gráficos industriais e os sistemas de distribuição apenas começavam a se modernizar ${ }^{22}$. 0 cenário se inverte a partir da segunda metade do século, quando

crescimento acima de $1 \%$ nos índices de alfabetização. Dentre as mulheres, dois departamentos ultrapassam os 3\%. Dizem Furet e Sachs: "il se caractérise aussi par une accélération du trend d'alphabétisation dans beaucoup de départements retardataires à partir de la fin du XVIIIe siècle. Sauf accidents locaux, la Révolution française, loin d'avoir contrarié cet élan, semble l'avoir favorisé. Sans doute les historiens républicains de la fin du XIXe siècle avaient-ils tort de sous-estimer l'immense acculturation populaire (notamment rurale) réalisée dans le dernier siècle de l'Ancien Régime; mais ils avaient raison, dans l'ensemble, de voir dans la Révolution une promotion culturelle globale des classes populaires" [caracteriza-se também por uma aceleração da tendência de alfabetização em vários dos departamentos retardatários a partir do fim do século XVIII. À exceção de acidentes locais, a Revolução Francesa, longe de ter contrariado esse esforço, parece têlo favorecido. Sem dúvida, os historiadores republicanos do final do século XIX erraram ao subestimar o imenso aculturamento popular (especialmente rural) que ocorreu no último século do Antigo Regime; mas eles tinham razão, como um todo, de ver a Revolução como uma promoção cultural global das classes populares]. Cf. Ibidem, p. 731.

${ }^{21}$ BELLANGER, Claude et al. (orgs.). Histoire générale de la presse française. Paris: Presses universitaires de France, tomo II, 1969, p. 15.

${ }^{22}$ Ponderam Charlet e Ranc: "En 1850, la France ne dispose encore que de $3525 \mathrm{~km}$ de voies ferrées, alors que le réseau mondial est de 38000 km" [em 1850, a França ainda dispõe de apenas 3525 quilômetros de vias férreas, ao passo que a malha mundial equivale a 38 mil quilômetros]. Ibidem, p. 20. 
“as tiragens dos grandes periódicos políticos parisienses atingem e às vezes superam os 50 mil exemplares, e sendo que, ao final de 1865, o le Petit Journal [...] já tem mais de 250 mil exemplares impressos"23. René de Livois também salienta em sua Histoire de la presse française o fenômeno de aumento da circulação dos veículos onde justamente mais eram publicados retratos literários. Ele tenta ilustrar o que chama de "conquista do público pela imprensa"24 não através do volume de exemplares, mas também por meio da quantidade de títulos: “em 1860, há quinhentas publicações em Paris e quase mil no interior"25. E o que parece ainda mais relevante em se tratando da popularização dos retratos literários segundo Livois, “a leitura dos jornais tornou-se uma necessidade nova e não é o interesse pela vida política que criou esse fascínio. As publicações são cada vez mais interessantes $[\ldots] " 26$.

Até agora, tratamos dos elementos materiais, da alfabetização e da circulação da imprensa, que, somados ao amadurecimento de um pensamento estético realista e naturalista, criaram as condições para a popularização do gênero retrato literário no século XIX francês. Uma terceira questão, de cunho sobretudo histórico e filosófico, no entanto se impõe. Michel Foucault a evoca na conferência Qu'est-ce qu'un auteur?, publicada pela primeira vez no Bulletin de la Société Française de Philosophie, em 1969:

Cette notion d'auteur constitue le moment fort de l'individualisation dans l'histoire des idées, des connaissances, des littératures, dans l'histoire de la philosophie aussi, et celle des sciences. [...] Comment l'auteur s'est

\footnotetext{
23 "Les tirages des grands quotidiens politiques parisiens atteignent et dépassent parfois 50000 exemplaires, cependant qu'à la fin de 1865 le Petit Journal [...] tire déjà à plus de 250000 ". Cf. Ibidem, p. 24.

24 "Le public est conquis par la presse". Cf. Ibidem, tomo I, p. 272.

25 "En 1860, Il y a cinq cents publications à Paris et près d'un millier en province". Cf. Idem.

26 “La lecture des journaux est devenue un besoin nouveau et c'est n'est pas l'intérêt pour la vie politique qui a créé cet engouement. Les publications sont de plus en plus interessantes [...]”. C $f$. Idem.
} 
individualisé dans une culture comme la nôtre, quel statut on lui a donné, à partir de quel moment, par exemple, on s'est mis à faire des recherches d'authenticité et d'attribution, dans quel système de valorisation l'auteur a été pris, à quel moment on a commencé à raconter la vie non plus des héros mais des auteurs, comment s'est instaurée cette catégorie fondamentale de la critique "l'homme-et-l'oeuvre", tout cela méritait à coup sûr d'être analysé. ${ }^{27}$

Com a ascensão do moderno Estado Francês, é a ideia de nação que passa a ser reconstruída e revisitada, o que pressupõe uma reflexão sobre seu patrimônio intelectual, sobre aquilo que mais profundamente a define. É nesse momento que surge, como Olivier Nora bem nota, a figura do "escritor autônomo", cujos traços definidores são o "reconhecimento jurídico dos direitos autorais" e o "reconhecimento social da condição de homem de letras"28. 0 autor emprega palavras-chave fundamentais para a compreensão desse processo. Ao escritor, diz Nora, é conferida a "legitimidade" para exercer "o novo papel de encarnação da opinião pública" e seu prestígio se vê condicionado a um "estatuto fundado no direito"29. Em outras palavras, o escritor, assim como o artista, é transformado em uma instituição nacional baseada na garantia legal de propriedade sobre a obra. As implicações dessa mudança de visão sobre o papel social do artista são inúmeras e delas, como citamos acima, Foucault lista uma boa parcela. Mas o que nos interessa, em especial, é que ela contribui em larga medida para o desenvolvimento de um gênero como o retrato literário, que se volta, sobretudo, à

\footnotetext{
27 “Essa noção de autor constitui o momento forte da individualização na história das ideias, dos conhecimentos, das literaturas, também na história da filosofia e das ciências. [...] Como o autor se individualizou em uma cultura como a nossa, qual estatuto lhe foi atribuído, a partir de qual momento, por exemplo, passamos a fazer pesquisas de autenticidade e autoria, a qual sistema de valoração o autor foi agregado, em que momento começamos a contar não mais a vida de heróis, mas sim de autores, como se instaurou essa categoria fundamental da crítica do "homem e sua obra", tudo isso merecia certamente ser analisado". FOUCAULT, Michel. Dits et écrits. Paris: Quarto Gallimard, tomo I, 2001, p. 820.

${ }^{28}$ NORA, Olivier. La visite au grand écrivain. In NORA, Pierre. Les Lieux de mémoire. Paris: Gallimard, 1997, tomo II, p. 565.

${ }^{29}$ Idem.
} 
preservação da memória, visual e intelectual, desses seres. São, em outras palavras, verdadeiros monumentos erigidos sobre letras.

A grande popularização dos retratos literários no século XIX francês é, assim, produto de uma complexa combinação de fatores, de natureza não apenas literária, mas também política, social e histórica, gerando uma nova sociabilidade literária. Trata-se de uma França cujo número de leitores dispara; que, por conseguinte, passa a ver uma multiplicação de jornais e revistas em circulação por todo seu território; que, após a queda de uma monarquia absolutista, se propõe à construção de um estado nacional; e que se vê às voltas com pensamentos estéticos como o naturalismo e o realismo, expressão artística da modernização dos sistemas de conhecimento científico naquele momento.

Seria, contudo, limitante reduzir o retrato literário ao que Dufour define logo ao início de seu estudo como gênero de "textos publicados originalmente na imprensa, e então reunidos em séries, cada qual intitulado com um nome próprio e voltado à representação, em poucas linhas, em poucas páginas, de uma personalidade, de um escritor célebre"30. É relevante que o "mestre" Charles Augustin Sainte-Beuve ${ }^{31}$, aquele a quem se reputa a "invenção" do termo retrato literário com a publicação da antologia Critiques et portraits littéraires em $1832^{32}$, tenha sido o responsável pela configuração de um verdadeiro método crítico biográfico visceralmente ancorado no formato desse gênero. 0 retrato literário descrevia escritores, pintores, músicos, etc., associava-os ou não a esses tipos

\footnotetext{
30 “Textes publiés à l'origine dans la presse puis rassemblés en série, chacun lui-même titré d'un nom propre et s'attachant à représenter, en quelques lignes, en quelques pages, une personnalité, un écrivain célèbre". $C f$. DUFOUR, Hélène. Op. cit., p. V.

${ }^{31}$ Ibidem, p. 17.

32 Ibidem, p. 9.
} 
sociais, mas sua caracterização também implicaria e seria imprescindível ao julgamento de uma produção intelectual, e vice-versa. Sainte-Beuve acreditava que, até aquele momento, um retrato literário poderia ser resumido a "elogios acadêmicos", o estudo da obra de um artista "com relação a certas regras de retórica"33. Mas, também pelas razões de fundo estrutural que citamos acima, ele inclui nessa conjuntura a figura do autor, de modo que:

On ne saurait s'y prendre de trop de façons et par de trop de bouts pour connaître un homme, c'est-à-dire autre chose qu'un pur esprit. Tant qu'on ne s'est pas adressé sur un auteur un certain nombre de questions et qu'on n'y a pas répondu, ne fût-ce que pour soi seul et tout bas, on n'est pas sûr de le tenir tout entier, quand même ces questions sembleraient les plus étrangères à la nature de ses écrits: - Que pensait-il en religion? - Comment était-il affecté du spectacle de la nature? - Comment se comportait-il sur l'article des femmes? Sur l'article de l'argent? - Était-il riche, était-il pauvre? - Quel était son regime, quelle était sa manière journalière de vivre? etc. Enfin, quel était son vice ou son faible? Tout homme en a un. Aucune des réponses à ses questions n'est indifférente pour juger l'auteur d'un livre et le livre lui-même, si ce livre n'est pas un traité de géométrie pure, si c'est surtout un ouvrage littéraire, c'est-à-dire où il entre de tout. ${ }^{34}$

Difícil se deparar com uma passagem da obra de Sainte-Beuve que melhor resuma sua concepção de retrato literário. Presente no texto Chateaubriand jugé par un ami intime en 1803, parte integrante dos seus Nouveaux Lundis de 1878, esse excerto estabelece um eixo, linear e equilibrado, entre o autor e sua obra. Uma parte corresponde e condiciona a outra. Sem a apreensão de um ser, propósito primeiro do retrato literário, o entendimento daquilo que seu intelecto produz, de sua expressão artística, seria impossível. Religião, vida amorosa, condição

\footnotetext{
33 Ibidem, p. 15.

34 "Não há como nos fiarmos por diversas maneiras e por meio de diversas sugestões para conhecer um homem, isto é, outra coisa que não um espírito puro. Antes de dirigir a um autor um certo número de questões e sem que ele as responda, em si e no mínimo, não podemos ter a certeza de possuí-lo por inteiro, por mais que essas questões sejam o que há de mais estranho à natureza de seus escritos: - 0 que ele pensava sobre religião? - Como o espetáculo da natureza o afetava? Como ele se comportava no quesito mulheres? No quesito dinheiro? - Ele era rico ou ele era pobre? - Qual era seu regime, qual era sua forma cotidiana de viver ? etc. - Enfim, qual era seu vício ou sua fraqueza? Todo homem possui uma. Nenhuma das respostas a essas perguntas é indiferente para julgar o autor de um livro e o próprio livro se essa obra não é um tratado de geometria pura, caso se trate, sobretudo, de uma obra literária, isto é, aquela que o contém como um todo". Ibidem, p. 14.
} 
financeira, percepções morais, esses e tantos outros "caracteres" da vida de um autor seriam significativos daquilo que pensa e, portanto, explicariam e seriam explicados pela obra. Sainte-Beuve acredita, assim, ser possível apreender a essência do homem através do que produz. Limitar o estudo de um texto a questões estéticas seria ater-se a ele e ignorar o homem que, para falar como Dufour, "se mascara" por trás dele. Por sinal, ela própria enumera uma série de breves comentários nos quais Sainte-Beuve reafirma essa noção: no retrato literário de Jean-Jacques Ampère, quando diz que o mais importante em seus retratos seria "descobrir, se possível, o homem em si"35; no de Pierre Bayle, ao desejar apreender "o espírito e o gênio do autor"36. Em mais uma hipérbole de Dufour, os exemplos seriam "infinitos"37. Todos representativos da tentativa de Sainte-Beuve de dissecar a obra e o autor para encontrar um no outro.

Eis uma mostra clara do exercício crítico de Sainte-Beuve, retirada do retrato Pierre Corneille, de 1828:

Corneille, hors de son sublime et de son pathétique, avait peu d'adresse et de tact. Il portait dans les relations de la vie quelque chose de gauche et de provincial; son discours de réception à l'Académie, par exemple, est un chef-d'ouvre de mauvais goût, de plate louange et d'emphase commune. Eh bien! il faut juger de la sorte sa dédicace à Montauron, la plus attaquée de toutes, et ridicule même lorsqu'elle parut. Le bon Corneille y manqua de mesure et de convenance ; il insista lourdement là où il devait glisser ; lui, pareil au fond à ses héros, entier par l'âme, mais brisé par le sort, il se baissa trop cette fois pour saluer, et frappa la terre de son noble front. Qu'y faire? Il y avait en lui, mêlée à l'inflexible nature du viel Horace, quelque partie de la nature débonnaire de Pertharite et de Prusias [...] $]^{38}$

\footnotetext{
35 SAINTE-BEUVE, Charles-Augustin. OEuvres. Paris: Gallimard, Bibliothèque de la Pléiade, 1949, p. 945

36 Ibidem, p. 986.

37 DUFOUR, Hélène. Op. cit., p. 15.

38 "Corneille, fora de seu sublime e de seu patético, tinha pouco jeito e tato. Ele conduzia as relações da vida de maneira um tanto quanto estranha e provinciana; seu discurso de recepção na Academia, por exemplo, é uma obra de arte do mau gosto, de louvações rasas e de ênfase banal. E, vejam! Assim se deve julgar sua homenagem a Montauron, a mais criticada de todas e realmente ridícula quando foi publicada. Faltou ali o bom Corneille, ponderado e conveniente; ele insistiu com peso onde deveria ter deslizado; ele, parecido no fundo com seus heróis, íntegro na alma, mas aniquilado pela sorte, inclinou-se demais dessa vez para saudar e bateu sua nobre testa na terra. 0 que fazer? Ele carregava consigo, mesclado à natureza inflexível do velho Horácio, algo da natureza afável de
} 
Mais de um século separa a morte de Pierre Corneille (1606-1684) do nascimento de Sainte-Beuve (1804-1869). De modo que, daquele, este não conheceu mais que a obra. Mas, como dissemos, para o modelo beuviano de retrato literário, concebido, antes de mais nada, como um método crítico biográfico, obra e autor correspondem, o que permite que a produção artística de Corneille explique e então seja explicada pelo seu caráter. A oração "ele trazia nas relações da vida algo de desajeitado e provinciano" simboliza esse pensamento. Somos levados a nos questionar: como sabe ele, Sainte-Beuve, desse traço de personalidade de Corneille? Através de uma biografia? O depoimento de um íntimo? A correspondência do artista? 0 autor imediatamente nos responde, em tom de justificativa, que o discurso de recepção de Corneille na Academia Francesa (essa é sua fonte) se constitui numa "obra prima de mau gosto, de elogios superficiais e de ênfase comum". Todos, ressalte-se, juízos de valor fundamentados numa apreciação subjetiva de textos de Corneille, e não (o que seria impossível) da pessoa de Corneille. Para que não restassem dúvidas de que traços da personalidade de um autor poderiam ser depreendidos de sua obra, ele, mais adiante, ainda insiste que Corneille "se parece no fundo com seus heróis", de modo que tanto sua "natureza inflexível" quanto sua "natureza afável" constariam do caráter de personagens de algumas de suas tragédias: Horace, de 1640, Pertharite, de 1651, e Nicomède, também de 1651. Como não pôde conviver com Corneille em vida, Sainte-Beuve recorre a seus personagens, a suas obras, e delineia o pressuposto de que estes trazem consigo a essência de seu criador.

Pertharite e de Prúsias". SAINTE-BEUVE, Charles-Augustin. Portraits Littéraires. Paris: Bouquins, 1993, p. 33. 
O método crítico biográfico foi bastante bem-sucedido no século XIX e Sainte-Beuve logrou desenvolver um verdadeiro patronato ao seu redor. Disso é emblemática a quantidade de autores que, ao longo do período, não apenas aplicaram a técnica a seus retratos literários como também escreveram eles próprios perfis do "mestre", para fazer seu elogio. Dufour cita vários casos. De Gustave Merlet, que, no seu Hommes et livres de 1869, chama Sainte-Beuve de "o iniciador, o guia e o maestro do coro", ao lionense Edmond Biré, que afirma no prefácio de seu Études et portraits, com tom de certo orgulho, ter sido classificado por um crítico de Paris como "Sainte-Beuve provinciano"39. A grande aclamação, contudo, não lhe poupou de críticas. A mais célebre, embora se trate de obra póstuma e inacabada, sendo da lavra de Marcel Proust.

Contre Sainte-Beuve, cujos manuscritos foram compostos por volta do ano de 1908, carrega oposições que Proust já havia feito constar mesmo de textos anteriores. Lemos, por exemplo, uma passagem bastante categórica no artigo Sur la lecture, publicado originalmente na edição de 15 de junho de 1905 da revista $L a$ Renaissance latine, e incorporado em 1906 como prefácio a sua tradução do Sesame and lilies de John Ruskin"0: "Sainte-Beuve não compreendeu nenhum dos grandes escritores de seu tempo"41. São nesses esboços lacunares, contudo, que Proust conseguiu pela primeira vez sistematizar sua crítica ao "mestre" dos retratos literários como meio, segundo Pierre Clarac, de formular e promover um modelo crítico próprio ${ }^{42}$. Ou, ainda, em suas próprias palavras, foi neles que se propôs a demonstrar "que seu tão admirado método crítico é absurdo" e que

\footnotetext{
${ }^{39}$ DUFOUR, Hélène. Op. cit., p. 17.

40 CSB, p. 160.

41 "On peut dire que Sainte-Beuve a méconnu tous les grands écrivains de son temps". Cf. Ibidem, p. 190.

42 Ibidem, p. 820.
} 
Sainte-Beuve "é um escritor ruim"43. Proust principia sua argumentação advogando por um divórcio entre a linguagem e a vida, na medida em que a inteligência não seria o meio ideal, ainda que o único, para a apreensão da existência humana ${ }^{44}$. É verdade que essa ideia, a insuficiência da linguagem para a percepção do homem no tempo, se encontra em voga nas correntes ditas espiritualistas da filosofia francesa da virada do século $\mathrm{XIX}$ ao $\mathrm{XX}$, e ganha contornos relevantes nos trabalhos de Henri Bergson45. Mas Proust aí deseja, acima de tudo, combater o pensamento de Sainte-Beuve de que "a literatura não é [...] distinta ou ao menos separável do restante do homem"46. Ao tratar da relação entre Sainte-Beuve e Baudelaire, ele afirma que, na realidade:

l'homme qui vit dans un même corps avec tout grand génie a peu de rapport avec lui, que c'est lui que ses intimes connaissent, et qu'ainsi il est absurde de juger comme Sainte-Beuve le poète par l'homme ou par le dire de ses amis. Quant à l'homme lui-même, il n'est qu'un homme, et peut parfaitement ignorer ce que veut le poète qui vit en lui. ${ }^{47}$

Haveria então um total descolamento entre os seres e aquilo que produzem em arte. O conhecimento social, aquele dos "íntimos" e dos "amigos", estaria sempre fadado à superficialidade. Pela leitura proustiana, o fato de Corneille, por exemplo, proferir um discurso, segundo Sainte-Beuve, "de mau gosto", não

\footnotetext{
${ }^{43}$ Ibidem, p. 218.

44 Ibidem, p. 216.

${ }^{45}$ Ao introduzir o Essai sur les données immédiates de la conscience de Bergson, Emmanuel Picavet observa que, segundo essa filosofia do conhecimento, "a linguagem não serve à expressão de todas as nuances dos estados internos; as descrições da linguagem, aqui relacionadas ao senso comum, contrariam a restituição da atividade viva do eu". É o que, mais adiante, refletindo sobre o sentimento estético, argumenta o próprio Bergson: "a arte busca muito mais imprimir sentimentos sobre nós do que os exprimir; ela os sugere e passa facilmente por imitação da natureza quando encontra os meios mais eficazes". Cf. BERGSON, Henri. Essai sur les données immédiates de la conscience. Paris: Flammarion, 2013, pp. 37, 63.

${ }^{46}$ CSB, p. 221.

47 "O homem que habita um mesmo corpo com qualquer grande gênio possui pouca relação com ele, e não é mais que ele que seus íntimos conhecem, de modo que, assim, é absurdo julgar, como Sainte-Beuve, o poeta pelo homem ou dito através de seus amigos. No que diz respeito ao homem em si, ele não é mais que um homem, capaz de ignorar perfeitamente o desejo do poeta que nele habita". Ibidem, p. 248.
} 
necessariamente significaria que a pessoa desse autor também participa desses mesmos vícios. Muito pelo contrário:

Comme le ciel de la théologie catholique qui se compose de plusieurs ciels superposés, notre personne, dont l'apparence que lui donne notre corps avec sa tête qui circonscrit à une petite boule notre pensée, notre personne morale se compose de plusieurs personnes superposées. Cela est peut-être plus sensible encore pour les poètes qui ont un ciel de plus, un ciel intermédiaire entre le ciel de leur génie, et celui de leur intelligence, de leur bonté, de leur finesse journalières, c'est leur prose. 48

Poucas noções como essa, de diferentes dimensões de pensamento habitando um mesmo corpo, terão tamanha importância ao longo da obra de Proust. E uma das explicações que, em incontáveis momentos, o ciclo romanesco $\grave{A}$ la recherche du temps perdu encontrará para esse dado da complexidade dos seres é o efeito dinâmico e transformador do tempo sobre suas personalidades. Quando cremos atingir a verdade dos seres, revela-se ao narrador proustiano a ação da passagem do tempo, e tudo se modifica, os outros e nós mesmos: já não estamos mais diante do mesmo objeto, da mesma paisagem, das mesmas pessoas. Jean-Yves Tadié não se cansa de sublinhar esse traço da estética proustiana em diferentes obras críticas. Em Proust et le roman, chama esse recurso de "técnica do ponto de vista e das perspectivas", isto é, a constituição de um herói cujo "campo de visão", cujas "relações com o mundo e com os outros" se dão numa "galeria de lentes deformadoras através das quais busca a verdade"49. E, na biografia Marcel Proust, afirma que a arte do narrador proustiano é aquela "do paradoxo, que, sob a

\footnotetext{
48 "Como o céu da teologia católica, composto de vários céus superpostos, nossa pessoa, cuja aparência é dada por nosso corpo, com sua cabeça, que circunscreve a uma pequena bola nosso pensamento, nossa pessoa moral se compõe de várias pessoas superpostas. Isso é talvez ainda mais sensível para os poetas que possuem um céu a mais, um céu intermediário, entre o céu e seu gênio, aquele de sua inteligência, de sua bondade, de sua fineza de cada dia, sua prosa". Ibidem, p. 249.

${ }^{49}$ TADIÉ, Jean-Yves. Proust et le roman. Paris: Gallimard, 1971, pp. 34-35.
} 
aparência, busca uma realidade contrária a ela"50. A superfície é, nesse sentido, enganadora. Ela segreda verdades interiores que, além de tudo, se encontram em constante transformação. A obra de arte não seria mais que a expressão imprecisa dessas verdades, em diferentes instantes do tempo. Tomá-las, à moda de SainteBeuve, como viés universal para a apreensão da psicologia, da personalidade, da essência, enfim, para o estabelecimento do retrato de um ser, significaria ignorar esse incontornável dado dinâmico de sua existência: um achatamento, uma simplificação.

Proust foi, ele próprio, um retratista e teve inúmeras oportunidades, anteriores ou mesmo concomitantes à construção da Recherche, ainda durante a juventude, de demonstrar os princípios estéticos, os valores de representação da imagem humana que tinha em mente ao contestar o método de Sainte-Beuve. Embora, como reconhece Yuri Cerqueira dos Anjos, a presença do autor nas páginas da imprensa parisiense da Belle Époque seja esporádica, inconstante, ocasional, enfim, aquela que se espera de um "outsider" 51 , ora preocupado com a promoção de seus trabalhos, ora buscando a penetração num círculo social através de elogios públicos, são vários seus textos que podemos considerar como retratos literários, na medida em que, retomando a definição de Dufour, se revelam "textos publicados originalmente na imprensa, então reunidos em série, cada qual intitulado com um nome próprio e voltado à representação, em poucas linhas, em

50 TADIÉ, Jean-Yves. Marcel Proust. Paris: Gallimard, 1996, pp. 600-601.

51 "Si, dans la masse virtuellement infinie des textes publiés dans la presse de l'époque, sa production ne semble représenter que peu de chose, à l'échelle de sa carrière et de sa production prise dans son ensemble, elle représente beaucoup. La presse occupe en effet une bonne partie de sa trajectoire et joue un rôle important dans ses réflexions et son écriture de manière générale" [Se, diante da massa virtualmente infinita de textos publicados na imprensa da época, sua produção não parece representar algo substantivo, quando levamos em conta sua carreira e o conjunto de sua produção, ela passa a representar muita coisa. A imprensa ocupa, na realidade, uma boa parcela de sua trajetória e desempenha um papel importante em suas reflexões e em sua escritura de maneira geral]. Cf. ANJOS, Yuri Cerqueira dos. Proust et la presse de la Belle Époque. Paris: Honoré-Champion, 2018 , p. 63. 
poucas páginas, de uma personalidade, de um escritor célebre" 52 . E poderíamos ainda ir além: textos nos quais, invariavelmente, tenta complexificar seu modelo, revelar uma existência inesperada, oculta, por vezes surpreendente e contraditória resguardada sob a camada superficial das aparências - o engin intérieur que o herói da Recherche vislumbra, por exemplo, através dos olhos do barão de Charlus, sob a grossa camada de pó de seu rosto de ator de teatro ${ }^{53}$. Como já enumeramos ao introduzir esse estudo, foram selecionados treze desses vários textos por lhes julgarmos os mais representativos do gênero retrato literário. Outros dos artigos jornalísticos de Proust também trazem consigo descrições de escritores, músicos, atores, intelectuais e, especialmente, mundanos de seu convívio. Mas, como priorizam como objeto de interesse as circunstâncias de sociabilidade desses indivíduos e não a tentativa, propriamente dita, de apreensão dos traços definitivos de sua pessoa, acreditamos que se enquadrariam com maior propriedade dentre as crônicas de salão escritas por esse autor, um gênero à parte na obra proustiana, sobre o qual muito já se tratou ${ }^{54}$.

Dufour enumera uma série de distintas "dimensões" de retratos literários 55. Trata-se, na realidade, de modalidades do gênero segundo as circunstâncias que motivaram a confecção do texto e que justificaram sua publicação em um dado momento. Houve, assim, retratos sob a forma de lorgnons, cujos autores se diziam "retratistas cirúrgicos" manuseando lentes de aumento para "dissecar" e "perfurar"

\footnotetext{
52 “Textes publiés à l'origine dans la presse puis rassemblés en série, chacun lui-même titré d'un nom propre et s'attachant à représenter, en quelques lignes, en quelques pages, une personnalité, un écrivain célèbre". $C f$. DUFOUR, Hélène. $O p$. cit., p. V.

${ }^{53} \mathrm{Cf}$. Capítulo 3 - Torreões e bibliotecas, p. 91.

${ }^{54} \mathrm{Cf}$. PINSON, Guillaume. Fiction du monde : De la presse mondaine à Marcel Proust. Montréal: Presses de l'Université de Montréal, 2008.

55 DUFOUR, Hélène. Op. cit., p. 109.
} 
as aparências de outros artistas ${ }^{56}$. Mas também os portraits-souvenirs,

testemunhos da amizade de um retratista com um modelo já morto ${ }^{57}$; os primeiros

encontros, relatos da visita do retratista a um grande escritor 58 ; e os medalhões,

textos bastante breves, voltados sobretudo à apreensão caricatural e divertida dos

traços e gestos de um personagem célebre ${ }^{59}$. Essas categorias, é importante

ressaltar, estão longe de serem absolutas. Entre elas, se dão inúmeros cruzamentos

e encontros, de modo que a distinção proposta, no caso de Marcel Proust, nos serve

muito mais a identificar os temas e preocupações sobre as quais esse autor se

debruçou, assim como situá-las no interior de uma parcela específica de sua

produção jornalística.

Dos treze retratos que analisamos, cinco focalizam modelos já mortos por ocasião de sua publicação: John Ruskin; Une grand-mère; Gustave de Borda; Une miniaturiste du seconde empire: Madame Herbelin; e Le Salon de la Princesse Edmond de Polignac: musique d'aujourd'hui, échos d'autrefois. Os quatro primeiros podem ser caracterizados até mesmo como artigos necrológicos, na medida em

\footnotetext{
${ }^{56}$ Caso de Gustave Merlet, que defende "enfoncer le scalpel jusqu'au cœur" dos modelos mortos e "disséquer tout vifs". Cf. MERLET, Gustave. Portraits d'hier et d'aujourd'hui, attiques et humoristes. Paris: Didier \& Cie, 1863, pp. 3-4.

${ }^{57}$ É assim que Charles Monselet se recorda de seu saudoso amigo, Gérard de Nerval: "Je suis heureux que ce livre me fournisse l'occasion de rassembler quelques notes sur un homme dont j'aimais le cœur autant que le talent, et à côté de qui j'ai vécu pendant une huitaine d'années, rapprochés par une certaine conformité d'humeur et quelquefois aussi par les mêmes études. Jusqu'à présent, mû par un sentiment de douloureuse discrétion, j'avais fait taire mes souvenirs ; aujourd'hui il m'est permis de les évoquer, de les grouper" [Fico feliz por esse livro me dar a oportunidade de reunir algumas anotações sobre um homem cujo coração amava tanto quanto o talento, e ao lado de quem vivi por oito anos, aproximados por uma certa conformidade de humor e às vezes também pelos mesmos estudos. Até hoje, movido por um sentimento de dolorosa discrição, calei minhas lembranças; hoje, tenho permissão para evocá-las e agrupá-las]. Cf. MONSELET, Charles. Les Ressuscités. Paris: Calmann-Lévy, 1876, p. 185.

${ }^{58}$ Exemplo de Auguste Barbier, relatando seu primeiro encontro com o poeta Alfred de Vigny: "C'est en 1829, rue Notre-Dame des Champs, chez M. Victor Hugo, que je vis pour la première fois le comte de Vigny" [Foi em 1829, na rue Notre-Dame des Champs, na casa do Sr. Victor Hugo, que vi pela primeira vez o conde de Vigny]. $C f$. BARBIER, Auguste. Souvenirs personnels et silhouettes contemporaines. Paris: Dentu, 1883, p. 277.

${ }^{59}$ Segundo Barbey d'Aurevilly, medalhões seriam um "paquet d'épigrammes, lesquelles allaient avec une gaieté cruelle plus ou moins directement à leur adresse" [pacote de epigramas, os quais partiam com uma alegria cruel mais ou menos diretamente ao seu destino]. $C f$. D'AUREVILLY, Barbey. Les quarante médaillons de l'Académie Française. Paris: Albert Savine, sem data, p. V.
} 
que é primeiro o episódio da morte de seus modelos e somente depois a lembrança, a recapitulação de seu legado e de seu impacto na vida do autor que embasa a construção do texto. O filósofo John Ruskin morre em 20 de janeiro de 1900, e Proust publica seu retrato sete dias depois com uma abertura diga-se quase noticiosa, tão impactante e chamativa quanto uma manchete se levarmos em conta o verbo conjugado no passé composé (com valor de pretérito perfeito) sustentando o tempo de uma breve e fatídica oração, com valor explicativo, introduzida por dois pontos:

On craignait l'autre jour pour la vie de Tolstoï ; ce malheur ne s'est pas réalisé; mais le monde n'a pas fait une perte moins grande: Ruskin est mort.60

De modo semelhante em Une Grand-mère. Mais uma vez, após uma pequena reflexão inicial, responsável por pautar o argumento que se estende ao longo de todo esse retrato, em torno da oposição entre força física e espiritual ("Il y a des personnes qui vivent sans avoir pour ainsi dire de forces, comme il y a des personnes qui chantent sans avoir de voix"61), seu narrador não noticia apenas a morte de Madame de Rozière, avó materna de seu amigo de infância, Robert de Flers. Ele também informa, isolados em uma oração adjetiva explicativa, o local e a data de seu velório, proporcionando assim a razão de ser factual, mesmo noticiosa daquele retrato:

\footnotetext{
60 "Temíamos outro dia pela vida de Tolstoi; esse infortúnio não se realizou; mas o mundo não sofreu uma perda menor: Ruskin morreu". CSB, p. 439.

61 "Há pessoas que vivem, por assim dizer, sem forças, bem como há pessoas que cantam sem voz". CSB, p. 545 .
} 
La grand-mère de notre cher collaborateur et ami, Robert de Flers, Mme de Rozière, qu'on enterre aujourd'hui au Malzieu, n'était qu'intelligence et que sentiment. ${ }^{62}$

Outro exemplo em Gustave de Borda, retrato no qual Proust homenageia o esgrimista que testemunhou a seu lado no duelo contra Jean Lorrain, em fevereiro de 189763 . Uma vez mais a morte do modelo retratado é noticiada por Proust logo no primeiro parágrafo, com a garantia do tom de referencialidade do passé composé, e, mais além, isolada no interior de uma oração adjetiva explicativa:

M. Gustave de Borda, qui est mort la semaine dernière et qui était surtout connu et légendaire sous le surnom de 'Borda Coup d'épée', avait en effet passé sa vie l'épée à la main, redoutable aux méchants, mais doux aux bons et compatissant aux malheureux, comme un chevalier du Romancero dont il avait la figure. ${ }^{64}$

Esse tom de referencialidade, proporcionando passagens nas quais se tem a impressão de leitura de um lead, indicação de um fato, seus agentes, local e momento, construção tão típica do jornalismo moderno, dos veículos de

\footnotetext{
62 "A avó do nosso caro colaborador e amigo Robert de Flers, Madame de Rozière, sepultada hoje em Le Malzieu, não era mais que inteligência e sentimento". CSB, p. 545.

${ }^{63}$ Eis uma breve recapitulação desse episódio. 0 esgrimista Gustave de Borda e o pintor Jean Béraud foram testemunhas de Proust em um duelo de armas contra o crítico Jean Lorrain. Em um artigo do dia 3 de fevereiro de 1897, ele havia ironizado o convite feito por Proust a Alphonse Daudet para que prefaciasse seu Les plaisirs et les jours. Lorrain afirmou que Daudet teria aceitado a proposta "porque não recusa nada a seu filho Lucien", à época suspeito de manter um relacionamento amoroso com Proust. Essa provocação coincide com um momento bastante turbulento em seu círculo familiar. Seu pai reprova, mesmo antes de ter acesso a ela, uma série de oito imagens feitas pelo fotógrafo Otto com Marcel sentado entre Robert de Flers e Lucien Daudet, que o observa contemplativamente. 0 duelo com Lorrain ocorreu no bosque de Meudon, no Ermitage de Villebon. Foram disparadas duas balas, mas nenhum dos dois saiu ferido. Na correspondência de Proust encontramos uma interessante carta de Madame Léontine Arman de Caillavet, amante de Anatole France, elogiando a "coragem" de Proust e lamentando que "o monstro" (Lorrain) tenha saído ileso do combate. Cf. Corr., II, p. 174; TADIÉ, Jean-Yves. Op. cit., pp. 497-503.

64 "O Sr. Gustave de Borda, falecido na semana passada e, sobretudo, famoso e lendário pelo apelido de "Borda Espadada", passou de fato sua vida com o sabre empunhado, temido pelos maus, mas doce com os bons e piedoso com os desafortunados, como um cavaleiro do romanceiro, de quem ele possuía os traços". CSB, p. 549.
} 
comunicação de massa65, auxilia Proust a justificar a razão de ser daquele texto, sua relevância ao leitor. Trata-se de uma forma de retrato literário que, apesar do que possui de rememoração da vida de um personagem e de meditação acerca de sua personalidade, se revela sempre movida pela ocasião, impregnada pelo valor de um obituário. A única exceção a esse critério ocasional seria o retrato Une miniaturiste du seconde empire: Madame Herbelin, que não nos informa da morte dessa pintora mundana. Ainda assim, esse retrato faz entrever o que há de mais relevante em um obituário: a enumeração categórica, biográfica, de tudo aquilo que, na vida do modelo, guardou importância suficiente para que sua morte fosse lembrada e publicamente registrada. Enfim, para que fosse justificada sua eternização sob a forma de um monumento. Nenhuma aresta da listagem dos méritos de Madame Herbelin fica de fora, e lemos a humildade com que participava de seu elevado grupo social ("cette vieille dame, si vive, si douce et si simple, avait été mêlée à la vie la plus fastueuse, à la société la plus brillante de la monarchie de Juillet et du second Empire"), a grande qualidade de seu legado artístico ("ces miniatures qui, pourtant, ne resteront pas seulement comme des documents de premier ordre [...] mais aussi parmi les spécimens les plus séduisants et les plus achevés d'un art difficile et délicieux"), a posição privilegiada com que assistiu ao

\footnotetext{
${ }^{65}$ Entre as décadas de 1940 e 1960, submersos em um ambiente de crescente profissionalização na imprensa, teóricos americanos da comunicação produziram uma quantidade nada desprezível de manuais de redação com o objetivo de sistematizar o fazer jornalístico. A forma como à época definiram o parágrafo inicial de uma matéria de jornal, o lead, demonstra como esse saber já se encontrava cristalizado nas práticas de redação há quase um século. 0 Modern Journalism, de Siegfried Mandel (1962), se refere ao lead como "o clímax da história", a partir do qual se desenrola o restante da narrativa. Journalism, de Carl Miller (1962), o define como o parágrafo no qual o repórter faz constar o "elemento distintivo" da história. Exploring journalism, de Roland Edgar Wolseley e Laurence Randolph Campbell (1943), chega a tratar a questão pela perspectiva do público da matéria e coloca o lead, para além de sua construção, como o instante em que "o leitor não precisa ir mais adiante na história, a menos que deseje maiores detalhes". Proust, escrevendo na virada do século, e mesmo sem jamais ter sido colaborador regular de qualquer veículo jornalístico, demonstra em seus retratos domínio claro dessa técnica de redação. Cf. MANDEL, Siegfried. Modern Journalism. Nova York: Pitman Publishers, 1962, p. 332; MILLER, Carl. Journalism. Nova York: Holt, Rinehart and Winston, 1962, p. 30; WOLSELEY, Roland Edgar; CAMPBELL, Laurence Randolph. Exploring journalism. Upper Saddle River: Prentice Hall, 1943, p. 158.
} 
desenrolar da história francesa ("elle avait puisé à la source même les récits encore tout vivants de cette épopée impériale dont son père n'avait pas été l'un des moindres acteurs") e a virtuosa família a que pertencia ("ses deux nièces, auprès de qui elle s'était retirée et qui l'ont jusqu'à la dernière heure chérie et soignée comme si elles avaient été ses filles") ${ }^{66}$.

Poder-se-ia contrapor que vários desses aspectos podem ser identificados em Le Salon de la Princesse Edmond de Polignac: musique d'aujourd'hui, échos d'autrefois, também consagrado a um modelo morto. Mas o fato de ter sido publicado dois anos após o sepultamento do príncipe Edmond de Polignac, seu modelo, faz saltar aos olhos algumas diferenças que o tornam um retrato distinto de um mero obituário. Sendo o falecimento já notório, o artigo se volta com preponderância a uma outra forma de rememoração de sua pessoa. Lá estão também os méritos de seu modelo, todas as virtudes que o tornariam um ser humano especial, as chaves de entrada no panteão. Mas o que se percebe com preponderância são passagens nas quais o retratista busca encaixar o modelo no próprio contexto de sua vida. A figura do retratista se entrevê e os episódios da biografia do retratado são narrados apenas na medida em que o autor do retrato deles participa. É o que Dufour, como acima indicamos, chama de portrait souvenir - em poucas palavras, o retratista busca uma narrativa na qual relembra sua convivência com o modelo e expressa sua "afetividade" por ele ${ }^{67}$. No caso de

\footnotetext{
66 "Essa velha senhora, tão vivaz, tão doce e tão simples, fizera parte da vida mais faustosa, em meio à sociedade mais brilhante da Monarquia de Julho e do Segundo Império"/ "essas miniaturas, as quais, no entanto, não sobreviverão apenas como documentos de primeira linha [...], mas também dentre os espécimes mais sedutores e acabados de uma arte difícil e deliciosa" / "ela extraiu da própria fonte as narrativas ainda totalmente vívidas dessa epopeia imperial da qual seu pai não fora um dos atores menores"/ "suas duas sobrinhas, com as quais foi morar e que, até o último instante, acalentou e cuidou como se tivessem sido suas filhas". CSB, pp. 487-489.

${ }^{67}$ DUFOUR, Hélène. Op. cit., p. 110.
} 
Proust, as cenas são impregnadas de recordações pessoais do autor, meditações que beiram o saudosismo:

peut-être même les sauteries gaies d'autrefois feront-elles retentir de nouveau le grand hall de musiques qui ne ressemblent en rien aux sonates de Bach ou aux quators de Beethoven qu'il a coutume d'écouter ${ }^{68}$.

Se, em seus obituários, Proust às vezes intercala à narração do legado e à descrição do perfil do falecido rápidas menções a si próprio e a sua convivência com o modelo ("moi qui avais vu ses larmes de grand-mère"69, "M. Marcel Proust, qui a toujours gardé pour lui un véritable culte"70), o mesmo não se percebe com igual força e dimensão em seus portraits souvenirs. Neles, as proporções da experiência subjetiva do retratista são tão substantivas que se torna ele mesmo, a partir de suas memórias, também um modelo retratado. É o que se lê aqui:

D'une politesse exacte et charmante avec tous ses invités, on voyait la figure du prince (la plus fine que nous ayons connue) s'animer d'une joie et d'une tendresse paternelles quand entraient les deux incomparables jeunes femmes [...].71

O uso do pronome on como sujeito da oração não é fortuito. Ele transporta para o centro da cena a figura do próprio retratista, criando a ilusão de que apenas o príncipe Edmond de Polignac está sendo retratado quando, na realidade, também é a contemplação do narrador, seu deslocamento para dentro da cena, sua observação daquele momento que nos surge representada. A descrição do modelo

68 "Talvez mesmo as festas animadas do passado uma vez mais ressoarão no grande hall com músicas que não se parecem em nada com as sonatas de Bach ou com os quartetos de Beethoven, que ele tinha o costume de ouvir". CSB, p. 469.

69 "Eu, que vi suas lágrimas de avó". Ibidem, p. 545.

70 "O Sr. Marcel Proust, que sempre alimentou por ele um verdadeiro culto". Ibidem, p. 549.

71 "De uma polidez exata e charmosa com todos seus convidados, víamos a figura do príncipe (a mais fina que conhecemos) ser tomada por uma alegria e por uma ternura paternais quando entravam as duas incomparáveis moças". Ibidem, p. 468. 
ocorre como reflexo da descrição do próprio retratista. E essa passagem ilustra a distinção fundamental entre os obituários e o portrait souvenir em Proust. Ela demonstra a diferença entre a recapitulação dos elementos biográficos de um modelo para que seja justificada a relevância e o caráter oportuno do registro de sua morte (traço característico dos artigos necrológicos) e a lembrança dos traços definidores de um modelo como meio de retratar a ele, mas também ao próprio retratista, na convivência privilegiada e, justamente, "afetiva" que se estabeleceu no passado entre os dois.

Todos os demais retratos de nossa seleção se dedicam a figuras vivas no momento de sua publicação. E mesmo aqueles que só foram publicados postumamente também possuíam como modelo apenas pessoas em vida no momento de sua escrita (0 Portrait du Prince Léon Radziwill, por exemplo, cujo modelo morreu em 1927 mas que é datado do final de 1903 ou do início de 1904). Em todo caso, nesse conjunto remanescente, podemos identificar outras duas variedades de retratos literários aos quais Proust se dedicou: as silhuetas (Silhouette d'artiste) e o que Dufour chama de portraits-études (Un Professeur de beauté, Camille Saint-Saëns, Opinions sur M. Alphonse Daudet: œeuvre d'art, Robert de Flers e La Comtesse de Guerne), variedade de retrato enraizada na escola de SainteBeuve, voltada à relação entre o autor e suas obras, mas que, em Proust, ganha novos ares, negando através de seus paradoxos qualquer relação direta que se tente estabelecer entre essas duas dimensões.

Não é pacífica a classificação de uma silhueta como retrato literário. De fato, uma silhueta não apresenta jamais um nome próprio, o que faz com que a descrição careça de um modelo reconhecível e se inscreva inexoravelmente no 
campo das irônicas caricaturas de tipos e categorias sociais, herdeiras claras daquilo que afirmamos no início ser a corrente naturalista balzaquiana na tradição oitocentista do retrato literário francês. Insistimos, contudo, na inclusão desse artigo em nossas análises pelo simples fato de que a única silhueta de que se tem notícia na obra proustiana, intitulada Silhouette d'artiste, comporta uma série de recursos descritivos e mesmo críticos que, como veremos mais adiante, se reverberarão em passagens da Recherche. Trata-se do riso do narrador proustiano, que por vezes não consegue ver sem ironia o contraste entre a aparência exterior dos seres e seus movimentos psicológicos mais profundos. 0 alvo, nesse caso, será o pretenso crítico de arte. Aquele "tipo" (genre) ${ }^{72}$ que, sob um primeiro olhar, "cultiva hábitos de elegância"73, "vai com frequência ao teatro"74, é "um homem jovem"75, mas que, na realidade mais profunda, se vale dessas aparências para tão somente "adular as belas atrizes"76, lançar um "tom paternal" sobre as iniciantes ${ }^{77}$ e "tomar emprestado de outras artes"78 os termos de suas comparações. Quantos não são os personagens da Recherche que veem o herói proustiano se apropriar de seus traços típicos para ironizá-los, para apontar-lhes contradições entre a aparência e o caráter? Veremos vários exemplos no momento oportuno, quando nos debruçarmos sobre as contribuições da prática do gênero retrato literário para a escrita de À la recherche du temps perdu, independentemente do rótulo que se deseje atribuir aos textos ditos "silhuetas".

\footnotetext{
72 CSB, p. 397.

73 Ibidem, p. 397.

74 Ibidem, p. 397.

75 Ibidem, p. 398.

76 Ibidem, p. 398.

77 Ibidem, p. 398.

78 Ibidem, p. 398.
} 
Algo bastante distinto se dá sob a forma dos portraits-études. Assim como nos obituários e portraits-souvenirs, Proust elege um modelo com nome próprio, pertencente à vida real. E dele tenta apreender os traços definidores no contraste entre sua exterioridade e interioridade. Tendo em vista, contudo, que os modelos desses textos se encontram vivos no momento de sua publicação, não haveria condições para neles se imiscuir o tom da lembrança e da rememoração. De sorte que seu foco se volta com bastante clareza para a produção intelectual desses artistas. Nem sempre, como há pouco dissemos, à moda de Sainte-Beuve. Mas, sobretudo, em busca de uma ruptura com as aparências e superficialidades que se criam ao seu redor. Todos os retratos aos quais decidimos atribuir esse rótulo apresentam esse argumento como principal fio condutor. Un Professeur de beauté apresenta o crítico de arte Robert de Montesquiou, por exemplo, como mais um "acadêmico" aos olhos de "talentos militantes" 79. Entenda-se, um crítico conservador diante de artistas que se arrogam a vanguarda. Mas Proust lança mão até mesmo de uma paródia com o vocabulário pedante de Montesquiou ("de quelle piaffante, trépidante, trépignante et caracolante allure"80) para surpreender seu leitor, romper com um certo senso comum formado em torno da imagem pública de Montesquiou, e apresentá-lo, enfim, como um pensador que proporcionaria, até mesmo aos membros da Academia Francesa, "dias maravilhosos" e especiais. Porque ninguém saberia melhor que ele "recepcionar" os novos acadêmicos, proporcionar-lhes "hospitalidade". Porque sua obra, apesar de inferior aos livros de um crítico com a estatura de John Ruskin"1, apresenta a "verdade do julgamento

\footnotetext{
${ }^{79}$ Ibidem, p. 511.

${ }^{80}$ Com que cabriolante, trepidante, calcante e caracolante aparência. Ibidem, p. 509.

81 Ibidem, p. 512.
} 
artístico" e a "justeza do gosto"82. Porque, afinal, mirando para além de seu eruditismo e de seu preciosismo (aos olhos de Proust a imagem óbvia e superficial), encontraremos um Montesquiou com “dom crítico maravilhoso", que é aquele de "ver distintamente onde outros veem apenas indistintamente" 83 . E essa tendência segue em meio aos incontáveis exemplos dessa tentativa de ruptura com uma imagem óbvia, imediata e superficial do modelo em Un professeur de beauté, o mais longo dos retratos de Proust, recheado com uma quantidade surpreendente de referências, alusões e comparações ao universo artístico de seu tempo.

Embora menores, os retratos Camille Saint-Saëns, Opinions sur M. Alphonse Daudet: œuvre d'art, Robert de Flers e La Comtesse de Guerne, ilustram ainda mais a forma proustiana de relacionar a obra à personalidade de seu autor. Uma relação que não é direta, determinante e explicativa como dita o método de Sainte-Beuve, mas que reconhece o mérito artístico justamente nas diferenças e contradições entre as duas instâncias. Note-se que essa noção crítica de Proust já se manifestava mesmo em escritos bastante anteriores a seu Contre Sainte-Beuve. Em 1895, ao buscar apreender o gênio musical de Saint-Saëns, Proust lança mão de uma longa enumeração com mais de uma dezena de atributos para qualificar sua obra, os quais serão encadeados rumo a um final apoteótico, já na dimensão do sublime, elevando o modelo à posição de um demiurgo da criação musical, um ser capaz de:

s'amuser comme un dieu et comme le diable à faire tenir le monde dans la musique, la musique dans l'harmonie, toute l'étendue de l'orgue dans l'exiguïté du piano, voilà les jeux habiles, déconcertants, diaboliques et divins de cet humaniste musical [...]. ${ }^{84}$

\footnotetext{
82 Ibidem, p. 512.

83 Ibidem, p. 514.

84 "divertir-se como um deus e como o diabo ao abarcar o mundo com a música, e a música com a harmonia, toda a grandiosidade do órgão com a exiguidade do piano: eis as brincadeiras hábeis, desconcertantes, diabólicas e divinas desse humanista musical". Ibidem, p. 386.
} 
Ora, e é precisamente o contrário que nos é apresentado logo de início. A despeito de toda a grandiosidade da obra de Camille Saint-Saëns, sua figura nos é apresentada como aquela de um ser arredio, discreto, que desaparece feito um "duende" no exato instante em que todo seu saber seria louvado pelo público. 0 traço sublime se estende do início ao fim do retrato. Mas, no que diz respeito ao "estudo" da obra de seu modelo, o gênio artístico é situado não nas coincidências lógicas, nas explicações determinantes, e sim no complexo de contradições e diferenças. 0 deus Camille Saint-Saëns que se vê ostentar a divindade na música, mas não no trato pessoal, na manifestação de sua personalidade.

Ainda no campo da música, tome-se o exemplo de La Comtesse de Guerne. No caso de Saint-Saëns, é a pessoa do modelo que Proust utiliza para desmentir uma imagem superficial gerada a partir do caráter monumental da obra. Com essa cantora lírica mundana, o esquema se inverte, mas o princípio crítico é o mesmo. Ainda se está diante do mesmo narrador que manobra as dimensões da obra e da autoria não para se explicarem umas as outras, mas sim revelarem a dita "verdade do julgamento artístico" de que trata no retrato de Montesquiou. Cantora lírica mundana, seu círculo social não reuniria as condições necessárias para compreender seu talento:

Sans doute les gens du monde connaissent l'admirable talent qu'ont rehaussé tous les décors de l'élégance et invoque tous les appels de la charité. Mais ce qu'il a de plus raffiné, d'à peu près unique, leur échappe bien souvent et n'est guère sensible qu'aux artistes. ${ }^{85}$

No momento, contudo, em que Proust a apresenta a um "puro tecnicista da música", isto é, a alguém com competência intelectual suficiente para julgá-la, toda

\footnotetext{
85 “Os mundanos, sem dúvida, conhecem o admirável talento que realçaram todos os cenários da elegância e que invocaram todos os apelos da caridade. Mas o que há de mais refinado, quase único, lhes escapa com bastante frequência e é tão somente sensível aos artistas". Ibidem, pp. 503-504.
} 
a imagem que superficialmente se havia estabelecido acaba desconstruída. No choque entre autor e obra, e não em sua contiguidade, surge delineada a imagem do modelo:

Je ne crois certes pas qu'il s'imaginât entendre en Mme de Guerne une femme du monde plus ou moins agréablement douée pour le chant. [...] Il croyait entendre une vraie, une grande chanteuse, mais semblable à bien d'autres dont la réputation l'avait attiré, et le talent l'avait déçu. ${ }^{86}$

Sem nos estendermos muito mais sobre essa questão, ressalte-se que a mesma abordagem é proporcionada aos dois demais retratos que julgamos portraits-études. Robert de Flers faz parte dos "jovens que se iniciaram no universo das letras há alguns anos"87, o que poderia ser interpretado como traço de inexperiência, mesmo imaturidade. Mas Proust nos enumera um volume incrível de realizações que mesmo a pouca idade de seu modelo já comporta e resume em uma passagem a contradição reveladora:

À vingt ans je le vois, versificateur prôné des versificateurs, sentant jusqu'au fond par exemple les vers de Mallarmé, les phrases de Barrès, écrire des nouvelles exquises, ne pas laisser passer une légende, un fait, sans en extraire le sens et la poésie [...].88

De modo semelhante quando retrata o escritor Alphonse Daudet já ao final da vida, combalido por uma infecção de sífilis. Sua condição física é penosa, de modo que o narrador sequer consegue compreender: "comment il avait pu résister

\footnotetext{
86 "Não creio de modo algum que ele pensava ouvir em Madame de Guerne uma mulher mundana mais ou menos agradavelmente dotada do canto. [...] Acreditava ouvir uma verdadeira, uma grande cantora, mas semelhante a várias outras cuja reputação o cativara e o talento, decepcionara". Ibidem, p. 504.

87 Ibidem, p. 403.

88 "Aos vinte anos eu o vejo, versejador louvado pelos versejadores, sentindo no fundo, por exemplo, os versos de Mallarmé, as frases de Barrès, escrever deliciosas novelas, sem deixar que uma lenda, que um fato sequer passe sem lhe extrair o sentido e a poesia". Ibidem, p. 403.
} 
à ces attaques quotidiennes de la douleur"89. Mas Proust deseja demonstrar o engano daqueles que acreditam que o drama desse estado físico necessariamente interferiria em sua produção intelectual. Em uma analogia, seria beuviano demais associar a decadência física de um autor à decadência literária de sua obra. Esse é o instante em que o narrador proustiano busca se mostrar surpreendido e também surpreender:

Je vis ce beau malade, que le mal embellissait encore, ce poète, à l'approche de qui la souffrance devenait poésie, comme le fer s'embrase dans le feu, qui, détaché de lui-même et tout à nous, préoccupé de mon avenir et de l'avenir d'autres amis, nous souriait, qui célébrait le bonheur, l'amour, la vie, qu'il employait mieux que combien de nous, continuant à penser, à composer, à dicter, à écrire, passionné comme un jeune homme pour la vérité, la beauté, le courage, nous parlant sans cesse, et plus héroïquement encore nous écoutant. ${ }^{90}$

Dentre os vários retratos escritos por Proust, nos deparamos então com obituários, portraits-souvenirs, silhuetas e portraits-études. Essas categorias de um mesmo gênero não são excludentes. Encontramos em uma traços das outras. De modo que a divisão apenas favorece um entendimento mais preciso das contingências, dos temas, enfim, das preocupações que o autor manifestou com a composição do retrato. No obituário, o registro de um legado biográfico diante da perda recente. Nos portraits-souvenirs, a rememoração afetiva e a intersecção entre a vida do retratado e do retratista. Nas silhuetas, a ironia com os contrassensos de tipos sociais. E, enfim, nos portraits-études, a tentativa de apreensão de uma personalidade a partir de sua obra, e vice-versa. Mas não com base no

\footnotetext{
89 "Como pôde resistir a esses ataques diários de dor". Ibidem, p. 400.

90 "Eu vi esse belo doente, que o mal ainda embelezava, esse poeta, ao lado de quem o sofrimento tornava-se poesia, assim como o ferro se incendeia em meio ao fogo, que sorria, desapegado de si próprio e tudo para nós, preocupado com meu futuro e de seus demais amigos, que celebrava a alegria, o amor, a vida, que ele aproveitava melhor que muitos de nós, continuando a pensar, a compor, a ditar, a escrever, apaixonado como um jovem pela verdade, pela beleza, pela coragem, conversando conosco sem parar e, o mais heroico, ainda nos escutando". Ibidem, p. 401.
} 
determinismo do método de Sainte-Beuve. Sobretudo a partir de uma visão complexa do retratado, que prioriza as contradições e o dado surpreendente no lugar das coincidências e do óbvio.

Todas essas considerações a respeito do retrato literário francês, as condições históricas e sociais através das quais se popularizou, o método crítico no qual acabou se desdobrando e o laboratório estético que representou para o jovem romancista Marcel Proust, são úteis para a compreensão de uma outra forma de representação de figuras humanas, num momento histórico bastante distinto, e na imprensa de outro país. Parece-nos relevante questionar que aspectos, afinal, afastam ou aproximam o gênero retrato literário do tipo textual que, no Brasil e em outros diversos países, a partir de meados do século XX, passou a se disseminar em jornais e revistas com o nome de perfil jornalístico.

Tomemos para análise, de início, esse excerto da abertura do artigo Frank Sinatra has a cold, publicado por Gay Talese na revista americana Esquire, em 1965, e comumente apresentado por estudiosos do chamado "jornalismo literário" como o mais representativo dos perfis jornalísticos e da escola de reportagem a que pertence, o new journalism:

Frank Sinatra, holding a glass of bourbon in one hand and a cigarette in the other, stood in a dark corner of the bar between two attractive but fading blondes who sat waiting for him to say something. But he said nothing; he had been silent during much of the evening, except now in this private club in Beverly Hills he seemed even more distant, staring out through the smoke and semidarkness into a large room beyond the bar where dozens of young couples sat huddled around small tables or twisted in the center of the floor to the clamorous clang of folk-rock music blaring from the stereo. The two blondes knew, as did Sinatra's four male friends who stood nearby, that it was a bad idea to force conversation upon him when he was in this 
mood of sullen silence, a mood that had hardly been uncommon during this first week of November, a month before his fiftieth birthday. ${ }^{91}$

Uma primeira leitura faz logo saltar aos olhos como não é adjetiva a técnica descritiva desse autor. Quase não há qualificativos. Não sabemos como são os olhos, os cabelos, o nariz, a boca, mesmo a forma do rosto do cantor americano. Apenas elementos coadjuvantes da cena recebem atributos físicos, ainda assim pobres - os casais "jovens" frequentando o local e as duas mulheres ao redor de Sinatra, simplesmente "loiras" e "atraentes". A imagem do modelo é apreendida muito mais através de substantivos e formas verbais, aquilo que possui, os gestos que produz, o espaço que domina a cena. 0 copo de uísque, o cigarro entre os dedos e a atmosfera da boate, que não é "escura", ou "lúgubre", mas sim tomada pela "fumaça" e submersa em "semiescuridão". O delineamento da figura de Sinatra, nesse sentido, não parece partir de sua subjetividade, mas sim de dados externos a ela, objetivos, notadamente o espaço. E o principal dado subjetivo desse excerto, qual seja, o sentimento de Sinatra, seu mal humor, não é construído senão através do que há de objetivo na cena. A maneira como nos aproximamos da imagem do cantor, penetrando nesse ambiente obscuro, cuja carência de luz contrasta com a celebridade do modelo, faz lembrar muito o Sainte-Beuve de Zola, cujo caráter é apreendido através dos atributos quase místicos de sua recôndita

\footnotetext{
91 "Frank Sinatra, com um copo de bourbon em uma mão e um cigarro na outra, estava em um canto escuro do bar, entre duas loiras atraentes, mas desbotadas, que se sentaram esperando que ele dissesse algo. Mas ele não disse nada. Ficara em silêncio na maior parte da noite. Só que agora, nessa boate em Beverly Hills, ele parecia ainda mais distante, observando através da fumaça e da meia luz um grande salão na frente do balcão, onde dezenas de jovens casais se amontoavam ao redor de pequenas mesas ou giravam no centro da pista ao clamoroso tinido de uma música folkrock que estourava nas caixas de som. As duas loiras sabiam, assim como os quatro amigos de Sinatra que estavam ao seu lado, que era má ideia forçar uma conversa com ele nesse humor de silêncio rabugento, um humor que raramente foi incomum nessa primeira semana de novembro, um mês antes de seu aniversário de cinquenta anos". Cf. TALESE, Gay. Frank Sinatra has a cold. Esquire, Nova York, p. 89, abril de 1966.
} 
residência. Com a ressalva de que, em Zola, os traços físicos do modelo chegam a ser descritos num último momento ("son visage blanc aux traits forts et épais"92) e o narrador se apresenta na cena, por meio de verbos na primeira pessoa ("et je trouvai l'éminent critique debout au milieu de son cabinet"93). Aqui não. Não se vê a imagem de Talese na cena como se vê aquela de Zola. E apenas a configuração do espaço em que se encontra o modelo e dos objetos que possui ao seu redor é que sustenta a descrição do silêncio e do mau humor de Sinatra, sua personalidade naquele momento (o mood), assim como a personagem de Madame Vauquer, no romance balzaquiano, que é determinada pelo aspecto da pensão de que é dona.

Quanto a esse aspecto, do ponto de vista do estilo, o new journalism parece ser mais velho do que aparenta. No casamento que propõe com a literatura, o perfil jornalístico oferece o que, há pelo menos um século, retratistas realistas franceses já publicavam em seus jornais e revistas. Não se trata, bem entendido, de estabelecer uma origem comum, uma genealogia compartilhada entre o jornalismo francês e o americano. Isso nos desviaria do propósito de nossa argumentação. 0 ponto é outro e se dirige ao diálogo enredado entre os dois estilos. Por pressão da objetividade que o jornalismo profissional e de massa promete a seus leitores no século XX, é verdade que os adjetivos são mais escassos (Zola é mais qualificativo que Talese) e a figura do retratista desaparece (não se vê Talese em cena). E, no entanto, como são próximas, ainda assim, as formas de percepção da figura humana entre os perfis jornalísticos da década de 1960 e os retratos realistas de meados do século XIX, ambos determinados pela atmosfera dos ambientes que

\footnotetext{
92 ZOLA, Émile. Op. cit.

93 Ibidem.
} 
seus modelos frequentam, mesmo pelos objetos que têm ao seu redor, pelo ofício que desempenham, pelas formas de sociabilidade de que participam.

O que, sim, se altera, é a gênese, os processos de criação do texto. Se Zola, por exemplo, parte de suas memórias pessoais para a composição da cena, Talese se esforça para fazer valer o que há de jornalístico no "jornalismo literário" e importa ao máximo os recursos técnicos da reportagem. Talese jamais esteve diante de Sinatra para a composição de seu perfil. Mas o pressuposto que assume, tanto através da construção narrativa (o present continuous, em "holding a glass", por exemplo, transportando o personagem para diante de nossos olhos) quanto no veículo de comunicação em que é publicado (uma revista jornalística), é o de que a imagem toda é verdadeira. Para configurar as cenas em que insere o cantor, apreender seus hábitos e estados psicológicos, o jornalista se fundou, como adverte um breve prefácio à reedição do texto na própria revista Esquire, sobre inúmeros depoimentos, conversas, entrevistas com "amigos, sócios, familiares"94. 0 retratista oitocentista francês não busca terceiros para descrever seu modelo. Suas fontes de dados para a construção de um retrato se limitam a encontros pessoais (as visitas aos grandes escritores), quando muito à leitura crítica das obras que produziu (no caso do método de Sainte-Beuve). Muito pelo contrário, o new journalist lança mão do que Norman Sims chama de "imersão"95. Tentam viver como seus modelos, dominar seus campos de conhecimento, viajar ao lado deles, em uma pretensão de intuir o que é ser o próprio modelo, colocar-se em seu lugar, e, então, transmitir ao leitor aquilo que entendem como suas verdades. Sims oferece como exemplo o caso do jornalista Richard West, que buscou retratar a

\footnotetext{
94 TALESE, Gay. Op. cit.

95 SIMS, Norman. The Literary Journalists. Nova York: Ballantine Books, 1984, p. 7.
} 
vida dos trabalhadores de um célebre restaurante de Nova York no perfil The Power of 21, publicado na revista New York:

He followed the action of the restaurant upward, from the basement and the early morning prep crew, to the kitchen and the chefs, then at lunchtime out onto the floor with the bartenders and the maitre d'. His night shifts began around 4 p.m., when another crew arrived, and ended at 1 a.m. He inhaled the air of the kitchens, thick with steam and cooking aromas, and of the dining rooms, heavy with cigar smoke and status. 96

Jamais um retratista francês no século XIX procederia dessa maneira. Pesquisas bastante recentes demonstram que Proust se revelou, em vários de seus artigos da imprensa, um verdadeiro crítico musical ${ }^{97}$. Mas, para delinear o retrato de Camille Saint-Saëns, por exemplo, ele não se sente obrigado a aprender ou mesmo tentar compor peças musicais da mesma forma que seu modelo. Em uma analogia: ele não se junta a trabalhadores, como West, para aprender a cozinhar. Não há "imersão". Porque, embora escrevendo textos para jornais e revistas, ele, ou mesmo Sainte-Beuve, que publicou ao longo de duas décadas, entre 1849 e 1869, todas as segundas-feiras, seus retratos na coluna Causeries $d u$ lundi ${ }^{98}$, não se sente um jornalista de ofício. São escritores publicando na imprensa. “Outsiders”, para retomar a expressão de Yuri Cerqueira dos Anjos, às vezes tentando se encaixar em um ethos da imprensa e mesmo se dando licença para criticá-lo99. Vide a Silhouette

\footnotetext{
96 "Ele acompanhou panoramicamente o movimento do restaurante, indo do porão, com a equipe de preparo logo cedo pela manhã, até a cozinha, com os chefs, e então em todo o horário de almoço, no salão, com os bartenders e o maître d'. Seus turnos da noite começavam em torno das $16 \mathrm{~h}$, quando uma outra equipe chegava, e terminava à $1 \mathrm{~h}$ da manhã. Ele inalou $\mathrm{o}$ ar das cozinhas, adensado pelo vapor e os aromas de cozimento, e aquele das salas de jantar, pesado com fumaça de cigarros e status". SIMS, Norman. Ibidem, p. 11.

${ }^{97} \mathrm{Cf}$. LEBLANC, Cécile. Proust écrivain de la musique: l'allégresse du compositeur. Turnhout: Brepols Publishers, 2017.

${ }^{98} \mathrm{Cf}$. SAINTE-BEUVE, Charles-Augustin. Causeries du lundi. Paris: Garnier frères, 15 vol.

99 "En tant qu' " outsider ", son statut lui permet de problématiser cette adhésion [aux règles d'écriture de la presse], de pasticher les protocoles, d'y réfléchir, de les déjouer, faisant donc preuve d'une vision très sensible du phénomène médiatique de la Belle Époque" [Enquanto "outsider", seu
} 
d'artiste de Proust, retratando ironicamente a figura do crítico de arte profissional dos jornais e revistas de seu tempo. Não são, enfim, repórteres diariamente estabelecidos em redações. Bem ao contrário do "jornalista literário", que é, antes de mais nada, um repórter cultivado nas redações de grandes veículos, partícipe de uma cultura de precisão e objetividade. Ele lança mão de recursos da linguagem poética, se vale de uma construção narrativa própria do domínio literário, mas tudo apenas na medida em que consegue se ancorar em fatos, demonstrar que possui uma percepção empírica daquilo que escreve e conta.

Os especialistas no fenômeno do new journalism enumeram outras várias características que atravessam a maior parte dos perfis jornalísticos. Não é nosso objetivo nos aprofundarmos no tema para além, como dissemos, das aproximações e divergências com o gênero retrato literário. Mas convém lembrar, apenas para reforçar nosso ponto, que, para além da "imersão" de que trata Sims, Mark Vitullo, debruçando-se sobre a leitura que Richard Kallan faz da obra de Tom Wolfe, tido como o pai dessa corrente jornalística, identifica outros quatro elementos hipoteticamente comuns às mais diversas manifestações desse tipo textual: sua construção em cenas, o uso extensivo de diálogos, a perspectiva em terceira pessoa, desvelando o perfilado ao leitor, e registros da busca de uma percepção absoluta do modelo ${ }^{100}$. Falamos em aspectos hipoteticamente comuns porque nem todos se encaixam de modo tão geral em perfis do new journalism. Vide o caso que há pouco analisamos, do perfil de Sinatra, no qual os diálogos entre perfilado e perfilador, por exemplo, jamais existiram. Mas os três tópicos remanescentes, mais dos protocolos, refletir sobre eles, desvirtuá-los, comprovando assim uma visão bastante sensível do fenômeno mediático da Belle Époque]. Cf. ANJOS, Yuri Cerqueira dos. Op. cit., p. 63.

100 VITULLO, Mark. Riding the strange torpedo: Hunter S. Thompson and the invention of gonzo journalism - Tese de Doutorado de Mark Vitullo, Radboud Universiteit Nijmegen, 2016, inédita, pp. 31-32. 
do que cobrirem em boa medida o estilo dos perfis jornalísticos, parecem, com efeito, aproximá-los da estética que muito tempo antes já havia tomado as páginas da imprensa, por meio de retratos literários.

No Brasil, o grande bastião dos perfis jornalísticos e do new journalism entre as décadas de 1960 e 1970 foi a revista Realidade. Longas reportagens, marcadas por seu aprofundamento, por seu viés crítico ao regime militar brasileiro, pela incorporação de elementos da linguagem poética... A lista de atributos é longa, podendo ser resumida na máxima de J. S. Faro, de que Realidade foi uma "experiência excepcional no conjunto da imprensa brasileira"101. Não apenas em seus três primeiros anos de existência, de 1966 a 1969, considerado seu período mais aguerrido e politizado, como querem esse e outros autores ${ }^{102}$. Mas, de fato, inclusive nas fases editoriais subsequentes ao Ato Institucional № 5 , de dezembro de 1969, que outorgou a censura na imprensa brasileira. É precisamente esse "segundo momento" de Realidade, tão desprezado pelos estudiosos da revista, que nos interessa. De 1969 a 1972, a revista publicou uma série de dez textos que dificilmente conseguiríamos restringir como retrato literário ou perfil jornalístico em suas formas puras, na medida em que, como veremos a seguir, seu autor, o dramaturgo Jorge Andrade, logrou combinar os dois estilos descritivos, atribuindo a um aquilo de que carece o outro. Afirmamos, há pouco, que os perfis do new journalism apresentam uma série de recursos descritivos que já estavam presentes, às vezes até de maneira mais complexa e aprofundada, isto é, com maior subjetividade, nos retratos do século XIX francês. Ao mesmo tempo, os novos jornalistas teriam promovido um método de "imersão" na vida do retrado que

\footnotetext{
${ }^{101}$ FARO. J. S. Realidade (1966-1968): tempo da reportagem na imprensa brasileira. Porto Alegre: Editora da ULBRA, 1999, p. 4.

${ }^{102}$ Cf. MORAES, Letícia Nunes de. Leituras da revista Realidade. São Paulo: Alameda, 2007.
} 
ignoram os retratistas franceses, trazendo ao leitor uma verdadeira riqueza de detalhes e um substantivo trabalho de investigação. Quando publicou os dez perfis de artistas, escritores e mundanos brasileiros que apresentamos na introdução desse estudo, Jorge Andrade uniu essas duas pontas. Ele visita seus entrevistados, adentra em suas casas, conversa com terceiros, mas também se coloca, em primeira pessoa, na cena que descreve, deduz seus estados psicológicos e os associa a suas expressões corporais - tudo na medida em que proporciona ao leitor uma noção muito clara dos fatos e de sua veracidade jornalística, indicando o tempo e o espaço de seu desenrolar. Enfim, pulverizando um lead ao longo do texto. A seguinte passagem, extraída do perfil do pintor Wesley Duke Lee, intitulado Duke Lee, o nosso Surrealista tipo Exportação, dá mostra do que pretendemos demonstrar:

Desde que cheguei ao seu estúdio - 18 metros de comprimento por 8 de largura,um pé-direito de 6 metros - senti minha atenção prêsa ao seu quadro "Meus Pais". Os olhos da mãe de Wesley me seguiam desde o momento em que entrara no estúdio. Pareciam querer me agredir, defendendo uma verdade que só ela deveria conhecer.

- Esses quadros, Wesley, contam a sua história. E eu lhe pergunto: nêles, que aspectos vêm da sua avó lavadeira e quais os que vêm do avô religioso?

No quadro, os olhos da mãe de Wesley ficaram um pouco mais duros, com um brilho metálico.

- Até há pouco tempo eu também não sabia. Depois da experiência com o ácido lisérgico e da análise, consegui compreender. Já tomou ácido lisérgico?

- Não.

- Eu tomei há oito anos, em busca da verdade. Mas ela não se revela de uma só vez.

Olhamos os quadros à nossa volta: fatos da vida de Wesley estavam presentes em quase todos. Continuei sentindo que os olhos da mãe me observavam. Wesley atende ao telefone e determina o despacho de um quadro seu para a Venezuela - é êle quem faz tudo, não tem despachante. Todos os seus trabalhos estão fichados, catalogados. No caos que parece ser o seu estúdio há uma organização perfeita. Na aparente confusão dos milhares de coisas espalhadas pelas mesas e paredes há um sentido procurado - talvez o desejo de distrair a atenção de quem chega, para que o mundo dêle não seja percebido 
na sua essência. Revelando mente metódica e grande capacidade de continuar um pensamento interrompido, Wesley começa a contar como foi sua experiência com o ácido lisérgico. ${ }^{103}$

A primeira pessoa atravessa todo o excerto, de modo que o narrador de Jorge Andrade se desloca para o interior da cena, posicionando-se ao lado do modelo Wesley Duke Lee no foco da atenção do leitor. No primeiro parágrafo, o pintor sequer tem voz, e a única figura que ocupa a cena é a de Jorge Andrade, do passeio de seus olhos pelo ateliê e das sensações que produz um dos quadros, aquele dos pais de Duke Lee, que, em outros momentos desse perfil, motivará o autor a lançar mão de uma série de associações entre o modelo e o conceito de complexo edipiano de Freud. Mas todas essas impressões, embora onipresentes, não dominam a totalidade do texto. E, em meio a essa descrição tão subjetiva quanto mística do espaço, na qual obras de arte se animam e ganham vida ("os olhos da mãe de Wesley [na tela 'meus pais'] me seguiam desde o momento em que entrara no estúdio"), o autor intercala um aposto de precisão matemática com as dimensões daquele local. Ele não hesita em demonstrar o que há de jornalístico em seu “jornalismo literário". Só em seguida Wesley Duke Lee se expressa. E não através do discurso indireto, dominado pelo narrador. Abre-se um diálogo, fundado numa troca de perguntas e respostas, remetendo-nos ao formato de uma entrevista. Por sinal, a primeira questão do jornalista Jorge Andrade nessa passagem já traz consigo um pressuposto bastante delimitado. Ela condiciona a figura do modelo àquela de seus avôs e, alocando um ao domínio do trabalho e o outro ao universo da espiritualidade (a avó lavadeira e o avô religioso), fixa na imagem do pintor uma personalidade estabelecida em, ao menos, duas dimensões, ou, se preferirmos, camadas. Esses "níveis" na pergunta de Jorge Andrade não são

\footnotetext{
103 R.R., maio de 1971, p. 102.
} 
fortuitos. Eles anteveem a resposta de Duke Lee, que faz menção a símbolos de transcendência (o ácido lisérgico e, mesmo em outro ponto do texto, sua fé budista) e percorrem toda a descrição, por assim dizer, material e metódica do último parágrafo do excerto - seu ambiente de trabalho, seus hábitos burocráticos, seus procedimentos de organização do espaço e os meios de sistematização do pensamento ("é êle quem faz tudo, não tem despachante"; "todos os seus trabalhos estão fichados, catalogados"; "revelando mente metódica e grande capacidade de continuar um pensamento interrompido").

A conjugação desses traços revela nos perfis de Jorge Andrade um cruzamento entre as inovações do new journalism e um estilo que já nos retratos literários franceses do século XIX era recorrente. Jorge Andrade deixa claro ao leitor que entrevistou Wesley Duke Lee, que esteve em sua casa, que conhece até mesmo o tamanho de suas paredes. Houve uma “imersão" naquela vida. Mas o retrato do modelo passa inevitavelmente pelo retrato de sua própria condição como retratista, evocando o artifício da primeira pessoa em uma escala estranha até mesmo a um tipo de texto jornalístico que se arroga o uso de técnicas ditas "literárias". Zola nos transmite as sensações que tem, os pensamentos que lhe assaltam a mente quando penetra no ninho de Sainte-Beuve ("le silence frissonnant de cette pièce, la lumière attendrie me firent rêver que je venais d'être brusquement transporte dans le nid tiède et caché d'un jeune ménage en pleine lune de miel"104), mas nada nos autoriza sequer imaginar o que se dá na subjetividade de Talese no momento em que passa pelos locais frequentados por Sinatra. Mais além, há o diálogo entre os dois - comum a textos do new journalism na visão de Vitullo, mas que, em Jorge Andrade, produz um efeito distinto. A série 
de perguntas e respostas não reúne, por exemplo, apenas dados ou informações biográficas, ela desvela o quão complexa é, aos olhos do narrador, a personalidade de Duke Lee. 0 pintor reúne em sua subjetividade universos quase antagônicos, o materialismo da avó lavadeira e o idealismo do avô religioso, de modo que a busca de uma verdade (seu mundo "na sua essência") se revela uma tarefa árdua, digna de perscrutadores, à qual se lança um repórter-narrador ("Wesley começa a contar").

Todos os perfis de Jorge Andrade apresentam esse caráter. Expressam as normas do new journalism e seus pontos de convergência com a estética do retrato realista francês do século XIX. Mas, ao mesmo tempo, jamais hesitam em se desvencilhar de ambos através de um viés descritivo de cunho subjetivo e psicológico, sempre inserindo o próprio retratista no desenrolar da cena. É assim no perfil de Antonio Houaiss:

Diante de mim, sentado em sua biblioteca, está Antonio Houaiss. Enquanto leio o discurso de Afonso Arinos, ele me observa, procurando tirar de mim, tanto quanto eu tento tirar dele. 105

Mas também no de Marília Pêra:

Marília faz um traço em volta da bôca, marcando-a num sentido cínico. Vendo isso, penso como é difícil encontrar a verdade dos atôres. Nunca se sabe quando começaram ou pararam de representar. A verdade dêles é sempre um desafio, um enigma proposto. ${ }^{106}$

No de Dercy Gonçalves:

Eu percebia que ela representava, que o que dizia não era tôda a verdade. Mesmo assim, envôlta em sua capa de pele, brincando com

105 R.R., abril de 1972, p. 116.

106 R.R., junho de 1971, p. 13. 
seus caríssimos anéis de brilhantes, encolhida na poltrona como uma gata - posição preferida em que se mantém quase o tempo todo -, olhando-me sempre com o sorriso malicioso, perguntou-me:

- Não acredita em mim?107

E assim poderíamos seguir a lista de exemplos à exaustão. Excertos nos quais transparece a técnica de reportagem por "imersão" do new journalism (Jorge Andrade lê com Antonio Houaiss em sua biblioteca), a relação de determinismo entre o ser e seu espaço do retrato realista francês (Dercy está encolhida em sua poltrona "como uma gata"), mas que, acima de tudo, busca uma "essência", uma "verdade", um "mundo" interior (todas palavras empregadas recorrentemente por Jorge Andrade) responsável pelo transbordamento do perfil nos meandros do subjetivo e do psicológico, daquilo que não é nem jornalístico, para o new journalism, e nem literário, na acepção realista do termo. Daquilo que nos parece muito mais proustiano na medida em que, rompendo com o método de SainteBeuve, esse autor introduziu em seus próprios retratos literários algo do inatingível dos seres e de suas complexidades interiores. É verdade que os perfis de Jorge Andrade não tratam de figuras mortas, não trazem marcas de saudosismo ou fazem caricaturas de tipos sociais. Bem diferente de Proust, sua escolha de modelos segue critérios artísticos e políticos, evocando pintores, escritores, atrizes e intelectuais que, em algum momento, colidiram com o sistema político que então vigia no Brasil. Seja o choque político de caráter institucional, caso do socialista Antonio Houaiss, afastado da carreira diplomática em 1964, ou mesmo de natureza social, a exemplo do estilista Clodovil Hernandes, homossexual assumido num cenário de ascensão de ideias conservadoras. Mas neles, em todo caso, também está retratada a relação entre o artista e sua obra (o escritor Érico Veríssimo, que 
vê nos personagens do ciclo $O$ Tempo e o vento reflexos de sua vida familiar), assim como essa busca de uma imagem de si através da imagem do outro, o narrador proustiano que encontra seu próprio passado revirando as memórias de seu modelo.

É a partir desse ponto que desejamos desdobrar nosso debate para outro ângulo, relativo aos aspectos formais dessa comparação, entre a singularidade de Jorge Andrade, perante o new journalism, e aquela de Marcel Proust, frente ao retrato realista. Assim daremos continuidade a esse estudo. 


\title{
II. Seres divididos
}

\section{A representação da realidade nos retratos de Jorge Andrade e Marcel Proust}

\begin{abstract}
Enquanto observo Clodovil dando conselhos a milhares de ouvintes sôbre moda - o programa tem a duração de cinco minutos, com grande audiência -, revejo os dias que passei a seu lado e chego à conclusão de que êle é um exemplo perfeito dos sêres divididos, dos personagens de exceção. Clodovil tem a inteligência dos homens e a perspicácia das mulheres. Em seu corpo de homem, muitas mulheres vivem prisioneiras. Em sua sensibilidade feminina, muitos homens estão presos, mas inatingíveis. Pode sonhar, desejar homens e mulheres, mas seu corpo rolará sempre insatisfeito, sedento como alguém amarrado à beira da água sem poder atingí-la. A solidão é o seu continente, onde habita apenas o seu trabalho. Na agudeza de seu olhar, aparece constantemente a capacidade de observação; na fluidez das expressões, na inconstância do sentir, surge sempre a compreensão que só os sêres divididos possuem. Ouvi sua voz lânguida, mas que pode se tornar dura, metálica, de uma hora para outra ${ }^{1}$.
\end{abstract}

O perfil do estilista Clodovil Hernandes, É Clodovil sim. Alguma coisa contra?, um dos dez que o dramaturgo Jorge Andrade publicou na revista Realidade entre 1969 e 1972, busca situar seu modelo, do início ao fim, no horizonte dos seres especiais, que, de alguma forma, se destacam de seu grupo social a ponto de justificar editorialmente a apuração de uma reportagem. De acordo com os preceitos do gênero retrato, todo ser humano guarda alguma dimensão extraordinária e distinta, que vem a formar sua individualidade. Por isso, Jorge Andrade tanto empenha seus recursos narrativos num esforço de descolar o modelo de um conjunto maior de pessoas. Ele precisa provar para seus leitores e editores que trata de algo diferente e único. Clodovil "é um exemplo perfeito dos sêres divididos", "tem a inteligência dos homens" e "a perspicácia das mulheres".

\footnotetext{
${ }^{1}$ R.R., agosto de 1971, p. 71.
} 
Essas e outras tantas orações do perfil trazem consigo sentido de completude ou de totalidade, seja através do adjetivo "perfeito", denotando o que há de magistral e primoroso, seja no emprego nada ingênuo dos artigos definidos a preceder as categorias abstratas de que se vale na análise do entrevistado. Clodovil não possui "algo" da inteligência dos homens ou uma "chispa" da perspicácia feminina. Ao conviver com o estilista, o repórter afirma aos leitores poder lhe apreender a integralidade e a exatidão desses conceitos, que, de tão amplos e gerais (poder-seia mesmo dizer vagos), tornam o personagem que os manifesta tanto quanto especial. É tão intenso o propósito de justificar a pertinência do entrevistado para o perfil, que predomina a linguagem poética no excerto, traduzida em diversas figuras de estilo. Em apenas dois momentos, ele se serve de referencialidade, na tentativa de recuperar algumas rédeas do jornalismo profissional e tornar razoável a inscrição do texto numa revista mensal, de grande circulação nacional e internacional2 ${ }^{2}$ Primeiro, a oração apositiva "o programa tem a duração de cinco minutos, com grande audiência", compreendida, entre travessões, como certificação de que dados empíricos foram vasculhados e de que, portanto, a voz narrativa pertence a um "repórter". Depois, as orações "revejo os dias que passei a seu lado", evidenciando tanto o trabalho in loco de apuração quanto a expressão de certa tradução jornalística dos fatos pelo repórter, conotada pelo verbo "rever". Como há pouco comentávamos, todos traços bastante característicos da âncora à qual se prende o new journalism para preservar aquilo que possui de jornalístico em sua conceituação. E, ainda assim, nesse ponto último, como é incompleta a referencialidade, haja vista sua contaminação pela primeira pessoa.

\footnotetext{
2 Pode-se ler nas capas das edições de Realidade no período entre 1969 e 1972 a indicação do preço de venda da revista em escudos, moeda portuguesa à época. Também não são raras as mensagens de leitores portugueses publicadas na seção de cartas à redação.
} 
Está-se, assim, diante de uma representação ${ }^{3}$. E Jorge Andrade, talvez porque praticou o jornalismo somente após consagrar-se dramaturgo, apresenta a essência de um ser da realidade como se redigisse rubricas com o estado de espírito que deseja imprimir a uma personagem de teatro. Seu narrador se apresenta como repórter, mas julga ter apreendido justamente aquilo que o empiricismo do método jornalístico não permite, os estados psicológicos mais profundos de uma pessoa. Ficamos sabendo que Clodovil possui traços femininos e masculinos oscilantes em seu interior e que isso produz nele insatisfação e isolamento. Mas nada indica que o entrevistado tenha comunicado esses estados, sob a forma de um depoimento. Aquilo que é percepção subjetiva do repórter aparece como descoberta objetiva. Ora, de que maneira mensurar ou mesmo qualificar a capacidade de observação de alguém, como na expressão "agudeza de seu olhar", sem se colocar no lugar do outro, numa atitude de quase onisciência? E como compreender a sina imposta através do futuro do presente no excerto "seu corpo rolará sempre insatisfeito, sedento como alguém amarrado à beira da água sem poder atingí-la"? 0 método jornalístico tradicional quer se limitar à narrativa, mas não deixa de abrir espaço para percepções e intuições que pertencem somente a um ficcionista 4 . Não há sequer um perfil de Jorge Andrade onde não se perceba

\footnotetext{
${ }^{3}$ Compreendemos o termo "representação" no sentido que Anatol Rosenfeld atribui à elaboração de personagens. Na ficção, há uma "transfiguração" operada "pela energia da imaginação e da linguagem poética que visam a uma expressão 'mais verdadeira', mais definitiva e mais absoluta [dos seres] do que outros textos". Trata-se, assim, de um caso de Gestalt, nas palavras desse crítico, haja vista a atribuição de uma intenção, de um sentido à realidade, capaz de lhe prover "autonomia ôntica" e de, assim, lhe revelar certa "elaboração imaginária". Cf. ROSENFELD, Anatol. Literatura e Personagem. In: CANDIDO, Antonio (org.). A personagem de fiç̧̃̃o. São Paulo: Perspectiva, 2014, p. 22.

4 "Método jornalístico tradicional" deve ser compreendido como o que Nelson Traquina classifica de "culto" ou mesmo "obsessão" pelos fatos na imprensa a partir do final do século XIX e, com ainda maior intensidade, em meados do século XX. Segundo esse estudioso, a figura do repórter foi, ao longo desse período, construída como o "esforço supremo" em prol desse "mundo de fatos". Esforço que "tentava transformar o jornalismo numa máquina fotográfica da realidade, ou seja, na sua ideologia profissional, o espelho da realidade". Cf. TRAQUINA, Nelson. Teorias do jornalismo. Volume I. Florianópolis: Insular, 2005, pp. 52-53.
} 
esse mergulho do narrador-jornalista em searas nada acessíveis ao discurso jornalístico. Trata-se de uma forma de perscrutação, como acima dissemos, inusitada mesmo ao jornalismo dito literário. 0 leitor se vê projetado em uma dimensão de intimidade que não contempla apenas o modelo do perfil, mas que também engloba o próprio narrador. Em Jorge Andrade, o retrato do outro também é o retrato de si próprio.

Encerramos o capítulo anterior citando alguns exemplos desse mecanismo. A cada nova leitura dos perfis andradinos, no entanto, tem-se a impressão de que os casos de intromissão do repórter na revelação de seu entrevistado são ainda mais numerosos e jamais se esgotam. Falávamos do perfil de Marília Pêra, Cem mil volts, mas só no palco, cujo narrador lamenta a dificuldade de encontrar a "verdade" dos atores. Mas, poucos parágrafos adiante, ele volta a se dirigir ao leitor para comentar uma vez mais (e com orgulhosa astúcia) sua experiência ao lado da atriz: "nos dias que passei com Marília, às vezes [sic] sentia que ela estava me usando, ou brincando comigo. Mas, quanto mais me usava ou brincava, mais se revelava" ${ }^{5}$. 0 mesmo se dá com Érico Veríssimo, em A Liberdade será sempre a minha causa: "Sei que ela [sua risada com uma troça do escritor] tenta disfarçar o escrúpulo que cresce em mim, por estar sondando a verdade íntima daquele homem" 6 . Também (e com que presunção!) em Murilo, um poeta da liberdade, texto dedicado ao poeta Murilo Mendes: "Murilo continua sorrindo enigmático e somente eu, no meio de tanta gente, percebo o sentido de suas sobrancelhas"7. E no de Gilberto Freyre, Sir Gilberto Freyre: "há oito dias que frequento sua biblioteca tôdas as manhãs. Os

\footnotetext{
${ }^{5}$ R.R., junho de 1971, p. 15.

${ }^{6}$ R.R., fevereiro de 1972, p. 66.

${ }^{7}$ R.R., agosto de 1972, p. 86.
} 
fatos narrados por Gilberto Freyre até o momento me desconcertam"8. Neste exemplo, o presente do indicativo transmite ao leitor até mesmo a sensação de acesso a um diário íntimo do narrador. E sua ocorrência não é isolada nessa narrativa das visitas de Jorge Andrade ao célebre sociólogo pernambucano. Ela se repete sempre que o narrador entrevê uma oportunidade: "olho Gilberto parado diante da porta"; "olho a biblioteca à minha volta"; "ouço a voz de dona Madalena"9. Esse posicionamento do narrador entre seus leitores e modelos produz efeito nada desprezível. Mais do que um jogo de reflexos, segundo o qual ver o retrato de um modelo implica também a observação de seu próprio retratista, os desvios que Jorge Andrade opera na narrativa, direcionando-a para si próprio, cumprem a função de exibir os obstáculos metafísicos nos quais esbarra sua proposta de perfil jornalístico. 0 ônus de Marília Pêra se "revelar" é que o narrador se sinta despistado (ela "brinca" com ele). Sua cerimônia diante de Érico Veríssimo, ela só ocorre por estar "sondando" a personalidade do grande escritor. Diante de Murilo Mendes, ele domina os códigos de uma expressão "enigmática". Durante oito dias o entrevistador visita Gilberto Freyre, há uma convivência entre os dois, mas nada logra eliminar um certo "embaraço".

Evocar suas próprias impressões, sua presença na cena, serve a Jorge Andrade como instrumento revelador dos espaços enigmáticos que investiga. Não fosse seu sentimento de dúvida, de incerteza, por vezes até mesmo de constrangimento, como um tímido narrador a observar com sagacidade seus modelos, jamais seria produzido o precioso efeito de perscrutação da verdade dos seres. Porque, para Jorge Andrade, as essências não podem ser alcançadas de

\footnotetext{
${ }^{8}$ R.R., dezembro de 1971, p. 24.
}

${ }^{9}$ Ibidem, p. 32. 
forma, digamos, jornalisticamente objetiva. Elas são instâncias volúveis, fluídas, passageiras da personalidade. E, se esse narrador por vezes crê alcançá-las, não é sem esforço e sem que haja grande dispêndio de energia como repórter. Por isso se lamuria em seus retratos, por isso sente pudores e constrangimentos. Pois não há um método direto rumo a seu objetivo, traçar a individualidade de seu entrevistado. Os inúmeros desvios e contornos que lhe são impostos geram incertezas e instabilidades, e o jornalista questiona mesmo seu propósito.

Essa insegurança na busca por verdades profundas também se expressa em um outro importante aspecto do estilo andradino. Para além da construção da aura do perfilado, a tornar-lhe um ser especial capaz de justificar a pertinência da reportagem, e da abordagem ficcional que o jornalista atribui à sua apuração, posicionando-se diante do que pode apenas intuir, há sempre uma separação entre aquilo que seus entrevistados aparentam exteriormente e o que manifestam interiormente. "Ser dividido" que é Clodovil, seu corpo de homem abriga a essência de uma mulher. E, ainda mais que isso: mesmo os traços exteriores e interiores não são, cada qual, lineares ou estáveis. Seus modelos surgem sempre revelados em aspectos mutantes e, muitas vezes contraditórios. Tudo não se resume ao homem Clodovil conter mulheres em seu íntimo, clara alegoria de sua orientação sexual. Conhecer o estilista também desvelou ao escritor-repórter a "inconstância do sentir", perceptível, dentre outros elementos, em "sua voz lânguida, mas que pode se tornar dura, metálica, de uma hora para outra". Se o jornalismo tradicional busca o contexto ou o referente ${ }^{10}$, ao que se mostra positivamente apreensível, a contaminação de seu método com práticas da ficção permite a apresentação de

\footnotetext{
${ }^{10}$ Falamos aqui como Roman Jakobson em seu Linguística e Comunicação, quando afirma que a linguagem referencial é aquela com "orientação para o contexto" e caráter "denotativo", "cognitivo". Cf. JAKOBSON, Roman. Linguística e Comunicação. São Paulo: Cultrix, 2003, p. 122.
} 
uma realidade mais complexa porque plural e, por vezes, mesmo contraditória e inconstante.

O perfil da atriz Marília Pêra apresenta passagens importantes para essa discussão. Em boa medida porque se trata de uma atriz, uma oportunidade preciosa para um escritor de grande verve dramatúrgica e já bastante propenso a compreender a variedade de personalidades que compõem os seres. No instante em que Marília Pêra se encontra prestes a subir no palco para interpretar a personagem Joana Martini, da peça A Vida escrachada de Joana Martini e Baby Stompanato, de Bráulio Pedroso, o autor do perfil se vê às voltas com uma profusão quase cubista de imagens sobrepostas de um mesmo ser:

Desconfiado de que estava enredado por personagens e pela Marília real, voltei-me e vi a porta do camarim aberta e, nela, Joana Martini: plumas brancas nos cabelos, capa de brocado bordada com pedrarias - mas a roupa de baixo não daria para vestir uma criança de dois anos. Agitada, mas não numa agitação de Marília Pêra, ela me encanta. Tive impressão de que queria dizer alguma coisa. Mas, em cima, a música anuncia que a cortina vai se abrir, e ela caminha para a escada que leva ao palco, mascando um chiclete numa expressão grossa, lembrando a personagem que vai nascer logo mais. Ela pára nos primeiros degraus e volta-se para mim: e novamente era a Marília Pêra com seu sorriso triste, com sua fragilidade. ${ }^{11}$

No breve intervalo de um rosto que se volta para trás, quantas não são as imagens que assaltam seu olhar. Personagem e Intérprete se imiscuem produzindo um todo plural e complexo. Dele se depreende um intenso efeito de oscilação das perspectivas do retrato. Joana Martini é e não é Marília Pêra. E o narrador se perde entre elas, cedendo a um ambiente de quase esquizofrenia que atravessa, por sinal, todo o texto. A instantaneidade das visões está na base desse frenesi cubista ("e

\footnotetext{
${ }^{11}$ R.R., junho de 1971, p. 16.
} 
novamente era a Marília Pêra"). Mas seria equivocado falar em transformação. Toda a força do narrador desses perfis está voltada para a contiguidade de nossos distintos estados de personalidade. De sorte que não há modificação, por exemplo, da personagem à intérprete. Há tão somente uma passagem, de sorte que uma jamais exclui ou supera a outra. Ou ainda, para empregar uma metáfora bastante cara a Jorge Andrade: o ser se revela na mesma medida com que se mascara. Quando seu narrador assiste aos ensaios de Marília Pêra no papel de Joana Martini, é um verdadeiro camaleão de traços e personalidades que desenha:

Durante uma semana venho observando sua Joana Martini no palco, estudando seus movimentos, suas expressões, sua energia carregada de malícia, sua sensualidade agressiva como uma espécie de vingança. Mas ali no camarim, Joana Martini só estava presente na máscara que nascia lentamente, como se a personagem vivesse dentro das bisnagas, ou no meio das purpurinas. Quem continuava à minha frente era Marília Pêra, um ser frágil de sorriso triste, dando impressão de desamparo. Ou representando isso? 12

Está-se aqui diante do narrador que se interpõe ao retrato de seu modelo para expressar as dificuldades que a perscrutação de personalidades lhe impõe. E nesse ambiente de dúvidas, incertezas e insegurança diante daquilo que se deseja apreender, a essência dos seres se estilhaça, compondo uma complexa totalidade de diferentes formas e aspectos. Seria a Joana Martini espalhafatosa e exagerada apenas o falseamento da Marília Pêra "frágil", "triste" e "desamparada". Somos levados a crer nessa série de hipóteses até que o narrador chancela sua reflexão com uma dúvida carregada de relativismo. Mesmo a Marília de fora dos palcos pode estar interpretando.

\footnotetext{
12 Ibidem, p. 12.
} 
Outro caso: o perfil do escritor gaúcho Érico Veríssimo, publicado por Jorge Andrade na Realidade de fevereiro de 1972. Uma das grandes tensões que atravessam o texto, para além do descolamento e autonomia entre exterioridade e interioridade é, com efeito, o reconhecimento das barreiras que se pressupõe a busca pela interioridade do modelo de um retrato ou perfil. Veja-se a seguinte passagem, quando o narrador descreve a caminhada ao lado do escritor por uma ladeira do bairro de Petrópolis, em Porto Alegre. Ele a compara a uma sessão de psicanálise e associa o gesto de descê-la rumo às margens do rio Guaíba a um mergulho na consciência de seu entrevistado:

Naqueles dez dias de convivência, Érico vinha, dia após dia, anunciando a frase "eu me amo, mas não me admiro". Fechado, cuidadoso com o que fala, ele dissera a mesma frase de maneiras diferentes, disfarçando sua autocrítica. Admirado pelos principais intelectuais brasileiros, respeitado como homem coerente; esse sentimento de autocensura me desconcerta, mas me intriga. $O$ que deverá estar escondido atrás dele? Ele olha a ladeira que desce se escondendo em curva, e volta-se para mim. Há qualquer coisa de diferente em sua expressão. Suas sobrancelhas se encontram, hirsutas, muralhas defensivas. Percebo o homem tentando se esconder atrás de um olhar que se torna opaco, numa expressão de passividade índia ${ }^{13}$.

As orações adjetivas reduzidas "admirado pelos principais intelectuais brasileiros" e "respeitado como homem coerente" cumprem função de enaltecimento, operam como justificativa editorial para o perfil e indicam o critério de especialidade do perfilado, que, de tão abstrato, posto que amparado por categorias gigantescas ("principais intelectuais brasileiros") ou mesmo sequer identificadas ("respeitado" não se sabe por quem), apresentam-se como verdades que devem contar com a adesão voluntária do leitor. Jorge Andrade também

\footnotetext{
${ }^{13}$ R.R., fevereiro de 1972, p. 68.
} 
recorre, para tanto, à linguagem poética, sustentada por metáforas como "muralhas defensivas" e "expressão de passividade índia". O que não deve ser entendido como ausência de referencialidade, pois precisa se afirmar repórter e indicar o trabalho de apuração de dados in loco de que é oriundo o texto. Daí a razão de ser da expressão adverbial que abre a passagem ("naqueles dez dias de convivência") e o emprego das aspas para uma citação da lavra do próprio entrevistado ("eu me amo, mas não me admiro"), sugerindo preocupação com a fidedignidade do testemunho. Mas o mais intrigante se encontra ao final do trecho. Diante da convivência com o jornalista, seus questionamentos e indagações, o modelo perfilado passa a apresentar algo de "diferente em sua expressão", o que leva o narrador a questionar: “o que deverá estar escondido atrás dele?”. Já aí se depara com um descolamento e nos vemos diante de duas dimensões distintas. Há uma superfície visível, mas tão somente invólucro de algo misterioso e secreto, uma verdade profunda que aguarda ser descoberta e que move a curiosidade do repórter. E, não bastasse esse movimento de apreensão do entrevistado em perspectiva (sua aparência física, seus trejeitos, sua linguagem, por um lado, e seus vícios, virtudes, desejos, aflições, por outro), o Érico Veríssimo, tal qual percebido por Jorge Andrade, apresenta as mesmas dificuldades para abrir-se e revelar-se em sua completude. Quando o repórter tenta aprofundá-lo rumo às suas verdades interiores, "sobrancelhas se encontram, hirsutas, muralhas defensivas".

Não desejamos nos redundar nessas observações. No entanto, para afastar qualquer suspeita de que esses traços do estilo do jornalista Jorge Andrade sejam ocasionais, nos parece interessante pontuar como ocorrem em seus demais perfis. De Dercy Gonçalves, em No fundo ela é família, não se tem "tôda a verdade". Ela é "irreverente" em cena, sucumbe ao escracho, mas em sua casa "ninguém diz 
palavrão". Há sempre nela um jogo de "realidade" e "fantasia"14. Murilo Mendes, cuja expressão carrega um "sorriso enigmático", um "sorriso de estátua", é definido como "católico e contestador, cristão e ecumênico"15. Em Ela é a mãe de Pinky?, Danuza Leão e sua filha, Pinky Weiner, são ora "mãe e filha" ora "duas mulheres que, embora tivessem 22 anos de diferença de idade, se igualavam na condição de mulher"16. Wesley Duke Lee, em Duke Lee, o nosso surrealista tipo exportação, "entrega-se" ao narrador, oferece a "revelação de sua verdade". 0 pintor trabalha em meio ao "caos que parece ser seu estúdio", na "aparente confusão de milhares de coisas espalhadas pelas mesas e paredes". Contudo, "na sua essência", manifesta "mente metódica e grande capacidade de continuar um pensamento interrompido"17. Em O Operário da palavra, Antonio Houaiss "é um homem cordial, mas, às vezes, ele se torna diabólico"18. Há, assim, sempre mistério e incerteza. 0 escritor Jorge Andrade sempre se interpõe ao retrato jornalístico, à pintura de seus modelos, para manifestar o campo de insegurança que adentra. É notável, nesse sentido, a repetição das palavras enigma e máscara. Dessa descontinuidade dos seres com os quais trava contato derivam personalidades múltiplas e fragmentadas. A dúvida faz germinar visões que contrastam estados de espírito. Jorge Andrade não descreve jamais sem paradoxos. Há traços bastante empíricos nos perfis andradinos. Como dissemos, o autor não abdica do que há de jornalístico em seus textos de imprensa. Contudo, quanto aos aspectos propriamente pertinentes à literatura, já não se pode ver ali uma atualização da estética realista, à moda de tantos autores de perfis e retratos ligados ao new journalism. 0 narrador

\footnotetext{
${ }^{14}$ R.R., outubro de 1969 , p. 86.

15 R.R., agosto de 1972, pp. 86, 88.

${ }^{16}$ R.R., setembro de 1971, p. 29.

17 R.R., maio de 1971, pp. 102-103.

18 R.R., abril de 1972, p. 118.
} 
de Jorge Andrade duvida da realidade que lhe é apresentada e expõe sua intimidade, sentimentos e sensações, na mesma medida que seus entrevistados. Essa nos parece uma característica fundamental de Jorge Andrade, qual seja redigir uma narrativa jornalística com uma visão complexa e dinâmica das personalidades que formam os seres humanos.

Esse princípio descritivo, de que o real possivelmente se encontre muito mais no que há de transitório, mutável e contraditório do que em elementos mais verossímeis ou constantes, é muito próximo daquele que se nota, sem maiores dificuldades, não apenas em passagens do ciclo romanesco À la recherche du temps perdu, mas também em diversos textos menores e esparsos da lavra de Marcel Proust. Causa surpresa como Proust nunca foi tomado em profundidade nos inúmeros estudos dedicados ao estilo de Jorge Andrade. É bem verdade que essa comparação é sugerida nos estudos de Terezinha Tagé ${ }^{19}$ e que somente seu trabalho havia se consagrado até o momento à produção jornalística do dramaturgo, refletindo sobre seu encaixe em uma complexa trama de grandes narrativas e temas que superam obras individuais e que comporiam, sob essa perspectiva, toda uma unidade de sentido ${ }^{20}$. Mas essa parece ser uma justificativa

\footnotetext{
${ }^{19}$ Discorrendo sobre o estilo de Jorge Andrade, a autora afirma que "seus métodos de trabalho para criação de peças teatrais, ficção televisiva e publicações na imprensa incorporaram experiências de sua formação pessoal, reelaborando continuamente as marcas de seus ancestrais, homens e mulheres ligados ao cultivo da Terra em sua memória emotiva intensificada pela leitura incorporada de Marcel Proust e Henri Bergson. Cruzavam-se a memória emotiva e a memória textual. Sua obra resulta deste amálgama como produto enunciativo de seu imaginário". Cf. TAGÉ, Terezinha. Jornalismo e dramaturgia: o mundo composto de Jorge Andrade. 2010. 122 p. Tese de livre-docência - ECA/USP, pp. 5-6.

20 Tagé acredita que os textos jornalísticos de Jorge Andrade, em diálogo com o conjunto maior de sua dramaturgia e com a própria cultura de seu tempo, formam, nos termos de Yuri Lotman, uma "semiosfera". Ela explica o conceito: "assim como a biosfera de [Vladimir] Vernadski é um mecanismo cósmico que tem um lugar definido na estrutura do planeta, envolvendo completamente toda a matéria viva, transformando-a e conservando-a, a semiosfera é um espaço pleno de signos e abstrato, fechado, dentro do qual é possível a geração e transformação do sentido produzido na materialidade sígnica que nos envolve. Uma camada protetora de signos que são modelizados em textos da Cultura para permitir a Comunicação". Ibidem, p. 98.
} 
pouco convincente. Como veremos oportunamente, esse estilo tão caro a Proust não é restrito apenas a sua obra jornalística. Ele também se manifesta nas narrativas teatrais e romanescas de Jorge Andrade, já bastante aprofundadas por vários outros autores. Em Recursos estilísticos na dramaturgia de Jorge Andrade, Elizabeth Azevedo salienta o aspecto "expressionista" do autor e define esse posicionamento artístico como uma busca por "atingir a essência da experiência humana e permitir ao artista a expressão de seus conflitos internos sem nenhum tipo de barreira"21. Ela cita adiante o trabalho de Jean-Michel Glikson, para quem, expressionismo evoca na obra de arte fenômenos como "instabilidade da visão, do sentimento de si e dos meios artísticos"22. Nada poderia ser mais proustiano - o tatear à procura de imagens visto a insuficiência dos recursos de linguagem para expressar o que buscamos; aquilo que Leo Spitzer, a partir da leitura do célebre texto de Léon Pierre-Quint ${ }^{23}$, definiu como a moda das disjunções complexas em Proust, seus esforços por uma economia sintática capaz de comportar a "variabilidade do mundo", a marcante recorrência do advérbio peut-être nos longos períodos de seu romance ${ }^{24}$. E, no entanto, a Recherche acaba

\footnotetext{
${ }^{21}$ AZEVEDO, Elizabeth. Recursos estilísticos na dramaturgia de Jorge Andrade. São Paulo: Edusp, 2014, p. 28.

22 Idem.

${ }^{23}$ Cf. PIERRE-QUINT, Léon. Marcel Proust, sa vie, son œuvre. Paris: Le Sagittaire, 1935.

${ }^{24}$ Segundo Spitzer, há no estilo proustiano um contraste entre o arbitrário e o cuidado na elaboração das imagens, de modo que "Proust observa com amor e individualmente tudo o que descreve, mas não deixa de nos lembrar o quão contingente é o objeto individual - ainda que claramente determinado - e como que apreendido ao acaso em meio à profusão dos seres" [Proust schaut alles, was er beschreibt, liebevoll und individuell, aber er läßt uns nicht vergessen, wie zufällig und dabei eindeutig bestimmt das Individuelle ist, das wir schauen, wie aufs Geratewohl herausgegriffen aus dem Füllhorn des Seienden, p. 398]. Essa contingência e acaso promoveriam "uma renúncia por assim dizer cósmica à explicação dos fenômenos complexos do psiquismo" e Spitzer então se questiona retoricamente: "não poderiam os peut-être se repetirem ao infinito?" [sondern als einen sozusagen kosmischen Verzicht auf Begründung der komplexen Ereignisse auf psychischem Gebiet: die peut-êtres könnten ja ins Unendliche weitergehen, p. 399]. Cf. SPITZER, Leo. Stilstudien. Munique: Max Hueber Verlag, vol. II, 1961.
} 
negligenciada ${ }^{25}$. Carlos Antônio Rahal comete a mesma omissão em Jorge Andrade:

um dramaturgo no espaço-tempo. Há apenas uma alusão a Proust, quando somos

introduzidos a um fragmento repleto de referências ao autor e ao fictício balneário

de Balbec - uma passagem do diálogo entre Noêmia e Isméria, personagens da

peça Senhora na boca do lixo ${ }^{26}$. Seu objetivo é sustentar a ideia de que o tempo

"transfigura" a memória dos personagens andradinos e condiciona a experiência

de rememoração ao fenômeno de "criação artística"27. Todas noções caras à

\begin{abstract}
${ }^{25}$ Soa curioso que, após aderir a uma leitura tão fragmentária e subjetivista do estilo do autor, Azevedo, mais adiante, o considere um "realista" (Op. cit., pp. 173-174). Penso no caso de uma peça como $O$ Telescópio, na qual o protagonista Francisco se recolhe à contemplação dos astros como meio de se exilar de uma arena de conflitos e intrigas familiares. Em suas reflexões, escapa de uma certa mesquinhez terrestre dirigindo-se a uma grandiosidade celeste e atemporal. Ora, o objetivo opera aqui como desvio e suspeita de uma realidade de valores apequenados e empobrecidos. Os objetos da cena Andradina são quase sempre símbolos do passado pelos quais personagens alimentam espécie de devoção e através dos quais se cegam, se despistam de sua "real" condição humana. Longe de expressarem e determinarem o que são os personagens andradinos, como seria apropriado ao realismo, esses objetos afirmam o que não são, o que não possuem, o mundo que vislumbram e do qual não podem fruir, proporcionando o conflito subjetivo que tanto parece apreciar esse autor. Que dizer de uma peça como A Escada, na qual o casal de idosos Antenor e Amélia não possuem mais casa própria e vivem sua individualidade, as reminiscências de um passado perdido nas escadarias do prédio onde moram seus filhos? É claro que há materialidade na configuração cênica e as rubricas mostram isso: "APARTAMENTO 1, DE MARIA CLARA: Mesa de jantar, sofá velho, muitos enfeites, quadrinhos bordados à mão nas paredes [...]" M.A.R., p. 343. Tudo é absolutamente concreto. Mas esse dado de "realismo" basta para julgar sua dramaturgia "realista"? Pode-se negligenciar o caráter simbólico da escada como interstício dos apartamentos entre os quais o casal se reveza, justamente como dimensão paralela à realidade frustrante que lhes acomete ao fim da vida? No que diz respeito à Escada, a leitura de Carlos Antônio Rahal nos parece bastante apropriada: as escadarias de Antenor e Amélia são um "espaço onírico", um "túnel do tempo", responsável por "uma fuga da realidade e do destino" (RAHAL, Carlos Antônio. Jorge Andrade: um dramaturgo no espaço-tempo. São Paulo: Perspectiva, 2015, p. 98). E acreditamos, mais além, que esse traço não é exclusividade dessa peça, mas antes característica disseminada em boa parte da obra dramatúrgica andradina. Há realismo em suas peças, mas sua vocação não se revela de modo algum realista.
\end{abstract}

${ }^{26}$ Eis a passagem:

NOÊMIA (meio perdida): Fugi de Paris e percorri a costa francesa. Na província, ainda se encontra a velha França. Visitando Trouville e Cabourg, localizei Balbec e a igrejinha querida de Proust. É linda!

ISMÉRIA (burra): Conheço bem a costa francesa. Não me lembro de Balbec.

NOÊMIA: Mas não existe!

ISMÉRIA: Você acabou de dizer que visitou.

NOÊMIA: Balbec é criação de Proust. É como certos lugares de nossa memória, transfigurados pelo tempo e revividos numa criação artística. Balbec é Trouville!

M.A.R. p. 294.

${ }^{27}$ Segundo Rahal, na dramaturgia de Jorge Andrade "a memória é transfigurada pelo tempo [...] e revivida em uma criação artística". Cf. RAHAL, Carlos Antônio. Op. cit., p. 115. 
estética proustiana como veremos adiante. Em Teatro da memória, de Luiz Humberto Martins Arantes, é verdade que o cerne da argumentação se equilibra sobre o estilo historiográfico de Jorge Andrade, entendido como o espaço privilegiado que ocupam em sua obra os conflitos geracionais e o choque entre temas arcaicos e modernos. Ainda assim, causa estranhamento que o texto clássico de Georges Poulet, L'Espace proustien, seja analisado sem qualquer cotejo com a obra proustiana. Como temos insistido, o romancista francês também foi autor de mais de uma centena de artigos jornalísticos. Um levantamento conduzido por Yuri Cerqueira dos Anjos nos dá conta da expressividade dessa parcela da obra de Proust ${ }^{28}$. Mas a relevância, como mostraremos, não é apenas numérica. Ela também se revela sob a perspectiva do estilo desse autor. Como dissemos na introdução desse estudo, foram selecionados doze retratos literários reunidos no Contre Sainte-Beuve da coleção Bibliothèque de la Pléiade para demonstrar isso. Todos textos consagrados a escritores, músicos, dramaturgos e mundanos da Belle Époque parisiense - um critério de escolha de modelo, diga-se de passagem, relativamente próximo daquele empregado várias décadas depois, e num contexto histórico e social bastante distinto, pelo dramaturgo-jornalista Jorge Andrade.

Temos sob os olhos a seguinte passagem do retrato La Personne d'Alphonse Daudet : « aEuvre d'art », publicado em 11 de agosto de 1897 no jornal La Presse:

Dans la figure de M. Daudet, l'intensité de la souffrance n'a pas altéré la perfection de la beauté. La gloire de ce front, où la chevelure est partagée comme en deux ailes puissantes et légères, n'est pas seulement celle d'un martyr. C'est celle d'un dieu ou d'un roi. Car le charme royal, l'aisance souveraine des formes et des attitudes, la noblesse visible existent ailleurs que

\footnotetext{
28 Tem-se conhecimento de 107 textos publicados por Proust em revistas e jornais franceses entre 1890 e 1922. São trabalhos que se inserem nos mais diversos gêneros jornalísticos: da crônica à entrevista e ao artigo de opinião. Esses textos estão listados (e parte deles pode ser lido) no endereço eletrônico: http://proustetlapresse.blogspot.com.br/ (acessado em 4 de março de 2016). Cf. ANJOS, Yuri Cerqueira dos. Proust et la presse de la Belle Époque. Paris: Honoré-Champion, 2018.
} 
dans l'imagination des snobs et les romans pour les concierges. Moins physique que la beauté, moins spirituelle que la noblesse de l'esprit et du caractère, elle est, si l'on veut, comme l'habitude de cette noblesse, c'est-àdire cette noblesse devenue inconsciente convertie en belles lignes du corps et $d u$ visage, en mouvements larges et simples, de la noblesse qui a pris corps. ${ }^{29}$

A publicação desse perfil ocorre quatro meses antes da morte de Daudet, já bastante combalido pelo estágio avançado de uma infecção de sífilis. Sentimos a todo momento o peso de sua sobrevivência e o grande suplício que são suas injeções de morfina. Proust descreve com enorme carga de realismo e criaturalidade a deformação do rosto de seu amigo, revestido pelo brilho de uma torrente de suor. Sua imagem, no entanto, não inspira pena ou dó. Proust acrescenta a ela sempre que possível um dado de resistência ao sofrimento. Tratase de um mártir. Tanto assim que se atinge a unidade de uma oração como l'intensité de la souffrance n'a pas altéré la perfection de la beauté. Não se trata, bem entendido, de ver um personagem ora mortificado ora aliviado. Essas diferentes instâncias se associam num mesmo amálgama, compondo um único estado complexo. São como seus cabelos: semelhantes a um par de asas poderosas ao mesmo tempo que leves. Nesse contraste entre força e fragilidade se expressa inclusive a nobreza do personagem, sua condição digna de deuses e reis. A despeito da deterioração física, da decadência material, Daudet não se desvencilha do "hábito soberano", aquele que se depreende de uma altivez do caráter e do espírito. Nos personagens proustianos, vide a avó do herói da Recherche, a

\footnotetext{
${ }^{29}$ Na figura do senhor Daudet, a intensidade do sofrimento não alterou a perfeição da beleza. A glória dessa fronte, na qual os cabelos se dividem como em duas asas poderosas e leves, não é apenas aquela de um mártir. É aquela de um deus ou de um rei. Porque a fleuma real, a naturalidade soberana das formas e atitudes, a nobreza visível existem para além da imaginação dos esnobes, dos romances dos porteiros. Menos física que a beleza, menos espirituosa que a nobreza do espírito e do caráter, ela é, se preferirmos, o hábito dessa nobreza, isto é, essa nobreza tornada inconsciente, convertida em belas linhas do corpo e do rosto, em movimentos grandiosos e simples, uma nobreza que se incorporou. CSB, pp. 399-400.
} 
aproximação da morte, longe de debilitar suas capacidades intelectuais, cada vez mais as fortalece, criando instantes marcados até mesmo por certa transcendência ${ }^{30}$. Daudet revela força na fraqueza e a morte lhe proporciona senão vida. Seu físico, tal qual uma máscara, ao deteriorar-se, faz entrever uma essência perene e admirável. A superfície e o interior do ser estão demarcadas em níveis. Quanto à interposição do narrador na imagem de seu modelo, ela surge poucas linhas adiante e não de modo menos pessoal que nos perfis andradinos. 0 escritor volta para si o foco descritivo a fim de manifestar o sentimento de culpa que o atormenta quando diante das agruras de Daudet:

Je ne pouvais comprendre comment il pouvait cependant continuer à produire. Surtout je me rappelais combien des souffrances, si faibles auprès des siennes qu'il les eût sans doute goûtées comme un répit, m'avaient rendu indifférent aux autres, à la vie, à tout ce qui n'était pas mon corps malheureux, vers lequel mon esprit restait obstinément tourné, comme un malade dans son lit reste la tête tournée contre le mur. ${ }^{31}$

Decerto uma confissão de egoísmo, a expressão de mea culpa através do expediente da primeira pessoa. Mas isso seria dizer muito pouco. Ao retratar o amigo moribundo, o escritor retrata a si próprio e revela as suas próprias mazelas

\footnotetext{
30 Poderia citar várias passagens desse episódio. Mas penso, sobretudo, no momento em que o médico Cottard recorre a sanguessugas para descongestionar o coágulo cerebral de Bathilde. Quando uma das piores crises da uremia da avó se ameniza, o que o herói Marcel enxerga são: "[des yeux] peut-être encore plus surchargés d'intelligence qu'ils n'étaient avant sa maladie, parce que, comme elle ne pouvait pas parler, ne devait pas bouger, c'est à ses yeux seuls qu'elle confiait sa pensée, la pensée qui tantôt tient en nous une place immense, nous offrant des trésors insoupçonnés, tantôt semble réduite à rien, puis peut renaître comme par génération spontanée grâce à quelques gouttes de sang qu'on tire"[olhos talvez ainda mais sobrecarregados de inteligência do que eram antes de sua doença, pois, como ela não podia falar e não devia se mexer, era apenas a eles que confiava seu pensamento, o pensamento que ora ocupa em nós uma região imensa, oferecendo-nos tesouros inimagináveis, ora parece reduzido a nada, podendo renascer em seguida como que por geração espontânea, graças a algumas gotas de sangue que retiramos]. R.T.P, II, p. 630.

${ }^{31}$ Eu não compreendia, no entanto, como ele conseguia continuar produzindo. Recordava-me, sobretudo, de quantos sofrimentos, tão sutis perto dos seus que ele os teria, sem dúvida, aproveitado como uma trégua, me haviam tornado indiferente aos outros, à vida, a tudo aquilo que não era meu corpo infeliz, para o qual meu espírito obstinadamente se voltava, assim como um doente que, em seu leito, mantém a cabeça contra a parede. $C S B$, p. 400.
} 
ao leitor. 0 modelo, em passagens dessa natureza, não é mais que um anteparo sobre o qual o narrador traça o seu próprio perfil. É o que, no princípio, chamamos de um "jogo de reflexos" revelador dos obstáculos metafísicos que a perscrutação de modelos impõe a um retratista. E não poderíamos dizer que, à diferença de Jorge Andrade, Proust não recorre à interposição do narrador para expressar dúvidas e incertezas. Todo o retrato de Daudet se equilibra sobre uma insegurança fundamental relacionada aos meios de sobrevivência do personagem. "Je ne pouvais comprendre", "sans pouvoir comprendre"... por todos os lados expressões desse gênero nos atingem e, além de revelarem no escritor certa desconfiança com o poder dos meios da linguagem para a representação da vida (o enigma), concorrem para sublimar ainda mais a figura retratada. A incompreensão do caráter de Daudet no plano terreno serve para comprovar a filiação do personagem ao plano celestial, culminando com sua comparação ao Cristo: "je vis cette chose sublime, qui doit nous faire rougir, nous tous lâches que nous sommes, ou plutôt, comme la parole de celui par qui nous connûmes que nous étions non des malades et des serfs mais des esprits et des rois [..." $]^{\prime 32}$.

Em Proust et le roman, debruçando-se sobre o fenômeno de desaparecimento e aparecimento de personagens que vemos ao longo da Recherche, Jean-Yves Tadié interpreta como o romancista opera essa transitoriedade do caráter físico ao psicológico no correr do tempo. Ao ser recuperado pelo narrador proustiano em incontáveis ocasiões do ciclo, um personagem torna-se a evidência de que, "a despeito das repetidas buscas do narrador, ele não será capaz de afirmar 'sua

\footnotetext{
${ }^{32} \mathrm{Vi}$ aquela coisa sublime, que nos leva a enrubescer, nós, fracos que somos, ou melhor, segundo a palavra daquele através de quem descobrimos ser não doentes e servos, mas espíritos e reis [...]. CSB, pp. 400-401.
} 
verdade objetiva'”33. Isso porque "não se trata de fazer reaparecer, inteiro e imutável, um herói bastante conhecido, nem mesmo penetrar sob seu disfarce, mas sim permitir a Swann, Morel e Saint-Loup de se mostrarem de outra maneira, de serem outro"34. Dissemos que o tempo de convivência entre Jorge Andrade e Clodovil, por exemplo, proporcionou as condições para que a imagem desse perfilado se apresentasse e fosse apreendida como algo plural, inconstante e, por isso mesmo, complexa (corpo de homem/sensibilidade feminina; voz lânguida/voz dura). Em Proust, isso não é distinto. Para não nos esgotarmos no exemplo do retrato de Alphonse Daudet, vejamos como essa técnica, o princípio do "mostrar-se de outra maneira" e de "ser outro" de que trata Tadié, apresenta-se também em uma passagem substantiva do retrato La comtesse de Guerne, publicado no jornal Le Figaro em 7 de maio de 1905:

Je ne crois certes pas qu'il s'imaginât entendre en Mme de Guerne une femme du monde plus ou moins agréablement douée pour le chant. Il avait reçu le témoignage ou les impressions de trop de grands et purs artistes. Il croyait entendre une vraie, une grande chanteuse, mais semblable à bien d'autres dont la réputation l'avait attiré, et le talent l'avait déçu. Mme de Guerne chanta. Debout, dans une attitude immobile à laquelle son masque dramatique et son regard inspiré donnaient une sorte de caractère pythique elle laissa échapper, comme de calmes oracles, des notes qui semblaient, pour ainsi dire, extra-humaines. Je dis qu'elle les laissait échapper, car les voix des autres chanteurs sont des voix appuyées à la gorge, à la poitrine, au coeur, qui semblent garder de l'émouvant contact quelque chose d'humain presque de charnel et, si immatérielles qu'elles soient, ne viennent à nous que comme un parfum qui traînerait avec lui quelques pétales de la corolle arrachée. Rien de tel en Mme de Guerne. C'est probablement l'unique exemple d'une voix sans support physique, d'une voix non seulement pure, mais tellement spiritualisée qu'elle semble plutôt une sorte d'harmonie naturelle, je ne dirai même pas les soupirs d'une flûte, mais d'un roseau dans le vent. Devant la

\footnotetext{
33 "Malgré les recherches répétées du narrateur, il lui sera impossible de dire 'sa verité objective'”. Cf. TADIÉ, Jean-Yves. Proust et le roman. Paris: Gallimard, 2003, p. 76.

34 "Il ne s'agit pas de faire réapparaître, entier, immuable, un héros bien connu, ni même de le pénétrer sous son déguisement, mais de permettre à Swann, à Morel, à Saint-Loup, de se montrer sous um autre jour, d'être autre". Ibidem, p. 74.
} 
production mystérieuse de ces sons indéfinissables, le musicien dont je parlais restait immobile, en un sourire extasié. 35

O elogio de Proust a Madame de Guerne se enraíza em uma longa distinção entre sua pessoa social - a burguesa Marie-Thérèse de Ségur, uma das gens $d u$ monde do sétimo arrondissement de Paris - e sua pessoa intelectual - a cantora lírica de grande "naturalização artística" 36. Há um sentido de surpresa na construção desse antagonismo, projetado sobretudo no personagem do amigo anônimo do narrador, "um puro tecnicista da música"37, cuja evocação concorre para atribuir estatuto científico e absoluto a uma imagem que, a seu ver, não é facilmente concebível: que uma burguesa mundana apresente dotes artísticos, não supérfluos ou banais, mas, sim, verdadeiros e dignos de admiração. Ao ouvir Madame de Guerne e ter seus preconceitos dissipados, a sensação do crítico musical é de êxtase e satisfação. Seu espanto diante da revelação da cantora é tamanho que perde os movimentos. Ele está pasmo e seu sobressalto é associado à grande carga mística da descrição, configurada em uma descoberta inesperada e sublime. Depreende-se da personagem tudo aquilo que possui de celeste como meio de fazer frente ao grande universo material que a envolve em sua vida

\footnotetext{
35 Não creio de modo algum que ele imaginava ouvir em Madame de Guerne uma mulher mundana mais ou menos agradavelmente dotada do canto. Escutara o testemunho ou as impressões de muitos grandes e puros artistas. Acreditava ouvir uma verdadeira, uma grande cantora, mas semelhante a várias outras cuja reputação o cativara, e o talento o decepcionara. Madame de Guerne cantou. De pé, em uma atitude imóvel à qual sua máscara dramática e seu semblante inspirado proporcionavam espécie de caráter pítico, ela deixou escapar, como de calmos oráculos, notas que pareciam, por assim dizer, sobre-humanas. Digo que ela as deixava escapar porque as vozes de outros cantores se sustentam na garganta, no peito, no coração, porque parecem preservar do emocionante contato algo de humano, quase carnal e, de tão imateriais que são, nos atingem apenas como um perfume que carrega consigo algumas pétalas da corola roubada. Nada disso em Madame de Guerne. Trata-se provavelmente do único exemplo de voz sem suporte físico, de voz não apenas pura, mas tão espiritualizada que parece, antes de mais nada, uma espécie de harmonia natural, não diria sequer os suspiros de uma flauta, mas do junco ao vento. Diante da misteriosa produção desses sons indefiníveis, o músico de quem eu falava permanecia imóvel, num sorriso extasiado. CSB, p. 504.

36 Ibidem, p. 503.

37 Ibidem, p. 504.
} 
cotidiana e pública. São planos de sua personalidade que, a despeito do que possuem de contraditório e antagônico (a possibilidade de, na visão do narrador, um burguês da Belle Époque parisiense possuir louvável gosto estético), coexistem na construção de uma imagem complexa, que é aquela que mais se aproxima da realidade sob uma perspectiva proustiana. Toda a poética que sustenta o retrato de Madame de Guerne manifesta uma essência etérea, ligada aos sentidos e às sensações. Ela é entidade mítica, uma musa da antiguidade clássica que nos ocorre como perfume, como vento e, principalmente, como som. 0 escritor deseja tanto ultrapassar a barreira do aparente, subverter o superficial e atingir uma verdade interior alheia à vida social - e por isso tanto mais humana - que suprime de suas metáforas tudo que pode haver de concreto e palpável. Nas palavras do próprio autor, Madame de Guerne se difere dos demais bons cantores de seu tempo porque sua voz prescinde de um suporte físico, de um princípio "carnal”. É como se nos dissesse que a talentosa dama da alta sociedade francesa, cuja imagem pública se associa ao terreno, ao luxuoso, ao passageiro e ao desimportante, fosse capaz de revelar àqueles que aceitam se enveredar em sua subjetividade e dissecar sua essência tudo aquilo que pode haver de valoroso, elevado e atemporal em um indivíduo. Assim tece a imagem complexa, dinâmica e, acima de tudo, misteriosa da imaterialidade que pode existir no interior do mais material dos seres. São terras ocultas que aguardam seu desbravamento e que nos assombram quando acabam finalmente desveladas por conta do abismo que as separa das nossas expectativas e impressões primordiais. Nesse esforço de representação da realidade, articulamse níveis superficiais e profundos, o aparente concreto e o interior abstrato, separados sempre por um segredo. Sua resolução depende do importante pressuposto de que a convivência estendida e desenrolada no curso do tempo 
permite a apreensão de um indivíduo de várias formas. Tanto assim que, além dessa passagem, o retrato de Madame de Guerne oferece a seu leitor menções de outros encontros entre a cantora e o escritor, transmitindo a ideia de que a compreensão de sua modelo não é algo pontual, mas sim produto de uma convivência, resultado de um esforço de perscrutação de sua personalidade ${ }^{38}$. Não é menos do que afirma Antonio Candido, no ensaio Realidade e Realismo, ao comparar o estilo proustiano àquele dos escritores naturalistas franceses do século XIX:

O olhar do escritor [naturalista] pára na superfície e não discrimina em perspectiva, nem correlaciona as impressões com referência a um princípio integrador. Daí cada pessoa ou objeto adquirir um valor por assim dizer absoluto, que se esgota na descrição ou no juízo. Ao contrário, a arte do narrador proustiano pretende descrever de muitas maneiras, recomeçar de vários ângulos, ver o objeto ou a pessoa de vários modos, em vários níveis, lugares e momentos, só aceitando a impressão como índice ou sinal. É uma visão dinâmica e poliédrica, contrapondo-se a outra, estática e plana ${ }^{39}$.

\footnotetext{
${ }^{38}$ Ao final do retrato, o narrador expõe seu profundo conhecimento da vida social da residência de Madame de Guerne: "la comtesse de Guerne habite avec son mari le comte de Guerne, une gracieuse demeure de l'avenue Bosquet - c'est là qu'on entendit pour la première fois les choeurs d'Esther, ce que M. Reynaldo Hahn a peut-être écrit jusqu'ici de plus beau, où toutes les grâces du récit biblique et de la tragédie racinienne se sont transposées et comme exaltées, - demeure ennoblie de tous les témoignages d'admiration que les compositeurs ont donnés à l'artiste, depuis Gounod, qui lui dédiait ses mélodies, jusqu'à Hébert, qui a fait son portrait; soutenue par de légères colonnes de Corinthe, résonant tantôt au son de la lyre et tantôt de la harpe, et d'une voix aussi qui charme comme l'une et qui émeut comme l'autre, cette demeure heureuse ressemble à la fois à la maison du sage et au temple des muses" [a condessa de Guerne mora com seu marido, o conde de Guerne, num gracioso recanto da avenida Bosquet - foi lá que se ouviu pela primeira vez os coros de Esther, que é talvez o que o senhor Reynaldo Hahn escreveu até hoje de mais belo, nos quais todas as graças da narrativa bíblica e da tragédia raciniana são transpostas e como que exaltadas -, morada enobrecida por todos os testemunhos de admiração que os compositores prestavam à artista, de Gounod, que lhe dedicava suas melodias, até Hébert, que a retratou; sustentada pelas leves colunas de Corinto, ressoando às vezes ao som da lira, às vezes ao da harpa, e também com uma voz que encanta como uma e que emociona como a outra, essa alegre residência parece ao mesmo tempo o lar do sábio e o templo das musas]. CSB, p. 506.

${ }^{39}$ CANDIDO, A. Realidade e Realismo (via Marcel Proust). In: Companhia das Letras, 1993, p. 127. Recortes. São Paulo:
} 
Tratamos até aqui do retrato de Alphonse Daudet e de Madame de Guerne, mas tais traços estilísticos nos parecem aplicáveis a todos os demais perfis escritos por Proust. Chamemos esse mecanismo descritivo de visão dinâmica e poliédrica, como quer Candido, ou de uma permissão ao diferente, como prefere Tadié ${ }^{40}$, o fato é que sempre os retratos de Proust, ou mesmo passagens inteiras da Recherche, descrevem personagens ao longo do tempo a partir de inúmeros ângulos, às vezes contraditórios, às vezes complementares, segredados por dados superficiais e aparentes, ou ainda, para empregar palavras caras a Proust, escondidos sob as máscaras do hábito. A pintora Madame Herbelin, em Une miniaturiste du second Empire, era uma senhora tão "doce" e "simples", que “adorava passar longas horas atrás das vidraças de sua janela", apenas assistindo, "imóvel e silenciosa", aos "lilases do jardim". Mas seu passado guarda uma vida "faustosa" no seio da "sociedade mais brilhante" da Monarquia de Julho e do Segundo Império ${ }^{41}$. Madame de Rozière, em Une grand-mère, vive a decadência física e a proximidade da morte, mas "flutua" sobre "os mais assustadores picos de sua doença" com tanta "fragilidade" quanto "leveza". E nos instantes em que todos a creem devastada, ela se revela pronta a supervisionar a carreira de seu neto, o dramaturgo Robert de Flers ${ }^{42}$. Ele, por sinal, também um dos modelos proustianos: aos vinte anos, é "versejador louvado pelos versejadores", mas "nunca um entusiasmo maravilhou os expectadores de um teatro dramático ou de um caféconcerto [...] a ponto de iludir por uma hora sequer o jovem sábio e impedi-lo de racionalizá-lo depois" ${ }^{43}$. Em Um professor de beleza, o dândi Robert de Montesquiou poderia ser apenas mais um pedante a laudar por todos os lados sua

\footnotetext{
${ }^{40}$ TADIÉ, Jean-Yves. Op. cit., p. 74.

${ }^{41}$ CSB, p. 487-489.

42 Ibidem, p. 545.

${ }^{43}$ Ibidem, p. 403-404.
} 
erudição, mas a sua elegância "se mistura talvez um pouco de impertinência". Caso fosse eleito para a Academia Francesa, afirma o narrador, durante seus discursos "encobriria com uma decente doçura suas tempestuosas justiças e injustiças" 44 . 0 príncipe Edmond de Polignac, em Le Salon de la princesse Edmond de Polignac, traz no físico a "máscara de sua linhagem", dotada dos traços guerreiros de um "torreão", mas seu espírito virtuoso e sábio, sua "alma individual" assemelha-se a uma "biblioteca"45. Gustave de Borda "passou de fato sua vida com o sabre empunhado, temido pelos maus, mas doce com os bons e piedoso com os desafortunados". E o habilidoso esgrimista "não lançava mão de sua extraordinária destreza com a espada senão para moderar os efeitos de sua força, da qual não abusava jamais"46. Finalmente, o compositor Camille Saint-Saëns: um artista de “jogos hábeis, desconcertantes, diábolicos e divinos", um "humanista musical" que se diverte dominando a música "como um deus e como o diabo"47. Poderíamos seguir enumerando ad aerternum as antinomias que os retratos proustianos proporcionam aos seus leitores, mas isso seria incorrer no risco da redundância. Nos parece clara a essa altura a ideia de que, em se tratando da obra jornalística de Marcel Proust, a todo momento a conformação da personalidade dos seres faz germinar grandes contrastes. E da costura dessas contraposições depende a força desse estilo, que, como tanto temos salientado, atinge sua unidade na amálgama de distintas, inúmeras e dinâmicas facetas de um mesmo ser. Alain de Lattre muito bem resumiu: o personagem proustiano é "em cada um muitos e muitos em cada um"; compreendê-lo passa pela oscilação entre essas duas instâncias da

\footnotetext{
44 Ibidem, p. 506-509.

45 Ibidem, p. 465.

46 Ibidem, p. 549.

47 Ibidem, pp. 385-386.
} 
personalidade, uma ida e vinda da "pluralidade à simplicidade"48. Contudo, os recentes esforços da crítica genética na arqueologia dos manuscritos de Proust mostram o quão equivocado estava de Lattre na década de 1980, quando afirmou que essa forma de conceber personagens equivale a um "nó desconcertante de relações aleatórias", sem "nenhuma lógica, nenhuma probabilidade"49. Proust possui um raro domínio racional de sua criação. A gênese de sua obra pode revelar tudo, menos um escritor a seguir influxos desordenados ou aleatórios. Ainda assim, até mesmo uma teórica como Enid Marantz, das mais ferrenhas críticas de Lattre, não hesita em reconhecer que Proust "não se conformava [...] com os contornos de personagens que deveriam obedecer aos imperativos de uma natureza predeterminada" 50 .

Até aqui, a propósito dos retratos de Marcel Proust e dos perfis de Jorge Andrade, se falou dos mecanismos de enaltecimento do modelo, a torná-lo alguém suficientemente especial para ocupar o espaço das páginas de jornais e revistas; do uso da linguagem referencial, a contribuir para um efeito de verossimilhança e de adesão do texto ao método jornalístico; do descolamento entre os níveis físicosuperficial e psicológico-profundo para compor o retrato de um entrevistado, a permitir que as aparências sejam - no máximo - índices de uma essência distinta e oculta; e, finalmente, dos obstáculos intrínsecos à busca dessas mesmas essências. Todas essas características da constituição da realidade em Proust se inscrevem, como dissemos na abertura desse estudo, na mesma linhagem estilística das Mémoires de Louis de Rouvroy, o duque de Saint Simon. Não seria pertinente nos

\footnotetext{
48 LATTRE, Alain de. Le Personnage proustien. Paris: José Corti, 1984, p. 20.

${ }^{49}$ Ibidem, pp. 21, 26.

50 MARANTZ, Enid. La Genèse du personnage proustien. Bulletin Marcel Proust, Illiers-Combray, n. 53, 2003, p. 53.
} 
alongarmos muito nos comentários a seus diários (são oito tomos na edição da Bibliothèque de la Pléiade), mas convém ressaltar certos modos de descrição que séculos depois os leitores de Proust encontrariam em sua obra. No ensaio Das unterbrochene abendessen, Erich Auerbach define os diários de Saint Simon como um caso bastante particular da literatura francesa setecentista ${ }^{51}$. No auge do moralismo francês, esse autor teria composto em sua obra uma complexidade psicológica bastante inovadora que apenas o século XX lograria recuperar. A base de seu estilo residiria em um esforço pela condensação do caráter de um retratado, de modo que suas lembranças passam a ser encadeadas e enumeradas num fluxo memorialístico volumoso e bastante livre, onde traços por vezes contraditórios ou pouco harmônicos se coadunam. Suas personagens sempre operam um "contraste entre o efeito buscado e o efeito real da ação", produzindo uma "forma sintática" caracterizada pela introdução de uma série de "antíteses semânticas". A crença de Saint Simon é de que, somando lembranças num tempo imediato, conforme elas lhe ocorrem, em uma "acumulação desorganizada", o todo "formará uma imagem homogênea e clara". Disso deriva um sentido de hibridismo cuja síntese é bastante "imprevisível" e que pode ser resumida na seguinte formulação de Auerbach: "o físico é sempre significativo do caráter, o ser interior não é nunca, ou muito raramente descrito sem suas manifestações sensíveis, e, com frequência, as duas ordens se fundem em uma única palavra ou em uma única imagem [...]"52. É preciso ponderar que, para alguns, a assimilação das Mémoires de Saint-Simon por Proust pode não ser tão direta quanto somos levados a crer. Em um estudo da década de

51 AUERBACH, Erich. Das unterbrochene Abendessen. In: Mimesis: Dargestellte Wirklichkeit in der abendländischen Literatur. Tübingen: Francke Verlag, 2001, p. 386 sqq.

52 "das äußere Merkmal hat immer charakterologischen Audruckswert, das innere Wesen wird nie oder sehr selten ohne seine sinnlichen Erscheinungsformen geschildert, und oft verschmilzt beides in einem einzigen Wort oder Bild [...]". AUERBACH, Erich. Op. cit., p. 395. 
1960, Herbert de Ley demonstra como Proust não apenas leu as Mémoires de maneira bem mais esparsa, fragmentária e diminuta do que se pode imaginar ${ }^{53}$ como também se esforçou para evitar "fazer as vezes de Saint-Simon"54. No entanto, o alinhamento do estilo proustiano com a representação dos seres em Saint-Simon é tão forte, a visão de realidade que os dois autores partilham é tão convergente que mesmo as reservas de Herbert de Ley cedem, e seu argumento se vê obrigado à seguinte conclusão: "assim, a libertação de Proust do estilo e da visão de Saint-Simon foi incompleta. Em seu grande romance, Proust cede mais do que imagina ao seu apreço pelas Mémoires e encontra mais do que poderíamos imaginar aquilo que desejara abandonar"55.

Resta ainda nos debruçarmos sobre um derradeiro aspecto marcante da forma como esses dois autores buscam representar a realidade, e que, em última instância, nos ocorre como uma manifestação plástica dos princípios estéticos que estudamos. Trata-se do olhar dos personagens, seus sorrisos, enfim, a forma como suas faces são apresentadas. Vejamos a seguinte passagem, extraída do artigo Une grand-mère, publicado por Marcel Proust no Figaro de 23 de julho de 1907:

Elle se rendait si malade à se soigner qu'elle aurait peut-être mieux fait de prendre tout simplement le parti si compliqué d'être bien portante. Mais cela était au-dessus de ses forces. Dans les dernières

\footnotetext{
53 "Proust connaissait-il alors un tiers ou un quart des Mémoires ? Peut-être. Peut-être d'ailleurs en connaissait-il davantage. Cependant, la manière dont Proust se sert de son modèle suggère qu'il en connaissait plutôt moins" [Nesse sentido, Proust conhecia um terço ou um quarto das Mémoires? Talvez. Talvez, aliás, as conhecesse ainda mais. No entanto, a maneira como Proust lança mão de seu modelo sugere que ele as conhecia ainda menos]. $C f$. DE LEY, Hebert. Marcel Proust lecteur de Saint-Simon. Bulletin de la Société des amis de Marcel Proust et des amis de Combray, IlliersCombray, n. 16, 1966, p. 435.

54 "Dans le roman Proust a évité de "faire du Saint-Simon». Il a rejeté sur certains de ses personnages une partie du style et des préoccupations des Mémoires" [Em seu romance, Proust evitou "fazer as vezes de Saint-Simon". Ele recusou em alguns de seus personagens uma parte do estilo e das preocupações das Mémoires]. Ibidem, p. 439.

55 "Ainsi la libération de Proust du style et de la vision de Saint-Simon a été incomplète. Dans son grand roman Proust cède plus qu'il ne croit à son goût pour les Mémoires et rencontre plus que l'on ne l'aurait cru ce qu'il avait voulu abandoner". Ibidem, p. 440.
} 
années ses yeux ravissants, qu'elle avait couleur de jacinthe, tout en reflétant de plus en plus ce qui se passait en elle, cessèrent de lui montrer ce qui se passait alentour : elle était devenue presque aveugle. Du moins, elle l'assurait. Mais moi je sais bien que si Robert avait seulement un peu mauvaise mine, elle était toujours la première à s'en apercevoir!56

Dissemos há pouco que, nesse artigo, Proust traça o retrato de Madame de Rozière, avó do jornalista Robert de Flers, editor do Figaro e seu amigo íntimo desde os tempos de estudante secundário no Lycée Condorcet, em Paris ${ }^{57}$. 0 texto se justifica no jornal como uma homenagem por ocasião de sua morte e é publicado no dia de seu sepultamento no castelo da família, na comuna de MalzieuVille. Mas sua importância literária ultrapassa a condição de prova biográfica da leal amizade que Proust alimentou por toda a vida com Flers. Tadié, por exemplo, lança mão da crítica genética e considera que esse artigo "anuncia o texto da Recherche a respeito da avó" do narrador, presente em Le côté de Guermantes. E podemos ainda entrever a percepção do modelo em perspectiva, de que, há pouco, tanto se falou, no momento em que o escritor distingue aquilo que "se passait en

56 Era-lhe tão penoso tratar-se que talvez teria feito melhor se decidisse simplesmente pelo caminho bastante complicado de ser saudável . Mas isso estava além de suas forças. Nos últimos anos, seus olhos brilhantes cor de jacinto, ainda que mostrassem cada vez mais o que havia nela, deixaram de lhe mostrar o que havia ao redor dela: estava quase cega. Ela o jurava, pelo menos. Mas eu sei bem que, se Robert tivesse apenas um pouco de enxaqueca, ela era a primeira a se dar conta! CSB, p. 547.

${ }^{57}$ Ressalte-se a frutífera correspondência mantida entre os dois, especialmente a carta endereçada por Proust a Flers, nos dias 6, 7 ou 8 de novembro de 1913 (a data não é certa), na qual pede que o lançamento de seu livro seja noticiado na coluna de notas do Figaro, intitulada Échos de Paris. 0 texto é de suma importância à crítica proustiana uma vez que, nele, o autor expõe a Flers sua visão global do projeto de À la recherche du temps perdu: «Mon livre paraît le 14 et ceci est une "indiscrétion» littéraire (langage d'éditeur). L'ouvrage total s'appellera à la Recherche du Temps Perdu [...] Ce qu'il faut dire ce que ce ne sont nullement mes articles du Figaro mais un roman à la fois plein de passion et de méditation et de paysages. Surtout c'est très différent des Plaisirs et les jours et n'est ni « délicat », ni « fin ». Cependant une partie rassemble (mais en tellement mieux) à la Fin de la jalousie » [Meu livro será lançado no próximo dia 14 e é uma "indiscrição" literária (jargão de editor). A obra completa se chamará Em busca do tempo perdido [...]. 0 que é preciso dizer é que não são de modo algum meus artigos do Figaro, mas sim um romance repleto tanto de paixão, quanto de meditação e de paisagens. É, acima de tudo, muito diferente de Os Prazeres e os dias, não é nem "delicado", nem "fino". No entanto, uma parte se parece (mas muito melhor) com $O$ Fim do ciúme]. Corr., XII, pp. 298-299. 
elle" daquilo que "se passait alentour". Sem contar a marca da primeira pessoa ("mais moi je sais bien..."), atentando-nos, a despeito da marca forte das metáforas, isto é, do uso poético da linguagem, para o que há de referencialidade no retrato. Entenda-se, a certificação de uma convivência com o modelo representado. Foquemos, não obstante, o tratamento que Proust provê aos olhos do modelo. Eis uma fonte de encantamento ("ravissants"). Mais que instrumento de apreensão do mundo, o narrador os prioriza como "fendas" através das quais o mundo exterior tenta adentrar ou mesmo vislumbrar a essência da personagem. Acima de tudo, o tempo ("les dernières années") fez com que refletissem o que há "nela" muito mais que o contrário. E, mesmo quando a cegueira a acomete, a forma de percepção que o narrador valoriza, aquela que apreende sentimentos e estados de espírito ("elle était toujours la première à s'en apercevoir!"), acaba mantida. Tadié afirma que, em Proust, "o olhar poético remete a certos elementos naturais, flores ou pedras, não a uma significação psicológica"58. Isso é verdadeiro quando se pensa uma metáfora presente nesse mesmo retrato, como "ses yeux ravissants, qu'elle avait couleur de jacinthe", ou mesmo de outros textos esparsos, por vezes sequer publicados em vida por Proust. Caso do Portrait du Prince Léon Radziwill59, no qual o jovem aristocrata de origem polonesa tem seus olhos descritos como "si expressivement inexpressifs, comme ceux des statues grecques, petites excavations où la mer en se retirant a laissé deux petites flaques couleur de pierres précieuses, émeraudes ou saphirs selon l'heure, prendrait la morne hébétude du crétinisme endurci" 60. Parece, contudo, difícil justificar uma ausência de

\footnotetext{
58 "Le regard poétique renvoie à certains éléments naturels, fleurs ou pierre, non à une signification psychologique". TADIÉ, Jean-Yves. Op. cit. p. 89.

59 CSB, p. 474.

60 Os olhos, tão expressivamente inexpressivos, como aqueles das estátuas gregas, pequenas escavações nas quais o mar, ao recuar, abandonou duas pequenas poças cor de pedras preciosas,
} 
"significação psicológica" quando se pensa no "tout en reflétant de plus en plus ce qui se passait en elle", do retrato de Madame de Rozière, indicando o olhar muito mais como veículo, canal de acesso a uma dimensão interior e profunda do que mero adorno ou arroubo estilístico a destacar a personagem de um conjunto maior de seres. É o que nota, afinal, Colette Rougerie em seu estudo sobre as estruturas simbólicas dos rostos dos personagens de À l'ombre des jeunes filles en fleurs. Longe de mero estetismo, de mera fruição do belo, essas imagens revelam um narrador "fascinado" por faces e que "parte rumo à conquista de suas verdades". Com elas, o narrador-protagonista Marcel (e acreditamos que também o jornalista Marcel Proust) "se dirige ao próprio cerne de cada rosto para deles apreender a visão interior". Isso porque, acima de tudo, o que motiva sua busca de elementos faciais é uma "angústia”, um “desejo" de conhecimento absoluto61.

Todos os perfis de Jorge Andrade abordam o olhar de seus modelos. Mas, em poucos, sua concepção para esse traço facial surge tão clara quanto em Ela é a mãe de Pinky?, publicado em Realidade em setembro de $1971^{62}$. Trata-se de um perfil duplo. Sua entrevistada não é apenas a modelo Danuza Leão, mas também sua filha, Débora Weiner, de dezesseis anos, apelidada de Pinky, de sorte que a todo momento nos sentimos diante de um quadro da relação particular entre uma mãe

esmeraldas ou safiras a depender da hora, capturavam a morna letargia de uma estupidez enrijecida. $C S B$, p. 475. É bastante curiosa a semelhança entre a metáfora empregada por Jorge Andrade no perfil do escritor Murilo Mendes e esta que Marcel Proust compõe para o Portrait du prince Léon Radziwill. Se Proust, de um lado, vê seu modelo como uma "statue grecque" cujo interior segreda "délicatesses extrêmes", Jorge Andrade descreve seu entrevistado, após passar dias ao seu lado em Roma, como dono de aparência "marmórea". Diz o narrador de Jorge Andrade em certa altura: "o sorriso que se esconde no rosto marmóreo, estatuário, continua sempre presente. Agora, às portas das termas [de Diocleciano, em Roma], ele se acentua ainda mais. Por um momento, lembra o enigma da expressão das estátuas que permanecem através dos tempos". E, mais além: "as linhas de sua alma, muriladas em pedra juiz-forana, se transfiguram em arte ocidental, em poemas brasileiros". R.R., agosto de 1972, pp. 82, 86.

61 ROUGERIE, Colette. Les structures symboliques du visage dans "À l'ombre des jeunes filles en fleurs". Bulletin de la Société des amis de Marcel Proust et des amis de Combray, Illiers-Combray, n. 22, 1972, p. 1468.

${ }^{62}$ R.R., setembro de 1971, pp. 24-30. 
e sua filha. Diz-se particular porque, nesse perfil, as categorias familiares raramente se apresentam rijas. Há uma constante oscilação entre as imagens da filha e da mãe. Pinky, apesar da aparência jovem, assume por vezes postura maternal. Danuza, em que pese a meia-idade, veste-se como adolescente e vive crises de maturidade. Que mais busca o título do perfil, em seu trocadilho, senão salientar justamente esse conflito entre aparência e essência? Danuza, mãe de Pinky: na ambiguidade entre uma locução adjetiva e um complemento nominal, somada à homofonia entre a cor pink e o apelido Pinky, entrevê-se a mãe vaidosa temendo o envelhecimento, no conflito com os hábitos e com a estética de uma geração a que pertence tão somente sua filha. Isso sem contar a interrogação, a colocar em xeque os dois estatutos de Danuza Leão: tanto o de mãe quanto o de mulher jovem e arrojada. Todas essas questões, responsáveis pela estruturação do sentido do texto de Jorge Andrade, impactam a configuração dos rostos de seus personagens. Vejamos a forma como Andrade descreve os olhos de Pinky:

Pinky, ou Débora, dezesseis anos, 1,75 $m$ de altura, olhos azuis, olhos de raposa que se movimentam horizontalmente, misteriosos. Vestida simplesmente, despenteada, descalça e encolhida no sofá. Põe o prato em cima da mesa, acende um cigarro. Mantêm-se silenciosa, olhando o mar que invade o apartamento ${ }^{63}$

Depois os de Danuza Leão:

Os movimentos são elásticos, abertos, e, quando para, parece plantada no chão, saindo dele como um coqueiro. Não pretende ser bonita, apenas jovem - mas, é: o conjunto obedece a uma harmonia que vem do descontraído, do estar no mundo e gostar de estar nele. Olha os outros nos olhos. E, quando cumprimenta, pega mesmo em nossa mão, não como uma concessão, mas como comunicação $0^{64}$

63 Ibidem, p. 27.

${ }^{64}$ Idem. 
Não é difícil perceber as diferenças que uma e outra representação do olhar carrega em cada um desses casos, integrantes de um mesmo texto. A descrição de Pinky lembra muito o tipo de caracterização que encontramos num romance realista da estirpe de Le père Goriot. Idade, altura, gênero, vestimenta... categorias representativas do que Henry Amer chamou de "estilo balzaquiano" de descrição ou, ainda, de "método realista tradicional", uma vez que visa apenas "o pitoresco" da pessoa, num esforço de demonstrar que "a aparência é uma manifestação da verdade" 65 . Aliás, ressalte-se que uma metáfora da ordem de "olhos de raposa" se acomoda muito bem nos moldes naturalistas apregoados por Balzac no AvantPropos de sua Comédie Humaine, quando aproxima tipos sociais de tipos biológicos e se questiona se "a sociedade não produz do homem, de acordo com os meios nos quais sua ação se desenrola, tantos homens diferentes quanto há variedades na zoologia?"66. Isso não torna a descrição menos proustiana, bem entendido, na medida em que, como já sublinhamos, a tendência da descrição do olhar em Proust é também de associá-los, sob a forma de figuras de estilo, a elementos da natureza. O que coincide com uma observação que o próprio Amer faz a seus leitores, de que, ao menos em parte, são fortes os traços balzaquianos mesmo nos retratos proustianos, pois o narrador da Recherche também se mostra, por vezes, muito interessado no "aspecto característico da pessoa"67. Mas o mesmo tipo de

\footnotetext{
${ }^{65}$ AMER, Henry. Littérature et portrait: Retz, Saint-Simon, Chateaubriand, Proust. Études Françaises, Montréal, v. 3, n. 2, 1967, p. 150.

66 "La Société ne fait-elle pas de l'homme, suivant les milieux où son action se déploie, autant d'hommes différents qu'il y a de variétés en zoologie?" [A sociedade não produz do homem, de acordo com o meio no qual sua ação se desenrola, tantos homens diferentes quanto há variedades na zoologia?]. BALZAC, Honoré de. La Comédie Humaine. Vol. I. Paris: Gallimard, Bibliothèque de la Pléiade, 1976, p. 8.

${ }^{67}$ AMER, Henry. Op. cit., p. 158. É o que vemos em inúmeras passagens de Le côté de Guermantes, quando o narrador busca delimitar o que há de mais típico, particular, pitoresco e geral num "clã familiar" como aquele dos Guermantes: "tous les Guermantes, de ceux qui l'étaient vraiment, quand
} 
percepção já não se tem quanto ao olhar de Danuza Leão. Se, em Pinky, os olhos servem à sua caracterização típica, em Danuza eles operam à moda da outra faceta descritiva de Proust, de ordem psicológica e subjetiva, que é justamente aquela que o distingue de seus predecessores realistas. Não sabemos como são seus olhos do ponto de vista físico, mas compreendemos aquilo que significam da perspectiva mais profunda de sua personalidade. "Olha os outros nos olhos", conotando franqueza, retidão de caráter, humildade, muito mais que traços de sua exterioridade e aparência. E, mesmo quando a descrição do olhar de Danuza começa a se insinuar como algo físico, a exemplo da passagem "Danuza sorri, os seus olhos cinzentos se tornam frios"68, é um estado de espírito, uma condição subjetiva, um traço de uma alma o que o narrador leva o leitor a entrever através das fendas da máscara superficial de sua entrevistada. Em resumo, no que diz respeito à representação da face de personagens e modelos, especialmente de seus olhares, temos nos perfis de Jorge Andrade marcas que remetem às duas principais maneiras como tal preocupação se manifesta nas descrições proustianas. Primeiro, as metáforas com elementos da natureza - pedras preciosas, flores e, por vezes, mesmo animais -, trazendo à tona o que ainda sobrevive de balzaquiano na representação da realidade em Proust. Depois, os olhos como veículos de acesso a uma interioridade mutável, escondida, a ser revelada - típica pincelada proustiana.

on vous présentait à eux, procédaient à une sorte de cérémonie, à peu près comme si le fait qu'ils vous eussent tendu la main eût été aussi considérable que s'il s'était agi de vous sacrer chevalier. Au moment où un Guermantes, n'eût-il que vingt ans, mais marchant déjà sur les traces de ses aînés, entendait votre nom prononcé par le présentateur, Il laissait tomber sur vous, comme s'il n'était nullement decidé à vous dire bonjour, un regard généralement bleu, toujours de la froideur d'un acier qu'il semblait prêt à vous plonger dans les plus profonds replis du coeur" [Todos os Guermantes, dentre os verdadeiros, quando éramos apresentados a eles, procediam com uma espécie de cerimônia, quase como se o fato de nos terem estendido a mão tivesse sido tão honrável quanto nossa consagração como cavaleiros. No momento em que um Guermantes, com vinte anos no máximo, mas já caminhando sobre as pegadas de seus antecessores, ouvia nossos nomes serem pronunciados pelo apresentador, sempre despejava sobre nós, como se, de modo algum, estivesse certo a nos cumprimentar, e com uma expressão geralmente pálida, a frieza de uma barra de aço que ele parecia prestes a fazer mergulhar nas dobras mais profundas do coração]. R.T.P., II, p. 736.

68 R.R., setembro de 1971, p. 29. 
Tem-se assim que, tanto Marcel Proust quanto Jorge Andrade, ao se proporem a retratar figuras notáveis e célebres do universo social de seu tempo, fiaram-se em técnicas descritivas bastante semelhantes. Seja nas páginas de jornais e revistas da Belle Époque parisiense, seja na revista Realidade durante o mais severo momento da ditadura civil-militar brasileira, ambos buscaram ressaltar, em seus textos, traços que distinguiam seus entrevistados; nunca furtaram-se ao uso da primeira pessoa como indicativo da convivência com os modelos; descreveram aspectos das faces das pessoas a partir de metáforas com elementos da natureza e os conceberam como meio de acesso a um nível mais profundo de personalidade; por fim, o que se mostra ainda mais relevante: souberam descolar a aparência externa das características subjetivas de uma pessoa, sensíveis às transformações que uma e outra sofrem sob os efeitos da passagem do tempo. 


\title{
III. Torreões e bibliotecas
}

\section{Contribuições do jornalismo ao romance de Marcel Proust e Jorge Andrade}

\begin{abstract}
Sans doute s'il n'avait pas eu ces yeux, le visage de M. de Charlus était semblable à celui de beaucoup de beaux hommes. Et quand Saint-Loup en me parlant d'autres Guermantes me dit plus tard: 'Dame, ils n'ont pas cet air de race, de grand seigneur jusqu'au bout des ongles, qu'a mon oncle Palamède', en confirmant que l'air de race et la distinction aristocratiques n'étaient rien de mystérieux et de nouveau, mais qui consistaient en des éléments que j'avais reconnus sans difficulté et sans éprouver d'impression particulière, je devais sentir se dissiper une de mes illusions. Mais ce visage, auquel une légère couche de poudre donnait un peu l'aspect d'un visage de théâtre, M. de Charlus avait beau en fermer hermétiquement l'expression, les yeux étaient comme une lézarde, comme une meurtrière que seule il n'avait pu boucher et par laquelle, selon le point où on était placé par rapport à lui, on se sentait brusquement croisé du reflet de quelque engin intérieur qui semblait n'avoir rien de rassurant $[. . .]^{1}$
\end{abstract}

O retrato do barão de Charlus compõe uma das várias cenas da estadia do herói Marcel no balneário de Balbec. São imagens de sua juventude, da aprendizagem de prazeres sensoriais e mundanos. Assistimos, dentre tantos, ao episódio de sua embriaguez no jantar de Rivebelle, na companhia de Robert de Saint-Loup ("l'ivresse réalise pour quelques heures l'idéalisme subjectif, le

\footnotetext{
${ }^{1}$ Sem dúvida, se não possuísse aqueles olhos, o rosto do senhor de Charlus seria semelhante ao de vários belos homens. E, quando Saint-Loup, conversando comigo sobre outros Guermantes, me disse mais tarde: 'minha nossa, eles não têm esse espírito de raça, de grande senhor até o último fio de cabelo, que possui meu tio Palamède', confirmando que o espírito de raça e a distinção aristocrática não eram de modo algum mistério ou novidade, mas, sim, elementos que eu havia reconhecido sem dificuldade e sem experimentar uma impressão particular, eu acabaria por sentir a dissipação de uma de minhas ilusões. Mas esse rosto, ao qual uma fina camada de pó atribuía um pouco o aspecto de um rosto de teatro, o senhor de Charlus poderia até mesmo lhe cerrar hermeticamente a expressão, seus olhos eram como uma fenda, como a única seteira que não pôde obstruir e através da qual, de acordo com o ponto no qual nos posicionávamos em relação a ele, nos sentíamos bruscamente atravessados pelo reflexo de alguma máquina interior que não parecia possuir nada de seguro [...]. R.T.P., II, pp. 119-120.
} 
phénoménisme pur"2), ou mesmo aos inúmeros instantes em que expressa sua atração por Albertine e suas amigas, Andrée e Gisèle ("son amie avait des yeux extraordinairement clairs, comme est dans un appartement à l'ombre l'entrée, par la porte ouverte, d'une chambre où donnent le soleil et le reflet verdâtre de la mer illuminée"3). São passagens de sua gradual introdução ao restrito clã dos Guermantes, permeadas por toda forma de choque que um novo conhecimento, na visão proustiana, é capaz de gerar. Seja por meio da frustração de expectativas ou pela confirmação de impressões alimentadas na infância, o fato é que o narrador começa a concretizar, trazer ao universo terreno o antigo ideal onírico da criança que, ainda em Combray, assistindo ao casamento da filha de madame de Guermantes, se via tomada por um grande e pueril encantamento ${ }^{4}$. 0 efeito é tributário do plus-que-parfait ("j'avais reconnus"), que sobrepõe uma dimensão pretérita a outra, proporcionando as condições para que duas percepções distintas de um mesmo ser, no passado, sejam comparadas e eventualmente contrapostas. Essa poética, fundada no deslocamento de um ideal a uma realidade complexa, produto das permanências e transformações que tal movimento enseja na construção do caráter dos personagens proustianos, atribui sentido ao temor e ao enigma que emanam do encontro com Charlus. Para esse herói, todo ser é, por

\footnotetext{
${ }^{2}$ A embriaguez realiza por algumas horas o idealismo subjetivo, o puro fenomenalismo [...]. Ibidem, p. 173.

${ }^{3}$ Sua amiga tinha olhos extraordinariamente claros, assim como, em um apartamento sob a penumbra, a entrada, através de uma porta aberta, de um quarto no qual batem o sol e o reflexo verde do mar iluminado. Ibidem, p. 237.

4 Faço alusão ao seguinte excerto: "mais elle, je la revois, surtout au moment du défilé dans la sacristie qu'éclairait le soleil intermittent et chaud d'un jour de vent et d'orage, et dans laquelle Mme de Guermantes se trouvait au milieu de tous ces gens de Combray dont elle ne savait même pas les noms, mais dont l'infériorité proclamait trop sa suprématie pour qu'elle ne ressentît pas pour eux une sincère bienveillance, et auxquels du reste elle espérait imposer davantage encore à force de bonne grâce et de simplicité" [mas ela, eu a revejo sobretudo no momento do desfile na sacristia que iluminava o sol intermitente e morno de um dia de vento e trovoadas, e na qual madame de Guermantes se encontrava no meio de toda essa gente de Combray cujo nome ela sequer conhecia, mas cuja inferioridade proclamava demais sua supremacia para que ela não sentisse por eles um sincero afeto, e sobre os quais, no mais, ela esperava se impor cada vez mais através da força de sua graça e simplicidade]. R.T.P., I, p. 175.
} 
essência, um fingidor. Como ele próprio afirma, o tempo leva algumas ilusões a se esvaírem e conduz cada vez mais à aproximação de uma realidade por princípio inatingível. Nessa insolúvel condição humana, segundo a qual se tenta alcançar o inalcançável, é que se enraíza uma passagem da estirpe de "M. de Charlus avait beau en fermer hermétiquement l'expression [...], on se sentait brusquement croisé du reflet de quelque engin intérieur". Ela guarda em seu cerne uma contradição fundamental, que é estar fadado a sempre se entrever algo ainda que hermeticamente isolado e protegido. Ou ainda, a maneira quase que espontânea e involuntária com que nossas verdades, ainda que absolutamente protegidas, se lançam ao mundo e se modificam de acordo com "o ponto" no qual nossos interlocutores se posicionam, isto é, suas condições psicológicas em dado instante do tempo. Antes mesmo disso, o rosto de Charlus é associado também a uma máscara de teatro e seus olhos se aproximam do que seria uma fresta. A real essência do personagem se encontra revestida, encoberta ou mesmo, se preferirmos, "maquiada". A única via de acesso ao seu interior é, por definição, estreita e atravessa toda a vasta espessura de uma muralha. Por essa fenda, não se pode mais que entrever o que ele chama de "engin intérieur", o maquinário que move a personagem, sua essência profunda, e cuja lógica de funcionamento, à primeira vista, soa incompreensível ao narrador. 0 herói, assim, reconhece as barreiras intransponíveis que vê se erguerem a sua volta sempre que deseja compreender alguém. Salta aos olhos sua cautela e notamos o quão forte é sua insegurança diante do que pode vir a se deparar ao tentar submergir na consciência de um personagem.

Comentávamos vários desses traços de estilo há pouco em nosso estudo sobre os retratos jornalísticos de Proust. A publicação do retrato de Charlus em $\grave{A}$ 
l'ombre des jeunes filles en fleurs pode até remontar a 1919, mas vários desses princípios da representação proustiana da realidade já se faziam presentes nos artigos de jornal. A repartição do ser em múltiplas camadas, algumas mais superficiais, outras mais profundas, e o estabelecimento de uma relação adversativa ou complementar entre elas são alguns dos aspectos mais aparentes. Mas há também a busca do narrador por uma essência misteriosa, de difícil acesso, assim como a função enganadora das aparências. 0 retrato do barão de Charlus e tantos outros excertos semelhantes mostram como uma determinada chave de compreensão do ser humano e da vida resistem às fronteiras dos gêneros e se fazem presentes em distintas modalidades textuais. Talvez porque seja equivocado afirmar que Proust se dedicou primeiro ao jornalismo e depois ao romance, como se toda a questão de sua estética pudesse ser resumida a uma evolução linear de sofisticação atravessando distintos gêneros. 0 trabalho de Yuri Cerqueira dos Anjos é bem claro ao demonstrar que as duas atividades, a de articulista da imprensa e romancista, quase sempre se entrecruzaram, de modo que a complexa experiência jornalística nas páginas da imprensa parisiense também participava da gestação de um grande projeto romanesco5 ${ }^{5}$ Há, enfim, uma continuidade do estilo, uma convergência nas formas de representação do ser humano no romance e no jornal. É difícil encontrar um modelo dos retratos jornalísticos de Proust que, à

\footnotetext{
${ }^{5}$ Não destacamos o advérbio também por acaso. Cumpre bem delimitar o argumento desse autor. Segundo Anjos, a função experimental era uma dentre várias pertinentes à produção jornalística de Proust. 0 foco de seu estudo é, com efeito, a complexa e nem sempre pacífica inserção do escritor na imprensa de seu tempo, um encaixe, a seu ver, "compósito, fragmentário, instável e intermitente". Dessa feita, se bem compreendo seu raciocínio, o que propõe é sobretudo uma ponderação: a leitura de tais artigos de imprensa somente como "laboratório romanesco" poderia se revelar um grande "anacronismo" ou "desconhecimento" de todo um contexto mediático. Ou seja, não se nega o que chama de "effet-brouillon" [efeito rascunho], aqui nosso objeto primordial de atenção. Longe disso: ele existe e é um recorte possível. Apenas se propõe que sejam somadas outras perspectivas (contextuais) capazes de comportar a grande complexidade de uma parcela da obra proustiana por muito tempo submetida como "massa incoerente" de textos à hegemonia do romance. Cf. ANJOS, Yuri Cerqueira dos. Proust et la presse de la Belle Époque. Paris: Honoré-Champion, 2018, pp. 54, 243.
} 
semelhança de Charlus, não faça entrever um "engin intérieur" e que, com sua volatilidade, não surpreenda o narrador. Nós vimos isso no "je ne pouvais comprendre" do retrato de Alphonse Daudet ${ }^{6}$ e na "production mystérieuse de ces sons indéfinissables" do retrato da condessa de Guerne ${ }^{7}$. Mas, mesmo no mais longínquo dos artigos que estudamos, o retrato do compositor Camille Saint-Saëns, publicado no Le Gaulois de 14 de dezembro de 1895 (mais de duas décadas, portanto, anterior à publicação de À l'ombre des jeunes filles en fleurs), já se lê a preocupação do narrador com a busca de uma essência interior e seu princípio de fugacidade. Com ares de misticismo, Proust compara Saint-Saëns a um gnomo e se questiona: "va-t-il maintenant échapper aux prises de ma pensée qui cherche à le saisir, et ne me laissera-t-il, entre les mains, comme un lutin disparu, que 'du vent'?"8. Notemos a força expressiva do pronome em "le saisir". Muito falamos de consciência, essência, interioridade, verdades, mas Proust é capaz de ser ainda mais enfático e preciso. A concretude de um pronome como esse demonstra que é do homem total que sua consciência sai à caçada. Uma empresa cujo malogrado destino, por sinal, é dado desde o início. Não terá entre os dedos senão o vento e estará fadado para sempre a perseguir mistérios. Enigmas como as profundezas de Charlus, das quais só se tem uma fugaz suspeita, tão somente um indício, e que se escondem, e que nos enganam, obrigando-nos a espreitar rostos, posicionarmonos a partir de diferentes ângulos, e, ainda assim, sem qualquer possibilidade de sucesso.

\footnotetext{
${ }^{6}$ CSB, p. 400.

7 Ibidem, p. 504.

${ }^{8}$ Será que ele agora não escapará das amarras de meu pensamento, que busca apreendê-lo, e não me deixará somente com “vento" entre as mãos, como um duende fugidio? Ibidem, p. 385.
} 
O laboratório de estilo que constituem os retratos proustianos não deve ser compreendido, no entanto, somente in abstracto. Proust demonstra ter consciência do caráter experimental desses textos e não negligencia a possibilidade de reaproveitá-los na construção de seu projeto mais ambicioso e complexo. Significa dizer que a convergência estética que observamos entre textos jornalísticos e romanescos também se dá, em alguma medida, de modo positivo. Há passagens quase integrais de retratos proustianos reproduzidas ao longo da Recherche, o que fornece a evidência empírica da continuidade de um estilo. 0 que dissemos até aqui não equivale a uma impressão, a uma mera interpretação diegética dessas narrativas. Entre o jornalismo de Proust e seu romance, há um esforço para a manutenção de uma estética, para a preservação da poética que tentamos descrever. 0 recurso aos manuscritos de Proust proporciona esse elo. Neles, a despeito de modificações mínimas, vemos trechos de retratos sendo incorporados à narrativa romanesca - seja para a configuração de um personagem, seja como parte de alguma reflexão mais ampla e geral do herói Marcel.

O caso mais notável dessa conexão entre o jornalismo proustiano e seu romance nos parece a descoberta de Nathalie Mauriac ao se debruçar sobre o retrato Le salon de la princesse Edmond de Polignac: musique d'aujourd'hui; échos d'autrefois, publicado no jornal Le Figaro em 6 de setembro de $1903^{9}$. 0 seguinte excerto chamou particularmente sua atenção e exemplifica nosso argumento.

La nature, qui continue les races et ne prévoit pas les individus, lui avait donné un corps élancé. Un visage énergique et fin d'homme de guerre et d'homme de cour. Peu à peu le feu spirituel qui habitait le Prince Edmond de Polignac sculpta sa figure à la ressemblance de sa pensée. Mais son masque était resté celui de son

9 Cf. MAURIAC, Nathalie. Edmond de Polignac. In: TADIÉ, Jean-Yves (org.). Proust et ses amis. Paris: Gallimard, 2010, p. 217. 
lignage, antérieur à son âme individuelle. Son corps et sa face ressemblaient à un donjon désaffecté qu'on aurait aménagé en bibliothèque ${ }^{10}$.

A princípio, a descrição do príncipe Edmond de Polignac segue os pressupostos estilísticos que tanto já comentamos e, nesse sentido, não apresenta nenhuma grande novidade. Sua construção se dá a partir de uma grande antítese. Por um lado, há signos como "corpo esguio" e "face enérgica e fina de guerreiro e nobre" associando-se ao núcleo semântico da "linhagem" de Edmond de Polignac, o que se conecta a sua aparência física, aos traços que compartilha com os demais membros de sua "raça", e que não chega a se aprofundar ao nível do individual. Por outro lado, a convivência pregressa entre o narrador e o finado príncipe lhe revelara outras faces da mesma pessoa, por conseguinte, tornando-a mais complexa. Edmond de Polignac não se esgota em sua exterioridade "nobiliárquica". Eis, no máximo, um índice primeiro a convidar o narrador a imersões mais profundas, ao nível do psicológico. Ora, o "fogo espiritual" do príncipe se descola da imagem da "máscara de sua linhagem" e o personagem passa a manifestar uma "alma individual" distinta, quiçá oposta a tudo que sua superficialidade indica. Ao final do excerto, a combinação desses signos antitéticos, fruto da percepção de um narrador que permite ao seu modelo "mostrar-se de outra maneira" e "ser outro", para falar como Jean-Yves Tadié ${ }^{11}$, resulta em uma rica metáfora de Polignac: com a contaminação entre aparência física e essência espiritual, a partir dessa complexa

\footnotetext{
${ }^{10} \mathrm{~A}$ natureza, que prossegue as raças e não prevê os indivíduos, lhe havia dado um corpo esbelto. Um rosto enérgico e fino de homem guerreiro e nobre. Pouco a pouco, a chama espiritual que habitava o príncipe Edmond de Polignac esculpiu sua imagem à semelhança de seu pensamento. Mas sua máscara permaneceu aquela de sua linhagem, anterior a sua alma individual. Seu corpo e sua face assemelhavam-se a um torreão abandonado que teria sido transformado em biblioteca. Ibidem, p. 465.

${ }^{11}$ Cf. TADIÉ, Jean-Yves. Proust et le roman. Paris: Gallimard, 2003, p. 74.
} 
amálgama, o narrador conclui que "seu corpo e sua face se assemelhavam a um torreão desabitado na qual se poderia encontrar uma biblioteca".

Esse fragmento, no entanto, encerra mais um procedimento criativo bastante relevante. Se folhearmos as páginas de À l'ombre des jeunes filles en fleurs como o fez Mauriac, veremos que o príncipe Robert de Saint-Loup, um personagem da ficção, surge descrito através da mesma metáfora:

Sous la peau fine, la construction hardie, l'architecture féodale apparaissaient. Sa tête faisait penser à ces tours d'antique donjon dont les créneaux inutilisés restent visibles, mais qu'on a aménagées intérieurement en bibliothèque. ${ }^{12}$

A construção do período é distinta e, na passagem do retrato ao romance, com o desdobramento de duas orações (uma principal e sua subordinada adjetiva) em três (uma principal, uma subordinada adjetiva e uma subordinada adversativa), nos damos conta com maior clareza do "desenho em meandros" de que trata Leo Spitzer ${ }^{13}$ ao descrever a construção sintática dos períodos proustianos. De fato, a versão romanesca ganha maior precisão e a fluidez de sua nova organização sintática torna verossímil a imagem que sugere Spitzer, de um rio avolumando-se graças a uma multidão de afluentes que lhe complementam ${ }^{14}$. 0 único gesto de coesão é a contração de "son corps et sa face" em "sa tête". Todos os demais núcleos semânticos da passagem se encorpam e se alongam. 0 simples "donjon désaffecté" passa a integrar as "tours d'antique donjon" como núcleo do adjunto adnominal do complemento da oração; acrescenta-se a oração "dont les

\footnotetext{
${ }^{12}$ Sob a fina pele, surgiam a construção indômita, a arquitetura feudal. Seu crânio lembrava aquelas fortalezas de antigos torreões cujas ameias abandonadas permanecem visíveis, mas que, interiormente, foram transformadas em bibliotecas. R.T.P., II, p. 176.

${ }^{13}$ Cf. SPITZER, Leo. Stilstudien. Munique: Max Hueber Verlag, vol. II, 1961, p. 369.

${ }^{14}$ Idem.
} 
créneaux inutilisés restent visibles", antes inexistente; e a expressão “aménagé en bibliothèque" ganha o adjunto adverbial "intérieurement", índice de precisão espacial nada fortuito, nós bem vimos, em se tratando da imagem proustiana de uma face e a personalidade complexa que segreda. Contudo, o que mais salta aos olhos, a despeito de questões formais, é a apropriação no romance de uma metáfora concebida primordialmente durante a escrita de um texto jornalístico. E mais: uma metáfora que, de início, fora empregada na descrição de um ser da realidade e que, agora, surge, em essência imutável, na conformação de um personagem ficcional. Trata-se do uso de textos jornalísticos e da realidade objetiva que acreditam descrever como laboratório de experimentação literária, no qual recursos estilísticos, instrumentos estéticos, enfim, uma determinada visão poética do homem passa a se amadurecer. E tal passagem do jornal ao livro, como acima frisamos, não se dá de maneira ocasional. Ela não é, em outras palavras, uma simples coincidência, um acaso da criação literária. A continuidade estilística revela-se objeto de um esforço consciente do artista, que, embora outsider na imprensa15, vê a experiência jornalística como passo relevante em sua formação de escritor.

A equiparação dessas duas passagens torna bastante claro o que Mauriac chama de "transposição direta"16 na obra proustiana. E evidências genéticas e escriturais fazem de outros casos exemplos ainda mais evidentes e explícitos de como o jornalismo desempenha papel de relevo na construção da Recherche. Ainda no retrato do príncipe Edmond de Polignac, Mauriac identificou uma segunda contribuição para o romance, localizada logo após a metáfora dos torreões e

\footnotetext{
${ }^{15} \mathrm{Cf}$. ANJOS, Yuri Cerqueira dos. Op. cit., p. 63.
}

${ }^{16}$ Cf. MAURIAC, Nathalie. Op. cit., p. 222. 
bibliotecas, no instante em que o narrador rememora a decoração do funeral do modelo:

Je me souviens qu'au jour désolé de son enterrement dans l'église où les grands draps noirs portaient haut en écarlate la couronne fermée, la seule lettre était un P. Son individualité s'était effacée, il était rentré dans sa famille.

Il n'était plus qu'un Polignac ${ }^{17}$.

Seria redundante retornar ao debate sobre o divórcio que promove o estilo proustiano entre a aparência de um ser e sua interioridade. Sem nos aprofundarmos para além do que já foi dito, cumpre apenas observar que, uma vez mais, esse princípio estético aqui se faz presente. Na realidade, trata-se do esclarecimento da metáfora imediatamente anterior. 0 que víamos como a "biblioteca interior" se revela sob a forma da "individualidade" extinta com a morte. E os "torreões" e suas fortalezas nos são apontados como sua "família", simbolizada através de seu secular sobrenome, espécie de rótulo que o homogeneíza diante de seus pares. Em todo caso, o mais interessante é que Proust lida com esse excerto do retrato de Polignac de modo bastante semelhante ao que acabamos de expor com relação ao trecho anterior, citado logo acima. Notemos que os primeiros leitores de Le temps retrouvé, o último volume da Recherche, publicado postumamente em 1927, dificilmente se recordavam ou sequer conheceram esse artigo, impresso em 1906 e recuperado apenas em 1971 por Pierre Clarac e Yves Sandre para o Contre Sainte-Beuve da Bibliothèque de la Pléiade. No entanto, ao atravessar as páginas que narram o funeral de Saint-Loup,

\footnotetext{
17 Recordo-me que, no triste dia de seu funeral, na igreja onde grandes flâmulas negras ostentavam no alto, em escarlate, a coroa fechada, a única letra que havia era um "P". Sua individualidade fora apagada, ele havia regressado a sua família.
}

Ele não era mais que um Polignac. CSB, p. 465. 
morto nas trincheiras da Primeira Grande Guerra, era com a seguinte imagem que seus olhos se deparavam:

Et ce Guermantes était mort plus lui-même, ou plutôt plus de sa race, en laquelle il n'était plus qu'un Guermantes, comme ce fut symboliquement visible à son enterrement dans l'église Saint-Hilaire de Combray, toute tendue de tentures noires où se détachait en rouge, sous la couronne fermée, sans initiales de prénoms ni titres, le G du Guermantes que par la mort il était redevenu ${ }^{18}$.

Ora, uma vez mais o romance absorve uma construção originária do jornalismo de Proust. Poderíamos ressalvar que a formulação poética do excerto jornalístico é muito mais intensa do que a simples reorganização sintática do exemplo anterior. Não se trata de mero desdobramento de novas orações num mesmo período. Surgem elementos como a igreja de Saint-Hilaire, a cidade de Combray ou mesmo a família dos Guermantes - entidades ficcionais cultivadas ao longo de todo o ciclo romanesco e totalmente alheias à modesta narrativa do retrato de Polignac. 0 que importa, no entanto, é que estamos, a rigor, diante de uma mesma metáfora: o ser dividido entre aparências e essências cuja morte apaga a individualidade e eterniza a superfície aristocrática, simbolizada pela inicial de seu sobrenome (o rótulo atávico) encerrada no interior de uma coroa fechada. Proust preserva até mesmo a cor das bandeiras hasteadas em homenagem a seu amigo! Assim como no enterro do príncipe Edmond de Polignac, o grande G dos Guermantes figura rubro sobre um tecido negro. A clareza dessa aproximação bastaria para, uma vez mais afirmarmos o uso experimental do texto jornalístico

\footnotetext{
${ }^{18} \mathrm{E}$ esse Guermantes morreu sem ser mais ele mesmo, ou, pelo menos, sem ser mais que sua raça, na qual não era senão um Guermantes, como foi simbolicamente visível em seu funeral na igreja Saint-Hilaire de Combray, toda decorada com tapeçarias negras sobre as quais se sobressaía rubro, sem iniciais de nomes ou sequer títulos, o G de Guermantes que, pela morte, ele voltara a ser. R.T.P., IV, p. 429.
} 
por Proust. Mas, nesse caso, algo ainda mais forte e evidente logrou demonstrar Nathalie Mauriac, no momento em que localizou essa passagem de Le temps retrouvé em seus manuscritos. Na margem direita da página, no interior de um balão em destaque, Proust fez constar as seguintes observações: "voir ceci déjà écrit et l'article Polignac"19. É o lastro empírico do que há pouco chamávamos de continuidade estilística entre o jornalismo e o romance proustiano. 0 certificado, de acordo com Mauriac, de que o texto jornalístico, embora escrito muitos anos antes de Le temps retrouvé, serviria a esse autor em ocasião futura, aquela do desenvolvimento de um projeto romanesco de maior envergadura e sofisticação. Não se deve cair na tentação biográfica de afirmar que Saint-Loup é Polignac. Isso significaria desconsiderar toda a riqueza de um processo criativo, a "transposição direta" do jornal ao livro. Mais correto seria, tal como Mauriac afirma, julgar Polignac o protótipo de Saint-Loup, no sentido de um exemplar original, de uma versão preliminar no aguardo de seu aperfeiçoamento.

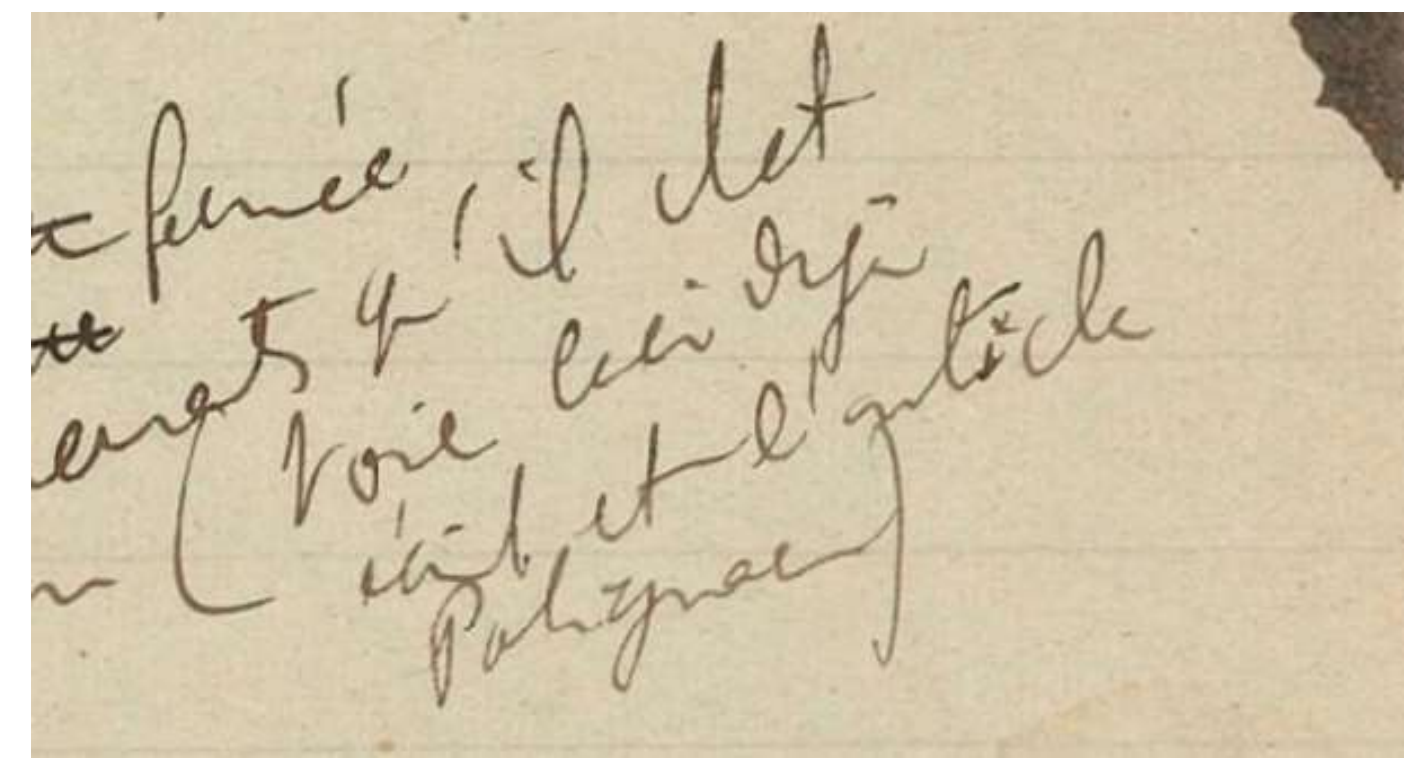

Figura 1 - Detalhe dos rascunhos de Le temps retrouvé (cahier 74, fo 126 vo)

\footnotetext{
${ }^{19}$ Ver o que já está escrito e o artigo Polignac. Cf. Cahier 74, fo 126 vo․
} 
Não pretendemos deixar a impressão de que há apenas um caso desse tipo de enlace entre jornalismo e romance. Nada poderia ser mais equivocado do que crer que definimos uma regra a partir de exceções. Os dois exemplos envolvendo o retrato Le Salon de la princesse Edmond de Polignac (um incorporado em À l'ombre des jeunes filles en fleurs e o outro absorvido em Le temps retrouvé), não são de forma alguma isolados ou pouco representativos de um procedimento criativo. Na realidade, quanto mais a crítica proustiana alarga suas fronteiras e se dedica aos textos menores e esparsos desse autor, mais pontes descobre entre o estilo jornalístico e o romanesco. A mesma sorte de "aproveitamentos" do retrato de Edmond de Polignac, por exemplo, pode ser verificada também com o estudo do artigo Les Éblouissements, publicado por Proust em 15 de junho de 1907 no suplemento literário do jornal Le Figaro. Não podemos ceder à tentação de classificá-lo como um retrato literário da condessa Anna de Noailles, ainda que, a todo instante, se entrecruzem interpretações poéticas sobre o fazer artístico e a caracterização do pensamento estético dessa dama da sociedade. Parece-nos bastante claro que se trata de um artigo de crítica literária debruçado sobre a leitura da antologia poética homônima de Noailles. Seria exagero depreender de sua leitura, como vemos em vários outros artigos jornalísticos de Proust, uma tentativa de apreensão de uma personalidade recôndita e profunda mascarada por aparências. De todo modo, os manuscritos originais desse artigo comportam um excerto suprimido da versão do jornal, mas que Proust reaproveita de maneira bastante elaborada em À l'ombre des jeunes filles en fleurs. Lemos o seguinte trecho nos manuscritos de Les Éblouissements, transcritos por Pierre Clarac e Yves Sandre para o Contre Sainte-Beuve de 1971: 
Je me souviens qu'un jour où je partais en voyage, ayant quitté Paris légèrement grisé par le vin dont un philosophe nous a dit qu'il nous donne momentanément la liberté, regardant du wagon les seins bombés des côteaux de Sèvres, le fleuve, l'arche immense du ciel, je les sentais reposer légèrement - de simples peintures - sur le globe de mon oeil qui saillait, s'offrant à porter bien d'autres fardeaux [...] sur sa surface délicate. Le cercle de mon regard se trouvait insuffisamment rempli par la sphère de l'horizon; tout ce que la nature m'apportait de vie dans les jours d'été me semblait un souffle bien chétif et court auprès de l'immense aspiration qui gonflait ma poitrine. La vie n'était pas hors de moi dans le monde; elle était en moi. Je n'étais pas perdu dans l'univers; l'univers était perdu dans mon coeur infini où je m'amusais dédaigneusement à le jeter dans un coin. Aussi, à cette minute, la pensée que je mourrais un jour, que la force éternelle qu'il y avait en ces côteaux, en ce fleuve, en ce soleil, me survivrait, et que je n'étais qu'un grain de poussière sous ses pieds divins, cette pensée me fit sourire. Comment pourrais-je durer moins longtemps que ces choses, comment pourraient-elles m'opprimer de leur puissance, puisqu'elles étaient en moi, puisque c'est l'univers qui était prisonnier et perdu au sein de ma conscience, comme ces coteaux et ce ciel ensoleillé reposaient sur mon oeil? Sans doute l'ivresse artificielle et vulgaire dont j'évoque ici la raisonnable frénésie ne peut donner qu'une idée bien imparfaite de l'inspiration qui possède Mme de Noailles [...]. Mme de Noailles a beau nous dire parfois qu'elle ne croit pas à l'éternité de la pensée et remplacer les vieilles croyances par des fables gracieuses [...], la philosophie à laquelle elle se rattache et qu'elle exprime quelquefois directement dans ses vers, est démentie ou tout au moins dépassée par une philosophie plus haute qui se dégage, qu'elle le veuille ou non, de sa poésie. Sans doute elle appelle son livre: "Les Éblouissements", mais si l'univers l'éblouit, elle sait rendre feu pour feu à toutes les clartés qu'il lui verse. ${ }^{20}$

\footnotetext{
${ }^{20}$ Recordo-me de um dia em que fui viajar, deixando Paris levemente atordoado pelo vinho, que um filósofo nos disse ser capaz de oferecer momentaneamente a liberdade, contemplando do vagão os seios arredondados das colinas de Sèvres, o rio, o arco imenso do céu, eu os sentia levemente repousar - simples pinturas - sobre o globo de meu olho, que se projetava, oferecendo-se para carregar muitos outros fardos [...] sobre sua superfície delicada. 0 horizonte de meu olhar se encontrava insuficientemente preenchido pela esfera do horizonte; tudo que a natureza me oferecia de vida nos dias de verão me parecia um sopro bem débil e curto perto da imensa aspiração que inflava meu peito. A vida não estava fora de mim no mundo; ela estava em mim. Eu não estava perdido no universo; o universo estava perdido em meu coração infinito, onde eu me divertia, com desdém, pondo-lhe de escanteio. Nesse momento, também, a ideia de que eu morreria um dia, de que a força eterna que havia naquelas colinas, naquele rio, naquele sol, me superaria, e que eu não era mais que um grão de areia sob seus pés divinos, esse pensamento me fez sorrir. Como poderia eu durar menos que essas coisas, como poderiam elas me oprimir com todo seu poder se elas estavam em mim, se é o universo que estava aprisionado e perdido no cerne de minha consciência, como é que essas colinas e esse céu ensolarado repousavam sobre meu olho? Sem dúvida, o êxtase artificial e vulgar cujo razoável frenesi eu aqui evoco não oferece mais que um pensamento bem imperfeito da inspiração que possui Madame de Noailles [...]. Ainda que Madame de Noailles por
} 
Esse excerto acompanharia no artigo uma reflexão de Proust a respeito do que chama o "idealismo mais profundo" da poesia de Noailles ${ }^{21}$. Seu argumento é de que essa dama da sociedade teria logrado construir uma visão mais subjetiva e sensível para o "esplendor do universo"22. A beleza do mundo em Les Éblouissements se revelaria muito mais uma expressão de grandeza vinda do espírito de seu autor (a "interiorização" do idealismo) do que uma percepção da vida exterior através de sentidos aguçados. E essa expressão é tão difícil, tão rara e tão associada a um sentimento de liberdade que, apenas quando embriagado pelo vinho, o narrador se sente capaz de intuí-la. Embora se recomende cautela com a "crítica literária" de Proust dado que, em inúmeros momentos, ela reveste uma poderosa vocação à lisonja e o cuidado de satisfazer certas normas da cortesia mundana de seu tempo ${ }^{23}$, não se pode negligenciar nela, por vezes, uma proposta estética típica que se manifesta em abundância ao longo da Recherche: o estilo sobre o qual tanto já nos debruçamos e que localiza a realidade mais precisa do mundo na subjetividade recôndita e, em última instância, inacessível dos seres. Proust argumenta que a grandeza do universo não existe em si. Ela parte de nós mesmos, ainda que sejamos mero "grão de areia". E o artista nobre, de gosto elevado, é aquele capaz de reconhecer essa interioridade. Seja como for, anos após

vezes nos diga não acreditar na eternidade do pensamento e substitua velhas crenças por graciosas fábulas [...], a filosofia com a qual ela se alinha e que às vezes exprime diretamente em seus versos, acaba desmentida ou ao menos superada por uma filosofia maior que se depreende, quer queira, quer não, de sua poesia. Sem dúvida, ela chama seu livro de "Deslumbramentos", mas, se o universo a deslumbra, ela sabe refletir com igual força toda a claridade que ele lhe derrama. CSB, p. 931-932. Para os manuscritos, ver o caderno das Chroniques (NAF 16634), fo $128 v^{0}$-129ro.

${ }^{21}$ Ibidem, p. 540.

22 Idem.

${ }^{23}$ Com efeito, ressalta Pierre Brunel que "abundam os elogios" nesse artigo do Figaro e na correspondência entre Proust e Noailles de modo geral. $C f$. BRUNEL, Pierre. La Comtesse de Noailles. In: TADIÉ, Jean-Yves (org.). Proust et ses amis. Paris: Gallimard, 2010, p. 21. 
a publicação do texto jornalístico, o leitor de À l'ombre des jeunes filles en fleurs,

atravessando a cena da visita do herói Marcel ao quarto de Albertine, no grande

hotel de Balbec, se deparou com a seguinte passagem:

Elle me regardait en souriant. À côté d'elle, dans la fenêtre, la vallée était éclairée par le clair de lune. La vue du cou nu d'Albertine, de ces joues trop roses, m'avait jeté dans une telle ivresse, c'est-à-dire avait pour moi la réalité du monde non plus dans la nature, mais dans le torrent des sensations que j'avais peine à contenir, que cette vue avait rompu l'équilibre entre la vie immense, indestructible qui roulait dans mon être, et la vie de l'univers, si chétive en comparaison. La mer, que j'apercevais à côté de la vallée dans la fenêtre, les seins bombés des premières falaises de Maineville, le ciel où la lune n'était pas encore montée au zénith, tout cela semblait plus léger à porter que des plumes pour les globes de mes prunelles qu'entre mes paupières je sentais dilatés, résistants, prêts à soulever bien d'autres fardeaux, toutes les montagnes du monde, sur leur surface délicate. Leur orbe ne se trouvait plus suffisamment rempli par la sphère même de l'horizon. Et tout ce que la nature eût pu m'apporter de vie m'eût semblé bien mince, les souffles de la mer m'eussent paru bien courts pour l'immense aspiration qui soulevait ma poitrine. La mort eût dû me frapper en ce moment que cela m'eût paru indifférent ou plutôt impossible, car la vie n'était pas hors de moi, elle était en moi ; j'aurais souri de pitié si un philosophe eût émis l'idée qu'un jour même éloigné, j'aurais à mourir, que les forces éternelles de la nature me survivraient, les forces de cette nature sous les pieds divins de qui je n'étais qu'un grain de poussière ; qu'après moi il y aurait encore ces falaises arrondies et bombées, cette mer, ce clair de lune, ce ciel! Comment cela eût-il été possible, comment le monde eût-il pu durer plus que moi, puisque je n'étais pas perdu en lui, puisque c'était lui qui était enclos en moi, en moi qu'il était bien loin de remplir, en moi, où, en sentant la place d'y entasser tant d'autres trésors, je jetais dédaigneusement dans un coin ciel, mer et falaises ? ${ }^{24}$

\footnotetext{
${ }^{24}$ Ela me olhava sorrindo. Ao seu lado, na janela, o vale era iluminado pela luz do luar. A visão do pescoço nu de Albertine, daquela face tão rósea, me lançou em tamanho êxtase, isto é, tanto apresentava para mim a realidade do mundo não mais na natureza, mas sim na torrente de sensações que eu mal conseguia conter, que rompeu o equilíbrio entre a vida imensa e indestrutível que pulsava em meu ser e a vida do universo, tão débil em comparação. 0 mar, que eu percebia ao lado do vale pela janela, os seios arredondados das primeiras falésias de Maineville, o céu onde a lua não se encontrava mais elevada ao zênite, tudo isso parecia muito mais leve que as plumas na hora de ser carregado pelo globo de minhas pupilas que, entre minhas pálpebras, eu sentia dilatadas, resistentes, prontas a suportar muitos outros fardos, todas as montanhas do mundo, sobre suas delicadas superfícies. Suas órbitas não mais se encontravam suficientemente
} 
Trata-se de uma clara transposição de um excerto do manuscrito do texto jornalístico para a construção de uma cena do romance. Não apenas pela visão estética que manifesta, aquela sensação de conter o universo dentro de si, a tal ponto que a natureza se apequena e que mesmo a morte se relativiza, mas também pela preservação das mesmas imagens que já no jornal se faziam presentes. Não é difícil notar a manutenção de uma série de metáforas: les seins bombés des coteaux de Sèvres / les seins bombés des premières falaises de Maineville; le cercle de mon regard se trouvait insuffisamment rempli par la sphère de l'horizon / leur orbe ne se trouvait plus suffisamment rempli par la sphère même de l'horizon; tout ce que la nature m'apportait de vie dans les jours d'été me semblait un souffle bien chétif et court auprès de l'immense aspiration qui gonflait ma poitrine / tout ce que la nature eût pu m'apporter de vie m'eût semblé bien mince, les souffles de la mer m'eussent paru bien courts pour l'immense aspiration qui soulevait ma poitrine; je n'étais qu'un grain de poussière sous ses pieds divins / les forces de cette nature sous les pieds divins de qui je n'étais qu'un grain de poussière; l'univers était perdu dans mon coeur infini où je m'amusais dédaigneusement à le jeter dans un coin / en moi, où, en sentant la place d'y entasser tant d'autres trésors, je jetais dédaigneusement dans un coin

preenchidas pela própria esfera do horizonte. E tudo aquilo que a natureza pudesse me proporcionar de vida pareceria bem frágil, os sopros do mar seriam muito breves perto da imensa aspiração que arrebatava meu peito. Mesmo se a morte atentasse contra mim naquele momento, isso me pareceria indiferente ou até mesmo impossível, porque a vida não estava fora de mim, ela estava em mim; eu teria esboçado um sorriso de piedade se um filósofo proferisse a ideia de que, num futuro longínquo, eu morreria, de que as forças eternas da natureza me superariam, as forças dessa natureza em cujos pés divinos eu não era mais que um grão de areia; que, depois de mim, ainda haveria essas falésias arredondadas e curvas, esse mar, essa luz do luar, esse céu! Como tudo isso seria possível, como o mundo poderia durar mais se não era eu quem estava perdido nele, se era ele que estava contido em mim, eu que ele estava longe de conseguir preencher, em mim, onde, sentindo que havia espaço para empilhar tantos outros tesouros, eu escanteava com desdenho o céu, o mar e as falésias? R.T.P., II, pp. 285-286. 
ciel, mer et falaises. Eis uma incorporação evidente do jornalismo pelo romance. Há, não se pode negar, uma reorganização sintática dos períodos - Spitzer nos ensina que eles se alongam e se encorpam. Mas não poderíamos jamais considerar essa transposição como "menos direta" do que aquela que se dá entre o retrato de Edmond de Polignac e a descrição de Robert de Saint-Loup. É notável como Proust mantém praticamente intocados os núcleos semânticos do artigo dedicado a Anna de Noailles: encostas, esfera do horizonte, sopro, peito, grão de areia, pés divinos, gesto de desdenho... nenhum deles é desprezado ou sequer modificado! Pierre Clarac e Yves Sandre já haviam se apercebido dessa apropriação em 1971, quando publicado o Contre Sainte-Beuve da Bibliothèque de la Pléiade ${ }^{25}$. E Pierre Brunel a salientou em 2010 para demonstrar as formas como o apreço de Proust pela condessa de Noailles se manifestam ao longo de sua obra. Por sinal, sugerindo a comparação que acabamos de traçar, Brunel aponta para uma conclusão bastante pertinente: “o texto desse artigo [Les Éblouissements], de qualquer maneira, era suficientemente importante aos olhos de seu autor para que ele recuperasse em $\grave{A}$ l'ombre des jeunes filles en fleurs uma parte de seu desenvolvimento tal qual concebido no manuscrito"26. É o esforço de continuidade estilística que Proust apresenta no momento em que escreve seu longo romance. É a consciência desse autor de que, mesmo nos momentos em que escreve textos menores, mais simples, publicados nas páginas perecíveis dos jornais, o que se vislumbra ao fundo, no horizonte, são os contornos mais complexos, sofisticados e, em alguma medida, mais perenes do gênero romanesco. E não de qualquer tipo de romance. Acima de tudo, uma narrativa fundada na memória, no recorrente recurso ao passado como meio de conhecimento presente, e que, como ambiente de experimentação estética,

${ }^{25}$ CSB, p. 932.

${ }^{26}$ Cf. BRUNEL, Pierre. Op. cit., p. 21. 
se apega a gêneros nada arbitrários - um deles o portrait-souvenir de que tratamos em um primeiro momento e que concentra os esforços criativos do autor na enunciação do fenômeno da rememoração. Seria possível contra-argumentar que o narrador da Recherche se apresenta de forma mais sofisticada que aquele dos retratos jornalísticos. É verdade que o romance disponibiliza o espaço que o jornal não possui para que não apenas nossos objetos de atenção se transformem, mas também nós mesmos. Ao contrário do que ocorre nos retratos, não são apenas os personagens da Recherche, em si, que sempre ressurgem distintos. É também seu narrador. Ainda assim, impossível negar que, no jornal, está o esforço da lembrança, da preservação de uma memória, com todos os obstáculos e desafios que tal empenho é capaz de ocasionar, desenvolvendo-se um campo fértil para a experimentação de práticas romanescas.

No capítulo anterior, demonstramos como há uma convergência entre o estilo de Marcel Proust e de Jorge Andrade em seus escritos jornalísticos. Salientamos como os perfis escritos por esse dramaturgo também expõem personagens fracionados em camadas mais aparentes e mais profundas de seu caráter e como o propósito de sondar-lhes a essência também lança seu narrador em uma atmosfera de insegurança, instabilidade e dinamismo. Mas há mais pontes entre os dois autores do que apenas as aproximações estilísticas. A gênese de obras mais longas e sofisticadas de Andrade também lança mão de instrumentos bastante caros a Proust. Neste momento, parece-nos relevante observar que, seis anos após deixar a redação de Realidade, Jorge Andrade publicou um romance memorialista com a forma de um longo e ininterrupto fluxo de consciência. Labirinto, publicado pela editora Paz e Terra no ano de 1978, tem como protagonista o narrador Jorge (às vezes também chamado Aluízio, primeiro nome 
de Jorge Andrade), dramaturgo e jornalista que entremeia suas trajetórias profissional, familiar e amorosa como meio de enveredar-se no passado e atingir uma compreensão precisa de seu ser no presente. Autor do prefácio à primeira edição da obra, Sábato Magaldi sugere que seu subtítulo poderia ser "Em busca do pai perdido", uma "paráfrase do título proustiano"27. 0 crítico pensa sobretudo na longa tensão entre pai e filho que atravessa a narrativa e que descreve a luta de seu protagonista para afirmar e exercer sua vocação artística. Mas a associação de Labirinto à Recherche também se inscreve em certas formas de composição dos dois romances. Temos em mãos a seguinte passagem da obra de Andrade, na qual Jorge, em meio a um diálogo com o escritor Érico Veríssimo, se vê longamente absorto pelas lembranças que partem de uma violenta briga com o pai, conservador fazendeiro do Oeste Paulista, até a reconciliação na idade madura:

Vejo meu pai com o braço musculoso em volta de meu ombro, puxando-me para a briga, como se desejasse que eu batesse nele. Agora, sei que ele não se importaria, contanto que eu reagisse como um homem. Liberto-me do braço dele e recuo com olhos de solidão onde estão refletidos vinte e três anos de ansiedade por carinho, por afeto, por uma palavra de compreensão pelo que eu era. Sei que vou ser odioso, não batendo nem brigando, mas matando com palavras. Tento correr ladeira abaixo, mas minhas próprias palavras pegamme na calçada.

- Pela primeira vez estive em seus braços, mas não como filho. Nunca os senti em meus ombros, nem suas mãos em minha cabeça. Olhe bem em meus olhos, papai! Olhe! Estou com eles vidrados, estraçalhados pelos cachorros da sua suspeita. Mas eu vou vencer, está ouvindo? Eu vou vencer! Volto aqui para ajustarmos contas. Aí, eu poderei lhe bater como um homem. Sabe como? Provando a você que sou alguém. Alguém que não tem nada seu. Que vence apesar de ser seu filho.

${ }^{27}$ Lab., p. 7. 
— Então, vá e volte logo! Mas, volte como um homem. Estarei à sua espera.

— Eu vou vencer. Está ouvindo? Não quero nada seu. Nem seu nome!

Vejo-me correndo pela ladeira e desaparecendo entre os carros. Meu pai cai de joelhos na calçada de tábuas largas e bate a mão no chão como se quisesse destruí-la. Recuo, preso de grande remorso, e encosto-me ao muro. Meu pai, subitamente envelhecido, encosta a cabeça no chão e rompe em soluços. Meu Deus! Não há nada que fira mais do que as palavras! Ele levanta-se, não mais preparado para a caçada, mas de terno e gravata e se aproxima de mim. Não estamos mais na "ladeira da inspiração", mas na Rua Paim, em frente ao Teatro Maria Della Costa. As pessoas que passam saem do teatro, onde acabaram de assistir A Moratória. Ele se aproxima de mim, passa o braço em meu ombro e descemos em silêncio para a Avenida 9 de Julho. Subitamente, ele para e olha-me com imenso amor, puxando-me para ele e me abraçando. Sua voz sai da garganta montada nos soluços, tropa xucra da dor:

- Eu não sabia, filho. Eu não podia compreender. Peço que me perdoe. Agora, sei que há muitas maneiras de amar a mesma coisa. Nunca li um livro! Sou fazendeiro atrasado, não podia saber que...! Perdoe-me, meu filho!

Não papai! Não chore! Não me aprisione no remorso para o resto da vida. Silencioso, meu pai se volta, passa entre os carros estacionados e desaparece. Liberto, sentindo uma paz imensa, atravesso a ladeira, aproximo-me de Érico e pego em seus braços, carinhoso. Fico olhando em seus olhos sem poder dizer nada.

—Que foi, Jorge? Por que está me olhando assim?

- Obrigado, Érico!

- Obrigado por quê, meu amigo?

- Por tudo. Sei muito de sua vida, coisas publicáveis e não publicáveis. Como existem na minha vida.

— Eu acho que tudo é publicável, Jorge.

— Só ainda não sei que fim teve seu pai.

Olho o rosto de Érico e lá estavam as sobrancelhas hirsutas contraídas, formando muralha em volta do olhar opaco, que reflete a sua impenetrabilidade índia. A sensação pronunciada de ser movido por sentimento de culpa desenha-se novamente em seu rosto. 
- Meu pai acabou perdendo tudo em Cruz Alta. Em 1930, a Revolução getulista o levou para São Paulo. Fui despedir-me dele na estação. Estava com um capote velho e percebi que não tinha um tostão no bolso, quando me disse que havia esquecido o pacote de linguiças fritas na casa onde vivia. Eu também não tinha nada para dar a ele. Saí correndo e fui buscar o pacote. Quando voltei, o trem partia e eu vi meu pai na última plataforma. Corri e entreguei as linguiças. A canseira da corrida e a emoção me trancavam a voz. Fiquei parado, vendo a figura dele ir diminuindo. Com uma das mãos o velho Sebastião me acenava e com a outra apertava contra o peito a linguiça frita embrulhada em um jornal manchado, sujo. Nunca mais tornei a vê-lo. Morreu em São Paulo e seu túmulo jamais foi localizado. Sumiu no tempo e no espaço. ${ }^{28}$

Esse longo excerto dá mostra de como Labirinto se alimenta de um intenso entrecruzamento e superposição de episódios passados da vida do narrador Jorge. A lembrança da caminhada ao lado de Érico Veríssimo pelas ladeiras de Porto Alegre vai levá-lo a evocar momentos ainda anteriores de sua própria vida, uma espécie de pretérito mais-que-perfeito. Aqueles que cruzam seu caminho operam sempre como gatilhos da memória involuntária, em certa medida alargando e compartilhando de seus conflitos internos. Os dilemas que acreditava apenas seus, o narrador os vê refletidos nas confissões de todos ao seu redor. E esse é o instante da redenção de suas agruras. Vemos a agressiva luta de um jovem contra o pai, que reprova suas pretensões artísticas. Vemos a reconciliação entre os dois, já na maturidade, após a representação do espetáculo A Moratória (1955). Mas é a revelação das questões familiares de Érico Veríssimo que o pacifica, o “obrigado, Érico!" que se segue ao despertar da profunda rememoração do narrador. São momentos em que vê seus dramas transformados em verdades da condição humana. As abruptas transições a outras dimensões de tempo e espaço são responsáveis pelo efeito "labiríntico" da narrativa e configuram justamente o ${ }^{28}$ Lab., pp. 204-206. 
enredo do qual o narrador busca se desemaranhar. Esse princípio estético é, por vezes, tão radical que, em inúmeros momentos, uma mesma ação comporta mais de um tempo. Pensemos na passagem "ele levanta-se, não mais preparado para a caçada, mas de terno e gravata e se aproxima de mim". Há um enroscamento de fios narrativos: o pai da juventude, que se ajoelha após a cizânia, ressurge "envelhecido" e se ergue em outro contexto, com vocação pacificadora e amistosa. É a performance de um mesmo e contínuo movimento, de descer e se reerguer, sendo desenvolvido por seres distintos e em distintos pontos do tempo e do espaço. Tais recursos narrativos trazem consigo pressupostos bastante claros: de que o presente é uma complexa composição de estados passados e de que há verdades universais da condição humana passíveis de serem intuídas através da perscrutação da interioridade do outro. A pluralidade de visões que invadem o mundo do narrador a partir da rememoração de episódios de sua vida profissional e familiar é tamanha que chegamos mesmo a entrever em Labirinto alguns dos traços de estilo das peças de teatro de Jorge Andrade ${ }^{29}$. Não é apenas o caráter de seus diálogos, todos bastante dramáticos, ou o aspecto performático de certos parágrafos cujos índices de movimento e expressão se transformariam com grande facilidade em rubricas de uma narrativa dramatúrgica ${ }^{30}$. Essa intensa alternância e entrelaçamento de planos da vida do narrador nos faz imaginar a complexa

\footnotetext{
${ }^{29}$ Comentando a passagem do romance em que Jorge Andrade "retrabalha" cenas da reportagem Quatro Tiradentes baianos (R.R., novembro de 1971, p. 47-54), Elizabeth Azevedo apresenta a mesma interpretação: "os trechos desse romance autobiográfico em que apresenta a cena da execução dos conspiradores são verdadeiras cenas teatrais, cheias de tensão e suspense". $C f$. AZEVEDO, Elizabeth. Recursos estilísticos na dramaturgia de Jorge Andrade. São Paulo: Edusp, 2014, p. 16.

30 É o que se percebe com a leitura dessa e outras passagens: "Vejo-me correndo pela ladeira e desaparecendo entre os carros. Meu pai cai de joelhos na calçada de tábuas largas e bate a mão no chão como se quisesse destruí-la. Recuo, preso de grande remorso, e encosto-me ao muro. Meu pai, subitamente envelhecido, encosta a cabeça no chão e rompe em soluços". Lab., p. 205. Não é apenas a abundância de verbos de ação que sustenta essa leitura (correr, desaparecer, cair, bater, encostar, romper). Ou mesmo a determinação concreta da cena (ladeira, carros, calçada, muro). É como se Jorge Andrade, figurando-se como o protagonista Jorge, se colocasse como personagem de uma grande e complexa peça de teatro que fora sua vida.
} 
cenografia que sustenta as alternâncias abruptas de tempo em uma peça como $A$ Moratória, ou mesmo a sobreposição de slides e filmes sobre o próprio público, à moda de Erwin Piscator, num espetáculo como O Sumidouro ${ }^{31}$. Buscar nossas verdades perdidas no passado é, enfim, enfrentar um denso emaranhado narrativo, cujo princípio de elucidação é o reflexo de nossas crises e dramas no outro.

Esses nós, contudo, não são inéditos em Labirinto. 0 romance, como dissemos, os entrelaça, lhes atribui um sentido coletivo de busca e elucidação de verdades absolutas em meio a um emaranhado. Mas seus surgimentos são anteriores e estão associados a outros escritos de Andrade. 0 percurso narrativo "labiríntico" que o leitor desse romance experimenta é também tributário do trânsito do repórter Jorge Andrade pelas suas próprias vivências jornalísticas. Principiamos o percurso pela visita ao ateliê de Wesley Duke Lee; passamos à infância do narrador na fazenda de Barretos; retornamos ao ateliê; somos transportados à Bahia; o hotel em Salvador, chamado Vila Romana, lhe remete à vida de Murilo Mendes em Roma; tornamos a Wesley Duke Lee... itinerários como esse, que associam o exercício da memória involuntária a uma completa relativização do tempo e do espaço, têm todas as suas referências fincadas em escritos anteriores desse autor. Para além de reportagens, como Quatro Tiradentes baianos $^{32}$, e várias peças do ciclo Marta, a árvore e o relógio, como As Confrarias ${ }^{33}$, Labirinto incorpora a sua estrutura romanesca inúmeras passagens de vários dos perfis jornalísticos de Jorge Andrade que, há pouco tempo, analisávamos. 0 pintor Wesley Duke Lee, o sociólogo Gilberto Freyre, o historiador Sérgio Buarque de

31 "Nas últimas peças [...] Jorge Andrade insere projeções de filmes e slides, ora sobre o palco e sobre os atores, ora em telas, para apresentar lembranças e referências biográficas das personagens". $C f$. RAHAL, Carlos Antônio. Jorge Andrade: um dramaturgo no espaço-tempo. São Paulo: Perspectiva, 2015, p. 31.

${ }^{32}$ R.R., novembro de 1971, pp. 34-54.

${ }^{33}$ M.A.R., p. 21. 
Holanda, o enciclopedista Antonio Houaiss, os escritores Murilo Mendes e Érico

Veríssimo - todos deixam seus retratos em Realidade para se tornarem

personagens das memórias do protagonista Jorge. O leitor de Labirinto que, seis

anos antes de sua publicação, tivesse em mãos o exemplar de fevereiro de 1972 de

Realidade, encontraria no perfil de Érico Veríssimo, A Liberdade será sempre a

minha causa, a seguinte passagem:

De repente, fico com todos os sentidos alertas. Sem saber por que, olho o teto do escritório de Érico, no porão, que fica bem embaixo de seu quarto. Olho as paredes à minha volta, procurando sentir a casa, conhecer um pouco de sua alma, mas não sei por que, ela me dá a sensação de lugar por onde se passa, como se suas paredes não estivessem alicerçadas num tempo que se perde na memória. Só consigo perceber, vindas do teto, descendo pelas paredes, envolvendo livros, mesa, máquina de escrever, tudo, as raízes da transcendência do escritor: em cima, os filhos; embaixo, os livros. E todas as raízes se confundindo e se enraizando numa casa hipotecada e perdida em Cruz Alta. Então, a pergunta brota em minha mente: que visões, ainda inconfessáveis, o menino deve ter tido de sua casa ou da farmácia infernal, escondido entre flores ou frutos de sua nespereira?

- Érico! Você trabalhou a vida toda na Livraria do Globo e na Editôra Globo; que ficava lá das 8 às 18 horas; que traduzia para a Editôra noite adentro; que só conseguia escrever seus livros nas aparas de tempo; que só usa calças velhas quando escreve; que vive de seus direitos autorais, recebendo por mês de 8000 a 10000 cruzeiros; que nunca teve pretensões acadêmicas; que ocupou o cargo de diretor do Departamento de Assuntos Culturais da União PanAmericana, em Washington; que lecionou literatura brasileira em universidades americanas. Sei muito de sua vida, coisas publicáveis e não publicáveis. Só ainda não sei que fim teve seu pai.

Érico levanta o braço magro, cheio de pelos longos, de veias saltadas, e eleva o volume do rádio. Olha para mim erguendo o corpo e o apóia no encosto do sofá. Penso comigo: ele está procurando sua posição de índio. E lá estavam as sobrancelhas hirsutas contraídas, formando uma muralha em volta do olhar opaco, que reflete a impenetrabilidade índia que existe nele. A sensação pronunciada de ser movido por sentimento de culpa desenha-se novamente em seu rosto.

- Eu disse que foi para São Paulo em 1930. Fui despedir-me dele na estação. Estava com um capote velho e percebi que não tinha 
um tostão no bolso, quando me disse que havia esquecido o pacote de lingüiças fritas na casa onde vivia. Eu também não tinha nada para dar a ele. Saí correndo e fui buscar o pacote. Quando voltei, o trem partia e eu vi meu pai na última plataforma. Corri e entreguei as lingüiças. A canseira da corrida e a emoção me trancavam a voz. Fiquei parado, vendo a figura dele ir diminuindo. Com uma das mãos o velho Sebastião me acenava e com a outra apertava contra o peito a lingüiça frita embrulhada em um jornal manchado, sujo. Nunca mais tornei a vê-lo. Morreu em São Paulo e seu túmulo jamais foi localizado. Sumiu no tempo e no espaço.

Do escritório onde estamos - galho da sua nespereira -, Érico dirige a idealização e reconquista de um pai impossível mas profundamente amado, fonte da humanidade de muitas de suas personagens. ${ }^{34}$

Ora, há excertos escritos a princípio para o perfil de Realidade que se encontram absolutamente intocados no romance Labirinto. São momentos marcantes como "sei muito de sua vida, coisas publicáveis e não publicáveis [...], só ainda não sei que fim teve seu pai" e mesmo todo o parágrafo "olho o rosto de Érico e lá estavam as sobrancelhas hirsutas contraídas, formando muralha em volta do olhar opaco, que reflete a sua impenetrabilidade índia. A sensação pronunciada de ser movido por sentimento de culpa desenha-se novamente em seu rosto". Poderíamos nos questionar: uma mera reprodução? Um simples caso de autoplágio? Nada seria mais equivocado! Acusar Jorge Andrade de lançar mão de qualquer um desses expedientes em Labirinto significaria negligenciar as sutilezas de seu método criativo. Proust, nós bem vimos, procede da mesma maneira quando se apropria de passagens do retrato do príncipe Edmond de Polignac e as incorpora com mudanças muito sutis à estrutura romanesca de $\grave{A}$ l'ombre des jeunes filles en fleurs e de Le temps retrouvé. É verdade que, no caso do artigo sobre Les Éblouissements, obra da condessa de Noailles, Proust se revela capaz de operar

\footnotetext{
${ }^{34}$ R.R., fevereiro de 1972, p. 76.
} 
transformações radicais no interior das passagens, pulverizando unidades semânticas do texto jornalístico ao longo de trechos mais longos e densos do romance. Mas, ainda assim, não estaríamos diante de um caso de "transposição direta" do retrato ao romance, para empregar termos da lavra de Nathalie Mauriac? No perfil de Érico Veríssimo, as "coisas publicáveis e não publicáveis" preparam uma interrogação a respeito do misterioso desfecho da história do pai do escritor. São a insinuação de uma curiosidade, quase de uma indiscrição. Por outro lado, em Labirinto, a mesma passagem surge como parte de um agradecimento pela abertura da intimidade, responsável pela libertação do narrador Jorge de seus fantasmas familiares. Tanto assim que, no romance, o excerto "só ainda não sei que fim teve seu pai" é divorciado do conjunto inicial do perfil jornalístico, abrindo espaço mesmo para a interposição de uma das várias falas de Érico Veríssimo que antes absolutamente desconhecíamos: o "eu acho que tudo é publicável, Jorge". A mudança de sentido que esses pequenos ajustes provocam é substantiva e sua ocorrência não é fortuita. Vimos que, nos perfis, a interposição do narrador andradino à descrição de seus modelos é grande ${ }^{35}$, mas que, ainda assim, os entrevistados seguem sempre como o foco primário de atenção e interesse, como o ser do qual o repórter se vê obrigado a extrair revelações. Não no romance. Em Labirinto, é a perscrutação dos meandros do próprio protagonista Jorge que importa. Ela é o foco primeiro do desenvolvimento do enredo e somente com relação a ela se dá o recurso a esses tantos personagens que atravessaram a vida do protagonista. São personagens em cujos conflitos o narrador se projeta tentando escapar dos labirintos de sua consciência. Daí a absorção de trechos dos perfis sob perspectiva distinta. Se, nas páginas de

\footnotetext{
${ }^{35}$ Cf. Capítulo 2 - Seres divididos, p. 64.
} 
Realidade, víamos o retrato dos modelos com traços da sombra do repórter Jorge Andrade ao fundo, em Labirinto temos o oposto: a proeminência é dos traços de personalidade do protagonista Jorge e, neles, vemos os reflexos desses vários personagens que o autor do romance absorve de suas experiências pessoais. Os ajustes operados no trecho imediatamente seguinte evidenciam ainda mais essas mudanças de sentido. A narrativa de Érico sobre o destino final de seu pai é preservada em grande medida. Com efeito, há apenas uma sutil alteração em seu princípio. No perfil de Realidade, lemos “eu disse que foi para São Paulo em 1930”. Um período bastante referencial, com datação histórica, próprio da vocação jornalística de precisão. Tanto assim que seu verbo, conjugado no pretérito perfeito (eu disse), concorre para engrenar a narrativa subsequente em um sistema maior, aquele de um questionário, de um inquérito ao qual o interrogado busca somar e conectar novas informações com alguma coerência. Já no romance, todo esse excerto é substituído por "meu pai acabou perdendo tudo em Cruz Alta. Em 1930, a Revolução getulista o levou para São Paulo". A construção se enriquece com a inserção de "Revolução getulista", que abre nossos olhos para um contexto mais dramático, aquele da convocação do pai miserável para um conflito armado. Mas há mais do que isso. A primeira parte da nova passagem (meu pai acabou perdendo tudo em Cruz Alta) comporta um tema disseminado ao longo de toda a obra andradina, sobretudo em Labirinto: as mazelas da decadência econômica, a falência de um patriarca, a traumática subtração do patrimônio familiar. Incrustando essa passagem, inexistente no artigo jornalístico, Jorge Andrade desloca o foco da narrativa. Érico Veríssimo ainda é personagem relevante, mas não mais a dimensão primordial do texto. A todo momento, ajustes como esse garantirão que o grande retratado do romance seja o protagonista Jorge e que os 
antigos modelos dos perfis se tornem anteparos para a projeção dos próprios dilemas do narrador.

Para que não tenhamos a impressão equivocada de que o caso de transposição direta do perfil de Érico Veríssimo é único, é possível mencionar ainda outros exemplos pertinentes. As passagens em que Jorge relembra a visita ao poeta Murilo Mendes, em Roma, são bastante ilustrativas. Lemos na edição de agosto de 1972 de Realidade a seguinte descrição do físico do poeta mineiro:

O rosto de Murilo é extremamente jovem para a idade que tem, fazendo contraste que choca à primeira vista. Alto, curvado pela idade, sempre refinado, ele caminha lentamente, esperando que eu passe à sua frente. Ele faz sempre - do ônibus, da rua, da praça, do elevador, da sala de aula - um lugar de quem passou pelo Itamarati. Murilo jamais se esquece - em qualquer lugar ou situação em que esteja - os deveres de cortesia. Com um sorriso enigmático que se esconde no rosto, desce os poucos degraus que levam às termas. Há dias que estou intrigado com esse sorriso, sem conseguir descobrir seu significado mais profundo. Quando chega diante da porta, Murilo recua ligeiramente, apontando delicadamente com a mão, para que eu passe. Nos quinze dias que passei em Roma, convivendo com ele, em nenhum momento quebrou, ou mesmo trincou, a imagem do homem refinado. Olho Murilo e sinto que as dificuldades dos primeiros encontros, o homem distante que se defende, começam a desaparecer entre nós. ${ }^{36}$

Trata-se da mesma descrição encontrada em Labirinto, lapidada com algumas alterações:

Murilo, alto, curvado, sempre refinado, espera que eu passe à sua frente. Ele jamais esquece - em qualquer lugar ou situação - os deveres da cortesia. Com sorriso enigmático que se esconde no rosto, desce os poucos degraus que levam às termas. Há dias que estou intrigado com esse sorriso, sem conseguir descobrir o significado mais profundo. Quando chega diante da porta, Murilo recua apontando delicadamente para que eu passe. Reparo que, às vezes, ele repuxa o

${ }^{36}$ R.R., agosto de 1972, p. 82. 
canto esquerdo da boca num movimento que quase une lábios e sobrancelhas. $O$ movimento me intriga. Já o notara em diversas situações, mas não consigo ainda descobrir suas raízes. $O$ sorriso que se esconde no rosto-mármore continua sempre presente. Agora, às portas das termas, ele se acentua ainda mais. Por um momento, lembra o enigma da expressão das estátuas que permaneceram através dos tempos. Diante de mim está um homem cuja verdade se confunde com a arte, com a estética. ${ }^{37}$

Ora, não é difícil notar o grande esforço de coesão na passagem do perfil ao romance. São suprimidos grandes períodos e orações, sem contar a subtração de alguns adjuntos ("ligeiramente") e complementos ("pela idade"). Mas o que mais chama atenção é o acréscimo e a adaptação de três outros trechos retirados de instantes pouco mais adiantados do texto jornalístico, situado à mesma página dessa edição de Realidade, e que, em sua origem, possuíam as seguintes configurações: (1) "reparo que, às vezes, ele repuxa o canto esquerdo da boca num movimento que quase une os lábios e sobrancelhas. 0 movimento me intriga. Sinto que ele vem de um estado de alma que não lhe é muito agradável. Já notara o tique em diversas situações, mas não consigo ainda descobrir suas raízes"; (2) "0 sorriso que se esconde no rosto marmóreo, estatuário, continua sempre presente. Agora, às portas das termas, ele se acentua ainda mais. Por um momento, lembra o enigma da expressão das estátuas que permanecem através dos tempos" e (3) "Sinto que diante de mim está um homem cuja verdade se confunde com a arte, com a estética"38. Nesse sentido, em uma esquematização genética, seria esse o itinerário de acréscimos, supressões e transformações que, no romance, Jorge Andrade promove sobre tais excertos dos perfis:

\footnotetext{
${ }^{37}$ Lab., p. 72.

${ }^{38}$ R.R., agosto de 1972, p. 82.
} 
$\theta$ rosto de Murilo é extremamente jovem para a idade que tem, fazendo contraste que choca à primeira vista. [Murilo,] A[a]lto, curvado pela idade, sempre refinado, ele caminha lentamente, esperando [espera] que eu passe à sua frente. Ele faz sempre-do ênibus, da rua, da praça, do elevador, da sala de aula-um lugar de quem passou pelo Itamarati. Murilo [Ele] jamais se esquece - em qualquer lugar ou situação em que esteja - os deveres de[a] cortesia. Com um sorriso enigmático que se esconde no rosto, desce os poucos degraus que levam às termas. Há dias que estou intrigado com esse sorriso, sem conseguir descobrir seu[o] significado mais profundo. Quando chega diante da porta, Murilo recua ligeiramente, apontando delicadamente com a mão, para que eu passe. Nos quinze dias que passei em Roma, convivendo com ele, em nenhum momento quebrou, ou mesmo trincou, a imagem do homem refinado. Olho Murilo e sinto que as dificuldades dos primeiros encontros, o homem distante que se defende, começam a desaparecer entre nós. [Reparo que, às vezes, ele repuxa o canto esquerdo da boca num movimento que quase une es lábios e sobrancelhas. 0 movimento me intriga. Sinto que ele vem de um estado de alma que não the muito agradável. Já [o] notara o tique em diversas situações, mas não consigo ainda descobrir suas raízes. [0 sorriso que se esconde no rosto marmóreo [rosto-mármore]; estatuário,continua sempre presente. Agora, às portas das termas, ele se acentua ainda mais. Por um momento, lembra o enigma da expressão das estátuas que permanecem [permaneceram através dos tempos]. [Diante de mim está um homem cuja verdade se confunde com a arte, com a estética]].

Fica claro como Jorge Andrade soma três excertos de pontos distintos de um mesmo perfil jornalístico para construir uma única descrição romanesca. E como, no interior deles, promove uma série de ajustes visando a maior coesão. Mas não poderíamos jamais negligenciar, para além disso, o que nos parece mais relevante: os efeitos estilísticos dos ajustes que os casos de transposição direta ensejam no romance andradino. Não foram trechos aleatórios os suprimidos por Jorge Andrade, e sim aqueles mais dominados por um discurso referencial e jornalístico: "ele faz sempre - do ônibus, da rua, da praça, do elevador, da sala de aula - um lugar de quem passou pelo Itamarati"; "nos quinze dias que passei em 
Roma"; "o homem distante que se defende". São todos índices que orbitam a figura de Murilo Mendes, sua biografia, o período da visita a ele em Roma e as dificuldades de acesso a sua personalidade. Enfim, são índices de sua centralidade naquela narrativa. Por outro lado, os trechos que Jorge Andrade preserva ou acrescenta desempenham papel inverso: "há dias que estou intrigado com esse sorriso"; "o movimento me intriga"; "não consigo ainda descobrir suas raízes". São todas passagens que concentram a narrativa sobre a própria figura do protagonista Jorge e sobre os efeitos que o personagem de Murilo Mendes provoca sobre ele. Murilo Mendes nelas não importa senão como suporte para que os sentimentos, as impressões, os relevos mais subjetivos do narrador em um dado momento sejam expressos. É como há pouco dizíamos: ainda que, nos perfis, já haja uma grande interposição do narrador na apreensão do entrevistado, o protagonismo da narrativa pesa sobre o modelo, ao passo que, em Labirinto, a transposição direta de excertos jornalísticos é operada de modo a transferir toda a atenção para o drama do personagem de Jorge Andrade. Sem dúvida, um procedimento poético e criativo, na medida em que, segundo Anatol Rosenfeld, o mundo fictício "frequentemente reflete momentos selecionados e transfigurados da realidade empírica exterior à obra", o que o torna "representativo para algo além dele, principalmente além da realidade empírica, mas imanente à obra"39. E, no caso de Labirinto, poderíamos ainda acrescentar: não qualquer forma de "seleção" e "transfiguração", mas sim, reiteramos, a transposição do texto jornalístico ao texto romanesco.

${ }^{39} \mathrm{Cf}$. ROSENFELD, Anatol. Literatura e personagem. In: CANDIDO, Antonio (org.). A Personagem de ficção. São Paulo: Perspectiva, 2014, p. 15. 
Parece-nos pertinente salientar ainda uma forma a mais de ocorrência da transposição direta no romance andradino. Trata-se daquela que se apoia não somente sobre textos jornalísticos, mas também sobre a vasta obra dramatúrgica desse autor, criando um rico enlace entre perfis, prosa e, finalmente, peças de teatro. Em outras palavras, o sofisticado movimento em que, segundo Terezinha Tagé, “ora o espaço semiótico do jornalismo invade o dramatúrgico, ora os recursos da arte dramática servem de referência para o que, no espaço dos textos de fronteira, consideramos como arte de reportar"40. Em Labirinto, no momento em que o protagonista Jorge rememora sua visita a Sérgio Buarque de Holanda, lhe surge, em um grande devaneio, a imagem onírica do bandeirante Fernão Dias, personagem da peça $O$ Sumidouro. Inicia-se, então, um longo e dramático debate sobre questões difíceis como a verdade histórica e a formação dos mitos nacionais:

Não pude deixar de sorrir da referência à riqueza conquistada nas minas do Potosi, ao me lembrar de uma pesquisa feita por um historiador americano, na qual ele tenta provar que o "Primo Guilherme", o famoso Padre Guilherme Pompeu, pai de muitos filhos naturais, foi riquíssimo porque não passou de um falsário, fabricante de cunhos falsos! Tão falsos quanto as esmeraldas do bandeirante mítico. Volto-me e o escritório de Sérgio - ou seria o estúdio de Wesley? - se transforma em imensa clareira de uma mata. Fernão Dias se destaca do meio das árvores e para admirando alguma coisa em suas mãos. Ele cai de joelhos sobre os livros de Sérgio - ou entre as telas de Wesley? - e implora:

- Repitam comigo: às margens do Sumidouro, nós achamos pedras verdadeiras de ótima qualidade e eram as sonhadas esmeraldas! Jurem!

Fascinado, aproximo-me de Fernão Dias, sento-me numa pilha de Dicionários Larousse e me encosto nos volumes da História da Companhia de Jesus no Brasil. Olho Fernão Dias, subitamente sem piedade. Seria já influência de Sérgio? Ou é a interpretação dialética que começa a tomar conta de mim?

${ }^{40}$ Cf. TAGÉ, Terezinha. Jornalismo e dramaturgia: o Mundo Composto de Jorge Andrade. Tese de Livre Docência. Escola de Comunicações e Artes da Universidade de São Paulo, São Paulo, 2010, pp. 9-10. 
- Fernão Dias! Se as pedras são verdadeiras, para que o juramento?

- Deixe-me morrer em paz.

- Depois que se duvida do que procuramos tanto, ninguém morre em sossego.

— Por que começar pelo fim?

- Porque se trata de sua vida e precisa voltar dentro dela. Estou diante de você porque voltei dentro da minha. Pode vê-la, inteira, antes de morrer.

- Ver para quê?

- Para salvá-lo da mentira. Deseja viver só na imaginação de historiadores medíocres que pactuaram com toda sorte de injustiças? Compiladores que o apresentam como desbravador heroico, alargando fronteiras? Não é melhor viver na verdade? Mesmo que ela seja amarga? Eu também estou procurando a minha. ninguém.

- Deixe-me com minhas pedras. Elas não prejudicam

- Isto é o que pensa. Há muitas maneiras de se matar um filho. Permitindo que os meus sejam criados na mentira, eu também estarei matando.

— Você não pode mudar os acontecimentos.

- Mas posso interpretar. É por isto que estou neste escritório. Volte para o seu lugar e represente seu verdadeiro papel. $O$ que escolheu livremente. O que fizemos fica e a história é impiedosa.

- Tornei um sonho realidade.

- Sonho que brotou da violência, de um horror indescritível.

- A violência fazia parte do meu mundo.

- Faz também parte do meu.

- Eu dei minha palavra. Que quer? Que voltasse atrás? Eu tinha fé.

- Quer ver em quem acreditou? Precisa conhecer o rei e as personagens que fizeram de sua vida uma tragédia; que usaram seu sonho.

— Não. Não quero! 
Fernão Dias desaparece entre os volumes da História geral das bandeiras paulistas. ${ }^{41}$

Em um primeiro momento, somos informados de que o ambiente da densa mata do bandeirante Fernão Dias é uma transfiguração do escritório de Sérgio Buarque de Holanda - um espaço tão encantado que o narrador chega a se imaginar em miniatura (o "eu-menino") descendo "nos degraus de livros" e desaparecendo "na fumaça do cigarro de Sérgio" 42. Uma ocorrência contemporânea, diga-se de passagem, do tema moderno da visita ao grande escritor que vimos ao tratar do retrato de Charles Augustin Sainte-Beuve por Émile Zola, sempre impregnando o espaço de trabalho do artista com enorme carga simbólica ou mesmo mística ${ }^{43}$. E a questão retórica, interposta logo em seguida, entre travessões, aventando a possibilidade de ser aquele também o ateliê do pintor Wesley Duke Lee, contribui para o efeito de busca labiríntica por verdades universais que tanto orienta o romance. De todo modo, essa cenografia de uma oficina intelectual, com abundância de livros desorganizados pelo uso contínuo, é tributária da descrição que Jorge Andrade já havia feito da casa do historiador seis anos antes, no perfil jornalístico 42 anos A.C., publicado em Realidade no mês de junho de 1972. Lemos a essa altura do romance uma série de trechos quase idênticos àqueles que haviam sido publicados na revista e cuja transposição promove os mesmos princípios que acabamos de descrever para o caso do perfil

\footnotetext{
${ }^{41}$ Lab., pp. 221-223.

42 Ibidem, p. 218.

${ }^{43}$ Cf. Capítulo 1 - No ninho de Sainte-Beuve, p. 14 sqq. Antonio Candido também comentou a formação de imagens desse gênero. Lendo Baudelaire, o crítico percebe que a passagem do campo à cidade, da "embriaguez dos espaços abertos" à "clausura na mansarda" como espaço privilegiado da criação artística criou "uma espécie de retiro graças ao qual o poeta poderá conseguir o verdadeiro objetivo da poesia com que sonha, isto é, a criação de um mundo factício que manifesta a soberania da mente". Cf. CANDIDO, Antonio. O Albatroz e o chinês. In: O Albatroz e o chinês. Rio de Janeiro: Ouro sobre azul, 2010, p. 23.
} 
do poeta Murilo Mendes e do escritor Érico Veríssimo. Em outras palavras, são proporcionados pequenos ajustes que alçam o escritor do local secundário do repórter do perfil à posição de protagonista do romance. Lemos no perfil, por exemplo, o seguinte excerto:

Sérgio olha-me, divertido, enquanto observo à minha volta. Nas estantes, entre livros, microfilmes de toda a correspondência dos representantes diplomáticos americanos no Brasil de 1809 a 1906. Sobre uma mesa, um visor grande de microfilmes. Esparramados entre os livros - como um bric-à-brac -, vidros de colírio Moura Brasil, envelopes de Engov, lápis adesivos, cinzeiros, um vidro de Agarol, Sonrisal, fósforos, latas de leite em pó, garrafas de uísque, remédios para dormir e outros para o manter acordado. ${ }^{44}$

Ora, no romance, todo o trecho é preservado, salvo o aposto "como um bric-à-brac", que acaba apenas aportuguesado e associado a Wesley Duke Lee segundo o esforço de universalização de experiências individuais, ganhando a forma de "como no bricabraque de Wesley"45. Essas transposições, nós bem sabemos, não são novas e vimos que orientam todo o labirinto em que se perde Jorge Andrade. 0 que há de distinto nesse exemplo e que nos interessa acima de tudo surge logo em seguida à apresentação espacial. Trata-se da interposição de um diálogo entre o protagonista e o bandeirante Fernão Dias, personagem fictício da peça O Sumidouro. A conversa é motivada por uma reflexão com Sérgio Buarque de Holanda sobre o verdadeiro ofício historiográfico ${ }^{46}$ e se configura como clara

\footnotetext{
${ }^{44}$ R.R., junho de 1972, p. 72.

45 Lab., p. 217.

46 Diga-se de passagem, reflexão também absorvida do perfil jornalístico. No retrato de Sérgio Buarque de Holanda, o historiador afirma que "escrever história é ter visão dialética do passado" (R.R., junho de 1972, p. 76). No romance, por sua vez, o protagonista toma para si essa convicção: “eu vim ali para procurar explicações históricas, portanto dialéticas [...]”. Lab., p. 218.
} 
adaptação dessa peça de teatro metalinguística. As ordens "repitam comigo" $e$ "jurem", assim como os demais temas da busca por esmeraldas, são diretamente transpostas do texto teatral, onde se lê o seguinte diálogo entre o bandeirante, seus filhos e os demais oficiais da colônia:

FERNÃO DIAS (erguendo-se com grande esforço): Ajoelhem-se.

GARCIA PAIS: Que foi, pai? Por que está assim?

FERNÃO DIAS: Em nome de Nosso Senhor Jesus Cristo, jurem que as pedras são verdadeiras. Jurem! Todos!

CAPITÃO 1: Fernão Dias. As pedras...

GARCIA PAIS: Não. Não diga nada.

JOSÉ DIAS (surge ao fundo e troca um olhar com Fernão Dias. Uma expressão de amor profundo domina seu rosto.)

FERNÃO DIAS: Afirmem, por onde passarem, que vimos e tocamos em pedras verdadeiras.

JOSÉ DIAS (aproximando-se): E chegamos na serra que brilha mais que o sol, pai!

FERNÃO DIAS: E chegamos na serra que brilha mais que o sol! Jurem em nome de Deus... e se em qualquer tempo disserem o contrário... que sejam malditos para sempre. Jurem! Onde não existe crença... tudo deixa de existir. Repitam comigo: às margens do Sumidouro... Repitam!

Todos (menos José Dias): Às margens do Sumidouro...

FERNÃO DIAS: Nós achamos pedras verdadeiras...

TODOS: ... nós achamos pedras verdadeiras...

FERNÃO DIAS: ... de ótima qualidade...

TODOS: ... de ótima qualidade...

FERNÃO DIAS: ... e eram as sonhadas esmeraldas!

TODOS: ... e eram as sonhadas esmeraldas! 
FERNÃO DIAS: (Agonizando) Procurar... procurar... procurar... que mais poderia ter feito...? ${ }^{47}$

"Jurem que as pedras são verdadeiras”, "repitam comigo”, “às margens do Sumidouro"... eis algumas de tantas falas de um personagem dramático incorporado a um romance para um diálogo com o protagonista. Um diálogo que atribui a Jorge, no romance, o mesmo lugar de fala de outro personagem dessa peça, o dramaturgo Vicente, autor de Fernão Dias em constante embate ético com sua própria criatura. Nesse deslocamento, o que se percebe, uma vez mais, é o movimento de busca de proeminência para a figura do escritor. 0 repórter se faz ver nos perfis, mas é o romance a solução encontrada para tornar-lhe o grande retratado da narrativa. E o dramaturgo também se percebe nas peças pela natureza dos conflitos dos personagens, pelas teses que evocam, mas é com o romance que ele finalmente se desvela como o centro de uma grande constelação de personagens e símbolos. Tanto assim que a crítica andradina sempre insistiu em ver no personagem Vicente, seja na peça Rasto Atrás, seja em sua segunda aparição, em $O$ Sumidouro, um alter ego de Jorge Andrade ${ }^{48}$. Tanto na incorporação de textos jornalísticos quanto na adaptação de diálogos dramáticos, é nesse sentido que sempre opera o mecanismo de transposição direta no romance Labirinto. Ela ilumina e esculpe, no romance, o ser humano que, em outros textos anteriores, apenas entrevíamos ou pressentíamos sob a égide do entrevistador. E não qualquer ser humano, não uma "entidade autônoma", mas sim seu personagem, o ser "intermediário", para falar como Philippe Willemart, que serve

\footnotetext{
${ }^{47}$ M.A.R., pp. 593-594.

${ }^{48}$ Cf. RAHAL, Carlos Antônio. Op. cit., p. 125; AZEVEDO, Elizabeth. Op. cit., p. 119; SANT'ANNA, Catarina. Op. cit., p. 38.
} 
de "ponto de convergência", de "instrumento a serviço dos acontecimentos, do inconsciente, do gozo, dos outros 'eu', [...] e, enfim, dos outros com os quais se relaciona" 49 .

O recurso, portanto, a experiências jornalísticas aproxima a construção do romance em Jorge Andrade daquela que se conhece em Marcel Proust. E aquilo que uma leitura superficial acusaria de autoplágio ou mera cópia revela-se, na realidade, um sofisticado procedimento criativo capaz de atribuir novo sentido a uma narrativa ao mesmo tempo em que preserva um estilo, uma determinada forma de representar o ser humano, sua vida e seu mundo. Nada autoriza dizer que Jorge Andrade possuía conhecimentos aprofundados da gênese do romance proustiano. A organização do chamado Fonds Proust, acervo em posse da Bibliothèque Nationale de France reunindo os documentos manuscritos e datilografados que deram origem à Recherche, só foi concluída em 1985, cerca de um ano após a morte de Andrade. E mesmo a edição dos 21 volumes da correspondência de Proust, catalogada por Philip Kolb, só foi levada a termo no ano de 1993. De modo que sua leitura da Recherche jamais comportou as conclusões às quais recentemente chegou a crítica genética da obra proustiana. Ainda assim, a "transposição direta" de passagens relevantes dos retratos e reportagens que publicou na revista Realidade, entre 1968 e 1972, se revela, nós bem vimos, procedimento frequente em Labirinto. Que não se duvide, a despeito daquilo que a proximidade com textos jornalísticos pode sugerir, dos esforços de criação de Jorge Andrade nesse romance. A crítica andradina por muito tempo insistiu em relegar Labirinto ao mero estatuto de uma "obra autobiográfica". Como

\footnotetext{
${ }^{49} \mathrm{Cf}$. WILLEMART, Philippe. Os Processos de criação na escritura, na arte e na psicanálise. São Paulo: Perspectiva, 2009, p. 142.
} 
se, nos enredos que o protagonista Jorge nos propõe, nada mais houvesse que uma confirmação empírica dos elos entre a biografia do autor e os dilemas vividos pelos personagens de suas peças teatrais. Cito, por exemplo, Catarina Sant'Anna, para quem Labirinto é apenas "uma obra essencialmente autobiográfica, que o próprio autor afirmou ser fundamental para o entendimento de seu teatro, por explicar o pano de fundo em que se criaram suas peças" 50 . É inegável a existência de aspectos autobiográficos e me ocorre, sobretudo, o instante em que o narrador do romance afirma ter feito "muitos perfis difíceis como o de Sérgio Buarque de Holanda ou Antônio Houaiss" e se questiona do porquê de sentir "tanta dificuldade em fazer o de Wesley [Duke Lee], evadindo-me a toda hora?"51. Ali há, com efeito, elementos da "vida real" do autor Jorge Andrade, sua experiência como redator de perfis jornalísticos. 0 tom de confissão, o uso da primeira pessoa e a referência a pessoas e textos que existem para além do romance evidencia tal leitura. Mas esse não é o cerne absoluto da obra. Quantas não são as confissões em primeira pessoa ao longo da Recherche e quantas não são as alusões dessa obra a textos da vida "real". Ainda assim, dizer o mesmo do romance proustiano seria o mesmo que afirmar analogicamente que o herói Marcel representa a pessoa de Marcel Proust, desprezando todo o esforço criativo que, embora se alimente de uma epistemologia objetiva e se caracterize pela autonomia ôntica de que trata Anatol Rosenfeld ${ }^{52}$, ainda é, sobretudo, poético e caracteriza em última instância o

\footnotetext{
${ }^{50} \mathrm{Cf}$. SANT'ANNA, Catarina. Metalinguagem e teatro. São Paulo: Perspectiva, 2012, p. 57. Esse também é o entendimento de Elizabeth Azevedo. Cf. AZEVEDO, Elizabeth. Op. cit., pp. 16 e 22.

51 Não poderíamos deixar de sublinhar a semelhança dessa imagem de Jorge Andrade, o pintor que se "evade a toda hora", com uma comparação que já citamos, feita por Proust entre o compositor Camille Saint-Saëns e um gnomo: "va-t-il maintenant échapper aux prises de ma pensée qui cherche à le saisir, et ne me laissera-t-il, entre les mains, comme un lutin disparu, que « du vent »?". CSB, p. 385.

52 "Uma das diferenças entre o texto ficcional e outros textos reside no fato de, no primeiro, as orações projetarem contextos objectuais e, através destes, seres e mundos puramente intencionais, que não se referem, a não ser de modo indireto, a seres também intencionais (onticamente
} 
fenômeno literário. "Essencialmente", Labirinto é uma obra poética. Seu autor se apropria do que há de empírico na vida e o transpõe a uma narrativa plena de sonho e de encantamento, onde os mais distintos textos, pertencentes aos mais variados gêneros se entrecruzam. A leitura de Luiz Humberto Martins Arantes é acertada: Labirinto não representa apenas uma coleção de episódios biográficos, trata-se antes da "memorização de uma vida"53. O que significa que, "nesse percurso, a imaginação do dramaturgo vai se encarregando da criação desse material, tornando difícil separar o que é experiência e o que é elaboração artística"54. E essa confusão não é trivial. Ela se revela produto de um método consciente de criação artística que Marcel Proust empregara no início do século XX, que alarga o fictício à fronteira máxima com o real e que concebe o jornalismo como campo fértil para a experimentação literária, para o amadurecimento de um princípio estético, para o desenvolvimento de um estilo descritivo.

autônomos), ou seja, a objetos determinados que independem do texto". $C f$. ROSENFELD, Anatol. $O p$. cit., p. 17.

${ }^{33} \mathrm{Cf}$. ARANTES, Luiz Humberto Martins. Teatro da memória: história e fiç̧ão na dramaturgia de Jorge Andrade. São Paulo: Annablume/Fapesp, 2001, p. 35.

${ }^{54}$ Ibidem, p. 40. 


\section{Considerações finais}

Ao longo desse estudo, buscamos comparar o estilo presente nos textos jornalísticos de Marcel Proust com aquele que encontramos em Jorge Andrade com o intuito de reconhecer ao menos três aspectos fundamentais da visão estética desses autores: primeiro, a maneira inovadora como ambos se inseriram na imprensa de suas épocas, oferecendo às tendências realistas (no caso francês) e neorrealistas (no caso brasileiro) uma contrapartida de grande sofisticação e profundidade psicológica; depois, a proximidade de suas técnicas de descrição, sempre voltadas a um divórcio entre a máscara de um ser e sua alma, na expressão que dá nome a esse texto; por fim, os grandes benefícios que a experimentação jornalística trouxe, em ambos os casos, para a construção de obras memorialistas em prosa, mais sofisticadas e longas.

Algumas questões, no entanto, persistem, e uma delas, que absorvo do ensaio Ressonâncias, de Antonio Candido ${ }^{1}$, pode ser enunciada da seguinte maneira: a presença do estilo proustiano em retratos jornalísticos de Jorge Andrade, assim como a semelhança entre algumas de suas técnicas de construção romanesca, constitui um caso de inspiração ou de citação? A diferença entre essas duas formas de fertilização de um texto literário receptor por outro gerador não é nada fortuita e possibilita estabelecer, finalmente, a natureza da relação que nos esforçamos para traçar entre esses dois autores. Segundo Candido:

$N a$ inspiração, o texto gerador fornece ao texto receptor uma ou mais ideias que contribuem para a sua configuração, tendo um caráter de generalidade que afeta o significado final do todo ou de uma das suas partes. É portanto algo essencial, mesmo quando

${ }^{1}$ CANDIDO, Antonio. Ressonâncias. In: azul, 2010, pp. 81-89. O Albatroz e o chinês. Rio de Janeiro: Ouro sobre 
expresso por palavras diferentes das que ocorrem no texto gerador, pois o que ela transpõe são temas.

A citação, ao contrário, é algo acessório e particular em relação ao significado geral, ou parcial, pois consiste em transpor palavras ou frases que não os afetam necessariamente, mas aumentam a eficiência localizada do discurso, por lhe darem maior beleza ou alcance. Forçando a nota, e falando como se fosse possível existir ideia sem palavra e vice-versa, poderíamos dizer que a inspiração consiste sobretudo na impregnação de ideias, enquanto a citação é transporte de palavras. Portanto, a primeira afeta a estrutura e a mensagem, enquanto a segunda é mais uma questão de estilo. $^{2}$

Nenhuma expressão imediatamente apreensível do romance proustiano ou dos retratos jornalísticos desse autor pode ser encontrada nos perfis de Jorge Andrade. Poderíamos ponderar que palavras como "essência", "verdade" e "alma" abundam tanto nesses artigos da revista Realidade quanto na obra de Proust. Mas seu significado nos parece demasiado amplo para se sustentar o dado positivo e empírico que o argumento da citação demanda ${ }^{3}$. Em outras palavras, termos dessa espécie não são suficientemente específicos do texto gerador quanto exige o juízo da citação. Montaigne fala inúmeras vezes em "alma" ao longo de seus Essais ("si mon ame pouvoit prendre pied, je ne m'essaierois pas, je me resoudrois" ${ }^{4}$ ), e, no entanto, teria grande cautela ao afirmar que sua visão dos seres fertiliza aquela de Jorge Andrade. A ressonância de Proust nos textos receptores de Jorge Andrade nos parece, nesse sentido, muito mais geral e associada a uma visão de mundo do escritor. É o que Candido chama de tema, mas que seria mais apropriado tratar de estilo, na medida em que o termo usado pelo crítico se enquadra muito mais no que entendemos como expressão. De todo modo, sem nos aprofundarmos em um debate terminológico, o ponto que nos interessa é que a percepção proustiana dos

\footnotetext{
2 Ibidem, pp. 81-82.

3 "A citação pode ser comprovada objetivamente, comportando, assim, menor risco para o estudioso". Ibidem, p. 82.

${ }^{4}$ Se minha alma pudesse se sustentar, eu não me ensaiaria, eu me resolveria. $C f$. MONTAIGNE, Michel de. OEuvres complètes. Paris: Gallimard, Bibliothèque de la Pléiade, 1950, p. 899.
} 
seres como uma complexa amálgama entre traços superficiais (a máscara) e um caráter profundo, secreto e obscuro (a alma), orienta a concepção de personalidade que o jornalista Jorge Andrade manifesta no momento em que desenha seus entrevistados. Proust é citado sete vezes no romance Labirinto, por vezes em metáforas que são, com efeito, claras alusões à Recherche ("vejo jardins, flores e moradias passando e penso que estou em Combray de Marcel Proust", p. 263). No entanto, o dado proustiano do estilo de Jorge Andrade, como bem vimos, é tão impregnado na descrição de cada um de seus modelos que limitá-lo a um punhado de casos de citação e de enxertos de palavras ou expressões concorreria para uma compreensão absolutamente redutora. A "leitura incorporada de Proust", para falar como Terezinha Tagé ${ }^{5}$, realmente proporcionou em Jorge Andrade uma técnica de representação do ser humano que "afeta o significado geral do todo" nos retratos desse autor e em seu romance. Trata-se, portanto, de um caso claro de inspiração, com eventuais ocorrências de citação que, longe de serem exceção à tese, só vêm confirmá-la e atestar objetivamente a procedência de um influxo criativo fundamental, a "impregnação de ideias". A descrição dos seres nos retratos jornalísticos de Jorge Andrade possui de fato algo "essencialmente" proustiano. 0 que está em jogo não são as menções "acessórias e particulares" a Proust, as meras "migrações de textos" da Recherche que formam "a expressão que todo homem instruído compõe a partir do acervo em grande parte automatizado das heranças culturais"6. Embora também existam nos textos jornalísticos e romanescos de Jorge Andrade, essas menções diretas a Proust não possuem de modo algum o mesmo poder de "configuração" narrativo que os instrumentos propriamente

\footnotetext{
${ }^{5}$ Cf. TAGÉ, Terezinha. Jornalismo e dramaturgia: o mundo composto de Jorge Andrade. 2010. 122 p. Tese de livre-docência - ECA/USP, pp. 5-6.

${ }^{6}$ CANDIDO, Antonio. Op. cit., p. 88.
} 
proustianos de descrição. É claro que, como Candido ressalva, aludindo a Antônio Soares Amora, "é difícil distinguir entre influência e coincidência"7. Mas o mais curioso do caso é que, embora secundário a nosso ver, o que há de citação a Proust em Jorge Andrade contribui justamente para afastar qualquer suspeita de coincidência na presença desse estilo. A influência das formas proustianas de descrição nos retratos andradinos salta aos olhos; essa é a mais importante modalidade de ressonância nesse caso, e as citações ao autor concorrem justamente para confirmá-la e afastar quaisquer suspeitas de casualidade.

Outra questão que ainda se impõe é mais ampla e diz respeito ao espaço que o romance Labirinto ocupa no curso da moderna literatura brasileira. Responder a isso implicaria sem dúvida um novo estudo e aqui desejamos apenas lançar sementes. Penso no fato de os idos da década de 1970 terem sido marcados pela publicação de outros romances que, assim como Labirinto, pautam sua verve memorialista em um distanciamento do meio urbano e, por conseguinte, em um retorno às origens no espaço rural e provinciano. Ainda mais que isso: romances cujos autores, à semelhança de Jorge Andrade, sempre se disseram profundamente influenciados pela leitura da obra proustiana. Além de Labirinto (1978), citaria $A$ Menina do sobrado (1979), de Cyro dos Anjos, a série Boitempo (1968-1979), de Carlos Drummond de Andrade, e as Memórias, de Pedro Nava, compostas por sete romances: Baú de ossos (1972); Balão cativo (1973); Chão de ferro (1976); Beiramar (1979); Galo das trevas (1981); O Círio perfeito (1983); e Cera das almas $(2006)^{8}$. Da afeição de Jorge Andrade por Proust já tratamos muito ao longo de nosso estudo, mas seria interessante sublinhar o laço que une esses demais

\footnotetext{
7 Ibidem, p. 89.

${ }^{8}$ Este último inacabado e publicado postumamente.
} 
autores ao romance do escritor francês. Drummond traduziu Albertine Disparue em 1956 para a editora Globo de Porto Alegre9; Cyro dos Anjos enviou a Drummond cartões postais de Illiers (Combray) e de Cabourg (Balbec), dizendo que estivera há dois anos no "país proustiano", mas que "um devoto gosta de voltar"10; e, de Pedro Nava, nos resta, dentre tantos estudos a esse respeito, aquele de Maria do Carmo Savietto11, para quem as Memórias do romancista mineiro são alimentadas por uma constante remissão a Proust. Tudo nos faz crer que, em todas essas memórias, o retorno à juventude interiorana foi ao menos potencializado pela leitura das passagens provincianas de $\grave{A}$ la recherche du temps perdu. 0 historiador Etienne Sauthier já havia suscitado essa auspiciosa possibilidade ao tratar da recepção da obra proustiana por escritores brasileiros anteriores, como o poeta alagoano Jorge de Lima. Em uma bela imagem, ele resume o que tentamos dizer: "trata-se de trocar os pomares floridos e o frescor de Balbec pelas alamedas ensolaradas, pelo sol a pino e pelas praias tropicais do Rio de Janeiro, ou pelos espaços rurais do Nordeste"12. Ao que parece, poderíamos ainda alargar a metáfora de Sauthier, somando às alamedas e praias cariocas, ou ao campo nordestino, também os cafezais do oeste paulista ou os planaltos mineiros. Mais além, surpreende a profusão de obras com essas características publicadas em um intervalo de tempo que, no juízo comum dos estudos literários, é tão diminuto (somente quinze anos separam a publicação de $O$ Círio perfeito do primeiro volume

\footnotetext{
9 PROUST, Marcel. A Fugitiva. Tradução de Carlos Drummond de Andrade. Porto Alegre: Globo, 1956.

10 ANJOS, Cyro dos; ANDRADE, Carlos Drummond de. Cyro e Drummond: correspondência de Cyro dos Anjos e Carlos Drummond de Andrade. São Paulo: Globo, 2012, p. 260.

11 SAVIETTO, Maria do Carmo. Baú de madeleines: o intertexto proustiano nas Memórias de Pedro Nava. Florianópolis: Nanquim, 2002.

12 Il s'agit de passer des pommiers en fleurs et de la fraicheur de Balbec aux allées ensoleillées, au soleil de plomb et aux plages tropicales de Rio de Janeiro ou aux espaces ruraux du Nordeste. $C f$. SAUTHIER, Etienne. Brasilianiser Proust: la nature comme élément d'assimilation de l'importation culturelle - (1920-1960). Forum for Inter-American Research, vol. 9, n. 2, p. 56.
} 
de Boitempo). Uma profusão de obras disseminada, além de tudo, em um grande espectro de gêneros, predominando o romance, claro, mas também se enveredando em peças de teatro (Marta, a árvore e o relógio, em 1970) e na poesia (a série Boitempo, de 1968 a 1979).

Foge ao escopo desse trabalho desenvolver quaisquer hipóteses a esse respeito. E mesmo as dúvidas que aqui suscitamos não surgem senão como insinuação para problemas de ordem bem maior que a comparação estilística do jornalismo de Marcel Proust e de Jorge Andrade. Mas uma hipótese de natureza sociológica nos ocorre e torna esse debate ainda mais atraente. A década de 1970 representa, no curso da evolução da economia brasileira, momento crucial de sua modernização. Ocorre-nos que, em 1973, o produto interno bruto (PIB) do país registrou a maior expansão já verificada até os dias de hoje $(13,97 \%)^{13}$ e que, entre os anos 60 e 70, a população urbana superou em definitivo o contingente rural ${ }^{14}$. E poderíamos citar ainda outros vários indicadores econômicos e demográficos que delimitam essa realidade do contexto (a ascensão dos setores da indústria e dos serviços sobre o meio agropecuário, os aumentos expressivos no produto interno bruto per capita, etc). Nesse sentido, o recurso de Jorge Andrade e de outros memorialistas de seu tempo à obra proustiana para fertilizar o tema do "retorno às origens" poderia ser interpretado como uma resposta à acelerada modernização do país naquela ocasião. Possibilidade que se encorpa sobretudo se levarmos em conta que todos os escritores aos quais aludimos nasceram no interior, mas

\footnotetext{
13 World Bank. Brazil - GDP growth (annual \%), 2016. [online] Disponível na internet via: https://data.worldbank.org/topic/economy-and-growth?locations=BR. Consultado em 8 de dezembro de 2017.

${ }^{14}$ Fausto Brito diagnostica uma "recente e acelerada urbanização" no caso brasileiro. Ele ressalta que "a célere expansão urbana no Brasil ocorre dentro do processo de formação das grandes regiões metropolitanas a partir dos anos 1970" e que, nesse mesmo contexto, "mais da metade da população urbana já residia em cidades com mais de cem mil habitantes". Cf. BRITO, Fausto. 0 deslocamento da população brasileira para as metrópoles. Estudos Avançados, vol. 20, n. 57, p. 224.
} 
desenvolveram suas vidas profissionais e interagiram com o debate artístico dos grandes focos dessa evolução do capitalismo brasileiro - as grandes capitais da região sudeste.

Outra hipótese, de modo algum oposta, mas sim complementar, vem da lavra de Antonio Candido. Em um interessante ensaio intitulado A Literatura brasileira em 1972, o crítico resume da seguinte maneira o debate literário daquele momento:

A natureza discursiva da palavra está se sentindo por assim dizer constrangida pelo exagero do seu emprego não-referencial, sobretudo pela desarticulação da sintaxe causada pelas tendências de vanguarda desde os anos 20. E que, em consequência, na medida em que é empurrada para fora da poesia e mesmo do romance, esta vocação referencial volta sob outras formas, para satisfazer a uma necessidade profunda da nossa sensibilidade e da nossa inteligência. ${ }^{15}$

E a consequência desse retorno ao referencial como resposta ao transbordamento "exagerado" das vanguardas para além dos limites do literário seria, por sua vez, "um traço característico da literatura brasileira atual: a importância crescente dos livros de autobiografia, gênero que sempre foi raro no Brasil, apesar de algumas exceções famosas". E Candido segue citando No tempo da flor, de Augusto Meyer (1966); A Idade do serrote, de Murilo Mendes (1970) e Baú de ossos, de Pedro Nava (1972) - todos livros que, narrados na primeira pessoa, "correspondem sem dúvida à biografia de um homem; mas tratados de tal modo que se lêem também como obras de ficção"16. Dessa feita, a julgar pela interpretação de Candido, o traço proustiano que distinguimos no "retorno ao passado provinciano" de cada uma dessas obras se revela um "mecanismo de

${ }^{15}$ CANDIDO, Antonio. A Literatura brasileira em 1972. Revista Iberoamericana, vol. 43, n. 98-99, 1977, p. 12.

16 Idem. 
defesa" por meio do qual a literatura daquele momento "parece querer preservar os seus elementos discursivos e o seu direito a uma sintaxe regular"17.

Trata-se da contrapartida, digamos, estética do argumento socioeconômico que há pouco propusemos. Em todo caso, uma "resposta", uma "defesa" - seja contra a acelerada modernização capitalista que arrebata o país, seja contra uma "excessiva" desarticulação dos meios de linguagem difundida pelas correntes artísticas de vanguarda. E, tivesse sido escrito poucos anos depois, por ocasião da publicação de Labirinto, em 1978, arriscaríamos dizer que o ensaio de Candido trataria também de Jorge Andrade e talvez de Proust, pois o elo entre os dois escritores esclarece não apenas o estilo de certos textos de imprensa ou de um romance isolado, mas sobretudo a profunda influência da Recherche sobre a literatura de um tempo e de um espaço.

17 Ibidem, p. 13. 


\section{Referências bibliográficas}

\section{Sobre Marcel Proust}

AMER, Henry. Littérature et portrait: Retz, Saint-Simon, Chateaubriand, Proust. Études Françaises, Montréal, v. 3, n. 2, 1967, pp. 131-168;

ANJOS, Yuri Cerqueira dos. Proust et la presse de la Belle Époque. Paris: HonoréChampion, 2018;

AZAGURY, Sol Yaelle. Psychologie et portrait littéraire chez Proust. Bulletin Marcel Proust, Paris, n. 55, 2005, pp. 63-77;

BANDEIRA, Manuel. No mundo de Proust. In: Crônicas da Província do Brasil. São Paulo: Cosac Naify, 2006;

BOUILLAGUET, Annick; ROGERS, Brian G. Dictionnaire Marcel Proust. Paris: Honoré Champion, 2004;

BRUNEL, Pierre. La Comtesse de Noailles. In: TADIÉ, Jean-Yves (org.). Proust et ses amis. Paris: Gallimard, 2010;

CANDIDO, Antonio. Realidade e Realismo (via Marcel Proust). In: Recortes. São Paulo: Companhia das Letras, 1993;

CARVALHAL, Tania Franco. L'écriture autobiographique au Brésil: l'héritage proustien. Revue de littérature comparée, vol. 4, n. 316, 2005, pp. 419-430;

LATTRE, Alain de. Le Personnage proustien. Paris: José Corti, 1984; 
LEBLANC, Cécile. Proust écrivain de la musique: l'allégresse du compositeur. Turnhout: Brepols Publishers, 2017;

LEY, Hebert de. Marcel Proust lecteur de Saint-Simon. Bulletin de la Société des amis de Marcel Proust et des amis de Combray, n. 16, 1966;

MARANTZ, Enid. La Genèse du personnage proustien. Bulletin Marcel Proust, Illiers-Combray, n. 53, 2003;

MAURIAC, Nathalie. Edmond de Polignac. In: TADIÉ, Jean-Yves (org.). Proust et ses amis. Paris: Gallimard, 2010;

MENDES, Nancy Maria. Rembrandt e Proust: Dois retratistas. Itinerários, Araraquara, v. 14, 1999, pp. 13-28;

PIERRE-QUINT, Léon. Marcel Proust, sa vie, son œuvre. Paris: Le Sagittaire, 1935;

PINSON, Guillaume. Fiction du monde : de la presse mondaine à Marcel Proust. Montréal: Presses de l'Université de Montréal, 2008;

ROGERS, Brian G. The role of journalism in the development of Proust's narrative techniques. French Studies, n. 18, 1964, pp. 136-144;

ROUGERIE, Colette. Les structures symboliques du visage dans "À l'ombre des jeunes filles en fleurs". Bulletin de la Société des amis de Marcel Proust et des amis de Combray, Illiers-Combray, n. 22, 1972;

TADIÉ, Jean-Yves. Proust et le roman. Paris: Gallimard, 1971; 
Marcel Proust. Paris: Gallimard, 1996;

TAMRAZ, Nayla. Proust portrait peinture. Paris: L'harmattan, 2010;

\section{Sobre Jorge Andrade}

ARANTES, Luiz Humberto Martins. Teatro da memória: história e ficção na dramaturgia de Jorge Andrade. São Paulo: Annablume, 2001;

AZEVEDO, Elizabeth. Recursos estilísticos na dramaturgia de Jorge Andrade. São Paulo: Edusp, 2014;

FARO. J. S. Realidade (1966-1968): tempo da reportagem na imprensa brasileira. Porto Alegre: Editora da ULBRA, 1999;

GUIDARINI, Mário. Jorge Andrade na contramão da história. Florianópolis: Editora da UFSC, 1992;

NEVES, Larissa de Oliveira. Jorge Andrade e Anton Tchekhov: uma proposta de pesquisa. Cadernos Letra e Ato, ano 1, n. 1, 2011, pp. 3-10;

NOSELLA, Berilo Luigi Deiró. A presença de Luigi Pirandello e Jorge Andrade no moderno teatro brasileiro, ou como Décio de Almeida Prado enxerga-os através da lente da formação. Pitágoras 500, vol. 3, 2012, pp. 69-84.

RAHAL, Carlos Antônio. Jorge Andrade: um dramaturgo no espaço-tempo. São Paulo: Perspectiva, 2015;

SANT'ANNA, Catarina. Metalinguagem e teatro. São Paulo: Perspectiva, 2012; 
TAGÉ, Terezinha. Jornalismo e dramaturgia: o mundo composto de Jorge Andrade. 2010. 122 p. Tese de livre-docência - ECA/USP;

\section{Obras literárias auxiliares}

ANJOS, Cyro dos; ANDRADE, Carlos Drummond de. Cyro e Drummond: correspondência de Cyro dos Anjos e Carlos Drummond de Andrade. São Paulo: Globo, 2012;

BALZAC, Honoré de. La Comédie humaine. Paris: Gallimard, Bibliothèque de la Pléiade, tomos I e III, 1976;

BARBIER, Auguste. Souvenirs personnels et silhouettes contemporaines. Paris: Dentu, 1883;

D'AUREVILlY, Barbey. Les quarante médaillons de l'Académie Française. Paris: Albert Savine, sem data;

.XIXe Siècle: les a uvres et les hommes. Paris: Alphonse Lemerre, tomo XVI, 1898;

MERLET, Gustave. Portraits d'hier et d'aujourd'hui, attiques et humoristes. Paris: Didier \& Cie, 1863;

MONSELET, Charles. Les Ressuscités. Paris: Calmann-Lévy, 1876;

MONTAIGNE, Michel de. Essais. Paris: Gallimard, Bibliothèque de la Pléiade, 2007;

SAINTE-BEUVE, Charles-Augustin. Causeries du lundi. Paris: Garnier frères, 15 vol.; 
. OEuvres. Paris: Gallimard, "Bibliothèque de la Pléiade", 1949;

Portraits Littéraires. Paris: Bouquins, 1993;

ZOLA, Émile. CEuvres complètes. Paris: Cercle du livre précieux, 1968;

\section{Obras de apoio teórico e específico}

AUERBACH, Erich. Mimesis: Dargestellte Wirklichkeit in der abendländischen Literatur. Tübingen: Francke Verlag, 2001;

BELLANGER, Claude et al. (orgs.). Histoire générale de la presse française. Paris: Presses universitaires de France, tomo II, 1969;

BERGSON, Henri. Essai sur les données immédiates de la conscience. Paris: Flammarion, 2013;

BOYLE, Brenda M. The Vietnam War: topics in contemporary north american literature. Nova York: Bloomsbury, 2014;

BRITO, Fausto. O deslocamento da população brasileira para as metrópoles. Estudos Avançados, vol. 20, n. 57, 2006;

CANDIDO, Antonio. A Literatura brasileira em 1972. Revista Iberoamericana, vol. 43, n. 98-99, 1977; 
Poesia e ficção na autobiografia. In: A Educação pela noite. São Paulo: Ática, 2003;

Ressonâncias. In: O Albatroz e o chinês. Rio de Janeiro: Ouro sobre azul, 2010;

DESJARDINS, Lucie. Entre sincérité et artifice: La mise en scène de soi dans le portrait mondain. Tangences, n. 77, 2005, pp. 143-155;

DUFOUR, Hélène. Portraits, en phrases: les recueils de portraits littéraires au XIXe siècle. Paris: Presses Universitaires de France, 1997;

FOUCAULT, Michel. Dits et écrits. Paris: Quarto Gallimard, tomo I, 2001;

FURET, François; SACHS, Wladimir. La croissance de l'alphabétisation en France (XVIIIe-XIXe siècle). Annales. Économies, Sociétés, Civilisations, vol. 29, n. 3, 1974;

JAKOBSON, Roman. Linguística e Comunicação. São Paulo: Cultrix, 2003;

KUPISZ, K et al. Le portrait littéraire. Lyon: Presses Universitaires de Lyon: 1988;

MANDEL, Siegfried. Modern Journalism. Nova York: Pitman Publishers, 1962;

MILLER, Carl. Journalism. Nova York: Holt, Rinehart and Winston, 1962;

MIRAUX, Jean-Philippe. Le Portrait littéraire. Paris: Hachette, 2003; 
MORAES, Letícia Nunes de. Leituras da revista Realidade. São Paulo: Alameda, 2007;

NORA, Olivier. La visite au grand écrivain. In NORA, Pierre. Les Lieux de mémoire. Paris: Gallimard, tomo II, 1997;

PLANTIÉ, Jacqueline. La mode du portrait littéraire en France (1641-1681). Paris: Honoré Champion, 2016;

POMMIER, Édouard. Théories du portrait: de la Renaissance aux Lumières. Gallimard: Paris, 1998;

ROSENFELD, Anatol. Literatura e Personagem. In: CANDIDO, Antonio (org.). A personagem de ficção. São Paulo: Perspectiva, 2014;

SAUTHIER, Etienne. Brasilianiser Proust: la nature comme élément d'assimilation de l'importation culturelle - (1920-1960). Forum for Inter-American Research, vol. 9, n. 2, 2016;

SAVIETTO, Maria do Carmo. Baú de madeleines: o intertexto proustiano nas Memórias de Pedro Nava. Florianópolis: Nanquim, 2002;

SIMS, Norman. The Literary Journalists. Nova York: Ballantine Books, 1984;

SPITZER, Leo. Stilstudien. Munique: Max Hueber Verlag, vol. II, 1961;

TALESE, Gay. Frank Sinatra has a cold. Esquire, Nova York, p. 89, abril de 1966;

THÉRENTY, Marie-Ève. Paroles, paroles, paroles: Du portrait littéraire à l'interview d'écrivain. In: BLAISE, Marie; TRIAIRE, Sylvie; e VAILLANT, Alain 
(orgs.). L'histoire littéraire des écrivains. Paroles vives. Montpellier: Presses universitaires de la Méditerranée, 2009;

TRAQUINA, Nelson. Teorias do jornalismo. Volume I. Florianópolis: Insular, 2005;

VITULLO, Mark. Riding the strange torpedo: Hunter S. Thompson and the invention of gonzo journalism - Tese de Doutorado de Mark Vitullo, Radboud Universiteit Nijmegen, 2016;

WILLEMART, Philippe. Os Processos de criação na escritura, na arte e na psicanálise. São Paulo: Perspectiva, 2009;

WOLSELEY, Roland Edgar; CAMPBELL, Laurence Randolph. Exploring journalism. Upper Saddle River: Prentice Hall, 1943; 
ANEXOS 
ANEXO I

RETRATOS PUBLICADOS POR JORGE ANDRADE

NA REVISTA REALIDADE ENTRE 1969 E 1972 


\section{No fundo ela é família}

Quem a vê de longe pensa que ela é alegre e irreverente, só isso. Mas Dercy Gonçalves, de perto, é ainda a menina solitária que não teve o carinho de ninguém, numa infância sem brinquedos.Como quem se defende, ela representa continuamente contra tudo e contra todos, até contra si mesma. Só não representa contra o público e os dois netos - sua única paixão.

\section{Suas jóias são os dois netos}

Quando viu o pai, Dolores tentou correr mas foi agarrada. Então abriu a bôca no mundo:

- Êste homem que me fez mal. Socorro!

As pessoas que passavam se aproximaram. 0 delegado de polícia também. Formou-se o maior bochincho da paróquia.

- É esta que é minha filha.

- Não conheço êste homem. É um tarado.

- É ela. Chama-se Dolores e fugiu de casa.

- Mentira, seu delegado. Êste homem é louco.

- Você é filha dêle, menor, e vai voltar para casa.

- Não volto. Não volto nunca mais.

- Volta nem que seja arrastada.

— Seu delegado. Não sou mais môça donzela. Êle não me manda mais.

- Quem foi? Quem foi?

— Sei lá. Alguém me fêz mal!

Dercy volta-se para mim com sorriso malicioso e completa:

- Era mentira, mas eu só pensava em partir para sempre. Faria qualquer coisa. Falavam muito de mim e já estava me convencendo de que não prestava mesmo. Boquejavam porque eu namorava todos os viajantes que apareciam em Madalena, cidadezinha onde nasci, no interior fluminense. E daí? Gostava de namorar. Quando a companhia Dramática Maria Castro chegou lá, trabalhei vendendo bilhetes do espetáculo de porta em porta. Sabia que era a minha oportunidade. Naquele tempo, poucas companhias teatrais se aventuravam até a minha terra. De vez em quando aparecia um cirquinho mixo. Era tudo. Na noite em que a companhia devia partir, fiz um boneco de pano e coloquei em minha cama. Depois me escondi no banheiro do trem. Assim eu parti. Mas na estação mais próxima tive uma vontade desgraçada de ver se já estava longe e levantei a vidraça do trem: fui vista por um parente. Meu pai foi me esperar em Macaé, parada seguinte da companhia.

Dercy sorri e acrescenta:

- 0 negócio que falaram do cantor era mentira, mas foi a maneira de me livrar daquele homem. 
Eu percebia que ela representava, que o que dizia não era tôda a verdade. Mesmo assim, envôlta em suacapa de pele, brincando com seus caríssimos anéis de brilhantes, encolhida na poltrona como uma gata - posição preferida em que se matém quase o tempo todo - , olhando-me sempre com o sorriso malicioso, perguntou-me:

— Não acredita em mim?

- Acredito - respondi. Logo pensei na pureza e na ingenuidade dos sêres simples. - E seu pai? - perguntei.

- Ficou plantado no meio da rua enquanto eu me afastava dêle e daquela vida miserável. Meu pai era um xumberga, coitado. Grau 33 da maçonaria. Também, lá todo mundo era grau 33! Meus pais não viviam bem e minha mãe teve que fugir quando eu tinha três anos. Minha mãe era boa, meu pai é que era safado. Êle tinha uma amante. Nós vivíamos numa casa de barro em Madalena, onde o fogão era uma trempe, não tínhamos guarda-vestidos, cada um possuía uma malinha, como se estivéssemos sempre de partida. Num mesmo quarto dormiam quatro irmãs e tudo na mesma cama. Mesmo assim, ainda quero comprar aquela casa.

Dercy observa os brilhantes no dedo - 150000 cruzeiros novos os dois, anuncia - e, enquanto brinca com êles, acrescenta:

- De Madalena guardo uma lembrança sem brinquedos. Tive uma bonecade pano que eu mesma costurei. Fiz meus brinquedos, como tudo que conquistei na vida.

Ela puxa a gola do casaco, encolhendo-se num gesto de defesa. Há uma pequena pausa e ela continua sem olhar:

- Não tive o carinho de ninguém e isso me irritava e ainda me irrita. Nunca mais consegui acreditar nos carinhos de ninguém. Tentei muitas vêzes, faço fôrça, mas não acredito.

— Nos carinhos de ninguém?

- Não falo das pessoas da minha casa. Estou pensando em gente do mundo. Subitamente, ela grita, pedindo que alguém traga pastéis.

- Gosto muito de pastéis. Você não?

- Gosto, mas não quero - respondo.

Ela muda a posição na cadeira, mas conserva-se sempre encolhida.

- De uma coisa nunca me esqueci: a gripe espanhola. Pois é! Todo mundo corria em minha casa de barro, pelas ruas de madalena, por tôda parte; outrosmorriam; uns na cama, outros de pé... e eu, sentadana escada, tremendo de frio. Ninguém me dava atenção. Ouvi uma conversa que limão era bom. Corri para o quintal e comi alguns. Fiquei boa. Eu me curei. E assim foi a vida inteira. É por isso que não me incomodo com o que pensam de mim. Tudo o que fiz faria novamente. Dolores é isso, Dolores é aquilo... como falavam os safados. Que eu era precoce, era. Gostava de dançar, de falar com todo mundo. Era censurada, respondia com agressão. Quebrei a cabeça de muita gente com pedra. Era uma gata selvagem e custei muito a sair disso, só mesmo depois que fiz análise. Sabe que faço análise há sete anos? Queria descobrir, entre outras coisas, as razões que me levam a falar tanto palavrão no palco. Agora continuo falando, mas conscientemente. No palco, hein! Na minha casa ninguém diz palavrão. Nem eu. Ri e pense: ela é antes de tudo, um bom caráter.

- No palco, eu falo e na hora certa. É por isso que os tais intelectuais torcem o nariz para o meu teatro. Mas o público está lá e é a êle que devo 
agradecer. Mas esses desgraçados não me incomodam. Já não ouvi dizer que o pior calçado é o que vende mais?

- Já - respondo. - Se está pensando, não sou um dêles. Gosto de seu teatro como êle é.

- Eu também - acrescenta, maliciosa. - Falo, mas não gosto de ouvir. Francamente, nem sei o que é palavrão. Quando digo algum, sei que estou xingando, nada mais. Coisas que aprendi quando era pequena. Palavrão não é, porque não incomoda ninguém. Esquematizaram o palavrão, essa é a verdade. Bêsta pra burro! Os palavrões em Roda Viva, por pessoas que normalmente não diriam. Era tudo premeditado e sem sentido. Eu, não. Não blefo o público, ridicularizo o drama. A minha vontade é dar alegria e não problemas. Quero que acreditem que a própria desgraça é uma brincadeira, que ela pode ser modificada e vencida, quando se brinca. Veja o tal teatro agressivo. Francamente não sei o que esse teatro quer dizer. Agredir por quê? Acho que aquela cambada de efeminados quer é agredir a eles mesmos. Eu, não. Eu me comunico com o público por que sou verdadeira, eu me entrego a êle em vez de dar porrada na cara dele.

Enquanto Dercy falava, lembrei-me de que ela só não representa contra o público, mas contra a peça, contra o cenário, contra os outros intérpretes, contra as roupas e até contra ela mesma. - mas nunca contra o público. A sua principal característica é sair da personagem e fazer observações pessoais irreverentes sôbre a representação, a começar por ela mesma. É o crítico menos ortodoxo do mundo: muitas vezes interrompe o andamento de uma cena para dizer: "Como é enjoado êsse pedaço". E para o público: "Vocês não estão achando isso tudo muito cacête? Não sei como vocês suportam". Ninguém vai ver Dercy com a intenção de se divertir com a peça, pois tudo o que há nela pertence ao imprevisto. Se a peça resiste, acaba fazendo figura ridícula. Com ela, a crítica não se pode fiar: nunca se sabe qual a peça que ela vai representar no dia seguinte.

Sentado no palco do Teatro das Nações, em São Paulo, ouvindo-a falar de sua vida, concluí que ela faz a mesma coisa com os fatos de sua vida. Ela representa uma ignorância a respeito de tudo - é talvez um de seus traços mais característicos - e nessa representação consegue confundir as linhas de sua verdade. É um jogo teatral que ela usa em todos os momentos e que a faz melhor atriz fora do palco. Lembrei-me do poeta português Fernando Pessoa: "O poeta é um fingidor/ Finge tão completamente/ Que chega a fingir que é dor/ A dor que deveras sente".

Nesse jôgo de realidade, fantasia e promoção, é difícil segurar Dercy. Lembro-me do caso de Eugênio Paschoal, cantor da companhia Castro com quem Dercy fugiu de casa. Antes que ela me escapasse, perguntei:

— E Eugênio Paschoal? Você prometeu contar. Fugiu com ele por amor?

- Amor!

A voz sai metálica. Arranja a franja da peruca - uma entre as dezenas que possui -, puxando-a mais para baixo, como se tentasse encobrir mais o rosto. Percebi que, se tivesse que revelar a verdade, teria que fazer um forçoço. E ele foi feito. De seu rosto, eu via apenas a boca e o nariz. Tudo que podia revelar mais do que queria escondera-se. A voz começou macia e foi ficando áspera e dura. Repetiu:

- Amor! Quis apenas me livrar de Madalena. Fui à praça e me sentei num banco de cimento e pensei. Penso sempre, discuto comigo mesma antes de tomar qualquer resolução. Foi sempre assim. No lugar daquele banco, hoje tem um busto 
meu. Fui na inauguração. Foi uma badalação que não tinha fim. Mas o busto é bacana. Lembro-me que fiquei durante muito tempo pensando se fugia ou não. Eu nem sabia por que queria fugir. Mas queria mais do que tudo. Naquele banco, eu dei o meu veredicto. Sabia que meu pai ia sofrer. Não liguei para o sofrimento dele. Minha mãe também sofreu e foi embora. Eu também tinha que ir. Quando a companhia da Maria Castro chegou na outra cidade depois de Macaé, lá onde houve o forró do delegado, eu e o Paschoal já fomos para o hotel como marido e mulher. Era lá que ia acontecer. Era um quarto antigo, com mesinha de cabeceira, cama de arame e, ao lado, uma bacia com pés de ferro. Deitei, apaguei a luz e pensei: o negócio agora é entregar a rapadura.

Dercy brinca com o colar, enrolando-o nos dedos. Lembrei-me da boneca de pano, das pedras e dos limões na gripe espanhola. Diante do meu silêncio, ela olha para mim e percebo que algo de muito pungente se escondera atrás do sorriso malicioso, dos longos cílios postiços, da representada ignorância. De repente, não me senti como um repórter, mas como um autor que vive à procura de suas personagens. Diante de mim estava uma mulher extraordinária e eu não consegui segurá-la. E foi com uma expressão infantil, com sorriso de menina, que acrescentou:

- Paschoal foi o primeiro homem da minha vida, mas vivi com ele sem sexo, sem amor. Êle me apavorou, foi cruel naquela noite! Morreu tuberculoso.

Antes que eu perguntasse, ela completou meu pensamento.

- Depois dele tive uma meia dúzia de homens bem contados. Mas homens, hein! Homens ali no duro. Mas vamos deixar isso pra lá. Tenho filha, netos, pra que falar sobre isso, você não acha?

- Acho. Mas a vida de pessoas como você pertence ao público.

- Está bom. Tive alguns homens pra ver se acertava, mas eles me acertaram. Fôrça eu fiz. Sempre arrisquei, mas foi como comprar bilhete de loteria: sempre tirei apenas o mesmo dinheiro. Casei só uma vez: com Danilo Bastos. E me desquitei. Êle me ajudou muito na vida artística, me orientou, aprendi com ele muita coisa. Mas depois meteu os pés pelas mãos, perdeu tudo.

Dercy manda comprar sementes de abóbora e até o fim do nosso diálogo, ela come sem parar.

- Tinha medo daquela gente de Madalena. Sentia-me trancada numa casa de joão-de-barro. Sabe que o João-de-barro fecha a porta do seu ninho quando a Joana comete traição? Tranca e morre todo mundo lá dentro. Era assim que eu me sentia. Tinha perdido até Floripes, a irmã mais velha que me criou.

- Perdeu por quê?

- Casou. Eu e minhas irmãs sentimos ciúmes, foi como se tivessem roubado a Bita. É assim que chamo Floripes. 0 marido dela era muito ciumento e eu só conseguia vê-la pelas frestas da porta e das janelas. 0 marido achava que eu era perniciosa, portanto fez tudo para afastá-la de mim. Desde então, passei a não ligar para nada. Hoje, Floripes mora em São Paulo, na rua Guaianases.

- Eu sei - respondi. - Estive falando com ela.

Dercy fica excitada e algo temerosa.

- Que foi que ela contou a você? Fala logo!

- Que criou você, que você ardia como pimenta. Tanto que tinha o apelido de "pimenta-malagueta", que naquele tempo as môças não usavam trabalhar, mas que mesmo assim você foi ser bilheteira do único cinema de Madalena quando tinha apenas doze anos. Contou-me que você assistia aos filmes e copiava os 
vestidos das atrizes, fazendo-os a mão. À noite colocava fita nos cabelos, imitava os penteados, o andar, tudo das atrizes. E por isso era chamada de Pola Negri ou Teda Bara. Que desde criança você gostava muito de teatro. Quando alguma garota a convidava para brincar de boneca, você respondia: "Deixa de ser bêsta. Vamos brincar é de teatro". Sabe o que mais Dercy?

- Como é que eu vou saber? Não estive lá.

A aparente indiferença da voz não conseguiu esconder uma certa apreensão.

- Disse que até hoje você é muito medrosa. Covarde, às vezes.

- Não mentiu. Sempre tive medo. Não sei de onde vem, mas tenho. Veja meus netos...

\section{Dercy desconhece o palavrão}

Dercy pára sùbitamente. Uma nova expressão que não vinha de Madalena nem da atriz dominou seu rosto. Não era a primeira vez que citava os netos. Aliás, é a sua mais constante citação. Desde o começo ficara claro que eles são sua verdadeira obsessão. Tudo, até os brilhantes que compra, é pra eles. Quando fala dos netos, revela imediatamente que há algo em sua vida que é intocável; se alguém tentar tocar, a gata vira onça.

- Tive um mêdo desgraçado quando meus netos nasceram. Tenho mêdo que me roubem êles, que morram, que não estudem, que não virem gente. Quero que sejam grandes homens. Não sei explicar, mas estou sempre com mêdo.

0 sorriso domina seu rosto e ela acrescenta:

- Quando me encontro com meus netos, fico fazendo chácara e êles tudo feito cachorrinho à minha volta, esperando meus presentes. Mas vou dando devagar, para saborear as carinhas. Só êles me fazem esquecer de tudo; me dão paz, felicidade. Êles e minha filha - não quero mais nada. Se eu morresse hoje... todo mundo morre, não é mesmo? É muito chato, mas é verdade. Mas, se eu puder driblar a morte, eu driblo. E se me perguntarem: vai você ou o vizinho? Mando o vizinho. E, se for para entrar na fila, entro em último lugar.

Senti que ela não revelara a verdadeira razão e insisti na pergunta:

- Mêdo do quê?

—É a incerteza da vida, só isso. Sei muito bem em que você está pensando. Mas não é isso, não.

- E o que é que estou pensando? isso?

- Que meus netos venham a me criticar e sentir vergonha de mim. Não é

— Não é bem isso, mas gostaria de saber sua opinião a respeito.

- Quando começarem a entender o que é a vida, sei que vão ter orgulho de mim, de todos nós. Sabe por quê? Porque nós somos gente. É por isso que quero que sejam gente: para saber dar valor. Tudo o que faço é pra êles. Que vá para o diabo quem pensar o contrário.

Por um momento não conseguiu disfarçar uma expressão de insegurança. A representação também tem um limite, e agora ela fala de personagens verdadeiras de seu mundo. Se Dercy brinca com os papéis que representa no palco, com o público, com a crítica, consigo mesma, quando fala da filha e dos netos, a Dolores 
toma conta da Dercy e olha para os anéis de brilhantes como se trouxesse presa em seus dedos magros a segurança dêles. A menina que fez sua própria boneca, que se tratou sozinha para não morrer, falava de crianças suas mais caras que o mundo.

- Minha filha sempre foi tudo pra mim. É uma dama. Fêz o curso completo da Cultura Inglêsa. A responsabilidade é minha, não tem culpa de nada, não me pediu pra vir a este mundo. Darei a ela tudo a que tem direito. Sei que gosto mais dos meus netos do que dela. Mas é assim mesmo, não é? Quando estamos juntos, eu e meus netos temos a mesma idade.

Pensei comigo: junto deles e longe também. Afinal, representar não é um jôgo? E jogar não é brincar? Olho-a firme nos olhos e jogo a pergunta:

- Dizem que está milionária e que emprega muito bem o que ganha, é verdade? Se foi para êles que ganhou, não precisa temer pelo futuro.

- Não preciso mesmo. Comprei muitos apartamentos e jóias pra danar. Êste ano paguei cento e cinqüenta milhões de impôsto de renda.

Dercy abre a bôlsa e tira dois anéis enormes. Olha para êles como se fôssem brinquedos. Por um momento não sabemos se é o valor ou o brilho que a atrai tanto. Revira-os diante dos olhos, admira-os à distância, enquanto fala:

- Gosto de jóias bem grandes, exageradas. Êste é feito com um ponto de macumba.

- 0 que é ponto?

- Na umbanda, quando êles baixam, têm um ponto de firmeza: a estrêla de Salomão, e dentro dela a cruz e as flechas. Estrêla d'água do povo de Iemanjá. Êste vale cinqüenta milhões e o outro, perto de vinte. Somando tudo, os que estão em meu dedo e êstes, são duzentos e vinte milhões. Tenho um cofre cheio dêles em um banco, para meus netos.

- Nós vamos chegar no que você juntou para os netos, Dercy. Mas por enquanto vamos voltar ao hotel onde você e Eugênio Paschoal se registraram como marido e mulher. Lembra-se? Que aconteceu depois.

- Fiquei na companhia de Maria Castro. Vivi com Paschoal durante quatro anos. Depois, êle morreu e eu fiquei doente. Mais tarde reencontrei Maria Castro no Teatro Recreio, no Rio de Janeiro, e ela me deu nova oportunidade. Mambembei pelo Brasil afora. Em 1933, o empresário Duque inaugurou o teatro Casa de Caboclo, na Praça Tiradentes, Rio de Janeiro, onde era o antigo Teatro São José. Só representavam textos regionais e eu estreei em Alma de Caboclo. A princípio, como cantora, especializei-me em interpretações sentimentais. Até que um dia, Duque me chamou para contracenar com Jararaca e Ratinho, a dupla caipira. Armei um forró daqueles; gritei que não era "trapézio" dos dois. Como Duque insistisse, fiz o papel. Mas, para vingar-me, desvirtuei completamente a cena e o diálogo, querendo com isso que o quadro fôsse cortado da peça. 0 público riu a valer. Eu fui o sucesso da noite. Assim nasceu a atriz cômica de revista. Até 1952, dominei a Praça Tiradentes, ganhando altos lucros como rainha do rebolado. Foi quando anunciei que ia fazer teatro de mais substância e um desgraçado qualquer escreveu: "Lá vem chanchada, ou tudo issi é propaganda". Desmenti. Aluguei o Regina na Cinelândia - paguei cem mil cruzeiros mensais, uma fábula na época - contratei dezenas de artistas, um cenógrafo de nome e o diretor mais exigente: Chianca de Garcia. Daí nasceu a Túnica de Vênus.

Entre uma semente de abóbora e outra, ela se vira para mim e grita: 
- Se tivesse a vida que tive, como agiria? Se fôsse me criticar, o que diria? Você pergunta demais, mas não abre o falador!

Lembro que em arte não há gêneros superiores e inferiores, e aproveito para perguntar sua opinião sôbre Nélson Rodrigues.

- Hoje dizem que é um maluco, amanhã será um gênio. Como tudo no Brasil: depois que morre é que descobrem o valor. Quem pode garantir o que é certo? Acho que êle escreve sôbre o que passa na cabeça dêle. Mas dizem que isso é ser gênio! Eu não sei. O Portinari também é tido como gênio com aquela gente tudo doente que pintou. Eu, não. Gosto de coisa bonitinha, perfeitinha, como êsse príncipe aí na parede. Gente burra, feia e doente, chega o berço. Você, por exemplo, eu não conheço. Nunca ouvi falar.

- Não sei por que deveria me conhecer - arrisco.

- Ora, deixe de fricote. Conheço gente de teatro. Mas vou dizer uma coisa: se você não fôsse a pessoa que é, já tinha liquidado a conversa. Você tranqüiliza a gente, é por isso que dei o serviço inteiro. É verdade! Não precisa fazer essa cara de bêsta.

- Pensei que gostasse de ler - respondo, disfarçando.

- Não leio nada. 0 único livro que leio é o de psicanálise. Ler me dá sono. Não gosto de aprender as coisas dos outros. Se fico lendo, eu me perco. Quero saber é de mim. Vivo cheia de mim. Os outros não me interessam. Gosto de mim e de brilhantes. Sou tarada por brilhantes! Já li muita mentira sobre o que falo. Certo jornal publicou que eu gostava muito de Guilherme de Almeida e do Vinicius. Nem sei quem são. Conheço um como beberrão e outro porque morreu há pouco tempo. Lembro-me de que alguém me disse: "O Guilherme morreu". Fiquei tristíssima, saí correndo e me pendurei num telefone. Mas não era o Guilherme que eu pensava, o que eu conhecia como adido cultural em Paris. Como é mesmo o nome?

— Deve ser o Guilherme Figueiredo. É este?

- É qualquer coisa assim.

\section{Passeata, só fez em procissão}

Penso em muita gente que finge conhecer os poetas dêste País e que não conhece. Não vejo porque Dercy deveria conhecer. Foi neste instante que me veio à lembrança a grande comunicabilidade da atriz. Perguntei:

- Alguma vez não conseguiu se comunicar com o público?

Durante um instante, ela pensa e me observa.

- Só uma vez. Foi um show de boate. Eu fazia o papel duma tal Elza Maxwell, uma cronista social qualquer. Senti-me falsa, não era eu e o público ficou me esperando, vendo se me encontrava. Eu também. Fiquei encabulada, tive vontade de fugir, fugi. Não quis nem receber. E não era só por causa do papel que representava, não. Fico danada com gente que bebe. Parece que engolem até o juízo, fica tudo de ôlho parado. Horrível! Pior só me senti quando estive em Portugal.

- Que foi que aconteceu?

- Quiseram encenar meus sucessos da Praça Tiradentes. Foi o fiasco. Também, em Portugal, êles falam da mãe do princípio ao fim. Aqui a gente nem se lembra de que tem. Um jornaleco caiu em cima de mim como urubu na carniça. A companhia era tão pobre, tão pobre, que no final da peça todos os artistas se 
juntavam no palco e cantavam: "Philips, Philips, oh! Philips", com luzes acendendo e apagando pra todo lado. Era a miséria.

Dercy interrompe o pensamento quando percebe que eu a examino.

- Que foi? Perdeu alguma coisa na minha cara?

- Estava reparando como ainda é môça. Não parece ter a idade que dizem ter.

- Mas tenho. Sessenta e um anos bem vividos. Não é o que dá pra quem nasceu em 1908? Se a gente não ama o corpo que tem, o que vai amar?Fiz quatro operações de plástica por amor a mim. Pitangui e Fabrini, os mais famosos do Rio de Janeiro. Três operações na cara e uma na barriga. E faço vinte se fôr preciso. Onde cair eu mando tirar. Não nasci com coisa pendurada.

Não me contive e minha gargalhada ecoou em todo teatro. Esperou que eu acabasse de rir e acrescentou:

- Sabe que aprecio você? É verdade. Até agora não me contou nenhuma piada. Detesto homem que conta anedota.

Fico sem jeito e percebo que tenho muito mais defesas do que ela. Fujo, jogando a pergunta:

- Que pensa de Karl Marx?

— Quem é êsse cara? Não me viro pra esse lado.

- E passeata, já fez?

- Só em procissão em Madalena.

- Acha que o homem e a mulher são iguais?

- Iguaizinhos. São diferentes só na barba. Quanto a sexo, então, todo mundo tem na cabeça e não no lugar certo. Eu, não. Penso assim: se hoje é dia de comer feijoada, então eu como. Se não tiver, não como nada. Agora, se tiver, eu como um prato cheio. Criaram um fantasma em torno disso, que nem êsses cabeludos são capazes de vencer.

\section{Ainda procurando a si mesma}

Nessa altura, quase não preciso fazer perguntas. Depois de dois dias dialogando comigo, Dercy se entregava mais livremente. Acrescenta:

— Você também não pensa assim? Como é que você pensa a êsse respeito?

Replico que não sou eu que estou sendo entrevistado, que o público quer saber quem é Dercy, e não Jorge Andrade. Ela mastiga algumas sementes de abóbora e me conta:

- Sabe que fui pedida em casamento por um sultão do Líbano? Pois fui. Perguntei quantas espôsas êle tinha. Três respondeu. Êle disse que me daria jóias, carros e não sei o que mais. Tudo isso eu tenho, respondi. E homem eu quero um só pra mim. Inteirinho.

Súbitamente, ela empurra a peruca para trás: - Não acha que já falei demais? Já estou cheia.

Faço de conta que não percebo sua irritação e pergunto:

- 0 que é que emociona você, Dercy?

Pela expressão, percebo que ela não está cheia de nada, que ela gosta de falar, que a sua grande arte é a da comunicação. Olha pra mim e sorri:

- A natureza, o mar, as montanhas, tudo isso é lindo, principalmente o brilhante.

Levanta a mão e acaricia os anéis com o olhar. 
- Como é lindo o brilhante - sussurra. - Choro quando ouço o hino nacional fora do Brasil, fico arrepiada quando vejo um touro entrar na arena; e nem sei o que sinto quando vejo a rainha da Inglaterra sair naquela carruagem. Fico ensando no trabalho que ela tem pra ser tudo aquilo.

E apertando a gola do casaco de pele no pescoço: sociedade?

- Acha que, se eu estudasse, seria uma mulher formidável para a

Quando tento organizar uma argumentação, ela conta:

- Êta pergunta bêsta, não?

- Por quê?

- Porque já estive muitas vezes no meio de quatrocentões. Achei quase tudo meio maluco, só pensando em passado. 0 que ia ser de mim se ficasse prêsa ao passado, pensando em Madalena? Deus me livre. Passado pra mim foi ontem e o futuro é hoje. Conheço umas donas que arranjam até vestido emprestado, só pra passar pelo que não são mais. Pra que isso? Bom é viver feliz com a gente mesmo. A semana passada, uma môça veio ao meu camarim. Até que era bonitinha, a coitada. "Sou uma môça da sociedade." Olha que apresentação! Lá isso é título? Tão baratinada, tão perua.

Mentindo que ela já estava se atrasando para o espetáculo da noite, representa $A$ Viúva Recauchutada, lanço meu último argumento:

- Todo mundo fala da lua como...

- Já encheu até.

- Por quê?

- Depois que êsses caras foram para a lua, eu fiquei preocupada comigo nesta bola de terra. Não sei por que, mas fiquei baratinada comigo mesma, com meus netos, com tudo. A lua era tão bonita e agora não passa de uma porcaria. Porcaria lançada de vulcão. Um lixo. Estragaram com as noites. Não tenho mais vontade de olhar pra cima.

É verdade que você detesta sol? Como vai se arrumar sem lua e sem sol?

- Não gosto mesmo. 0 sol descobre muita coisa na gente, é luz demais pra mim. Sol é para as crianças, as plantas, os passarinhos.

Dercy se agita, fica algo nervosa e uma sombra de preocupação passa por seu rosto:

- Falam tanto de mim e até hoje não me disseram quem eu sou. Gostaria de saber. Sei que procurei amor. Fugi das perseguições, fugi da falta de amor. Uma palavra, um carinho, um gesto me conquistam. Não disfarço nada pra mim nem para os outros. Eu sinto na dura. Não gosto de fantasiar nada. Me parece que tudo complica cada vez mais.

Como é mesmo a frase que você perguntou?

- Ser ou não ser, eis a questão. É esta?

- Esta mesma. Como é que vou saber se eu mesma estou procurando e não consigo descobrir o quê? Agora preciso me arrumar. 0 público já está chegando e penso nele em primeiro lugar. Boa noite.

Quando se voltou para sair, ainda trazia o sorriso malicioso.

- Boa noite - respondi. Peguei minha máquina e saí. A sala de espera estava repleta. Andando pela rua, aquela menina sentada na escada, tremendo de frio e costurando sua boneca, não me saía do pensamento. 


\section{Duke Lee, o nosso surrealista tipo exportação}

Wesley Duke Lee, 39 anos, desquitado, autor de 600 quadros, é um homem e um artista muito discutido. Recusado em sete Bienais de São Paulo, tirou o $1^{\circ}$ prêmio na Bienal de Tóquio. Seus trabalhos são procurados por museus do mundo inteiro, mas, entre nós, há quem diga dêle: "Não passa de um Salvador Dali com malária". Outros dizem simplesmente: "Lee é um gênio".

Na sala havia apenas uma mesa e uma máquina de escrever. Wesley Duke Lee - pintor brasileiro nascido em São Paulo, com pinta de mandarim, neto de lavadeira portuguêsa e de pastor metodista parente do general Lee, chefe das fôrças sulistas na guerra de secessão americana - parou um pouco assustado. 0 homem magro, pequeno, afundado atrás da máquina com ar insolente e autoritário, olhou para êle com certo desprêzo:

- Profissão?

- Pintor.

- Pintor de quê?

- De quadros.

- Isso não é profissão.

- Para mim, é.

- Que tipo de pintura você faz?

- Surrealista. Ou pode escrever que sou um pintor contemporâneo.

— Então você é comunista?

- Não.

- Como é que não é? Todos os artistas são!

- Eu não sou!

- Quantos quadros já pintou?

- Perto de seiscentos.

- Você vive de seu trabalho?

- Claro. É a minha profissão.

- Profissão! Quanto já ganhou com ela?

— Mais ou menos 700 milhões. Ou melhor: 700.000 cruzeiros novos.

— Como?!

- Vendendo quadros. E tenho um acervo de trabalhos meus que valem 500.000 .

— Você dá muita orgia em seu estúdio?

- Nunca dei nenhuma. Meu estúdio é minha casa.

- Tem mulher pelada em sua casa?

- Sim, quando alguma toma banho.

— E êste telegrama? 0 que significa? 
— Não sei que telegrama é êste.

— "Rodriguinho barra limpa primeiro realista mágico de Niterói manda dizer ao tio Lee que a ordem do dia é: fralda larga e leite môrno. Assinado o pai." Isto é código!

— É apenas meu amigo Sérgio Mendes participando o nascimento do filho.

- Ninguém participa nascimento de filho dêsse jeito. Vamos investigar a história dêste telegrama. Enquanto isso, você fica prêso.

Wesley troca o cachimbo pela cigarrilha, puxa o bigode que cai ralo sôbre a bôca, bigode de mandarim:

- Nunca senti tanto mêdo.

\section{Psicanálise e LSD, para aprender}

Desde que cheguei ao seu estúdio - 18 metros de comprimento por 8 de largura, um pé-direito de 6 metros - senti minha atenção prêsa ao seu quadro "Meus Pais". Os olhos da mãe de Wesley me seguiam desde o momento em que entrara no estúdio. Pareciam querer me agredir, defendendo uma verdade que só ela deveria conhecer.

- Êsses quadros, Wesley, contam a sua história. E eu lhe pergunto: nêles, que aspectos vêm da sua avó lavadeira e quais os que vêm do avô religioso?

No quadro, os olhos da mãe de Wesley ficaram um pouco mais duros, com um brilho metálico.

- Até há pouco tempo eu também não sabia. Depois da experiência com o ácido lisérgico e da análise, consegui compreender. Já tomou ácido lisérgico?

- Não.

- Eu tomei há oito anos, em busca da verdade. Mas ela não se revela de uma só vez.

Olhamos os quadros à nossa volta: fatos da vida de Wesley estavam presentes em quase todos. Continuei sentindo que os olhos da mãe me observavam. Wesley atende ao telefone e determina o despacho de um quadro seu para a Venezuela - é êle quem faz tudo, não tem despachante. Todos os seus trabalhos estão fichados, catalogados. No caos que parece ser o seu estúdio há uma organização perfeita. Na aparente confusão dos milhares de coisas espalhadas pelas mesas e paredes há um sentido procurado - talvez o desejo de distrair a atenção de quem chega, para que o mundo dêle não seja percebido na sua essência. Revelando mente metódica e grande capacidade de continuar um pensamento interrompido, Wesley começa a contar como foi sua experiência com o ácido lisérgico. 


\section{Uma segunda visão da vida}

- Eu estava sentado na poltrona de couro e comecei a sentir o relaxamento nos pontos de menor tensão em mim: primeiro nos ombros, logo em seguida nos músculos da mandíbula, na virilha e nos pés. Percebi que tinha partido para uma libertação mental. As palavras que vinham ao meu pensamento eram diferentes. As primeiras impressões estão ligadas aos sons: a capacidade de audição torna-se aguda. A percepção espalha-se para todos os planos da vida, do pensamento, das recordações, do espaço e das sombras. A outra dimensão das coisas e de mim mesmo já estava presente antes que o médico tirasse a agulha de minha veia.

- Médico?

- Usei ácido lisérgico como procura estética. Era uma experiência, portanto a fiz com a presença de um médico.

- Você acha que a experiência pode criar um mundo de fantasia para qualquer um?

- Não. Quem não tem nada dentro de si mesmo não pode encontrar nada. Eu procurei, sobretudo, minha segunda visão da vida, da que sempre estêve em mim, mas que não conseguia compreender. Senti que tinha perdido o mêdo, os preconceitos desapareceram junto com a desinibição. Senti-me cheio de prazer até mesmo diante das linhas erradas. Passei a viver no movimento e nas cores. Tudo em mim e no mundo era ação. Minha mão e meus dedos estavam cheios de audácia; meus olhos começavam a ver além da aparência das coisas e dos fatos.

De repente, Wesley levanta-se e vai pegar um envelope cheio de fotografias. Olha para mim meio hesitante como se não quisesse continuar. Mas a vontade de comunicação nêle é mais forte do que tudo, e êle deixa o envelope em cima da mesa.

- Comecei a me sentir dividido em dois e percebi que uma das partes era meu próprio fiscal. Sem saber por que comecei a chorar. Subitamente, veio à minha memória meu irmão aos dois anos montado no cavalinho de pau. Suas pernas, cobertas pelo aparelho de paralisia infantil, desenharam-se à minha frente como certos desenhos surrealistas. À nossa volta percebi as hortênsias de meu avô... e sôbre uma delas apareceu e desapareceu uma imensa borboleta amarela, lembrando um laço de fita. No primeiro momento não percebi o que mais me irritava: se as pernas de meu irmão ou a borboleta amarela! 
Wesley olha-me irritado, como se eu estivesse obrigando-o a falar. Segura um copo de uísque e me observa. 0 copo é de cristal, lapidado - Wesley é todo finesse. Mas de repente explode em palavrões.

\section{Muitas atenções para meu irmão; nenhuma para mim}

A história da borboleta amarela e das pernas do irmão de Wesley não saíam da minha cabeça. Como não se despregavam de mim os olhos de sua mãe, no quadro. Êle continua rememorando a sua "viagem" com LSD:

- A lembrança de meu irmão, no cavalinho de pau, trazia a grande mágoa que eu sentia aos quatro anos, vendo tantas atenções para êle e nenhuma para mim. Mas aquelas pernas paralisadas eram uma terrível acusação que, por mais que eu procurasse fugir, meu fiscal não permitia. E, enquanto descobria que minhas lágrimas eram determinadas não por injustiças cometidas contra mim, mas cometidas por mim mesmo, meu avô ergueu-se do meio das hortênsias e caminhou para mim.

Wesley vai até uma das mesas e do meio de centenas de objetos tira um relógio de bôlso. No quadro, os olhos da mãe pareceram vigiar, ciumentos, os movimentos do filho.

- Enquanto meu avô caminhava para nós, meus olhos não saíam da corrente de seu relógio de ouro. Recordei suas promessas carregadas de sentido ético: "O neto que não beber, não fumar e não jogar até os 21 anos ganhará êste relógio".

- 0 relógio é êste. Depois que o ganhei, rompi as promessas feitas. Tenho a impressão de que fiquei sem beber ou fumar só para vencer meu irmão.

Wesley vai até a estante, tira um caderno de capa preta e folheia.

— Eis o pecado da minha juventude: o meu diário. Escrevo-o desde 1951.

Continua, vagando:

- Nós somos o que temos dentro de nós mesmos. 0 que vamos tirando da vida e guardando. A primeira experiência com o ácido lisérgico me pôs em órbita como se fôsse o Super-Homem. A segunda me trouxe de volta como HOMEM, ensinando-me uma coisa muito importante: é preciso viver a vida, mas é preciso vivê-la com os outros.

É um de seus traços marcantes: acha o que tirar de qualquer um. De repente, sua atenção se fixou no envelope amarelo em cima da mesa. Como se tomasse a decisão contra a qual estivera lutando, Wesley abre o envelope e despeja seu conteúdo: uma porção de fotografias antigas. A suspeita de conflito de fundo edipiano positivava-se de momento a momento.

\section{As bailarinas cobriram a minha cabeça; tive mêdo}

- Êste envelope é como a caixa de Pandora. Eu o abro e meus demônios ficam soltos no estúdio. Veja êste retrato: minha mãe, minha avó comigo no colo e 
minha bisavó. Três mulheres de mãos poderosas! Três leoas! Esta de maiô em 1924 é minha mãe.

A filha da lavadeira portuguêsa, casada com o filho do pastor metodista, tinha no olhar, ainda mocinha, a mesma fôrça que revelava no quadro. Como se quisesse tomar alento para enfrentar as verdades que se aproximavam, ou sentindo realmente a presença de seus demônios, Wesley levanta-se, agitado, e se apóia na mesa.

- Gosta de música? Recebi um disco notável de músicas hindus e um aparelho nôvo do Japão. É uma beleza de som.

Êle pára, volta-se para mim com sorriso malicioso, mas hesitante.

- Quando estive no Japão para a Bienal, assisti a um espetáculo popular que me marcou para sempre. As bailarinas entram dançando no estrado que fica à altura do rosto dos espectadores, vestidas só com um pano na cintura. Você se aproxima do estrado, ela se agacha e prende sua cabeça com os joelhos, cobrindo com o pano. Fiquei então com mêdo, sabe? Com mêdo do mar!

Ou o mêdo de onde vem a vida, pensei, lembrando-me do pastor metodista, enquanto Wesley se afastava. Comecei a perceber o domínio que êle exercia sôbre mim, ao mesmo tempo em que os sons da cítara, shenai e tabla - instrumentos hindus -, se elevavam, trazendo ao estúdio os mistérios do Oriente. Wesley, supostamente entregando-se a mim, dirigia a revelação de sua verdade, até mesmo na escolha da música. Ficava cada vez mais claro que êle não admite que nada, ou ninguém, quebre a ordem e a harmonia de seu mundo.

\section{Eu era um retalho que minha mãe bordava}

Tudo nêle lembra um caos, mas há uma ordem mal percebida. 0 bigode que cai sôbre a bôca pode sugerir desregramento, mas suas raízes metodistas não suportam o desregramento gratuito. Nele, o instinto funciona como em Henry Miller: tudo é vivência que leva a uma visão estética. Estava pensando no sentido egoísta dos grandes artistas, defendendo-se para melhor dar, quando ouvi sua voz que se aproximava, áspera e amarga.

- No jardim da minha memória, onde meu irmão em seu cavalinho de pau ficou como centro de reivindicações, onde meu avô aparece sempre falando sòzinho ou mexendo na terra, cercado de hortênsias, nunca deixei que minha mãe entrasse.

Todos os meus sentidos ficaram aguçados: o demônio maior se apresentava. Enfrentei os olhos da mãe no quadro, sentindo prazer na disputa pela verdade de seu filho, da compreensão do que viera buscar: os traços fundamentais do artista Wesley Duke Lee.

- Eu sei o que aconteceria. Ela é uma mulher que pensa que todo o universo deve estar acordado, se ela está. Ou dormindo, enquanto ela dorme. Quando eu era adolescente, ela tinha uma pequena fábrica de blusas bordadas e espalhava trabalhos para diversas bordadeiras portuguêsas em São Paulo. Minha 
vida era andar de endereço para endereço, levando ou buscando blusas. Meu irmão já tinha sarado, era forte como um touro. Mas era eu, sempre eu, que tinha a obrigação de fazer o que detestava. Eu não passava de um retalho onde minha mãe bordava suas vontades. Ela queria que eu fosse comerciante - ser artista, dizia, é coisa do diabo.

O julgamento é de hoje, como foi de ontem: quem projeta a figura dos outros é porque tem parte com o demônio, vive como êle, dividido em mil pedaços. À minha volta, em quadros pequenos ou grandes, começavam a se juntar os pedaços do artista Wesley. Da série de desenhos sôbre ligas em coxas de mulheres até os últimos retratos - perto de seiscentos trabalhos - espalhados no estúdio, em casas e museus brasileiros ou estrangeiros, está a longa caminhada num jardim de hortênsias entre sermões metodistas e bordados portugueses.

Wesley observa fixamente o seu quadro "Meus Pais". Olho também. A violência dos olhos maternos, com um olho em duplicata, sugeriam que não se fecham nunca. 0 sapato prêto, a mão segurando alguma coisa vermelha como sangue, o broche da côr dos sapatos, tudo naquela figura lembrava prepotência, vontade férrea, loba destruidora. A seu lado, a figura plácida, fraca, amorosa do pai. Esmaecida, esvaindo-se, quase etérea. De sua cabeça sai a frase "papai, você é a minha cachoeira", sugerindo ligações inconfessáveis. Mas, de todo o quadro, os olhos maternos - como duas verrumas - , olhos que conhecem a verdade do homem-artista, me incomodavam tanto quanto a Wesley. Pareciam dizer: você pode ir para onde quiser, mas só eu o conheço. Você pode possuir todas as mulheres do mundo, mas nenhuma te possuirá.

\section{Entrar de joelhos no quarto japonês}

Compreendi por que aquela mulher não pode aparecer no jardim de sua memória. As formas aparentes da bêleza revelariam a essência verdadeira das coisas e que não precisam ser reveladas. 0 amarelo em volta da cabeça do pai lembrou-me a fotografia em cima da mesa: Wesley aos cinco anos com vestido de menina e grande laço de fita amarela nos cabelos loiros. Voltou à minha lembrança a borboleta parecendo um laço de fita, pousada na hortênsia. Desviei os olhos, percebendo que há fronteiras que não devem ser atravessadas. Mas, ao desviar, vi o quadro de Freud sugerindo o pai. As êsteiras japonesas penduradas no alto da escada lembravam o quarto. Não sei exatamente se foram as êsteiras, a borboleta ou os olhos da mãe. Ou, quem sabe, foi a figura do pai?

- Posso ver seu quarto?

Wesley sobe a escada de madeira e abre a porta de papel japonês. Entro propositadamente a êle me segura quase que com violência.

— Num quarto japonês não se entra calçado!

Ainda sentindo a pressão de seus dedos fortes em meu braço, olho para baixo: Wesley estava de joelhos e olhava o quarto.

- Num quarto como êste, a gente devia entrar de joelhos. 
Examinando o quarto, percebo por que pedira para vê-lo: procurava qualquer sinal da passagem da mulher, com quem vivera durante treze anos. Tinha visto retratos dela pintados por Wesley, uma ou outra fotografia, mas nada que indicasse sua passagem por ali como dona da casa. No quarto, menos ainda.

- Não consigo perceber a presença de sua mulher. E vocês acabaram de se separar. Por quê?

- Às vêzes, eu penso: será que ela estêve mesmo aqui? No meio dos milhares de coisas que estão neste estúdio, não há nenhuma que ela tenha colocado. Nunca proibi. Ela simplesmente não colocou. Ela nunca exigiu nada de mim. Mas como podemos viver com uma pessoa que não tem exigências? Parecia que a tinha colocado aqui como qualquer dêsses quadros, ou como um objeto muito bonito.

- Você tem fama de ser homem de muitas mulheres.

- Eu sou homem de muitos casos, mas de nenhuma mulher. Há mulheres terríveis! Elas vão com você para a cama e logo se julgam donas de sua arte, as inspiradoras absolutas. E a nossa vivência? Não levei meu avô, meu pai, minha mãe para a cama. E não estão presentes em meus trabalhos? Não pertenço a ninguém porque não posso pertencer.

\section{Sacudi o abacateiro e só caíram taturanas}

- Para você, de que maneira a ligação com uma mulher seria ideal?

- Ideal, não sei se existe. Mas poderia ser boa se tanto ela quanto eu continuássemos livres para qualquer tipo de experiência, de descoberta do mundo. Mas sempre tendo entre os dois as experiências fundamentais. Em matéria de ligações sentimentais, muitas vezes sacudi o abacateiro e só caíram taturanas.

Naquela atmosfera quase surrealista, um dos olhos do quadro pareceu piscar para mim. Por um momento tive a impressão de estar em Colona, lugar do exílio de Édipo, e diante de mim, amorosos e vigilantes, os olhos de Jocasta, sua mãe.

- Não acha que os mitos que iluminam a experiência humana são sempre os mesmos, apenas revivendo em formas diferentes?

- Claro que acho. Sabe que conheço a Grécia palmo a palmo?

- Por que se lembrou da Grécia?

— Estamos falando em arte, em mitos, não estamos?

- Mas tinham me dito que você é irreverente com tudo, principalmente com o passado.

- Você precisa viver para saber. Tenho grande respeito pelo passado, o que não me impede de comentá-lo. Sem ter a visão certa de tudo o que nos foi legado, como podemos caminhar? Fui recusado em oito bienais: "Não é artista, não sabe desenhar, só desenha para propaganda, e isto e aquilo". Ao longo dêstes anos aprendi o fundamental: não parar de trabalhar. Às vêzes, neste estúdio, eu me vejo 
como meu avô, falando sozinho: não pare de trabalhar, Wesley! Não pare! Deixe falar o que quiserem, mas trabalhe!

\section{Um garôto vestido de menina; os cachos loiros}

A enorme bandeira vermelha pendurada no teto do estúdio chamou minha atenção.

- 0 que significam aquêles sinais japoneses na bandeira?

- VENDE-SE TUDO; E vendo mesmo.

- Até o quadro dos pais?

- Por que não? A gente pinta para que alguém possa consumir. Eu sou profissional, não pinto para mim mesmo. Venha! Venha ver a piscina que estou construindo. Sòmente agora eu comecei a admitir o verão. Eu me sentia muito bem no inverno, porque as roupas protegem nosso corpo. Aqui, na piscina, poderei ficar nu diante dos outros e, o que é melhor, nu diante de mim mesmo. É pensando nessa verdade que começo a sentir, à minha volta, projeções dos trabalhos de minha próxima exposição. Lembra-se do poema que aquêle amigo meu escreveu quando acabei o quadro sôbre meus pais? "É sempre necessário que a gente mate alguém para começar a viver!" Aqui, eu afogarei o pastor metodista, tôdas as bordadeiras portuguêsas, e só me verão inteiramente nu os olhos puros de meu pai!

Enquanto Wesley ficou olhando a piscina, voltei ao estúdio. 0 sol da tarde, batendo nos vitrôs do teto, dava um tom amarelado a tudo. Os olhos maternos continuavam lembrando os cem olhos de Argos que não fecham nunca, vigiando naquele estúdio, como num exílio, um garoto com vestido de menina e grande laço de fita amarela nos cabelos loiros. 


\section{Marília Pêra, cem mil volts. Mas só no palco.}

A atriz mais discutida do teatro brasileiro de hoje trabalha desde os cinco anos, casou com quinze e separou-se com dezoito. Jorge Andrade separa Marília Pêra, uma mulher livre ("quando eu quero dormir com um homem, eu durmo"), da cafonice das suas personagens.

Estou no camarim do Teatro Ipanema, onde há quatro meses a casa tem estado repleta para ver "A Vida Escrachada de Joana Martini e Baby Stompanato". Sentada à minha frente, Marília Pêra, vedete do espetáculo, começa a se maquilar. Durante uma semana venho observando sua Joana Martini no palco, estudando seus movimentos, suas expressões, sua energia carregada de malícia, sua sensualidade agressiva como uma espécie de vingança. Mas ali no camarim, Joana Martini só estava presente na máscara que nascia lentamente, como se a personagem vivesse dentro das bisnagas, ou no meio das purpurinas. Quem continuava à minha frente era Marília Pêra, um ser frágil de sorriso triste, dando impressão de desamparo. Ou representando isso?

- Quando eu era pequena, arranjava um lugar nas coxias do palco e ficava vendo meus pais representarem. Exatamente como Ricardo, meu filho de nove anos, faz agora. Enquanto estou em cena, êle fica nos bastidores imitando os meus passos.

Marília aproxima o rosto do espelho, coloca enormes cílios postiços sôbre as pálpebras pintadas de azul - como seu anel. Observei a enorme pedra azul em seu dedo e lembrei-me de que ela me contara dois dias antes, no seu apartamento no Leblon.

- Nunca tinha visto no teatro tantos homens bonitos como naquela noite em 1968, em São Paulo, na peça "Roda Viva”, de Chico Buarque. A surpresa do ataque foi o que trouxe a maior angústia. Depois do espetáculo, eu estava no camarim tirando a maquilagem, só de calcinha e sutiã. Ouvi um barulho como se centenas de cavalos estivessem se aproximando; de milhares de patas batendo no chão. Gritos, sons de vidros quebrados, porta batendo, gemidos, xingação. Abri a porta e fiquei gelada! No corredor, um homem batia a cabeça de uma das artistas na parede. Ela gritava e não conseguia escapar. A camareira empurrou-me para dentro do camarim e tentamos manter a porta fechada. Os homens empurravam e xingavam:

— "Sem vergonha! Vagabunda!"

- Afastei-me para o fundo do camarim e a camareira, que estava grávida, cobriu-me com seu corpo. Os homens começaram a quebrar tudo que estava à nossa volta, a rasgar nossos vestidos. Eu só sabia murmurar: "Mas por quê? Por quê?" Fomos empurradas para fora e tivemos que passar por um corredor de 
homens armados com cassetetes. Estávamos como ratos acuados. Eu olhava à minha volta e só via pessoas frágeis, usadas, transformadas em bagaço. Quando vi, estava na rua quase nua. Percebi que o anel azul que meu pai me dera não estava em meu dedo. Voltei correndo ao camarim, como uma desesperada e fui encontrálo entre os montes de vidros. Ao encontrar o anel, veio a reação: subi em cima da cadeira e comecei a pular, gritar, rir sem parar!

\section{Quem tem a chave para abrir meu cadeado?}

Marília continua se maquilando, enquanto fala da noite dos cavalos. 0 camarim é pequeno, mal dá lugar para nós dois, e está cheio de plumas brancas, pretas, vermelhas; lamês dourados e prateados; dezenas de potes de maquilagem, de purpurinas azuis, vermelhas, roxas, de tôdas as côres. Com mão firme, Marília vai fazendo os traços sôbre os olhos. Do rosto magro, pálido, triste, quase assexuado da verdadeira Marília Pêra, pouco resta. A máscara debochada de Joana Martini vai tomando conta, revelando o mau gosto, a safadeza, a cafonice da personagem que vai levar ao público a mensagem do deboche.

- Às vezes, no palco, eu me sinto como naquele corredor de agressores. Certas insinuações são como cassetetes levantados sôbre minha cabeça. Mas eu vou em frente! Pode parecer basbaquice de minha parte, mas, quando o público aplaude, eu me sinto recompensada. Posso agüentar o corredor, porque sinto que o público me ama, e quando me amam eu dou tudo. Mas tem uma diferença: posso amar trezentas pessoas na platéia, como posso odiar trezentas da mesma forma.

- Que quer dizer?

- Há uma cena no espetáculo em que pergunto se alguém tem a chave para abrir o cadeadinho que trago pendurado na altura da calça. Geralmente êles riem, um ou outro responde que tem, mas sempre na base de divertimento. Mas, na semana passada, um espectador levantou-se e disse que tinha a chave. Subiu no palco e aproximou-se de mim. O safado queria era me bolinar. Estive a ponto de explodir e de partir para a agressão. Mas ao mesmo tempo ouvi uma voz diferente na platéia: "Nós estamos com você, Marília. Se êste tipo engrossar de nôvo, nós vamos dar nêle!" Todo ódio desapareceu e voltou o amor ao público.

Marília é viúva há pouco mais de dois anos de Paulo Graça Mello, filho do ator Graça Mello, filho do ator Graça Mello. Ricardo, seu filho de nove anos, entra no camarim e faz um carinho na mãe. A máscara de Joana Martini ainda deixa passar a expressão da mãe Marília Pêra. Durante aquela semana, eu vira o filho entrando e saindo do camarim, brincando entre os atôres seminus. Vira-o no apartamento de Marília, preparando-se para uma festa de aniversário. Com seus cabelos longos, as feições finas, parece um príncipe de festa infantil.

- Mãe! Eu quero ir ao aniversário com esta roupa.

- Não. Está chovendo e você vai se resfriar.

- Eu gosto é desta.

— Ricardo! Vê se não insiste porque senão eu vou engrossar. 
- Eu engrosso também, mãe.

- Você, hoje está teimando que não é normal.

No camarim, onde Joana Martini vai nascendo, Ricardo é a lembrança do pai falecido, que foi também ator. Seu carinho pela mãe, seu ciúme dela, o sentido de proteção já desenvolvido são muito evidentes nêle. Ricardo olha o rosto da mãe no espelho e sai correndo. Marília sorri e volta-se para mim.

- Fui criada para casar e ficar. Estudei piano dos quatro aos catorze anos. Tenho doze anos de estudos de balé, dois de canto e de violão. Tive rígida formação religiosa, casei virgem aos quinze anos, separei-me de Paulo com dezoito e fiquei viúva aos 26. Sou uma mistura disso tudo e da vida massacrada que levei. Recebi muita lambada nas costas. Tive noites tão ruins quanto aquela dos cassetetes.

Marília faz um traço em volta da bôca, marcando-a num sentido cínico. Vendo isso, penso como é difícil encontrar a verdade dos atôres. Nunca se sabe quando começaram ou pararam de representar. A verdade dêles é sempre um desafio, um enigma proposto. Nas centenas de papéis que cada um representa, no palco ou fora dêle, é quase impossível descobrir-se o seu papel verdadeiro. Ou serão todos?

- Para mim, cada dia é diferente. É possível que amanhã eu diga que tudo isso que estou contando é mentira, que sua reportagem é inventada. Mas, pra que saber o que será o dia de amanhã? Hoje, eu sou isso. Penso assim. Amo e odeio assim. Vamos deixar o dia de amanhã para amanhã.

\section{Gosto de pessoas limpas na cabeça}

De repente, Marília, mesmo maquilada, revela expressão cansada, completamente diferente da atriz em cena, onde seu poder de comunicação é fora do comum. Fiquei alerta. Naqueles dias que passei ao seu lado, no teatro, em táxis, na televisão, em restaurantes, em seu apartamento, na convivência com seus amigos, eu ia encontrando a Marília Pêra em momentos fugidios, em pequenos pedaços. Ninguém é total num instante só, a na oser nos de grande paixão. Era um deles que eu esperava encontrar, nos caminhos de Marília que eu percorria.

- Sabe? Eu gosto do mundo, das pessoas, não sou capaz de curtir sofrimento. Tenho horror de magoar as pessoas. Mas, quando me agridem, eu engrosso mesmo e não vejo o que falo ou faço. Assim foi minha vida com Agildo Ribeiro: vivíamos nos agredindo. Hoje somos bons amigos. Não faz muito tempo, eu e Agildo passamos uma semana em Quitandinha. Dormíamos juntos, mas como amigos, nada de sexo. É o que sempre acontece: depois que me separo dos homens é que começo a gostar deles, como amigos.

Lembrei-me do restaurante Gardênia, onde, dois dias antes, eu, ela e Agildo tínhamos jantado juntos. Êles rememoraram o seu caso, entre risos e piadas. Depois, na madrugada, ela saiu dirigindo o Fusca do Agildo, subindo em calçadas, atravessando sinais fechados, confundindo o breque com acelerador. No dia que 
amanhecia, eu ficara, na calçada, ouvindo as gargalhadas dos dois, e avoz dela que sumia:

- Meu Deus! Eu nunca vou aprender a guiar um carro. Nunca!

Foi o momento mais descontraído de tôda a nossa convivência de oito dias. Ricardo continua entrando e saindo do camarim. Marília fala de tudo, até de seus amôres, na frente do filho com naturalidade. Ricardo reage da mesma forma.

- Sabe? Eu nunca minto para meu filho. Não quero que êle seja criado na mentira, como eu fui. Não sei dizer se sou boa mãe ou não. Sei que gosto dêle, e êle de mim. Acho que cada um pensa ser modêlo numa coisa ou noutra. E eu não quero ser modêlo de nada.

- Você conversa com êle sobre tudo?

- E por que não? Sei que êle gostaria que eu me casasse de novo. Mas já falei para Ricardo: não quero homem me enchendo a paciência. Quando quiser dormir com alguém, eu durmo. Acho impossível viver com uma pessoa trinta anos. Num clima de amizade, eu viveria.

- Teve, então, muitos homens?

- Não tanto quanto imaginaram por aí. Eu nunca fui muito cantada. Sempre escolhi.

- E o que a leva a escolher?

- Gosto de pessoas limpas na cabeça. A limpeza é muito importante pra mim. As pessoas que se aproximam de mim não se aproximam porque eu seja bela. Não sou bonita! Eu vejo um homem como êle é, depois é que começo a fantasiar o côco. Até nisso eu sei jogar areia nos olhos dos outros.

- Areia?

- Foi meu pai quem me ensinou. Conheceu o ator Manuel Pêra? Foi bom ator. Quando eu era pequena e ia me apresentar em um teatro, meu pai dizia: "Não faça como as outras, não cumprimente segurando a sainha. Encare o público como dama, olhando bem nos olhos de todos, da primeira fila até a última. Se fizer isso com firmeza, estará jogando areia nos olhos da platéia, que verá você de maneira diferente". Jogar areia é enfrentar o público não como a gente é, mas como êle quer que a gente seja.

\section{Ganho milhões agora, mas nunca vou ser rica}

Marília aproxima o rosto do espelho para fazer uma enorme pinta no queixo. Comecei a pensar em que momento ela tinha jogado areia em meus olhos, e a sala de maquilagem da televisão veio à minha memória. Um dia antes, tinha ido com ela à TV Globo, onde ela ia gravar vários capítulos da novela "O Cafona", onde faz grande sucesso com a personagem Shirley Silveira. Com blusa simples, calça de cotelê de algodão, penteada simplesmente, ela foi passando pelo corredor, cumprimentando a todos. A camareira, o maquilador, o diretor, os colegas foram tratados da mesma maneira. Ela sentou-se para ser maquilada e eu fiquei observando pelo espelho. Astros e estrelas, amados ou odiados pelo público das 
novelas, entravam e saíam, riam, contavam piadas, alguns se exibiam numa frescura total, outros representavam mais no camarim ou nos corredores do que quando deveriam representar. Marília continuava calma e seu sorriso apenas aflorava no rosto magro e abatido. Seus olhos eram tristes e revelavam a verdadeira Marília Pêra. Pelo menos pensei no momento que revelavam. Enquanto os outros representavam quando não era necessário, ela simplesmente era. Quando os outros pensavam que estavam representando e eram apenas eles, ela representava mesmo e não era.

Mas agora, em seu camarim, começo a me perguntar: qual será a verdadeira: Marília, Joana ou Shirley? Ou será a soma das três? Marília afasta-se do espelho, observa a pintura no queixo, examina sua maquilagem, sente-se satisfeita.

- Sinto mágoa porque meu pai não aproveitou o meu sucesso. Veio um pouco tarde pra êle. A verdade é que a gente trabalha a vida inteira e acaba morrendo na miséria. Sei que nunca vou ser mulher rica.

Marília sempre viveu no bairro do Rio Comprido, no Rio, onde sua mãe e sua única irmã Sandra ainda vivem.

— Detesto aquêle bairro. E sei que pra lá não voltarei nunca mais.

- Mas por que acha que nunca vai ser rica?

- Sei representar qualquer papel. Mas a empresária enche. Aí eu sou mesmo uma canastrona. Não sei pôr ninguém na rua.

- Mesmo quando isso é necessário?

- Em qualquer situação. Acho que a única profissão mais desgraçada que a de atriz é a de bailarina. Fui bailarina de teatro de revista, boates, circo. Nessa época, meu marido tocava frigideira na orquestra e eu dançava em volta de uma caixa, onde uma mulher devia ser serrada. Entre um contrato e outro a gente passava fome. Perdi dois filhos por má alimentação. Mas eu queria ter meu filho! Quando peguei minha primeira ponta num espetáculo, estava grávida do Ricardo. Eu tinha que representar o papel de uma garôta virgem. E a barriga começava a crescer. Sabe o que fazia? Apertava minha barriga com cinta para que a gravidez não aparecesse. Às vêzes, saía de cena para vomitar, tinha hemorragias. Não sei exatamente o que eu queria provar. Acho que ter uma coisa que fôsse só minha!

Nos dias que passei com Marília, às vêzes sentia que ela estava me usando, ou brincando comigo. Mas, quanto mais me usava ou brincava, mais se revelava. Ela pode brincar à vontade, mas seus olhos são como cortinas abertas de um palco, onde sua verdade é representada com grande honestidade.

- Procurei um médico para não perder meu filho. Sabe o que êle recomendou? Que eu repousasse! Mas, se eu parasse, eu o perderia também, passando fome. Trabalhei até quinze dias antes que Ricardo nascesse. Minha mãe, a atriz Dinorá Marzulo, também representou comédias comigo dentro da barriga até o nono mês.

De repente, Marília se torna áspera. Volta-se para mim com expressão dura. Seus olhos, até então opacos, brilharam com as lágrimas.

— Vê se não me faz chorar! Isso estraga a maquilagem. 


\section{Homossexuais?! Não, apenas sêres humanos.}

Sentada, semivestida, magra, curvada, concentrava-se novamente na máscara de Joana Martini. No espetáculo, seu corpo é de uma vedete. No camarim, não é. Num momento parece um garôto adolescente, um instante depois torna-se uma mulher desejável. Nessa ambigüidade, ela vive no palco ou fora dêle.

- Minhas piores lembranças são as da infância. Eu gostava de estar no teatro com meus pais. Mas sentia falta de ar livre, de outras crianças. Mas, se não estivesse no teatro, quase sempre estava em pensões horríveis!

- Não acha que está acontecendo a mesma coisa com seu filho?

- Não. Eu posso inventar coisas para êle. Ricardo pode sentar em uma mesa e almoçar, jantar. Dorme em camas limpas, freqüenta a escola. Sei que êle tem problemas, mas todo mundo tem.

- E isso basta? Que tempo você dá a êle?

0 tempo que me sobra. Por enquanto é o que posso dar.

- Não acha que essa vida não vai lhe permitir uma escolha?

— Êle tem sangue de atôres, é como uma ilha cercada de atôres por todos os lados. Como poderá escapar? Também, escapar por quê? Acho que cada um deve ganhar a vida com as qualidades que tem, com o que gosta.

- Mas um espetáculo que critica o teatro rebolado, portanto cheio de homossexuais... seu filho o tempo todo no meio dêles...

- Homossexuais?! Para mim são serês humanos. Apenas isso!

Senti que ela estava retesada. Marília não gosta que toquem nas pessoas que a rodeiam. Ela volta-se pra mim, ainda segurando o pincel cheio de tinta roxa. Seus olhos estão duros, mas sua voz sai macia, calma.

- Tenho três coisas na vida que me dão segurança: meu filho, a carreira e meus amigos. Sei como tratam por aí as pessoas que me cercam: as Marilhetes, o gado de Marília! Não importa o que são ou o que os outros pensam dêles. São meus companheiros de trabalho, sempre estiveram comigo, passaram fome e privações juntos comigo, e até por minha causa. Eu vejo na TV, ou por aí, um bando de bajuladores, gente que não sente amizade por ninguém. Estão apenas querendo tirar pedaços, como piranha.

- Ofendi você com o que disse sobre homossexuais?

- Não. Se tivesse ofendido, eu pediria para você sair. Comigo é sempre assim. Quando não gosto de um lugar, ou alguém me agride, vou embora tranquilamente. Ninguém consegue nada de mim na base da agressão. 0 que odeio mesmo é ser olhada como objeto. Você não me olha assim.

\section{Pelé?! Um homem certo demais.}

— Você ganha mais de 8000 cruzeiros na TV, largaria isso? 
- Se me encherem, eu largo. Sinto, mas largo. Não quero fazer mais nada de que não goste. Chega! Não serei nunca uma grande dama. Êsse papel não sei representar. Não gosto de me sentar direito, comer direito, sêr toda certinha 24 horas. Já imaginou o que é ser sempre bem educada? Gosto de ser grossa de vez em quando, ou sempre, não sei.

Inteiramente maquilada, com cabeleira de incrível mau gosto - cabelos de Joana Martini, porque os de Marília Pêra são escorridos, curtos, descoloridos de tanta tintura - ela se ergue para que a camareira vista a roupa da Luxúria - é assim que ela entra no espetáculo.

- E sabe o que mais? Não gosto de restaurantes metidos a bêsta, detesto boates onde ninguém se enxerga, não vou à praia, odeio fazer feira, não sou mulher culta e nem quero ser. Não gosto de futebol, Pelé pra mim é apenas um jogador e um homem certo demais para o meu gôsto.

Agora ela vai se vestir, a porta se fecha atrás de mim. Ouço o barulho dos espectadores que começam a lotar a platéia. Os atôres, já prontos, sobem para o palco. Andando entre os camarins, no meio daquela confusão, lembrei-me do restaurante Vivará, onde, no dia da minha chegada ao Rio, tinha ido com Marília: no restaurante ia ser gravado um dos capítulos de "O Cafona". Já vestida com Shirley, Marília estava sentada comigo numa das mesas.

- E o meu marido de quem é viúva? Não gostava dêle?

- Eu não sei dizer "vamos parar por aqui, por causa disso ou daquilo". Isso me enche. Parto logo para a agressão até perder a pessoa. Depois é que bate o sofrimento. Tudo isso é muito difícil de explicar, mas eu sou assim. 0 sentimento de posse dos outros me fecha!

Desconfiado de que estava enredado por personagens e pela Marília real, voltei-me e vi a porta do camarim aberta e, nela, Joana Martini: plumas brancas nos cabelos, capa de brocado bordada com pedrarias - mas a roupa de baixo não daria para vestir uma criança de dois anos. Agitada, mas não numa agitação de Marília Pêra, ela me encanta. Tive impressão de que queria dizer alguma coisa. Mas, em cima, a música anuncia que a cortina vai se abrir, e ela caminha para a escada que leva ao palco, mascando um chiclete numa expressão grossa, lembrando a personagem que vai nascer logo mais. Ela pára nos primeiros degraus e volta-se para mim: e novamente era a Marília Pêra com seu sorriso triste, com sua fragilidade.

- Que foi Marília?

- Em todo êsses dias em que esteve comigo, penso que deveria ter falado mais do meu marido. Êle morreu em um desastre de carro perto de Americana, em São Paulo. Eu gostava dêle, mas êle era muito criança, muito imaturo. Nós dois juntos não poderíamos escapar. Senti que, se não me separasse dêle, eu que tinha mais possibilidades de escapar, nós dosi iríamos para o fundo, como essas pessoas que morrem no fundo do mar: um agarrado no outro, mas mortos. 


\section{Eu sei que vocês vão me chamar de antiquada}

Estava diante de mim, na roupa branca e emplumada de Joana, a Marília de quinze anos no dia de seu casamento, olhando pela janela traseira de um carro. Quase cheguei a pensar que ela fossê jogar um buquê de flôres de laranjeira. Era ela ou eu quem fantasiava o côco?

- E agora... a Luxúria!

E Joana Martini surge no fundo do cenário, parecendo ter cem mil volts no corpo. 0 público explode em aplausos, enquanto, numa conga incrìvelmente debochada, ela dança em direção da platéia. Nada mais resta de Marília Pêra: é a vedete transfigurada com seus gestos sensuais, suas expressões safadas, suas insinuações grossas. Enquanto espreme os seios, ou puxa a calcinha na frente e atrás, vai dizendo numa voz vulgar: "Eu sei que vocês vão me chamar de antiquada, mas eu sou contra o nu, não gosto de mulher pelada. Não parece, mas eu sou uma senhora. Uma senhora tem que ter seu berço, a sua dignidade, a sua moral. Eu não fico pelada de jeito nenhum, acho o fim da picada ficar pelada!".

Diante do público, Joana Martini podia até estar pelada, mas nunca Marília Pêra estivera tão bem vestida diante de mim. Joana jogava areia nos olhos da platéia. Marília não estava presente. Inatingível, escondida entre a realidade e a ficção, continuava abraçada, em Paulo com seu vestido de noiva, branco como as espumas do mar, ou as plumas de Joana Martini. Paulo morreu esmagado por um carro. Marília começa a ser esmagada, esmagada por uma máquina infernal de mil olhos que aplaude para melhor sugar e destruir. 


\section{É Clodovil, sim. Alguma coisa contra?}

Uma vez em Paris, uma senhora lhe perguntou: "Desde quando homem usa capa de vison?" E ele respondeu: "Quem disse que eu sou homem?". Quem é Clodovil, o maior figurinista do Brasil?

Clodovil Hernandes, Clô para os íntimos, 34 anos, considerado por muitos como o melhor figurinista brasileiro, cruza com elegância suas pernas com botas de pelica, olha para mim, ajeita a gola alta do pulôver branco que ressalta sua ascendência negra e, com expressão impassível, quase impenetrável, declara:

- A noite era escura e abafada. Parecia que ia chover. Eu estava na enfermaria, com febre. De repente, ouvi duas batidas na parede, Sonhando, eu sabia que não estava. Nem delirando. Meus sentidos ficaram aguçados e percebi um acariciar na parede. Inconscientemente, bati também. As batidas, vindas do quarto do professor, se repetiam. Tornei a bater. Eu tinha apenas onze anos, estava interno em um ginásio, não podia saber, nem medir o que fazer. Olhei à minha volta e só vi escuridão. Subitamente, percebi a presença de alguém no quarto. Simultaneamente, a mão, flácida, com uma lavanda horrorosa, acariciou meu queixo. Foi o que ficou daquela noite: o cheiro horrível da lavanda barata. Acho que não a esquecerei nunca mais!

- Só a lavanda? Então, não aconteceu nada?

- Aconteceu. Mas foi o que ficou: o cheiro de lavanda.

Comecei a perceber, depois de tantos dias de convivência, que Clodovil não podia ser medido por padrões comuns. Revi Ingrid, a belíssima socióloga e manequim, desfilando dois dias antes no atelier de Clodovil. Entre um modelo e outro, havia me dito:

- Clodovil tem grande criatividade, talvez a maior que nós temos. Não se pode julgá-lo. Ele escapa a qualquer padrão.

E Bety, universitária na USP e também manequim, ajudará:

- Ele é profundamente humano, bom, compreensivo e camarada! Mas não tente brincar em serviço!

Ainda estava pensando na lavanda, quando ouvi a voz de Clodovil:

- Foi assim minha primeira experiência: envolta pela escuridão em qualquer sentido que você a queira tomar. Uma escuridão sem pontos de referência, a não ser os da dor e da solidão.

Clodovil acaricia os cabelos erguendo uma mecha em cada lado da cabeça, gesto que repete constantemente, com movimentos lentos e graciosos. Olha firme em meus olhos e sorri. Sorriso triste de pessoa sem ponto de referência no mundo do que a cerca. Sorriso de marginal, no melhor sentido do conceito de Stonequist, sociólogo americano: "O homem marginal é um homem que oscila na incerteza psicológica entre dois ou mais 'mundo social', refletindo em sua ala os desacordos e as harmonias, as repulsões e as atrações desses dois mundos, um dos quais às 
vezes 'domina' o outro". Tentando compreender qual - o homem ou a mulher estava naquele momento sentado à minha frente, perguntou:

- Por que não? Aconteceu, não aconteceu? Não minto aos outros e muito menos a mim mesmo. Sou o que sou. Gosto muito da cor preta por que ela é o que é, sem gradações. Não vá me dizer que você é igual a essa gente horrorosa que anda por aí, pensando ofender pessoas como eu.

\section{Enfrenta críticas: "Não dou a mínima"}

- Não sou. Por isso acho tão difícil fazer reportagens com pessoas como você, compreendendo-as sem desrespeitá-las.

- Quando a verdade é dita como deve ser, não ofende ninguém.

- Eu sei. Tudo se resume numa questão de forma.

- Claro! É por isso que sou o melhor figurinista: sei tudo a respeito de 'formas' da mulher brasileira. Conheço-as por fora tão bem quanto as conheço por dentro. É claro que estou me referindo a tipos físicos e mentalidades!

- Eu não disse nada.

- Não disse, mas penso. Você se esquece de que já estou acostumado com certos tipos de pensamentos a meu respeito?

- E você não se importa?

- Não dou a mínima! Não me afetam em nada.

Foi nesse instante que a Rádio Jovem Pan deu o sinal para começar o programa com Clodovil, que vai ao ar todos os dias, às 11 horas, diretamente de seu escritório. Nele, Clodovil, dá, graciosamente, conselhos sobre moda a ouvintes da capital paulista e do interior. A voz do locutor sua no pequeno escritório, forrado de veludo com desenhos imitando couro de zebra:

- Bom dia, Clodovil.

- Bom dia.

- A primeira ouvinte, Iolanda, 25 anos, 1,65 metros de altura, morena, 63 quilos, quer saber: que roupa deve usar no aniversário de sua filhinha de três anos? Vai dar uma festa à noite que terá como convidados mais adultos do que crianças. Gostaria de saber também como deve vestir sua filhinha.

Clodovil olha para mim, enquanto ouve, com ar de desgosto. Estampa-se em seu rosto a ironia e a impaciência.

- Em primeiro lugar, essa senhora está mais preocupada em fazer festa para ela do que para a filha. Está claro que a mãe está querendo é se divertir. Festa de criança deve ser cheia de sorvetes, gritarias, correrias, aquelas coisas que as crianças sabem fazer muito bem, atormentando os grandes. Como deve ser um tormento para uma criança só ver adultos em sua festa. Festa à noite, onde vão mais adultos do que crianças, é porque a mãe está louca para se exibir, ou exibir a filha. Que faça a festa durante o dia, que é tempo de criança, tomando cuidado para não vestir a filha de anão, com sandálias trançadas, botas, saia longa, esse horror que não é nem adulto, nem criança, mas um monstro! Crianças usam sapatos de 
verniz, laços de fita, golinhas brancas, coisas infantis. Crianças vestidas de gente grande é uma praga!

Enquanto observo Clodovil dando conselhos a milhares de ouvintes sobre moda - o programa tem a duração de cinco minutos, com grande audiência -, revejo os dias que passei a seu lado e chega à conclusão de que ele é um exemplo perfeito dos seres divididos, dos personagens de exceção. Clodovil tem a inteligência dos homens e a perspicácia das mulheres. Em seu corpo de homem, muitas mulheres vivem prisioneiras. Em sua sensibilidade feminina, muitos homens estão presos, mas inatingíveis. Pode sonhar, desejar homens e mulheres, mas seu corpo rolará sempre insatisfeito, sedento como alguém amarrado à beira da água sem poder atingi-la. A solidão é o seu continente, onde habita apenas o seu trabalho. Na agudeza de seu olhar, aparece constantemente a capacidade de observação; na fluidez das expressões, na inconstância do sentir, surge sempre a compreensão que só os seres divididos possuem. Ouvi sua voz lânguida, mas que pode se tornar dura, metálica, de uma hora para outra.

- Sou filho adotivo. Não se de onde venho. Mas aqueles que me criaram foram pais verdadeiros. São imigrantes espanhóis. Meu pai já morreu. Minha mãe vive comigo e é, para mim, o centro do universo. Saber disso nunca foi motivo de tristeza.

- Sabe o quê?

- Que sou filho adotivo. Não sou pessoa triste, muito menos complexada. Acho que a vida é feita com coisas eu trazem encantamento: flores, cores, mulheres. É com isso que trabalho: tecidos, cores, pedrarias, plumas, miçangas, desenhos que devem criar beleza e encantamento. Vivo e trabalho para as mulheres. As de bom gosto, é claro. Portanto, identifico-me com elas em tudo.

- Amando homem também?

\section{Quem são seus pais? “Nunca desejei saber!”}

É difícil ser muito objetivo com Clodovil. Ele passa, rapidamente, de um assunto para outro e se perde em sua imaginação sensível, criando imagens como cria desenhos para mulheres refinadas. Forço o diálogo para não perdê-lo.

- Em que cidade nasceu?

- Nasci em Elisiário, cidadezinha perto de Catanduva, em São Paulo. Com três anos fui para Floreal, onde morei quinze anos.

- Seus pais verdadeiros também moravam lá?

— Não sei. Não os conheci, nem nunca desejei conhecê-los. Não me deram? Meu pai adotivo tinha um armazém de secos e molhados. Sete portas abrindo sobre a calçada, que guardavam bacalhau, sacarias, tecidos baratos, coisas plásticas, aquele horror que você deve conhecer. Nas vitrinas sujas de pó botões, fivelas um lixo! Mas no quintal havia uma amoreira que era uma glória! Um pé de jasmim, divino! Grande parte do tempo, eu passava cantando em cima da amoreira, como um passarinho. Uma vez por mês, um teco-teco passava voando em cima de 
Floreal. Sabe o que fazia? Rezava para que ele caísse, assim apareceria gente nova na cidade!

\section{Sabe tudo de moda. “Aprendi sozinho!”}

— Não gostaria de voltar lá?

- Não costumo usar água-de-colônia francesa para nariz que não sabe cheirar. Lá tenho saúde para esse deboche?

Nunca ninguém lhe ensinou nada sobre moda, gosto ou refinamento, mas Clodovil tem tudo isso como dom natural. Tendo só o diploma do curso normal pretendia estudar filosofia - é um autodidata em matéria de alto costura. A mãe ainda é analfabeta, sabendo apenas anotar os números de telefones que chamam constantemente o filho.

- Penso que vou morrer latino-modas. Você acha que no Brasil é possível usar perfume? Claro que não. Só água-de-colônia. Mas adianta falar? Nunca! Acha que perfume combina com nosso clima? 0 que fica, então? 0 nojo!

- Clodovil! Vamos voltar a Floreal. Quando criança, você já gostava de desenhar?

- Claro. Desenhei todos os vestidos da minha mãe.

- E seu pai? Como reagia?

- Vou contar um incidente que explica tudo. Uma vez, fui passar o dia no sítio de uma amiga. Voltei na hora do jantar. Meus pais já estavam sentados à mesa: ele com tromba enorme e minha mãe com a cara dentro da sopa. Sentei-me e me servi de salada de agrião. Foi aí que ele explodiu: "Com que, então, meu filho é fresco?" Eu posso? Já viu, não é?

- 0 que respondeu?

- Olhei para meu pai sem nenhum ressentimento, dizendo: "O senhor acredita mais em estranhos do que em mim. Em todo caso, meu afeto não vai mudar por isso. Se o seu já mudou, o problema é do senhor". Continuei comendo a salada de agrião. Afinal, meu pai sofria mais do que eu. Nunca tome essas coisas como ofensa, elas não me atingem. Sei o que sou, e não sou porque quero ser. Meu pai foi grosseiro, por isso era mais digno de pena. Só me ofendem mesmo quando procuram destruir meu trabalho.

Clodovil deixa sempre claro que o trabalho é exatamente importante, não permitindo que nada interfira nele. Nem costuma confundir deveres com relacionamentos. A resposta pronta, o sarcasmo deram a ele fama de louco, fama que gosta de exercer quando é preciso.

\section{Cobra caro. "Eu vendo qualidade"}

Clodovil é cáustico quando fala da profissão, não conseguido falar a não ser nela. Quando estava no ginásio, seus cadernos já viviam rabiscados com desenhos de vestidos. O professor costumava chamá-lo de Jacques Fath. Entre doze e 
dezessete anos, os modelos que fazia já eram problemáticos para as costureiras de Floreal. Com expressão de desprezo pelo passado, ele explica:

- A simplicidade é sempre muito difícil de ser alcançada e compreendida. Questões de meio cultural. Eu posso com o nosso?

- Na Europa, por exemplo, quando um figurinista vai a uma recepção, é um ser humano, a expressão de uma criação artística que entra. E aqui? 0 costureiro, por melhor que seja conceituado, não passa de um bobo da corte. Isso reflete, afinal de contas, a cultura. Lá, nós estamos numa realidade. Aqui, em outra. Lá, arte é um dom que não se adquire. Tem-se ou não se tem. E aqui? Que pensa dos criadores? É aquela vigarice, o reino da vigarice!

- Foi muitas vezes à Europa?

- Dez vezes a Paris, três à Itália, conheço a Inglaterra, Portugal, Espanha e Argentina. Na Argentina não suportei, ficar dois dias. Um horror!

De repente, Clodovil sorri evocativo crispando ligeiramente as mãos delicadas, vibráteis.

\section{- Que foi?}

- Lembrei-me da primeira vez que fui na França. Foi a entrada mais gloriosa que alguém já fez em Paris. Era primavera! Flores em todas as praças e casas. Rosas lindas! Meus amigos foram em esperar em Orly. Sabe o que estava me esperando na porta do aeroporto? Aquele Rolls-Royce preto, forrado de camurça cinza, com champanha gelado e um chofer. Foi a glória! A saída foi um pouco pior.

- Por quê?

- A alfândega. A mulher da polícia, uma daquelas mulheres horrorosas, burguesa até a raiz dos cabelos, viu minha capa de vison no braço e perguntou:

- 0 que é isto?

- Minha capa de vison, é claro.

- Desde quando homem usa capa de vison?

- E quem disse que sou homem? - Enquanto a mulher arregalava aqueles olhos, meu vison passou.

Minha gargalhada tomou conta do escritório. Senti que ele começava a confiar mais em mim não estava tanto com o pé atrás.

- Seus vestidos são muito caros?

- Minhas clientes são mulheres muito ricas, porque na verdade eu sou quem cobra mais caro e faço questão de cobrar, porque não vendo gato por lebre. 0 que é meu é bom e de primeira qualidade. Gosto de vestir mulheres que podem comprar e, o que é melhor, que costumam pagar. Comprar e pagar também fazem parte da elegância.

\section{Como ser elegante? “Tome banho!”}

— $O$ que é elegância para você?

- Um conjunto de coisas. A roupa é apenas a moldura. Acho que na elegância o mais importante é o alicerce: a educação. A mulher mal educada jamais 
poderá ser elegante. Digo mal educada em todos os sentidos: no timbre da voz, na forma de ser, na maneira de se sentar socialmente, de se relacionar com o sexo oposto, na conduta moral, tomar banho todos os dias, e por aí afora. A elegância, portanto, é um conjunto.

- Que quis dizer com "tomar banho todos os dias"?

- Isto mesmo: tomar banho.

Em cima da mesa, o castiçal com a vela vermelha Rigaud acesa, própria para perfumar o ar. Sua chance bruxuleante lembrou-me a casa de Clodovil em Floreal. Ele tinha poucos anos e estava dormindo. Vozes o acordaram no meio da noite. Ele se levantou, abriu a cortina que separava os quartos e viu uma mulher lindíssima, vestida de branco discutindo com sua mãe adotiva. Nunca mais aquela imagem de mulher de branco, discutindo com sua mãe adotiva saiu da sua imaginação. Teria sido a mãe de verdade? Olho para ele e penso: quem seriam seus pais verdadeiros? Onde deve ter nascido? Por que teria sido dado? Clodovil percebe meu olhar fixo na vela acesa e sorri.

- Acendo a vela porque fumo muito.

Clodovil puxa novamente as mechas de cabelos e sua expressão fica mais triste.

- Penso que os figurinistas no mundo inteiro são pessoas muito solitárias, não é caso sòmente dos nacionais. No fundo, é porque não fazemos parte do mundo de uma sociedade que frequentamos e para a qual trabalhamos. Para ela, muitas vezes, não passamos de enfeites, decoração viva e divertida. Em todo caso, quero que fique bem claro que quero ser considerado o melhor por aqueles que entendem, ser amado pelo povo e odiado pelos concorrentes sem talentos.

- Você acha que o Brasil já tem moda própria?

- Claro que acho. Mas aqui a moda não é interesse de governo, um interesse direto, uma economia. Por se assunto de ordem particular, os figurinistas não podem se aventurar internacionalmente, porque não existe um esquema promocional, nem interesse econômico e industrial. Por que a indústria nacional de tecidos e de confecções não consegue atingir um desenvolvimento satisfatório? A explicação é simples: o Brasil gosta de cópia.

Clodovil é considerado por muitos como o primeiro figurinista brasileiro que se preocupou em interpretar, crìticamente, os destinos da moda autenticamente nacional e todo o seu complexo econômico-social.

- A gente não consegue erguer os alicerces de uma costura verdadeiramente nacional, porque a vigarice corrói tudo. A pior coisa em nossa profissão é a mão de obra e os métodos empregados para tirar um colaborador.

- Você disse que cobra caro porque não vende gato por lebre. Em média, quanto custam seus vestidos?

- Variam de 2000 a 15000 cruzeiros. Alguns, principalmente os de noiva, às vezes chegam a custar 20 000. Tenho freguesas que gastam 70 000, $80000 \mathrm{mil}$ cruzeiros em vestidos numa única compra.

- Quem? 
- Não gosto de citar nomes e não cito. Nunca fiz listas de mulheres mais elegantes. Acho isso uma vigarice!

\section{Não é rico. "Mas vivo muito bem!"}

— Os vestidos são feitos por encomenda?

- Claro. A freguesa conversa primeiro com minha gerente de alta costura, paga uma porcentagem do preço e só depois disso é que sobe para o meu escritório. Faço assim, porque, no começo, muitas se aproveitam de desenhos meus para fazerem em suas costureiras particulares. Não preciso dizer que ficaram aquele horror! Não basta só desenhar, mas saber confeccionar. Dependendo do tipo físico, cor dos olhos, dos cabelos; conforme a finalidade do vestido é que ele é desenhado. Além disso, sugiro tudo sobre o toalete: desde o sapatos e meias até jóias e maquiagem e penteados. Os vestidos são retirados mediante o pagamento completo.

- Você ficou rico com o trabalho?

- Não. Moro com minha mãe em casa alugada. Mas vivo muito bem. Acho que tenho medo de me enraizar. Posso perder tudo, e isso não fará diferença para recomeçar, porque dependo só do que sei, da minha sensibilidade criativa.

- Por que tem medo de se enraizar?

- Não sei. Talvez pelo fato de ser um marginal, como você falou. Qual foi mesmo o sociólogo americano que citou?

- Stonequist.

- Não sei mesmo de onde venho, nem quero saber. Penso no dia de hoje. Não basta?

- Qual lembrança que guarda do seu pai?

- Que horror! Que homem mais bisbilhoteiro!

O sorriso apenas passa em seu rosto que, impassível, não demonstra qualquer espécie de angústia. Seu olhar percorre as paredes forradas de veludo. Sigo sua expressão, refletida na mesa toda de vidro, e penso no armazém de Floreal, sujo de pó, repleto de coisas baratas. Penso na amoreira, no pé de jasmim, na salada de agrião e na enfermaria do ginásio. Ouço as batidas na parede!

- É o que o seu pai disse durante a salada de agrião?

Sua voz vem firme, mas seu rosto tem qualquer coisa de profundamente infantil:

- Não. Sabe? Meu pai era muito bom, dava crédito para todo mundo. No interior, as pessoas que trabalhavam no campo só podem pagar suas contas na safra. Mas compram durante todo o ano. Havia fazendas que compravam mercadorias que davam para encher um caminhão. Meu pai só ia entregando! Muitos, depois das colheitas, mudavam de fazenda ou fugiam. Assim, meu pai empobrecendo até perder o armazém. Tivemos que mudar para o norte do Paraná. A lembrança que guardo dele é a da última vez que o vi. Fui visitar meus pais no Paraná quando já morava em São Paulo. Quando o trem se aproximava da pequena estação, vi meu pai sozinho no meio da plataforma. Saltei e andei para ele. 
Sùbitamente, parei com o coração cheio de amor: meu chorava como criança, olhando para mim com ansiedade. No abraço que nos demos, todas as coisas ficaram esquecidas. Meu pai me aceitara como eu era, como não podia deixar de ser, mesmo que quisesse. 


\section{Ela é a mãe de Pinky?}

“Viver é a glória! Isto é o paraíso! Continuarei agarrada ao tempo, nem que seja a reboque!"

\section{Ela é a filha da Danuza?}

O apartamento projetado por Sérgio Bernardes se abre sobre as praias do Leblon e Ipanema, e dá uma sensação de calma. Ela aparece: blusa preta, calças compridas, cabelos soltos desordenados no rosto fino. Magra, alta, elegante.

A empregada entra na sala com um prato e, ali mesmo no sofá, informal, ela começa seu almoço de passarinho.

Nasceu em Itaguaçú, Espírito Santo, há 38 anos. Casou em 1954, com Samuel Wainer (ex-proprietário da "Ultima Hora"), vinte anos mais velho. E dele se separou em 1961, com três filhos.

Os movimentos são elásticos, abertos, e, quando para, parece plantada no chão, saindo dele como um coqueiro. Não pretende ser bonita apenas jovem - mas, é: o conjunto obedece a uma harmonia que vem do descontraído, do estar no mundo e gostar de estar nele. Olha os outros nos olhos. E, quando cumprimenta, pega mesmo em nossa mão, não como uma concessão, mas como comunicação.

- Você me disse que quer fazer um trabalho sério. Mas eu não sou uma mulher séria. Quero dizer, não costumo refletir sobre problemas sérios. A vida já é muito complicada, por si só, por que complicar mais ainda?

Termina o almoço, meia dúzia de garfadas, volta-se para mim:

—Vou à chácara, em Jacarepaguá. Quer ir?

Dispensa o chofer:

- Tenho horror de ver alguém fazendo coisas que eu mesma posso fazer.

Um instante depois, corríamos pela avenida Niemeyer. Enquanto guia com a mão direita, acende um cigarro com a esquerda. E fala dos filhos, que tem livre trânsito na sua casa e na casa do ex-marido;

- Claro que existem problemas. Mas não sei se não determinados por isso. Conheço tantos casais que são tão certinhos, e tem filhos com cada problema de arrepiar. Vivemos assim, achamos que está certo. A chácara é esta.

Enquanto Joaquim, o jardineiro, sorri enlevado, ela escolha plantas para o apartamento. Sugiro algumas que ela acha lindas, mas acaba não acatando nenhuma das minhas sugestões: ela sabe o que foi buscar. Logo, partimos. Ela dá marcha ré e o carro fica pendurado na pequena ponte. Sua reação é de espanto alegre e em nenhum momento revela medo ou desorientação.

- Eu já disse que só devo guiar para frente. Quando vou para trás, ou caio numa ponte, ou amasso a porta de um Galaxie qualquer. 
Empurramos o carro e saímos ventando pela estrada que acompanha o mar. Não faz nenhum comentário sobre o incidente, coisa sem importância. Seu mundo está cheio demais para se preocupar com pequenos incidentes. Com decisão breca o carro na porta do apartamento. Entramos. Pinky está no linving, sentada no sofá com um prato de creme na mão. Sorri, luminosa.

- Tenho uma fome!

\section{Danuza: “Quero pagar a pintura das unhas"}

Pinky, ou Débora, dezesseis anos, 1,75 m de altura, olhos azuis, olhos de raposa que se movimentam horizontalmente, misteriosos. Vestida simplesmente, despenteada, descalça e encolhida no sofá. Põe o para em cima da mesa, acende um cigarro. Mantêm-se silenciosa, olhando o mar que invade o apartamento. De repente, vira-se para mim:

- Por que uma reportagem sobre nós duas?

- Porque são mãe e filha.

— Só isso não justifica uma reportagem.

— Mas, quando mãe e filha são como dizem que vocês são, justifica?

- E como somos?

- É o que pretendo descobrir.

- Não somos mais mãe e filha. Somos duas mulheres. Procuro trabalhar para viver, para levar a vida que eu acho que devo levar.

- Você começou a justificar a reportagem.

Pinky sorri, maliciosa, uma malicia fugidia. Percebo que ela está mais relaxada no sofá.

-Você tem mesmo dezesseis anos? Não parece.

-Nasci no dia 8 de dezembro de 1954. Faça as contas. Pareço uma mulher formada, mas sou também a idade que tenho. A gente acorda achando uma coisa, dorme achando outra. É tudo tão complicado na idade em que estou!

Danuza reaparece. Sorrindo, senta-se ao meu lado, cruzando as pernas numa atitude de iogue. Ouve um final da nossa conversa e entra no assunto.

- Eu me sinto muito bem quando estou com pessoas mais jovens do que eu. É porque segui o tempo, me agarrei a ele e vou com ele.

Pinky vira-se para mim, quase com uma desaprovação.

- Pois eu prefiro me situar numa faixa que vai dos vinte aos 45 anos. Gosto - mas nem sempre - de andar com pessoas mais velhas do que eu. Sinto-me bem no meio dessas pessoas.

Danuza olha Pinky; Percebo que há uma zona de silencio entre as duas. 0 telefone toca, Pinky levanta-se. Danuza tem um gesto de irritação:

- Aposto que é seu pai. Não sei por que telefona tanto!

Pinky, carinhosa:

— Oh! Paizinho! Você está legal? 
- Não falei?! Samuel telefona o dia inteiro. Mas estávamos falando em idade, não é? Sabe que há dois anos eu fui barrada na porta do Alfredão, boate da barra muito pesada? Pensaram que eu fosse menor! Foi o dia mais glorioso da minha vida.

Pinky desliga o telefone. Danuza está falando que o lugar da mãe não é dentro de casa, na cozinha.

- Quem não trabalha não pode estar por dentro do mundo de hoje. Fazer obra de caridade como umas peruas que conheço, não significa trabalhar. Acho que a mulher precisa contribuir para manter a casa e os filhos que desejou ter. 0 que aliena a mulher é não saber o que custa ganhar a vida. Não suporto pensar que um homem dever sair às 8 da manhã para pagar a pintura das minhas unhas, meus sapatos, o cabeleireiro e outras coisas, sem falar na educação dos filhos.

- E você, Pinky?

- Não sou tão radical quanto a mamãe;

- Mas você trabalha e gosta de ser independente aos dezesseis anos.

- Acho muito interessante trabalhar. Mas, se fosse casada e os argumentos do meu marido me convencessem a não trabalhar, eu aceitaria.

\section{Pinky: “É terrível não saber envelhecer"}

A voz e as expressões de Pinky estão carregadas de críticas à mãe. Danuza percebe, mas disfarça, não aceitando o desafio.

- Você acha o mundo adulto muito quadrado? - Pergunto a Pinky.

- Não. $\mathrm{O}$ mundo adulto é tudo isto que está feito aí. Penso que não é pouco, você não acha?

- Claro. Mas eu pertenço a ele, não sou jovem como você.

- Acho que, quando o mundo adulto não quer ser outra coisa além do que é, aí não tem grilo. Mas forçar a barra, quando todas as raízes prendem a pessoa ao passado, aí, sim, não dá pé. Acho que as pessoas são válidas como elas são, não como querem representar que sejam.

Houve um imperceptível movimento de Danuza: ela compreendeu a outra marretada da filha, embora procurasse não demonstrar. Não estavam mais diante de mim a mãe e a filha, mas duas mulheres que, embora tivessem quase 22 anos de diferença de idade, se igualavam na condição de mulher. Danuza sorri, os seus olhos cinzentos se tornam frios.

- Pois, para mim, o grande charme do passado é que ele já acabou. Simplesmente isso.

Pinky encolheu-se no sofá, como uma gata angorá, e finque que o que diz não é para a mãe. Olha-me diretamente nos olhos.

- Acho terrível quando uma pessoa não sabe envelhecer. Quem começou bem só pode terminar bem. Para que, então temer a idade que se tem? 
Danuza tem uma expressão enigmática, como se quisesse dizer: "Ah, a juventude sabe tão pouco". Mas, como acredita na juventude acima de tudo, sua expressão é terna:

- Não sinto a idade, simplesmente não consigo pensar nisso. Enquanto eu estiver vivendo, tudo está dando pé. Só não gosto da morte. Ela é definitiva demais. Se algum dia você ouvir dizer que caí da janela, foi alguém que me empurrou. Pode depor a meu favor que suicídio, não foi.

Pinky, representando o papel de reveladora da mãe, revela-se mais.

- Às vezes, eu penso que o mundo tentou me preparar para ser boneca, bem vestida, bem-falante, inconseqüente essas coisas. Mas gosto de ser como sou, procuro ser autêntica na medida do possível.

- Eu também, minha filha! É por isso que vivo como vivo.

Resolvo intervir:

- Você nunca se sente só, Danuza?

- Em solidão inútil, não. Quando chego a uma cidade, por exemplo, eu me sinto inteiramente só, mas essa sensação de solidão pe que me faz feliz. E tive mais momentos, é claro.

- Que momentos foram esses?

- Há cinco anos, eu estava na França e sai de Paris para assistir às corridas de Le Mans. Como duram 24 horas, há um momento em que você deseja ver outras coisas. Perto havia um parque de diversões. Em um dos barracões estava anunciado um strip-tease sensacional. Paguei 1 franco, entrei: vi várias gaiolas, tipo aquário, com areia no chão. Em cada uma delas, uma mulher nua, deitada no meio de cobras, ratos, hienas. Um horror. Senti-me extremamente mal, percebi que eu também era responsável pela presença daquelas mulheres num lugar tão sujo. Aquele momento ficou para sempre, como a noite das hienas.

O olhar de Pinky está longe, mas percebo que ela está presente, ouvindo a mãe. Sua expressão melancólica contrai-se, quando Danuza diz?

- Acho muito bom que Pinky não tenha de ruim para se lembrar.

Ela senta-se firme no sofá, voltando-se nem gesto brusco.

- Quem disse que não tenho?

— Não estou afirmando, minha filha. Estou desejando que não tenha.

- Nós duas conversamos sobre qualquer assunto. Somos diretas e não sabemos fingir. Por isso posso contar na frente de minha mãe qual foi a minha noite das hienas.

\section{Pinky: “Também já tive a minha noite das hienas"}

Danuza, enigmática, olha para Pinky, em expectativa. A tensão no living é quase palpável. Pinky acende um cigarro, calma:

- Eu tinha sete anos e estava sentada no sofá. De repente minha mãe deitou-se no meu colo, chorando, desesperada. Eu via seu corpo sacudido pelos soluços, sentia aqueles gemidos subindo dentro de mim mesma. Minha mãe tinha 
rompido com seu segundo marido, o jornalista e compositor Antonio Maria. Subitamente, as coisas ficaram claras à minha frente. Até então, ela era simplesmente minha mãe. Mas, naquele momento, aprendi que ela era também um outro ser que eu não compreendia. E eu que era uma garota, comecei a perder minha infância. Não eram só os brinquedos que existiam na vida. Alguma coisa me colocara num aquário com ratazanas, cobras e hienas.

- Não fui eu, minha filha.

- Não estou dizendo que foi. Mas acho que é por isso que não deixo que ninguém se apaixone por mim. Quando percebo que um dos amigos está numa faixa de relacionamento diferente, eu destruo na hora, fico fula com a história.

- Já disse, Pinky, não são duas ou três experiências sexuais que fazem de você uma mulher. São mil experiências, no trabalho, nos relacionamentos, nos fatos vividos diariamente, enfim, tudo que acontece.

- Mas a experiência sexual não é importante? - pergunto.

- Muito importante, graças a Deus. 0 que uma mulher não pode é se entregar a qualquer um, apenas como novidade. Isso não tem sentido!

Percebo que Danuza está magoada. Querendo fugir desta faixa de diálogo ela ri e acrescenta:

- Mas também tenho outros tipos de maus momentos. Meu pobre Vasco, por exemplo! Quer ouvir o hino do Vasco?

Rindo, ela se levanta. Pinky observa-a com expressão de carinho.

- A verdade é que nossa família é como todas: os mesmos sofrimentos, as mesmas tristezas, as mesmas alegrias.

Pinky se encolhe novamente no sofá. Pergunto:

- Acha que Danuza ficou magoada com a sua história sobre as hienas?

- Não. Mamãe não é mulher para se magoar inutilmente. Somos duas mulheres que se respeitam e procuram compreender uma à outra.

\section{Danuza: "Amo a vida, morrerei agarrada a ela"}

Danuza volta ao living, anunciando que vai ao cabeleireiro. Quando está saindo, volta com um sorriso verdadeiramente fascinante:

- Sabe? Tenho muitas esperanças de que esta vida, que é tão boa e tão maravilhosa, não termine por aqui mesmo. Viver para mim é a glória! Para mim, o paraíso é o mundo! Amo as coisas materiais. Não vou dizer que o dinheiro não traz felicidade, acho isso uma hipocrisia. Quero a vida com tudo que ela me deu - meus filhos, minha casa, meus vestidos e perfumes, meus momentos felizes e infelizes - e tudo que ela ainda vai me dar. Continuarei seguindo o tempo, nem que seja a reboque!

Danuza sai. Pinky olha para mim. Sorri carinhosa:

- Mamãe terminou fazendo uma declaração. Também quero fazer. Quando você tira o mistério que envolve as coisas, fica só o caroço. Mas o que importa mesmo é o caroço. Hoje, os jovens fazem tudo, até mesmo o amor, sem se envolver 
em pensamentos sujos. Somos como somos! Acho que as outras gerações faziam mal feito, porque só se interessavam pelos mistérios, não chegavam a nenhum caroço. Se agimos com convicção, não tem grilo nenhum, tudo acontece como deve acontecer.

Enquanto Pink fala, lembro-me do diário de Danuza, onde ela escreveu quando Pinky ainda era garotinha: "Pinky me disse:" Mamãe no seu retrato de biquíni, parece uma flor - o corpo é o caule, a cabeça, a corola ". E acrescentou que, quando crescer, quer ser cantora, dessas que descem escadas vestidas de banco, com plumas na cabeça, e cercada de moças de maiô. Minha conclusão: vedete". 


\section{Admirado, odiado, um homem desconhecido: Sir Gilberto Freyre}

A rainha Elizabeth o fêz nobre do Império Britânico. Um de seus livros embora tratando de difícil tema da sociologia - teve 35 edições, em oito línguas. Êle é o mais premiado intelectual brasileiro, mas alguns o consideram omisso, alienado, reacionário. Numa rara e comovente entrevista de onze dias, com Jorge Andrade, a figura mitológica transformou-se num homem brasileiro, capaz de amar brancas, negras e mulatas.

Estamos na biblioteca do Solar de Apipucos, Recife, construído no século XVIII, onde Gilberto Freyre vive há mais de trinta anos, desde que se casou com Madalena Guedes Pereira, vinte anos mais jovem e descendente de famílias tradicionais da Paraíba. Há oito dias que freqüento sua biblioteca tôdas as manhãs. Os fatos narrados por Gilberto Freyre até o momento me desconcertam e não consigo reencontrar a imagem do homem inacessível, do aristocrata pernambucano intolerante, do escritor vaidoso, como o haviam descrito. Olhando os livros, lembro-me das advertências, feitas principalmente por pernambucanos do Recife:

- Gilberto Freyre não recebe ninguém na parte da manhã; não dirá uma palavra sem um gravador presente; é difícil percebê-lo, tal a couraça de vaidade que o envolve; transpira presunção; ficou parado no tempo; só dá valor ao que escreve.

Volto-me e olho Gilberto Freyre sentado com a perna esquerda no braço da cadeira colonial - posição que não é de senhor de engenho, mas de trabalho: Gilberto escreve numa pequena tábua que apoia sôbre o joelho.

- Para mim, a mesa é sempre burocrática. Lembra-me tabelião.

Gilberto sorri, passando a mão magra nos cabelos inteiramente brancos. 0 olhar, agudo, me examina constantemente, com qualquer coisa de profundamente irônico. Sua camisa de tecido e desenhos africanos, sua maneira de ser, os gestos, o tom de voz, tudo nêle revela refinamento. De repente, êle se ergue, ágil, e com certo carinho coloca a mão em meu ombro, perguntando-me:

- Então?

— Deve ser bom ter uma biblioteca com 20000 livros, à volta do lugar onde se trabalha.

- Olhe os livros, mas não a estante cheia de medalhas, comendas e títulos. Ela, às vezes, me faz sentir como se não estivesse mais vivo. Sinto-me jovem. Afinal, com 71 anos, nem óculos preciso usar.

Sua fisionomia se contrai ligeiramente, o olhar fica meio anuviado, quando acrescenta:

- A estante e o que muitos pensam de mim por êste Brasil. Dominando o pensamento que o amargura quando se lembra do conceito que fazem dêle, o 
homem em pé à minha frente, com qualquer coisa de judeu no rosto, ganha uma expressão maliciosa quando pergunta:

— Vamos agora à pitangada? É de minha invenção: pinga, pitanga e licor de violetas.

Sei que só tenho mais uma hora de entrevista naquela manhã: a pitangada indica que o momento de partir se aproxima. Gilberto almoça e vai para o Instituto Joaquim Nabuco, do qual é presidente do conselho diretor, e onde trabalha às tardes. Olho à minha volta: sôbre mesas, em molduras de prata, retratos de casamento de seus filhos Fernando e Sônia. Numa mesa menor, também em prata, os dois netos. Sôbre estantes, imagens barrocas de grande valor. Do pátio interno mourisco, cheio de plantas, vem o som calmante de água que cai, produto da sabedoria árabe. Por tôda parte, azulejos do século XVIII, móveis coloniais que pertenceram a antepassados, louças preciosas, pratarias, livros raros, quadros de Pancetti, Cícero Dias, Lula Cardoso Ayres. Numa das estantes, a estatueta de ouro do prêmio La Madonnina, um dos principais prêmios literários italianos - entre seus ganhadores estão Salvador Dali, Graham Greene e Jorge Luis Borges -, e o diploma do prêmio americano Apsen, de 30000 dólares, recebido também por Benjamin Britten, considerado o maior compositor britânico vivo, e pelo arquiteto grego Doxiadis. 0 prêmio Apsen é dado a pessoas em qualquer parte do mundo, que tenham contribuído para o desenvolvimento das humanidades. Entre os prêmios, o título de Sir do Império Britânico, dado pela rainha da Inglaterra. Estava olhando a estante de prêmios, quando Gilberto volta com dois cálices em uma salva de prata:

- Minha pitangada foi muito apreciada por Roberto Roselini, John dos Passos e muitos outros. Aldous Huxley, abstêmio, apreciou apenas a côr.

Gilberto Freyre encosta o cálice no meu. De repente, o movimento de minha mão pára. Olho a côr amarelada da pinga e, de dentro do cálice, vêm o cheiro da terra da zona da mata, a côr dos canaviais, o aroma do melaço, o perfume das pitangueiras em flor, o roxo das violetas que lembra as paixões do pernambucano. Do pequeno cálice, como se contivesse um oceano de recordações, começa a brotar o que Gilberto me contara até então:

Em outubro de 1930, na sala do palácio do govêrno, o jantar continua, enquanto as balas de fuzis vêm morrer no chão ou nas paredes. Estácio Coimbra, governador de Pernambuco, e vários de seus amigos mais íntimos, entre êles Gilberto Freyre, continuam impassíveis a conversa.

Entrimcheiradas na rua Aurora, as fôrças vindas da Paraíba atacam o palácio. Aconselhados pelo comandante da tropa federal no Recife, o governador e os amigos passam a noite nas docas, enquanto o ataque deve ser repelido. $\mathrm{Na}$ manhã seguinte, porém, as tropas federais embarcam para destino ignorado: a revolução getulista vencia. Sem proteção, governador e amigos vão para o engenho Morim, de propriedade de Estácio Coimbra, perto da praia de Tamandaré, no sul de Pernambuco. De Tamandaré seguem para Salvador, onde pegam o navio "Belle Île", com destino a Dakar, no Senegal. 
$\mathrm{Na}$ aparente calma do embarque, vozes de amigos que ficam se elevam por todos os lados:

- Gilberto! Leve êsse capote.

- Mais um mês e a Europa estará gelada.

- Leve essas duas camisas.

- Como vão se arrumar?

- Daremos um jeito.

Lentamente o navio se afasta, enquanto a noite cai e o exílio começa. Gilberto Freyre está sendo exilado e sem convicções políticas, apenas por ligações de amizade. Ou seria por ligações mais profundas? De onde nasceria o fascínio que aquêle homem, agora dormindo no camarote do navio, exercia sôbre êle? Gilberto Freyre, debruçado na amurada do navio, sente o cheiro forte da terra que vai se distanciando. 0 exilado - aparentemente gratuito, mas movido por fôrças imponderáveis - lembra do que se seguiu à sua volta de universidades americanas ao Brasil, em 1923, quando se viu sem saber que rumo tomar, desajustado, sem amigos firmes. Primeiro, sustentado pelo pai - sempre desconfiando que aquêles anos em universidades americanas nada iam acrescentar de bom - e pelo irmão Ulysses, grande amigo seu. Depois, o trabalho no jornal "A Província", até que sobreveio a revolução de 1930, que o obriga, por coerência, a se exilar.

Por um momento, parece a Gilberto Freyre, debruçado na amurada do navio, que os cursos nas universidades de Baylor e Columbia seriam perdidos. Que as pesquisas em Oxford e os encontros na Europa com artistas brasileiros como Brecheret, Tarsila, Oswald de Andrade, Vicente do Rêgo Monteiro nada iam acrescentar ao seu futuro. E como se fôsse um tempo perdido, se vê andando por Recife sem destino, aparentemente sem raízes. Dividido entre dois mundos: na Europa, sempre com saudade do telúrico; diante das fôrças telúricas, sentindo-se cosmopolita. Caminhadas solitárias pelas ruas do Recife que o levam sempre à presença elegante e máscula de Estácio Coimbra, para os sons de piano de sua mãe Francisca ou para os braços da sensual Amália, teúda e manteúda, mas amando o jovem doutor.

Vindo pelo cheiro môrno da terra - sobrepondo-se a tudo - o rosto da mulata Amália, moradora da travessa do Forte, faz-se presente, esquentando os sentidos do homem. Mulata canela, cabelo bom, enxuta, muito sexo, demais sensualidade, analfabeta mas inteligente, instinto puro. A lembrança faz Gilberto sorrir.

- O meu doutor está com muita ruga na testa. Que pensa?

- Tenho preocupação profunda, mas não sei o que é.

- Com você é só amor. Não se preocupe com dinheiro, não.

- Não se trata disto.

- 0 meu doutor que veio da estranja com tanta sabedoria e tanta...

A lembrança parda, sensual, se esconde numa onda do mar, ainda trazendo movimentos de pernas quentes como torrões de terra, ou morenas como rapadura. 
Amália aprofundava ainda mais a importância fundamental do sexo para Gilberto Freyre, como homem, e a importância do sexo com origens africanas ou exóticas na formação da família e da sociedade brasileira. Era nos braços de Amália que se sentia também mulato, prêso em correntes atávicas, percebendo por todo lado e em todos os tempos a miscigenação largamente praticada, corrigindo desníveis, encurtando distâncias, determinando formação de raça, de sociedade.

Sobrepondo-se ao rosto pardo, como pardas são as terras ricas do litoral ou dos engenhos Noruega, Dois Leões, Mupan, Japaranduba, Queimadas, que tantas vêzes visitara, aparece o rosto da sinhàzinha muito branca, delgada, cabelos castanhos, olhos extraordinàriamente belos, voz musical e sem a estridência nordestina. Com vestido leve e claro, sem nenhuma jóia, parece ter vindo correndo sôbre o mar, acompanhando o navio como nova Moema, mas aristocrática, espanholada. Sua voz de prata vem pelo prateado do luar:

- Gilberto, você é o pernambucano mais pernambucano que conheço.

— É a minha condição. Vem de dentro de mim, do meu passado, de tôdas as coisas. E você?

— Também me sinto assim. Nasci numa Casa Grande.

Partia também com Gilberto o amor pelo semelhante, amor dentro da classe, da família, amor endogâmico, quase incestuoso. Sùbitamente, agitado, Gilberto Freyre volta-se, desfazendo a presença branca, a voz argentina. Apoiado na amurada, deixa a cabeça pender para trás, sentindo o vento passar entre os cabelos; fecha os olhos tentando descobrir por que a lembrança da môça branca o agita tão profundamente, como se pensar nela com desejo fôsse cometer pecado maldito, possuir a própria irmã. 0 sentimento desconhecido que sempre o agita traz à sua memória a figura da mãe que, durante a sua meninice, fôra a mulher mais bela entre todas, até o dia, quando aos sete anos, deitado em seu colo, aparentemente dormindo, mas maliciosamente escutando, ouvira a voz dura do tio:

- Francisquinha! Em tôdas as famílias existem sempre os feios. Na minha, por exemplo, é o meu filho, Alcindo. Acho que na sua é Gilberto.

Com os sentidos aguçados, Gilberto esperara um protesto, a defesa, a indignação materna. Mas nenhuma tinha vindo. 0 silêncio da mãe que aprovava transformou-se em carrapichos circulando em seu sangue. A palavra feio aliou-se imediatamente a tudo que êle considerava realmente feio, não apenas a feiúra física, mas outras inconfessáveis que podem vir de dentro de cada um. A mágoa atingira-o profundamente, começando a perceber que feio era ser diferente, como êle; que sempre fôra um menino não muito querido pelos mais velhos, como se fôsse um garôto cacête.

Gilberto afasta-se da amurada e caminha observando o navio. Mas prêso nas garras de tempos mortos e vivos, cacho de recordações que se exila, cadinho de fôrças ancestrais, vai encontrando presenças - mortas e vivas - em cada canto do "Belle Île". Revê sua fuga de casa com uma pequena trouxa e um naviozinho, seu brinquedo predileto. Com êle, anda por ruas do Recife, anda muito, mas a saudade 
da mãe vai, pouco a pouco, guiando seus passos para a casa materna, onde domina o pai, amante da odiada matemática, do terrível latim. As vozes do passado ressoam no tombadilho:

- Êsse menino está com oito anos e ainda não aprendeu a ler, nem a escrever!

- Êsse menino é retardado.

- Para que serve desenhar? Desenha o dia inteiro!

- Quem não é bom na matemática, não faz nada na vida.

Do verde do mar vem o verde claro dos canaviais batidos pelo vento, com suas flôres lembrando penachos em batalhas coloniais, quando o sangue negro, índio, português, flamengo, argamassavam o pernambucano. Envolvem o navio como um laço de aromas, o cheiro do jasmim de banha, das pitangueiras, de cajás e maracujás. No rosto crispado do homem surge o sorriso e êle revê o menino andando embaixo de mangueiras, olhando fascinado os canaviais, mas dêles não se aproximando, pois não era nêles que o temível bandido Cabeleira - arruaceiro urbano famoso - ia se esconder? No tombadilho escuro, ressoa a frase - "cada pé de cana é um pé de gente" - ouvida não sabe onde, acompanhando o exilado, como o acompanha o aroma do melaço, virando cheiro de suor, inhaca da raça negra ou índia. Menino de engenho, sofrendo, crescendo, pensando, partindo, mas sempre voltando.

A imagem do menino de engenho, que aparece tanto na obra de Gilberto Freyre, começa a ganhar corpo na sua própria luta de menino contra as coisas, contra adultos, contra o mundo. Brincando com seu naviozinho de papel - feito pela mãe, sempre pela mãe - no rêgo d'água do Engenho São Severino, o menino ouve os sons do piano que vêm da casa grande e descobre que sua mãe determina realmente a única dimensão do mundo. De repente, o menino corre para a casa grande, ainda ouvindo o canto das negras do engenho:

- Fecha a porta, Rosa; Cabeleira aí vem, pegando mulheres e meninos também.

Mãe branca na sala grande tocando Chopin, mãe preta nos restos de senzala cantando cantigas populares, contando estórias. Estórias de sofrimento negro, de maldade branca; de navios com brancos ao sol, e negros em porões escuros; de brancas emprenhadas em alcovas fechadas, de negras animalizadas em espaços abertos; de amoré carícias brancas, de amor e proteção negra. Estórias de solidão negra ou branca que foram se cravando como carrapichos na memória do menino que gosta de brincar com naviozinhos feitos pela mãe, em regos d'água de engenhos poderosos.

De repente, atormentado, Gilberto Freyre olha o mar e só vê a imensidão enluarada. Os fantasmas tinham passado, todos, para dentro de si mesmo. Comovido, começa a perceber que o mundo das casas grandes estava moribundo. Pior ainda: já estava morto. Não morto pelas balas que atingiram o palácio do govêrno, mas pelo tempo, dentro de um processo histórico. A revolução de 1930, que o exila, apresenta-se como um grande divisor de águas. 0 que parecia ser 
presente já era passado, história. 0 homem brasileiro - branco ou negro - já caminhava em outras vertentes. Mas o solitário do tombadilho sabe que, mesmo morto, mas fixado no tempo e no espaço, aquêle tempo é essencial para se compreender o Brasil; que nenhum futuro pode ser divorciado da experiência já vivida, fôsse qual fôsse: das casas grandes, senzalas, mulatas, sobrados e mocambos, cana, café, cacau, pelourinho, argolas, troncos, índio, português, mouro, francês, judeu, africano, holandês - raças e fatos que devem ser assumidos para compreender o presente e ter alguma perspectiva de futuro.

De imagens refletidas no mar - a mulata Amália, a filha do governador e a mãe; de angústias que vinham de dentro dêle mesmo, o menino e o adolescente incompreendido; do navio que deixa para longe a terra mãe; da fôrça que o impele para as costas da África, para o desconhecido — , de tudo aquilo, pouco a pouco, longìnquamente, como os primeiros movimentos de um feto, começa a nascer, em Gilberto Freyre, o livro "Casa Grande \& Senzala". Nascerá como carne e como sangue; como memória; nascerá como amor puro, sensual ou inconfessável; como filho branco e negro da nossa mulatice social; nascerá como morte de épocas e princípio de outras.

A travessia do Atlântico para o mundo africano e português - dois pilares de sua futura obra-prima - é longa, cheia de incertezas, parecendo uma viagem para dentro de uma noite sem fim. Mas o que parecia ser apenas espírito de aventura é, na verdade, a fôrça intangível da criação que o leva de um lado para outro. Primeiro, no Senegal, o aprofundamento do contato com a raça negra. Em cada rosto que encontra, nas tribos senegalesas que visita, volta sempre a face do mundo das senzalas, das cozinhas brasileiras, das negras bondosas à beira das tachas, das sinhamas amamentando brancos que as escravizam. Depois, em Portugal, o mundo branco - mas não tanto! - as casas com pátios mouriscos, os costumes, a língua, os alicerces do mundo que o exilara, mas sempre vivo em cada esquina que dobra. Nada ficara para trás, tudo o acompanhara. Em Lisboa fica sabendo que sua casa no Recife fôra saqueada e incendiada pelas fôrças getulistas, perdendo, para sempre, livros, móveis, coisas preciosas da família. Até o piano da mãe fôra roubado.

Disseram que tinha sido o povo enfurecido. Gatunagem! Quando que o povo dêste país ficou enfurecido, a ponto de saquear e incendiar residências?

As semanas que passa em Lisboa são terríveis. Gilberto e Estácio Coimbra vão morar numa pensão na rua Alexandre Herculano, em um quarto do lado da sombra, por ser mais barato.

- Fiquei sabendo, então, o que a pobreza sofre no inverno. Em nosso quarto mal cabiam duas camas e o sol quase nunca nos visitava.

Para não sofrer tanto com o frio, Gilberto senta-se nas praças de Lisboa, aproveitando o sol. Demor-se nos cafés ou nas bibliotecas públicas, pesquisando documentos sôbre o Brasil, aquecendo o corpo e o espírito. Para se sustentar, dá lições de inglês a brasileiros exilados. À noite, freqüenta o salão da embaixatriz brasileira, onde encontra a alta sociedade portuguesa, nobres europeus, 
destacando-se o duque de Medina e Sidônia. Naquele mundo refinado, ninguém pode imaginar que êle e Estácio Coimbra vivem pràticamente à beira da miséria. Vida dupla que o humilha, mas que o prepara para o trabalho que, dia a dia, vai germinando. Quando saem do salão da embaixatriz, onde se alimentam bem, discutem as tendências da arte e os caminhos da política, vão brigar com a dona da pensão:

- Os senhores precisam pagar mais pelo quarto.

- Estamos pagando o que foi combinado.

- Os banhos são separados.

- Banho faz parte da pensão.

- Não banho todos os dias. Não sei por que se lavam tanto.

Quando a noite é fria demais, Gilberto corre para os braços da Maria. Mais uma vez, é mulher da raça negra quem o embala. É com Maria, negra angolana, prostituta desinteressada que fala sôbre a África enquanto bebe ginja, bebida popular portuguêsa. E, certamente, encostado nos grandes peitos da angolana Maria, peitos que pareciam feitos para alimentar a humanidade, Gilberto começa a armar alguns dos seus mais belos trechos sôbre a ascendência negra na alma brasileira: “... trazemos todos a marca inconfundível da influência negra. Da escrava ou sinhama que nos embalou. Que nos deu de mamar. Que nos deu de comer, ela própria amolegando na mão o bolão de comida. Da negra velha que nos contou as primeiras histórias de bicho e de mal-assombrado. Da mulata que nos iniciou no amor físico e nos transmitiu, ao ranger da cama de vento, a primeira sensação completa de homem".

O carteiro pára Gilberto na porta da pensão e entrega a salvação selada: convite da universidade americana de Stanford para dois cursos: um de conferências, outro de seminário em nível de doutorado.

- Estácio Coimbra foi me levar no cais e chorou. Deixei com saudade Lisboa, tendo apenas o suficiente para a travessia do Atlântico e bilhetes de estrada de ferro para chegar à Califórnia.

Mais uma vez os caminhos tinham o sentido da obra que germinava: primeiro África, depois Portugal e, agora, documentos preciosos da biblioteca de Stanford. Na Califórnia encontra novamente o sol, as palmeiras, o espanhol das residências, a presença moura. Se tem apenas um terno e duas camisas que êle mesmo lava, em compensação encontra na universidade a coleção completa da "Brasiliana" e os preciosos "Inquéritos Parlamentares Britânicos sôbre as Condições da Escravidão no Brasil", feitos na metade do século XIX. "Casa Grande \& Senzala" vai se corporificando. Depois de um ano em Stanford, com algum dinheiro economizado, Gilberto volta à Inglaterra para novas pesquisas. Da Inglaterra, regressa ao Brasil, indo morar no Carrapicho, casa de seu irmão Ulysses, assim denominada pelo grande número de carrapichos que havia à sua volta. Lá, começa a luta para arrancar dos fatos presos no tempo e no espaço pernambucanos sua sociologia nascida da memória, proustiana. Essa luta dura mais de um ano, quando vive pràticamente como prisioneiro do Carrapicho. 
- Eu sabia que não queria ser político, nem professor, e ser escritor no Brasil seria patinar na areia. Mas foi isto que escolhi, mesmo sabendo o preço que um intelectual paga em meu país.

O negro Manuel Santana, herança da família, vai morar no Carrapicho e se torna a sombra protetora de Gilberto, fazendo de tudo, vigiando, ciumento, o seu sinhô. Enquanto Gilberto escreve, deitado na esteira comprada por Manuel na feira, êste planta mangueiras, jaqueiras, bananeiras, para o sustento do escritor.

- Manuel tinha mão especial para plantar: bastava colocar na terra.

Enquanto Gilberto escreve e lê, Manuel cuida das plantas da casa, vai buscar a marmita na casa de dona Francisquinha, vende frutas ou vigia a vizinhança para que não atrapalhe o trabalho do "doutor". Aos amigos do Rio - Villa-Lôbos, Sérgio Buarque de Hollanda, Manuel Bandeira, Rodrigo de Mello Franco de Andrade escreve constantemente:

- Estou felizmente sem ler jornais, isolado neste Carrapicho, onde só me ocupo em plantar bananeiras, côco, jaca, jambo e agora manga, e no livro. Saio raras vêzes.

Do outro lado da rua, bem em frente ao Carrapicho, mora Josefina Minha Fé, preta catimbozeira que faz seu próprio catimbó, ninho de feitiços e bruxarias. Sua filha, Maria, amante do cônsul português no Recife, alonga os olhos para dentro do Carrapicho. Manuel, ciumento, ronda a casa como cão de guarda, tentando defender o filho branco, o trabalho do seu doutor.

- Cuidado com essa Maria, doutor. Pode querer explorar.

- Explorar o quê? Não tenho nada de meu. Só muito amor para dar.

- Nêga feiticeira. Perigosa com êsse negócio de mandinga. Cuidado com mandinga de nêgo, doutor.

— Não é só mandinga que a Maria sabe fazer, Manuel!

- Cruz credo, Virgem Maria.

- Vai ao povo e procure compreendê-lo, Manuel. Exatamente o contrário do que fazem êsses imbecis que são quase todos doutôres, sacerdotes, mestres e bacharéis brasileiros que, mesmo quando vêm da parte mais humilde do povo, se afastam do povo.

Manuel sai. Gilberto se estira no chão, recordando as carícias da Maria, de tôdas as Marias e Amálias que encontrara. De repente, salta de pé e vai ler o diário que escreve desde os quinze anos. Lá está o que tenta escrever desde que acordou:

“Recife 1915. Saltando o muro de detrás do quintal, cauteloso como um gato fui ao quarto de A., que vem me tentando com todos os seus encantos. Muito cuidado contra os riscos de emprenhar o diabo da mulatinha, que me tratou como se eu fôsse um bebê e ela uma mestra empenhada em me ensinar tudo numa lição só. Desde os quatorze anos que um indivíduo pode emprenhar. 0 medo me acompanhou o tempo todo: medo de uma variedade de perigos e não apenas dêsse. Cama de lona de um ranger traiçoeiro que me parecia chegar aos ouvidos de tôda a gente da casa, anunciando meu pecado. Preocupação. Prazer perturbado. Desapontamento. Remorso. Sensação de ato incompleto mas mesmo assim 
definitivo na minha vida. Ato criador de outro eu dentro do meu eu. Já não sou o mesmo. Já não posso abraçar e beijar minha mãe como a abraçava e beijava. Nem a minhas irmãs. Sou outro. Curioso que a mulatinha tenha gemido como se eu estivesse ferindo. E estava: a ela e a mim".

A frase, registrada a mais de quinze anos, completa o sentido do trecho que procura escrever: "Da mulata que nos iniciou no amor físico e nos transmitiu, ao ranger da cama de vento, a primeira sensação completa de homem".

Preocupado, Manuel volta à sala:

- Esta semana não temos frutas para vender. As mandiocas estão ainda muito moderninhas.

- Avise os amigos que farei leilão de livros e quadros.

Quando o cansaço é demais, Gilberto sai à noite, sozinho anda pelas ruas do Recife, freqüenta clubes populares e se perde na noite, ouvindo o agogô, os atabaques e é levado nos terreiros de xangô ou exum-ceci, pelo rodamunho branco, negro, mulato, cafuzo.

Por isto, seu pai continua a não compreendê-lo e Estácio Coimbra o apelida:

- Gilberto, o meu socialista.

Quando o dinheiro acaba, na biblioteca do Carrapicho, cheia de amigos, a voz de Gilberto se eleva dentro da noite:

- Quem dá mais por êste livro de Anatole France? Vejam! Êste quadro de Manuel Bandeira é obra-prima. E o quadro de Vicente do Rêgo Monteiro? Quem dá mais? Dou-lhe uma, dou-lhe duas, dou-lhe três...

E nos leilões são consumidos livros, quadros, pratas, gravuras antigas, pratos de porcelana inglêsa.

- Com a venda de livros vou me agüentando perfeitamente e gozando daquela paz do Senhor que Êle não reserva só para os ricos. Preciso realmente cuidar da vida. As frutas e os leilões apenas me permitem escrever o danado do livro. Só interrompo essa vida para cuidar de umas galinhas que me deram para criar e para uma ou outra farra, com o meu grupo.

Numa noite de maio de 1933, os amigos comparecem ao Carrapicho, não para leilões, mas para a festa comemorativa da partida do último capítulo do livro para o Rio de Janeiro. Às 9 horas da noite, vários carros da turma do sereno - que não fôra convidada - já enchem a rua para ver quem vai comparecer à festa.

- Foi da turma do sereno que começaram a sair os piores comentários sôbre a minha pessoa, sôbre a festa, interpretando tudo como devassidão, orgia desenfreada. No outro dia, Recife estava cheia dos comentários, que meu livro era um insulto à família brasileira, expressão da gente devassa que havia comparecido ao Carrapicho.

Enquanto a turma do sereno se morde de despeito, Luiz Jardim entra vestido de fidalgo português; Carmelita e Iaiázinha Gibson, primas da mãe do atual chanceler brasileiro, passam vestidas de sinhás de casa grande; Teresita Bandeira de Melo, também de sinhá; Antiógenes Chaves e sua mulher, de senhor de engenho e mucama; e, arrancando gargalhadas na rua, entra Olívio Montenegro, com 
penachos de cacique. 0 sucesso da festa revela a grande curiosidade sôbre o livro; os comentários maledicentes, o que se pensa do solitário do Carrapicho. Do outro lado da rua, Maria - a filha da catimbòzeira Josefina Minha Fé - suspira saudosa das noites calmas, mas cheias de amor, que passou no Carrapicho. Saudosa e ressentida, pois não estêve em seus braços, como está entre as fôlhas de seu livro? E por que não está lá, comemorando também?

- Doutor diferente! Gosta de escrever e de amar no chão, em cima de esteira.

Na festa, Gilberto não larga da taça de champanha, de certo já pensando na sua futura pitangada.

- Eu me perdi na festa. Queria me libertar de tudo que havia passado para escrever meu livro. Nem sei se fui à saleta "Refugium Angelorum", onde iam os casais que queriam se beijar, se acariciar. Só um escritor conhece a solidão que toma conta dêle, quando se esvazia das personagens. E elas estavam tôdas à minha volta, cantando, dançando, se amando.

No Carrapicho já vazio, no dia que amanhece, Gilberto Freyre cambaleia, completamente bêbado. 0 negro Manuel abraça o branco Gilberto:

- Venha, meu filho. Venha dormir.

Gilberto escapa, apóia-se na parede, vendo tudo girar à sua volta. De sua garganta, a voz sai pastosa:

- Consegui, Manuel... consegui... meu filho livro...

Manuel abraça-o novamente, angustiado, sofrendo pelo filho branco:

- Por todos os santos do céu. Venha dormir, meu doutor.

- Onde estão as casas grandes, os sinhôs, as mucamas, as sinhamas? Onde foram parar as sinhás, Manuel?

- Já foram se embora, doutor. Venha dormir. É tarde. Tinham desaparecido da memória, escondendo-se em páginas brancas, transformando-se em palavras, frases, capítulos, no livro que abalaria as letras brasileiras na década de 30 , começando a ensinar a nacionais e estrangeiros as raízes da formação de nossa sociedade, com suas 35 edições: dezessete em português, oito em francês, quatro em inglês, duas em espanhol, e em italiano, alemão, japonês e iugoslavo.

Sinto novamente a biblioteca de Apipucos à minha volta. Ouço a água caindo no pátio interno mourisco. Olho o líquido amarelo da pitangada e percebo que Gilberto acaba de bater seu cálice no meu:

- Ao trabalho realizado!

- De todos os intelectuais brasileiros!

Os fantasmas de Gilberto, que tinham passado para mim, desaparecem novamente quando sinto a pitanga passar em minha garganta. Descubra os caminhos por onde passou um homem, e você o conhecerá sem mesmo ter visto sua face. Estava pensando nisto, quando ouço a voz de Gilberto:

"O mundo brasileiro, saído principalmente de casas grandes e senzalas em engenhos, fazendas de criar, estâncias, fazendas de café, fazendas de cacau -, é o mais meu dentre os mundos que formam o Brasil total e estão à sua raiz e dentro 
do seu presente e do seu futuro e não apenas do seu passado. Por isto, procurando revelá-lo, interpretá-lo, compreendê-lo, creio ter conseguido revelar uma parte essencial e até germinal do homem brasileiro como um homem situado num espaço e num tempo diferente dos outros: dos europeus, asiáticos, africanos e do anglo-americano".

Lembro-me do que um pernambucano ilustre me dissera dois dias antes:

- Pernambuco não dá glória a ninguém. Cada um que trate de erguer sua própria estátua.

Olho Gilberto parado diante da porta que se abre para o jardim e compreendo sua verdade profunda, dramática: tudo nêle é pedreiro, escultor, artesão, criador da estátua a que julga ter direito de deixar, um dia, não só em Pernambuco, que ama profundamente, mas sobretudo no Brasil. Gilberto sabe, tem consciência dolorosa do silêncio que se criou em tôrno dêle. Então, de Apipucos, êle dirige há muito tempo, numa luta desesperada contra o tempo, as obras de seu próprio pedestal.

De tôdas as partes de Apipucos, avista-se Engenho do Meio, Caxangá, Camaragibe, o serpenteado do Capibaribe, que passa quase dentro de seu jardim; rio de margens canavieiras, de sofrimento escravo, seguindo em curvas para dentro do Recife. A luz avermelhada do sol bate em Gilberto, diante da porta, patinando suas feições, e o sociólogo que alguns brasileiros - por ignorância, maldade ou paixão política - acham que devia ser tomabado pelo patrimônio histórico, continua em minha frente, palpitante, jovem, coerente consigo mesmo, ainda amando, odiando, lutando, errando, sonhando. A pergunta atravessa a minha mente, como descarga elétrica: será que a nossa falta de cultura chega ao ponto de tentarmos destruir a imagem dos nossos grandes criadores? Onde está o pernambucano intolerante, o escritor vaidoso, o homem inacessível? Diante de mim, parado à porta, só permanece o trabalhador, o escritor que passou fome e frio para escrever. De repente, a porta que liga a biblioteca à sala de jantar senhorial abre-se num movimento brusco e dona Madalena, mulher de Gilberto, sinhá autoritária de engenho paraibano, entra na sala e sua presença dominante toma conta de tudo. Mãe branca que não toca Chopin, mas que também saiu de casa grande, vizinha de senzalas. Sinhá que não vem pelas ondas do mar como nova Moema, mas pisando firme nas tábuas largas do chão, olhando à sua volta, possessiva, dona e senhora da casa, do homem e da família. Instintivamente, olho o quadro de dona Francisca, mãe de Gilberto, pendurado no canto da biblioteca, meio escondido, aparentemente exilado. Lembro-me de Estácio Coimbra, senhor de engenho, distinto, belo, másculo, quixotesco: é o último representante de um mundo que passará a viver, para sempre, na obra de seu amigo Gilberto. Pois não é êle um senhor de engenho? Ou será muito mais do que isto?

Olho a biblioteca à minha volta, que guarda a riqueza que Gilberto acumulou durante a vida, e me lembro da carta que escreveu quando chegou, exilado, a Lisboa, em 1930: 
"Peço todo o cuidado para os livros, porque dêles vou depender muito na minha vida. Penso às vezes que todos êsses desastres, tôda essa desgraça, tudo isso 'foi por bem', como diz a lenda ou anedota do Castelo de Cintra, que um dêsses dias visitei. Assim como por um estado místico que não sei explicar, eu vinha com antecipação clara de uma desgraça na vida; tenho agora outra intuição, de que 'foi por bem', embora isso signifique recomeçar tudo de nôvo, num esfôrço doloroso. Às vezes só com um grande solavanco como êsse certas forças adormecidas naqueles que vêem tudo como 'tanta lida pra tão curta vida', despertam por um momento e dão de si alguma coisa. Mais pela dor ou pelo orgulho, que são sempre criadores, do que pelo entusiasmo de fazer coisas, privilégio dos que não sentem por tôda parte vozes de 'não vale a pena', menos solenes, porém mais irônicas do que os 'nevermore' do poema célebre".

Ouço a voz de dona Madalena, dominadora mas amável:

- Gilberto só fala em Pernambuco. Mas tudo que há de bom aqui veio da Paraíba. E não é verdade?

- Claro, Madalena. Pois você não está aqui?

E tôdas as sinhás se corporificaram na biblioteca. Nos retratos dos filhos e netos, o amor ao negro. E todos os amôres formando uma única família: a família brasileira. 


\section{A liberdade será sempre a minha causa}

Respeitado pelos intelectuais brasileiros por sua bondade e inabalável coerência, Érico Veríssimo acha que, num mundo de violências, o menos que o escritor deve fazer é acender sua lâmpada, iluminando a realidade.

Érico Veríssimo salta do táxi no alto de Petrópolis, bairro de Porto Alegre, olha à sua volta exibindo-me mais uma vez sua vista predileta. Caminha, procurando um ponto onde ela seja mais ampla. Silencioso, econômico de palavras, Érico acaricia com o olhar a paisagem. Estatura média, magro, desempenado, inteiramente grisalho, fontes fundas, levanta o braço apontando:

- Lá está o Guaíba. É formado por cinco rios que vêm do interior gaúcho. Entre eles está o rio Jacuí, que passa perto de Cruz Alta, minha cidade natal. Sabe que em Cruz Alta já existe um museu Érico Veríssimo?

Ao falar no museu, um sorriso irônico domina seu rosto. É este sorriso que me faz lembrar a pergunta de um repórter, quando Érico esteve muito doente:

- É verdade, Érico, que vai entrar para Academia Brasileira de Letras?

- Como, se já sou quase uma vaga?

Érico dá sempre a impressão de quem pede desculpas pelas coisas de sua vida, pelos livros que escreveu, desculpas que geralmente vêm acompanhadas por um sorriso leve de timidez. Parece sempre dizer:

- Sou apenas um contador de estórias. Desculpem-me.

Ouço sua voz que quase nunca se eleva, ou trai seus sentimentos.

- Mas não falemos de museus. Vamos conversar sobre a paisagem e, principalmente, sobre gente. Tu não achas mais interessante? Sobre quem tu queres que eu fale?

Seu tratamento gaúcho na segunda pessoa havia tornado cada vez mais íntimas as nossas conversas. Percebo que a expressão irônica volta em seu rosto, quando olha a ladeira à nossa frente, por onde teremos que descer.

- Há pessoas que fazem psicanálise deitadas em sofás, pagando uma nota. Eu faço contigo, de graça, descendo esta ladeira. Preciso sugerir esta nova técnica ao meu amigo analista, dr. Meneghini.

Minha risada se perde no espaço aberto de Petrópolis. Sei que ela tenta disfarçar o escrúpulo que cresce em mim, por estar sondando a verdade íntima daquele homem. Mas o perfil do escritor precisa ser feito. É para isso que estou em Porto Alegre há dez dias.

- Vamos começar a análise, caminhando em nosso sofá?

- Tu queres mesmo? Eu não tenho importância.

- Com a maioria dos romances traduzidos para o inglês, alemão, italiano, russo, húngaro, holandês, norueguês, espanhol, tendo alcançado, só em língua 
portuguesa mais de 2 milhões de exemplares, acha que não tem importância? Não foi seu romance "O Continente" considerado pelos melhores críticos brasileiros como obra-prima, que o professor alemão Sieben constatou, numa pesquisa, ter sido o livro latino-americano mais vendido na Alemanha de 1945 até hoje, alcançando uma tiragem de 320000 exemplares?

- Foi.

- Então?

Subitamente, ele caminha um pouco apressado. Eu o advirto:

- Cuidado, Érico. Lembre-se do que o cardiologista disse: caminhar como velha inglesa, parando a qualquer pretexto.

- É verdade: como velha inglesa. Se Mafalda, minha mulher, estivesse aqui, eu receberia uma repreensão. Percebeste como ela me vigia como se tivesse cem olhos? Cem olhos azuis?

Dona Mafalda, que Érico conheceu em Cruz Alta e com quem se casou há quarenta anos, forma com ele um dos pares mais perfeitos de marido e mulher. Há dez anos, Érico teve um enfarte grave e, desde então, é extremamente cuidadoso com sua saúde. Mas sente-se em tudo a presença vigilante de dona Mafalda. É uma vigilância amorosa, nunca agressiva. É no alto de Petrópolis, entre outros lugares de Porto Alegre, que Érico vai, todas as manhãs, caminhar a conselho médico. Há dez anos que ele e a mulher são vistos, sempre juntos, caminhando pelas ruas nas manhãs ensolaradas.

\section{Meu pai ressonava entre cinzas}

Se tivesse "escrito" uma personagem para ser minha companheira, eu não teria conseguido fazer uma criatura tão completa quanto Mafalda. Com a teimosia de meu avô tropeiro, levei um tempão para compreender que ela era, em muitos respeitos, a melhor cabeça da casa. Sei que não é fácil ser mulher de um escritor, como sei que é duro viver ao lado de um homem do meu temperamento. Apaixonado? Violento? Imprevisível? Nada disso. Silencioso, distraído, meio vago e, às vezes, quase apático. Mafalda tem humor, sabe dar uma boa risada (e como essa risada me tem ajudado!), conserva os pés firmemente plantados na terra e possui um talento especial para o convívio. Ela me conhece tão bem, que já desisti de esconder dela fatos e sentimentos. Ela lê tudo em meu rosto.

Enquanto fala, uma expressão envergonhada de carinho toma conta de seu rosto. Ouço sua voz, britanicamente dosada, observando a rua em que estamos e que Érico denomina de "ladeira da inspiração", porque foi ali que pensou e arquitetou seus últimos livros. Começo a descida lenta, caminhando em nosso "sofá" de análise.

- Você falou sobre dona Mafalda. Quero ouvir sobre você.

— Eu me amo, mas não me admiro.

- Deixe que eu conclua isso. 
- Como queiras. Mas não te esqueças de que sou um romancista, eu explico as personagens.

- E eu, como dramaturgo, deixo que elas se expliquem.

Naqueles dez dias de convivência, Érico vinha, dia após dia, anunciando a frase "eu me amo, mas não me admiro". Fechado, cuidadoso com o que fala, ele dissera a mesma frase de maneiras diferentes, disfarçando sua autocrítica. Admirado pelos principais intelectuais brasileiros, respeitado como homem coerente; esse sentimento de autocensura me desconcerta, mas me intriga. 0 que deverá estar escondido atrás dele? Ele olha a ladeira que desce se escondendo em curva, e volta-se para mim. Há qualquer coisa de diferente em sua expressão. Suas sobrancelhas se encontram, hirsutas, muralhas defensivas. Percebo o homem tentando se esconder atrás de um olhar que se torna opaco, numa expressão de passividade índia.

- Uma das noites mais terríveis da minha vida foi a de 2 de dezembro de 1922. Eu havia chegado de Porto Alegre, feliz com a idéia de rever minha família, minha casa, de passar em Cruz Alta as férias de verão. Mal chegado, porém, percebi que a situação doméstica havia se deteriorado de maneira talvez irremediável. Naquela noite, minha mãe resolveu abandonar meu pai, tentando salvar o que restava da família. Se levarmos em conta a época, o tamanho da cidade e a nossa posição na comunidade, a resolução dela era um ato de admirável coragem moral. A casa não nos pertencia mais, sua hipoteca não fora resgatada. A separação de meus pais e o abandono da casa onde eu nascera me traumatizaram profundamente. Desde então, andei à procura da casa perdida.

Por um momento, há um silêncio cheio de recordações. Nas pessoas que passam, começo a ver fantasmas de Cruz Alta. Na manhã cheia de sol, os mortos começam a se misturar aos vivos.

- Naquela noite, minha mãe, sem coragem, mandou-me um bilhetinho de seu quarto, perguntando-me se eu iria embora com ela. Fui.

Cruz Alta - berço de Jacarecanga e Antares, cidades importantes na criação literária de Érico - ia nascendo na ladeira, revelando a casa de seu pai, onde habitavam a solidão e o emparedamento de pessoas que se comunicam por bilhetinhos, morando tão próximas.

- Depois da separação, trabalhei num armazém de secos e molhados. Do armazém, passei para uma casa bancária e finalmente, antes de vir definitivamente para Porto Alegre, tive uma farmácia, como meu pai tivera e perdera. Um dia, eu tinha dezenove anos, um amigo entrou gritando em minha farmácia: "Érico! Seu pai está caído na sarjeta. Vá acudi-lo". Saí correndo.

Instintivamente, nossos passos se apressam na calçada. Os de Érico, dirigidos pelos movimentos do passado; os meus, pela ansiedade da descoberta que se aproxima. Érico pára embaixo dos galhos de uma árvore que saem de um jardim, encosta-se no murinho e olha-me calmo. 
- Meu pai não estava mais caído na sarjeta. Alguém o havia carregado para um pequeno quarto de terra batida. Quando entrei ele estava sobre um monte de cinzas. Meu pai, bêbado, ressonando entre cinzas!

Na ladeira em que descemos, ficam claros os tons cinza de certas passagens da obra de Érico. Seu olhar de uma opacidade cinza, memória de descampados cinza, de paisagens agrestes, desoladas, batidas pelo vento. À nossa volta também o vento faz os cinamomos de Porto Alegre agitarem os galhos. Olhando aquele rosto que sempre reflete bondade, lembro-me de Ana Terra, uma das personagens do livro "O Tempo e o Vento": "Sempre que me acontece alguma coisa importante, está ventando", costumava dizer Ana Terra. Mas, entre todos os dias ventosos de sua vida, um havia que lhe ficara para sempre na memória, pois o que sucedera nele tivera a força de mudar-lhe a sorte por completo".

\section{Minha mãe censurava, suspirando}

A amizade que nascera entre nós durante aqueles dias de entrevistas transformara-se, para mim, sem que eu soubesse precisamente em que momento, num carinho especial. Érico levanta-se do murinho e retomamos nossos passos. Quando vou segurar seu braço para atravessar a rua, ele segura o meu. Sinto o contato firme de seus dedos, enquanto a buzina do Opala estoura em nossa nuca. Ao subir a sarjeta, meu pensamento volta a Cruz Alta, para o monte de cinzas. Antes que eu faça a pergunta, ele revela que seu pensamento também não saíra de lá. Érico vive desligado do mundo que o cerca, profundamente preso ao interior. Pode ouvir uma pessoa durante muito tempo, denotando grande atenção, e estar perdido em distâncias longínquas, em paragens e fatos muito bem guardados em um silêncio que, às vezes, se torna compacto.

- Foi depois daquele monte de cinzas que me aconteceu uma coisa terrível. Escrevi a meu pai uma carta em que...

Érico interrompe a frase, desviando o olhar da sarjeta. Atraso-me ligeiramente, percebendo a dificuldade da confissão, o esforço parra revelar fatos de sua vivência mais íntima. Érico se volta, segurando-me. Ficamos parados no meio da calçada, ignorando os que passam, atrapalhando pedestres, completamente distantes de tudo que nos rodeia.

- Escrevi uma carta a meu pai, censurando seu comportamento, exigindo que ele se afastasse de Cruz Alta, pois sua presença e conduta punham em perigo os esforços que fazíamos, eu e minha mãe, por uma vida melhor. No outro dia, encontramo-nos em um café. Ele tirou a carta do bolso e, numa frase que nunca mais esqueci, disse: "Por favor, rasga esta carta. Faz de conta que nunca a escreveste". Rasguei. Hoje, sei que o sentimento de culpa que me seguiu a vida inteira não vem do fato de ter seguido minha mãe, abandonando-o; ou por não ter feito nada diante daquele monte de cinzas; mas por ter escrito aquela carta. Ela ficou, para mim, como certas palavras que pronunciamos e que nos seguem como moscas. 
Pouco a pouco, em nossa descida, os espaços abertos, entre as casas, vão descobrindo novas paisagens. Cercando um vale atapetado de telhados, ergue-se o morro da Polícia, com casas já escalando o seu sopé.

- Do outro lado daquele morro está o colégio Cruzeiro do Sul, onde estudei. Naquela época, o morro era símbolo de cativeiro, de polícia. Também me sentia assim em relação ao rio Guaíba, encrespado pelo vento. No inverno, o morro coberto de neblina lembrava-me um soldado de poncho, andando de um lado para outro, montando guarda à prisão onde eu vivia.

Observo-o de lado e vejo que suas sobrancelhas estão contraídas novamente, parecendo abas de um chapéu, protegendo o olhar opaco de índio que observa a passagem do tempo, ou do vento.

- 0 vento me inspira temor, como se fosse portador de mistérios. Quando interno no colégio, eu sofria de insônia e ficava ouvindo o gemido do vento, trazendo-me medo de sepultura, de asfixia. Tinha vontade de abrir todas as janelas do dormitório. Hoje, o Guaíba está aceito: lembra-me o verde de lago alpino. Afinal, tenho quarenta anos de Porto Alegre e apenas 25 de Cruz Alta.

- Não acha que uma obra literária fundamenta-se em nossos primeiros dezoito anos de vida?

Percebo que digo isso como um esboço de crítica à sua obra literária. Érico se julga homem urbano, de certa maneira, de trânsito internacional. Para mim, as obras que revelam essa posição são menores do que as plantadas no interior, que refletem o quadro histórico-social gaúcho, projeção sociológica que as obras de arte contêm.

- É por isso que o capitão Rodrigo de "O Tempo e o Vento" tem muito de meu pai. Assim como minhas heroínas, fortes, realistas, possuem de minha mãe.

- Ou de dona Mafalda?

- Também.

- É no disfarce que o escritor mais se revela. Não acha?

- É possível. Sei que minha mãe era o cumprimento do dever levado ao fanatismo.

- E seu pai?

- Meu pai cultivava o beber e o comer bem, a gravata e a roupa bonita, nada com o horário, ou a obrigação e, sobretudo, cultivava a arte de fazer amor. Mulher para ele era doença: não havia hora, lugar ou escolha. Tudo servia: rica, pobre, remediada, negra, branca ou mulata. Enfim, tudo que usasse saia. Um cunhado dele costumava dizer: "O Sebastião só respeita as irmãs".

Érico sorri, como se pensasse em um filho descabeceado.

- Não respeitava nem mesmo meu território.

\section{É preciso manter a lâmpada acesa}

Vamos descendo para o reino Veríssimo de mortos. Érico havia me contado que seu pai era baixo, ombros estreitos, ventre desenvolvido, sem beleza máscula, 
voz ligeiramente efeminada. Procuro visualizar esse sátiro que lembra Sancho Pança, solto nas ruas de Cruz Alta, mas não consigo. Sinto que ele nos espreita na ladeira, talvez escondido entre as saias das gaúchas que passam na calçada. Meus sentidos ficam alertas quando percebo que debruçamos em um poço profundo, cheio de verdades que podem turvar suas águas.

- Ele tinha uma capacidade especial para a conquista amorosa. A farmácia dele - Farmácia Brasileira - era o mais importante ponto de reunião dos vadios e aposentados da cidade. 0 prático tinha de preparar as receitas cercado de intrusos e curiosos, e era no meio duma algazarra e de um vaivém de feira que lidava com drogas que podiam ser mortíferas quando não pesadas com precisão de miligramas. Era um ambiente de cio permanente. Prostitutas circulando, práticos bolinando, gente trepando atrás de portas, anedotas picarescas. Nossa casa era pegada à farmácia, portanto minha mãe devia pressentir tudo.

Mas silenciava. Silenciava e suspirava, como certas personagens minhas que censuram mais pelos silêncios e suspiros, do que pelas palavras.

— Como a mãe de seu romance "Caminhos Cruzados"?

- Isso mesmo.

Nossos passos de velhas inglesas vão vencendo a distância que nos separa do no 1415 da rua Filipe de Oliveira, onde vive Érico. Ao mesmo tempo, vai se afigurando o mundo sujo, doente, sensual, saindo do inferno da farmácia, invadindo ruas, casas, envolvendo a nespereira de seu quintal em Cruz Alta árvore, reino e brinquedo - onde a sensibilidade e a imaginação do menino Érico vão germinando. Da nespereira - floresta, castelo, mirante —, seus olhos infantis estão sempre observando: na farmácia - o formol, vísceras humanas, gente doente, perseguida, dilacerada; em sua casa, o pai escravo de instintos, a mãe ferida, fechada em silêncio; uma família doente que, pouco a pouco, se dilacera. Érico vai revelando seus fantasmas, e eu vou localizando-os em sua obra. Lembrome de seu último romance, "Incidente em Antares", que faz grande sucesso - três edições de 10000 exemplares em um mês -, e compreendo o nascedouro da atmosfera de decomposição que domina a cidade de Antares, principal personagem do livro. Nela, sete mortos insepultos descem do cemitério envoltos numa nuvem de moscas, sentam-se no coreto da praça principal, espalhando sua presença decomposta pela cidade, como terrível acusação aos vivos que, ao longo do livro, cheiram pior do que eles.

- Muitas das minhas lembranças fundamentais estão enraizadas naquela farmácia. Lembro-me que, um dia, foi arrastado para a sua sala de curativos um desconhecido de origem humilde, espancado pela polícia. Fui chamado - eu tinha onze anos - para segurar a lâmpada enquanto se faziam os curativos. Vejo ainda um polegar pendurado por um tendão, uma cabeça escalpelada, um ferimento de navalha que rasgava a boca até a orelha. Naquela noite nasceu em mim o sentimento de justiça, de repugnância pela violência, que me domina até hoje. Sei que não tenho nenhuma qualidade de líder, mas detesto mandar ou ser mandado. 
0 passado e o presente vão se revelando, ladeira abaixo. 0 homem que sempre esteve e está contra a violência, venha de onde vier, continua em minha frente, sereno, coerente. Abro minha pasta e tiro um livro de Érico que trago sempre comigo desde que cheguei a Porto Alegre.

- Que foi?

- Quero situar a passagem do homem espancado pela polícia, numa declaração sua que li neste livro.

- Sobre a obrigação de acender a lâmpada?

- Exato. Aqui está: “... sempre achei que o menos que um escritor pode fazer, numa época de violência e injustiças como a nossa, é acender a sua lâmpada, fazer luz sobre a realidade de seu mundo, evitando que sobre ele caia a escuridão, propícia aos ladrões e aos assassinos. Segurar a lâmpada, a despeito da náusea e do resto. Se não tivermos uma lâmpada elétrica, acendamos o nosso toco de vela ou, em último caso, risquemos fósforos repetidamente, como um sinal de que não desertamos nosso posto".

Suas atitudes coerentes, que incluem a defesa da liberdade de expressão, seu respeito ao homem, ligam-se no tempo e no espaço. É por isso que se coloca decididamente contra a censura prévia de seus livros, não por eles mesmos, mas porque sabe que isso determinará a morte de qualquer criação. Fígaro, a personagem de Beaumarchais, passa em minha cabeça gritando sua advertência: "Sem a liberdade de censurar, não há elogio que lisonjeie; só os homens pequeninos temem os pequenos escritos".

\section{0 gaúcho tem pudor com palavras}

Em todos esses dias que passo em Porto Alegre, por mais que faça, não consigo fazer Érico falar da mãe, traçar seu perfil. Sempre que começa a falar da mãe, passa instintivamente para o pai.

- Meu pai acabou perdendo tudo em Cruz Alta. Em 1930, a revolução getulista o levou para São Paulo.

Estamos diante da casa de Érico: branca, janelas azuis, despretensiosa; ilha confortável cercada de flores por todos os lados. Érico e dona Mafalda moram nela há trinta anos. Seu filho Luiz Fernando, casado com a carioca Lúcia Massa, mora com eles.

- Saímos da casa de meu pai e chegamos à minha: esta é a casa perdida, mas reencontrada. Minha casa é o meu mundo, minha verdade. Não desejei nada além dela - assim mesmo como ela é.

Compreendo que o menino que dirigia batalhas, trepado na nespereira árvore que se transforma em floresta, jangada, veleiro ou castelo - , apenas sonhara com o humanamente fundamental: uma casa solidamente plantada, filhos e netos. A transcendência pela família e pelo trabalho, produzindo, em quarenta anos de vida literária, 32 livros. Olho a casa e tenho um vago sentimento de que ela não é, fundamentalmente, a coisa procurada. 
Dizem que o verdadeiro gaúcho tem pudor com as palavras, que é lento em suas resoluções, escondendo no silêncio o desenvolvimento de suas decisões. Érico é assim. Nunca é o gaúcho de fronteira, macho (pronuncia-se matcho) folclórico de churrascaria fronteiriça, ou que vive dizendo "che". Esta comédia ele não representa. Ele é - diante de sua obra, dos outros e da vida - o que é diante do filho, por exemplo, a quem de vez em quando diz: "Sou teu pai. Não te esqueças". 0 filho sorri em silêncio, um dos silêncios mais compactos que já conheci, só igualado ao do próprio pai. Érico só sabe representar Érico. Parece ainda viver em Cruz Alta, não acreditando muito no que fez. Para ele, a vida se transformou numa frondosa nespereira, de onde não mais dirige batalhas, mas se diverte contando estórias para o resto do Brasil. Tem sabedoria de viver, irônico, brincalhão, trocadilhando tudo.

— Você nunca usou bombachas, Érico?

- Não aprecio muito o carnaval.

Enquanto minha risada anuncia a nossa chegada, ladeamos a casa pelo canteiro de hortênsias e saímos no pátio interno, onde a família passa grande parte dos dias. Cercados por canteiros de flores, ali almoçam ou jantam quando o tempo permite; ali, Érico costuma receber turmas de estudantes que vêm entrevistá-lo. Pedro, o neto caçula, brinca no pequeno quadrado de areia. As netas Mariana e Fernanda, sentadas na pequena mesa, esperam pelo almoço. Dona Mafalda, aproveitando o sol, está sentada, aparentemente sem prestar atenção às coisas, mas sentindo tudo que se passa à sua volta. Recebe-me e encara-me com extrema naturalidade, perguntando:

— Então? Andaram mesmo como duas velhas inglesas?

- Velhíssimas, esclerosadas. Viemos nos arrastando.

Dona Mafalda sorri. Olho seu rosto calmo, refletindo equilíbrio interior, e procuro descobrir de onde virão seus olhos azuis como duas contas: da ascendência alemã Halfen da mãe, ou da italiana Volpe do pai. Sua expressão estrangeira é bem a face de um imenso Rio Grande do Sul, contrastando com o rosto índio de Érico. Dona Mafalda não diz uma palavra a mais, nem faz um gesto desnecessário. Sua suavidade, porém, guarda uma vontade férrea, companheira perfeita para o escritor. Mas, nessa companheira, Érico encontra um ser muito mais próximo de seu pai do que de sua mãe com suspiros e silêncios que reprovam. Deve ter preparado a mamadeira de um filho da mesma maneira como, ouvindo Vivaldi, prepara seu copo de uísque. Em dona Mafalda, o silêncio é para preservar, nunca para censurar.

Quando pedi a Dona Mafalda que falasse sobre o marido, respondeu firme:

— Érico se conhece muito bem, e é seu próprio dono. Ele que fale.

Mas um de seus olhos está sempre, disfarçadamente, observando, perscrutando o rosto de Érico. Se ele leva a mão ao peito, ela logo pergunta:

- Que foi?

— Nada Mafalda. Não posso me coçar? 


\section{Não sou escritor para escritores}

E ela volta ao seu tricô, ou ao copo de uísque, sem maiores comentários, mas deixa no ar a direção de seus sentidos, inteiramente voltados para ele. Lembra Penélope à espera de Ulisses, lutando contra o tempo com as armas de suas agulhas e linhas, prendendo em cada laçada uma fração do tempo conquistado. Érico, em sua poltrona predileta, enrolado no novelo de seu silêncio, olhando as malhas que pendem das agulhas de dona Mafalda, sente-se protegido, perde-se nos fios emaranhados da memória, que nascem em volta de uma nespereira. Depois de quarenta anos de vida em comum, o silêncio é mesmo mais rico do que as palavras. Na noite em que ficamos, praticamente sós, na sala cheia de objetos que lembram viagens, de repente compreendi que filhos, netos, obra literária, tudo é importante, mas que Érico está só diante de dona Mafalda, ou que os dois estão sós diante do mundo. Ele preocupado com o tempo que o coração lhe pode dar; ela fazendo tudo para que esse tempo seja o maior possível, não tanto pela obra literária, mas por ela mesma. 0 caso entre os dois é de amor, no melhor sentido que a palavra contém.

Observo-o agora ao sol e sinto que é ela quem dá a dimensão do mundo daquela casa. Sua voz, serena, mordaceia no pátio:

- Aposto que, caminhando, não foram tão velhíssimas como deveriam.

— Mafalda! Queremos café e meu copo de Ponjal.

Érico toma constantemente grandes copos de Ponjal - suco de grapefruit. Faz parte do tratamento para o coração. Entramos em sua sala de trabalho no porão - 4 metros por 3 - onde escreveu a maioria de seus livros. Atrás da porta, retrato do cientista Oppenheimer, do filósofo Teilhard de Chardin e do escritor John dos Passos, amigo pessoal. Um busto de Eça de Queirós, uma máquina de escrever Royal, retratos dos três netos americanos - sua filha Clarissa é casada com um físico americano e mora nos Estados Unidos. Um sofá simples, uma poltrona, um fogão cilíndrico de ferro para o inverno. Sobre a mesa pequena atulhada de papéis e livros, vários copos cheios de lápis: Érico costuma desenhar o rosto de suas personagens, enquanto escreve. Às vezes, quando não consegue encontrar a frase que procura, irritado, passa descompostura em si mesmo:

- Burro, idiota, cretino! Depois de quarenta anos, ainda não aprendeste a escrever?

Érico liga o rádio na estação da Universidade e estende-se no sofá.

- Gosto de escrever, aprecio meu trabalho de escritor, mas não gosto de vida literária. Não sou escritor para escritores. Não quero dizer que não gosto de ver gente. Gosto muito. Tu viste o grupo de amigos que vem a minha casa quase tôdas as noites.

Despreocupado com a posteridade, não coleciona coisas sobre ele, como retratos, cartas ou artigos. Em suas estantes - modestas no número de livros - 
não há muitas das primeiras edições de suas obras, faltando mesmo alguns livros. Não é vaidoso, mas tem um tremendo amor-próprio.

- Nunca pedi a ninguém que lesse um livro meu. Eles estão nas livrarias para serem lidos e são como eu pude ou desejei escrevê-los. Rotularam-me de superficial no começo de minha carreira, e esse rótulo ficou até hoje para qualquer coisa que escreva. Acho que também tem havido muito exagero a meu favor. Isso me irrita.

Érico tem sempre uma curiosidade mesclada de receio, quando lê o que escrevem sobre seu último livro. Trata a crítica com certa impaciência, principalmente quando é dogmática.

— Fico intrigado e irritado quando, dentro da literatura brasileira que não é excepcionalmente rica em grandes escritores, sou tratado como romancista menor, o que não é justo. Posso ser menor num plano internacional, mas não no nacional. Por um momento, os sons do concerto de Brahms tomam conta do pequeno escritório. Olho a mão magra de Érico só com a aliança, levando o copo de Ponjal à boca. Percebo que em seu rosto não há mais nenhum traço de ironia.

- Tenho medo de perder a capacidade de indignação e cair na aceitação, que é sempre perniciosa para a vida em sociedade. Não quero ser indiferente. Dentro de mim ouço sempre meu grito de indignação. Quando choro pelo outro, sei que estou chorando por mim. Quando tenho receio pelo outro, tenho também por mim. Não sou santo, sou homem.

Observando a placidez daquele rosto, já sem dor pelos sofrimentos do passado, lembro-me de um trecho de carta que Jorge Amado lhe escreveu de Nova York, depois de ter varado uma noite e um dia lendo "Incidente em Antares": "Parabéns, mestre Érico, parabéns a você e a todos nós. Um grande romance numa hora de tanto romance ruim, mofino, de tanto truque modernoso". Volta à minha lembrança o que Antônio Cândido, Paulo Duarte e outros intelectuais brasileiros haviam dito dele e que passava a ser meu próprio julgamento: "É um dos homens mais dignos e íntegros deste país, de uma bondade fora de série”. Aquele Érico que certa vez declarou: "É preciso alertar a consciência do mundo e exigir-lhe ao menos alguma coerência. Não me parece lógico condenar Pedro pelos mesmos crimes que toleramos ou mesmo aplaudimos quando cometidos por Paulo. Sempre repeli com horror aqueles que, sob o pretexto de nos salvarem a alma, querem queimar-nos os corpos. Não aceito a idéia totalitária de que os fins justificam os meios. Odeio todas as formas de ditadura, inclusive as chamadas benignas ou paternalistas. Detesto qualquer forma de coação. A causa daqueles que lutam pela liberdade será sempre a minha causa. Não aceito como são e válido nenhum regime político e econômico que não tenha como base o respeito à pessoa humana".

\section{Andei à procura da casa perdida}

De repente, fico com todos os sentidos alertas. Sem saber por que, olho o teto do escritório de Érico, no porão, que fica bem embaixo de seu quarto. Olho as 
paredes à minha volta, procurando sentir a casa, conhecer um pouco de sua alma, mas não sei por que, ela me dá a sensação de lugar por onde se passa, como se suas paredes não estivessem alicerçadas num tempo que se perde na memória. Só consigo perceber, vindas do teto, descendo pelas paredes, envolvendo livros, mesa, máquina de escrever, tudo, as raízes da transcendência do escritor: em cima, os filhos; embaixo, os livros. E todas as raízes se confundindo e se enraizando numa casa hipotecada e perdida em Cruz Alta. Então, a pergunta brota em minha mente: que visões, ainda inconfessáveis, o menino deve ter tido de sua casa ou da farmácia infernal, escondido entre flores ou frutos de sua nespereira?

- Érico! Você trabalhou a vida toda na Livraria do Globo e na Editôra Globo; que ficava lá das 8 às 18 horas; que traduzia para a Editôra noite adentro; que só conseguia escrever seus livros nas aparas de tempo; que só usa calças velhas quando escreve; que vive de seus direitos autorais, recebendo por mês de 8 000 a 10000 cruzeiros; que nunca teve pretensões acadêmicas; que ocupou o cargo de diretor do Departamento de Assuntos Culturais da União Pan-Americana, em Washington; que lecionou literatura brasileira em universidades americanas. Sei muito de sua vida, coisas publicáveis em não publicáveis. Só ainda não sei que fim teve seu pai.

Érico levanta o braço magro, cheio de pelos longos, de veias saltadas, e eleva o volume do rádio. Olha para mim erguendo o corpo e o apóia no encosto do sofá. Penso comigo: ele está procurando sua posição de índio. E lá estavam as sobrancelhas hirsutas contraídas, formando uma muralha em volta do olhar opaco, que reflete a impenetrabilidade índia que existe nele. A sensação pronunciada de ser movido por sentimento de culpa desenha-se novamente em seu rosto.

- Eu disse que foi para São Paulo em 1930. Fui despedir-me dele na estação. Estava com um capote velho e percebi que não tinha um tostão no bolso, quando me disse que havia esquecido o pacote de lingüiças fritas na casa onde vivia. Eu também não tinha nada para dar a ele. Saí correndo e fui buscar o pacote. Quando voltei, o trem partia e eu vi meu pai na última plataforma. Corri e entreguei as lingüiças. A canseira da corrida e a emoção me trancavam a voz. Fiquei parado, vendo a figura dele ir diminuindo. Com uma das mãos o velho Sebastião me acenava e com a outra apertava contra o peito a lingüiça frita embrulhada em um jornal manchado, sujo. Nunca mais tornei a vê-lo. Morreu em São Paulo e seu túmulo jamais foi localizado. Sumiu no tempo e no espaço.

Do escritório onde estamos — galho da sua nespereira - Érico dirige a idealização e reconquista de um pai impossível, mas profundamente amado, fonte da humanidade de muitas de suas personagens. 


\section{o Operário da palavra}

Os pais dele vieram do Líbano - como tantos que chegaram de todas as partes do mundo. Ele pesquisou e estudou a história e a alma de milhões de palavras, transformando-se em uma enciclopédia humana. Hoje, é admirado no país inteiro como tantos brasileiros que muito fizeram por sua terra.

Ele se chama Antonio Houaiss.

Em 27 de agosto de 1971, Afonso Arinos de Melo Franco, senador, exchanceler brasileiro, ergue-se na Academia Brasileira de Letras para fazer o discurso de recepção a Antonio Houaiss (pronuncia-se uáis), professor, filósofo, enciclopedista e ex-diplomata do Itamarati. A voz do ilustre político mineiro, pouco a pouco, toma conta da sala:

"A Academia, ao sufragar, sem oposição, o vosso nome, incorporou ao seu quadro uma das mais lúcidas inteligências do Brasil contemporâneo, infatigável operário da cultura nacional".

"Sois um brasileiro representativo, nasceste no Rio de Janeiro, a mais brasileira das metrópoles, como filho de pais imigrantes, o que representa a outra face do vosso autêntico brasileirismo"

Diante de mim, sentado em sua biblioteca, está Antonio Houaiss. Enquanto leio o discurso de Afonso Arinos, ele me observa, procurando tirar de mim, tanto quanto eu tento tirar dele. Sinto certo receio de falar em sua presença, pois não é lê o homem que conhece a raiz de quase todas as palavras da língua portuguesa? Não orientou 165000 verbetes da Enciclopédia Delta Larousse? Não orienta, agora, 8000 verbetes com 17 milhões de palavras da Enciclopédia Mirador Internacional? Uma mente lúcida, racional: um homem cerebral no mais amplo sentido da palavra, Houaiss por fazer, na hora, o verbete de qualquer palavra; é sempre "uma pertinaz ignorância que se quer menos ignorante..." As palavras são suas armas de defesa, de ataque e de sobrevivência. Quando se esconde atrás delas, torna-se quase impossível encontrá-lo novamente. Proponho a ele:

- Quero fazer seu perfil com alguns verbetes feitos por você, no momento.

- Quais, por exemplo?

- Os de Ascendência, Copacabana e Dedal, tirei da Delta Larousse. Mais Juventude, Liberdade, Revolução, Transcendência e Homem, queria vê-lo fazer no momento da entrevista.

- Podemos começar.

\section{Ascendência}

Substantivo feminino. Ação ou efeito de ascender, de elevar-se. Movimento para o alto. Origem, procedência: "uma ascendência humilde". Conjunto de ascendentes ou antepassados de um ser vivo. Exemplo: Habib Assad Houaiss veio para o Brasil em 1898, de Burj-I Barajine, subúrbio de Beirute, no Líbano. Volta 
novamente ao Brasil em 1905, casando aqui com Malvina Farjalla, dezesseis anos mais jovem. Do segundo casamento nascem sete filhos, dos quais o quinto é Antonio Houaiss.

- Lembro-me de meu pai como homem de testa alta, olhos luminosos, pele quase de mulato de tanto sol que tomava. Não era alto, mas entroncado, de força poderosa. Gostava muito de pescar. Algumas vezes eu o acompanhava.

Muitos caminhos o nome Houaiss percorreu, desde de Beirute até ser saudado por Afonso Arinos, na Academia Brasileira de Letras: "Vossa formação, sr. Antonio Houaiss, foi também representativamente brasileira, quero dizer, carioca e popular. Toda vossa instrução foi feita nesta Estado, único onde todos os brasileiros se sentem como no seu próprio Estado. Cumpristes o vosso primário na escola pública; o curso de contador em instituto oficial da cidade-estado; e o superior na antiga Universidade do Distrito Federal e, em seguida, na Universidade do Brasil".

\section{Copacabana}

Península ao sul do lago Titicana, atravessada pela linha limítrofe do Peru e da Bolívia. È formada por sua capela, onde está uma imagem, supostamente milagrosa, da Virgem Maria. A transferência de uma réplica dessa imagem ara o santuário de Nossa Senhora de Copacabana, no Rio de Janeiro, GB, é que originou o nome da praia e do bairro.

- Você sempre morou em Copacabana?

- Sempre. Primeiro na atual avenida Atlântica, ainda não aberta como rua. Mais tarde fomos para o Leme. Antes dos onze anos, não conheci o mundo além do Túnel Alaor Prata, antigo túnel Velho. Colhi pitangas nos morros, a praia era nosso quintal, e o mar costumava encher minha camisa de sardinhas. Havia muito espaço. Hoje também há. Cada um faz seu próprio espaço. 0 que não há muito mais são camisas cheias de sardinhas.

Olho Houaiss sentado à minha frente, short azul, camisa esporte, uma das pernas encolhida sobre a cadeira, na biblioteca de seu belíssimo apartamento, no 13.o andar do prédio revestido de mármore branco, abrindo-se para a lagoa Rodrigo de Freitas, Corcovado, Jardim Botânico e a enigmática pedra da Gávea. Na janela da biblioteca, como um quadro aberto na parede, um dos morros Dois Irmãos, o Leblon e, distante, uma nesga do mar. Nos fundos do prédio, o morro coberto pela mata exuberante, povoada de pássaros. Para todo lado que se olhe, é a beleza da natureza, mas com bordaduras favelantes - sofrimento humano no paraíso.

Vista de seu apartamento, a lagoa, vestida de verde lodoso, é um espelho que não reflete nada. Mas, às vezes, ela se veste com o manto prateado de escamas mortas. A natureza é bela, por isso mesmo, traz problemas, pede soluções, sugere 
ação em benefício do homem. Antonio Houaiss - pensador, sociólogo, político está sempre pensando em problemas e soluções. Inteiramente grisalho, com calva que avança em semicírculo, 56 anos, 1 metro e 64 de altura, sempre nos 52 quilos Houaiss não gosta de memorar o passado, bom ou mau, só se aceitando em sua totalidade presente. Sereno, olha-me com olhos de cor indefinida que não costuma refletir o que pensa. Seu sorriso satiresco - tratando-se de Houaiss, podemos inventar palavras, pois ele entende a língua como uma criança investida num tempo sem fim - é um louvor constante ao que há de mais belo na natureza: a mulher.

- Eu tenho um grande encantamento de conviver com todas as criaturas humanas. Mas, quando estou em face de uma mulher que suspeito ser completa, é natural que esse encantamento se multiplique.

As palavras do discurso de Afonso Arinos voltam a minha lembrança:

"Cumpre não esquecer que a liberdade é, também, florão e destino cariocas. O Rio não é apenas cidade, no sentido urbano, mas também a civitas, a polis, ou seja, a condensação da consciência cívica, que, como nas cidades-estados helênicas, existem porque é livre. Toda a nossa história política mostra que, no Rio, a liberdade nunca se curvou à tirania. Tem sido suprimida, mas nunca conformada".

\section{Dedal}

Substantivo masculino. Pequeno tronco de cone oco, fechado na extremidade menor, e que se coloca num dedo para protegê-lo, quando se costura ou borda. (Serve para empurrar a agulha e é feita de metal, osso, matéria plástica, etc.) (Fig.) Pequena porção.

- Meu pai tinha um armarinho - Ao Atlântico - de tecidos, linhas, materiais de costura. Morreu passeando,na pedra que separa Ipanema de Copacabana. A onde veio, derrubou-o e ele bateu a cabeça numa pedra. Assisti à sua autópsia. Depois disto, minha mãe e minhas irmãs mais velhas sustentaram a casa com costuras. Minha mãe não rejeitava encomendas. Estava constantemente com o dedal. Era uma pequena porção de gente, frágil, mas com imensa determinação. Na mesa da sala de jantar, minhas leituras eram sempre acompanhadas pelo barulho da máquina de costura. Pessoas que ganharam a vida costurando tiveram importância fundamental na minha formação.

- Quem mais, além de sua mãe?

- Antonio Jose Machado, alfaiate português e anarquista. Sua alfaiataria ficava na rua Salvador Correia, atual avenida Princesa Isabel. Eu e alguns amigos, todos pelos doze anos, ficávamos sentados na soleira da porta da alfaiataria, ouvindo Antonio falar. Era um grande expositor. Falava com o cigarro pendurado nos lábios, tendo o bigode meio chamuscado de um lado. Curvado sobre as peças que cortava, expunha suas idéias. Foi ele quem me emprestou livros de Plekhanov, 
Haeckel, Bucarin, Marx e Engels. Ele me instigou muito precocemente para a busca do sociológico.

Aquele foi um dos raríssimos momentos em que Houaiss se deixou levar pelas recordações. Mas, mesmo aí, percebo que seus olhos continuam limpos, não refletindo nenhuma emoção. No movimento que faz, observando-me, a capacidade de amar ou odiar refletem é no queixo - ao lado do queixo. É esse que pode se tornar frio, cortante como ponta de faca. Sua cabeça, vista de frente, lembra um triângulo perfeito, tendo a base invertida, com o vértice terminando na ponta do queixo. Seu todo lembra construção cuja base seja muito pequena para o que tem de sustentar. Quando tento aprofundar suas memórias, Houaiss se defende com uma cachoeira de palavras bem empregadas. Em sua boca, elas ganham sentido, alma, história. Sabe de onde vem cada uma delas. São todas filhas adotivas de seu amor filosófico.

Nesse momento onde cada palavra tem peso mineral, voltar as de Afonso Arinos de Melo Franco:

"Vós aprendestes sempre, até hoje, porque sempre ensinastes, mestre Antonio Houaiss, pela voz ou pelo escrito. Antes dos vinte anos, já vossos estudos de línguas e letras eram feitos em comum com os vossos alunos de colégios particulares. Conheço meninos de então, hoje homens feitos, que nunca esqueceram as lições exatas, conscienciosas, abundantes, daquele mestre pouco mais idoso do que eles".

\section{Juventude}

Substantivo feminino abstrato. Do latim juventus. Esquema de desenvolvimento: faixa etária: primeira juventude, doze a dezesseis anos: segunda juventude. Dezessete a 21 anos: eixo psicológico: trânsito de aquisição de valores para a consolidação de projeto de vida (ideais, ideologia, programas). Socialmente, faixa etária percentualmente menor em países desenvolvidos do que nos subdesenvolvidos. Em todas as épocas, setor mais inovador da população, tendência que se agrava nos períodos de crise de desenvolvimento social. No Brasil, alta porcentagem, profundamente incompreendida por grandes setores etários mais velhos, inclusive a dos pais. Seção etária que sofre, mais do que todas as outras, as coerções sociais, donde três procedimentos típicos: uma fração evade-se no hedonismo (aquisição de vícios, etc.): outra fraca aprofunda-se no estudo de problemas, adquirindo visão própria extremamente fecunda para futuras mudanças sociais: outra fração aceita a camisa de força e conforma-se. Todas as faixas etárias humanas são humanamente sagradas: mas as sociedades só se salvarão harmoniosamente na medida em que, sem dar-lhes favor, assistirem globalmente a juventude que ou é sempre vítima ou sempre tem razão, inclusive quando é vítima. 
- Atravessei o túnel Alaor Prata, saindo pela primeira vez do mundo de Copacabana, quando comecei o ginásio. Éramos muito pobres. Eu não tinha tempo mais para praia ou pitangas. Meus deveres escolares eram feitos entre uma aula e outra, e ainda me sobrava tempo para ensinas colegas. Ensinei a vida inteira. Ensinei aprendendo dos outros. Cada ser é um livro, cada gesto ou palavra pode encerrar um conceito precioso não contido em compêndios. De manhã ia ao curso secundário e à tarde, ainda com meu uniforme ginasial, trabalhava na rua da Alfândega, numa casa de tecidos por atacado. Mais tarde trabalhei numa empresa de distribuição de filmes franceses. Quando tinha dezesseis anos, comecei a lecionar. Só que minhas aulas precisavam ser assinadas por um professor formado.

Em sua expressão não há nenhum traço evocativo, mas seus gestos medidos e contidos de diplomacia agitam-se um pouco mais. Percebo que acaba de se lembrar de acontecimento importante. Sua expressão é risonha neste momento, o que não quer dizer que seja uma lembrança feliz, já que Housaiss tem incrível capacidade para esquecer ressentimentos e ofensas. Seu espírito é tão superior que ressentimentos e ofensas entrariam no verbete "amar ao outro". Para ele, cada ser humano pode e der ser um amigo, não um competidor. Para cada gesto há sempre uma explicação, e os ressentimentos só servem para distorcer a imagem do homem, De resto, ele aceita o homem, como o homem é.

- Que foi, Houaiss?

- Talvez a lembrança não tenha importância. Ou melhor: teve em seu tempo.

Percebo que ainda tem. Houaiss é um homem cordial, mas, às vezes, ele se torna diabólico. Seu diabolismo, porem, tem sempre grande identidade com as gerações novas, com o ser diabolicamente jovem - o homem como deve ser em todas as idades. Mas, como todo o seu racionalismo, por um momento, é o Houaiss adolescente que sorri para mim.

- Todas as lembranças têm importância, Houaiss. Você deve saber disso melhor do que ninguém.

- Quando era inda jovem, talvez na primeira juventude, um padre maronita, amigo meu, procurou convencer meu pau de que eu devia seguir a carreira religiosa.

- Que foi que se pai disse?

- Que eu só devia fazer opção depois de ter experimento mulher. Antes, não.

- Vejo que seu pai era sábio.

- Pelo menos o foi em relação a esse problema. Problema fundamental.

- A mulher é mesmo um negócio muito sério. Não Acha, Houaiss?

Agora, o diabolismo é meu, tentando descobrir o homem à minha frente.

- Serí́ssimo.

Minha risada foi se confundindo com a voz de Afonso Arinos: 
"Professor, por concurso, de ensino secundário oficial, aos 23 anos, ensinastes até os trinta e, também, como professor visitante em Montevidéu. Foi nesse ambiente de professor aluno, no ano preciso do vosso licenciamento em letras clássicas, que vos juntastes a Ruth, vossa dedicada esposa e companheira que disfarçava então, sob a graça de moça baiana. A sisudez de professora de latim".

\section{Liberdade}

Substantivo feminino abstrato. Do latim libertas. No plano das utopias humanas é a mais constante e a mais universal. Nunca existiu em plenitude e alguns milênios ainda levaremos para conquistá-la: ela será "a consciência das necessidades", vale dizer, o domínio de nossas limitações, nossas impotências, de nossas carências, a fim de que possamos ilimitar-nos de tal modo que, superadas as retaliações presentes e passadas, os homens possam fazer-se a si mesmos, pois que no presente os homens se desfazem reciprocamente.

- Ser livre é conhecer, concluir, ter consciência, saber, criar. Nesse sentido, algumas pessoas tiveram grande influência em minha formação. Já me referi ao alfaiate Antonio José Machado. Agora posso citar o professo Ernesto Faria Junior. Devo muito a ele. Havia diferença de dez anos entre nós. Ele era magro, quase esquelético, apelidado pelos alunos de Caveirinha. Tinha grande prazer em ensinar, e eu, uma fome imensa de saber. Foi quem me convidou, quando eu tinha dezesseis anos, para lecionar. Foi ele também quem me apresentou Ruth. Um dia, disse-me:

- "Você vai se casar com minha aluna Ruth Marques de Salles".

— "Eu? Com, se nem a conheço?"

— "É aquela que está subindo."

- Voltei-me e via apenas duas pernas que subiam a escada e desapareciam no lance de cima. Ele concluiu:

- "Vai se casar, sim. É uma brilhante aluna de latim. É nascida no Rio de Janeiro, de mãe fluminense e pai baiano".

Houaiss conta fatos de sua vida com objetividades, como se escrevesse seu verbete, onde aparece como homem que não é de emoções fáceis, superficiais.

- Ruth e eu estamos casados a trinta anos. Você vice dizendo que mede tudo pela ação, nunca pelas palavras. Pois bem: estar casado há trinta anos é uma ação que esclarece tudo. Ela e minha mãe foram às mulheres definitivas em minha vida. Não tivemos filhos por opção. Mas houve sempre uma Mariana em nossa vida. Já conheceu nossa vizinha do $12^{\circ}$ andar?

- Já. É uma criança linda.

- Aqui, ou em todos os lugares do mundo onde moramos, sempre encontramos uma Mariana.

- Se tivesse que fazer um verbete sobre ela, como faria? 
- ABREU (Mariana Ferraz de), brasileira, futura grande mulher, três anos e meio de idade, filha de pais que suspeitam da sua predestinação gloriosa, vizinha do lado de baixo (lado que só agora ela precisa na sua aquisição das relações espaciais), eixo de afeto na vida de minha mulher e minha. Freqüenta-nos constante e variamente, transbordando nossa casa e nossos corações, com o luzeiro verde de seus olhos.

Recordo-me de Maria durante os dias em que freqüentei o apartamento de Houaiss. Ouvi sua voz na escada do prédio; presenciei Houaiss correndo para abrir-lhe a porta; observei-a andando soberana no apartamento; registrei o olhar de carinho profundo de Ruth e o encantamento de Houaiss. Lembrava-me de Mariana - a dos olhos verdes - quando ouvi novamente a voz de Houaiss:

- Para um operário das letras como eu, Ruth foi sempre uma mulher prodigiosamente econômica.

Enquanto Houaiss fala, o rosto de sua mulher desenha-se em minha frente, revelando em tudo ser mulher vital. Pode, com leve sorriso que não passa dos lábios para a parte superior do rosto, gelar uma pessoa que lhe desagrade. Mas, quando acontece o contrário, é extremamente agradável, convidando-nos constantemente ao riso. Quando dá uma risada. Deitando sua cabeça sobre o braço esquerdo estendido, é difícil que não nos faça rir também. Revejo seus movimentos, ouço sua voz, sem vacilações:

- Houaiss não tem a menor malícia ou astúcia. Está sempre presente na sua totalidade, mas é um desastre em matéria de finanças. Quando voltamos de nossa lua-de-mel, ele me disse:

— "Dê-me seu anel de ouro".

— "Para que?"

— "Vou por no prego. Não temos dinheiro nem para a barca da Cantareira."

- Quando saímos da Grécia, onde ele foi segundo-secretário da Embaixada do Brasil em Atenas, eu viajei na frente para o Rio de Janeiro. Deixei depositada em um banco grego uma soma considerável. Pois bem: fui esperá-lo no caias; podendo, Antonio evita andar de avião. Ainda de cima do navio, ele gritou:

— "Nós temos algum dinheiro?"

— "Deixei tudo em Atenas. Você gastou?"

- Fiquei gelada, pois tínhamos grandes despesas no Rio de Janeiro. Mas, em sua bagagem, ele me trazia um casaco de vison, uma estola de vison e quatro martas. Tudo isso para o clima "gelado" de Copacabana.

Ruth contou isto com tanta graça e malícia, que não pude evitar uma risada. Mas, de repente, seu rosto fica sério. Olha à minha volta, observando o apartamento admiravelmente bem arrumado, onde tudo tem lugar certo. Objetos belíssimos, ícones raros, quadros de Portinari, Pancetto, Heitor dos Prazeres, Di Cavalcanti, Djanira, Bandeira, Scliar e muitos outros de valor. Chão de pedras que ela mesma esmaltou. 
- Sei que Antonio não tem memória para coisas desagradáveis. Mas lutou e venceu, enfrentando desde menino todas espécie de dificuldades. Tudo na vida dele foi conquistado com batalhas, até mesmo o nosso casamento. Antonio sempre teve que vencer obstáculos: da pobreza, de preconceitos com sua ascendência e muitos outros que não vale a pena recordar. Posso dizer que muitas vezes ele foi posto ao fundo, mas ressurgia. A capacidade dele de se refazer é realmente espantosa.

- Que quis dizer com "preconceitos com sua ascendência"?

- Não faltou gente para chamá-lo de "turquinho". Mas Antonio nunca tomou isso como ofensa. Ninguém é mais brasileiro do que ele.

A entrada de Houaiss para a Academia Brasileira de Letras volta ao meu pensamento. Ouço novamente a voz do senador Afonso Arinos:

"Abandonastes o magistério para ingressar no corpo diplomático, em cujas funções tive oportunidade de conhecer-vos e de chefiar-vos, durante a minha missão nas Nações Unidas. Meu depoimento sobre vossa atuação é simplesmente o de que nunca encontrei, no exercício das funções, colaborador mais competente, mais devotado e mais dedicado aos interesses do Brasil e do nosso povo. Ali, também, vossos informes e relatórios eram lições".

\section{Revolução}

Substantivo feminino. Do latim revoluteio, "fazer uma volta completa". O étimo mostra bem a razão do emprego inicial da palavra para fins astronômicos. $O$ sentido crítico hoje é o de processos social que acarrete modificações estruturais. Como se trata de aspiração profunda de largas camadas humanas em todos os pontos da Terra, cada golpinho político se intitula uma revolução: forma mágica de, pela invocação da palavra, dar a ilusão de que se conseguiu o que se desejava e com isso afugentar o que não se deseja.

— Eu, Ruth e um grupo de amigos estávamos lendo a Bíblia. Lembro-me de que Ruth, em dado momento, comentou que gostava da vida de magistério, mas que ela dava muito pouca oportunidade de viajar. Nesse instante, o telefone tocou: uma antiga aluna minha nos convidava, Ruth e eu, para lecionarmos português e literatura brasileira no Instituto de Cultura Uruguaio-Brasileiro, em Montevidéu. Em uma semana estávamos lá. Um ano depois, entrei para o Itamarati por concurso. Para Ruth foi difícil aceitar, pois éramos dois soldados de igual valor no exercício da educação. A carreira diplomática ensinou-me muito e deu-me ótimos amigos.

- Gostaria de saber de que situação você não tira ensinamentos ou não os transmite, ou mesmo, não ganha amigos.

Houaiss sorri e, prisioneiro de sua objetividade ou do ser racional, continua: 
— Fui vice-cônsul do Consulado Geral do Brasil em Genebra (1947-49) e, no mesmo período, secretário da delegação permanente do Brasil junto ao escritório europeu da ONU. Nessa ocasião, fiz parte de delegações brasileiras à Organização Internacional do Trabalho, à Organização Mundial da Saúde, ao Comitê Intergovernamental de Migrações Européias. Exerci também os cargos de terceiro secretário em Ciudad Trujillo (1949-51), segundo secretário em Atenas (1951-53), primeiro-secretário e depois ministro da delegação permanente do Brasil junto à ONU (1961-64).

Sempre que Houaiss e Ruth falam do tempo do Itamarati, uma sombra aparece em seus rostos. Os comentários de Houaiss sobre essa época não se aprofundam nunca, talvez temendo revolver um dos poucos ressentimentos que guarda do passado.

- No período em que estive na ONU, participei da comissão de anistia dos presos políticos de Ruanda-Urundi, examinando processos de condenação de mais de 1200 presos, anistiados pelas Nações Unidas, por proposta da comissão de que eu participava juntamente com um canadense e um argelino. Ao longo de minha carreira sempre sofri perseguições veladas, que se manifestavam de diversas maneiras. Todas elas culminaram em 1964, quando fui cassado e aposentado da carreira diplomática.

Na Academia, um membro nada acadêmico

- Sei que você não é homem de estar pensando no que passou. Mas, desse período, qual o fato que aparece em seu pensamento neste momento?

- A fala de Nehru perante a ONU: "Meus filhos, rogo-lhes que bendigamos juntos este momento que passa. Pode ser que ele dure apenas algumas horas. Mas o fato é que este é o primeiro dia em que, há 3224 anos, não se verifica uma operação de guerra em nenhum ponto da Terra".

A Fala de Nehru perante a ONU mostrava o caminhar da humanidade; e a de Afonso Arinos na Academia Brasileira de Letras revela os caminhos do menino que nasceu muito pobre em Copacabana.

- "A súbita aposentadoria no serviço público restituiu-vos à exclusiva atividade intelectual da vossa juventude, e foi um bem para a cultura brasileira. É provável que, dedicado ao serviço público como éreis, só muito mais tarde vos sobrasse tempo para os esforços absorventes, a que hoje vos entregais. E não sei se, entre uma carreira e um destino, não ganhastes, e convosco, o Brasil".

- "Sois, essencialmente, o homem do livro. Talvez não exista, na atual geração, ninguém mais ligado a ele do que vós, porque viveis para o livro, tanto na sua forma, como no seu conteúdo. Gostando de percorrer os píncaros, estudastes agudamente a poesia de Drummond e empreendestes, como laborioso êxito, a aventura de traduzir 'Ulisses', de James Joyce. E, de algum tempo a esta parte, vinde-vos especializando nesta surpreendente profissão, que é a de coordenar enciclopédias." 


\section{Transcendência}

Substantivo feminino abstrato. Do latim transcendentia, "ultrapassagem, superação, transposição". O vocábulo é tardio em latim, e aparece nos escritos cristãos. $O$ radical já aparece no verbo transcendere, que desde Cícero, no primeiro século antes de Cristo, comporta o sentido material e espiritual. $O$ atributo de criatividade intrínseco ao homem faz deste um ser incompleto, insatisfeito, inacabado e imperfeito. Na medida em que ele cria, concomitantemente ele vai transcendendo-se, fazendo-se a si mesmo, completando-se, aperfeiçoando-se. Mas isso é um eterno. A visão de valores eternamente adquiridos faz do homem um ser parado irrevogavelmente. $O$ homem tem podido transcender-se, física e espiritualmente, apesar de todos os valores que erigiu como eternos. Mas o homem ainda está no limiar de sua própria história. Que será criatividade pura ou transcendência.

— Foi um momento negro em minha vida: cassação, doença de minha mãe que a levou à morte.

— Já li diversas vezes que aprendeu a cozinhar com ela, é verdade?

- É. Quando menino e adolescente, fui seu auxiliar de cozinha, nos pratos que preparava aos sábados e domingos. Minha mãe foi mulher Admirável. Foi com ela que aprendi a colocar o trabalho no centro de todas as coisas. Aprendi também que é o trabalho, somente ele, que transcende os homens; no que cada dia dá às gerações contemporâneas, ou deixa às gerações futuras.

- Como enfrentou este momento negro?

- Trabalhando noite e dia, durante onze meses, traduzindo "Ulisses", de James Joyce.

A tradução de "Ulisses" - "essa enciclopédia da literatura de vanguarda" é seu trabalho mais famoso, na qual transpôs para o português as complexas expressões e os neologismos usados por Joyce em seu famoso livro. É considerada, hoje, a melhor tradução da obra do escritor irlandês, no mundo. Filósofo no mais amplo sentido da palavra, crítico literário, ensaísta e tradutor. Houaiss é um cientista da língua brasileira, comparecendo nos congressos e reuniões em que se discute a criação lingüística em seus vários aspectos.

- Depois, veio o convite para organizar e ser o redator principal da Enciclopédia Delta-Larousse. Levei quatro anos organizando, lendo e revisando perto de 600000 fichas autônomas, das quais saíram 165000 verbetes, com 11 milhões de palavras.

— Você leu todos os verbetes?

— Todos, Em menos de dois anos foram vendidas perto de 60000 coleções da enciclopédia.

Atualmente, tendo perto de mil colaboradores em diversos níveis, constando com co-editores como Otto Maria Carpeaux, Francisco de Assis Barbosa e Alberto Passos Guimarães, Houaiss organiza e é o redator principal da Enciclopédia Mirador Internacional, que terá 8000 verbetes e 17 milhões de 
palavras, sendo considerado o intelectual brasileiro mais bem pago, recebendo pelo seu trabalho 18000 cruzeiros mensais. Referindo-se a Antonio Houaiss, assim se expressou o poeta Carlos Drummond de Andrade:

"Não é novidade para quem o conheça: esse homenzinho que mais parece um projeto de gente é um gigante intelectual, aberto a todas as curiosidades, e um dos brasileiros mais visceralmente ligado à sua terra (nem sempre benévola para com ele) e interessados em vossa afirmação nacional; por isso mesmo, o sentido universalista de seu espírito se revela naturalmente e impõe a realização de obras como a Grande Enciclopédia Delta-Larousse"

\section{Homem}

Substantivo masculino. Do latim homo, "homem genérico; também homem específico" (em grego, no primeiro sentido, é ánthropos; no segundo sentido é áner, andrós). É um mamífero primata que se suspeita ter o ápice nos hominídeos aparecidos cerca de 2 milhões de anos atrás, caracterizado pela emergência concomitante de três atributos: linguagem, trabalho inovador ou criatividade, afastamento pelos dois traços anteriores de sua vinculação com a natureza (cultural). O caminho da cultura é no homem o da criação de bens espirituais $e$ materiais. Aqueles são tanto mais meus quanto mais forem de todos. É velha a aspiração da humanidade que os segundos também assim o sejam. Enquanto isso não acontece, o homem não tem feito mais do que ser o lobo do homem.

Pela última vez, a vos de Afonso Arinos de Melo Franco elevou-se na biblioteca do apartamento no 13.0 andar do prédio revestido de mármore branco, às margens da lagoa Rodrigo de Freitas:

"Sr. Antonio Houaiss, encontrai-vos inteiramente em família nesta casa, no ambiente que sempre vos foi familiar, de escritores, de livros e de idéias. Aqui vos recebemos fraternalmente".

A vos de Afonso Arinos foi se perdendo em minha imaginação e, a de Houaiss, pausada, medida, racional, serena, foi dominando a biblioteca:

- A questão é singela: a busca do homem é cada vez mais detalhista, mas sintetizante.

Olhei o homem sentado à minha frente e lembrei-me de sua já célebre frase ao se autodefinir: "Uma pertinaz ignorância que se quer menos ignorante..." Sua camisa esporte rente ao corpo magro não está cheia de sardinhas, não lembrava mais a pesca milagrosa nas ondas de Copacabana. Mas sua cabeça, enorme para o corpo de adolescente que ainda tem, lembrava-me um viveiro cheio de cardumes de milhões de palavras douradas, vindas de todas as camadas do povo brasileiro, e que está à disposição de quem as necessite.

À disposição de todo mundo. 


\section{ANOS A.C.}

Ele tinha 42 anos e era um historiador ilustre quando seu filho, que se tornaria famoso, nasceu. É conhecido nos Estados Unidos e na Europa como um dos nossos maiores intelectuais, mas grande parte dos brasileiros o conhece apenas como o pai de Chico. Neste perfil, Jorge Andrade mostra quem é Sérgio Buarque de Hollanda, de quem Chico é filho.

Havia o silêncio habitual no Ministério de Educação, onde está hoje a Câmara dos Vereadores do Rio de Janeiro, na praça Marechal Floriano. Sentado no bar Amarelinho, um homem de 32 anos espera, observando as janelas ainda fechadas do Ministério: é Sérgio Buarque de Hollanda, futuro catedrático de História da Civilização Brasileira da Universidade de São Paulo, e professor de estudos brasileiros na Universidade de Roma. Com indignação concentrada e silenciosa, Sérgio observa os funcionários que começam a chegar. Algumas janelas são abertas. Carlos Drummond de Andrade, chefe de gabinete do ministro Gustavo Capanema, ouve barulho na ante-sala. Subitamente, a porta de sua sala abre-se violentamente e Sérgio, gritando furioso, empurra o empregado que tenta barrar sua passagem:

- Olha aqui, poetinha, deixa a garota...

Os funcionários correm, cercando Carlos Drummond, enquanto alguém grita, o que deixa Sérgio mais furioso:

- Chamem a polícia.

Um dos funcionários arranca a gravata de Sérgio. Os socos destinados a Carlos Drummond são desfechados contra o funcionário que grita pela polícia. Sérgio atira seus óculos ao chão - para melhor brigar - e investe contra Carlos Drummond. 0 poeta reage, valente. Sérgio sai - não apanhou nem bateu - depois de ter tirado satisfações pelo fato de Carlos Drummond estar dando em cima de sua namorada. Pelo menos foi o que ela havia insinuado.

Com 69 anos, Sérgio Buarque de Hollanda - o autor de Visão do Paraíso e Raízes do Brasil, considerado por muitos um dos maiores intelectuais brasileiros vivos - fala sobre o incidente como se narrasse um fato de nossa história: objetivamente, sem nenhuma paixão. Ele conta os cigarros do maço - Sérgio, supersticiosamente, nunca permite que tenha treze cigarros - , joga um ao chão e acrescenta:

- Para mim, Drummond é o maior poeta da sua geração, como da geração mais jovem é João Cabral de Mello Neto. Já imaginou um incidente assim?

- Não, principalmente quando os adversários no entrevero são os dois grandes intelectuais de hoje: o poeta e o historiador. E como tudo acabou? 
- Mais tarde, Manoel Bandeira promoveu nossa reconciliação. Naquele mesmo dia, ou no outro, não me lembro, Drummond levou meus óculos para Rodrigo de Melo Franco de Andrade, nosso amigo comum. Na ocasião ele afirmou:

- Foi tudo uma questão de promoção. A pequena sentiu-se preterida, sem ter direito.

Alto, corpulento, bochechas caídas, cabelos cinza, fumando constantemente, oferecendo uísque, Sérgio é sempre alegre, mesmo quando discorre longamente sobre assuntos brasileiros ou de nossa história. Seu espírito brincalhão e irreverente manifesta-se quando menos se espera. No último Congresso de Estudos Brasileiros, realizado na Universidade de São Paulo com a presença de professores do mundo todo, enquanto a equipe encarregada da parte de história chefiada por ele - não começava os trabalhos, Sérgio mandava à mesa propostas como: influências e conseqüências do consumo de uísque escocês na mentalidade das elites sul-americanas. Mas pode passar da brincadeira simples e ingênua a uma explosão como a do Ministério de Educação, contra Carlos Drummond de Andrade. Como essa, houve muitas ao longo de sua vida. Lembro-me do incidente do chicote e ele confirma:

- Quando meu filho Chico tinha catorze anos, um professor de história, ou geografia, não me lembro mais, formou, no colégio em que meu filho estava, um grupo de alunos "aristocratas", ligado a uma organização reacionária, tipo caça às feiticeiras. 0 professor começou a envolver Chico e eu notei que meu filho, geralmente despachado, alegre, irreverente, de repente estava ficando meio besta. Sabe o que fiz? Comprei um chicote e telefonei ao professor, dizendo que iria darlhe uma surra se procurasse meu filho novamente. Mandei Chico para um colégio em Cataguases, em Minas Gerais, onde ficou seis meses. Ameacei armar tal escândalo que o professor desapareceu do colégio.

Sérgio é casado há 35 anos com Maria Amélia Alvim, que ele conheceu no carnaval de 1935, no baile de Jockey Club do Rio de Janeiro. Prima de Afonso Arinos de Melo Franco e neta do governador de Minas Gerais, Cesário Alvim, e de Álvaro de Carvalho, senador e deputado por São Paulo, Maria Amélia é baixinha, magra, um feixe de nervos e determinação. É ela quem melhor controla as explosões e as brincadeiras de Sérgio, que muitas vezes podem levar à exasperação. Comentando o incidente do chicote, assim se expressou:

- Naquele dia a casa toda estremeceu com a fúria de Sérgio. Procurei o diretor do colégio e disse que não queria que meu filho fosse envolvido por pessoas reacionárias como aquele professor.

Observando Sérgio estirado em sua poltrona - contando novamente os cigarros no maço - , lembro-me de quando entrei em sua casa estilo normando no bairro do Pacaembu, São Paulo. Sua neta Izabel, de cinco anos, filha do cantor João Gilberto e de sua filha mais velha Heloísa Maria, estava ensaiando passos de dança. Olha para mim com naturalidade e continua sua brincadeira. Sérgio desce a escada que leva ao segundo pavimento, cumprimenta-se e apresenta a neta:

— Esta é minha avó (a neta). Já cumprimentou esta senhora (eu)? 
- Não.

— Então, apresente seu neto (ele).

A garota sorri, luminosa, continuando a dança. Sérgio testa a imaginação da neta constantemente, invertendo cores, sexo das pessoas, nome de objetos, tudo. Izabel reage protestando sempre. Há algo de fantástico no ambiente. Olho a garota e testo Sérgio:

- Um neto enorme para uma avó tão pequena. Acho que ela é Úrsula de Cem Anos de Solidão, de Gabriel Garcia Márquez, que foi diminuindo até caber numa caixa.

— Isto mesmo. Minha avó Úrsula.

A garota aproxima-se de mim, abaixa a voz e acrescenta, segredando-me:

- É brincadeira do velho, sabe? Ele gosta muito de brincar. Não viu que ele afirmou que o carcará é pesado, e o elefante, leve como uma borboleta? 0 papioto gosta muito de brincadeiras.

Sérgio solta uma risada, enquanto Izabel desaparece da sala, ainda dançando.

- Quer se sentar aqui mesmo?

- Prefiro entrevistá-lo em seu escritório.

- Prefere porque não conhece meu escritório.

Subimos a escada e vou observando, por entre portas entreabertas, os quartos onde cresceram seus sete filhos: Heloísa, Sérgio, Álvaro, Chico, Maria do Carmo, Ana Maria e Cristina. Quando entro no escritório, paro atônito. Sérgio ri do meu assombro. A impressão que se tem é de que todos os livros - centenas - vão desabar em nossa cabeça. Há milhares amontoados e esparramados por todos os lados. É um caos de capas e lombadas coloridas; um celeiro de obras.

- Você consegue encontrar o que deseja nesta barafunda?

- Quando arrumam é que me perco.

Sérgio olha-me, divertido, enquanto observo à minha volta. Nas estantes, entre livros, microfilmes de toda a correspondência dos representantes diplomáticos americanos no Brasil de 1809 a 1906. Sobre uma mesa, um visor grande de microfilmes. Esparramados entre os livros - como um bric-à-brac -, vidros de colírio Moura Brasil, envelopes de Engov, lápis adesivos, cinzeiros, um vidro de Agarol, Sonrisal, fósforos, latas de leite em pó, garrafas de uísque, remédios para dormir e outros para o manter acordado.

- Quando era pequeno, gostava muitos de letras. Comecei a dispô-las em ordem e assim aprendi a ler, sozinho. Mas não se esqueça: quando falo do passado, não sei mais se é recordar ou se é a lembrança da lembrança. Assim, as recordações perdem os contornos nítidos e se confundem, às vezes, com o que pode ser apenas imaginação.

De uma hora para outra, o espírito brincalhão de Sérgio se manifesta, como seu constante monólogo, partindo de um assunto, pode passar para outro completamente diferente. 
- Fui aluno comum, não me distinguindo entre os outros. Nem fui popular. Mas lembro-me de um colega de classe que usava sempre calças muito apertadas. Colocava uma enorme banana nanica no bolso quando queria sair do estudo. Levantava-se da carteira a qualquer pretexto para que o padre visse. A reação era imediata:

\section{- Vai lá forrrrra e ponha água frrria nos pulsos. É bom.}

Percebo que Sérgio, sem olhar, procura alguma coisa com as mãos, ao lado da poltrona.

- O garoto saía, comia a banana e ficava flanando no recreio. Quer um uísque?

Sérgio serve-se, sem se levantar. Tudo está ao seu alcance: a garrafa de uísque encostada à poltrona, e o copo no meio dos livros.

- Sou paulista de apenas 100 anos. Nasci para os lados da Liberdade. Mais tarde, fomos morar na rua Piauí. Nessa época, fiz o primário na Escola Caetano de Campos. Quando voltava para casa, atravessando as ruas de Higienópolis ainda cheias de barro, gostava de pular os quadrados da calçada e sentia sempre medo, como se o demônio viesse atrás de mim.

É na infância que a personalidade é formada, e certos traços da verdade profunda de cada um ficam guardados para o resto da vida, aparecendo nos trabalhos, ou na maneira de ser do indivíduo. Registro, neste momento, a repetição de duas coisas da infância de Sérgio: o receio de alguma coisa que o segue pelas ruas, e a mania, até hoje, de cobrir as orelhas para dormir, mesmo quando faz calor, enrolando-se no lençol, não conseguindo adormecer se não as sente protegidas. Em sua viagem de núpcias, Maria Amélia, sua mulher, levou muito susto quando, de manhã, viu Sérgio todo enrolado no lençol, segurando-o com os dedos dos pés.

Os pulos na calçada e as orelhas cobertas fazem-me lembrar de seu primeiro conto, publicado na Revista Nova, em 1931, dirigida por Paulo Prado, Mário de Andrade e Antônio de Alcântara Machado. 0 conto intitula-se A Viagem a Nápoles e contém dados autobiográficos. Em certa passagem do conto, o personagem principal, Belarmino, "sabe as esquisitices que pratica, muitas vezes sem mesmo reparar, e que ele próprio considera como um estigma humilhante. A mania que lhe vem certas vezes de contar os passos que dá desde casa até o bonde. Ou o hábito de cobrir as orelhas quando se deita, de medo que alguém as venha puxar durante o sono. Agora mesmo dava-se, sem pensar, ao seu antigo costume de pisar só no meio de cada um dos quadrados de cimento marcados na calçada, sem tocar com os pés nos riscos".

— Você é religioso, Sérgio?

- Não.

- Então, por que o medo do demônio?

- Não sei.

Uma expressão maliciosa toma conta de seu rosto, quando acrescenta: 
- Enquanto estive no Colégio São Bento, comunguei. Mas comungava só para comer bolo de chocolate depois. Também porque achava divertido ouvir o padre perguntar no confessionário:

- Meu filho. Você fez porcarrrrias?

- Fiz.

- Sozinho ou com outro?

- Com OUTRA, padre.

- Trezentas ave-marias. Você deve ser purrro, filho, porque Jesus querrr...

- Eu comecei muito antes que os padres podiam imaginar.

- Contaria sua primeira experiência?

- Por que não? Isso acontece com todo mundo, não acontece? Eu tinha treze anos. Todas as vezes que o bonde passava pela rua Itororó, em Santos, acho que era esse nome, eu sentia uma coisa diferente. Eu alongava os olhos e via mulheres nas portas e janelas. Havia gordas, magras, de todos os tipos. Um dia, lembro-me de que tinha 17 mil réis, saltei do bonde e caminhei na rua.

- Entra, simpático.

- Elas me chamavam, mas eu sabia o que queria. Ela estava na janela e meus passos pararam. Atravessei a porta de um quarto. Ela abriu uma gaveta, deume um livro onde havia homens e mulheres se amando em diversas posições. Enquanto tirava a roupa, perguntou-me:

- Que postura tu quieres, muchacho?

— Qualquer... QUALQUER UMA.

Sérgio sorri, acendendo outro cigarro: ele fuma constantemente, um cigarro atrás do outro. Quando começa a falar sobre qualquer assunto, não sabe onde Sérgio pode parar: na Polônia, em Roma, nos Estados Unidos, ou em qualquer parte do mundo. Pode passar do século XX à Idade Média, ligar um fato histórico a um incidente irreverente, como pode passar do estudo de documentos coloniais brasileiros ou paraguaios à leitura da revista infantil Luluzinha. Estava falando sobre sua primeira experiência sexual, quando seu pensamento se desviou da rua Itororó para uma de Berlim, na Alemanha.

- 0 professor de português e literatura brasileira na Universidade de Hamburgo foi me visitar em Berlim. Ele era muito moralista, grande defensor da superioridade do alemão, vivia decantando a raça germânica, o sentido íntegro do homem germânico. Sabe o que fiz? Levei-o a um salão de baile de lésbicas e fiquei esperando o resultado. Ele escolheu "uma" e muito formal, perguntou:

- Quer dançar? Madame ou mademoiselle?

Furiosa, ela respondeu:

- Monsieur.

Sérgio ri e pergunta:

- Você acha que o tom erótico está dominando meu perfil?

- Não acho, não.

Seu tom brincalhão, porém, esconde uma alta capacidade de seriedade no trabalho, de concentração numa pesquisa, trabalhando até tarde da noite. Para 
dormir, precisa tomar comprimidos ou algumas doses de uísque. Fica na poltrona, ou na máquina de escrever, até que o sono vença. Numa das noites, Maria Amélia nota que ele está demorando mais do que de costume. Vigilante, a mulher levantase e vai encontrá-lo deitado na cadeira, completamente relaxado.

- Sérgio. Venha dormir.

Ela sacode-o mas não consegue nenhuma reação. Maria Amélia tenta levantá-lo, mas não consegue. Sérgio quase cai ao chão, como se estivesse inconsciente. Vencido pelo cansaço, mas com o espírito inteiramente preso ao trabalho, tenta dizer alguma coisa que Maria Amélia não compreende.

- Eu te...nho que pro...curar um pouco mais.

- Amanhã, você procura.

- Ama...nhã tenho medo de per...der o fio. Li...vro...

- Qual livro, Sérgio?

— Lomba...da verme...lha...

Maria Amélia examina os livros ainda amontoados no braço da poltrona, pega o de lombada vermelha.

- 0 que quer saber?

- Quando os guaicu...rus se adaptaram ao uso cava...los...

Mesmo vencido pelo cansaço, sono, uísque, comprimidos para dormir, seu pensamento continuava com os índios guaicurus. Só depois que a informação é localizada e lida, é que Sérgio entrega-se totalmente ao sono. Às vezes, Sérgio, o historiador que acaba de dirigir a publicação da História Geral da Civilização Brasileira, pode ser confuso quando fala, mas é sempre claro e objetivo quando escreve, corrigindo centenas de vezes a mesma frase, revisando constantemente períodos inteiros. Seu trabalho é uma busca constante de perfeição na forma e no conteúdo. Sérgio tem memória aguda para fatos e pessoas que o interessam, sobretudo quando se trata de acontecimentos históricos. Mas, quando as pessoas ou os fatos não lhe dizem nada, há um branco quase total em seu pensamento. As paisagens sociais ou históricas são o seu continente, pertencendo vitalmente ao mundo dos livros. As belezas da natureza não chamam sua atenção.

- Não gosto de palmeira solitária em por de sol, ou de amanhecer.

Sérgio permanece muito tempo no escritório, perdido entre páginas de livros, mas sente, através da porta aberta, tudo o que se passa na casa. Curioso, quer saber a respeito de todas as coisas. Mas esta curiosidade não o leva a se meter na vida dos filhos, ou na dos amigos. É apenas a volúpia de saber. Nem significa indiferença: é sua maneira de ser e de deixar que o outro seja. É Maria Amélia quem afirma:

- Não me lembro, em todos esses anos de casada, de um mau exemplo dado por Sérgio. Heloísa, Sergito, Álvaro, Chico, Maria do Carmo, Ana Maria e Cristina são seres diferentes e igualmente respeitados, assumidos paternalmente. Pode-se fazer um retrato de Sérgio através dos filhos, ou melhor, pode-se descobrir Sérgio na desordem e na fantasia de Heloísa; na reserva das coisas que devem ficar guardadas, em Sergito; no gosto pelas viagens, em Álvaro; no sem-jeito, no andar e 
no espírito de grupo de Chico; na vontade de não influir de Maria do Carmo; na ternura e no paulistismo de Ana Maria; na raça física de Maria Cristina e na voz de todos os filhos homens.

- E o sentido da música? Vem também do pai?

- Meus filhos são todos musicais. Cristina gravou com Chico, e Heloísa foi quem ensinou Chico a tocar violão. Sérgio estudou sete anos de piano, e uma valsa composta por ele aos nove anos foi publicada pela revista Tico-Tico. Como vê, o sentido musical deve vir dele, não de mim.

Enquanto ouço a voz de Maria Amélia, penso: deu o amor pela música e pelos outros; trouxe o conhecimento do homem brasileiro no tempo e no espaço; viajou, visitou, brincou, ensinou, explodiu, permitiu que cada um crescesse vocacionalmente. Teve sempre as portas de sua casa abertas para as maiores expressões da cultura brasileira.

Sérgio iniciou-se na vida literária brasileira muito cedo, publicando artigos, contos, ensaios, estudos sociológicos e de crítica. Salientou-se no Movimento Modernista de São Paulo em 1922, fundando, com Prudente de Moraes Neto, a revista Estética, que teve influência na renovação dos estilos literários e artísticos do Brasil. É Antônio Cândido quem afirma:

- Os homens que estão hoje um pouco para cá ou um pouco para lá dos cinqüenta anos aprenderam a refletir e a se interessar pelo Brasil, sobretudo em termos de passado, em função de três livros: Casa Grande \& Senzala, de Gilberto Freyre, publicado quando estávamos no ginásio; Raízes do Brasil, de Sérgio Buarque de Hollanda, publicado quando estávamos no curso complementar; Formação do Brasil Contemporâneo, de Caio Prado Júnior, publicado quando estávamos na escola superior. São estes os livros que podemos considerar chaves, os que parecem exprimir a mentalidade ligada ao sopro de radicalismo intelectual e análise social que eclodiu depois da Revolução de 1930 e não foi, apesar de tudo, abafado pelo Estado Novo.

0 traço intelectual e artístico foi sempre sua principal característica, no trabalho, na vida com a família, nos momentos sérios ou brincalhões, aqui ou em suas viagens ao exterior. Assim, Sérgio, que na primeira mocidade fez versos nunca publicados -, quando esteve no Chile em 1963, por exemplo, escrevia a diversos amigos, entre eles Manoel Bandeira, cartas que ele intitulava de Novas Cartas Chilenas, imitando os célebres versos de Tomás Antônio Gonzaga, o poeta da Inconfidência Mineira:

Não cuides, Doroteu, que neste Reino Aonde alado batel me trouxe um dia Após largo adejar por sobre nuvens E altaneiras montanhas, a memória De amigos tão diletos se apagara Num terno coração. Aonde agora, Olhando da janela o casario 
Bem armado entre alamedas que

Retilíneas se cruzam, e o perfil

De airosa e encanecida cordilheira, A mim me perguntei: quanto não dera

Por tê-los a meu lado nesta casa

Entre os olmos e os choupos do Mapocho!

Se está dando cursos em universidades americanas e recebe carta de seu amigo Antônio Cândido, escrita em português seiscentista, responde em inglês, também seiscentista. Universalista como poucos, controvertido como pessoa, passa da expressão de uma razão pura à manifestação de uma loucura aparente; de tontice representada à seriedade mais profunda; violento como mostra na briga com Carlos Drummond de Andrade ou na ameaça de chicotear o professor reacionário, passa para o gesto de grande bondade, para o espírito de solidariedade, de companheirismo comovente. Não há ninguém que conheça política, sociologia, filosofia, história, como ele. Alto, imponente, lembra um patriarca, mas de mentalidade às avessas: nunca está sentado à cabeceira da mesa, impondo conceitos ou sua vontade. A mesa não é lugar sagrado de reuniões, como não há datas de comemoração obrigatória. Cada um vive como quer ou pode. Em sua casa ninguém sabe, nem se interessa pelo salário do outro. 0 dinheiro e o sucesso não ocupam lugar na escala de valores maiores da família. As reuniões são anticonvencionais e ninguém procura saber quem é quem, se é convidado ou não. Mas ele gosta de ver os filhos reunidos em seu aniversário, quando costumam cantar:

\section{Gosta de uísque,}

De um bom papo e de fofoca.

Dança twist com qualquer velha coroca.

Mas chamar de velho, isso é demais.

Ele até que ainda tem panca de rapaz.

Ele é boêmio, mas não quer saber do Rio.

Gosta do mar, só de dentro de um navio.

Mas chamar de velho, isso é demais.

Toma remédio noite e dia sem parar.

Roupa marrom, ele diz que dá azar.

Mas chamar de velho, isso é demais.

Composta por sua filha Heloísa, tocada por seu filho Chico e cantada por todos os filhos, a música alegre e a letra irreverente revelam bem a figura do homem, do pai, do historiador que costuma dizer:

- Geralmente, confundem historiador com antiquário, adorador do passado. Escrever história é ter visão dialética do passado e, eventualmente, de suas conseqüências no presente. É iluminar o passado com o presente, ou vice- 
versa. É o presente que importa e é através dele que compreendemos a evolução humana.

Diante dos filhos, porta-se sempre de igual para igual. É por isso que pode afirmar:

- A juventude de hoje é melhor do que a do meu tempo. A de hoje pode pensar mal, às vezes, mas pensa. A minha só pensava em se divertir, ou nem isso. Querer que a juventude de hoje seja igual à de ontem é tomar uma atitude antihistórica.

Mas, muito brincalhão com os filhos, torna-se difícil perceber quando está realmente brincando ou zangado, até que vem o estouro. Assim, os filhos têm certo receio de seu espírito caçoísta. É Maria do Carmo, uma de suas filhas, quem afirma:

- Ele nunca representou em nossa casa, nem em lugar nenhum, o papel de grande intelectual, ou de historiador. Se ia nos dar uma aula de história, sobre dom Pedro I, por exemplo, acabava geralmente na babá do imperador. Brincava e fazia tal confusão que, para nós, nunca funcionou como professor de história.

No dia em que estive reunido com seus filhos, Heloísa, de partida para os Estados Unidos, falou sobre ele com expressão carinhosa:

- Nunca houve relações formais em nossa casa. Papai é muito curioso, está sempre querendo saber o que se passa à sua volta. Penso que historiador, no fundo, é um pouco fofoqueiro. Quando eu era adolescente, papai, indiscreto, costumava ouvir minhas conversas ao telefone. Pegava a extensão do telefone e ouvia. Mais tarde, quando uma das amigas aparecia, ele dava conselhos a respeito dos problemas que ela havia externado ao telefone. Eu morria de vergonha. Não se pode ter confiança: ele conta tudo, não se agüenta.

Seu filho Chico, o mais conhecido e popular de seus filhos - de quem Sérgio tem orgulho, não tanto pelas músicas, mas por suas atitudes coerentes -, assim se referiu ao pai:

- Ele vive desligado da realidade doméstica, preso ao mundo de seus livros. Quando sai do escritório, ele pensa que entra em nossa realidade, mas não entra. Ele vive distante das coisas cotidianas, como está das pequenas glórias brasileiras. Mas está sempre ligado aos nossos grandes momentos, como está aos momentos importantes do Brasil.

Enquanto ouço os filhos, Sérgio ronda a sala com passos leves, tentando ouvir o que eles estão me contando. Os filhos sorriem, percebendo. Quando subimos para o escritório, antes mesmo de se sentar, Sérgio se volta para mim e propõe:

- Pode fazer perguntas a partir das observações de meus filhos.

Não consegui evitar a risada. A expressão de seu rosto era a imagem viva da curiosidade. Mas tudo em Sérgio é apenas maneira de ser, nada é determinado para um fim desejado, como educar filhos, por exemplo. Mas foi exatamente sua maneira de ser que educou os filhos, que os formou como são. Há inúmeros exemplos ao longo de sua vida. Em 1953, esteve dois anos na Itália, onde dava um curso de cultura brasileira, na Universidade de Roma. Durante esses dois anos, 
viajava muito e levava os quatro filhos mais velhos: Heloísa, Sergito, Álvaro e Chico. Juntos com ele, conheceram Florença, Veneza, Ravena, Tarqüínia, sul da Itália, Suíça, Paris. Levava os filhos para conhecer as obras de arte, como Piero de La Francesca, em Borgo San Sepolcro e Arezzo. Chico, que era ainda pequeno, costumava pentear o cabelo para o alto para aparentar mais idade e entrar em lugares proibidos, como a casa do prostíbulo nas ruínas de Pompéia, ou para conhecer os túmulos etruscos em Tarqüínia com seus murais obscenos.

- Em um dos túmulos etruscos que visitamos, numa das paredes havia uma pintura mostrando um homem e uma mulher ao ato do amor. Ao lado, aprovador, um touro observa. Mas, na parede em frente, as mesmas personagens estão praticando um ato reprovável e o touro, furioso, investe sobre eles. Chico riu a valer. Sempre gostei de viajar e, onde podia, levava meus filhos. Já contei que morei na Alemanha quando era solteiro?

Eu já tinha lido que certo espírito de aventura, de ânsia de conhecimento objetivo de fatos históricos, de gente e terras o havia levado, ainda moço, à Europa, fazendo-o percorrer, como jornalista, vários países, especialmente a Alemanha, onde morou por quase três anos, estudando e trabalhando.

- Contou, sim. Mas parou no momento que conheceu a garota, cujo pai levava o café na cama para vocês.

— Em 1930 eu freqüentava a Universidade de Berlim, fazendo um curso de história e ciências sociais. Meu alemão não era o de Goethe, mas dava para estudar, trabalhar. Era correspondente em Berlim de 0 Jornal e fazia letreiros em português para filmes da UFA. Foi nessa época que fiz as legendas para 0 Anjo Azul, primeiro grande sucesso de Marlene Dietrich. Conversei com ela, tomamos cerveja no estúdio.

- Teve muitas aventuras na Alemanha?

- Algumas. De uma delas, nasceu um filho.

O filho alemão nasceu em dezembro de 1930. Durante o reinado do terror nazista, Sérgio teve de mandar, através da embaixada alemã, vários atestados de batismo - até a terceira geração - para provar que seu filho não tinha sangue de judeu. Nessa época já estava casado com Maria Amélia que, muito preocupada, queria que Sérgio mandasse buscar o menino. Mas nunca obtiveram resposta. Sérgio não conheceu o filho e acha que deve ter desaparecido durante a Guerra. Quando Sérgio volta à Europa, seu tipo de holandês faz com que perguntem:

— O senhor é filho de alemão?

— Não. Sou pai de alemão.

Izabel, a neta, filha do cantor João Gilberto, passa correndo na escada, nuazinha, procurando roupa para o banho. Maria Amélia, com paciência infinita, procura conter a vitalidade da menina. Sérgio logo grita:

- Izabel. Tira esse capote. Está muito quente.

- Estou sem roupa, papioto.

— Está nada. Olha a cauda imensa do seu vestido. 
Maria Amélia, com sorriso maternal, agarra a neta e a conduz ao banheiro. Sérgio atende o telefone. Aproveito e desço para observar as salas de baixo, também com paredes forradas de livros, donos absolutos da casa. Não é somente o escritório de Sérgio que lembra "do mundo nada se leva". É a casa, o próprio espírito da família. Logo na entrada, debaixo da escada que leva ao segundo andar, há um piano de cauda. Em cima do piano: pedra, pena, lâmpada queimada, cálice, volumes de Genealogia Paulistana, outros da História da Província do Paraguai, embrulhos, óculos e livros sobre as artes plásticas. Embaixo do piano: velocípede, banquinho nordestino, bola, brinquedos da neta. Sobre o tapete, sapatos esquecidos. Por todo lado, a presença de um gato que serve, com certeza, de peso para papéis. A casa não tem a desordem caótica do escritório, mas só dá valor às coisas do espírito, nunca aos objetos pelos objetos, revelando a alma de sua dona. Maria Amélia, destituída de qualquer vaidade, sempre com sorriso no rosto, eixo e esteio do lar, é um ser admirável, nunca convencional ou burguesa.

- Minha casa não conhece a mentira.

Ela freqüenta qualquer tipo de recepção, por mais refinada que seja, como guia o fusca de São Paulo a Assunção, no Paraguai, para que Sérgio faça uma pesquisa histórica. Sem ser desordeira, faz parte profundamente da desordem bondosa e altamente intelectual de Sérgio.

$\mathrm{Na}$ última vez em que estive na casa normanda, cercada de quaresmeiras, era manhã de domingo. Maria Amélia estava sentada comigo no sofá do living. Izabel desenhava, deitada no colo da avó. Sérgio, que havia dormido às 4 da manhã, foi acordado pelo seu sentido de curiosidade: ele sabia que eu iria entrevistar sua mulher. Ele desce a escada, entra na sala ainda com expressão de sono, com seu andar de corpo todo na frente, a cabeça erguida de quem olha por cima, de pessoa que não tem nada do que se envergonhar. 0 caráter, a retidão, a limpeza de espírito estão sempre presentes em sua expressão. Ele pára no meio do living, envolto em seu robe azul mal amarrado, meio decomposto, e pergunta antes mesmo de me cumprimentar:

- Maria Amélia. Nesta casa não mora uma menina que se chama Bebel e pensa chamar-se Izabel?

- Mora.

— Ela se chama Bebel e tem apelido de Izabel. Isto determina uma grande confusão.

Izabel levanta os olhos do desenho, sorri paciente e compreensiva, como se tivesse a idade dele, e continua a desenhar. Maria Amélia, carinhosa, olha Sérgio como se ele tivesse a idade de Izabel. Eu observo os três, personagens de uma casa fantasiosa, sem idade. Foi aí que me lembrei do menino que compôs valsa e escreveu versos, que ainda tenta proteger as orelhas com medo de que alguém as puxe. E então, do conferencista da Sorbonne e das universidades americanas de Colúmbia, Harvard, Califórnia, Indiana, Nova York e Yale; do ex-diretor do Museu do Ipiranga e ex-vice-presidente do Museu de Arte Moderna de São Paulo; do expresidente da Associação Brasileira de Escritores; do historiador ilustre que 
sempre estudou o homem brasileiro no tempo e no espaço social e histórico brotou a criança que costumava pular a calçada, como no jogo de amarelinhas. Sérgio tem a pureza infantil das mentes de exceção. De seu mundo aparentemente caótico e certamente cultural e profundamente humano, nasce constantemente a fantasia. É natural que dele também nascesse um Chico Buarque de Hollanda. 


\section{Murilo, um poeta da liberdade}

Aos nove anos, ele vê o cometa Halley no céu de Juiz de Fora e se descobre poeta; aos onze, aprende a metrificar. Na década de 20 escandaliza o Rio de Janeiro com sua boêmia e seus poemas contestatórios. Em 1943 é internado em um sanatório, tuberculoso. Em 1947 casa-se com Maria da Saudade Cortesão que também é poeta. Em 1957 vai morar na Itália e passa a ensinar literatura na Universidade de Roma. E em março último, pouco antes de completar 71 anos de idade, o poeta brasileiro Murilo Mendes recebe, das mãos do dramaturgo Eugene Ionesco, o prêmio Etna-Taormina, o mais importante prêmio de poesia da Itália, conferido ao seu livro Poesia Liberdade - uma antologia dos poemas que escreveu entre 1925 e 1970 - em edição bilíngüe organizada por Ruggero Jacobbi. Este é um resumo da vida de Murilo, um brasileiro que conseguiu ser nome importante na Europa, sem nunca ter tocado numa bola de futebol, sem nunca ter feito um samba. E que, por causa disso, também é notícia para o Brasil.

O poeta Murilo Mendes pára no meio da praça romana e aponta:

- Aqui está o Museu Nacional Romano das termas de Diocleciano. É um dos meus lugares predileto em Roma.

As ruínas das termas, construídas em 306 por Diocleciano e Maximiliano, imperadores Romanos, estão situadas na Piazza della Republica. Em seu corpo central havia uma enorme piscina cercada de jardins, com capacidade para 3000 banhistas. Olho os restos de paredões monumentais e cheios de plantas nascidas entre as pedras, enquanto Murilo me observa, ainda desconfiado com minha presença em Roma para entrevistá-lo.

- Para mim, é um lugar verdadeiramente inspirante, bom para se pensar nos limites do humano.

Murilo, com capote longo e cinza-escuro, volta-se e caminha, vagaroso e curvado, para a porta do museu. Os degraus que descem para a entrada estão cheios de turistas jovens, loiros e revelando ascendência nórdica. Murilo pára e observa os jovens, sobretudo as jovens. Por seu rosto passa um sorriso fugidio, talvez lembranças de sua vida boêmia e meio louca no Rio de Janeiro, na década de 20. Atraso-me ligeiramente, fingindo fazer apontamentos, e observo o poeta que nasceu em Juiz de Fora, Minas Gerais, e que assim a define:

- Juiz de Fora naquele tempo era um trecho de terra cercado de pianos por todos os lados.

A cidade de Murilo foi, no começo do século, um centro vivo de cultura, onde a música era muito cultivada. Agora, estamos muito distantes dela, mas suas raízes continuam plantadas lá. Observando-o à porta das termas, lembro-me da caminhada que fizermos pelo Corso Victor Emmanuele em direção ao ponto de ônibus - Murilo pega dois ônibus para chegar à Universidade de Roma - quando 
ele cumprimentou o porteiro, o jornaleiro, pedestres, gente que há oito anos o encontra em seu caminho.

- Buon giorno.

- Como stai, professore?

- Grazie.

- Molto gentile. Ciao.

Vendo-o caminhar e cumprimentar, lembro-me de uma rua importante de sua vida, tão bem descrita em seu livro A Idade do Serrote:

- Faço o footing na rua Halfeld da minha infância e adolescência, os fundadores da cidade são alemães, a música é muito obedecida aqui, ainda não é tempo de rádio, eu mesmo toco piano, pianino, de ouvido; passam donas de olhos, boca e outras delícias vedadas aos menores de dezessete anos, inclusive uma certa dona ourodentada...

A descrição se perde em minha memória, quando vejo Murilo desviar-se dos jovens com mochilas às costas nos degraus das termas, e caminhar para uma mulher sentada no chão: é a terceira esmola que eu o vejo dar somente nesta manhã.

- Quem dá aos outros, empresta a Deus.

Seu poema "Mapa" - que situa o poeta católico na geografia de seu corpo e e no tempo e no espaço de hoje - vem à minha lembrança, e deixo que o poema me ajude a traçar o perfil daquele que é considerado no Brasil e na Itália um dos grandes intelectuais da atualidade:

\author{
Me colaram no tempo, me puseram \\ uma alma viva e um corpo desconjuntado. Estou \\ limitado ao norte pelos sentidos, ao sul pelo medo, \\ a leste pelo Apóstolo São Paulo, a oeste pela minha educação.
}

0 rosto de Murilo é extremamente jovem para a idade que tem, fazendo contraste que choca à primeira vista. Alto, curvado pela idade, sempre refinado, ele caminha lentamente, esperando que eu passe à sua frente. Ele faz sempre - do ônibus, da rua, da praça, do elevador, da sala de aula - um lugar de quem passou pelo Itamarati. Murilo jamais se esquece - em qualquer lugar ou situação em que esteja - os deveres de cortesia. Com um sorriso enigmático que se esconde no rosto, desce os poucos degraus que levam às termas. Há dias que estou intrigado com esse sorriso, sem conseguir descobrir seu significado mais profundo. Quando chega diante da porta, Murilo recua ligeiramente, apontando delicadamente com a mão, para que eu passe. Nos quinze dias que passei em Roma, convivendo com ele, em nenhum momento quebrou, ou mesmo trincou, a imagem do homem refinado. Olho Murilo e sinto que as dificuldades dos primeiros encontros, o homem distante que se defende, começam a desaparecer entre nós.

Me vejo numa nebulosa, rodando, sou um fluido, 
depois chego à consciência da terra, ando como os outros, me pregam numa cruz, numa única vida.

Colégio. Indignado, me chamam pelo número, detesto a hierarquia. Me puseram o rótulo de homem, vou rindo, vou andando, aos solavancos.

O gesto de sua mão me faz lembrar da aula a que assisti na Universidade de Roma - onde Murilo é professor de literatura brasileira - quando discorria sobre Machado de Assis, num italiano quase perfeito. Na revolução universitária de 1968, Murilo foi um dos poucos professores da universidade respeitados pelos alunos, que o têm em alta conta, não só pelo valor literário, como por suas atitudes democráticas. Durante a aula permaneceu com uma das mãos no bolso e a outra, expressiva, longa, delicada, dava volteios no ar, lembrando asa de pássaro. 0 sorriso meio contrafeito pela minha presença entre os alunos - sorriso que desaparece à medida que fala do mundo machadiano - torna seu rosto ainda mais enigmático. Reparo que, às vezes, ele repuxa o canto esquerdo da boca num movimento que quase une os lábios e sobrancelhas. 0 movimento me intriga. Sinto que ele vem de um estado de alma que não lhe é muito agradável. Já notara o tique em diversas situações, mas não consigo ainda descobrir suas raízes.

$\mathrm{Na}$ aula, pouco a pouco, o Rio de Janeiro do século XIX sai das páginas de Machado de Assis, torna-se vivo na voz de Murilo e domina a imaginação de perto de cem alunos, atentos e reverentes. Mesmo quando se senta - sempre ao nível dos alunos -, mantém a mão direita no bolso, e a mão esquerda, sempre expressiva, continua vibrátil no ar. Quando fala da elegância de espírito de Machado, ele é a própria representação desta elegância. 0 pescoço, já revelando a idade, meio solto no colarinho branco como algodão, sustenta a cabeça bem proporcionada; o rosto fino, ainda belo, traz sempre o sorriso que apenas aflora e que me intriga tanto. Depois de terminada a aula, foi cumprimentando e me apresentando pelo corredor, se interessando por um ou por outro. Falou com porteiros, com ascensoristas, alunos, garçons do bar da universidade, com a mesma cortesia que mantém com pessoas do mundo oficial. Depois da aula, Murilo costuma ir ao bar da universidade beber uma dose de Campari. 0 sorriso que se esconde no rosto marmóreo, estatuário, continua sempre presente. Agora, às portas das termas, ele se acentua ainda mais. Por um momento, lembra o enigma da expressão das estátuas que permanecem através dos tempos.

Vendo-o caminhar entre as arcadas gigantescas das termas, lembro-me de suas confissões em A Idade do Serrote:

- Nasci coisando, nasci com a música. Recordo-me perfeitamente de ouvir nosso Orfeu número 1, Isidoro, flauteando na casa de meu pai, de Titiá e de Sinhá Leonor, tendo eu três anos de idade; Mamãe Zezé pianolando e cantando, mais tarde soube, árias de Porpora e Caldara. Um homem de ouvido afeito desde cedo à visitação da música não suporta o mesmo normal desafinamento, quanto mais o cliquetis de espadas e ruídos de bombas. 
Murilo - o poeta, o crítico de arte, o apresentador de grandes pintores, escultores e poetas, o conhecedor de Mozart, o homem altamente considerado nos meios artísticos europeus - volta-se para mim, no momento em que me lembro de Juiz de Fora, de cidade e paisagens mineiras. Sinto que diante de mim está um homem cuja verdade se confunde com a arte, com a estética. Percebo que não importa dizer como é o homem, mas mostrar sua alma, irmã da poesia, das manifestações da arte em geral. Foi quando ouvi sua voz pausada, ciciante, respeitando os que admiram as peças expostas:

- No século XVI, Michelangelo adaptou as ruínas das termas, transformando-as na Igreja Santa Maria dos Anjos e no convento dos Cartuxos; As salas do convento abrigam desde 1889 riquíssima coleção de esculturas e peças arqueológicas gregas, romanas e cristãs. Você verá mosaicos raros, sarcófagos, esculturas originais. As principais peças também estão expostas no Pequeno Claustro e no Grande Claustro, também desenhados por Michelangelo.

Subitamente, Murilo pára admirando as enormes abóbadas. Começo a sentir os efeitos do banho de cultura que ele me dá há mais de dez dias. Em seu rosto, já não tão enigmático, estampa-se um amor profundo.

- Quando penso que isto tem vinte séculos; que Michelangelo tocou nessas paredes, nas colunas, nos capitéis. Aqui, ele passava horas e horas, amando o grandioso, o gigantesco, as proporções perfeitas. Já visitou o Capitólio, uma das obras dele?

— Diante do Capitólio, fiquei sem respiração.

Murilo tem prazer de falar, não para exibir conhecimentos, mas porque fala de coisas que ama acima de tudo.

Foi o centro religioso de Roma antiga. É no Capitólio que está o famoso sino Patarina que anuncia, há sete séculos, os principais acontecimentos históricos de Roma. Já visitou a capela Sistina?

— Juntamente com 100000 japoneses, 200000 americanos e milhares de indianos. É muito bom ver tanta gente com o rosto voltado para o alto, admirando pinturas de Rafael, Botticelli, Perugino, Michelangelo. É a arte não mais como patrimônio de meia dúzia, mas propriedade do povo; de todos os povos.

— Roma é isto: sente-se a presença de gênios como eles para qualquer lugar que se vá.

- E o monumento a Vittorio Emmanuele?

O tique reaparece no rosto de Murilo: o canto esquerdo dos lábios ergue-se, encontrando-se com a sobrancelha. Descubro sua origem: é a irritação profunda e silenciosa que faz repuxar seus lábios. Falar no monumento a Vittorio Emmanuele naquele lugar parece a ele um sacrilégio de minha parte.

- Aquilo é uma dentadura num riso quase obsceno.

Murilo caminha, saindo no jardim interno onde estão espalhadas diversas estátuas sem cabeça, braços, sexo; pedaços de colunas, de monumentos; fragmentos de mármore que marcam um tempo e um espaço. Murilo senta-se no parapeito de mármore e se volta para mim: 
- Roma é uma cidade que não se entrega ao primeiro contato. Há muitas Romas. Seu povo é belo. As pequenas ruas nos prendem como visgo. 0 ocre das casas e palácios lembra sangue, carne, paixão. Roma é sobretudo as obras mestras que contém, que marcam o caminhar maravilhoso do homem.

Estou com os meus antepassados, me balanço em arenas espanholas, é por isso que saio às vezes pra rua combatendo personagens imaginários, depois estou com os meus tios doidos, às gargalhadas, na fazenda do interior, olhando os girassóis do jardim.

Estou no outro lado do mundo, daqui a cem anos, levantando populações... Me desespero porque não posso estar presente a todos os atos da vida.

Percebo que Murilo está um pouco cansado. Ele leva vida metódica desde 1943, quando esteve internado em um sanatório, tuberculoso. Muitas das dificuldades do relacionamento com ele provêm de seu método rígido de vida. Murilo é casado com a poetisa Maria da Saudade Cortesão, filha do historiador português Jaime Cortesão, e mora em Roma há quinze anos. Casal sem filhos, que se completa no amor pela arte.

- 0 arco da minha curiosidade é vastíssimo. 0 de Saudade também. Em 25 anos de casamento, sempre vivemos bem. É uma mulher extraordinária.

Atualmente o casal reside em um apartamento no Palácio Malvezzi, Via del Consolato, transformado em prédio de apartamentos como muitos em Roma. A pintura do teto do apartamento é do século XVIII. O apartamento é belo, mas simples. Suas paredes brancas lembram as de Ouro Preto. Poucos móveis, muitos livros, quadros e gravuras de valor. Trabalhos dedicados a ele por Miró, Chagall, Leger e outros artistas famosos. Muitas dedicatórias: Cocteau, Ezra Pound, André Breton, Camus, Max Ernst, Bernanos, Chelderode, Ungaretti, Malraux, Di Chirico. Fotografias de Mallarmé, Picasso, Baudelaire e Raquel Welch. A fotografia de Raquel Welch é, de vez em quando, substituída por outra, mas sempre de mulheres belas. Desde criança que as mulheres exercem tremendo fascínio sobre Murilo.

- Mulher é uma coisa importantíssima.

Murilo volta-se e observa a estátua bem às nossas costas. Seu rosto de linhas retilíneas, de traços helênicos, parece completar o cenário. Seus olhos descem e sobem acariciando o mármore da estátua. Por um momento, tenho impressão de que há diálogo entre eles, diálogo que deve existir entre estátuas, enquanto na sua eternidade observam os homens que passam.

- Se tivesse cabeça ou braços, não teria, talvez, o mesmo mistério que o tempo conferiu. Quem teriam sido essas pessoas? Isto me impressiona muito. Sabe que as estátuas sofrem quando são tocadas?

Enquanto observo seu relacionamento com a estátua, lembro-me mais uma vez de seu livro A Idade do Serrote, onde afirma:

- Ainda menino eu já colava pedaços da Europa e da Ásia em grandes cadernos. Eram fotografias de quadros e estátuas, cidades, lugares, monumentos, 
homens e mulheres ilustres, meu primeiro contato com um futuro universo de surpresas.

Muito mais do que naquele jardim, compreendo que Murilo sempre viveu enquadrado no espaço intelectual e artístico europeu. Seu prazer em ver, em ensinar-me a ver também, leva-me sempre a seu livro:

- 0 prazer, a sabedoria de ver chegavam a justificar minha existência. Uma curiosidade inextinguível pelas formas me assaltava e me assalta sempre. Ver coisas, ver pessoas na sua diversidade, ver, rever, ver, rever. 0 olho armado me dava e continua a me dar força para a vida.

Murilo é um esteta da vida. Com sua arte, criou uma imagem do Brasil antitropicalista, nada folclórica, cultural no melhor sentido da palavra. São muito poucos os brasileiros que podem, como ele, representar tão bem o Brasil no mundo artístico europeu. Tenho uma infinidade de perguntas a fazer-lhe, mas o deixo falar. Já percebi que não gosta de ser perguntado. Fica irritado quando seu pensamento é cortado. Nele, a palavra é solta, fluente. Dá sempre a impressão de ter descido no laboratório da linguagem, penetrando no reino das palavras, lá onde elas assumem mil faces secretas.

\section{Andarei no ar.}

Estarei em todos os nascimentos e em todas as agonias, me aninharei nos recantos do corpo da noiva, na cabeça dos artistas doentes, dos revolucionários.

Tudo transparecerá:

vulcões de ódio, explosões de amor, outras caras aparecerão na terra, o vento que vem da eternidade suspenderá os passos, dançarei na luz dos relâmpagos, beijarei sete mulheres, vibrarei nos canjerês do mar, abraçarei as almas no ar, me insinuarei nos quatro cantos do mundo.

Murilo - católico e contestador, cristão e ecumênico - tem um verdadeiro culto pela ordem, pela limpeza, por cada coisa em seu lugar. Noto que ele se irrita com um turista que passa, falando muito alto, importunando com a sua câmara fotográfica homens e estátuas. A reação de Murilo é silenciosa, como deve ser a das estátuas que sofrem quando são tocadas. De repente, como se fugisse, levanta-se e caminha admirando as esculturas e fragmentos expostos ao longo das platibandas do jardim, nos monumentais muros das ruínas.

- Veja que massas colossais.

Naquele cenário que lembra a grandeza romana, Murilo sente-se em seu elemento espectador privilegiado da arte vinda através dos séculos. Assim também é diante da pintura, da música, da literatura e, sobretudo, da religião. Ao vê-lo caminhando entre os canteiros, lembro-me do dia em que me levou para conhecer a praça Navona, e o fez como se me mostrasse uma jóia. Entrou lentamente na praça para que eu sentisse sua extraordinária beleza. 
- A fonte do centro é uma obre prima de Bernini. Veja que sua bacia circular é decorada com quatro grandes estátuas. Elas representam o rio Nilo, o Ganges, o Danúbio e o rio da Prata, símbolos da universalidade da Igreja. Aquele é o palácio Pamphili, um dos mais belos de Roma. Pertenceu à familia do papa Inocêncio X. Atualmente é propriedade do governo brasileiro. É onde está nossa embaixada.

Vendo-o andar curvado, mas sempre atencioso, à volta da fonte de Bernini, que, como ele, expressou através da arte o amor religioso, o respeito ao outro, fico pensando no meio da praça Navona, e observando nossa embaixada, no que um governo deveria fazer por seus grandes poetas, por aqueles que projetam o nome de seu país no cenário internacional. Já revelando os efeitos da velhice, do trabalho de longos anos, de um caminhar constante difundindo cultura, Murilo-grandepoeta continua homem sem reservas, vivendo do que ganha em Roma. Para a maioria do povo brasileiro, que praticamente desconhece seus homens mais representativos e cultos, é realmente dificil conhecer a importância de Murilo no mundo artístico. Mas as manifestaçoes dessa importância vêm quase sempre acompanhadas pela irreverência muriliana, restos arlequinescos do Murilo da década de 20, do folião de carnavais-anticarnavais, dos gestos aloucados nas premières no Municipal do Rio de Janeiro, das reuniões boêmias nas noites cariocas, onde a poesia e a mulher eram a única verdade.

Essa importancia fica clara para mim, quando vou à Galeria de Arte Marlborough, na Via Gregoriana, onde Murilo faz a apresentação do livro La Luce, com vinte poesias autografadas de Giuseppe Ungaretti e treze litografias a cor de Piero Dorazio. Está presente o mundo artústico romano, que recebe Murilo com carinho especial. Mas, mesmo sentado à mesa, entre pintores e críticos, depois de ter feito sua apresentação, levanta suas sobrancelhas expressivas indicando-me, ao meu lado, uma belíssima romana inteiramente nua debaixo de seu vestido de rendas. Maria da Saudade, sua sombra européia, a companheira que o valoriza, que o compreende, que o estimula, segreda em meu ouvido:

- Deve ser uma das apaixonadas do Murilo. Aquela loira também é. É sobrinha do pintor Di Chirico.

— Ele foi sempre assim?

- Quando se apaixona, é delirante. Sempre teve vários flertes, que nunca me deram muito trabalho.

Presidindo a mesa, Murilo continua sorrindo enigmático e somente eu, no meio de tanta gente, percebo o sentido de suas sobrancelhas. Ouço sua voz saindo de poemas:

- A mulher é o juízo final do homem.

À entrada do claustro - onde obras-primas estão expostas —, Murilo detém-se para que eu passe à frente. Há algo de frio em sua expressão; qualquer coisa da indiferença do mármore. Mas foi aí que começou o grande banho; onde Murilo, com respeito religioso foi me apresentando estátua por estátua. Sobre pedestais ou em blocos, passou a inteireza compacta do equilíbrio grego ou da 
paixão romana dos césares. Tempos e espaços, nos limites de sociedades - grega, romana, etruscas — , se fizeram presentes em fragmentos de mármore ou de pedra, matérias-primas de comunicações transcendentes. Com as sociedades, vieram usos e costumes; com a religião, deuses e templos; com o poder temporal, leis e governantes - tudo o que só pode continuar vivo pelo trabalho dos grandes artistas. No silêncio cheio de séculos; diante das formas frias repletas de humanidade; de verdades em expressões estatuárias; das linhas que saíram de mãos que anteciparam os tempos em todos os momentos, Murilo foi conduzindo pela mão aquele que queria ver e aprender com o poeta que não representa na Europa um Terceiro Mundo, mas uma Segunda Europa, no Brasil. As linhas de sua alma, muriladas em pedra juiz-forana se transfiguraram em arte ocidental, em poemas brasileiros. Ao me conduzir, revelava-se o amante do belo, o homem que assumiu a condição da arte como o ar que se respira.

- Agora que é de moda entre tantos escritores esnobar a literatura, continuo a fazer profissão de fé literária. Afronto mesmo o ridículo do pejorativo: fui e sou literato desde o ventre da minha mãe.

E dos tempos passados - indo para os vindouros - a comunicação entre os homens pela arte se transfigurou em estátuas, mozaicos e pinturas. Passou a Niobida dos Jardins Sallustinos; a Vênus de Cirena; o Discóbolo do Castelo Porziano, do V século antes de Cristo; a Filha de Antium, encontrada na Vila de Nero; o Efebo de Subíaco, do século IV antes de Cristo; o Gaulês Matando Sua Mulher e a Si Mesmo; o Lutador em Repouso, de Apolônio: a Atena, do século V antes de Cristo; a Vênus no Banho, de Menophant; o Augusto Pontifice Márimo; o Marte em Repouso, atribuído a Lysippe; o Apolo, que inspirou um dos sonetos célebres de Rilke.

- Veja as pinturas do palácio de Lívia, mulher de Augusto. Olhe os mosaicos como são belos. Esta é a famosa cabeça de Afrodite, achada no rio Tibre. Possivelmente, nesta banheira, Diocleciano tomava banho. Aqui no claustro está a árvore que dizem ter sido plantada por Michelangelo.

E toda a beleza de Roma se fez presente: da Pietá ao Capitólio, de Michelangelo; da capela Sistina à igreja de São Clemente; das ruazinhas silenciosas no amanhecer envoltas numa atmosfera ocre às barulhentas tratorias do Trastevere. E lá, na paz que só existe no continente da arte, soou novamente a voz do noeta mineiro:

\section{Detesto os que se tapeiam,}

os que brincam de cabra-cega com a vida, os homens "práticos"...

Viva São Francisco e vários suicidas e amantes suicidas, os soldados que perderam a batalha, as mães bem mães, as fêmeas bem fêmeas, os doidos bem doidos.

Vivam os transfigurados, ou porque eram perfeitos ou porque jejuavam muito... viva eu, que inauguro no mundo o estado de bagunça transcendente. 
Enquanto estive em Roma, Murilo e Maria da Saudade deram um coquetel para comemorar o prêmio Etna-Taormina. Seu apartamento estava cheio de pintores, poetas, romancistas, criticos, professores. Não estavam presentes, para desgosto meu, o romancista Alberto Moravia e o poeta Rafael Alberti, que são amigos de Murilo, mas que não puderam comparecer. Por causa do método rígido de vida de Murilo, às 9 horas já tinham partido todos, menos uma duquesa, com quem ele não sabia o que fazer.

Para Murilo, a amizade sempre foi fundamental, desde a que manteve com tios meio loucos em Juiz de Fora, com Jorge de Lima e Ismael Nery no Rio de Janeiro, com Ruggero Jacobbi e Luciana Stegagno Picchio em Roma, com uma infinidade de brasileiros e europeus ilustres, no passado e no presente. Murilo não gosta de citar nomes.

— Ou você menciona todos, ou não mencione nenhum. Tenho e tive grandes amigos, igualmente importantes. Porém, entre todas as figuras que o marcaram, três se sobressaem: seu sogro, Jaime Cortesão, sua madrasta - Murilo perdeu a mãe quando tinha um ano - e seu pai, que assim ele define em seu livro de prosa autobiográfica:

- Que me legou meu pai de grande e permanente? Sem dúvida a religião católica, apresentada por ele, ao invés de certos padres, mais na sua flexibilidade do que na sua rigidez, incluindo o respeito pelas crenças ou descrenças alheias; o interesse pela pessoa espantosa de Jesus Cristo; a sensação, sempre renovada no catolicismo, de que me acho diante de questões formidáveis. Moviam meu pai, conservador-progressista, a tradição, a grandeza de ânimo, a tolerância, a ternura anti-sentimental, o bom senso.

Ouvindo-o nunca reparei que lhe faltava o canudo de doutor. Praticou a paz, não a paz telegráfica e a de comícios; viveu a paz em música de câmara, amando-a total na sua carne e no seu espírito.

Agora, no meio de obras de arte, mais do que a figura de seu pai e de uma infinidade de amigos ilustres, é o Murilo-criança que sinto nos espreitando no claustro, brincando de esconde-esconde entre as estátuas, reencontrando o que sempre amou, desde quando brincava nas ruas de Juiz de Fora. E mais uma vez $A$ Idade do Serrote volta ao meu pensamento, enquanto nos dirigimos para a saída das termas:

- Cedo atraíam-me as esfinges, as gárgulas, as medusas, as máscaras, as mascarilhas, as gigantas, as figuras de proa, as demônias, as participantes das metamorfoses de Siva ou Vishnu, as sacerdotisas; paralelamente às pessoas em carne e osso, via figuras e pessoas míticas.

Passamos novamente embaixo das abóbadas monumentais pelos caminhos que Michelangelo também percorreu, e me sinto como alguém que esteve mergulhado nas águas profundas do belo. Saímos na praça ensolarada. Japoneses e americanos cruzam conosco e entram nas termas.

O ônibus parte levando Murilo. Fico plantado na calçada, olhando a fonte das Náiades com seus corpos perfeitos e nus, numa festa aquática. Recordo os 
caminhos que percorri naqueles dias em Roma com Murilo. Mais do que os momentos artísticos, a amizade que nascera entre nós, as obras de arte que conhecera, ficou em mim a voz do poeta, ressoando numa festa poética.

Foi diante das náiades, envolvidas em jatos de água, que Murilo encerrou seu banho de estética, contando-me que as duas irmãs que posaram nuas para que Rutelli esculpisse as estátuas da fonte, depois de velhinhas, vinham à praça todas as manhas - cabelos brancos, corpos deformados pelo tempo, tristeza de desenganos - admirar suas próprias formas: a matéria efêmera havia sido transfigurada pela arte. As duas irmãs, transformadas em náiades, viverão para sempre no meio de águas que jorram sem parar, como a beleza suprema das formas.

Tudo o que de imperfeição humana poderia ter turvado as águas do meu relacionamento com o poeta Murilo Mendes também desaparece diante da arte de sua poesia que fica ressoando em mim, como o borbulhar de uma fonte de beleza perene. Compreendo então, hirto, que o sorriso enigmático que apenas aflora em seu rosto já é sorriso de estátua.

Sou a presa do homem que fui há vinte anos passados, dos amores raros que tive, vida de planos ardentes, desertos vibrando sob os dedos do amor, tudo é ritmo do cérebro do poeta. Não me inscrevo em nenhuma teoria, estou no ar, na alma dos criminosos, dos amantes desesperados, no meu quarto modesto da praia de Botafogo, no pensamento dos homens que movem o mundo, nem triste nem alegre, chama com dois olhos andando, sempre em transformação. 
ANEXO II

SELEÇÃO DE RETRATOS LITERÁRIOS PUBLICADOS POR MARCEL PROUST NA IMPRENSA PARISIENSE 


\section{Figures parisiennes : Camille Saint-Saëns}

\section{(Le Gaulois, 14 décembre 1895)}

«C'est un génie, dit une vieille légende, mais c'est un malin génie. Roi des esprits de la musique et du chant, il possède tous les secrets, et même celui, dès qu'on veut l'approcher, de s'enfuir au plus loin, toujours insaisissable. » $\mathrm{Au}$ moment d'Ascanio, pendant qu'on le cherche en France, il parcourt les Canaries. Ce soir, caché sous le nom d'un charmant musicien défunt qu'il va ressusciter, il se dérobera encore à nos hommages. Va-t-il maintenant échapper aux prises de ma pensée qui cherche à le saisir, et ne me laissera-t-il, entre les mains, comme un lutin disparu, que « du vent »?

Génie inspiré de la musique, doué d'une sensibilité profonde — vous n'avez, sans parler de la lyre et la harpe, qu'à parcourir Ascanio, cette lyre, ou Samson et Dalila, cette harpe, - il se plaît, comme un Gustave Flaubert, comme un Anatole France à la cacher sous sa richesse, sous sa science de grand écrivain musical. Car nul ne semble avoir mieux retenu cette pensée célèbre: «Toutes les beautés intellectuelles qui se trouvent dans un beau style, tous les rapports dont il est composé sont autant de vérités... plus précieuses peut-être que celles qui peuvent faire le fond du discours. »

Il Sait rajeunir une formule en l'employant dans sa vieille acception, et prendre, pour ainsi dire, chaque phrase musicale, dans son sens étymologique. Il emprunte leurs grâces à Beethoven et à Bach, ou plutôt, comme dans une de ses plus belles transcriptions, prête à Bach des grâces qui n'étaient pas à lui.

Peindre dans un accord, dramatiser avec la fugue, éterniser par le style ; faire tenir autant d'invention et de génie créateur dans l'emploi de la gamme qu'un autre dans le contour d'une mélodie, la faire courir autour d'une idée, comme le lierre antique qui préserve de la ruine le monument ; faire octroyer ainsi par l'archaïsme ses lettres de noblesse à la modernité ; donner peu à peu à un lieu commun la valeur d'une imagination originale par la propriété savante, singulière, sublime, de l'expression, faire d'un archaïsme un trait d'esprit, une idée générale, le résumé d'une civilisation, l'essence d'une race, un trait de génie jailli de l'outil ou tombé du ciel ; donner l'accent anglais à un prélude, prélude d'Henri VIII, le caractère matrimonial à une scène, duo d'Anne de Boleyn et d'Henri VIII, la lumière napolitaine à um chour, Quand vous chantez Scozzone, plaisanter un art dans une marche, Suite algérienne, fixer le style de l'orfèvrerie de la Renaissance dans un opéra, Ascanio ; enfin, pour faire comprendre une religion, détester un tyran, plaindre une femme, voir Éros, entendre l'Éternel, s'en tenir aux ressources non 
pas même de la musique, mais du langage musical, s'amuser comme un dieu et comme le diable à faire tenir le monde dans la musique, la musique dans l'harmonie, toute l'étendue de l'orgue dans l'exigüité du piano, voilà les jeux habiles, déconcertants, diaboliques et divins de cet humaniste musical qui fait éclater à chaque instant l'invention et le génie dans ce qui semblait le domaine borné de la tradition, de l'imitation et du savoir. 


\section{Silhouette d'artiste*}

\section{(La Revue d'Art Dramatique, janvier 1897)}

Cest un genre. Et, bien que la nécessité d'aller souvent au théâtre et l'illusion de s'y sentir regardé aient donné au monsieur qui le cultive des habitudes d'élégance, pour être drôlatique - il signe ses articles : « Le monsieur du contrôle » ou " un Pompier de service », faisant celui qui allume les quinquets ou celui qui vend les programmes. Souvent, c'est un jeune homme. Alors, de préférence, il fait des silhouettes d'aćtrices. Il flatte celles qui sont jolies, essaye de lancer celles qui n'ont pas de talent pour s'en bien faire venir, vendant son indépendance pour acheter leurs faveurs. Avec les débutantes il sait trouver un ton paternel. Pour les artistes qu'il admire, il énumère, compare, exalte leurs différents rôles. "Tour à tour cruel dans Néron, mélancolique dans Fantasio, impétueux dans Ruy Blas, etc. » empruntant d'ailleurs aux autres arts les termes de ses comparaisons. Quelquefois à la musique : «M. Worms ne pouvait être bon dans ce rôle. Il n'est pas écrit dans sa voix. » Plus souvent à la sculpture. Elle fournit les bas-reliefs « antiques », les «bronzes florentins», les « exquises tanagras». On se fait peintre pour louer les «nuances fondues » de la diction de Sarah Bernhardt, pour reconnaître en MounetSully « un Titien descendu de son cadre » et « marchant parmi nous ».

Les grands artistes ne sont jamais deux jours de suite les mêmes. Tant mieux, car l'irrégularité est une des marques du génie. Sarah Bernhardt un jour «cherchait visiblement à se surpasser ». Le lendemain, elle " était au-dessous d'elle-même » et «n'a pas donné ce qu'elle aurait pu ». Quelques-uns sont « en progrès ». D'autres «dans une mauvaise voie ». Les conseils à ceux-là ne leur sont point épargnés. Parfois un article est intitulé : «Un peu de conscience, messieurs de la comédie.»

S'il échappe au critique une locution telle que « tandi que M. Worms s'esbigne », il ajoute plaisamment « comme dirait feu Royer-Collard » ou « si j'ose m'exprimer ainsi ».

Et si le nom de M. Maubant «vient sous sa plume» il mettra entre parenthèses : «Vous êtes tous empoisonnés, messeigneurs. »

Avec lui nous entrons dans l'intimité des artistes. Nous apprenons que Mlle Z..., l'artiste, est doublée d'une «fine mouche » ou d'une « rusée commère », que M. Truffier est un délicat poète « à ses heures» et M. Duflos « un de nos plus intrépides pédaliers ».

Et sa vie à lui aussi nous la connaissons, car dans son besoin de se révéler, sa pensée lui semble trop impersonnelle, il nous livre ses habitudes. Nous apprenons que, dînant en ville le soir d'une première, il est parti avant le café pour 
arriver à l'heure et que le rideau ne s'est levé que longtemps après. Il prend le parti du public,

De celui qui paye, le vrai

(parodie d'un vers connu), incrimine l'administration du Vaudeville, met en cause le directeur des Beaux-Arts. Dans dix ans il réunira ses " silhouettes », " ses pointes sèches » et ses "sanguines ». À la première page une lettre de M. Duquesnel signifiera qu'il en accepte la dédicace. Pour le moment, il cherche à entrer à la Revue d'art dramatique.

*Ai-je besoin de dire que cette silhouette ne prétend ressembler à personne, et que tous les traits en sont inventés selon la fantaisie toute pure ? Si par hasard il se trouvait dans la presse un «Monsieur du Contrôle» ou un "Pompier de service », qu'il m'excuse d'avoir à mon insu pris son nom, comme je lui pardonne de m'avoir soufflé mon «mot»; il n'a rien à envier au "marchand de lorgnettes ». C'est ainsi que je devais d'abord signer cet article. Et j'ai des raisons bien meilleures que l'intention de m'y adonner quelquefois moi-même, pour ne pas médire sérieusement d'un genre récemment illustré par M. Henry Gauthier-Villars. 


\title{
La Personne d'Alphonse Daudet: « OEuvre d'art »
}

\author{
(La Presse, 11 août 1897)
}

En quelques rares artistes le corps a reçu comme l'âme la forme de la beauté. La contemplation de leur personne matérielle comme d'une de leurs cuvres, non de la moins personnelle, nous donne ce plaisir rêveur qu'on appelle plaisir esthétique. Leur portrait - que ce soit celui de M. de Goncourt par Bracquemond ou celui de M. de Montesquiou par Whistler - ne répond pas exclusivement, comme les autres portraits d'hommes de lettres, à la badauderie du public qui défile chaque année dans les expositions, également curieux de la calvitie d'un romancier et de l'embonpoint d'un vaudevilliste. Autant que du critique ils relèvent du peintre, leur pensée ne dessinant pas moins le caractère de leurs traits que le caractère de leurs livres.

On a tout dit sur M. Daudet artiste : je voudrais parler aujourd'hui de M. Daudet, oeuvre d'art.

C'est une ozuvre d'art unique, s'il est vrai que dans toutes les autres l'ardeur du sentiment, de [la] puissance expressive trouble la pureté plastique des lignes, comme la fusion d'une médaille en efface l'effigie. Dans la figure de M. Daudet, l'intensité de la souffrance n'a pas altéré la perfection de la beauté. La gloire de ce front, où la chevelure est partagée comme en deux ailes puissantes et legères, n'est pas seulement celle d'un martyr. C'est celle d'un dieu ou d'un roi. Car le charme royal, l'aisance souveraine des formes et des attitudes, la noblesse visible existent ailleurs que dans l'imagination des snobs et les romans pour les concierges. Moins physique que la beauté, moins spirituelle que la noblesse de l'esprit et du caractère, elle est, si l'on veut, comme l'habitude de cette noblesse, c'est-à-dire cette noblesse devenue inconsciente, convertie en belles lignes du corps et du visage, en mouvements larges et simples, de la noblesse qui a pris corps. Seulement où les snobs se trompent, c'est en la cherchant sur le trône ou elle se trouve rarement. En ce sens M. Alphonse Daudet est un roi, un roi maure au visage énergique et fin comme le fer d'une sarrasine. Je sais reconnaître aussi en un roi et en un prétendant une véritable grâce royale. C'est en le roi Charles I ${ }^{\mathrm{er}}$ peint par Van Dyck, et en le prince Hamlet joué par Mounet-Sully.

Mais si je me suis permis un instant de considérer M. Daudet comme un spectacle, c'est afin de pouvoir en dégager maintenant la grandeur réconfortante. Quand je me trouvai pour la première fois en face de M. Daudet, j'osais à peine lever les yeux [sur] lui. Je savais que depuis dix ans il souffrait si atrocement qu'il devait plusieurs fois par jour se piquer à la morphine. A peine couché, ses douleurs deviennent intolérables et, chaque soir, il avale une bouteille de chloral pour s'endormir. Je ne pouvais comprendre comment il pouvait cependant continuer à 
produire. Surtout je me rappelais combien des souffrances, si faibles auprès des siennes qu'il les eût sans doute goûtées comme un répit, m'avaient rendu indifférent aux autres, à la vie, à tout ce qui n'était pas mon corps malheureux, vers lequel mon esprit restai obstinément tourné, comme un malade dans son lit reste la tête tournée contre le mur. Alors, sans pouvoir comprendre comment il avait pu résister à ces attaques quotidiennes de la douleur, je sentais que pour lui ma vue devait être une fatigue, ma bonne santé une insulte, mon existence même une importunité. Alors, je vis cette chose sublime, qui doit nous faire rougir, nous tous lâches que nous sommes, ou plutôt, comme la parole de celui par qui nous connûmes que nous étions non des malades et des serfs mais des esprits et des rois, qui doit nous faire lever, rhumatisants ou paralytiques, nous rendre le calme, fiévreux, nous donner aux autres, égoïstes, nous rendre à la pensée, tous esclaves du plaisir ou de la souffrance de notre chair : je vis ce beau malade, que le mal embellissait encore, ce poète, à l'approche de qui la souffrance devenait poésie, comme le fer s'embrase dans le feu, qui, détaché de lui-même et tout à nous, préoccupé de mon avenir et de l'avenir d'autres amis, nous souriait, qui célébrait le bonheur, l'amour, la vie, qu'il employait mieux que combien de nous, continuant à penser, à composer, à dicter, a écrire, passionné comme un jeune homme pour la vérité, la beauté, le courage, nous parlant sans cesse, et plus héroïquement encore nous écoutant. Au milieu d'une discussion, il sortit un instant et de la porte jeta quelques mots enflammés et brûlants. En rentrant, il l'attisa de nouveau avec le même feu. Je sus que la reprise de ses douleurs avait été si violente que, pour ne pas la laisser paraître, il était allé se piquer à la morphine. Son front brillait de gouttes de sueur. Il semblait sortir d'une lutte, mais il respirait le calme de la victoire. Sur ce beau front, dans ses yeux où la " flamme » encore de la jeunesse était déjà, selon le beau vers de Victor Hugo, " de la lumière », je voyais le combat de la lumière, de la pensée, d'Hélios et des perfides esprits de la nuit. Hélios a vaincu, lentement les a repoussés au royaume sombre. Depuis un an M. Daudet va mieux. Après un voyage, un dernier acte d'héroisme qui semblait devoir lui coûter la vie, la vie lui est revenue. Dans son corps, il n'y avait plus d'espoir. Hé bien, de toute la force de cette énergie qui avait fait face aux ennemis pendant la guerre de 70, et qui avait dû se centupler dans ce combat silencieux, dans cet effrayant combat assis, couché, contre l'ennemi, c'est son âme qui a recréé l'espoir, la vie.

«M. Daudet va mieux »: c'est une parole que personne ne peut écouter sans frisson, comme toute parole qui, réveillant en nous de mystérieux souvenirs d'avant la vie, élève par-dessus la loi de fer de la nécessité physique, la loi de lumière de la toute-puissance de l'âme. C'est pourquoi je vais souvent, et je crois que tout homme aurait joie et profit spirituel à aller souvent rue de Bellechasse, en pèlerinage auprès de cette ozuvre d'art délicate et sublíme qu'est M. Daudet, et où la nature, dans un langage autrement expressif et vivant que le nôtre, à travers des prunelles plus transparentes que notre style, plus profondes que nos pensées, une peau plus purement colorée que nos images, et le rude vocabulaire des muscles 
plissés par la souffrance et redressés par l'énergie, nous enivre de tout le sens de la douleur, de la beauté, de la volonté et de l'esprit tout-puissants. 


\section{Robert de Flers}

\section{(La Revue d'art dramatique, 20 de janeiro de 1898)}

De tous les jeunes gens qui ont débuté dans les lettres depuis quelques années, M. Robert de Flers est peut-être le seul qui n'ait pas à se dire : « Je ne suis peut-être qu'un raté. C'est peut-être pour une ombre que j'ai lâché la proie. Ma vocation pour écrire - que tous les autres hommes de lettres d'ailleurs, et pourtant les seuls compétants, nient - se manifeste surtout par mon absence de vocation pour tout le reste, par l'absence totale des qualités diverses qui dans la vie font réussir. Je suis peut-être un Gustave Flaubert, mais je ne suis peut-être que le Frédéric Moreau de l'Éducation sentimentale.» M. de Flers est peut-être le seul qui ne puisse se dire cela, qui chaque jour, je ne dis pas seulement ait un succès de plus, mais une action de plus, ce qui est tout autre chose. Il a trouvé dans la vie le parfait milieu d'adaptation pour ses dons. Et cela est d'autant plus admirable, révèle, à mon avis, en lui une puissance d'autant plus merveilleuse et rare que, à la différence de tant d'autres, et je parle de ceux de premier ordre, chez lui les dons étaient multiples, je pourrais presque dire universels. Songez-y. M. de Flers a abordé la réalité qui gît au fond de la vie, à peu près par tous les bouts. À ses innombrables aspects son esprit a paru assez multiforme [pour] faire à peu près face. À vingt ans je le vois, versificateur prôné des versificateurs, sentant jusqu'au fond par exemple les vers de Mallarmé, les phrases de Barrès, écrire des nouvelles exquises, ne pas laisser passer une légende, un fait, sans en extraire le sens et la poésie; pendant ce temps-là suivre sur mer l'itinéraire de Paris à Jérusalem et rapporter ce livre de voyage qui ne se contente pas de charmer les lettrés, mais qui intéresse les savants, que couronne l'Académie. Aucune goutte de la vie n'est perdue pour lui. Pendant qu'il devient plus savant, qu'il dépouille les collections d'autographes, de pièces originales que nous rêvons tous de lire, mais où nous ne mettons jamais le nez, il est le critique littéraire et dramatique de plusieurs journaux. Il a la fièvre du présent comme du passé. Et pas un enthousiasme n'a soulevé les spectateurs d'un théâtre de drame ou d'un café-concert - ces étranges enthousiasmes que les vieux savants à la fin de leur vie regrettent quelquefois de n'avoir pas connus, craignant de s'être trompés de vie - qu'il n'en ait été fou pendant une heure, le jeune sage, pour en raisonner après. Vous croyez que c'est tout. Vous vous trompez bien. Ayez le même joyeux étonnement que celui de l'admirateur de sir John Lubbock, le grand naturaliste, quand il apprend que le Lubbock, grand directeur de difficiles entreprises commerciales, c'est le même. Ayez le même joyeux étonnement en apprenant que cet érudit, ce poéte, ce romancier, ce publiciste est le jeune directeur qui, depuis qu'il a pris les Escholiers, en a fait un théâtre où, de par son goût de grand lettré et son incroyable autorité 
sur les hommes, des artistes comme Granier, Mayer, de Max jouent des auteurs comme... tous les plus remarquables auteurs de ce temps, c'est le même. - Et si vous alliez dans la Lozère, et si vous saviez que chaque paysan n'a qu'un nom à la bouche, celui du jeune homme qui vit de sa vie, qui prend tant de peine pour qu'il ait pu avoir sa part de la justice et de la charité ignorées ailleurs, qui fait de son département une sorte de province fénelonienne, que diriez-vous en apprenant que ce Robert de Flers, dont on voudrait tant faire un député là-bas, c'est encore, c'est toujours le même? Ce n'est pas tout, mais pour aujourd'hui c'est assez. Et admirez avec moi celui qui vous apprend que le talent et le succès, que l'art et la vie, que les jouissances de la vie et le talent, que la hauteur morale et l'estime du peuple ne sont pas inconciliables.

De sorte que seul d'entre nous tous il me paraît travailler à la seule chose importante, à transformer la vie autour de nous, de façon à ce qu'elle devienne, au lieu de la forteresse de la bêtise, le temple du beau, au lieu [du] repaire de la méchanceté, l'asile de la justice. Pourquoi cela ? Parce qu'il a les dons que ceux qui ont talent et ceux qui connaissent les lois de la justice et veulent son règne (et qui ne sont d'ailleurs pas toujours les mêmes, et qui en lui sont le même) n'ont jamais. Sans doute, on en pourrait citer d'autres qui sont de grands lettrés, mais ceux-là croyez-vous qu'ils sauront imposer un auteur de talent, diriger un théâtre dans le sens de leur goût, parler seulement à une actrice? Ils seront exquis et impuissants. Sans doute dans nos provinces, il y a d'autres gens de cour. Mais sont-ce les mêmes qui sauront parler au peuple, s'en faire aimer, s'en faire croire, le mener où ils veulent? Sans doute il y a d'autres artistes raffinés goûtant les voluptés les plus subtiles que le baudelairisme ait découvertes dans le monde moral. Mais ceux-là ne seront ni érudits, ni bien souvent lettrés, presque jamais hantés de la réalisation des idées de justice dans la société, assurément jamais capables d'assurer cette réalisation. Robert de Flers est surtout cela. Si j'étais effrayé de la multiplicité de ses idées, si je me demandais où est le fond permanent et solide de tout cela, j'irais revoir ceux qui le connaissent le mieux, qui après tous les succès de Paris, le retrouvent toujours le même, tout à eux, les paysans témoins de la grandeur de son caractère, en dernier lieu véritable mesure de sa valeur. 


\section{John Ruskin}

\section{(La Chronique des Arts et de la Curiosité, 27 de janeiro de 1900)}

On craignait l'autre jour pour la vie de Tolstoï ; ce malheur ne s'est pas réalisé ; mais le monde n'a pas fait une perte moins grande : Ruskin est mort. Nietzsche est fou, Tolstoï et Ibsen semblent au terme de leur carrière; l'Europe perd l'un après l'autre ses grands « directeurs de conscience ». Directeur de conscience de son temps, certes Ruskin le fut, mais il fut aussi son professeur de goût, son initiateur à cette beauté que Tolstoï réprouve au nom de la morale et dont Ruskin avait tout poétisé, jusqu'à la morale elle-même.

Il était né en 1819, no 54, Hunter Street, Brunswick Square, d'un père négociant en vins, dont il aimait plus tard à faire le modèle du commerçant avisé et probe, et d'une mère ardemment calviniste. Son père avait l'habitude de faire tous les ans des voyages dans une voiture qu'il louait et qui arrêtait la famille à tout ce qui, sites de la nature ou monuments de l'art, pouvait former le goût. Celui de Ruskin fut de bonne heure ardent et sûr, et $M$. de la Sizeranne a raconté les emotions que ressentit l'enfant la première fois qu'il vit les montagnes. Il éprouvait déjà des passions pour les choses à un âge où généralement on n'en ressent pas encore pour les personnes. C'est, comme il arrive souvent, dans ses derniers livres qu'il s'est attardé à décrire ses premières années. Elles avaient gardé dans sa mémoire un charme ineffaçable qui s'est fixé à jamais dans ce livre de Praeterita, sorte d'autobiographie comme il en avait déjà esquissé une dans Fors Clavigera, et qui correspond, dans l'œuvre de Ruskin, à Vérité et Poésie dans l'œuvre de Gœthe.

La Gazette des Beaux-Arts tiendra à honneur, dans un prochain numéro, de donner de l'œuvre de Ruskin une idée, sinon complète, du moins fidèle, et moins sans doute d'en faire l'analyse totale que d'en donner l'impression juste. Ici nous ne pourrions essayer d'en résumer même le catalogue, qui, tel que nous l'avons sous les yeux, dressé méthodiquement par le disciple préféré de Ruskin, son savant ami M. Collingwood, comprend plus de 160 titres différents. Toujours imagés et comme enveloppés à dessein d'une sorte d'obscurité mystérieuse, plusieurs de ces titres sont d'ailleurs aujourd'hui familiers aux lettrés et aux artistes. Les Sept Lampes de l'architecture (1849), Les Deux Sentiers (1859), Munera Pulveris (1862-1863), Sésame et les Lys (1865), La Couronne d'olivier sauvage (1866), La Reine de l'air (1869), Aratra Pentelici (1872), Ariadne Florentina (1873), Deucalion (1875-1883), Les Matinées de Florence (1873-1877), Proserpine (1873-1886), Les Lois de Fiesole (1877-1878), Le Repos de Saint-Marc (1878-1884), Les Trois Colonnes du Préraphaélitisme (1878), sont maintenant, tout aussi bien que les Peintres modernes (1843) ou Les Pierres de Venise (1851), de véritables bréviaires de sagesse et d'esthétique. Les polémiques ardentes qu'ils excitèrent à leur apparition 
(il est inutile de rappeler le procès de Ruskin avec $\mathrm{M}$. Whistle, dont le souvenir est présent à tous les esprits) tombèrent peu à peu ; et quand Ruskin, atteint du mal qui l'avait forcé de renoncer à ses cours d'Oxford, se retira à Brantwood avec M. et Mme Severn, l'Angleterre, comme le fait observer le Times dans le très remarquable article qu'il a consacré à Ruskin dans son numéro du 22 janvier, l'Angleterre tout entière était devenue ruskinienne, et la célébration de son quatrevingtième anniversaire fut une sorte de fête nationale. Ses idées sur les préraphaélites ont été vulgarisées jusqu'à la banalité. Son admiration pour Turner, auquel il a consacré tant de livres (et l'on sait que les Peintres modernes ne furent d'abord conçus que comme une sorte de défense, et d'apologie de la peinture de Turner) et qui, jusqu'à la fin de sa vie, fut le mobile d'actes où elle semblerait n'avoir rien à faire*, a traversé le détroit, de l'autre côté duquel M. Groult en a réuni une colleetion incomparable.

Venise, Pise, Florence, ce sont pour les ruskiniens de véritables lieux de pèlerinage et, dans bien des ouvrages, des ceuvres d'art, des opinions contemporaines, c'est Ruskin lui-même qu'on pourrait reconnaître, comme sur une pièce de monnaie se distingue l'effigie du souverain du jour.

*Quand, en 1883, Ruskin résigna pour la dernière fois son enseignement à Oxford, une des deux raisons de cette décision fut que l'Université avait refusé d'acheter 1200 livres le Croissant de lune, de Turner. 


\section{Une miniaturiste du seconde empire: Madame Herbelin}

\section{(La Chronique des Arts et de la Curiosité, 23 de abril de 1904)}

Les jeunes gens de ma génération qui n'ont connu de Mme Herbelin que sa vieillesse retirée, charmante et discrète, n'auraient jamais pu deviner, tant elle aimait à jeter un voile mélancolique sur un passé éclatant, que cette vieille dame, si vive, si douce et si simple, avait été mélée à la vie la plus fastueuse, à la société la plus brillante de la monarchie de Juillet et du second Empire. Ils auraient encore moins appris d'elle-même qu'elle avait été un des peintres les plus parfaits et les plus originaux de cette époque - car elle était modeste profondément. Cette modestie avait même fini par prendre chez elle comme um carctère de tristesse, presque d'inquiétude : elle semblait douter dans ses dernières années de la valeur de ces miniatures qui, pourtant, ne resteront pas seulement comme des documents de premier ordre sur un temps déjà si lointain, mais aussi parmi les spécimens les plus séduisants et les plus achevés d'um art difficile et délicieux. Un portrait comme celui de Mme Andryane, que possède le musée du Luxembourg, ne le cède en rien aux plus belles miniatures de Mme de Mirbel et d'Isabey; et nous avouons, pour notre part, y goûter une facture plus savoureuse, dans sa vigueur comme resserrée, dans son coloris inattendu et charmant.

Ceux de nos lecteurs qui n'ont pas visité la collection de M. le prince d'Essling connaissent au moins, par les reproductions qu'on en a données (notamment celles qui ornent le livre de M. Armand Dayot sur le second Empire), les fameuses miniatures de Mme Herbelin qui représentent l'impératrice Eugénie et le Prince impérial. Nous citerons encore les portraits d'Isabey, d'Eugène Delacroix, de Rossini, de Guizot, de Rosa Bonheur, de Dumas père, de Dumas fils. Avant de devenir ses modèles, tous ces personnages marquants de l'époque avaient été les habitués de son salon. A côté d'eux, on rencontrait encore Mérimée, Guizot, Thiers, Émile Augier, Eugène Lami, Hébert, Gounod, Baudry. Quand on parvenait à faire parler Mme Herbelin de tous ces hommes géniaux ou distingués, qui aimaient à se retrouver chez elle, sa conversation devenait instructive et piquante comme la lecture d'authentiques Mémoires, des Mémoires qui auraient eu cette particularité remarquable que l'auteur y parlait beaucoup des autres, et jamais de lui-même. Ses souvenirs remontaient d'ailleurs plus haut que la génération dont elle restera le peintre fidèle et charmant. Fille du baron Habert, qui avait été volontaire en 1792, général de division en 1811 et gouverneur de Barcelone pendant la campagne d'Espagne, elle avait puisé à la source même les récits encore tout vivants de cette épopée impériale dont son père n'avait pas été l'un des moindres acteurs. Ellemême était née, en 1818, à Brunoy. Ses débuts avaient été brillants et rapides. À trente ans elle avait la grande médaille de l'Exposition Universelle, elle était décorée avec Rosa Bonheur. Elle avait conservé un charmant souvenir du « Dîner 
des Décorés » qui fut donné ce jour-là à Saint-Cloud par l'Empereur, le 2 août 1853. Pendant de longues années elle exposa régulièrement au Salon, toujours avec succès.

Puis l'heure de la retraite sonna pour elle, et elle aimait à passer de longues heures derrière les vitres de croisée qui donnait sur les lilas de son jardin, immobile, silencieuse et parlante, comme une de ces vieilles et charmantes miniatures qu'elle a signées et que nous « aimons à voir dans leurs cadres ovales ». Mais elle eut, pour embellir sa longue vieillesse, un sujet de juste fierté: ses deux nièces, auprès de qui elle s'était retirée et qui l'ont jusqu'à la dernière heure chérie et soignée comme si elles avaient été ses filles, n'étaient autres, en effet, que Mme Madeleine Lemaire et Mlle Suzette Lemaire.

Elle pouvait voir ainsi, dans des mains plus jeunes, le flambeau de l'art transmis et gardé avec un incompa rable éclat.

La gloire de Mme Madeleine Lemaire, la rare et l'exquise réputation de Mlle Suzette Lemaire remplirent ses dernières années de douceur et d'orgueil. Elle avait pour elles une admiration profonde, que le public et les connaisseurs ont dès longtemps ratifiée. 


\section{Le Salon de la Princesse Edmond de Polignac : musique d'aujourd'hui, échos d'autrefois}

\section{(Le Figaro, 6 de setembro de 1903)}

«Autrefois »... C'est qu'il serait impossible, c'est qu'il serait sacrilège d'en séparer tout à fait aujourd'hui. Je veux dire que la princesse de Polignac nous en voudrait de ne pas dire avant tout un mot du prince. «C'est un aimable prince que le prince Hamlet », dit Horatio, dans la tragédie de Shakespeare. "Bonne nuit, aimable prince, et que des essaims d'anges bercent en chantant ton sommeil » Hélas ! depuis tantôt deux ans le prince de Polignac est entré dans l'éternel sommeil, et sans doute les anges le bercent de ces chants, ineffables et liturgiques, qu'il affectionnait entre tous.

C'était un aimable prince, un grand esprit et un puissant musicien. Sa musique religieuse et ses mélodies sont aujourd'hui consacrées de l'admiration des plus raffinés. On connaissait peu sa musique, mais c'est qu'il était si difficile pour les exécutions... Les salles de concert lui faisaient horreur. Le plein air lui eût mieux convenu. La musique dans les bois lui semblait belle.

Une flûte invisible

Soupire dans les vergers.

La chanson la plus paisible

Est la chanson des bergers,

a dit Victor Hugo. De même, le prince de Polignac disait : «ma devise en musique est "Pleins champs" », mais il ne l'écrivait pas "plain chant ». Les amis de la comtesse Greffulhe se souviennent d'une soirée qu'elle avait voulu donner dans les bois de Varangeville pour faire entendre les musiques du prince

Sous les arbres bleuis par la lune sereine,

où

La mélodie encor quelques insiants se traîne. 
Pour ceux qui se rappellent combien les idées du prince de Polignac - non seulement en littérature et en art, mais même en politique - étaient avancées, en avance même sur celles-mêmes des plus avancés jeunes gens, c'est presque un miracle de penser qu'il était le fils du ministre réactionnaire de Charles $\mathrm{X}$, qui signa les fameuses Ordonnances, et fut emprisonné à Ham, en 1830. C'est pendant qu'il était à Ham que naquit le prince Edmond. La nature, qui continue les races et ne prévoit pas les individus, lui avait donné un corps élancé, un visage énergique et fin d'homme de guerre et d'homme de cour. Peu à peu le feu spirituel qui habitait le prince Edmond de Polignac sculpta sa figure à la ressemblance de sa pensée. Mais son masque était resté celui de son lignage, antérieur à son âme individuelle. Son corps et sa face ressemblaient à un donjon désaffecté qu'on aurait aménagé en bibliothèque. Je me souviens qu'au jour désolé de son enterrement dans l'église où les grands draps noirs portaient haut en écarlate la couronne fermée, la seule lettre était un P. Son individualité s'était effacée, il était rentré dans sa famille.

Il n'était plus qu'un Polignac.

Ses descendants trouveront qu'il ressemblait à ses ancêtres et à ses frères, et pourtant quelqu'un d'eux, d'une âme plus apparentée à la sienne, s'arrêtera plus longtemps devant son portrait que devant celui des autres, comme devant celui d'un frère qui lui aurait par anticipation ressemblé, autrefois. Au reste, il ne méprisait pas la noblesse, mais tenait celle de l'esprit pour la plus haute de toutes. Et un soir où Swinburne (chez lady Brooke, si je me rappelle bien) lui disait : « Je crois bien que ma famille est un peu parente de la vôtre et j'en suis flatté », ce fut bien sincèrement du fond du cőur que le prince lui répondit : «Croyez que des deux, le plus honoré de ce cousinage, c'est moi !»

Cet homme dont la vie était perpétuellement tendue vers les buts les plus hauts et l'on peut dire les plus religieux, avait ses heures de détente pour ainsi dire enfantine et folle, et les délicats, "qui sont malheureux », trouveraient bien grossiers les divertissements où condescendait ce grand délicat. Il était pourtant bien drôle quand il improvisait, paroles et musiques à la fois, la charge d'une soirée. Sous ses doigts, les valses ne s'arrêtaient pas et, pendant ce temps-là, c'était l'huissier annonçant chaque visite.

«Votre nom? monsieur.

- Monsieur Cucheval.

- Mais non, monsieur, je vous demande votre nom?

— Insolent ! monsieur Cucheval. »

Et l'huissier d'en référer au maître de la maison :

«Monsieur le baron, ce monsieur dit qu'il s'appelle M. Cucheval, faut-il l'annoncer tout de même? 
— Ah! diable, voyons, que faire ? Attendez un instant... je vais demander à Mme la baronne. »

Puis un grand émoi : on venait d'annoncer le docteur Ricord.

«Ah ! c'est vous, docteur, permettez, rien qu'un instant...

- Non, mon ami, c'est impossible, vous voyez bien...

- Nous pourrions aller un instant dans le petit salon.

- Non, non, pas de liqueurs, pas de tabac, pas de... »

Et les valses continuaient de plus belle, laissant à peine entendre le dialogue d'un couple qui se faisait des reproches : «Misérable, je t'ai attendu hier une heure au Jardin des Plantes, devant les singes. » Nous ne rirons plus de ces folies qui doivent paraître bien froides rapportées ainsi, mortes... comme lui.

Il passait ses étés, tantôt à Amphion chez la princesse de Brancovan, tantôt à Bonnétable chez le duc de Doudeauville, quelquefois à Chaumont chez la princesse Amédée de Broglie. Il avait une jolie propriété à Fontainebleau dont les paysages de forêt lui avaient inspiré plusieurs mélodies. Et quand on les exécutait chez lui, passait derrière l'orchestre une sorte d'immense agrandissement lumineux de photographies prises dans la forêt. Car toutes les innovations d'aujourd'hui, union de la musique et des projections, accompagnement par la musique des récitations parlées, il en fut l'un des promoteurs. Et quels qu'aient pu être les progrès ou les imitations survenus depuis, la décoration, pas toujours très harmonieuse du reste, de l'hôtel de la rue Cortambert est restée entièrement " nouvelle ». Les dernières années, il se plaisait surtout à Amsterdam et à Venise, deux villes entre qui son oil de coloriste et son oreille de musicien avaient reconnu la double parenté de la lumière et du silence. Il avait dernièrement acheté un beau palais à Venise, la seule ville, disait-il, où l'on peut causer la fenêtre ouverte sans élever la voix.

Il y a une dizaine d'années, le prince épousa Mlle Singer, dont les salons annuels de peinture avaient accoutumé de recevoir et de récompenser les remarquables envois. Il était musicien, elle était musicienne, et tous deux sensibles à toutes les formes de l'intelligence. Seulement elle avait toujours trop chaud, et lui était extrémement frileux. Aussi ne savait-il que devenir parmi les courants d'air incessants et voulus de l'atelier de la rue Cortambert. Il se garantissait du mieux qu'il pouvait, toujours couvert de plaids et de couvertures de voyage.

"Que voulez-vous ? disait-il à ceux qui le plaisantaient sur cet accoutrement. Anaxagore l'a dit, la vie est un voyage ! » 
Par son mariage, Mlle Singer, dont la søur avait épousé le duc Decazes, et qui vivait dejà dans un milieu très artiste et élégant, s'apparenta étroitement aux familles la Rochefoucauld, Croy, Luynes, et Gontaut-Biron. La sœur du prince de Polignac avait été la première femme du duc de Doudeauville. La princesse de Polignac devenait donc la tante de la duchesse de Luynes, née La Rochefoucauld, la grand-tante de la duchesse de Luynes, née Uzès, et de la duchesse de Noailles. Par les Mailly-Nesle, le prince de Polignac était plus étroitement parent encore avec la comtesse Aymery de La Rochefoucauld et la comtesse de Kersaint. C'est dire que les séances de musique du hall de la rue Cortambert, toujours admirables au point de vue musical, où l'on entendait tantôt des exécutions parfaites de musique ancienne, telles que des représentations de Dardanus, tantôt des interprétations originales et ferventes de toutes les dernières mélodies de Fauré, de la sonate de Fauré, des danses de Brahms, étaient aussi, comme on dit dans le langage des chroniqueurs mondains, "d'une suprême élégance ». Souvent données dans la journée, ces fêtes étincelaient des mille lueurs que les rayons du soleil, à travers le prisme des vitrages, allumaient dans l'atelier, et c'était une chose charmante que de voir le prince conduire à sa place, qui était celle du bon juge et du soutien fervent, celle de la beauté-reine, la comtesse Greffulhe, splendide et rieuse. Au bras du prince alerte et courtois elle traversait l'atelier dans le sillage murmurant et charmé que son apparition éveillait derrière elle et, dès que la musique commençait, écoutait attentive, l'air à la fois impérieux et docile, ses beaux yeux fixés sur la mélodie entendue, pareille à

\section{un grand oiseau d'or qui guette au loin sa proie.}

D'une politesse exacte et charmante avec tous ses invités, on voyait la figure du prince (la plus fine que nous ayons connue) s'animer d'une joie et d'une tendresse paternelles quand entraient les deux incomparables femmes que nous ne voulons que nommer aujourd'hui, nous réservant d'en parler plus tard, devant le magnifique et naissant génie desquelles il s'émerveillait déjà : la comtesse Mathieu de Noailles et la princesse Alexandre de Caraman-Chimay. Ces deux noms, qui ont la première place dans l'admiration de tout ce qui pense aujourd'hui, riches du double prestige de la gloire littéraire et de la beauté. Quelles heures charmantes! Le soleil éclairait en plein le plus beau tableau de Claude Monet que je sache : Un champ de tulipes près de Harlem. Le prince, avant son mariage, dans une vente, l'avait convoité. «Mais, disait-il, quelle rage ! ce tableau me fut enlevé par une Américaine dont je vouai le nom à l'exécration. Quelques années plus tard, j'épousais l'Américaine et j'entrais en possession du tableau ! »Ces belles heures, ces fêtes de l'élégance et de l'art reviendront. Et dans l'assistance, rien ne sera changé. Les familles la Rochefoucauld, Luynes, Ligne, Croy, Polignac, Mailly-Nesle, 
Noailles, Olliamson, entourent la princesse de Polignac d'une affection à laquelle la mort du prince n'a rien changé, qui s'est accrue, si l'on peut dire, d'une reconnaissance profonde pour les années de bonheur qu'elle a données au prince, lui qu'elle a si bien compris, dont elle a si affectueusement de son vivant, si pieusement depuis sa mort, réalisé les rêves artistiques. Peut-être même les sauteries gaies d'autrefois feront-elles retentir de nouveau le grand hall de musiques qui ne ressemblent en rien aux sonates de Bach ou aux quators de Beethoven qu'il a coutume d'écouter. Et la princesse, pour faire danser ses petitsneveux, chargera quelques-uns des amis du comte Édouard de La Rochefoucauld de s'occuper du cotillon, car le hall de la rue Cortambert a connu même des danseurs, depuis M. Verdé-Delisle jusqu'au comte Bertrand d'Aramon et au marquis d'Albufera (que l'on ne pourra plus bientôt appeler un danseur, car il prépare, avec un volume de Souvenirs sur son voyage en Tunisie, un résumé palpitant des Mémoires inédits d'un célèbre maréchal du premier Empire, mémoires dont seul M. Thiers avait eu connaissance et qu'il ne s'est pas fait faute d'utiliser en écrivant Le Consulat et l'Empire). Mais si charmantes qu'elles renaissent, consacrées à l'art ou au plaisir, graves ou futiles, ces heures inoubliées, quelque chose d'irremplaçable aura changé. Nous ne reverrons plus la figure du penseur, la figure de l'artiste, la figure de l'homme exquisement spirituel, aimant et bon qu'était le prince Edmond de Polignac. Ah! certes, "un aimable prince », comme dit Horatio. Et, comme lui encore, redisons au prince défunt qui tant aimait les chants angéliques et qui les entend sans doute en dormant le sommeil éternel : " Bonne nuit, aimable prince, et que des essaims d'anges bercent en chantant ton sommeil. » 


\section{La Comtesse de Guerne}

\section{(Le Figaro, 7 de maio de 1905)}

Il est assez singulier qu'une des deux ou trois grandes figures musicales devant lesquelles les véritables artistes s'inclinent entièrement appartienne précisément à ce qu'on serait tenté d'appeler, si l'on avait plus égard au hasard de la naissance qu'à la réalité du talent : «le monde des amateurs ». Certes, il y a longtemps que la comtesse de Guerne a reçu ses lettres de plus grande naturalisation artistique; et pour personne, pas plus pour les artistes que pour les gens du monde, elle n'est à aucun degré un amateur, mais une des deux ou trois plus grandes chanteuses vivantes. Mais, chose assez curieuse, au premier abord, et au fond assez naturelle, les artistes s'en rendent peut-être mieux compte que les gens du monde.

Sans doute les gens du monde connaissent l'admirable talent qu'ont rehaussé tous les décors de l'élégance et invoqué tous les appels de la charité. Mais ce qu'il a de plus raffiné, d'à peu près unique, leur échappe bien souvent et n'est guère sensible qu'aux artistes. J'ai eu occasion d'entendre dernièrement Mme de Guerne chanter devant un pur technicien de la musique, professant l'horreur du monde et, même au concert et au théâtre, constatant non sans tristesse combien il est rare d'entendre bien chanter.

Je ne crois certes pas qu'il s'imaginât entendre en Mme de Guerne une femme du monde plus ou moins agréablement douée pour le chant. Il avait reçu le témoignage ou les impressions de trop de grands et purs artistes. Il croyait entendre une vraie, une grande chanteuse, mais semblable à bien d'autres dont la réputation l'avait attiré, et le talent l'avait déçu. Mme de Guerne chanta. Debout, dans une attitude immobile à laquelle son masque dramatique et son regard inspiré donnaient une sorte de caractère pythique elle laissa échapper, comme de calmes oracles, des notes qui semblaient, pour ainsi dire, extra-humaines. Je dis qu'elle les laissait échapper, car les voix des autres chanteurs sont des voix appuyées à la gorge, à la poitrine, au cœur, qui semblent garder de l'émouvant contact quelque chose d'humain, presque de charnel et si immatérielles qu'elles soient, ne viennent à nous que comme un parfum qui traînerait avec lui quelques pétales de la corolle arrachée. Rien de tel en Mme de Guerne. C'est probablement l'unique exemple d'une voix sans support physique, d'une voix non seulement pure, mais tellement spiritualisée qu'elle semble plutôt une sorte d'harmonie naturelle, je ne dirai même pas les soupirs d'une flûte, mais d'un roseau dans le vent. Devant la production mystérieuse de ces sons indéfinissables, le musicien dont je parlais restait immobile, en un sourire extasié. La chanteuse cependant 
continuait d'égrener "l'éblouissant essaim des notes inégales ». Mais peut-on parler d'une chanteuse devant cette harmonie qui semblait moins produite par un artifice humain qu'émanée d'un paysage et faisait dans sa grâce antique invinciblement penser aux vers d'Hugo :

Viens, une flûte invisible

Soupire dans les vergers.

La chanson la plus paisible

Est la chanson des bergers.

Mme de Guerne ne serait pas l'émouvante chanteuse d'aujourd'hui si c'était simplement d'un calme paysage grec que sa voix semblât la voix. Non, c'est plutôt d'un paysage lunaire de Monticelli que d'un paysage de Théocrite qu'elle semble exprimer l'état d'âme, et elle est plutôt la musicienne du " silence » de Verlaine que de Moschus. Par là le charme antique de cet art prend quelque chose d'étrangement moderne. Et sans doute il n'y a rien qu'elle interpréterait aussi bien que Le Clair de lune, de Fauré, ce merveilleux chef-d' œuvre.

Aucune musique, on serait presque tenté de dire aucune diction, n'intervient ici pour rendre le sentiment qui n'est confié qu'à la qualité impressionnante du son. C'est la suprême distinction de cet art d'éviter les nuances faciles et les transitions banales. Il n'en est pas moins profond. Effacez la noble cendre qui couvre volontairement ces notes, pareilles à des urnes d'argent : vous y trouverez pieusement encloses et fidèlement gardées toutes les larmes du poète.

Ceux qui ont une fois entendu Mme de Guerne ne peuvent tromper qu'avec bien peu d'autres voix l'ennui de ne plus entendre la sienne, et aucune ne peut, en tout cas, [leur] en rendre exactement la douceur particulière, cet éclat adouci d'argent. Dans certaines idylles antiques comme l'admirable Phyllis de Reynaldo Hahn, c'est la flûte même de Pan qui semble accompagner au fond d'un bois sacré les vers charmants du poète. Et ici cette voix, ce n'est plus seulement

... la lyre naturelle,

La muse des guérets, des sillons et du blé;

c'est une lyre douloureuse qui exprime les mélancolies de l'amour et de la mort.

Ce serait une bien grande naïveté de croire que cette impression si étrange, la qualité naturelle de la voix de Mme de Guerne jointe à la force de son sentiment musical suffirait à la donner. Il y faut encore une profonde science du chant, science cachée mais nécessaire dont nous recueillons la moisson douce en sonorités dorées. Et pour s'en tenir à une partie purement matérielle de l'art du chant, ceux qui ne l'ont pas entendue chanter avec la merveilleuse Mme Kinen, le 
grand duo de Sémiramis, ignorent qu'elle sait vocaliser comme la Patti. Il serait injuste de ne pas associer au nom de Mme de Guerne celui du comte Henri de Ségur, son frère, qui est peut-être, comme compréhension et comme culture musicales, l'égal de sa sœur, mais qui, dans sa religieuse admiration pour elle, a borné toute son ambition à être son parfait et fidèle accompagnateur. Depuis la mort de son père, le marquis de Ségur, dont le titre est aujourd'hui porté par l'habile évocateur du salon de Mme Geoffrin, un académicien de demain, la comtesse de Guerne habite avec son mari le comte de Guerne, une gracieuse demeure de l'avenue Bosquet - c'est là qu'on entendit pour la première fois les chøurs d'Esther, ce que M. Reynaldo Hahn a peut-être écrit jusqu'ici de plus beau, où toutes les grâces du récit biblique et de la tragédie racinienne se sont transposées et comme exaltées, - demeure ennoblie de tous les témoignages d'admiration que les compositeurs ont donnés à l'artiste, depuis Gounod, qui lui dédiait ses mélodies, jusqu'à Hébert qui a fait son portrait ; soutenue par de légères colonnes de Corinthe, résonnant tantôt au son de la lyre et tantôt de la harpe, et d'une voix aussi qui charme comme l'une et qui émeut comme l'autre, cette demeure heureuse ressemble à la fois à la maison du sage et au temple des muses. 


\section{Un Professeur de Beauté}

\section{(Les Arts de la Vie, 15 de agosto de 1905)}

"L'histoire des petits souverains de Fezensac ne serait bonne que pour leurs héritiers, s'ils en avaient », a dit Voltaire dans L'Ingénu. Quelque opinion qu'on ait soi-même sur cette opinion de Voltaire, on peut penser que, si le comte Robert de Montesquiou-Fezensac, réussissant par un artifice qui n'eût certes pas été louable, à dissimuler sa personnalité spirituelle et à réserver son style, à faire vivre en quelque sorte sa merveilleuse intelligence à part et comme incognito, s'était contenté de compulser et de publier - cela ne signifie pas forcement d'écrire une histoire de sa famille, il y a bien une dizaine d'années qu'il aurait son fauteuil à l'Académie francaise, et tout le monde, excepté lui peut-étre, aurait lieu de s'en féliciter. Les académiciens d'abord, même et surtout aux petits jours, aux jours du dictionnaire, si, comme je le crois, personne aujourd'hui n'est presque au point de M. de Motesquiou sensible au visage, à l'allure, à la gesticulation, aux traditions, aux ridicules, aux préjugés, aux vertus de chaque mot, et n'en connaît mieux l'histoire, ne peut plus sûrement le suivre et le retrouver chez les classiques et chez les modernes, et cela jusqu'à dérouter et essouffler parfois son lecteur moins agile et qu'il feint, avec une politesse où il entre peut-être un peu d'impertinence, de croire aussi savant que lui, tandis que l'autre, qui n'en peut mais, voudrait bien comme M. Jourdain lui dire : «De grâce, monsieur, faites comme si je ne savais pas ». - «L'écrivain véritable, a dit Ruskin, doit connaître à fond la généalogie et l'armorial des mots, savoir au juste les fonctions qu'ils ont été appelés à remplir dans la noblesse nationale du vocabulaire, quelles alliances ils ont contractées entre eux, dans quelle mesure ils sont reçus* », etc. Personne ne répond mieux que M. de Montesquiou à cette définition. Tous ceux qui l'ont vu s'arrêter et comme se cabrer au moment de prononcer un mot (et de ceux qui jusque-là nous avaient le moins frappé), comme dans l'effarement** d'avoir vu tout d'un coup béant l'abîme du passé qui s'entrouvre sous ce mot dont l'accoutumance seule nous dissimule les profondeurs, dans le vertige d'y avoir aperçu la grâce native de ce mot, penchée là comme une fleur au bord d'un précipice, tous ceux qui l'ont vu saisir un mot, en

\footnotetext{
* Je ne puis naturellement, dans cet éloge si rapide et dans cet espace si resserré d'un article, discuter et approfondir cette opinion de Ruskin que je ne cite qu'au passage et pour faire honneur au maître et à l'ami à qui elle me semble s'appliquer. Mais dans l'édition que je donnerai prochainement de Sésame et les Lys, je dirai toute ma pensée sur cette maxime et sur d'autres analogues.

** Dans le beau sens qui s'applique aux chevaux de race : "Maîtrisant son cheval qui s'effare» (Heredia) ; «Un cheval effaré qui hennit dans les cieux » (Hugo) et qu'Hugo a étendu aux poètes : « J'irai, mage effaré ».
} 
montrer toutes les beautés, le goûter, faire presque la grimace à sa saveur spécifique et trop forte, le faire valoir, le répéter, le crier, le psalmodier, le chanter, le faire servir comme un thème à mille étincelantes variations, improvisées avec une richesse qui étonne l'imagination et déconcerte les efforts de la mémoire pour les retenir, celui-là peut s'imaginer quels jours merveilleux seraient, avec lui, à l'Académie, les jours de dictionnaire*. Mais que dire de ce que ce seraient, les grands jours, les séances de réception, si, comme il est de tradition, ce qu'il y faut et ce qui y charme c'est de la courtoisie, de l'éloquence, de la méchanceté, du goût et de l'esprit. On sait que « recevoir » est, - quand il n'est pas occupé à mieux, à réaliser son idéal, à combattre pour lui - une des choses où notre poète excelle, et qu'à accuellir l'arrivant - toujours un peu un « élu » — dans sa demeure qui est fort justement (et, pour parler comme lui, " préventivement ») dénommée celle des Muses, il prodigue des ressources d'esprit et d'éloquence que bien des académiciens seraient fort empêchés de mettre dans leurs discours. Sans doute saurait-il « recevoir l'élu » à l'Académie, celui qui a donné de l'hospitalité, comme de tant d'autres choses d'ailleurs - une formule pour ainsi dire nouvelle, faite de grâce majestueuse et d'infatigable esprit. « Et pour ce qui est du goût », qui

\footnotetext{
* Ne pourrait on pas voir comme un définitif article pour un dictionnaire idéal (et je plaindrais ceux qui verraient dans cet éloge une épigramme) dans la récente étude consacrée au ravissant coffret exposé par Mlle Lemaire, Cette étonnante litanie de citations de Montaigne, de Lesage, de Balzac, de Victor Hugo, de Flaubert, où reviennent comme un refrain les deux mots qu'il s'agit de définir et d'illustrer, «boîte » et " coffret », ces exemples à la fois fameux et oubliés destinés à préciser et à glorifier chacun d'eux : «le coffret de Cypsillus déposé dans le temple de Junon à Olympie », «le coffret où Néron offrit sa première barbe à Vénus Génitrix », le coffret renfermant les archives de France que laissa prendre Philippe VI à Crécy ", "le coffret contenant les bijoux de Charles le Téméraire dont s'emparèrent les Suisses à Morat » (j'en passe et des plus significatifs) tout cela n'apporte-t-il pas une contribution bien précieuse à l'article Boîte et à l'article Coffret? Ce savoir est d'ailleurs prodigué avec une absence de pédantisme qu'affirme suffisamment le genre du recueil dans lequel il a paru : Les Modes (numéro de juin 1905).
} 
donc pourrait-on citer qui l'eût meilleur pour juger de la valeur d'une oæuvre et pénétrer ses secrets jusqu'à en étonner l'auteur? Et sa compétence s'étend assez loin pour que ce ne soit pas les seuls littérateurs qu'on aimerait l'écouter accueillir dans une académie, mais les peintres et les musiciens. Je ne pense pas que $\mathrm{M}$. Helleu ni M. Fauré me contrediront. Sans doute, comme, par convenance au genre, Sarah Bernhardt jouant Assuérus à Saint-Cyr sait oublier les fureurs d'Hermione, M. de Montesquiou, aux discours d'académie, voilerait d'une décente douceur ses orageuses justices et injustices. Mais enfin « sous la coupole » on aime aussi à ce que le récipiendaire soit parfois houspillé. Et sans aller jusqu'à demander à $M$. de Montesquiou de s'y servir de sa foudre (peut-être n'y aurait-il pas d'ailleurs tellement besoin de le lui demander pour qu'il le fît), ses confrères s'arrangeraient à ce que ce fût lui qui le plus souvent fût chargé du rôle, traditionnel dans cette arène, de picador, qu'il comprendrait d'ailleurs sans doute d'une façon assez neuve. Certes on voit d'ici avec quelle incomparable et majestueuse légèreté, quelle alerte et noble et cruelle désinvolture, de quelle piaffante, trépidante, trépignante et caracolante allure, il saurait développer puis resserrer autour de la victime élue ou couronnée ses savantes évolutions, l'irritant, la piquant de mille traits variés et sûrs aux applaudissements d'un public avide, sinon de sang, du moins d'amourpropre, répandu. Mais tous ceux qui le connaissent sous cet aspect et dans ce rôle, soit pour lui avoir entendu prononcer, soit pour avoir lu des moreaux de ce genre, où sa plume électrisée s'escrime et fait feu de tous côtés, ceux-la savent que toutes les figures de la joute et du tournoi sont réglées par une logique supérieure et minutieuse et, comme une sorte de moralité, comportent souvent une haute leçon de sagesse et d'art. Je n'en veux pour exemple, particulièrement accessible et appréciable aux lecteurs des Arts de la vie, que les pages merveilleuses, militantes, mais au fond surtout prédicantes, qu'il y publiait récemment sur un sujet à vrai dire où (sauf pour des opinions incidentes dont je suis bien fondé à dénoncer l'injustice) je ne saurais me prononcer, ne connaissant pas, pour des raisons de fait et très regrettables, l'ozuvre de l'artiste dont il s'agit. Les lecteurs des Arts de la vie, j'en suis sûr, « ne sont pas encore reve- 
nus » du spectacle qu'ils ont eu ce jour-là et d'avoir vu M. de Montesquiou avec une dépense de verve qui laissait supposer, et, fort exactement, qu'il en gardait le centuple en réserve, de l'avoir vu - avec une maestria et une furia à étourdir sa victime et jusqu'aux spectateurs trop rapprochés - porter ses coups, couvrir dans le même temps d'une éclatante peinture tout le grand espace qu'il s'était réservé, corriger vingt portraits, repeindre dix tableaux, ici redessiner un bras, là allonger une main, plus loin changer un fauteuil de place, et finalement jeter tout le mobilier par la croisée, partout mettre sa couleur sur celle du maître peintre devenu, sans avoir eu le temps de protester, son écolier ; - et prodiguer avec une éloquence, une intelligence, une logique, un esprit qui ne sont qu'à lui, des conseils et des leçons que certes l'artiste ne lui demandait pas, qui sont peut-être injustes ou inexacts adressés à lui, mais qui resteront malgré cela justes et vrais, d'une vérité plus haute et d'une éternelle justice, en ce qu'ils prêchent, à propos d'un nom qui n'était peut-être pas celui qu'il fallait, je n'en puis rien dire, le bon, le nécessaire sermon sur le faux beau et sur le faux grand art, avec cet air - et ce grand air d'extraordinaire dignité évangélique de qui a conscience de séparer le bon grain de l'ivraie - et qui à vrai dire est plus que distinctif, est unique en ce vrai fils des croisés qui, " sur le cimier doré du gentilhomme », à côté de la " plume de fer » dont vous savez la " beauté », a mis la coquille du pèlerin du vrai, du missionnaire et du pur religieux de la Beauté. Dieu sait qu'on ne peut dire de lui comme Louis XIV du Bernin: "Il ne trouve pas beaucoup de choses à admirer. » Personne n'admire plus que lui parce que personne ne discerne la beauté d'un œil plus sûr et plus ravi. Et je crois bien, pour revenir à l'Académie - et la quitter - que le public spécial de ses jours de "réceptions» serait déçu dans sa malveillance en l'entendant plus souvent prononcer d'enthousiastes " éloges », que pulvériser tel ou tel, au cours des périties et des « incidents » de ces séances passionnées, pour la plus grande gloire de la poésie et des lettres. Tout cela pourtant n'est pas à regretter. D'abord parce que tout cela viendra. Ensuite parce que l'Académie dont on aurait grand tort de médire, et qui en somme réunit aujourd'hui ou achèvera de réunir demain la plupart de nos plus 
grands écrivains* et compte, peut-être, plus d'hommes supérieurs qu'aucune autre assemblée humaine, ne doit pas venir trop tôt à ces talents militants qui alimentent tout leur feu et jettent toute leur flamme dans la prédication et dans la lutte, qui ont besoin de se battre fût-ce contre des moulins à vent, de battre en tous sens le pays, [à] ces natures effrénées et belliqueuses, excellentes aux avant-postes et à qui il faut souhaiter que la position d'« inactivité », tant de grâce qu'ils y puissent déployer, soit offerte le plus tard possible, pour qu'ils restent plus longtemps chefs d'un détachement qui est une élite, hors cadres, plus libres de leur procédé et de leur mouvement.

Ces réflexions me venaient à l'esprit en lisant le dernier livre de $\mathrm{M}$. de Montesquiou, que, selon un goût et un talent d'intituler qu'il a en propre, il appelle d'un nom singulier dont il force aussitôt et étend l'image à un genre d'objets qui n'y ressortissaient pas, de façon qu'en les désignant elle reste, si agrandie que soit son application, excessivement frappante et précise. Hier, c'était les Autels privilégiés mot qui signifie, au propre, autel où on peut célébrer la messe des morts en un temps où cela

* On sait que l'élection immédiate (et nécessaire) de Barrès est assurée. Une jeune revue fort intéressante qui vient de se fonder sous l'ingénieuse direction de M. Paul Fort et qu'on ne saurait trop priser et trop recommander, Vers et Prose, nous cause une grande joie en annonçant que l'élection de notre cher et grand Henri de Régnier, cet écrivain puissant et délicieux, est prochaine. Notre plaisir sera plus complet encore si un troisième fauteuil est réservé à un philosophe, à un artiste auquel nous avons déjà eu et aurons prochainement l'occasion d'exprimer notre admiration profonde, M. Maurice Maeterlinck. Quant à savoir si un grand écrivain doit ou non désirer entrer à l'Académie, la question doit être tranchée par chacun en particulier, suivant ses préférences et décisions personnelles. Il ne peut y avoir de règle. Le fait que Flaubert n'ait pas voulu être de l'Académie ne suffit pas à sacrer grand écrivain tout contempteur de l'Académie, pas plus que, malgré l'exemple inverse de Victor Hugo, un poète n'est grandi d'être académicien. Les «commandements» spirituels les plus absolus et les plus minutieux doivent sur ce point rester muets et s'en remettre à la volonté et à la complexion de chacun. C'est affaire d'hygiène individuelle. 
est défendu de le faire aux autres autels. Aujourd'hui c'est Professionnelles Beautés. Autels Privilegiés, Professionnelles Beautés et Roseaux Pensants, voilà trois livres de critique d'art comme il n'y en a pas d'équivalents, et l'on peut dire bien peu d'égaux, en France. Certes la grande ozuvre de Ruskin, par le génie moral, par la grande puissance d'inspiration du cœur et de poésie, par l'unité du plan en quelque façon divin de cette sorte de discours sur la Beauté Universelle, est une bien plus grande ozuvre et bien supérieure à ces trois livres de M. de Montesquiou. Mais peut-on demander à cette suite de courts essais de ressembler à un ouvrage immense qui poursuit à travers cinquante volumes un même et transcendant dessein ? Encore faut-il avouer qu'il y a peut-être plus de vérité de jugement artistique, de justesse de goût, dans chacun de ces courts essais que dans les grands livres de Ruskin. Or, au strict point de vue de la critique d'art, un juste sentiment des ouvres, une exacte appréciation des valeurs, importe peut-être plus que les plus belles considérations. À peu près aucun des jugements artistiques de Ruskin, au moins sur ses contemporains, ne paraît devoir subsister. Enthousiasme pour les Préraphaélites, pour Meissonier, mépris pour Whistler. Et pourtant c'est le jugement sur les contemporains qui importe chez un critique. « Tout le monde est fort, a dit Sainte-Beuve, à prononcer sur Racine et Bossuet. Mais la sagacité du juge, la perspicacité du critique, se prouve surtout sur des ozuvres neuves, non encore essayées du public. Juger à première vue, deviner, devancer, voilà le don critique. Combien peu le possèdent! »

Or, ce ne sera certainement pas un des moindres titres de M. de Montesquiou d'avoir singulièrement devancé le goût de sa génération et de celle qui l'a précédée, de l'avoir averti, formé et excité, de l'avoir mis sur la piste de beautés nouvelles, qui furent toujours des beautés réelles. Jamais les plus séduisantes couleurs de la nouveauté qui ressemble au vrai beau ne l'abusèrent. Jamais il ne fut dupe de cette illusion d'optique qui colore à nos yeux des reflets d'un talent nouveau les simples efforts qui l'avoisinent et sont par eux-mêmes assez incolores. Les vrais talents sont comme les étoiles. Leur lumière met si longtemps à venir jusqu'à nous que quand nous pouvons enfin la distinguer, l'astre est déjà depuis longtemps éteint. Grâce à ses 
merveilleux télescopes spirituels, M. de Montesquiou distingua toujours, à leur naissance, les talents-étoiles. Et la lointaine portée de sa vue n'en diminue pas la précision : il ne salua jamais étoiles les planètes qui les avoisinent et tirent des étoiles et non d'elles-mêmes leur lumière. Mais ces étoiles, avec quelle joie, quelle vénération de roi-mage et quelle ferveur d'apôtre, il marcha vers elles, les adora, les fit voir de leurs yeux à ceux qui en possèdent, et les fit voir aux autres avec cet oil de la foi qu'est le snobisme. La beauté encore incomprise qu'il aima avant les autres, il l'a enseignée, l'a prêchée infatigablement et souvent dans le désert*.

Tous ces essais que nous lisons aujourd'hui, prennent en dehors de leur valeur littéraire intrinsèque, dont nous allons parler tout à l'heure, une valeur en quelque sorte humaine qui sera pour eux, plus tard, une grande garantie de durée et qui leur vient d'avoir été vraiment vécus, réchauffés d'un amour qui leur a donné la vie, et infatigablement professés. Ce ne sont pas pourtant comme les leçons d'un Villemain infiniment supérieur. D'abord le public était supérieur aussi, c'était une petite élite catéchisée avec une ferveur, une dépense de force spirituelle, nerveuse, sensible, physique vraiment uniques, élite qui pourra témoigner hautement pour ce maître, car elle est composée des hommes supérieurs de demain. Mais M. de Montesquiou ne s'est pas contenté de conserver des allocutions refroidies et de publier des cours. Chacun de ses essais écrits est une création originale, entièrement différente de son enseignement oral, longuement méditée, qui est loin de n'avoir qu'une valeur de transcription, qui a été pensée, «écrite», et avec quelle merveilleuse richesse, quelle force et quelle originalité ! Quels dons

\footnotetext{
* On sait que ce discernement, cette prévision de la beauté nouvelle, M. de Montesquiou l'a étendu jusqu'aux diverses industries d'art. Son nom est inséparable par exemple des noms de Gallé, de Lalique. Et toujours avec un éclectisme qui lui fit admirer et honorer les talents les plus opposés à ce qu'il semble qu'en apparence il aurait dû uniquement aimer (par exemple, qui ne se souvient de la statue, et de l'autel privilégié qu'il dressa à Mme Valmore? La servante de Mme Valmore a confié à M. de Montesquiou le soin d'entretenir sa tombe. Mais il avait déjà relevé et rajeuni sur cette tombe « l'arbre de grandeur »).
} 
particuliers, infiniment rares et précicux, ont été nécessaires pour cela, c'est ce que nous allons pour finir examiner brièvement.

Un de ces dons, qui est merveilleux pour un critique d'art et qui pourtant peut devenir dangereux*, est un don que Ruskin a possédé au plus haut degré et je serais bien embarrassé d'avoir à citer plusieurs autres noms que le sien et celui de M. de Montesquiou. Ce don consiste d'abord à voir distinctement là où les autres ne voient qu'indistinctement. Voir et savoir. M. de Montesquiou entre avec vous dans une cour plantée d'arbres. "Voilà de beaux arbres, dites-vous. - Ce sont, dit M. de Montesquiou, des arbres de Zachée, ceux-là mêmes sur lesquels monta ce petit homme avisé pour voir passer de plus près le Sauveur » (Professionnelles beautés, p. 17). Vous entrez au salon. Belles fleurs dans les jardinières. "Ces amarantes, dit M. de Montesquiou (ibid., 228) signifient en langage floral, etc. et il cite gracieusement Molière et Boulay Paty** ». On apporte des poires. " Ce sont des poires bon chrétien, dit $\mathrm{M}$. de Montesquiou, celles que $\mathrm{M}$. Thibaudier envoie à Mme d'Escarbagnas et qu'elle prend en disant : "Voilà du bon chrétien qui est fort beau". » Le maître de la maison entre, en un pantalon gris que M. de Montesquiou déclare balzacien. Vous hasardez: "Celui de Lucien de Rubempré. - En aucune façon, proteste M. de Montesquiou, celui de Pierre Grassou qui était "avantageux" ou plutôt encore celui de Sixte du Châtelet qui était prétentieusement provincial»(Roseaux pensants, p. 40)***. Une invitée avance la pointe de son soulier et M. de

* Il m'est impossible d'expliquer ici pourquoi. J'ai d'ailleurs trop longuement insisté sur ses dangers dans la préface de la Bible d'Amiens, pour ne pas ici parler plutôt de ses vertus qui en somme l'emportent sur eux.

**'avoue que Boulay Paty est ici ajouté par moi, après avoir lu dans Sainte-Beuve ses beaux vers sur l'amarante.

${ }^{* * *}$ Ça et là, sur Balzac, voir plus curieusement encore Professionnelles beautés, p. 298, 299 et 300 (César Birotteau) et 300 (La Vieille Fille). 
Montesquiou remarque que c'est le geste même de Mme Hulot auprès de Crevel, avance si pudique qu'il ne la comprit pas. Vous allez au Louvre et devant un Pisanello M. de Montesquiou vous montre, dans le fond du portrait, des fleurs que vous n'eussiez peut-être remarquées. Que dis-je des fleurs ? C'est là une généralité dont nos perceptions confuses sont bien obligées de se contenter. M. de Montesquiou vous a déjà nommé l'ancolie et fait remarquer avec quelle vérité elle est peinte. C'est ainsi que Ruskin, dans la représentation florale la plus vague, la plus simplifiée d'une enluminure de manuscrit du XIII e siècle, nomme immédiatement l'épine rose et la Polygala alpina, qu'il pouvait distinguer dans un des tableaux de Collins, un superbe Alisma plantago, et, dans le Berger mercenaire de Hunt, un non moins exact géranium que M. de la Sizeranne (La Peinture anglaise contemporaine, p. 262) nous dit, d'après M. Chesneau, être un géranium Robertianum et qui ne pouvait en effet être plus heureusement surnommé. Devant un admirable Benozzo Gozzoli, Les Anges quittant Abraham, Ruskin fait remarquer que ce qui est bien joli c'est qu'il y ait un ange d'un côté et deux anges de l'autre, car, en effet, dit-il, « rappelez-vous que l'Écriture dit qu'il y eut trois anges auprès d'Abraham, mais deux seulement s'en allèrent vers Loth et le troisième s'en alla d'un autre côté ». Et sans doute c'est Ruskin qui écrit cela, mais sans s'en douter il écrivait à ce moment-là comme devait parler cinquante ans plus tard (sans se douter davantage de la ressemblance) $M$. de Montesquiou. Mais revenons auprès de ce dernier que nous avons laissé devant le portrait de la princesse d'Este. Nous le retrouvons devant un portrait de Bruyas et il remarque (Professionnelles beautés, p. 209) « le transfert à l'index de la main gauche d'une bague chevalière apparemment trop large pour l'annulaire ». Quand on sait ainsi tout voir, tout distinguer, et tout nommer, on possède déjà un privilège inappréciable, pour tout décrire. Partout on notera la nuance juste: " un insaisissable ton d'althaea. » (Professionnelles beautés, p. 130), «les oillets rouges d'un Porbus n'y sont pas fanés par le velours capucine de Mme de Senones » (Ibid., p. 205), «le rouge et le noir d'un Méphisto, le rouge et le noir d'un vase étrusque, la tache vermillon d'un bouchon de 
ligne, ou de ce haillon rouge dont Corot a piqueté le vert gris d'un beau paysage*» (toute cette dernière phrase rien que pour préciser la qualité du rouge dans l'aile d'un papillon, le Pyrameis atalanta). Quand on est avec cela un étonnant écrivain on arrive à égaler l'œuvre qu'on décrit : «Peintures et pastels, je possède sept panneaux d'hortensias jardinés par Helleu, et dont les corymbes glauques ou blondissants, mirent en des plateaux d'argent comme des bouquets de turquoises mortes.» Ce qu'il y a de plus délicieux, de plus insaisissable et de plus indescriptible, semble-t-il, dans l'art du peintre est ici égalé. M. de Montesquiou ne nous dit pas si ces panneaux lui furent offerts en présent par Helleu. Si oui, nous leur appliquerions volontiers, en la changeant légèrement et en l'exaltant un peu, la phrase de Sainte-Beuve sur Goncourt : « Heureux qui voit payer sa magnificence d'une louange sans prix. »Et quel sentiment des reflets dans cette phrase : "Le modèle dont la rose chevelure a fait se dorer de son reflet tant de miroirs de cuivre.» Mais il n'y a pas une phrase qui ne serait à citer. Chacune contient des curiosités - naturelles et factices - des beautés - une intuition - une expérience. Il n'y a peut-être pas dans ce livre de 313 pages une seule phrase insignifiante et de remplissage. L'auteur a tant à dire qu'il ne perdrait pas deux mots pour ne rien dire, et dans sa hâte féconde, pressé de déposer son germe, il n'a pas la patience ou la frivolité de s'attarder aux détails biographiques**. Il brûle la première étape et la laisse à remplir à ceux qui n'iront pas plus loin.

\footnotetext{
* Comparez encore (Autels privilégiés, p. 265 et 266) : «Les deux écharpes de cachemire des Indes rouge, de ce rouge de géranium foncé qu'affectionnait Moreau, sont aussi celles qu'aimait Ingres qui en drapa Mesdames Rivière et Devançay, et que Prudhon a enroulées autour de sa Joséphine. Les robes sont d'une souple gaze rayée (peut-être un barège) de coton chaud que le siècle de Louis XIV appelait «couleur cheveux » et que la chevelure de Marie-Antoinette fit ensuite en s'éclaircissant qualifier cheveux de la Reine. C'est une sorte d'amadou diaphane. Un douloureux bracelet est tressé d'une natte pareille à celle qui couronne la pleureuse d'Orphée de Gustave Moreau. »

** «Certains esprits s'accommodent de ces faits... je les abandonne à leur aptitude. Je n'exprime que ce qui me passionne. La sécheresse que m'offre la biographie, je la repousse », etc. (Professionnelles beautés, p. 89).
} 
Sans doute une vision si extraordinairement minutieuse du détail caractéristique et précis exigeait - et a trouvé un vocabulaire infiniment varié, fournissant à toute minute le mot technique, le terme juste qui est souvent le terme rare. En réalité, quand nous relisons aujourd'hui attentivement certaines des pièces qui nous paraissent les plus classiques, nous voyons à les regarder de près, de combien de précision de détails parfois gênants à notre ignorance est faite leur beauté de loin si vague et si générale. Nous ouvrons la célèbre pièce : «À l'Arc de Triomphe » et nous sommes arrêtés par un abaque, par un attique, un chevet, un claveau, etc. Nous ouvrons Le Capitaine Fracasse de Théophile Gautier et dès les premières pages plus de vingt termes, inconnus de nous, nous surprennent. Et on peut peut-être soutenir que pour certains livres ces mots exacts sont comme les clous précieux qui fixent immuablement la trame du style et lui interdisent ce flottement qui ne résiste pas à l'outrage du temps. Ce qui parut singulier à cette époque ne paraît plus aujourd'hui que singulièrement approprié. Notre auteur exige le même genre d'effort. Il est certain que, parfois, un terme peu usité aussi nous arrête. L'érudition de l'auteur fait que toute chose évoque pour lui des souvenirs que nous n'avons pas tous aussi soigneusement rangés dans nos mémoires. «Un seul rosier, aux roses de face, de revers, de profil, (il s'agit d'une broderie) qui fait penser au rosier d'Hildesheim, planté par saint Bernard, au miracle de sainte Elisabeth, au rosaire de saint Dominique.» - «Elle voulut (il s'agit d'une hôtesse littéraire) associer Pétrone à Hugo, Quasimodo à Trimalcion, Borlunt à Apicius, réconcilier les maîtres-queux avec les maîtres sonneurs. Elle rêva d'être un bas-bleu qui serait un cordon-bleu, de marier le bouquet de persil et le bouquet à Chloris, d'assembler le laurier d'Apollon avec le laurier-sauce. Et elle fut la Julie d'Étanges du pot-au-feu, la Sablière du fritot et du fricot, la Geoffrin et la du Deffand des fricassées... faisant jaillir une Hippocrêne, un Raphidim de bons mots. » On est emporté dans ce tourbillon où parfois l'on n'aurait voulu s'aventurer qu'avec son dictionnaire. Mais, je le répète, on est souvent plus déconcerté encore par les mots qu'emploie Théophile Gautier. Chez M. de Montesquiou, d'ailleurs, comme chez lui, le terme rare est 
toujours un terme excellent, choisi dans les meilleurs " milieux » littéraires du XVIe, XVII ${ }^{\mathrm{e}}, \mathrm{XVIII}{ }^{\mathrm{e}}$ siècle et dans ce livre de Professionnelles beautés où il y a pourtant de choses difficiles à désigner et à différencier, je ne crois pas qu'il y ait moitié autant de mots rares que dans le premier volume du Capitaine Fracasse.

Il est d'ailleurs à noter que si M. de Montesquiou sait tout de la peinture, en revanche dès qu'il écrit il n'est plus qu'un écrivain. Vous ne trouverez jamais chez lui le moindre de ces " glacis », de ces "empâtements», de tous ces termes d'atelier qui restent comme une petite tache sur les plus merveilleuses descriptions de nature des Goncourt. Et pourtant M. de Montesquiou n'est jamais abstrait, ce qui arrive trop souvent à un autre critique d'art, et en cela inférieur à notre avis, Fromentin. Sans doute, Fromentin restera au fond de ses livres de critique d'art une des plus charmantes figures qu'on puisse aimer, qu'on doit aimer, puisque l'admirer on ne le peut toujours entièrement, et que sa faiblesse, ses défauts charmants, l'insuccès de son noble et mélancolique effort, du fond de l'ombre que l'indécision de sa facture épaissit sur ses traits peu distincts, semblent implorer et éveillent si naturellement la sympathie des générations. Mais est-ce le méconnaître et cela empéche-t-il de lui rendre toute son avance sur d'autres terrains que de confesser qu'il sut rarement dans ses livres, malgré tout son luxe d'explications fines, de raisonnements profonds, de touches techniques, nous faire voir un tableau, comme tout à l'heure nous « voyions » ce pastel d'Helleu, comme ailleurs nous sont magnifiquement montrées les Deux Sazurs de Chasseriau?

Cet esprit qui excelle à fixer le reflet d'une nuance et la singularité d'un contour ne se plaît pourtant à cela que de passage et dans la mesure où cela est utile à ce qu'il prétend prouver. Car il est avant tout philosophique et il n'a pas écrit une page qui ne soit mouvementée et émouvante, d'être en marche vers une démonśtration. Les conclusions toujours neuves et souvent profondes où il arrive, si elles ne paraissent pas plus considérables aux esprits superficiels, c'est qu'au lieu de les exprimer sous une forme abstraite, il veut leur donner une apparence plastique et piquante. Mais qu'on ne s'y trompe pas, et ce dernier trait l'achève et lui décerne la couronne. 
Ce n'est pas seulement comme l'appelait plaisamment un grand peintre « le seul critique d'art qui s'y soit jamais connu en peinture », c'est encore un vrai philosophe de l'art, celui qui terminait son étude sur Ingres par cette page superbe, nouvelle et définitive :

« Ingres-OEdipe, le voilà, faible et fort, doux et irrité, savant et inculte. Il crée autour de lui l'air raréfié, l'atmosphère d'altitude et l'irrespirable milieu où le modèle et le spectateur sentent qu'ils se pétrifient. Entendez-le s'écrier : "Il est beau de noircir les paupières des vieillards... il est beau de décolorer les paupières des femmes..." Traduisez son propre visage d'Olympien au front bas, habité et intérieurement heurté par l'emprisonnement, là, de son aigle. Sur ses lèvres un Quos ego, à l'adresse de ceux qu'il se retient de nommer, mais qu'il désigne ainsi : les grands machinistes. Un artifice des poèmes orientaux consiste à employer le pluriel lorsqu'on parle de l'amoureux, comme pour l'amplifier, le grandir. Ingres fait de même, parlant de l'ennemi : "ils veulent, ils nous opposent..." Mais ce n'est ni Rubens, ni Van Dyck, ni Rembrandt, ni Murillo, ni même Géricault... c'est un seul, l'innommable! Le bien nommé, selon la loi de Balzac, n'est-ce pas lui, désigné de ce nom à la sonorité nasillarde et griffue, pincée et rapace, et dont la rime est avaricieuse. Ingres, un prophète encore : Moïse de l'art contemplant de loin la Terre promise des couleurs et des reflets; Jonas plein d'imprécations et de prédictions ruineuses. Un autocrate inouï non content de la magnifique vérité qu'il lui fut donné de formuler et qui exige impérieusement de régir tout l'art. Et pourtant tel est le secret de sa force et de sa beauté. C'est la forme stricte du sonnet infligeant au rêve contraint une attitude plus rare. C'est la culture japonaise étirant, repliant ses rameaux selon des courbes plus exquises. C'est l'eau transformée en gerbes et en jets par une puissante hydraulique, et qui fournira cette belle similitude au grand Dominique : "La lumière est comme l'eau, elle se fait bon gré mal gré sa place, et prend à instant son niveau."

«Ingres s'est égalé au créateur, non comme um Pygmalion s'en remettant à l'amour du soin de vivifier sa Galathée, mais comme un Deucalion qui se fie à son orgueil du vouloir d'humaniser les pierres. Mais les pierres attendent en vain, en leurs attitudes rigides; en leurs frigides veines, le sang des cornalines circule, seul, et la violette de la mort bleuit sur leurs lèvres d'améthystes. Punition d'avoir voulu exister sans la vie. Biblique châtiment pour un crime mythologique. L'autre, l'ennemi, le rival innommé a, lui, vraiment dérobé la flamme, afin d'en vivifier sa création toute brûlante de feux et de pourpre, d'étoffes d'or, de bijoux ardents, de crinières de lions et de chevelures de femmes. Le bûcher de Sardanapale en flamboie, Ingres le voit et en rougit, et l'Incendie du Bourg qu'il admirait ne lui cause pas tant d'envie. Or, sa muse pour l'avoir contemplé, se change en sel - que dis-je ? - en ivoire. Et lui-même, autre Prométhée, expie un étrange forfait, éternellement enchaîné au rocher de son Angélique, et pour avoir volé - le froid*»

* Roseaux pensants, p. 49, 50 et 51. 


\section{Une Grand-Mère}

\section{(Le Figaro, 23 de julho de 1907)}

Il y a des personnes qui vivent sans avoir pour ainsi dire de forces, comme il y a des personnes qui chantent sans avoir de voix. Ce sont les plus intéressantes ; elles ont remplacé la matière qui leur manque par l'intelligence et le sentiment. La grand-mère de notre cher collaborateur et ami Robert de Flers, Mme de Rozière, qu'on enterre aujourd'hui au Malzieu, n'était qu'intelligence et que sentiment. Consumée de la perpétuelle inquiétude qu'est un grand amour qui dure toute la vie (son amour pour son petit-fils), comment eût-elle pu être bien portante! Mais elle avait cette santé particulière des êtres supérieurs qui n'en ont pas et qu'on appelle la vitalité. Si frêle, si légère, elle surnageait toujours aux plus effroyables sautes de la maladie, et au moment où on la croyait terrassée, on l'apercevait, rapide, toujours au sommet, et suivant de tout près la barque qui menait son petit-fils à la célébrité et au bonheur, non pour qu'il en rejaillît rien sur elle, mais pour voir s'il n'y manquerait de rien, s'il n'y aurait pas encore un peu besoin de ses soins de grand-mère, ce qu'au fond elle espérait bien. Il faut que la mort soit vraiment bien forte pour avoir pu les séparer !

Moi qui avais vu ses larmes de grand-mère - ses larmes de petite fille chaque fois que Robert de Flers faisait seulement un voyage, ce n'était pas sans inquiétudes pour elle que je pensais qu'un jour Robert se marierait. Elle disait souvent qu'elle avait envie de le marier, mais je crois qu'elle le disait surtout pour s'aguerrir. Au fond, elle avait encore plus peur de cette échéance fatale de son mariage qu'elle n'avait redouté son entrée au collège et son départ pour le régiment. Et Dieu sait seul - car on est courageux quand on est tendre - ce qu'elle avait souffert à ces deux moments-là ! Le dirais-je ? Sa tendresse pour son petit-fils ne me semblait pas devoir, quand Robert serait marié, être une source de tristesses que pour elle : je pensais à celle qui deviendrait sa petite-fille... Une tendresse aussi jalouse n'est pas douce toujours à ceux avec qui elle doit partager... La femme qu'épousa Robert de Flers accomplit avec une simplicité divine le miracle de faire de ce mariage si redouté une ère de bonheur sans mélange pour Mme de Rozière, pour elle-même et pour Robert de Flers. Tous trois ne se quittèrent ni ne se querellèrent un seul jour. Mme de Rozière disait bien que par discrétion elle ne continuerait pas à habiter avec eux et irait vivre de son côté, mais je ne crois pas que ni elle, ni Robert, ni personne ait jamais pu sérieusement envisager cela comme possible. Ce n'est que dans un cercueil qu'on a pu l'emmener. 
Une autre chose m'avait paru ne pas devoir aller sans des difficultés très grandes, qui, grâce à l'esprit et au cőur délicieux de Gaston de Caillavet, et de sa femme, se passa le plus simplement et le plus heureusement du monde. À partir d'un certain moment, Robert eut un collaborateur. Un collaborateur! Mais vraiment quel besoin pouvait-il avoir d'un collaborateur, lui son petit-fils, lui qui avait plus de talent à lui seul que tous les écrivains qui avaient jamais paru sur la terre ? Du reste, cela n'avait pas d'importance; il était bien sûr que dans les ouvres écrites en collaboration, tout ce qui serait bien serait de Robert, et que si, par hasard, quelque chose était moins bien, ce serait de l'autre, de l'audacieux... Eh bien! rien ne fut « moins bien » et pourtant elle déclara que tout n'était pas de Robert. Je n'irai pas jusqu'à dire que dans les triomphes incessants qui ont marqué cette collaboration, elle estimait que toute gloire devait revenir à Caillavet, mais il aurait été le premier à ne pas le souffrir. Et dans l'harmonieuse réussite, elle fit la part de dons différents qui savaient admirablement s'unir. C'est qu'elle était avant tout merveilleusement intelligente et que c'est encore ce qui rend le plus juste. C'est même sans doute pour cela que l'intelligence, qui est une si grande source de maux, nous apparaît tout de même comme si bienfaisante et si noble : c'est que nous sentons bien qu'il n'y a qu'elle qui sache honorer et servir la Justice. « Ce sont deux puissants dieux. »

Elle ne quittait pas plus son lit ou sa chambre que Joubert, que Descartes, que d'autres personnes encore qui croient nécessaire à leur santé de rester beaucoup couchées sans avoir pour cela la délicatesse d'esprit de l'un ni la puissance d'esprit de l'autre. Ce n'est pas pour Mme de Rozière que je dis cela. Chateaubriand disait de Joubert qu'il restait constamment étendu et les yeux fermés, mais que jamais il n'était si agité et ne se fatiguait tant que dans ces moments-là. Pour la même raison Pascal ne put jamais, sur ce point, suivre les conseils que lui prodigua Descartes. Il en est ainsi de beaucoup de malades à qui on recommande le silence, mais - comme la jeunesse au petit-fils de Mme de Sévigné — leur pensée « leur fait du bruit ». Elle se rendait si malade à se soigner qu'elle aurait peut-être mieux fait de prendre tout simplement le parti si compliqué d'être bien portante. Mais cela était au-dessus de ses forces. Dans les dernières années ses yeux ravissants, qu'elle avait couleur de jacinthe, tout en reflétant de plus en plus ce qui se passait en elle, cessèrent de lui montrer ce qui se passait alentour: elle était devenue presque aveugle. Du moins, elle l'assurait. Mais moi je sais bien que si Robert avait seulement un peu mauvaise mine, elle était toujours la première à s'en apercevoir ! Et comme elle n'avait pas besoin de voir au-delà de lui, elle était heureuse. Elle n'a jamais rien aimé, pour prendre l'expression de Malebranche, qu'en lui. Il était son dieu.

Elle a toujours été indulgente à ses amis, et sévère aussi, car elle ne les trouvait jamais dignes de lui. À aucun elle ne fut plus indulgente qu'à moi. Elle avait une manière de me dire : "Robert vous aime comme un frère », qui signifiait à la fois : «Vous ne ferez pas mal de chercher à le mériter », et «vous le méritez tout de 
même un tout petit peu ». Elle poussait l'aveuglement en ce qui me concernait jusqu'à me trouver du talent. Elle se disait sans doute que quelqu'un qui avait tant fréquenté son petit-fils n'avait pas pu ne pas lui en prendre amitiés aussi parfaites que celle qui unissait Robert de Flers à sa grand-mère ne devraient jamais pouvoir finir. Comment! deux êtres si entièrement correspondants que rien n'existait dans l'un qui ne trouvât dans l'autre sa raison d'être, son but, sa satisfaction, son explication, son tendre commentaire, deux êtres qui semblaient la traduction l'un de l'autre, bien que chacun d'eux fût un original, ces deux êtres n'auraient fait que se rencontrer un instant, par hasard, dans l'infini des temps, où ils ne seront plus rien l'un à l'autre, rien de plus particulier qu'ils ne sont à des milliards d'autres êtres ? Faut-il vraiment le penser ? Toutes les lettres de ce livre spirituel et passionné qu'était Mme de Rozière sont-elles devenues subitement des caractères qui ne signifient plus rien, qui ne forment plus aucun mot? Ceux qui comme moi ont pris trop tôt l'habitude d'aimer à lire dans les livres et dans les coeurs ne pourront jamais le croire tout à fait...

Je suis sûr que depuis bien longtemps Robert et elle, sans jamais se le dire, devaient penser au jour où ils se quitteraient. Je suis sûr aussi qu'elle aurait aimé qu'il n'eût pas de chagrin... Ce sera la première satisfaction qu'il lui aura refusée...

J'ai voulu au nom des amis de Robert de Flers, — ses jeunes amis à elle lui dire ce que je ne puis pas appeler un dernier adieu, car je sens que je lui en dirai bien d'autres, et puis, pour parler exactement, on ne dit jamais vraiment adieu aux êtres qu'on a aimés, parce qu'on ne les quitte jamais tout à fait.

Rien ne dure, pas même la mort ! Mme de Rozière ne pas encore en terre, et déjà elle recommence à s'adresser assez vivement à moi pour que je ne puisse m'empêcher de parler d'elle. Si on trouve que je l'ai fait par moments avec un sourire, qu'on n'aille pas croire que je n'avais pas pour cela moins envie de pleurer. Personne ne m'aura mieux compris que Robert. Il aurait fait comme moi. Il sait que les êtres qu'on a le plus aimés, on ne pense jamais à eux, au moment où on pleure le plus, sans leur adresser passionnément le plus tendre sourire dont on soit capable. Est-ce pour essayer de les tromper, de les rassurer, de leur dire qu'ils peuvent être tranquilles, que nous aurons du courage, pour leur faire croire que nous ne sommes pas malheureux ? Est-ce, plutôt, que ce sourire-là n'est que la forme même de l'interminable baiser que nous leur donnons dans l'Invisible? 


\section{Gustave de Borda}

\section{(Le Figaro, 26 de dezembro de 1907)}

M. Gustave de Borda, qui est mort la semaine dernière et qui était surtout connu et légendaire sous le surnom de "Borda Coup d'épée », avait en effet passé sa vie l'épée à la main, redoutable aux méchants, mais doux aux bons et compatissant aux malheureux, comme un chevalier du Romancero dont il avait la figure. Décoré pour sa belle conduite pendant la guerre, il était célèbre par ses talents d'escrimeur hors de pair et ses innombrables duels. Ce qu'on savait moins, c'est qu'il n'usait de son extraordinaire adresse à l'épée que pour modérer les effets de sa force dont il n'abusa jamais.

Il aurait pu être le plus dangereux des ennemis; mais comme il était le meilleur des hommes, il ne fut jamais que le plus modéré, le plus juste, le plus humain, le plus courtois des adversaires. Ce sont les møurs et non les opinions qui font les vertus; la bravoure a fait de ces pacifiques comme Borda; le pacifisme n'en fera pas. Le commerce et l'exemple d'un tel homme apprenaient à ne pas craindre la mort, à goûter d'autant mieux la vie. Sa sympathie, sa bonté étaient délicieuses, parce qu'on sentait que la peur, l'intérêt, la faiblesse, n'y entraient pour rien, que c'était le don volontaire et pur d'une âme vraiment libre. D'un esprit charmant et orné, il avait un goût vif et naturel pour les arts, pour la musique surtout, qu'il aimait facile comme il sied à un vieux brave. Stendhal, qui avait fait la campagne de Russie, ne préférait-il la musique italienne à toutes les autres ? Ce merveilleux duelliste qu'était $M$. de Borda, fut aussi, avec une compétence sans égale, avec une finesse et une bonté rares, un incomparable témoin.

Il a fallu la fatigue des toutes dernières années pour empêcher de continuer à aller sur le terrain comme témoin de ses amis, quand il eut passé l'âge d'y aller comme combattant. La dernière personne, si notre mémoire est exacte, qu'il assista sur le terrain en qualité de second, fut notre collaborateur, M. Marcel Proust, qui a toujours gardé pour lui un véritable culte. M. Gustave de Borda avait eu pour amis tout ce qui compte à Paris par le coeur, par la naissance, ou par la pensée. Mais celui qui lui était le plus cher de tous, en dehors de son médecin et ami, le docteur Vivier, c'était le grand peintre Jean Béraud. M. de Borda sentait en ce merveilleux artiste une nature qui, par des côtés moins connus du public, par la bravoure et par le coeur, était voisine de la sienne. Il reconnaissait en lui un de nos derniers chevaliers. 


\section{Portrait du Prince Léon Radziwill}

\section{(Cahiers Marcel Proust, 1927)}

I. Au physique. Léon Radziwill n'est pas de ces êtres qui - comme les bustes « spirituels » et assommants au-dessous desquels se détache la rosette de la Légion d'honneur en marbre - offrent au premier regard du passant un aspect sottement délimité et une expression au début saisissable. Comme toutes les choses grandes et belles - comme une sculpture gothique, comme un Rodin - il est, en même temps qu'infiniment délicat, si fruste qu'il présente plutôt l'aspect d'un bloc que d'une statue, et que c'est à la délicatesse, à la compréhension de celui qui l'observe, à le sculpter, à retrouver sa forme vraie, à déterminer sa beauté. " Quel est ton nom? demandait un poête à une déesse qu'il discernait mal dans l'ombre. - Dis-moi le tien, répondit-elle. Aux stupides je suis la stupidité, aux intelligents l'intelligence. » Un regard stupide prenant trait pour trait la figure de Loche y découvrira facilement la stupidité. La «noble pudeur » qui colore le visage de cet Hippolyte émancipé lui paraîtra la vulgaire rougeur de l'homme adonné uniquement à la vie matérielle. Les yeux, si expressivement inexpressits, comme ceux des statues grecques, petites excavations où la mer en se retirant a laissé deux petites flaques couleur de pierres précicuses, émeraudes ou saphirs selon l'heure, prendraient la morne hébétude du cretinisme endurci. La diction elle-même, d'une lenteur amusante et d'une fausse bonhomie, semblera comme empâtée par la bêtise et la naïveté. Mais pour ceux qui savent se placer derrière les choses au point générateur d'où découlent les lignes avec toute leur signification graphique et leur portée spirituelle, tout dans ce visage respirera à la fois la puissance et la délicatesse, le calme de la nature et les émotions de la sensibilité, le charme du naturel et la profondeur de la réflexion. Et le corps même du géant révèlera des délicatesses extrêmes d'attitudes et de lignes qui feront d'un salut, d'un geste de déférence ou d'empressement une chose pleine de grâce et de signification morale. Tel, double selon qu'il apparaît à un imbécile ou à un artiste, est au physique Léon Radziwill. Les femmes par un biais que dans le Banquet semble avoir prévu Platon, se rangent, bien qu'elles aient plutôt la mentalité des imbéciles, à l'opinion des artistes. Car le désir est une compréhension aveugle.

II. Intellectuellement. Nous mourons d'une maladie que Renan a classée morbus litterarius. Bien que fatale à l'esprit de chacun, elle est commode pour tous, en ce qu'elle permet aux plus bêtes de distinguer de loin, au pavillon de culture qu'ils font plus ou moins fièrement flotter à leur mât, les gens très intelligents, les gens médiocres, les imbéciles. Nul doute que Balzac, que Stendhal, que tant d'autres n'eussent été rangés dans la dernière catégorie. On fait quelquefois à Loche le même honneur, probablement immérité, car il n'écrira jamais le Curé de Tours ni la Chartreuse de Parme. Nous dirons pourquoi. - D'ailleurs même ceux qui sont les plus doués sont bien loin de commencer par la naïve observation de la nature. C'est après un long exil volontaire dans la chimère qu'ils éprouvent - par 
la nostalgie - l'amour du réel. Loche, observateur exquis de la réalité médiocre à vingt-cinq ans, observateur de la vie de tous les jours, des petits caractères et des petits esprits, observateur des réalités que peignit Chardin avant Balzac, est au premier abord un cas merveilleux. Aux orchidées qui ne nous rappellent rien, il préfère les gaietés «bien françaises » des fleurs d'un jardin de curé, le pissenlit farceur, le coucou qui sait ce qu'il vaut, la gueule-de-loup à qui on ne fait pas avaler ça. S'il n'était si tard, si je n'avais si froid dans la salle à manger, si je n'étais si éreinté, je dirais pourquoi j'ai peur que ces qualités délicieuses ne se realisent pas. Loche me paraît manquer de culture à un degré qui signifie indifférence à la littérature et indifférence à la beauté. Alors que tant d'autres ont la matière, le corps où incarner une ozuvre, mais point d'Esprit à y loger, je le vois riche d'une âme qui cherche éternellement un corps où elle pourrait s'incarner. Je gèle. Sera développé une autre fois.

III. Moralement. Il participe à la banalité des défauts de son temps, dont il diffère intellectuellement par une originalité si intéressante et si forte, promesse d'un talent si savoureux. Âme putain, se donnant au premier venu ou plutôt incapable de faire don de soi, plein de nobles choses, généreux, sensible, ne tenant à rien de vulgaire, ni à l'argent, ni à la célébrité, ni au monde (avec cette réserve qu'il déteste et méprise les gens chics, mais les redoute, ce qui lui ôte la souveraine aisance de conduite qu'ont même des gens mondains - j'ai trop froid pour développer, je ne sais plus ce que j'écris), capable de faire mille choses pour un ami, excepté d'être son ami, si ce mot implique préférence, fidélité, sécurité, persévérance, etc. D'autre part, certaines mauvaises habitudes de langage lui font tenir les propos classiques de l'envieux et du fourbe. «Moi qui aime énormément Y..., qui ai une extrême affection pour lui, je peux dire, car cela me fait une peine énorme, qu'il est 'incapable de, etc...» Mais ceci surtout défaut de phraséologie. Du reste défaut à surveiller. Facilité à enfiler distraitement comme des perles des phrases dont son attention ne contrôle pas le sens exact et qui tantôt lui donnent l'air fourbe, tantôt l'air bête. Ainsi une fois il m'a dit que le grand mérite de Ruskin était de rendre les idées les plus élevées accessibles et agréables à chacun. Est-ce l'infériorité littéraire, la trop grande insuffisance de culture autre qu'humaine et psychologique sur le vif qui lui a fait dire cela, ou n'est-ce pas plutôt le «parler pour ne rien dire »? Si peu de volonté, que même la vue de la réalité qui pourtant n'engage pas à l'action lui est presque aussi insoutenable que l'éclat du soleil. On le narcotise très vite en lui parlant de la réalité. Au bout d'un instant l'œil bleu s'amortit, l'anesthésique opère. Vous pouvez à ce moment-là dire quelque chose d'absolument choquant, il ne s'en aperçoit plus, on ne peut plus tirer un regard à l'œil fixe. Si on insiste trop, dans une convulsion suprême, il se tourne de côté. A ce moment-là on pourrait lui couper une jambe qu'il ne sentirait pas. Moi qui l'admire infiniment, par un phénomène nerveux très pénible, dès qu'il est là, je suis absent de moi-même, je ne puis rien dire, je deviens stupide. J'ai voulu vaincre cet enchantement, cela en a redoublé la force, comme l'effort qu'on fait pour ne pas 
rater une femme vous rend plus impuissant, ou pour s'endormir accroît l'insomnie. Au bout de trois ou quatre fois, quand on sonnait et qu'on disait : « Le Prince Léon Radziwill », j'étais ennuyé en pensant à cet état si pénible où j'allais être, et ennuyé aussi dans mon amour propre, sentant qu'il me trouvait si bête, qu'un des êtres de qui j'aimerais le plus être estimé n'aura jamais l'ombre d'idée de ce que je suis. Cela a commencé par tuer le plaisir à le voir. Mais dès que son arrivée s'est ainsi associée à un sentiment pénible, l'amitié était frappée de mort prochaine. L'affection est au contraire l'association d'un nom et d'une joie. Puis cet état à force d'être répété est devenu chronique, comme un malaise cardiaque trop souvent répété finit par devenir une cardiopathie. Première cause de destruction d'amitié. Il y en eut d'autres, tel que le sentiment, qui me fut très pénible au début, de l'impossibilité d'avoir la sienne. L'intelligence ne suffit pas à faire aimer. Non par utilitarisme, mais par solitude morale et tristesses inconsolables, j'ai besoin de natures non mouvantes avec lesquelles on puisse entretenir pacte solide et durable alliance. Les gouvernements éphémères et contradictoires qui se succèdent sous le nom de Loche sont de ceux avec qui on ne peut pas s'allier, parce qu'à tout moment c'est à une personne nouvelle qu'on s'adresse, bien excusable de ne pas tenir les engagements que son précédesseur, et non pas elle, a pris. Il y a d'autres excuses que je pourrais encore fournir ici à sa naturelle inconstance, mais je n'en peux plus...

MARCEL. 
ANEXO III

TRADUÇÃO COMENTADA DOS RETRATOS LITERÁRIOS SELECIONADOS NA OBRA DE MARCEL PROUST 


\section{Figuras Parisienses: Camille Saint-Saëns ${ }^{1}$}

\section{(Le Gaulois, 14 de dezembro de 1895)}

"É um gênio", disse uma antiga lenda, "mas um gênio maligno. Rei dos espíritos da música e do canto, ele guarda todos os segredos, e mesmo aquele, quando se deseja lhe aproximar, de se evaporar no infinito: sempre inalcançável". Por ocasião de Ascanio $^{2}$, enquanto o procuram na França, ele percorre as Canárias. Nesta noite, disfarçado sob o nome de um falecido músico que ele vai ressuscitar, ocultar-se-á até mesmo de nossas homenagens. Será que ele agora não escapará das amarras de meu pensamento, que busca lhe apreender, e não me deixará somente com "vento" entre as mãos, como um duende fugidio?

Gênio inspirado da música, dotado de uma profunda sensibilidade - basta, sem mencionar lira ou harpa, dar ouvidos àquela lira de Ascanio ou àquela harpa

\footnotetext{
${ }^{1}$ Este retrato, assinado por Marcel Proust, foi publicado em 14 de dezembro de 1895 no jornal Le Gaulois. A data de sua aparição coincide com o ensaio-geral da ópera Frédégonde, que estrearia dois dias depois na Ópera Nacional de Paris. Camille Saint-Saëns se encarregou de prosseguir os trabalhos deixados por Ernest Guiraud, morto em 1892. São de sua autoria o Hymne Guerrier, o balé que encerra o terceiro ato e a íntegra do quarto e do quinto ato. 0 poema é de Louis Gallet e a orquestração coube a Paul Dukas, discípulo de Guiraud no Conservatório de Paris. A musicóloga Laetitia le Guay-Brancovan desenvolveu um estudo minucioso a respeito da relação entre Proust e Saint-Saëns, demonstrando de que maneira transformou-se de uma profunda admiração em desprezo. Proust foi introduzido à música de Saint-Saëns no salão de Madeleine Lemaire, através de Reynaldo Hahn. Diz Le Guay-Brancovan que a Sonata para piano e violino, Op. 75, de Saint-Saëns, "se associou ao amor de Proust por Hahn como, em sua invocação literária, ao amor de Jean por Françoise, em Jean Santeuil, e como a 'pequena frase' da Sonata de Vinteuil, para o amor de Swann por Odette". Proust esteve uma única vez com Saint-Saëns, em Dieppe, em 19 de agosto de 1895, durante uma temporada ao lado de Hahn, a convite de Madeleine Lemaire. Em dezembro, quando publica este retrato, o envia ao compositor desculpando-se pelo fato de que "tout littérateur est incapable de parler musique" (todo literato é incapaz de falar de música) e pedindo que aceitasse "l'hommage d'un admirateur respectueux et passionné, encore sous le charme d'une certaine visite faite à Dieppe par M. Saint-Saëns à Madame Lemaire" (a homenagem de um admirador respeitoso e apaixonado, ainda sob o encanto de uma certa visita do Sr. Saint-Saëns a Madame Lemaire em Dieppe). Saint-Saëns jamais respondeu a essa carta e nunca trocou qualquer correspondência com Proust. Nos anos seguintes, o encanto do romancista pelo músico se esvaiu ao ponto de, em carta a Jean Cocteau, em junho de 1919, afirmar: "Jamais un musicien ne m’a autant emmerdé" (nunca um compositor me entediou tanto). Acredita Guay-Brancovan que Saint-Saëns aceitava participar do universo dos salões apenas na medida em que atendiam a suas preocupações musicais. Diferente de Proust, que teria, a seu ver, "feito da mundanidade um valor em si". Ver GUAY-BRANCOVAN, Laetitia le. Marcel Proust et Camille Saint-Saëns: L'Histoire trompeuse d'un désaveu. In: TADIÉ, Jean-yves (Org.). Le Cercle de Marcel Proust II. Paris: Honoré-champion, 2015. p. 129-143.

${ }^{2}$ Ópera em cinco atos estreada em março de 1890 na Ópera Nacional de Paris. Foi baseada na adaptação teatral de Paul Meurice (1852) para o romance Benvenuto Cellini (1843), de Alexandre Dumas, pai. Com composição de Camille Saint-Saëns e libreto de Louis Gallet, narra o amor do escultor italiano Benvenuto Cellini e de seu aprendiz, Ascanio, por Colombe, filha de Estourville, regente de Paris na corte de Francisco I. A paixão dos dois pela jovem provoca os ciúmes de Florentine Scozzone, apaixonada por Cellini, e da duquesa de Étampes, atraída por Ascanio. Cellini abre mão de Colombe em favor de Ascanio, mas percebe os perigos que os ciúmes de Scozzone e da duquesa podem provocar e decide escondê-la no relicário de um convento. Ao ter ciência da estratégia de Cellini, a duquesa se apodera do relicário, para poder trancafiar Colombe e lá sufocála. Mas Scozzone discorda dos planos e assume secretamente o lugar da jovem.
} 
de Sansão e Dalila ${ }^{3}$-, ele se regozija como um Gustave Flaubert ${ }^{4}$, como um Anatole France $^{5}$, de ocultá-la sob sua riqueza, sob sua ciência de grande escritor musical. Porque ninguém parece ter melhor compreendido este célebre pensamento: "todas as belezas intelectuais presentes em um belo estilo, todas as relações que o compõem são igualmente verdades... talvez mais preciosas que aquelas que fundamentam o discurso".

Ele sabe rejuvenescer uma fórmula empregando-a em sua antiga acepção, e capturar, por assim dizer, cada frase musical em seu sentido etimológico. Ele absorve seus encantos de Beethoven e de Bach, ou melhor, como em uma de suas mais belas transcrições, oferece a Bach encantos que não lhe pertenciam.

Pintar em um acorde, dramatizar com a fuga, eternizar através do estilo, proporcionar inventividade e gênio criativo tanto no uso da escala quanto no contorno de uma melodia, fazê-la atravessar uma ideia, como a antiga hera que preserva as ruínas dos monumentos; entregar assim suas cartas nobiliárquicas à modernidade; através da sábia, singular, sublime propriedade da expressão, pouco a pouco levar a um lugar comum o valor de uma imaginação original, tornar um arcaísmo um traço de espírito, uma ideia geral, o resumo de uma civilização, a essência de uma raça, um traço de gênio oriundo de um ofício ou vindo dos céus, dar sotaque inglês a um prelúdio, o prelúdio de Henrique VIII ${ }^{6}$, o caráter matrimonial de uma cena, o dueto de Ana Bolena e Henrique VIII, a iluminação napolitana de um coro, o Quand vous chantez Scozzone ${ }^{7}$, brincar com arte em uma marcha, a Suite Argelina ${ }^{8}$, agregar o estilo de um ourives renascentista a uma

\footnotetext{
${ }^{3}$ Ópera em três atos, com libreto de Ferdinand Lemaire, é reconhecida como o ápice do repertório lírico de Camille Saint-Saëns, quando o compositor logrou constituir um universo emocional singular e consistente. Estreou em 2 de dezembro de 1877, em Weimar, e ganhou 500 execuções ao longo das três décadas seguintes. Foi Franz Liszt quem garantiu que o espetáculo pudesse ser produzido na Alemanha após ser censurado em Paris devido ao seu teor bíblico. 0 enredo se passa em torno de 1150 a.C. Sansão, um guerreiro hebreu, lidera uma revolta contra os filisteus. Dagon, divindade dos filisteus, ordena que Dalila, a mais bela jovem daquele povo, seduza Sansão e descubra a origem de sua força. Quando descobre que o poder de Sansão reside em seus cabelos, corta-os, torna-o indefeso, e o entrega aos filisteus, que arrancam seus olhos. Sansão é, então, conduzido ao templo de Dagon. Ao ser debochado por seus inimigos, ele roga a Deus por sua força e destrói o templo, matando seus inimigos e a si próprio.

${ }^{4}$ Gustave Flaubert (1821-1880), escritor realista francês, autor de romances como Madame Bovary e L'Éducation Sentimentale.

${ }^{5}$ Anatole France (1844-1924), escritor francês, autor de Thaïs.

${ }^{6}$ Ópera em quatro atos de Saint-Saëns, com libreto de Léonce Détroyat e Armand Silvestre. Estreou em Paris, em 5 de março de 1883. Narra o amor do rei inglês Henrique VIII pela dama Ana Bolena, com quem se casa a despeito do amor da jovem pelo embaixador espanhol, Don Gomez de Feria, e da desaprovação do Papa.

${ }^{7}$ Verso do poema de Louis Gallet para Ascanio, entoado pelo coro de artesãos e aprendizes da oficina de Benvenuto Cellini quando a bela Florentine Scozzone canta Fiorentinelle, uma cantiga do século XVI: "Quand vous chantez, Scozzone! / A nos yeux tout-à-coup rayonne / Le ciel italien si riant et si doux!" (Quando você canta, Scozzone! / Aos nossos olhos de repente brilha / O tão risonho e doce céu italiano!).

${ }^{8}$ Proust se refere à Marche militaire française, quarto movimento da Suite Algérienne, Op. 60, escrita por Camille Saint-Saëns em 1880.
} 
ópera, Ascanio; enfim, para compreender uma religião, detestar um tirano, consolar uma dama, ver Eros, escutar o Eterno, não se pautar pelos recursos da música apenas, mas também da linguagem musical, divertir-se como um deus e como o diabo ao abarcar o mundo com a música, e a música com a harmonia, toda a grandiosidade do órgão com a exiguidade do piano: eis as brincadeiras hábeis, desconcertantes, diabólicas e divinas desse humanista musical que irrompe a cada momento a invenção e o gênio nesse que parecia ser o restrito domínio da tradição, da imitação e do saber. 


\section{Silhueta de artista*1}

\section{(La Revue d'Art Dramatique, janeiro de 1897)}

Trata-se de um tipo. E, ainda que a necessidade de ir com frequência ao teatro e a ilusão de lá se sentir observado tenham proporcionado hábitos de elegância ao senhor que o cultiva, - para ser bem-humorado - ele assina seus artigos como: "o homem do guichê" ou "um brigadista de incêndio", imitando aquele que acende as lâmpadas ${ }^{2}$ ou que vende os programas. Trata-se comumente de um rapaz. De preferência, então, traça silhuetas de atrizes. Adula as belas, tenta lançar aquelas que não possuem talento para seduzi-las, vendendo sua independência para adquirir seus favores. Com as principiantes, sabe assumir um tom paternal. Para os artistas que admira, ele enumera, compara, exalta seus diferentes papeis. "Alternadamente cruel como Nero ${ }^{3}$, melancólico como Fantasio", impetuoso como Ruy Blas ${ }^{5}$, etc.”, tomando ainda emprestado das outras artes os

\footnotetext{
${ }^{1}$ Silhouette d'artiste foi publicado na edição de novembro de 1896/junho de 1897 da Revue d'art dramatique, dirigida pelo jornalista Edmond Stoullig. Mais que um retrato, aqui se está diante de uma silhueta - um dos inúmeros tipos de textos jornalísticos descritivos que se popularizaram na imprensa francesa do século XIX. Diferente de um retrato dito "convencional" (ou de subgêneros como as "lápides", "camafeus" e "bustos"), os registros de silhuetas são sempre escassos o suficiente para que seja delineado, mais que uma individualidade, uma categoria social. São citados Willy e mesmo Félix Duquesnel. Mas se está diante, sobretudo, de uma caricatura bastante irônica da imagem dos jornalistas e críticos teatrais contemporâneos a Proust. "Um tipo", como ele próprio nos aponta, do qual se ridiculariza o pedantismo, as observações piegas e mesmo um certo eruditismo. A tese de doutoramento de Yuri Cerqueira dos Anjos oferece interessante interpretação para esse texto. Ele nota que Proust, ao extrair os traços estilísticos e o comportamento moral do crítico de teatro de um contexto particular (no qual seriam tomados por corriqueiros, banais, de praxe), contribui para ressaltá-los e, nesse sentido, caricaturizá-los. 0 autor estaria, assim, lançando mão de uma forma de moralismo bastante cara a Balzac, delineando o genre "crítico teatral" assim como o autor de $O$ Pai Goriot o faz, por exemplo, com o arrivista Eugène de Rastignac. $C f$. ANJOS, Yuri Cerqueira dos. Marcel Proust et la presse de la Belle Époque: ethos, poétique et imaginaire médiatiques. 2016. 330 f. Tese (Doutorado) - Universidade de São Paulo, São Paulo, 2016.

*Preciso eu dizer que esta silhueta não pretende se assemelhar a ninguém e que todos seus traços são inventados segundo a mais pura fantasia? Se havia na imprensa, por acaso, um "Homem do guichê" ou um "Brigadista de incêndio", queira ele me perdoar por haver desapercebidamente feito uso de seu nome, assim como lhe perdoo por haver sussurrado minha "palavra"; não há nada a se invejar no "vendedor de binóculos". É assim que eu inicialmente assinaria este artigo. E tenho razões bem melhores que a intenção de entregar-me às vezes eu mesmo a ele para não denegrir seriamente um tipo há pouco tempo ilustrado pelo Sr. Henry Gauthier-Villars†.

† Henry Gauthier-Villars (1859-1931), apelidado de Willy, foi crítico musical e romancista francês. No jornal L'Écho de Paris, segundo observação de Clarac e Sandre, ele assinava seus artigos como "l'Ouvreuse du Cirque d'Été" (Lanterninha do Cirque d'Été). Isso lança luz sobre a ironia de Proust, endereçada aos críticos que, arrogando-se elevada posição intelectual e social, assumiam por pseudônimo os nomes dos postos de trabalho mais baixos do mundo artístico (fiscais de ingressos, bombeiros, vendedores de libretos e binóculos, etc.). Willy foi também o primeiro marido da romancista Colette (1873-1954).

${ }^{2} \mathrm{O}$ retrato emprega o termo "quinquets", modelo de arandela inventado ao final do século XVIII pelo químico francês Antoine Quinquet. Trata-se de uma variação da lâmpada criada na década de 1760 pelo físico suíço Aimé Argand (1750-1803) e que era abastecida com óleo.

${ }^{3} \mathrm{O}$ imperador romano Nero, personagem principal da tragédia Britannicus, de Jean Racine (16391699).

${ }^{4}$ Fantasio, personagem principal da peça homônima de Alfred de Musset (1810-1857).

${ }^{5}$ Ruy Blas, personagem principal da peça homônima de Victor Hugo (1802-1885).
} 
termos de suas comparações. Às vezes da música: "o senhor Worms ${ }^{6}$ não poderia interpretar bem esse papel. Não se enquadra a sua voz". Mais comumente da escultura. Ela proporciona baixos-relevos "antigos", "bronzes florentinos", "delicadas tânagras". Somos levados a pintar para louvar as "nuances matizadas" da dicção de Sarah Bernhardt ${ }^{7}$, para reconhecer em Mounet-Sully "um Ticiano que desce de sua moldura" e que "caminha entre nós".

Os grandes artistas não são jamais os mesmos um dia após o outro. Melhor assim, pois a irregularidade é um dos traços do gênio. Um dia, Sarah Bernhardt "buscava visivelmente superar-se". No dia seguinte, ela "estava aquém de si mesma" e "não deu tudo que poderia". Alguns estão "progredindo". Outros, "em um caminho equivocado". Não lhes poupa conselhos. Às vezes um artigo é intitulado: "Um pouco de consciência, senhores da comédia".

Se escapa ao crítico uma locução como "enquanto o senhor Worms se esquiva", ele acrescenta com satisfação "como diria o saudoso Royer-Collard9" ou "se assim ouso me exprimir".

E se o nome do senhor Maubant ${ }^{10}$ "surge sob sua pluma”, ele colocará entre parênteses: "senhores, estão todos envenenados"11.

Com ele, adentramos a intimidade dos artistas. Descobrimos que a senhorita Z., a artista, é espertalhona como uma "ladina" ou uma "astuta mexeriqueira", que o senhor Truffier ${ }^{12}$ é um delicado poeta "quando consegue" e que o senhor Duflos ${ }^{13}$ "é um de nossos mais intrépidos ciclistas".

E, sua vida privada, também nós a conhecemos, pois, diante de sua necessidade de se revelar, seu pensamento lhe parece muito impessoal, e ele nos entrega seus hábitos. Descobrimos que, em um jantar na cidade na noite de uma estreia, ele partiu antes do café para não se atrasar e as cortinas se ergueram muito tempo depois. Ele toma o partido do público,

\footnotetext{
${ }^{6}$ Gustave-Hippolyte Worms (1836-1910) foi ator da Comédie-Française.

${ }^{7}$ Sarah Bernhardt (1844-1923), uma das mais célebres atrizes francesas da segunda metade do século XIX e do início do século XX. É frequentemente citada por Proust em sua correspondência. Foi um dos modelos para a construção da personagem Berma, de Em busca do tempo perdido.

${ }^{8} \mathrm{Cf}$. nota de rodapé 6 do retrato A pessoa de Alphonse Daudet: "obra de arte".

${ }^{9}$ Pierre-Paul Royer, chamado Royer-Collard (1763-1845), foi um filósofo e político liberal francês. Figura intelectual relevante da Restauração bourbônica, advogou pelo sistema monárquico parlamentarista.

${ }^{10}$ Henri-Polydore Maubant (1821-1902) foi ator da Comédie-Française.

${ }^{11} \mathrm{O}$ grito de Lucrécia Bórgia, na $2^{2}$ cena do $3^{3}$ ato da peça homônima de Victor Hugo: "Je viens vous annoncer une nouvelle, c'est que vous êtes tous empoisonnés, messeigneurs, et qu'il n'y en a pas un de vous qui ait encore une heure à vivre" (Eu lhes trago novas. Todos vocês, meus senhores, estão envenenados e não há ninguém que possua mais que uma hora de vida. Cf. HUGO, Victor. Théâtre Complet. Paris: Gallimard, Bibliothèque de la Pléiade, Tome II, 1964, p. 399).

${ }^{12}$ Jules-Charles Truffier (1856-1943) foi ator da Comédie-Française.

${ }^{13}$ Raphaël Duflos (1858-1946) foi ator da Comédie-Française.
} 
(paródia de um verso conhecido) ${ }^{14}$, incrimina a administração do vaudeville, questiona o diretor da Beaux-Arts ${ }^{15}$. Dentro de dez anos, ele reunirá suas "silhuetas", suas "pontas secas" e suas "sanguíneas". Na primeira página, uma carta do senhor Duquesnel ${ }^{16}$ significará que ele aceita a dedicatória. No momento, ele tenta ingressar na Revue d'art dramatique.

${ }^{14} \mathrm{O}$ verso originalmente citado por Proust é: De celui qui paye, le vrai. Trata-se de uma paródia de origem obscura. A julgar pelo tom irônico constante neste retrato, Proust está propositalmente considerando como "célebre" algo que, com efeito, toma por "banal" e que qualquer um poderia escrever.

${ }^{15} \mathrm{~A}$ École Nationale Supérieure des Beaux-Arts de Paris, à época deste retrato chamada apenas École Nationale des Beaux-Arts. Em 1887, sua direção passa do escultor Paul Dubois ao crítico de arte Jules-Antoine Castagnary.

${ }^{16}$ Félix Duquesnel (1832-1915) foi romancista, dramaturgo e crítico do jornal Le Gaulois. 


\section{A pessoa de Alphonse Daudet: "obra de arte"1}

\section{(La Presse, 11 de agosto de 1897)}

Em alguns raros artistas, o corpo recebeu, assim como a alma, a forma da beleza. A contemplação de seus seres materiais sob a forma de uma de suas obras não da menos pessoal - nos proporciona esse prazer onírico que chamamos de prazer estético. Seus retratos - seja aquele do senhor de Goncourt feito por Bracquemond $^{2}$ ou o do senhor de Montesquiou feito por Whistler ${ }^{3}$ - não atendem apenas, como os demais retratos de homens de letras, à pasmaceira do público que desfila de ano em ano por exposições, tão curioso pela calvície de um romancista quanto pela corpulência de um vaudevilista. Ressaltam o pintor na mesma medida que o crítico, pois seu pensamento delineia não apenas o caráter de seus traços, mas também o caráter de seus livros.

\footnotetext{
${ }^{1} \mathrm{O}$ retrato de Alphonse Daudet, tal como aqui se encontra, corresponde à tradução da versão manuscrita de Proust, arquivada na Biblioteca Nacional da França (Caderno NAF 16636, fólios 45ro$47 \mathrm{v}^{0}$ ). Outra versão desse texto foi publicada por Proust na edição de 11 de agosto de 1897 do jornal La Presse (página 2), sob o título de Opinions sur M. Alphonse Daudet. Acompanho a opinião de Pierre Clarac e Yves Sandre nos Essais et articles da Bibliothèque de la Pléiade. Para eles, a versão manuscrita se encontra mais bem acabada que aquela publicada no jornal. Uma leitura superficial indica sem maiores dificuldades períodos mal construídos, de sentido obscuro. Acrescento outro ponto a essa crítica: sob a pena de Proust, não há senão a edição do próprio autor, em seu processo de criação, ao passo que, na transposição para o jornal, a participação de outros agentes editoriais é possível e provável. Pareceu-me preferível a escolha do texto que mais puramente representaria o estilo descritivo do autor.

A propósito das relações de Proust com a família Daudet, recomenda-se a leitura do artigo Léon Daudet, de Laurence Teyssandier (TEYSSANDIER, Laurence. Léon Daudet. In TADIÉ, Jean-Yves (org.). Le Cercle de Marcel Proust II. Paris: Honoré Champion, 2015, p.45-64). Nesse estudo, seu autor formula uma interessante hipótese para a forma como Proust, descendente direto de judeus, preservou ao longo do tempo sua amizade com o filho mais novo de Alphonse, o também escritor Léon Daudet, a despeito do antissemitismo radical daquela família. Para Teyssandier, Proust sempre buscou sobrepor às posições políticas de um indivíduo considerações sobre seu caráter particular e vocação artística. Ele cita o anedótico episódio em que Proust, sob o frenesi gerado pelo Affaire Dreyfus, reuniu harmoniosamente em sua casa, para um jantar, partidários e opositores do capitão judeu acusado de conspiração. E cita uma frase de Proust reproduzida por Daudet em seus Souvenirs: "Monsieur, em vérité, Monsieur, tout dépend de la façon dont s'accrochent, dès le premier contact, les caractères" (Senhor, na realidade, Senhor, tudo depende do modo como se chocam, desde o primeiro contato, os caracteres. Cf. DAUDET, Léon. Souvenirs et polémiques. Paris: Robert Laffont, 1992, p. 505). É possível que a longeva amizade de Proust com os Daudet se deva, de fato, a esse "choque primeiro de caracteres". Ele foi apresentado a Alphonse Daudet e sua esposa, Julia, no salão de Arthur Baignières, no final de 1894 e, só em seguida, por obra de Reynaldo Hahn, acabou convidado a frequentar a residência do casal. Ao mesmo tempo em que lhes criticava certa "vulgaridade" e a "mania de julgar tudo segundo a raça", também reconhecia a "ternura" daquele "clã" (Cf. TEYSSANDIER, Laurence. Op. cit. p. 46). Em 1896, cerca de um ano antes da publicação desse retrato, Proust passa uma semana de férias ao lado de Léon em um hotel de Fontainebleu. Foi nesse período que o filho de Alphonse Daudet escreveu seu sexto romance, Suzanne, e que Proust trabalhava no que viria a ser o inacabado Jean Santeuil.

${ }^{2} \mathrm{O}$ retrato de Edmond de Goncourt (1882), gravura de Félix Bracquemond (1833-1914) com impressão em água forte. Uma das cópias se encontra em posse do Metropolitan Museum of Art de Nova York.

${ }^{3}$ O retrato do conde Robert de Montesquiou-Fezensac (1891-1892), óleo sobre tela do pintor norteamericano James McNeill Whistler (1834-1903). Compõe hoje a Frick Collection de Nova York.
} 
Já se disse tudo sobre o senhor Daudet artista: gostaria hoje de tratar do senhor Daudet obra de arte.

É uma obra de arte única se for verdade que, em todas as outras, o ardor do sentimento, do poder expressivo, confunde a pureza plástica das linhas como a fusão de uma medalha lhe apaga a efígie. Na figura do senhor Daudet, a intensidade do sofrimento não alterou a perfeição da beleza. A glória dessa fronte, na qual os cabelos se dividem como em duas asas poderosas e leves, não é apenas aquela de um mártir. É aquela de um deus ou de um rei. Porque o charme real, a naturalidade soberana das formas e atitudes, a nobreza visível existem para além da imaginação dos esnobes, dos romances para porteiros. Menos física que a beleza, menos espirituosa que a nobreza do espírito e do caráter, ela é, se preferirmos, o hábito dessa nobreza, isto é, essa nobreza tornada inconsciente, convertida em belas linhas do corpo e do rosto, em movimentos amplos e simples, uma nobreza que se incorporou. Os esnobes se enganam apenas ao procurá-la sobre o trono onde raramente se encontra. Nesse sentido, o senhor Alphonse Daudet é um rei, um rei mouro, de face enérgica e fina como o ferro de um gradeado sarraceno ${ }^{4}$. Consigo também reconhecer verdadeira graça real em um rei e em um aspirante. Está no Carlos I pintado por Van Dyck ${ }^{5}$ e no príncipe Hamlet interpretado por MounetSully 6 .

Mas, se me fosse permitido por um instante considerar o senhor Daudet como um espetáculo, o faria agora para poder lhe desvencilhar da cômoda grandiosidade. Quando estive pela primeira vez diante do senhor Daudet, dificilmente lhe ousava dirigir o olhar. Eu sabia que, há dez anos, ele sofria de modo tão atroz que precisava injetar morfina várias vezes ao dia. Tão logo se deita, suas dores tornam-se insuportáveis e, toda noite, ele traga um frasco de cloral para adormecer ${ }^{7}$. Eu não compreendia, no entanto, como ele conseguia continuar produzindo. Recordava-me, sobretudo, de quantos sofrimentos, tão amenos perto dos seus que ele os teria, sem dúvida, aproveitado como uma trégua, me haviam tornado indiferente aos outros, à vida, a tudo aquilo que não era meu corpo infeliz, para o qual meu espírito obstinadamente se voltava, assim como um doente que, em seu leito, mantém a cabeça contra a parede. Então, sem compreender como pôde resistir a esses ataques diários de dor, sentia que minha imagem devia serlhe um tédio, minha boa saúde, um insulto, minha própria vida, uma

\footnotetext{
${ }^{4}$ Sandre e Clarac observam que "sarrasine", no sentido empregado por Proust, representa um tipo de gradeado presente em fortificações mouriscas. Preferi a opção "gradeado sarraceno", esclarecendo a metonímia, para evitar a incompreensão do leitor contemporâneo.

${ }^{5} \mathrm{O}$ Retrato Equestre de Carlos I (1637-1638), óleo sobre tela da primeira metade do século XV, de autoria do pintor flamengo Anthony Van Dyck (1599-1641). Hoje compõe o acervo da National Gallery de Londres.

${ }^{6}$ Jean-Sully Mounet (1841-1916), célebre ator da Comédie-Française. Interpretou Hamlet, de William Shakespeare, em 1886.

${ }^{7}$ Proust emprega "chloral" como metonímia de hidrato de cloral, um forte anestésico. Alphonse Daudet padeceu de sífilis e, nos últimos anos de vida, viu a doença atingir o sistema nervoso central. Daí as fortes dores que Proust nos narra e que obrigavam Daudet a receber injeções de morfina.
} 
inconveniência. Nesse instante, vi aquela coisa sublime, que nos leva a enrubescer, nós, covardes que somos, ou melhor, segundo a palavra daquele através de quem descobrimos ser não doentes e servos, mas espíritos e reis, que nos faz levantar, reumáticos ou paralíticos, que nos acalma, febris, nos oferece aos outros, egoístas, nos leva a refletir, escravos todos do prazer ou do sofrimento carnal: eu vi esse belo doente, que o mal ainda embelezava, esse poeta, ao lado de quem o sofrimento tornava-se poesia, assim como o ferro se incendeia em meio ao fogo, que sorria, desapegado de si próprio e tudo para nós ${ }^{8}$, preocupado com meu futuro e de seus demais amigos, que celebrava a alegria, o amor, a vida, que ele aproveitava melhor que muitos de nós, continuando a pensar, a compor, a ditar, a escrever, apaixonado como um jovem pela verdade, pela beleza, pela coragem, conversando conosco sem parar e, o mais heroico, ainda nos escutando. Em uma conversa, ele saiu por um instante e, da porta, soltou algumas palavras inflamadas e ardentes. Ao retornar, animou-se novamente com o mesmo calor. Soube que a volta de suas dores fora tão violenta que, para disfarçá-las, se injetara morfina. Sua testa brilhava em gotas de suor. Parecia sair de uma luta, mas respirava a tranquilidade da vitória. Sobre sua linda face, em seus olhos, onde ainda havia a "chama" da juventude, já se via "luz", segundo o belo verso de Victor Hugo, e eu vislumbrava o combate entre a luz, o pensamento, Hélio e os pérfidos espíritos da noite ${ }^{9}$. Hélio venceu, lentamente recolhendo-lhes ao reino sombrio. Há um ano, o senhor Daudet se sente melhor. Após uma viagem ${ }^{10}$, último ato de heroísmo, que parecia lhe custar a vida, ela lhe retornou. Em seu corpo, não havia mais esperança. Pois bem! De toda a força dessa energia que enfrentou inimigos na guerra de $70^{11}$, e que teve de ser centuplicada nesse combate silencioso, nessa temerosa batalha ora sentada, ora deitada contra o inimigo, é sua alma que recriou a esperança, a vida.

"O senhor Daudet está melhor": essa é uma frase que ninguém consegue ouvir sem espanto, como qualquer frase que, revelando em nós misteriosas lembranças anteriores à vida, eleva sobre a lei de ferro da necessidade física a lei da luz da onipotência da alma. É por isso que sempre vou, e todo homem seria feliz e favoreceria o espírito visitando com frequência a rue de Bellechasse, em peregrinação a essa obra de arte delicada e sublime que é o senhor Daudet, e onde a natureza, em uma linguagem expressiva e vivaz diversamente da nossa, por meio

\footnotetext{
${ }^{8}$ Conforme bem aponta Sandre e Clarac nos Essais et articles, o excerto "détaché de lui-même et tout à nous" é mais uma referência religiosa desse retrato e faz alusão a uma expressão do apóstolo Paulo (I. Cor. IX, 22), omnibus omnia factus (fiz-me tudo para todos). Em conjunto, esses signos sustentam uma importante metáfora, que é a semelhança entre a aparência física de Daudet e a representação ocidental hegemônica do Cristo.

${ }^{9} \mathrm{O}$ verso de Victor Hugo é "Mais dans l'oeil du vieillard on voit de la lumière" (Mas no olho do velho vemos luz), parte do poema Booz endormi, da antologia La légende des siècles. Proust se baseia em um jogo de antíteses de Hugo, que associa a chama ao jovem e a luz aos mais velhos como quem contrapõe o material passageiro ao fenômeno perene, àquilo que se eterniza. $C f$. HUGO, Victor. $L a$ légende des siècles. Paris: Gallimard, Bibliothèque de la Pléiade, 1950.

${ }^{10}$ Em consulta aos diários dos irmãos Jules e Edmond de Goncourt, Sandre e Clarac verificaram que, em maio de 1895, Daudet esteve por três semanas em Londres.

${ }^{11}$ A Guerra Franco-Prussiana, de julho de 1870 a maio de 1871.
} 
de pupilas mais transparentes que nosso estilo, mais profundas que nossos pensamentos, uma pele mais puramente colorida que nossas imagens e o rude vocabulário de músculos retorcidos de sofrimento e recompostos pela energia, nos inebria de todo sentido de dor, de beleza, de desejo e do espírito onipotente. 


\section{Robert de Flers ${ }^{1}$}

\section{(La Revue d'art dramatique, 20 de janeiro de 1898)}

De todos os jovens que se iniciaram nas letras há alguns anos, o senhor Robert de Flers é, quem sabe, o único que não tenha de dizer a si próprio: "talvez não seja mais que um fracassado. Talvez tenha trocado o certo pelo duvidoso. Minha vocação para escrever - que, por sinal, todos os outros homens de letras, e, no entanto, os únicos competentes, negam - se manifesta, sobretudo, em minha falta de vocação para todo o resto, pela carência total das diversas qualidades que, na vida, conduzem ao sucesso. Sou talvez um Gustave Flaubert, mas talvez não seja

\footnotetext{
${ }^{1} \mathrm{O}$ retrato Robert de Flers foi publicado em 20 de janeiro de 1898 na Revue d'art dramatique. Não há qualquer assinatura, o que torna a autoria atribuída a Proust em alguma medida difícil de ser confirmada. No entanto, o estilo proustiano aqui, com efeito, salta aos olhos: grandes períodos, fartos em subordinações que quase sempre reservam para seu final as orações principais, sem contar longas e rítmicas enumerações a desembocar em alguma formulação de natureza essencialista, característica da busca (jamais concluída) desse autor pelas verdades interiores (mas sempre fugidias) de seus personagens ou modelos. Some-se a isso a profunda amizade que uniu ao longo da vida Marcel Proust a Robert de Flers. Os dois se conheceram ainda na adolescência, quando alunos do Liceu Condorcet, em Paris. Lá também integraram seu círculo de amizades o poeta Fernand Gregh e o historiador Daniel Halévy. A correspondência entre os dois escritores é vasta e testemunha a intimidade erigida entre os dois. Suas cartas tratam do luto pela morte de amigos e familiares (como a avó materna de Flers, Madame de Rozière, e seu principal colaborador, Gaston Arman de Caillavet) à alegria pela eleição do dramaturgo à Academia Francesa e sua condução a um posto da direção do jornal Le Figaro. Por sinal, mesmo enfermo, Proust trabalhou pela candidatura de seu amigo ao Quai de Conti. No início de fevereiro de 1920, quando Flers começa a desacreditar suas chances, Proust lhe escreve: “J'ai eu une grande joie dernièrement. Des membres de l'Académie Française avec qui je suis en contact sans avoir d'ailleurs de vues pour moi de ce côté, m'ont assuré que ton éléction en Juin était certaine" (Tive uma grande alegria recentemente. Membros da Academia Francesa com os quais estou em contato, por sinal sem esperar algo em troca, me asseguraram que sua eleição em junho era certa. $C f$. PROUST, M. Correspondance de Marcel Proust. Paris: Plon, 1991, tomo XIX, p. 110). De fato, Flers foi eleito para a Academia em 3 de junho daquele mesmo ano. Proust também escreveu uma importante carta ao dramaturgo entre os dias 6 e 8 de novembro de 1913, às vésperas da publicação de No caminho de Swann. Falando em nome de seu editor, Bernard Grasset, ele pede a Robert de Flers "qu'on annonçât dans um écho du Figaro la prochaine apparition de mon livre" (que fosse anunciado em um écho do Figaro o próximo lançamento de meu livro. Cf. PROUST, M. Correspondance de Marcel Proust. Paris: Plon, 1984, tomo XII, p. 298). 0 que segue na mesma carta à Flers é um importante testemunho de Proust quanto ao seu projeto editorial: "Mon livre [...] est une 'indiscrétion' littéraire (langage d'éditeur). L'ouvrage total s'appellera à la Recherche du Temps Perdu [;] le volume qui va paraître (dédié à Calmette*) : Du côté de chez Swann. Le second Le côté de Guermantes, ou peut'être À l'ombre des Jeunes Filles en fleurs ou peut'être Les Intermittences du Cøur. Le troisième : Le Temps Retrouvé ou peut'être l'Adoration Perpétuelle. Ce qu'il faut dire c'est que ce ne sont nullement mes articles du Figaro mais un roman à la fois plein de passion, et de méditation et de paysages" (Meu livro [...] é uma 'indiscrição' literária (linguajar de editor). A obra total se chamará à la Recherche du Temps Perdu [;] o volume que será lançado (dedicado a Calmette): Du côté de chez Swann. 0 segundo, Le côté de Guermantes, ou talvez À l'ombre des Jeunes Filles en fleurs ou talvez Les Intermittences du CeEur. 0 terceiro: Le Temps Retrouvé ou talvez l'Adoration Perpétuelle. É preciso dizer que não se trata em nada dos meus artigos do Figaro, mas sim de um romance ao mesmo tempo repleto de paixão e de meditação e de paisagens. Cf. PROUST, M. Idem).

* Gaston Calmette (1858-1914), jornalista e diretor do Le Figaro.
} 
mais que o Frédéric Moreau da Educação Sentimental"”. O senhor de Flers é talvez o único que não possa dizer isso; que, a cada dia, não digo apenas que possua um novo sucesso, mas uma nova ação, o que significa algo totalmente distinto. Ele encontrou na vida o perfeito meio de adaptação para seus dons. E isso é tão mais admirável, revela nele, a meu ver, um poder tão mais maravilhoso e raro que, diferente de tantos outros, e me refiro àqueles de primeiro escalão, nele os dons eram múltiplos, quase poderia dizer universais. Imaginem isso: o senhor de Flers abordou a realidade que jaz no fundo da vida quase que por todos os lados. Aos seus inúmeros aspectos, seu espírito pareceu bastante multiforme [para] ${ }^{3}$ quase se emparelhar 4 . Aos vinte anos eu o vejo, versejador louvado pelos versejadores, sentindo no fundo, por exemplo, os versos de Mallarmé ${ }^{5}$, as frases de Barrès ${ }^{6}$, escrever deliciosas novelas, sem deixar que uma lenda, que um fato sequer passe sem lhe extrair o sentido e a poesia; nesses tempos, seguir mar afora seu itinerário de Paris a Jerusalém, relatá-lo nesse livro de viagem que não se contenta em agradar os letrados, mas que interessa aos sábios, que é coroado pela Academia7. Não se perde para ele nenhuma gota da vida. Enquanto se torna mais sábio, examina com minúcia as coleções de autógrafos, de peças originais que todos sonhamos ler, mas nas quais jamais meteríamos o bedelho ${ }^{8}$, ele é o crítico literário e dramático de diversos jornais. Ele apresenta tanto a febre do presente como do passado. E sequer um entusiasmo provocou os expectadores de um teatro dramático ou de um café-concerto - esses estranhos entusiasmos que, por vezes, os velhos sábios lamentam, no fim de suas vidas, não terem conhecido, temendo terem escolhido o caminho errado - sem que ele, jovem sábio, não se extasiasse por uma hora para, depois, poder racionalizá-lo. Vocês pensam que isso é tudo. Mal sabem como se enganam. Entreguem-se à mesma feliz surpresa do admirador de sir John Lubbock ${ }^{9}$, o grande naturalista, quando descobre que o Lubbock, grande

\footnotetext{
${ }^{2}$ Frédéric Moreau é o herói de L'Éducation sentimentale, um dos mais célebres romances de Gustave Flaubert (1821-1880) e marco do realismo francês. Jovem arrivista, deixando o campo para estudar em Paris, ele paulatinamente vê os amores, a arte, a política e a sociedade burguesa levarem abaixo os ideais românticos que alimentaram o imaginário dele e de sua geração.

${ }^{3}$ A preposição entre colchetes, inexistente no texto publicado na Revue d'art dramatique, foi introduzida por Clarac e Sandre para cumprir com a demanda regencial da expressão adverbial "assez multiforme" seguida do infinitivo "faire".

${ }^{4} \mathrm{O}$ advérbio "quase" delimita uma ressalva importante em se tratando de Proust. Vê-se como o autor, para além dos momentos de criação do romance, sempre teve muito cara a si a ideia de que a vida, entendida como essência dos seres, não pode ser mais do que intuída. E mesmo os homens de intelecto mais elevado não puderam senão apenas se aproximarem dela.

${ }^{5}$ Stéphane Mallarmé (1842-1898), poeta simbolista francês, foi professor de inglês de Proust e Flers no Liceu Condorcet.

${ }^{6}$ Maurice Barrès (1862-1923), escritor francês, autor de romances como a trilogia Le culte du moi e Les déracinés.

${ }^{7}$ Flers foi premiado em 1896 pela Academia Francesa pelo romance Vers l'Orient, narrativa de viagem publicada após uma expedição pela Ásia e pelo Oriente Médio.

${ }^{8}$ Proust emprega a expressão popular "mettre le nez", que deve ser compreendida como "ingerência" ou mesmo "intromissão".

${ }^{9} \mathrm{O}$ banqueiro inglês John Lubbock (1834-1913), barão de Avebury, um dos precursores e entusiastas da arqueologia enquanto disciplina científica.
} 
dirigente de difíceis empresas comerciais, é a mesma pessoa. Entreguem-se à mesma feliz surpresa ao descobrir que esse erudito, esse poeta, esse romancista, esse publicitário é a mesma pessoa, o mesmo jovem diretor que, desde quando assumiu os Escholiers, tornou-o um teatro no qual, graças ao seu gosto de grande letrado e sua incrível autoridade sobre os homens, artistas como Granier, Mayer, de $\mathrm{Max}^{10}$ interpretam autores como... todos os mais notórios autores do momento. - E se forem a Lozère ${ }^{11}$, se souberem que todos os camponeses têm apenas um nome na boca, aquele do rapaz que vive da própria vida, que toma tanto as dores daqueles que alhures teriam tido seu direito à justiça e à caridade ignorado, que faz de sua região uma espécie de província feneloniana ${ }^{12}$, que diriam vocês ao saber que Robert de Flers, que lá queriam tanto tornar deputado ${ }^{13}$, é ainda e sempre o mesmo? Isso não é tudo, mas é, por hoje, o bastante. E admirem comigo aquele que lhes revela que o talento e o sucesso, que a arte e a vida, que os prazeres da vida e o talento, que a grandeza moral e a estima do povo não são inconciliáveis ${ }^{14}$.

De tal modo que, único dentre todos nós, ele me parece se empenhar sobre a única coisa que importa: transformar a vida ao nosso redor, de modo que ela se torne, no lugar da fortaleza da ignorância, o templo do belo; no lugar do covil do mal, o retiro da justiça. Por que isso? Porque ele tem os dons que aqueles que são talentosos, que conhecem as leis da justiça e desejam seu reinado ${ }^{15}$ (as quais, mundo afora, não são sempre iguais, mas que, nele, se mantêm o mesmo) nunca possuem. Sem dúvida, poderíamos citar outros que são grandes letrados, mas

\footnotetext{
${ }^{10}$ Três artistas dirigidos por Robert de Flers no teatro Les Escholiers. Jeanne Granier (1852-1939), uma das cantoras líricas de maior sucesso na Belle Époque parisiense; Édouard de Max (18691924), ator franco-romeno que passou a integrar a Comédie Française em 1915; e Henry Mayer (1857-1941), ator francês que interpretou em 1923 a peça Monsieur Brotonneau, escrita por Robert de Flers e Gaston Arman de Caillavet.

${ }^{11}$ Departamento de Lozère, região de Languedoc. Também citado no retrato fúnebre de Madame de Rozière, avó maternal de Robert de Flers.

${ }^{12}$ Relativo ao teólogo François Fénelon, principal representante francês do quietismo, doutrina cristã e mística que apregoa a passividade dos seres perante Deus, pressupondo que a alma, quando em repouso, harmoniza-se com a divindade e se une a ela. Fénelon foi um dos maiores opositores de Jacques Bossuet na celeuma produzida pelo quietismo no catolicismo francês do final do século XVII e início do século XVIII. O religioso também caiu em desgraça ao contestar a opressão e o autoritarismo do reinado de Luís XIV. 0 adjetivo "feneloniano", aludiria, assim, a algo que prima por uma discreta elevação espiritual ao mesmo tempo em que se opõe a demonstrações de soberba e poder dos mais fortes contra os mais fracos.

${ }^{13}$ Era forte e bastante conflituosa a tradição política em ambos os ramos da família de Robert de Flers. Seu pai era um convicto monarquista e ocupara cargos de confiança na prefeitura de Pontl'Évêque. Quando deixou o serviço público e se mudou com a família para Paris, causou-lhe enorme incômodo ter de morar na mesma residência de seu sogro, o senador Eugène de Rozière, um republicano, autodeclarado político de centro-esquerda. $C f$. FLERS, Philippe de; FLERS, Pauline de. Robert de Flers: du théâtre à la Coupole. Paris: Honoré Champion, 2013.

${ }^{14} \mathrm{~A}$ repetição "vida" e "prazeres da vida", bem como da palavra "talento", também ocorre no original francês: "Et admirez avec moi celui qui vous apprend que le talent et le succès, que l'art et la vie, que les jouissances de la vie et le talent [...]". Cf. CSB, p. 404.

${ }^{15}$ Há uma boa razão para a grande quantidade de menções ao senso de justiça de Robert de Flers. Seu retrato foi publicado em meio à efervescência do Affaire Dreyfus, que tanto tocou Proust, descendente de judeus pelo ramo materno da família. Uma semana antes era publicada no jornal L'Aurore a carta J'accuse!, de Émile Zola, endereçada ao presidente Félix Faure.
} 
acreditam vocês que saberiam impor-se como autores de talento, dirigir um teatro segundo seus gostos, conversar nem que seja com uma atriz? Serão incríveis e impotentes. Sem dúvida, no fundo, há outras pessoas de bom coração. Mas são elas as mesmas que saberão falar às pessoas, fazê-las amá-las, levá-las a acreditá-las, conduzi-las aonde desejam? Sem dúvida há outros artistas refinados deleitando-se nas volúpias mais sutis que o baudelairianismo descobriu no mundo moral. Mas esses não serão nem eruditos, nem a todo momento letrados, quase jamais tomados pela realização de ideias de justiça na sociedade, certamente jamais capazes de assegurar esse feito. Robert de Flers é sobretudo isso. Se me espantasse a multiplicidade de suas ideias, se me questionasse onde se encontra o fundo permanente e sólido de tudo isso, eu procuraria rever aqueles que o conhecem melhor, que, após todo o sucesso em Paris, o reveem sempre igual, todo entregue a eles: os camponeses que testemunham a grandiosidade de seu caráter, em última instância a real medida de seu valor. 
John Ruskin ${ }^{1}$

\section{(La Chronique des Arts et de la Curiosité, 27 de janeiro de 1900)}

Temíamos outro dia pela vida de Tolstoi²; esse infortúnio não se realizou; mas o mundo não sofreu uma perda menor: Ruskin morreu ${ }^{3}$. Nietzsche ${ }^{4}$ enlouqueceu, Tolstoi e Ibsen ${ }^{5}$ parecem ao final de suas carreiras; a Europa perde um após o outro seus grandes "mestres espirituais". Mestre espiritual de seu tempo certamente Ruskin o foi, mas foi também seu professor de estilo, seu preceptor nessa beleza que Tolstoi reprova em nome da moral e que Ruskin poetizou toda, até a própria moral.

Ele nasceu em 1819, no no 54 da Hunter Street, ao lado do Brunswick Square, filho de um mercador de vinhos, que, mais tarde, adorou tomar como o

\footnotetext{
${ }^{1}$ O retrato fúnebre de John Ruskin (1819-1900) é publicado em 27 de janeiro de 1900 na Chronique des arts et de la curiosité, com a assinatura "M.P.". O crítico inglês, autor de uma vasta e diversificada obra, notabilizado, dentre outros temas, por seus escritos sobre a pintura vitoriana e pré-rafaelita, foi um dos autores de maior apreço de Proust. Segundo Jérôme Bastianelli, apoiando-se em comentários de Henri Lemaitre, Ruskin foi "o profeta" do jovem Proust (Cf. BASTIANELLI, Jérôme. Ruskin, le prophète de Proust?. In RUSKIN, John; PROUST, Marcel. La bible d'Amiens, Sésame et les lys et autres textes. Paris: Robert Laffont, 2015, p. VII-XXXI). Os primeiros contatos com textos desse pensador inglês se deram através de algumas traduções publicadas no Bulletin de l'Union pour l'action morale, do jornalista Paul Desjardins (1859-1940). Mas foi o artigo Ruskin et la religion de la beauté, publicado por Robert de la Sizeranne (1866-1932) na Revue des deux mondes de março de 1897, que mais impactou Proust. Ao final da década de 1890, momento em que trabalhava em Jean Santeuil, romance que resultaria inacabado, Proust já conhecia parcela substantiva da obra de Ruskin. Foi-lhe particularmente marcante a leitura de Praeterita (1885), narrativa autobiográfica escrita por Ruskin já ao final da vida, e que o pesquisador John Gerard Coyle chamou de "a obra em língua inglesa mais próxima de Em busca do tempo perdido" (Cf. COYLE, John Gerard. Proust and Ruskin: a study in influence. Tese de doutoramento, Universidade de Glasgow, 1987). De Ruskin, Proust traduziu duas obras, La Bible d'Amiens (1904) e Sésame et les lys (1906), que contém seu célebre prefácio Sur la lecture. Como não dominava a língua inglesa, contou com o auxílio de amigos e mesmo de sua própria mãe. Mas seria equivocado inferir alguma falta de rigor de Proust a partir da barreira que o idioma representava para ele. Embora intelectuais da época apontassem esses esforços como "contrassensos" (caso de Constantin de Brancovin. Cf. PROUST, M. Correspondance de Marcel Proust. Paris: Plon, 1978, tomo IV, p. 38), a correspondência do autor é repleta de cartas nas quais busca soluções para suas dúvidas de inglês. Por sinal, sua insistente procura por correções e aprimoramentos chegou a tal ponto que, em uma carta com uma série de questões endereçada a Marie-Louise Nordlinger-Riefstahl (1876-1961), prima inglesa do companheiro Reynaldo Hahn, Proust desabafa: "ce veillard commence à m'ennuyer" (esse velho está começando a me aborrecer. Cf. PROUST, M. Correspondance de Marcel Proust. Paris: Plon, 1978, tomo IV, p. 49). A seus críticos, Proust dizia com frequência: "não tenho a pretensão de entender inglês, tenho a pretensão de entender Ruskin" (Cf. PROUST, M. Correspondance de Marcel Proust. Paris: Plon, 1978, tomo III, p. 38). A opinião de Bastianelli se alinha a esse argumento: "mais que a língua inglesa, ele aprendeu aquela de Ruskin" (Cf. BASTIANELLI, Jérôme. Op. cit. p. XIII).

${ }^{2}$ Leon Tolstoi (1828-1910), escritor russo, autor de romances como Guerra e Paz e Anna Karenina.

${ }^{3}$ Ruskin morreu em 20 de janeiro de 1900, em Coniston Lake, próximo à cidade de Brantwood, no norte da Inglaterra, onde adquiriu uma propriedade após deixar a carreira docente em Oxford.

${ }^{4} \mathrm{O}$ filósofo Friedrich Nietzsche, nascido em 1844 e morto em agosto de 1900, poucos meses após John Ruskin e a publicação desse retrato.

${ }^{5}$ Henrik Ibsen (1828-1906), dramaturgo norueguês, autor de peças como Um inimigo do povo.
} 
modelo do comerciante precavido e probo, e de uma ardente calvinista ${ }^{6}$. Seu pai possuía o hábito de viajar todos os anos em um carro que alugava e conduzia a família a tudo o que, recantos da natureza ou monumentos artísticos, pudesse formar seu gosto. 0 de Ruskin foi logo cedo ardente e decidido, e o Sr. de La Sizeranne contou as emoções que sentiu a criança na primeira vez que viu as montanhas ${ }^{7}$. Ele já experimentava paixões pelas coisas com uma idade na qual, geralmente, não as sentimos ainda pelas pessoas. É, como ocorre com frequência, nos seus últimos livros que ele se debruçou sobre a descrição de sua juventude. Ela preservara em sua memória um encantamento inapagável eternizado nesse livro de Praeterita $^{8}$, espécie de autobiografia como aquela que já havia esboçado em Fors Clavigera ${ }^{9}$, e que corresponde, na obra de Ruskin, a Poesia e Verdade ${ }^{10}$ na obra de Goethe.

A Gazette des beaux-arts ${ }^{11}$ terá a honra, numa próxima edição, de oferecer da obra de Ruskin uma ideia, senão completa, ao menos fiel, e sem dúvida menos preocupada em lhe proporcionar uma análise total do que em lhe atribuir uma impressão justa. Não poderíamos aqui tentar sequer resumir-lhe o catálogo, que, tal como nos ocorre, organizado metodicamente pelo discípulo preferido de Ruskin, seu sábio amigo, o Sr. Collingwood ${ }^{12}$, compreende mais de 160 títulos diferentes. Sempre ornamentados e como que revestidos em seus desenhos por um tipo de misteriosa obscuridade, vários desses títulos são hoje, por sinal, familiares aos letrados e artistas. As sete lâmpadas da arquitetura (1849), As duas veredas (1859), Munera Pulveris (1862-1863), Sésamo e os lírios (1865), A coroa da oliveira selvagem (1866), A rainha do ar (1869), Aratra Pentelici (1872), Ariadne Florentina (1873), Deucalion (1875-1883), Manhãs de Florença (1873-1877), Proserpina (1873-1886), As leis de Fésulas (1877-1878), O repouso de São Marcos (1878-1884) e As três colunas do Pré-rafaelismo (1878) ${ }^{13}$ são agora, assim como Pintores modernos (1843) e As pedras de Veneza $(1851)^{14}$, verdadeiros breviários

\footnotetext{
${ }^{6}$ Ruskin foi filho único de John James Ruskin (1785-1864) e Margaret Ruskin (1781-1871), primos de primeiro grau.

${ }^{7} \mathrm{Cf}$. nota 1.

${ }^{8} \mathrm{Cf}$. nota 1.

${ }^{9} \mathrm{Cf}$. nota 13 .

${ }^{10}$ Aus meinem Leben: Dichtung und Wahrheit, romance autobiográfico do escritor alemão Johann Wolfgang von Goethe (1749-1832).

${ }^{11} \mathrm{~A}$ Gazette des beaux arts, revista fundada em 1859 por Charles Blanc. A Chronique des arts et de la curiosité, onde é publicado esse retrato, era seu suplemento. Em 1900, Proust publica um grande artigo a respeito de Ruskin, a primeira parte em abril e a segunda em agosto.

${ }^{12}$ William Gershom Collingwood (1854-1932), artista e intelectual inglês, foi assistente de John Ruskin.

${ }^{13}$ Trata-se de um equívoco, impossível saber se de Proust ou algum editor (não há qualquer menção ao deslize em sua correspondência). A obra de Ruskin que o artigo cita se intitula The Three Colours of Pre-Raphaelitism.

${ }^{14}$ Proust faz essa longa enumeração de obras de John Ruskin em francês, mesmo para títulos que não foram traduzidos do inglês. Como meio de conciliar a opção de Proust com a possibilidade de acesso do leitor contemporâneo às obras de Ruskin, preferiu-se transpor no corpo do texto uma versão livre dos títulos em português e reproduzir, em nota, os originais: The Seven Lamps of
} 
de sabedoria e estética. As ardentes polêmicas que incitaram quando publicados (desnecessário se recordar do processo que opôs Ruskin ao Sr. Whistler, cuja lembrança é presente em todos os espíritos ${ }^{15}$ ) se apaziguaram aos poucos; e quando Ruskin, combalido pelo mal que lhe obrigara a abandonar seus cursos em Oxford, recolheu-se a Brantwood ${ }^{16}$ com o senhor e a senhora Severn ${ }^{17}$, a Inglaterra inteira, como observou o Times no importantíssimo artigo dedicado a Ruskin em sua edição do 22 de janeiro, havia se tornado ruskiniana e a celebração de seus oitenta anos foi uma espécie de festa nacional. Suas ideias sobre os Pré-Rafaelitas foram vulgarizadas ao nível da banalidade. Sua admiração por Turner ${ }^{18}$, a quem dedicou tantos livros (e sabemos que os Pintores modernos foram inicialmente concebidos apenas como uma espécie de defesa e de apologia à pintura de Turner), e a qual, até o fim de sua vida, foi o impulso de atitudes em lugares onde pareceria que não teriam utilidade alguma*, atravessou o canal, do outro lado do qual o Sr. Groult ${ }^{19}$ reuniu uma coleção incomparável.

Architecture; The Two Paths; Munera Pulveris; Sesame and Lilies; The Crown of Wild Olive; The Queen of the Air; Aratra Pentelici; Ariadne Florentina; Deucalion; Mornings in Florence; Proserpina; Laws of Fésole; St Mark's Rest; The Three Colours of Pre-Raphaelitism; Modern Painters e The Stones of Venice. Convém indicar que toda a obra de John Ruskin se encontra reunida na coleção crítica de 39 volumes organizada por Edward Tyas Cook e Alexander Dundas Ogilvy Wedderburn: Cook, E. T.; Wedderburn, Alexander (orgs.). The Works of John Ruskin. Londres: George Allen, 1903-1912.

${ }^{15}$ Em 1877, Ruskin foi processado pelo pintor americano James Abbott McNeill Whistler (18341903) por conta de suas fortes críticas à tela Nocturne in Black and Gold - The Falling Rocket (187277. Óleo sobre tela, 60,3 x 46,6 cm. Detroit, Detroit Institute of Arts). Disse Ruskin em um dos vários panfletos que dirigiu na década de 1870 ao proletariado inglês e que, depois, reuniu sob a coletânea Fors Clavigera: For Mr. Whistler's own sake, no less than for the protection of the purchaser, Sir Coutts Lindsay ought not to have admitted works into the gallery in which the ill-educated conceit of the artist so nearly approached the aspect of willful imposture. I have seen, and heard, much of Cockney impudence before now; but never expected to hear a coxcomb ask two hundred guineas for flinging a pot of paint in the public's face. [Para o bem do próprio Sr. Whistler, e não menos para a proteção do comprador, Sir Coutts Lindsay [proprietário da Grosvenor Gallery, onde se encontrava exposta a tela] não deveria ter permitido em sua galeria trabalhos nos quais uma presunção leiga do artista se aproxima tanto do aspecto de deliberada impostura. Eu já vi e ouvi no passado muita insolência cockney [gentílico atribuído aos habitantes do East End londrino, aqui empregado no sentido de "ignorante"]; mas jamais pensei ouvir um exibicionista pedir duzentos guineus [moeda inglesa feita de ouro] para jogar um pote de tinta na cara do público]. Cf. Ruskin, John. Letter the Seventy-ninth. In Fors clavigera: letters to the workmen and labourers of Great Britain. Londres: p.73. 0 júri acolheu a demanda de Whistler, mas fixou a indenização abaixo do valor que o pintor, em grave situação financeira, reivindicava e determinou que as custas do processo fossem divididas entre as partes.

${ }^{16}$ Cf. nota 3 .

${ }^{17}$ Arthur Severn (1842-1931), pintor inglês que se casou em 1871 com Joan Ruskin Agnew (18471924), prima de John Ruskin.

${ }^{18}$ William Turner (1775-1851), um dos maiores expoentes do romantismo na pintura inglesa.

*Quando, em 1883, Ruskin renunciou pela última vez à docência em Oxford, uma das duas razões dessa decisão foi que a Universidade havia recusado a aquisição da Lua crescente de Turner por 1200 libras†.

$\dagger$ Red sky and crescent moon. 1818. Aquarela e guache sobre papel, 12,5 x 24,7 cm. Londres, Tate Museum.

${ }^{19}$ Camille Groult (1832-1908), industrial francês. 
Veneza, Pisa, Florença, esses são, para os ruskinianos, verdadeiros pontos de peregrinação e, em várias obras, obras de arte, opiniões contemporâneas, é o próprio Ruskin que podemos reconhecer, assim como, sobre uma moeda, se distingue a efígie do soberano do momento. 


\title{
Uma miniaturista do segundo império: madame Herbelin ${ }^{20}$
}

\section{(La Chronique des Arts et de la Curiosité, 23 de abril de 1904)}

\author{
Os jovens da minha geração, que conheceram de madame Herbelin apenas a \\ velhice recolhida, charmosa e discreta, jamais poderiam supor, de tanto que \\ lançava um véu melancólico sobre um passado radiante, que essa velha senhora, \\ tão vivaz, tão doce e tão simples, fizera parte da vida mais faustosa, em meio à \\ sociedade de maior brilho da Monarquia de Julho e do Segundo Império ${ }^{21}$. Muito
}

${ }^{20} 0$ retrato de Jeanne-Mathilde Herbelin (1820-1904) foi publicado por Marcel Proust na Chronique des arts et de la curiosité de 23 de abril de 1904, por ocasião da morte dessa miniaturista célebre nos salões da burguesia parisiense de meados do século XIX. Herbelin foi tia de Madeleine Lemaire (1845-1928), também pintora e proprietária de um dos salões mais frequentados por Proust na virada do século. Era no salão de Lemaire que Proust se encontrava com o parceiro Reynaldo Hahn e foi em sua casa de veraneio, em Dieppe, que teve a oportunidade de conhecer o compositor Camille Saint-Saëns. A satisfação que Proust encontrava em poder participar desse círculo prestigiado e restrito parece justificar a homenagem que presta a Madeleine Lemaire e a sua filha, a também pintora Suzette Lemaire (1866-1946), pelos cuidados prestados a madame Herbelin ao final de sua vida. Lê-se através de um breve comentário de Marie Miguet-Ollagnier sobre a exposição Femmes peintres et salons au temps de Proust, de Madeleine Lemaire à Berthe Morisot, organizada no museu Marmottan-Monet em 2010, que madame Herbelin desempenhou papel fundamental na formação artística de sua sobrinha, apresentando-lhe a pessoa de Eugène Delacroix e educando-a não como diletante, mas sim como pintora profissional, "que se despertava no amanhecer para pintar até a hora do almoço" (Cf. MIGUET-OLLAGNIER, Marie. Comptes rendus: Femmes peintres et salons au temps de Proust, de Madeleine Lemaire à Berthe Morisot. In Bulletin Marcel Proust. Illiers-Combray: Société des amis de Marcel Proust et des amis de Combray, 2010, n. 60, p. 180-181). Mas algo para além da presença social da pintora encanta o narrador, notadamente a comparação entre o presente recolhido e o passado brilhante dessa artista de retratos perfeccionistas, pintados quase sempre sobre pequeninas placas de marfim. Os dados biográficos são, na realidade, índices para os traços da personalidade do modelo. Servem para informar o leitor leigo, mas também para construir o universo de uma personagem e, assim, qualificá-la, modelá-la à visão do retratista. Eis como o autor a descreve em dado momento: filha de um general, madame Herbelin "extraiu da própria fonte" a vivência do momento glorioso de um império, a ocupação francesa da Espanha. Nós, leitores, sabemos ao mesmo tempo quem é seu pai e os valores, "faustosos" para falar como o narrador, que modelaram seu caráter. Some-se a isso o que é ainda mais relevante: os efeitos da passagem do tempo sobre os seres. Proust estuda as transformações e permanências na aparência e na personalidade. É dessa reflexão que produz, em larga medida, uma imagem diversificada e complexa do modelo. Madame Herbelin, que pertencera aos salões mais prestigiados de seu tempo, ao final da vida preferiu recolher-se "discreta". Mas, sob sua humildade, encontram-se guardados traços que não se apagaram. Seu charme é um deles, e o adjetivo não ocorre no texto menos que seis vezes para caracterizar diferentes aspectos e momentos da vida do modelo, ora designando a própria pessoa de madame Herbelin, ora qualificando sua produção artística. Sua vivacidade também não deve ser desconsiderada: ela nasce na juventude, quando a convivência com o pai general, por exemplo, lhe levou a assistir a "epopeias imperiais", e se mantém na velhice, silenciosa, mas também "falante", atrás das vidraças que dão para seu jardim florido.

${ }^{21} \mathrm{Na}$ historiografia francesa, a Monarquia de Julho compreende o período entre as revoluções de 1830 e 1848, responsáveis pela ascensão e queda de Luís Filipe de Orléans (1773-1850), o rei burguês. O Segundo Império, por sua vez, designa a ditadura instalada em dezembro de 1851 pelo presidente Luís Napoleão Bonaparte (1808-1873), que dissolveu a Assembleia Nacional após lhe ser negado o direito de concorrer a um segundo mandato. Ao citar esses momentos, Proust associa a figura de madame Herbelin ao período de modernização burguesa da França, marcado, a despeito de forte autoritarismo e repressão, pela abertura do país aos mais diversos eventos artísticos e culturais. 
menos de sua própria boca teriam ficado sabendo que havia sido uma das pintoras mais perfeccionistas e mais originais daquela época - pois era profundamente modesta. Essa modéstia acabou até mesmo por assumir nela como que um caráter de tristeza, quase de inquietude: parecia duvidar nos últimos anos do valor de suas miniaturas, as quais, no entanto, não sobreviverão apenas como documentos de primeira linha sobre um tempo já tão distante, mas também dentre os espécimes mais sedutores e acabados de uma arte difícil e deliciosa. Um retrato como aquele de madame Andryane ${ }^{22}$, em posse do museu do Luxemburgo, não deve nada às mais belas miniaturas de madame de Mirbel $^{23}$ e de Isabey ${ }^{24}$; e confessamos, de nossa parte, nele nos deliciarmos com um feitio mais saboroso, em seu vigor, como que apertado, em seu colorido inesperado e charmoso.

Aqueles dentre nossos leitores que não visitaram a coleção do senhor príncipe de Essling ${ }^{25}$ conhecem ao menos, através das reproduções que delas fizeram (sobretudo aquelas que ornam o livro do senhor Armand Dayot ${ }^{26}$ sobre o Segundo Império), as miniaturas de madame Herbelin que representam a imperatriz Eugénie e o príncipe imperial ${ }^{27}$. Citaremos ainda os retratos de Isabey, de Eugène Delacroix, de Rossini, de Guizot, de Rosa Bonheur, de Dumas pai, de Dumas filho ${ }^{28}$. Antes de se tornarem seus modelos, todos esses personagens marcantes da época eram os habitués de seu salão. A seu lado, encontrávamos ainda Mérimée, Guizot, Thiers, Émile Augier, Eugène Lami, Hébert, Gounod, Baudry $^{29}$. Quando se conseguia fazer madame Herbelin falar de todos esses homens geniais ou distintos, que adoravam se encontrar em sua casa, a conversa com ela se tornava instrutiva e excitante como a leitura de autênticas Memórias, de Memórias que teriam tido essa particularidade notável, que é o autor nelas tratar muito dos outros, e jamais dele próprio. Na realidade, suas recordações remontariam ao passado da geração da qual permanecerá a pintora fiel e

\footnotetext{
${ }^{22}$ A miniatura Mme Andryane dans un fauteuil, âgée (1848. Marfim, 13,1 x 10,8 cm) se encontra hoje em posse do departamento de artes gráficas do Museu do Louvre, em Paris.

${ }^{23}$ Lizinska Aimée Zoé de Mirbel (1796-1849), miniaturista francesa, responsável por inúmeros retratos das cortes de Luís XVIII e Carlos X.

${ }^{24}$ Jean-Baptiste Isabey (1767-1855), miniaturista francês consagrado no Primeiro Império.

${ }^{25}$ Victor Masséna (1836-1910), duque de Rivoli e príncipe de Essling, deputado durante o Segundo Império e colecionador de arte.

${ }^{26}$ Armand Dayot (1851-1934), crítico de arte francês, fundador da revista L'Art et les artistes.

${ }^{27}$ A imperatriz Eugénia de Montijo (1826-1920), esposa de Luís Napoleão Bonaparte.

${ }^{28}$ Enumeração de retratados nas miniaturas de madame Herbelin: os também miniaturistas JeanBaptiste Isabey (Cf. nota 5) e Rosa Bonheur (1822-1899), o pintor Eugène Delacroix (1798-1863), o compositor Gioachino Rossini (1792-1868), o político François Guizot (1787-1874) e os escritores Alexandre Dumas, pai (1802-1870), e Alexandre Dumas, filho (1824-1895).

${ }^{29}$ Outra enumeração de retratados de madame Herbelin, na qual constam, para além da repetição daquele de François Guizot ( $C f$. nota 9), os nomes do escritor Prosper Mérimée (1803-1870), do presidente Adolphe Thiers (1797-1877), o poeta Émile Augier (1820-1889), os pintores Eugène Lami (1800-1890), Ernest Hébert (1817-1908) e Paul Baudry (1828-1886) e o compositor Charles Gounod (1818-1893).
} 
charmosa. Filha do barão Habert ${ }^{30}$, que fora voluntário em 1792, general de divisão em 1811 e governador de Barcelona durante a Campanha da Espanha, ela extraíra da própria fonte as narrativas ainda muito vívidas dessa epopeia imperial da qual seu pai não fora um dos atores menores. Ela mesma nascera em 1818, em Brunoy $^{31}$. 0 início de sua carreira fora brilhante e rápido. Aos trinta anos, ostentava a grande medalha da Exposição Universal, com a qual havia sido condecorada ao lado de Rosa Bonheur ${ }^{32}$. Ela tinha conservado uma charmosa lembrança do "Jantar dos Condecorados", que fora oferecido em Saint-Cloud ${ }^{33}$ naquele dia, 2 de agosto de 1853, pelo Imperador. Ao longo de vários anos, ela expôs com regularidade no Salão ${ }^{34}$, sempre com sucesso.

Então soou para ela a hora de se aposentar, e adorava passar longas horas atrás das vidraças de sua janela, que dava para os lilases do jardim, imóvel, silenciosa e falante, como uma dessas antigas e charmosas miniaturas que assinara e que nós "adoramos ver em suas molduras ovais". Mas ela contou, para embelezar sua longa velhice, com uma fonte digna de orgulho: suas duas sobrinhas, com as quais foi morar e que, até o último instante, a acalentaram e cuidaram como se tivessem sido suas filhas, não eram outras, com efeito, senão madame Madeleine Lemaire e a senhorita Suzette Lemaire ${ }^{35}$.

Ela podia assim ver, em mãos mais jovens, a chama da arte transmitida e guardada com incomparável fulgor.

A glória de madame Madeleine Lemaire, a rara e delicada reputação da senhorita Suzette Lemaire preencheram seus últimos anos de doçura e orgulho. Por elas alimentava uma profunda admiração, que o público e os conhecedores há muito tempo confirmaram.

\footnotetext{
${ }^{30} 0$ militar Pierre Joseph Habert (1773-1825), governador de Barcelona durante a Guerra Peninsular, alcunhado "Ajax da Catalunha" por haver resistido à ofensiva das frotas inglesas contra o exército napoleônico.

${ }^{31}$ Pequena cidade situada a cerca de vinte quilômetros de Paris. Tornou-se um refúgio campestre da burguesia francesa no século XIX.

${ }^{32}$ Há um equívoco de Proust (ou do editor do artigo). A pintora Rosa Bonheur ( $C f$. nota 9) e madame Herbelin foram homenageadas no Salão de Pintura e Escultura promovido pela Academia de Belas Artes em 1853, não na Exposição Universal. Naquela ocasião, o júri decidiu extraordinariamente que tanto Bonheur quanto Herbelin poderiam expor suas obras em salões futuros sem a necessidade de submetê-las à apreciação da Academia. A medalha de ouro da Exposição Universal foi entregue apenas a madame Herbelin, e no ano de 1855.

${ }^{33}$ Foi no Castelo de Saint-Cloud que Napoleão III se coroou imperador após o golpe de 1851 e no qual, junto à imperatriz Eugénia, passou a reunir sazonalmente sua corte. 0 edifício foi incendiado em 1870, durante a Guerra Franco-Prussiana.

${ }^{34} \mathrm{Cf}$. nota 13 .

${ }^{35} \mathrm{Cf}$. nota 1.
} 


\title{
O Salão da princesa Edmond de Polignac: música de hoje, ecos do passado $^{1}$
}

\section{(Le Figaro, 6 de setembro de 1903)}

\begin{abstract}
"Passado"... aquilo de que seria impossível, aquilo de que, com efeito, seria um sacrilégio separar o hoje. Quero dizer que a princesa de Polignac ficaria sentida conosco se não disséssemos uma só palavra sobre o príncipe. "É um amável príncipe o príncipe Hamlet", diz Horácio na tragédia de Shakespeare2. "Boa noite, amável príncipe, e que multidões de anjos embalem em coro seu sono" 3 . Infelizmente, há quase dois anos o príncipe de Polignac partiu para o repouso eterno, e, sem dúvida, os anjos o acalentam com seus cantos, inefáveis e litúrgicos, pelos quais, dentre todos, ele era apaixonado.
\end{abstract}

Era um amável príncipe, um grande espírito e um vigoroso músico. Sua música sacra e suas melodias são hoje consagradas com a admiração dos mais refinados. Conhecíamos pouco de sua música, mas é que ele era tão exigente para executá-la... Tinha horror às salas de concerto. 0 ar livre teria sido mais conveniente. A música nos bosques lhe parecia bela.

\footnotetext{
${ }^{1}$ Le Salon de la princesse Edmond de Polignac: musique d'aujourd'hui, échos d'autrefois, foi publicado por Proust, sob o pseudônimo Horatio, na edição de 6 de setembro de 1903 do jornal Le Figaro. Apresentado como salão mundano, vemos aqui muito mais um retrato literário póstumo do príncipe Edmond de Polignac (1834-1901) do que as descrições, sempre tão factuais e datadas, de alguma reunião social do tout-Paris. Os saraus oferecidos pela americana Winnaretta Singer (18651943), herdeira da indústria de máquinas de costura Singer, e seu marido, o príncipe Edmond de Polignac, desempenham aqui a função do gatilho que transporta o leitor à dimensão da memória do narrador. Todo o restante é uma tentativa bastante poética de apreensão da personalidade de Edmond de Polignac. Tentativa, por sinal, das mais felizes e bem-sucedidas em todo o conjunto de artigos jornalísticos publicado por Proust. Além de serem exemplos claros dos paradoxos que tanto agradam Proust na descrição de seus modelos, as metáforas que associam o espírito de Polignac a uma biblioteca e sua aparência a uma fortaleza medieval são deliberadamente recicladas para a constituição de Robert de Saint-Loup, personagem da Recherche ( $C f$. notas 9 e 10).

${ }^{2}$ A passagem não pertence ao personagem Horácio, de Hamlet, mas sim ao artigo Hamlet à la Comédie-Française [Hamlet na Comédie-Française], publicado por Anatole France (1844-1924) na edição de 3 de outubro de 1886 do jornal Le Temps e incluído no primeiro volume da série La Vie littéraire em 1921. Trata-se de uma crítica do autor francês à adaptação de Alexandre Dumas (1802-1870) e Paul Meurice (1818-1905) para a tragédia de William Shakespeare (1564-1616), escrita em 1848 e encenada pela primeira vez na noite de 28 de setembro de 1886. "Oui, c'est un aimable prince que le prince Hamlet. Il est beau, il est malheureux ; il sait tout et ne sait que faire. Il est digne d'envie et de pitié. Il est plus mauvais et meilleur que chacun de nous. C'est un homme, c'est l'homme, c'est tout l'homme" [Sim, é um amável príncipe o príncipe Hamlet. Ele é belo, ele é infeliz; ele sabe de tudo e não sabe o que fazer. Ele é digno de inveja e de piedade. Ele é mais malvado e melhor que cada um de nós. É um homem, é o homem, é todo o homem]. Cf. FRANCE, Anatole. La Vie littéraire. Paris: Calmann-Lévy, vol. I, 1921, p. 1.

${ }^{3}$ Fala de Horácio na cena II do quinto ato de Hamlet: "Now cracks a noble heart. Good night sweet prince: / And flights of angels sing thee to thy rest!" [Eis que se estilhaça um nobre coração. Boa noite, amável príncipe: / e que multidões de anjos embalem em coro seu sono].
} 


\section{... Uma flauta invisível \\ Suspira no matagal. \\ A canção mais agradável \\ É a canção pastoral, ${ }^{4}$}

disse Victor Hugo. Da mesma forma, o príncipe de Polignac dizia: "meu lema em música é 'campos planos"'. Mas não escrevia "canto plano"5. Os amigos da condessa Greffulhe se recordam de um sarau que ela quis oferecer no bosque de Varangeville ${ }^{6}$ para ouvir as músicas do príncipe

Sob árvores azuladas pela lua serena,

onde

\section{A melodia ainda alguns instantes se encadeia. ${ }^{7}$}

Para aqueles que se recordam do quão avançadas - não apenas em literatura e arte, mas também na política - eram as ideias do príncipe de Polignac, à frente mesmo daquelas dos mais avançados jovens, é quase um milagre imaginar que ele era o filho do reacionário ministro de Carlos X, que assinou as famosas Ordenações e acabou aprisionado em Ham em $1830^{8}$. Foi enquanto esteve em Ham que nasceu o príncipe Edmond. A natureza, que prossegue as raças e não prevê os indivíduos, lhe havia dado um corpo esbelto. Um rosto enérgico e fino de homem guerreiro e nobre. Pouco a pouco, a chama espiritual que habitava o príncipe Edmond de Polignac esculpiu sua imagem à semelhança de seu pensamento. Mas sua máscara permaneceu aquela de sua linhagem, anterior a sua alma individual. Seu corpo e sua face assemelhavam-se a um torreão abandonado que teria sido

\footnotetext{
${ }^{4}$ Os quatro primeiros versos do poema XIII das Contemplations de Victor Hugo (1802-1885): Viens! - une flûte invisible / Soupire dans les vergers. - / La chanson la plus paisible / Est la chanson des bergers. Cf. HUGO, Victor. OEuvres poétiques. Paris: Gallimard, Bibliothèque de la Pléiade, vol. II, 1967, p. 546.

${ }^{5}$ Trocadilho de Proust entre "pleins champs", campos planos, planícies, o ambiente supostamente ideal para a execução das obras do príncipe de Polignac, e "plain chant", o canto plano, modalidade de canto que remonta à música sacra medieval, também conhecido como cantochão.

${ }^{6}$ A comuna de Varengeville-sur-Mer, na Normandia, uma das cidades favoritas de pintores impressionistas como Georges Braque (1882-1963) e Claude Monet (1840-1926).

${ }^{7}$ Respectivamente os versos 708 e 707 do longo poema Eviradnus, parte de La Légende des siècles, de Victor Hugo (1802-1885): "La mélodie encor quelques instants se traîne / Sous les arbres bleuis par la lune sereine" [A melodia ainda alguns instantes se encadeia / Sob árvores azuladas pela lua serena]. Cf. HUGO, Victor. La Légende des siècles. Paris: Gallimard, Bibliothèque de la Pléiade, 1950, p. 251.

${ }^{8}$ Edmond de Polignac foi o filho caçula do príncipe Jules de Polignac (1780-1847), presidente do Conselho de Ministros sob o rei Carlos X (1757-1836). 0 episódio ao qual Proust se refere são as Ordenações de Saint-Cloud, de 1830, quando, dentre outras arbitrariedades, Carlos X dissolveu a Câmara dos Deputados em uma tentativa de reconstituir a maioria da bancada do Partido Ultrarrealista e manter o príncipe Jules de Polignac como presidente de seu Conselho de Ministros. Quando, apesar das manobras da monarquia, o Partido Liberal conquista a maioria da Câmara, Carlos X abdica e Jules de Polignac, dentre outros de seus ministros, é condenado à prisão perpétua.
} 
transformado em biblioteca ${ }^{9}$. Recordo-me que, no triste dia de seu funeral, na igreja onde grandes flâmulas negras ostentavam no alto, em escarlate, a coroa fechada, a única letra que havia era um "P". Sua individualidade fora apagada, ele havia regressado a sua família.

\section{Ele não era mais que um Polignac ${ }^{10}$.}

Seus descendentes perceberão que ele se parecia com seus ancestrais e irmãos, e, no entanto, qualquer um deles com uma alma mais aparentada à sua permanecerá por mais tempo diante de seu retrato do que dos outros, como diante daquele de um irmão que teria se parecido com ele por antecipação, no passado. No mais, ele não desdenhava da nobreza, mas alçava aquela do espírito à posição mais elevada de todas. E, numa noite na qual Swinburne ${ }^{11}$ (na casa de lady Brooke, se minha memória não falha) lhe dizia: "creio que minha família é um pouco aparentada à vossa e me sinto lisonjeado", foi com bastante sinceridade, do fundo do coração que o príncipe respondeu: "acredite que, dos dois, o mais honrado com esse parentesco sou eu!".

Esse homem, cuja vida foi perpetuamente dedicada às metas mais elevadas e, poderíamos dizer, às mais religiosas, tinha suas horas de descontração de certo modo pueril e excêntrica, e os delicados, "que são infelizes"12, acharão bem grosseiros os divertimentos que se consentia esse grande delicado. Era, no entanto,

\footnotetext{
${ }^{9}$ Proust transpôs essa passagem de modo muito semelhante ao volume À l'Ombre des jeunes filles en fleurs, no momento em que descreve o personagem Robert de Saint-Loup: "Sous la peau fine, la construction hardie, l'architecture féodale apparaissaient. Sa tête faisait penser à ces tours d'antiques donjons dont les créneaux inutilisés restent visibles, mais qu'on a aménagées intérieurement en bibliothèque" [Debaixo da pele fina, a construção atrevida, a arquitetura feudal apareciam. Sua cabeça fazia pensar nessas torres de antigos torreões cujas ameias não utilizadas permanecem visíveis, mas que foram arranjadas interiormente em biblioteca]. $C f$. RTP, II, p. 176. É a pesquisadora Nathalie Mauriac quem classificou o caso como "transposição direta" (Op. cit., p. 222) após descobrir nos manuscritos de À l'Ombre des jeunes filles en fleurs, na altura da passagem que acabamos de citar, o desenho de um balão com o seguinte lembrete: "Voir [...] l'article Polignac" [Ver (...) o artigo Polignac]. Cf. Cahier 74, fo 126 vo (O Caderno 74 de Proust se encontra na Bibliothèque Nationale de France e pode ser acessado no seguinte endereço eletrônico: http://bit.ly/2p4PRaP, acessado em 5 de maio de 2017).

${ }^{10}$ Segundo Nathalie Mauriac (Ibid., p. 222), outro caso de "transposição direta", dessa vez do retrato do príncipe Edmond de Polignac para a composição do episódio da morte do personagem Robert de Saint-Loup, em Le Temps retrouvé: "Et ce Guermantes était mort plus lui-même, ou plutôt plus de sa race, en laquelle il n'était plus qu'un Guermantes, comme ce fut symboliquement visible à son enterrement dans l'église Saint-Hilaire de Combray, toute tendue de tentures noires où se détachait en rouge, sous la couronne fermée, sans initiales de prénoms ni titres, le G du Guermantes que par la mort il était redevenu" [E, ao morrer, esse Guermantes não era mais ele mesmo, talvez fosse mais sua raça, na qual não era mais que um Guermantes, como foi simbolicamente visível em seu funeral na igreja Saint-Hilaire de Combray, toda adornada de flâmulas negras nas quais se destacava em vermelho, sob a coroa fechada, sem iniciais de nomes ou títulos, o G do Guermantes que, pela morte, ele voltara a ser]. $C f . R T P$, IV, p. 429.

${ }^{11}$ O poeta inglês Algernon Charles Swinburne (1837-1909).

${ }^{12}$ Passagem da fábula Contre ceux qui ont le goût difficile [Contra aqueles que têm um gosto difícil], de Jean de la Fontaine (1621-1695): "Les délicats sont malheureux" [Os delicados são infelizes]. Cf. LA FONTAINE, Jean de. CEuvres complètes. Paris: Gallimard, Bibliothèque de la Pléiade, vol. I, 1991, p. 70 .
} 
bem engraçado quando improvisava, com letras e música ao mesmo tempo, as incumbências de um sarau. Sob seus dedos, as valsas não findavam e, durante esse tempo, cada visitante era anunciado pelo porteiro.

"Vosso nome, senhor?

- Senhor Cucheval.

- Não, senhor, pergunto vosso nome.

- Insolente! Senhor Cucheval ${ }^{13 \prime \prime}$.

E o porteiro, tendo de consultar o anfitrião:

"Senhor barão, esse senhor diz que se chama Sr. Cucheval, devo anunciá-lo ainda assim?

- Ah! Mas que diabos, ora! Fazer o quê? Aguarde um instante, perguntarei à senhora baronesa".

Então, uma grande comoção: acabavam de anunciar o doutor Ricord.

“Ah! É o senhor, doutor, com sua licença, não levará muito tempo...

- Não, meu amigo, aqui, é impossível, queira notar que...

- Poderíamos ir por um instante ao pequeno salão.

- Não, não, nada de licores, nada de tabaco, nada de..."

E as valsas prosseguiam cada vez mais intensas, permitindo com dificuldade ouvir o diálogo de um casal que discutia: "miserável, te esperei ontem por uma hora no Jardin des Plantes, em frente aos macacos". Não riremos mais dessas maluquices que devem parecer bem frias se contadas assim, mortas... como ele.

Ele passava seus verões ora em Amphion, com a princesa de Brancovan ${ }^{14}$, ora em Bonnétable, com o duque de Doudeauville ${ }^{15}$, às vezes em Chaumont, com a princesa Amédée de Broglie ${ }^{16}$. Era dono de uma bela propriedade em Fontainebleau, cujas paisagens silvestres lhe inspiraram diversas melodias. E, quando eram executadas em sua casa, passava atrás da orquestra uma espécie de imensa amplificação luminosa de fotografias tiradas na floresta. Porque, de todas as inovações de hoje, união da música a projeções, acompanhamento musical para recitações faladas, ele foi um dos idealizadores. E, quaisquer que pudessem ter sido os avanços ou as imitações que surgiram a partir de então, a decoração, no mais nem sempre tão harmoniosa, da mansão da rue Cortambert permaneceu

\footnotetext{
${ }^{13}$ Trata-se de um trocadilho intraduzível entre as palavras "cul", bunda, e "cheval", cavalo. Proust zomba com o nome de seu professor de latim no Liceu Condorcet, Victor Cucheval-Clarigny (18301912).

${ }^{14}$ A poeta Anna-Élisabeth de Noailles (1876-1933).

${ }^{15} \mathrm{O}$ político Sosthène de La Rochefoucauld (1825-1908).

${ }^{16}$ Marie Charlotte Constance Say (1857-1943), herdeira de uma indústria de açúcar.
} 
inteiramente "nova". Nos últimos anos, lhe agradava sobretudo Amsterdã e Veneza, duas cidades entre as quais seu olho de colorista e seu ouvido de músico reconheceram o duplo parentesco da luz e do silêncio. Ele comprara há pouco tempo um belo palácio em Veneza, a única cidade, dizia, na qual podemos conversar com a janela aberta sem subir o tom de voz.

Há uma década, o príncipe se casou com a senhorita Singer, cujos salões anuais de pintura se habituaram a receber e a recompensar suas incríveis submissões. Ele era músico, ela era música, e os dois sensíveis a todas as formas de inteligência. A única diferença era que ela sentia sempre muito calor, enquanto ele era extremamente suscetível ao frio. E ele não sabia o que fazer em meio às incessantes e propositais correntes de ar do ateliê da rue Cortambert. Ele se precavia da melhor maneira possível, sempre envolto em mantas e cobertas de viagem.

"O que quer o senhor?”, dizia àqueles que riam desses trajes extravagantes, "Anaxágoras disse que a vida é uma viagem!"17.

Com seu casamento, a senhorita Singer, cuja irmã desposara o duque Decazes, e que já vivia em um meio bastante artístico e elegante, se aparentou com muita proximidade às famílias La Rochefoucauld, Croy, Luynes e Gontaut-Biron ${ }^{18}$. A irmã do príncipe de Polignac havia sido a primeira esposa do duque de Doudeauville. A princesa de Polignac tornava-se então tia da duquesa de Luynes, nascida La Rochefoucauld, e tia-avó da duquesa de Luynes, nascida Uzès, e da duquesa de Noailles ${ }^{19}$. No lado dos Mailly-Nesle, o príncipe de Polignac era parente ainda mais próximo da condessa Aimery de la Rochefoucauld e da condessa de Kersaint $^{20}$. É o mesmo que dizer que as sessões de música do hall da rue

\footnotetext{
${ }^{17}$ Proust emprega a mesma citação no episódio da morte do escritor Bergotte, em La Prisonnière: "Que voulez-vous, mon cher, Anaxagore l'a dit, la vie est un voyage" [0 que quer você, meu caro, foi Anaxágoras quem disse, a vida é uma viagem]. Cf. RTP, III, p. 689. Antoine Compagnon e PierreEdmond Robert ressalvam que a citação parece muito mais pertencer a um estoico como Sêneca (4 a.C.-65) do que a Anaxágoras (500 a.C - 428 a.C.). Cf. Ibid., p. 1739.

${ }^{18}$ A irmã de Winnaretta Singer, princesa de Polignac, é Isabelle Singer (1869-1896), casada com o atleta Jean Decazes (1864-1912), medalha de prata em vela nos jogos olímpicos de 1900, em Paris. Todas as famílias citadas logo após pertencem à tradicional aristocracia francesa e possuem notável presença em seu universo artístico, a exemplo do escritor François VI de la Rochefoucauld (16131680) e da mecenas Jeanne-Baptiste de Luynes (1670-1736).

${ }^{19}$ Trata-se da seguinte árvore genealógica: A irmã de Edmond de Polignac, Yolande Justine de Polignac (1830-1855), foi a primeira esposa de Sosthène II de La Rochefoucauld, duque de Doudeauville (1825-1908), mãe de Yolande Julienne de La Rochefoucauld, duquesa de Luynes (1849-1905), e, por conseguinte, avó de Honoré (1868-1924) e Yolande (1870-1952) de Luynes. Seu neto Honoré casou-se com Simone d'Uzès, transmitindo-lhe o título de duquesa de Luynes, e a neta Yolande casou-se com Adrien de Noailles (1869-1953), contraindo o título de duquesa de Noailles.

${ }^{20}$ Outro longínquo ramo da árvore genealógica dos Polignac: o trisavô de Edmond de Polignac, Scipion de Polignac (1660-1739), foi cunhado de Louis de Mailly-Nesle (1696-1767), antepassado das irmãs Blanche (1860-1929) e Henriette (1852-1913) de Mailly-Nesle. Blanche casou-se com
} 
Cortambert, sempre admiráveis do ponto de vista musical, nas quais ouvíamos ora execuções perfeitas de música antiga, como as representações de Dardanus ${ }^{21}$, ora interpretações originais e efervescentes de todas as últimas melodias de Fauré, da sonata de Fauré, das danças de Brahms ${ }^{22}$, que eram também, como dizem na linguagem dos cronistas mundanos, "de uma suprema elegância". Oferecidas normalmente durante o dia, essas festas cintilavam mil clarões que os raios de sol, através do prisma dos vitrais, iluminavam no ateliê, e era algo charmoso ver o príncipe conduzir ao seu posto aquela que era a boa juíza e a fervorosa entusiasta, a soberana beleza, a condessa de Greffulhe, esplêndida e risonha. De braços dados com o príncipe alerta e cortês, ela atravessava o ateliê no rastro murmurante e maravilhado que sua aparição despertava atrás dela, e, uma vez que a música se iniciava, ela a ouvia atenta, com um ar ao mesmo tempo imperioso e dócil, e seus belos olhos fixados sobre a melodia apreciada, semelhante a

\section{Um grande pássaro dourado que espreita de longe sua presa ${ }^{23}$.}

De uma polidez exata e charmosa com todos seus convidados, víamos a figura do príncipe (a mais fina que conhecemos) ser tomada por uma alegria e por uma ternura paternais quando entravam as duas incomparáveis moças que hoje desejamos apenas nomear, reservando-nos para mais tarde tratar delas, diante de seus magníficos e auspiciosos gênios, com os quais ele já se maravilhava: a condessa Mathieu de Noailles e a princesa Alexandre de Caraman-Chimay ${ }^{24}$. Esses dois nomes, que ocupam o primeiro lugar na admiração de todo aquele que hoje pensa, afortunados do duplo prestígio da glória literária e da beleza. Que horas charmosas! O sol iluminava pleno a mais bela tela de Claude Monet que conheço: Um campo de tulipas próximo de Haarlem ${ }^{25}$. 0 príncipe, antes de seu casamento, lhe cobiçara em uma venda. "Mas que raiva!", dizia ele, "essa tela me foi levada por uma americana cujo nome queria execrar. Alguns anos mais tarde, casei-me com a

\footnotetext{
Guy de Kersaint (1857-1921), de quem contraiu o título de condessa de Kersaint, e Henriette casouse com Aimery de La Rochefoucauld (1843-1920), assumindo o título de condessa de Aimery de la Rochefoucauld.

${ }^{21}$ Tragédia lírica de Jean-Philippe Rameau (1683-1764), apresentada pela primeira vez em 1739.

${ }^{22}$ No que diz respeito à referência a Johannes Brahms (1833-1897), não há dúvida de que se trata das Ungarische tänze (Danças húngaras, WoO 1). Já no caso de Gabriel Fauré (1845-1924), impossível precisar as melodias do compositor, que são inúmeras e nem todas catalogadas. A sonata, no entanto, é certamente a Sonata para violino e piano em lá maior, 0p. 13, a única sonata que Fauré havia escrito até a data de publicação desse artigo.

${ }^{23}$ Oitavo verso do soneto Le Cydnus [O Cydnus], de José-Maria de Heredia (1842-1905): “Cléopâtre debout en la splendeur du soir / Semble un grand oiseau d'or qui guette au loin sa proie [Cleópatra, de pé, no esplendor da noite / Parece um grande pássaro dourado que espreita de longe sua presa]. Cf. HEREDIA, José-Maria de. Poésies complètes. Genève: Slatkine, 1979, p. 83.

${ }^{24}$ As irmãs Anna-Élisabeth de Noailles (1876-1933) e Hélène de Caraman-Chimay (1878-1929).

${ }^{25}$ A tela à qual Proust se refere se chama, na realidade, Champ de tulipes, Hollande [Campo de tulipas, Holanda]. Cf. MONET, Claude. Champ de tulipes, Hollande. 1886. Óleo sobre tela, 65,5 x 81,5 $\mathrm{cm}$. Musée d'Orsay. Pintada em 1886, ela foi vendida em julho do mesmo ano para Winnaretta Singer. Cf. WILDENSTEIN, Daniel. Monet: catalogue raisonné. Paris: Taschen, vol. III, 1979, p. 403404.
} 
americana e me apossei da tela!". Essas belas horas, essas festas da elegância e da arte retornarão. E, em seu convívio, nada mudará. As famílias La Rochefoucauld, Luynes, Croy, Polignac, Mailly-Nesle, Noailles, Olliamson, envolvem a princesa de Polignac com um afeto que a morte do príncipe em nada alterou, ao qual se acresceu, por assim dizer, um reconhecimento profundo pelos anos de alegria que ela proporcionou ao príncipe, homem que ela compreendeu tão bem, para quem ela, tão afetuosamente em vida, tão piedosamente após sua morte, realizou os sonhos artísticos. Talvez mesmo as festas animadas do passado de novo ressoarão no grande hall com músicas que não se parecem em nada com as sonatas de Bach ou com os quartetos de Beethoven, que ele tem o costume de ouvir. E a princesa, para que dancem seus sobrinhos-netos, encarregará alguns dos amigos do conde Édouard de la Rochefoucauld de cuidar da quadrilha, porque o hall da rue Cortambert conheceu até mesmo dançarinos, do Sr. Verdé-Delisle até o conde Bertrand d'Aramon e o marquês de Albufera (que logo mais não poderemos chamar de dançarino porque prepara, baseado em um livro de memórias de sua viagem pela Tunísia, um resumo palpitante de memórias inéditas de um célebre marechal do Primeiro Império, memórias das quais apenas o Sr. Thiers tinha conhecimento e que não poupou ao escrever 0 Consulado e o Império) ${ }^{26}$. Mas, por mais charmosas que sejam, ao renascer, essas horas inesquecíveis, dedicadas à arte ou ao prazer, sérias ou fúteis, algo de insubstituível terá se alterado. Não veremos mais a figura do pensador, a figura do artista, a figura do homem requintadamente espirituoso, amável e bom que era o príncipe Edmond de Polignac. Ah! Certamente "um amável príncipe", como disse Horácio. E, ainda como ele, digamos uma vez mais ao finado príncipe, que tanto amava os cantos angelicais e que com certeza os ouve dormindo seu sono eterno: "Boa noite, amável príncipe, e que multidões de anjos embalem em coro seu sono".

\footnotetext{
${ }^{26}$ Trata-se do marquês Louis Joseph Suchet Albufera (1877-1953), duque de Albufera após a morte de seu pai, Raoul Napoléon Suchet Albufera (1845-1925). A obra à qual Proust se refere jamais foi publicada. Há conhecimento apenas das memórias que o bisavô de Louis Joseph, marechal Louis Napoléon Suchet Albufera (1770-1826), publicou em dezembro de 1828. Cf. SUCHET ALBUFERA, Louis Gabriel. Mémoires du maréchal Suchet, duc d'Albufera, sur ses campagnes en Espagne, depuis 1808 jusqu'en 1814, écrits par lui-même. Paris: Adolphe Bossange, vols. 1-2, 1828. Segundo JeanYves Tadié, Proust se tornou amigo do marquês a partir do final de 1902 e logo se interpôs ao seu relacionamento com Louisa de Mornand (1884-1963), uma atriz de pouco talento, numa atitude muito semelhante àquela que também teve diante da união do dramaturgo Gaston Arman de Caillavet (1869-1915) com a atriz Jeanne Pouquet (1874-1962). Com efeito, a atração de Proust por casais sempre produziu problemáticas difíceis em suas biografias, nem sempre muito conclusivas a esse respeito. A aproximação de Proust a Louisa através da amizade com Albufera leva Tadié a dividir-se entre duas hipóteses. Ou o escritor tentava camuflar sua homossexualidade, ou seu objetivo era provocar ciúmes em Albufera, de quem teria se aproximado mais pelo "nariz fino, irônico e cansado" (corr., III, p. 350) do que propriamente pela inteligência. Cf. TADIÉ, Jean-Yves. Marcel Proust. Paris: Gallimard, 1996, p. 494-497. Já a obra de Adolphe Thiers, presidente da República Francesa entre agosto de 1871 e maio de 1873, é Histoire du Consulat et l'Empire faisant suite à l'Histoire de la Révolution française [História do Consulado e do Império após a História da Revolução Francesa], em 20 volumes. Cf. THIERS, Adolphe. Histoire du Consulat et l'Empire faisant suite à l'Histoire de la Révolution française. Paris: Paulin, Paulin, Lheureux et Cie e Lheureux et Cie, vols. 1-20, 1845-1862.
} 


\section{A Condessa de Guerne ${ }^{1}$}

\section{(Le Figaro, 7 de maio de 1905)}

É bastante peculiar que uma das duas ou três figuras musicais diante das quais os verdadeiros artistas prestam total reverência pertença exatamente ao que tenderíamos a chamar, se tivéssemos maior consideração pelo acaso do nascimento do que pela realidade do talento, de "mundo dos amadores". Há muito tempo, bem entendido, à condessa de Guerne foram concedidos os títulos da maior naturalização artística; e, para ninguém, não mais para os artistas do que para os mundanos, ela não é em nenhuma medida uma amadora, e sim uma das duas ou três grandes cantoras vivas. Mas, coisa bastante curiosa à primeira vista, e, no fundo, bastante natural, os artistas talvez o percebam com maior facilidade que os mundanos.

Os mundanos, sem dúvida, conhecem o admirável talento que realçaram todos os cenários da elegância e que invocaram todos os apelos da caridade². Mas o que há de mais refinado, quase único, lhes escapa com bastante frequência e é tão somente sensível aos artistas. Tive recentemente a oportunidade de ouvir madame de Guerne cantar diante de um verdadeiro tecnicista da música que professava

\footnotetext{
${ }^{1} \mathrm{O}$ retrato La Comtesse de Guerne foi publicado em 7 de maio de 1905 no jornal Le Figaro, com a assinatura de um dos pseudônimos de Proust, "Écho". Escreveu-se muito pouco a respeito da relação de Proust com Madame de Guerne, nascida Marie-Thérèse de Ségur, muito provavelmente porque, à diferença de uma figura onipresente como a pintora Madeleine Lemaire, jamais essa dama da sociedade chegou a fazer parte do círculo mais íntimo de Proust. 0 primeiro contato entre os dois se deu através de Reynaldo Hahn, com quem Proust passou a frequentar inúmeros salões mundanos em meados da década de 1890. A ocasião foi provavelmente um sarau oferecido por Robert de Montesquiou (1855-1921) em sua residência no dia 8 de março de 1895, durante o qual Proust acompanhou a leitura de poemas do anfitrião em homenagem às condessas de Greffulhe, Potocka e Guerne. A publicação desse retrato coincide com a série de ensaios do coro de Esther, adaptação de Reynaldo Hahn para a tragédia de Racine, organizados na casa da condessa de Guerne, número 3 da avenue Bosquet, em Paris ( $C f$. TADIÉ, Jean-Yves. Marcel Proust. Paris: Gallimard, 1996, p. 373,761,766). Quanto aos princípios de representação da figura humana nessa breve narrativa, o leitor logo se apercebe do esforço de Proust para romper com uma visão estereotipada de seu modelo, a imagem de mera dama mundana cuja notoriedade decorreria mais de seu estatuto social do que verdadeiramente de seu talento musical. A condessa de Guerne é dona de um prestigiado salão parisiense. No entanto, e até mesmo um "verdadeiro tecnicista da música" é evocado pelo narrador para certificar isso, a aristocrata canta com espiritualidade e pureza inigualáveis, revelando-se sem artifícios, sem "nuances fáceis" ou "transições banais". E o resultado é algo de "sobre-humano", uma harmonia "natural" e sons "indefiníveis". Trata-se de mais um exemplo da busca de Proust por essências e verdades, descrições que almejam o que há de absoluto e definitivo em um ser, sempre que possível em sua transcendência, na ruptura das primeiras impressões e considerações superficiais que lhe tenham sido associadas por algum senso comum. Assim, constrói uma condessa de Guerne múltipla e dinâmica, que é dama da sociedade, mas também talentosa artista, a depender do momento e da abordagem com a qual a analisamos.

${ }^{2} \mathrm{O}$ texto publicado no Figaro difere nesse ponto da versão manuscrita deixada por Proust (caderno NAF 16634, fólios $63 \mathrm{r}^{\circ}-71 \mathrm{r}^{\circ}$ ). Ao final desse período, segue um novo trecho: "Mais ils savent seulement qu'il y a là, parmi eux, dans la fine fleur de cette coterie Ségur qui est une de plus fermées de Paris, une très grande artiste. C'est ce qu'elle a de plus délicieux, d'à peu près unique" [Mas eles sabem somente que há aí, dentre eles, na fina flor dessa confraria dos Ségur, que é uma das mais fechadas de Paris, uma grande artista. Que é o que ela possui de mais delicioso, de quase único]. A versão manuscrita pode ser lida online: http://bit.ly/2nEYeYs [acesso em 27/03/2017].
} 
horror à mundanidade e, mesmo nas salas de concerto ou nos teatros, constatava, não sem tristeza, como é raro ouvir alguém cantar bem.

Não creio de modo algum que ele pensava ouvir em Madame de Guerne uma mulher mundana mais ou menos agradavelmente dotada do canto. Escutara o testemunho ou as impressões de muitos grandes e puros artistas. Acreditava ouvir uma verdadeira, uma grande cantora, mas semelhante a várias outras cuja reputação o cativara e o talento, decepcionara. Madame de Guerne cantou. De pé, em uma atitude imóvel à qual sua máscara dramática e seu olhar inspirado proporcionavam espécie de caráter pítico ${ }^{3}$, ela deixou escapar, como de calmos oráculos ${ }^{4}$, notas que pareciam, por assim dizer, sobre-humanas. Digo que ela as deixava escapar porque as vozes dos outros cantores se sustentam na garganta, no peito, no coração, porque parecem preservar do emocionante contato algo de humano, quase carnal e, de tão imateriais ${ }^{5}$ que são, nos atingem apenas como um perfume que carrega consigo algumas pétalas da corola arrancada. Nada disso em Madame de Guerne. Trata-se provavelmente do único exemplo de voz sem suporte físico, de voz não apenas pura, mas tão espiritualizada que parece, antes de mais nada, uma espécie de harmonia natural, não diria sequer os suspiros de uma flauta, mas do junco ao vento. Diante da misteriosa produção desses sons indefiníveis, o músico de quem falava permanecia imóvel, num sorriso extasiado. A cantora, no entanto, continuava a debulhar "o deslumbrante enxame de notas desiguais". Mas pode-se falar de uma cantora diante dessa harmonia que parecia produzida menos por artifício humano do que emanada de uma paisagem e que, em sua graça antiga, levava inevitavelmente a pensar nos versos de Hugo:

\section{Vem! - uma flauta invisível \\ Suspira no matagal. - \\ A canção mais agradável \\ É a canção pastoral ${ }^{6}$}

Madame de Guerne não seria a emocionante cantora dos dias de hoje se fosse simplesmente com a voz de uma calma paisagem grega que se parecesse a sua. Não, é muito mais através de uma paisagem lunar de Monticelli ${ }^{7}$ do que de

\footnotetext{
${ }^{3}$ Relativo às pítias, sacerdotisas proféticas do templo de Apolo, em Delfos, na Grécia Antiga.

${ }^{4}$ Pierre Clarac e Yves Sandre corrigiram o texto publicado no Figaro com base no manuscrito original, substituindo "orages" [trovoadas] por "oracles" [oráculos]. 0 texto do Figaro pode ser lido em http://bit.ly/2mIMjK4 [acesso em 27/03/2017].

${ }^{5}$ Seguimos a opção de Clarac e Sandre, que preferem o "imaterial" do manuscrito de Proust ao "material" publicado no Figaro. De fato, essa parece ser a diferenciação do narrador entre cantores bons e cantores como Madame de Guerne. Daqueles, só sentimos uma essência; desta, recebemos a "materialidade".

${ }^{6}$ Importante notar que, além de fazer citações com bastante liberdade, Proust também não hesitava em repeti-las em diferentes artigos. Caso desses quatro versos das Contemplações de Victor Hugo, às quais Proust recorre no retrato do príncipe Edmond de Polignac para caracterizar o bucolismo das composições de seu amigo.

${ }^{7}$ Adolphe Monticelli (1824-1886), pintor francês.
} 
uma paisagem de Teócrito que ela parece exprimir o estado da alma, e ela é muito mais a música do "silêncio" de Verlaine ${ }^{8}$ do que de Mosco $^{9}$. É aí que o charme antigo dessa arte absorve alguma coisa de estranhamente moderno. E, sem dúvida, nada ela interpretaria melhor que o Le Clair de lune, de Fauré10, essa maravilhosa obra de arte.

Música alguma, e quase chegaríamos ao ponto de dizer nenhuma dicção, intervém aqui para transmitir o sentimento, que é confiado apenas à qualidade impressionante do som. É a suprema distinção dessa arte evitar as nuances fáceis e as transições banais. 0 que não é menos profundo. Espane as nobres cinzas que cobrem voluntariamente essas notas, semelhantes a urnas prateadas: nelas encontrará piedosamente contidas e fielmente guardadas todas as lágrimas do poeta.

Aqueles que alguma vez ouviram Madame de Guerne confundem com apenas outras pouquíssimas vozes o aborrecimento de não mais conseguir escutar a sua própria, e nenhuma lhes é capaz, em todo caso, de prover exatamente sua doçura particular, esse tenro estalo de prata. Em certos antigos idílios, como o admirável Phyllis, de Reynaldo Hahn ${ }^{11}$, é a própria flauta de Pan que parece acompanhar, no fundo de um bosque sagrado, os charmosos versos do poeta. E, aqui, essa voz não é mais tão somente

\section{... A lira natural, \\ A musa dos pousios, dos regos e do trigo ${ }^{12}$;}

trata-se de uma lira dolorosa que exprime as melancolias do amor e da morte.

Seria uma enorme ingenuidade crer que, essa impressão tão estranha, a qualidade natural da voz de Madame de Guerne, associada à força de seu sentimento musical, bastaria para a proporcionar. Resta-lhe ainda uma profunda ciência do canto, uma ciência recôndita, mas necessária, da qual recolhemos a doce ceifa em douradas sonoridades. E, para nos atermos a uma parcela puramente material da arte do canto, aqueles que não ouviram ser cantado com a maravilhosa

\footnotetext{
${ }^{8}$ Paul Verlaine (1844-1896), poeta francês.

${ }^{9}$ Mosco ( 150 a.C.), poeta grego antigo, de estilo predominantemente bucólico.

${ }^{10}$ Clair de lune, Op. 46, n. 2, canção composta por Gabriel Fauré (1845-1924) em 1887 com poema de Paul Verlaine (1844-1896).

${ }^{11}$ Reynaldo Hahn (1874-1947), pianista francês de origem venezuelana e alemã. Foi amante de Proust. Phyllis é a última de uma série de dez melodias que Hahn compôs em 1900, com base nos Études latines do poeta francês Leconte de Lisle (1818-1894).

${ }^{12}$ Versos da segunda estrofe do Epigramme funéraire de José-Maria de Heredia (1842-1905): Elle s'est tue, hélas ! la lyre naturelle, / la muse des guérets, des sillons et du blé. Cf. HEREDIA, José-Maria de. Poésies complètes. Paris: Slatkine, 1981, p. 50.
} 
madame Kinen o grande dueto de Sémiramis ${ }^{13}$ ignoram que ela sabe vocalizar como Patti ${ }^{14}$. Seria injusto deixar de associar ao nome de madame de Guerne aquele do conde Henri de Ségur ${ }^{15}$, seu irmão, que é, talvez, como cultura e compreensão musicais, o reflexo de sua irmã, mas que, em sua religiosa admiração por ela, restringiu toda sua ambição a ser seu perfeito e fiel companheiro. Desde a morte de seu pai, o marquês de Ségur, cujo título é hoje ostentado pelo hábil evocador do salão de madame Geoffrin, um acadêmico do futuro ${ }^{16}$, a condessa de Guerne mora com seu marido, o conde de Guerne ${ }^{17}$, numa graciosa morada da avenida Bosquet - foi lá que se ouviu pela primeira vez os coros de $E_{s}$ ther $^{18}$, que é talvez o que o senhor Reynaldo Hahn escreveu até hoje de mais belo, nos quais todas as graças da narrativa bíblica e da tragédia raciniana são transpostas e como que exaltadas -, morada enobrecida por todos os testemunhos de admiração que os compositores prestavam à artista, de Gounod ${ }^{19}$, que lhe dedicava suas melodias, até Hébert ${ }^{20}$, que a retratou; sustentada pelas leves colunas de Corinto ${ }^{21}$, ressoando às vezes ao som da lira, às vezes ao da harpa, e também com uma voz que encanta como uma e que emociona como a outra, essa alegre morada parece ao mesmo tempo o lar do sábio e o templo das musas.

\footnotetext{
${ }^{13}$ A ópera Semiramide, do compositor italiano Gioachino Rossini (1792-1868), com libreto de Gaetano Rossi (1774-1855) e inspirada na peça de Voltaire (1694-1778), Sémiramis. Foi interpretada pela soprano Anita Kinen.

${ }^{14}$ A soprano franco-italiana Adelina Patti (1843-1919), uma das mais célebres em seu tempo.

${ }^{15}$ Henri Marie Joseph, conde de Ségur (1855-1936), segundo filho de Anatole Henry Philippe, marquês de Ségur (1823-1902).

${ }^{16}$ Proust se refere a Pierre Marie Maurice Henri (1853-1916), irmão mais velho da condessa de Guerne, que assume o título de marquês de Ségur após a morte do pai, em 1902. Pierre de Ségur publicou em 1897 o estudo Mme Geoffrin et sa fille e foi eleito para a Academia Francesa em 1907.

${ }^{17}$ Albert Maloteau, conde de Guerne (1856-1937), marido da condessa de Guerne até 1907, quando o casal se divorcia e ele se casa com Valentine Euchêne (1870-1960).

${ }^{18}$ Esther, espetáculo lírico orquestrado por Reynaldo Hahn ( $C f$. nota 11) com base na tragédia de Jean Racine (1639-1699). Estreou em 1905 no Théâtre Sarah Bernhardt, em Paris.

${ }^{19} \mathrm{O}$ compositor francês Charles Gounod (1818-1893).

${ }^{20} \mathrm{O}$ pintor francês Ernest Hébert (1817-1904). 0 retrato ao qual Proust se refere, Portrait de MarieThérèse de Ségur, comtesse de Guerne, foi pintado por Hébert em 1898 e se encontra conservado hoje no Musée Carnavalet de Paris. Cf. HÉBERT, Ernest. Portrait de Marie-Thérèse de Ségur, comtesse de Guerne. 1898. Óleo sobre tela, 61,5 x 52,5 cm. Paris, Musée Carnavalet.

${ }^{21}$ Relativo à ordem coríntia, o último dos três grandes estilos arquitetônicos (e talvez o mais ornamentado) da Grécia Antiga.
} 


\title{
Um professor de beleza ${ }^{1}$
}

\section{(Les Arts de la Vie, 15 de agosto de 1905)}

\author{
"A história dos pequenos soberanos de Fezensac seria boa apenas para seus \\ herdeiros, se os possuíssem", disse Voltaire em $O$ Ingênuo ${ }^{2}$. Qualquer que seja a \\ opinião que tenhamos sobre essa posição de Voltaire, podemos imaginar que, se o \\ conde Robert de Montesquiou-Fezensac, logrando, através de um artifício que
}

${ }^{1}$ Un Professeur de beauté foi publicado pela primeira vez na revista Les Arts de la vie, edição de agosto de 1905, com a assinatura de Marcel Proust. Seu retratado, Robert de Montesquiou (18551921), é descrito por Luzius Keller no Dictionnaire Marcel Proust como "uma das figuras mais marcantes de sua época". Um dândi, herdeiro da velha aristocracia francesa, assíduo no entourage dos escritores Paul Verlaine (1844-1896), Stéphane Mallarmé (1842-1898) e Edmond de Goncourt (1822-1896). Como prova de amizade e admiração, Proust escreveu outros retratos de Robert de Montesquiou ao longo do ano de 1913. Um deles chegou a ser reunido postumamente por Sandre e Clarac na coletânea Essais et articles, sob o título de Robert de Montesquiou: le souverain des choses transitoires [Robert de Montesquiou: o soberano das coisas transitórias] (Cf. CSB, p. 405). Un Professeur de beauté, no entanto, foi o caso mais bem acabado, bem como o único a ser publicado. Ao lê-lo, o conde imediatamente escreve a Proust, nos primeiros dias de agosto, e o considera como uma "belle apologie, une apothéose de mon verbe" [uma bela apologia, uma apoteose de meu verbo] (Corr., V, p. 321). Sua impressão fora tão positiva que decidiu incluí-lo no apêndice de Altesses Sérénissimes, coletânea de ensaios publicada no ano de 1907. Segundo Annick Bouillaguet, esse artigo, um "ditirambo do conversador" que se propõe a "celebrar sua imensa cultura", foi escrito pouco tempo após a primeira visita de Montesquiou à casa de Proust. Os dois teriam sido apresentados no salão de Geneviève Halévy (1846-1926), mãe de Jacques Bizet (1872-1922), filho do compositor da ópera Carmen e colega de turma de Proust no Liceu Condorcet. Mas há também versões que afirmam que Proust o teria conhecido em abril de 1893, no salão da pintora Madeleine Lemaire (1845-1928), amante de Montesquiou. A figura de Robert de Montesquiou foi, assim, fundamental para a circulação de Proust pela aristocracia parisiense da Belle Époque. O jovem escritor via no conde, assim como em Charles Haas (1833-1902), nas palavras de Bouillaguet, um "duplo" de si próprio. Chegava ao ponto de imitá-lo, fazer caricaturas dele, e, ao compor a figura do barão de Charlus da Recherche, não receou colocar na boca de seu personagem um modo de falar, mesmo um vocabulário, um traquejo, enfim, uma forma de ser que muitos atribuíram sem grandes dificuldades a Montesquiou. Mais do que elogiar a erudição do conde, Proust parece nesse artigo lançar mão do método crítico que, num contexto bastante próximo, acabou por recusar: aquele de Charles-Augustin Sainte-Beuve (1804-1869), reprovado por Proust no projeto inacabado Contre Sainte-Beuve, e que consistia em explicar a personalidade de um autor a partir de sua obra. A abundância de referências dos mais diversos campos do saber, o tom enciclopédico de suas reflexões, as críticas espinhosas a um "inferior" Eugène Fromentin (1820-1876), esses e outros tantos aspectos nos revelam um narrador proustiano que, ao tentar esculpir em letras o intelecto de Montesquiou, acaba ele próprio tomando para si essa forma de se pensar, transformando trechos inteiros em claros pastiches. Cf. BOUILLAGUET, Annick. Montesquiou: le souverain des choses transitoires. In TADIÉ, Jean-Yves. Le Cercle de Marcel Proust II. Paris: Honoré Champion, 2015, p. 81; KELLER, Luzius. Comte Robert de Montesquiou-Fezensac. In BOUILLAGUET, Annick. Dictionnaire Marcel Proust. Paris: Honoré Champion, 2004, p. 644.

${ }^{2}$ L'Ingénu, romance filosófico de 1767 no qual Voltaire ironiza a inocência de um indígena canadense que, ao chegar deslumbrado à França, se vê confrontado pela tirania do regime de Luís XIV e de suas instituições. 0 trecho ao qual Proust se refere consta do capítulo X: "Tous deux riaient de pitié quand Il était question des souverains de Fezensac, de Fezensaguet et d'Astarac. Cette étude, en effet, ne serait bonne que pour leurs héritiers, s'ils en avaient" [Os dois riam de dó em se tratando dos soberanos de Fezensac, de Fezensaguet e de Astarac. Esse estudo, com efeito, seria bom apenas para seus herdeiros, se os possuíssem]. Cf. VOLTAIRE. Romans et contes. Paris: Gallimard, Bibliothèque de la Pléiade, 1979, p. 316. 
certamente não teria sido louvável, dissimular sua personalidade espiritual e reservar seu estilo, dar vida de alguma maneira à sua maravilhosa inteligência diferenciada, como que incógnita, tivesse se contentado em escrutinar e publicar o que não necessariamente significa escrever - uma história de sua família, já há uma década possuiria seu assento na Academia Francesa e todos, à exceção dele talvez, teriam a oportunidade de se regozijar. Se, como o creio, no que diz respeito aos acadêmicos antes de mais nada, mesmo e especialmente nas sessões a portas fechadas, nos dias do dicionário ${ }^{3}$, hoje ninguém sequer chegue perto do senhor de Montesquiou em sua sensibilidade às faces, às aparências, aos gestos, às tradições, aos ridículos, aos preconceitos, às virtudes de cada palavra, e não conheça melhor que ele suas histórias, não possa mais acompanhá-las e situá-las com maior certeza dentre os clássicos e os modernos, e isso até o ponto de, às vezes, desconcertar e exaurir seu leitor menos ágil, que ele finge, com uma elegância na qual se mistura talvez um pouco de impertinência, ser tão sábio quanto ele, ao passo que o outro, que nada pode fazer, desejaria muito dizer-lhe, como o senhor Jourdain: "por gentileza, senhor, aja como se eu não o soubesse"4. - "0 verdadeiro escritor", disse Ruskin", "deve conhecer a fundo a genealogia e a heráldica das palavras, saber com precisão as funções para as quais foram designadas na nobreza nacional do vocabulário, quais alianças firmaram entre si, em qual medida são recebidas*”, etc.

\footnotetext{
${ }^{3} \mathrm{O}$ "dia do dicionário" ao qual Proust se refere é a reunião semanal, a portas fechadas, que os imortais da Academia Francesa tradicionalmente dedicam à elaboração dos verbetes de seu dicionário de referência.

${ }^{4}$ Fala do personagem Jourdain em diálogo com um filósofo na cena IV do segundo ato de Le Bourgeois gentilhomme, peça de 1670 com texto de Molière (1622-1673) e música de Jean-Baptiste Lully (1632-1687): "Maître de Philosophie - Ce sentiment est raisonnable, Nam sine doctrina vita est quasi mortis imago. Vous entendez cela, et vous savez le latin sans doute. / Monsieur Jourdain - Oui, mais faites comme si je ne le savais pas. Expliquez-moi ce que cela veut dire" [Filósofo - Esse sentimento é razoável, Nam sine doctrina vita est quasi mortis imago. Vós compreendeis isso e sem dúvida sabeis latim. / Senhor Jourdain - Sim, mas agis como se eu não o soubesse. Explicai-me o que isso quer dizer]. $C f$. MOLIÈRE. CEuvres complètes. Paris: Gallimard, "Bibliothèque de la Pléiade", vol. II, 2010, p. 280.

${ }^{5}$ O crítico inglês John Ruskin (1819-1900).

*Naturalmente não poderia, neste elogio tão breve e neste espaço tão restrito de um artigo, discutir e aprofundar essa opinião de Ruskin, da qual não cito mais que uma passagem para honrar o mestre e amigo ao qual ela parece se aplicar. Mas na edição que em breve publicarei de Sésamo e os lírios, direi tudo o que penso a respeito dessa máxima e de outras análogas†.

† Proust se refere ao prefácio Sur la lecture, publicado primeiro na revista La Renaissance latine, em 1905, e depois em sua tradução de Sesame and lilies, obra de John Ruskin, em 1906.

${ }^{6}$ Excerto adaptado de Sesame and lilies, obra publicada pelo crítico John Ruskin em 1865 e traduzida por Proust em 1906: "A well-educated gentleman may not know many languages,-may not be able to speak any but his own,- may have read very few books. But whatever language he knows, he knows precisely; whatever word he pronounces, he pronounces rightly; above all, he is learned in the peerage of words; knows the words of true descent and ancient blood, at a glance, from words of modern canaille; remembers all their ancestry, their intermarriages, distant relationships, and the extent to which they were admitted, and offices they held, among the national noblesse of words at any time, and in any country" [Um senhor bem instruído pode não conhecer muitos idiomas, - pode não ser capaz de falar nenhum outro além de seu próprio, - pode ter lido pouquíssimos livros. Mas qualquer idioma que conhecer, o fará com precisão; qualquer palavra que pronunciar, o fará com correção; ele é, acima de tudo, conhecedor do parentesco das palavras; sabe, num relance, as palavras da verdadeira ascendência e do sangue antepassado das palavras das
} 
Ninguém se encaixa melhor que o senhor de Montesquiou nessa definição. Todos aqueles que o viram se paralisar e como que se eriçar no momento de pronunciar uma palavra (e daquelas que, até então, menos nos haviam chamado atenção), como no susto* de se ver de repente beirando o abismo do passado que sob ela se entreabre, cujo hábito somente nos dissimula as profundezas, na vertigem de haver apreendido a graça nativa dessa palavra, lá inclinada como uma flor na beira extremidade de um precipício, todos aqueles que o viram se apropriar de uma palavra, mostrar-lhe todas as belezas, degustá-la, fazer quase careta com seu sabor específico e demasiado forte, valorizá-la, repeti-la, gritá-la, salmodiá-la, cantá-la, torná-la tema de mil cintilantes variações, improvisadas com uma riqueza que surpreende a imaginação e desconcerta os esforços da memória em retê-las, todos podem supor que dias maravilhosos seriam, com ele, na Academia, os dias do dicionário*. Mas que dizer do que seriam as sessões solenes, as recepções se, como dita a tradição, o que elas pedem e o que as torna charmosas é a cortesia, a eloquência, a malícia, o bom gosto e a espirituosidade. Sabemos que "recepcionar" é - quando ele não está ocupado com algo melhor, dando vida a seus ideais,

massas modernas; recorda-se de todos seus ancestrais, de seus casamentos, relações distantes, e a medida na qual foram aceitas, os postos que ocuparam em meio à nobreza nacional das palavras, a qualquer momento e em qualquer país]. Cf. RUSKIN, John. Sesame and lilies. Londres: George Allen, vol. 18, p. 65.

*No belo sentido que se atribui aos cavalos de raça: "Domando seu cavalo que se assusta" (Heredia); "Um cavalo assustado que relincha nos céus" (Hugo) e que Hugo estendeu aos poetas: "Rumarei, mago assustado" $†$.

† Proust se refere ao penúltimo verso do soneto Soir de bataille ("Superbe, maîtrisant son cheval qui s'effare" [Soberbo, dominando seu cavalo que se assusta]), do poeta franco-cubano José-Maria de Heredia (1842-1905), e a duas passagens de Victor Hugo (1802-1885) - o último verso de Éblouissements ("Un cheval effaré qui hennit dans les cieux!" [Um cavalo assustado que relincha nos céus]) e os quatro da 29a estrofe de Ibo ("Donc, les lois de notre problème, / Je les aurai; / J'irai vers elles, penseur blême, / Mage effaré!” [Então, as leis de nosso problema, / Eu as terei; / Rumarei a elas, pensador pálido, / Mago assustado!]). Cf. HEREDIA, José-Maria de. Poésies complètes. Genève: Slatkine, 1979, p. 84 e HUG0, Victor. CEuvres poétiques. Paris: Gallimard, Bibliothèque de la Pléiade, vol. II, 1967, p. 157.

*Não poderíamos conceber como um verbete definitivo para um dicionário ideal (e eu lamento aqueles que veriam nesse elogio um epigrama) o recente estudo dedicado à maravilhosa urna exposta pela senhorita Lemaire? Essa surpreendente litania de citações de Montaigne, Lesage, Balzac, Victor Hugo, Flaubert, na qual ressurgem, como um refrão, as duas palavras que se encarrega de definir e ilustrar, "caixa" e "urna", esses exemplos ao mesmo tempo famosos e esquecidos destinados a especificar e a glorificar cada uma delas: "a urna de Cípselo depositada no templo de Juno em Olímpia", "a urna na qual Nero ofereceu sua primeira barba à Vênus Genitora", "a urna guardando os arquivos franceses que Filipe VI deixou ser levada em Crécy", "a urna contendo as joias de Carlos, o Temerário, que os suíços saquearam em Morat" (dentre outros ainda mais significativos), tudo isso não oferece uma contribuição bastante preciosa aos verbetes "caixa" e "urna"? Mais além, essa sabedoria é esbanjada com uma ausência de pedantismo que afirma suficientemente o gênero de antologia no qual foi publicado: Les Modes (edição de junho de 1905) †. †Proust alude ao artigo Variations sur la Boîte de Pandore, publicado por Robert de Montesquiou na edição de junho de 1905 da revista Les Modes, voltada ao universo das artes decorativas e com circulação nas quatro principais capitais globais daquele momento: Paris, Londres, Berlim e Nova York. Trata-se de um comentário de Montesquiou sobre uma urna pintada com guaches por sua filha, Suzanne Lemaire e exposta naquele ano pela Société Nationale des Beaux-Arts. O texto é dedicado à mãe de Suzanne, a também pintora, e amiga íntima de Proust, Madeleine Lemaire. A versão digitalizada desse artigo pode ser encontrada junto à Biblioteca Nacional da França, através do link http://bit.ly/2omNrjY (consultado em 11 de abril de 2017). 
lutando por eles - uma das coisas nas quais nosso poeta se excede, e que acolher um visitante - sempre um pouco como "um eleito" - em sua morada, que é muito justamente (e, para falar como ele, "preventivamente") denominada como aquela das Musas, ele não poupa recursos do espírito e da eloquência que muitos acadêmicos seriam firmemente impedidos de incluir em seus discursos. Sem dúvida, ele saberia "recepcionar o eleito" na Academia, ser aquele que proporcionou à hospitalidade - como, aliás, a tantas outras coisas - uma fórmula por assim dizer nova, feita de majestosa graça e de incansável espírito. "E, no que diz respeito ao gosto", quem então poderíamos citar que o tivesse melhor lapidado para julgar o valor de uma obra e penetrar em seus segredos ao ponto de surpreender seu autor? E sua competência se estende tanto ao além para que não sejam apenas os literatos aqueles que adoraríamos ouvi-lo acolher em uma academia, mas também os pintores e os músicos. Não creio que nem o senhor $\mathrm{Helleu}^{7}$, nem o senhor Fauré $^{8}$, discordariam de mim. Sem dúvida, como, por conveniência ao gênero, Sarah Bernhardt interpretando Assuero em Saint-Cyr sabe se esquecer da fúria de Hermíone ${ }^{9}$, o senhor de Montesquiou, nos discursos da Academia, encobriria com uma decente doçura suas tempestuosas justiças e injustiças. Mas, enfim, "sob a cúpula"10, aprecia-se também que o recipiendário seja por vezes repreendido. E, sem chegar ao ponto de pedir ao senhor de Montesquiou para lançar mão de seus raios de eloquência (aliás, talvez não haveria realmente necessidade de lhe pedir para que o fizesse), seus colegas se articulariam para que, na maior parte das vezes, fosse ele o encarregado do papel, tradicional nessa arena, de picador, o qual, aliás, compreenderia sem dúvida de modo bastante novo. Certamente vislumbramos daqui com que incomparável e majestosa leveza, com que vivaz e nobre e cruel desenvoltura, com que cabriolante, trepidante, calcante e caracolante aparência saberia ele desenvolver e, depois, enrijecer ao redor da vítima eleita ou coroada suas sábias evoluções, irritando-a, espetando-a com mil dardos variados e certeiros, para os aplausos de um público ávido, senão de sangue, a menos de amor-próprio derramado. Mas todos aqueles que o conhecem sob esse aspecto e nesse papel, seja porque o ouviram proferir, seja porque leram excertos desse gênero, nos quais sua pluma eletrificada se digladia e atira para todos os lados, esses sabem que todas as figuras da justa e do torneio são regidas por uma lógica superior e minuciosa e, como uma espécie de moralidade, compreendem normalmente uma lição elevada de sabedoria e de arte. Basta como exemplo, particularmente acessível e palatável aos leitores de Les Arts de la vie, as

\footnotetext{
${ }^{7} 0$ pintor francês Paul-César Helleu (1859-1927).

${ }^{8}$ O compositor francês Gabriel Fauré (1845-1924).

${ }^{9}$ Clarac e Sandre esclarecem que, no início de 1905, a atriz Sarah Bernhardt (1844-1923) encenou a tragédia Esther, de Jean Racine (1639-1699), da maneira mais próxima àquela de sua primeira estreia, em Saint-Cyr, no ano de 1689. Apenas mulheres compuseram o elenco e a ela coube o papel do rei Assuero. Dois anos antes, em 1903, ela havia interpretado outra tragédia de Racine, Andrômaca, daquela vez no papel feminino de Hermione.

${ }^{10}$ La coupole (a cúpula) é o salão nobre do Institut de France, edifício que abriga a Academia Francesa.
} 
páginas maravilhosas, militantes, mas, no fundo, sobretudo pregadoras que ele aqui publicou recentemente ${ }^{11}$, a respeito de um tema sobre o qual, para ser honesto, (salvo por meio de opiniões eventuais cuja injustiça tenho boas razões para denunciar) não saberia me pronunciar por desconhecer, devido a razões de fato e bastante lamentáveis, a obra do artista em questão. Os leitores de Les Arts de la vie, tenho certeza, "ainda não retornaram" do espetáculo que tiveram naquele dia, quando viram o senhor de Montesquiou esbanjando sua verve a tal ponto que se poderia supor, e com enorme exatidão, que reservava cem vezes mais dela, quando o viram - e com uma maestria e uma fúria capazes de atordoar sua vítima e até mesmo os espectadores demasiado próximos - desferir seus golpes, ao mesmo tempo cobrir de uma brilhante pintura todo o grande espaço ao qual se reservou, corrigir vinte retratos, repintar dez telas, redesenhar um braço aqui, alongar uma mão acolá, mais adiante trocar uma poltrona de lugar e, finalmente, jogar toda a mobília pela janela, sobrepor sua cor àquela do mestre pintor, transformado, sem ter encontrado tempo para protestar, em seu aprendiz; - e não poupar com uma eloquência, uma inteligência, uma lógica, um espírito que pertencem apenas a ele, conselhos e lições que certamente o artista não lhe pedia, que são talvez injustos ou imprecisamente dirigidos a ele, mas que permanecerão, a despeito disso, justos e verdadeiros, de uma verdade mais elevada e de uma eterna justiça, na medida em que pregam, a respeito de um nome que talvez não fosse aquele ao qual isso era devido, do qual eu nada poderia dizer, o bom, o necessário sermão sobre o falso belo e sobre a falsa grande arte, com esse ar - e esse grande ar - de extraordinária dignidade evangélica daquele que sabe separar o joio do trigo - e que, para falar a verdade, é mais que distintivo, é único nesse verdadeiro filho dos cruzados que, "sobre a cimeira dourada do cavaleiro", ao lado da "pluma de ferro" cuja "beleza" se conhece ${ }^{12}$, afivelou a concha do peregrino do

\footnotetext{
${ }^{11}$ Proust se refere a um artigo da edição de junho de 1905 da revista Les Arts de la vie no qual Robert de Montesquiou critica o pintor ítalo-americano John Singer Sargent (1856-1925). "Je ne ferai nulle difficulté d'avouer que M. Sargent ne soit un grand peintre" [Não teria a menor dificuldade em reconhecer que o senhor Sargent não é um grande pintor], conclui Montesquiou, para, em seguida, contar uma anedota: “On prétend que l'illustre Maître de M. Sargent, M. CarolusDuran, ayant eu quelques raisons de mécontentement contre son élève (genus irritable) se serait repenti de l'avoir conduit à l'immortalité, en plaçant sa tête dans l'angle d'un plafond du Louvre. C'est alors que notre grand portraitiste national aurait fait ériger à nouveau un échafaudage remisé, à seule fin d'effacer des traits qui, selon lui, n'avaient plus le droit d'être éternels. [...] En effet, il ne veut pas dire que les contemporains aient eu tort de mettre $M$. Sargent, à une place très en vue. Non. Il signifie seulement qu'on l'a peut-être accroché un peut haut" [Imaginemos que o ilustre Mestre do senhor Sargent, senhor Carolus-Duran [o pintor Charles Émile Auguste Durand (1837-1917)], estando por algumas razões descontente com seu aluno (genus irritable), teria se arrependido de tê-lo conduzido à imortalidade colocando sua cabeça em um dos cantos do teto do Louvre. É então que nosso retratista nacional teria mandado montar uma vez mais um andaime guardado apenas para apagar os traços que, a seu ver, não tinham mais o direito de serem eternos. [...] Com efeito, isso não quer dizer que os contemporâneos se enganaram ao colocar o senhor Sargent num pedestal. Não. Isso significa apenas que talvez eles o tenham colocado um pouco alto demais]. $C f$. MONTESQUIOU, Robert de. Le Pavé rouge. Les Arts de la vie, Paris, tomo III, n. 18, junho de 1905, p. 348.

${ }^{12}$ Termos extraídos dos versos de L'Esprit pur, de Alfred de Vigny (1797-1863): “J'ai mis sur le cimier doré du Gentilhomme / Une plume de fer qui n'est pas sans beauté" [Sobre a cimeira
} 
legítimo, do missionário e do puro religioso da Beleza. Deus sabe que não podemos falar dele como Luís XIV de Bernini ${ }^{13}$ : "ele não encontra muito o que admirar". Ninguém admira mais que ele porque ninguém discerne a beleza com um olhar mais certeiro e mais emocionado que ele. E tenho quase certeza, para voltar à Academia - e deixá-la -, que o público especial desses dias de "recepções" se decepcionaria, em sua malícia, ao ouvi-lo proferir entusiasmados "elogios" com maior frequência do que pulverizá-los aqui ou acolá, ao longo das peripécias e dos "incidentes" dessas sessões apaixonadas, em nome da glória maior da poesia e das letras. Tudo isso, no entanto, não se deve lamentar. Primeiro, porque tudo ocorrerá. Depois, porque a Academia, que seria muito injusto menosprezar, que, em suma, reúne hoje ou conseguirá reunir amanhã a maior parte de nossos maiores escritores* e que conta talvez com mais homens superiores que qualquer outra assembleia humana, não deve tão cedo estender a mão a esses talentos militantes que alimentam todo seu fogo e lançam todas suas chamas na pregação e na luta, que precisam guerrear ainda que contra moinhos de vento, peregrinar por todos os cantos do país, tomados por essas naturezas indômitas e belicosas, excelentes aos postos avançados e aos quais se deve desejar que a posição de "inatividade", mesmo com toda a graça que lhe possam proporcionar, seja oferecida o mais tarde possível, para que permaneçam por mais tempo chefes de

dourada do cavaleiro coloquei / Uma pluma de ferro à qual não falta beleza]. $C f$. VIGNY, Alfred. CEuvres completes. Paris: Gallimard, Bibliothèque de la Pléiade, vol. I, 1986, p. 166.

${ }^{13} \mathrm{O}$ escultor Gian Lorenzo Bernini (1598-1680), trazido em 1665 da Itália por Jean-Baptiste Colbert, ministro de Luís XIV, para projetar uma restauração do Palácio do Louvre, em Paris.

* Sabemos que a imediata (e necessária) eleição de Barrès é certa. Uma revista nova e muito interessante que acaba de ser fundada sob a engenhosa direção do senhor Paul Fort, e que não saberíamos como estimar e recomendar mais, Vers et Prose, nos transmite uma grande alegria ao anunciar que a eleição de nosso caro e grande Henri de Régnier, esse escritor poderoso e delicioso, se aproxima. Nossa satisfação será ainda mais completa se um terceiro assento for reservado a um filósofo, a um artista pelo qual já tivemos e teremos futuramente a oportunidade de exprimir nossa profunda admiração, o senhor Maurice Maeterlinck. Quanto a achar se um grande escritor deve ou não desejar ingressar na Academia, a questão deve ser considerada para cada caso em particular, de acordo com suas preferências e decisões pessoais. Não pode haver regra para isso. 0 fato que Flaubert não tenha desejado ingressar na Academia não é suficiente para consagrar como grande escritor todos aqueles que desdenham dela, nem mesmo, a despeito do exemplo inverso de Victor Hugo, um poeta se engrandece ao se tornar acadêmico. Os "mandamentos" espirituais mais absolutos e minuciosos devem, a esse respeito, permanecer calados e se submeter ao desejo e à complexidade de cada um. Trata-se de assunto de higiene individual. $\dagger$

† Proust trata da eleição do escritor Maurice Barrès (1862-1923) para a Academia Francesa, que ocorre em 1906, após a morte do poeta José-Maria de Heredia (1842-1905). Também comenta as especulações em torno da candidatura do escritor Henri de Régnier (1864-1936), que, de fato, acabaria eleito em 1911 ao assento de número 39. 0 escritor Maurice Maeterlinck (1862-1949) foi laureado com o Prêmio Nobel de Literatura de 1911, mas jamais ocupou um assento da Academia. No mais, Clarac e Sandre acreditam que o excesso de elogios a Henri de Régnier nessa nota de rodapé pode ser compreendido como uma alfinetada de Proust a Robert de Montesquiou. Um espisódio espinhoso ainda era fresco na memória dos leitores. Em 1897, apenas oito anos antes da publicação desse artigo, Régnier acusou publicamente Montesquiou de ter sido um dos homens que, com suas bengalas, agrediram mulheres para escapar primeiro do incêndio do Bazar da Caridade, um mercado beneficiente organizado pelo barão de Mackau (1832-1918) em Paris. 0 acidente com um projetor alimentado a éter devastou todo o edifício e deixou mais de uma centena de vítimas, a maioria mulheres e crianças. Após a acusação, os dois escritores se desafiaram em duelo e Montesquiou saiu levemente ferido. 
um destacamento que é uma elite autônoma, mais livres em seus procedimentos e movimentos.

Essas reflexões me ocorriam ao ler o último livro do senhor de Montesquiou, ao qual, segundo um gosto e um talento de intitular que lhe são próprios, atribui um nome singular cuja imagem logo força e estende a um gênero de objetos que dela não resultavam, de modo que, ao designá-los, ela permanece, por mais extensa que seja a sua aplicação, excessivamente chocante e precisa. Ontem, os Altares privilegiados eram palavras que significavam propriamente o altar no qual se celebra a missa dos mortos em épocas nas quais era proibido fazêlo em outros altares. Hoje, são Belezas profissionais. Altares privilegiados, Belezas profissionais e Caniços pensantes, três livros de crítica de arte sem igual e podemos dizer com pouquíssimos equivalentes na França ${ }^{14}$. Certamente a grande obra de Ruskin, em seu gênio moral, em seu grande poder de inspiração sentimental e poética, na unidade do plano de algum modo divino desse tipo de discurso sobre a Beleza Universal, representa uma obra bem maior e bem superior a esses três livros do senhor de Montesquiou. Mas podemos exigir dessa série de breves ensaios que se assemelhe a uma obra imensa que persegue ao longo de cinquenta volumes um mesmo e transcendente projeto? Ainda assim é preciso reconhecer que talvez haja mais verdade de julgamento artístico, de justeza de gosto em cada um desses curtos ensaios do que nos grandes livros de Ruskin. Ora, sob o ponto de vista estrito da crítica de arte, um sentimento justo das obras, uma apreciação exata dos valores importa talvez mais que as mais belas considerações. Quase nenhum dos julgamentos artísticos de Ruskin, pelo menos sobre seus contemporâneos, parece conseguir perdurar. Entusiasmo pelos Pré-Rafaelitas, por Meissonier ${ }^{15}$; desdenho por Whistler. E, no entanto, é o julgamento dos contemporâneos que importa em um crítico. "Todos são bons”, disse Sainte-Beuve, "discorrendo sobre Racine e Bossuet. Mas a sagacidade do juiz, a perspicácia do crítico é comprovada, sobretudo, quanto a obras novas, ainda não habituadas do público. Julgar à primeira vista, adivinhar, adiantar, eis o dom crítico. Quão poucos o possuem!"16.

\footnotetext{
${ }^{14}$ São três dos vários livros de ensaios críticos que Robert de Montesquiou publicou: Roseaux pensants (1897), Autels privilégiés (1898) e Professionnelles Beautés (1905). A leitura deste último é que motiva Proust a escrever esse artigo.

${ }^{15}$ Ernest Meissonier (1815-1891), pintor francês.

16 “C'est Mlle de Gournay qui l'a dit, et je le redirai, à ma manière, après elle: 'la pierre de touche véritable du jugement critique, ce sont les écrits contemporains. Tout le monde est fort à prononcer sur Racine et sur Bossuet [...]' " [Foi Mlle de Gournay quem o disse, e eu o repetirei à minha maneira, de acordo com ela: "a verdadeira pedra de toque do julgamento crítico são os escritos contemporâneos. Todos são bons discorrendo sobre Racine e Bossuet"]. Observação de uma nota de rodapé de Chateaubriand et son groupe littéraire, na qual seu autor, o crítico Charles-Augustin Sainte-Beuve (1804-1869), faz alusão a um comentário de Marie de Gournay (1565-1645), escritora francesa e amante de Michel de Montaigne (1533-1592). Cf. SAINTE-BEUVE, CharlesAugustin. Chateaubriand et son groupe littéraire. Paris: Garnier Frères, 1861, p. 117. Dois meses antes da publicação desse artigo, Proust havia empregado o mesmo excerto para criticar SainteBeuve em uma nota de rodapé do artigo Sur la lecture, publicado na revista La Renaissance latine.
} 
Ora, esse certamente não será um dos títulos menores do senhor de Montesquiou, por haver singularmente antecipado o gosto de sua geração e daquela que a precedeu, por lhe haver advertido, formado e estimulado, por lhe haver colocado na rota das novas belezas, que foram sempre belezas reais. Nunca o ludibriaram as mais sedutoras cores da novidade que se assemelha ao verdadeiro belo. Jamais foi ele manipulado por essa ilusão de óptica que colore em nossos olhos como reflexos de um talento novo os simples esforços que os avizinham e que são, em si, bastante incolores. Os verdadeiros talentos são como estrelas. Seu brilho leva tanto tempo para nos alcançar que, quando podemos enfim distingui-lo, o astro já há muito tempo se apagara. Graças aos seus maravilhosos telescópios espirituais, o senhor de Montesquiou sempre distinguiu, desde seu surgimento, os talentos estelares. E o horizonte distante de sua vista não lhe reduz a precisão: ele jamais saudou como estrelas os planetas que as orbitam e que retiram delas, e não deles mesmos, sua iluminação. Mas, essas estrelas, com que alegria, com que veneração de rei mago e com que fervor de apóstolo ele se dirigiu a elas, as adorou,

Esse é o mesmo texto que, pouco tempo depois, serviria de prefácio a sua tradução de Sesame and lilies, obra de John Ruskin: "souvent, quand un grand écrivain fait de la critique, il parle beaucoup des éditions qu'on donne d'ouvrages anciens, et très peu des livres contemporains. Exemple Les Lundis de Sainte-Beuve et La Vie littéraire d'Anatole France. Mais tandis que M. Anatole France juge à merveille ses contemporains, on peut dire que Sainte-Beuve a méconnu tous les grands écrivains de son temps. Et qu'on n'objecte pas qu'il était aveuglé par des haines personnelles. Après avoir incroyablement rabaissé le romancier chez Stendhal, il célèbre, en manière de compensation, la modestie, les procédés délicats de l'homme, comme s'il n'y avait rien d'autre de favorable à en dire! Cette cécité de Sainte-Beuve, en ce qui concerne son époque, contraste singulièrement avec ses prétentions à la clairvoyance, à la prescience. 'Tout le monde est fort, dit-il, dans Chateaubriand et son groupe littéraire, à prononcer sur Racine et Bossuet... Mais la sagacité du juge, la perspicacité du critique, se prouve surtout sur des écrits neufs, non encore essayés du public. Juger à première vue, deviner, devancer, voilà le don critique. Combien peu le possèdent' " [normalmente, quando um grande escritor escreve uma crítica, ele trata muito das edições de obras antigas e muito pouco dos livros contemporâneos. Por exemplo, Les Lundis, de Sainte-Beuve, e La Vie littéraire, de Anatole France. Mas, ao passo que o senhor Anatole France julga maravilhosamente seus contemporâneos, podemos dizer que Sainte-Beuve não compreendeu nenhum dos grandes escritores de seu tempo. E não vale alegar que ele era cego por birras pessoais. Após ter incrivelmente rebaixado o romancista que havia em Stendhal, ele consagra, como forma de compensação, a modéstia, os procedimentos delicados do homem, como se não houvesse mais nada de favorável a ser dito! Esse ceticismo de Sainte-Beuve, no que diz respeito a sua época, apresenta um contraste singular diante de suas pretensões à clarividência, à presciência. "Todos são bons", disse ele, em Chateaubriand et son groupe littéraire, "discorrendo sobre Racine e Bossuet... Mas a sagacidade do juiz, a perspicácia do crítico é comprovada, sobretudo, quanto a obras novas, ainda não habituadas do público. Julgar à primeira vista, adivinhar, adiantar, eis o dom crítico. Quão poucos o possuem!"]. Cf. CSB, p. 189.

* Sabemos que esse discernimento, essa previsão da nova beleza, o senhor de Montesquiou a estendeu às mais diversas habilidades artísticas. Seu nome é inseparável, por exemplo, daquele de Gallé, de Lalique. E sempre com um ecletismo que o levou a admirar e honrar os talentos mais opostos àquilo que aparentemente seriam as únicas coisas de que deveria gostar (quem não se recorda, por exemplo, da estátua e do altar privilegiado que ele erigiu para madame Valmore? A governanta de madame Valmore confiou ao senhor de Montesquiou o cuidado de conservar sua tumba. Mas ele já havia cultivado e rejuvenescido sobre essa tumba "a árvore da grandeza"). $\dagger$ † Robert de Montesquiou foi grande amigo dos artistas plásticos Emile Gallé (1846-1904) e René Lalique (1860-1945). Este ilustrou a capa de uma de suas coletâneas de poesia, Les Paons (1901). Quanto à poeta Marceline Desbordes-Valmore (1786-1859), Montesquiou lhe dedicara todo um ornamentado volume crítico em 1894, sob o título de Félicité : étude sur la poésie de Marceline Desbordes-Valmore. Cf. MONTESQUIOU, Robert de. Félicité : étude sur la poésie de Marceline Desbordes-Valmore. Paris: A. Lemerre, 1894. 
fez verem-nas com os próprios olhos aqueles que os possuem, e os levou a verem os outros com aquele olhar da fé que é o esnobismo. A beleza ainda incompreendida que amou antes dos outros, ele a ensinou, a pregou incansavelmente e normalmente no deserto*.

Todos esses ensaios que lemos hoje assumem, para além de seu valor literário intrínseco, do qual logo mais trataremos, um valor de certo modo humano que será, para eles, mais tarde, uma grande garantia de longevidade, de que acabaram de ser verdadeiramente vividos, reaquecidos com um amor que lhes deu a vida, e incansavelmente professados. Não são, no entanto, como os ensinamentos de um Villemain ${ }^{17}$ infinitamente superior. Antes de mais nada, o público também era superior, uma pequena elite catequizada com um fervor, com um dispêndio de força espiritual, nervosa, sensível, física verdadeiramente único, uma elite que poderá testemunhar apreço elevado por esse mestre, uma vez que é composta por homens superiores do amanhã. Mas o senhor de Montesquiou não se contentou em conservar alocuções envelhecidas, em publicar cursos. Cada um dos ensaios que escreveu é uma criação original, inteiramente distinta de seus ensinamentos orais, longamente meditadas, que está muito longe de possuir apenas um valor de transcrição, que foi pensada, "escrita", e com que maravilhosa riqueza, com que força e originalidade! Que dons particulares, infinitamente raros e preciosos foram necessários para tanto - é o que, para concluir, examinaremos brevemente.

Um desses dons, que é maravilhoso para um crítico de arte e que, no entanto, pode se tornar perigoso*, Ruskin o possuiu no mais alto grau e me sentiria constrangido de citar muitos outros nomes para além do seu e do senhor de Montesquiou. Esse dom consiste, primeiramente, em ver o distinto ali onde os demais veem apenas o indistinto. Ver e saber. 0 senhor de Montesquiou entra com você em um pátio margeado de árvores. "Veja só que belas árvores!”, você diz. "Essas são", diz o senhor de Montesquiou, "árvores de Zaqueu, aquelas mesmas que escalou esse pequeno homem sábio para ver mais de perto passar o Salvador"18 (Belezas profissionais, p. 17). Você entra no salão. Belas flores nas

\footnotetext{
* Impossível explicar aqui a razão. Por sinal, insisti de maneira exaustiva sobre esses perigos no prefácio da Bíblia de Amiens, para não falar aqui somente de suas virtudes, que, em suma, prevalecem sobre eles.

${ }^{17}$ Abel-François Villemain (1790-1870), ministro francês da Instrução Pública de 1839 a 1845.

${ }^{18}$ Alusão ao Evangelho segundo Lucas, 19: 1-10: E, tendo Jesus entrado em Jericó, ia passando. E eis que havia ali um homem chamado Zaqueu; e era este um chefe dos publicanos, e era rico. E procurava ver quem era Jesus, e não podia, por causa da multidão, pois era de pequena estatura. E, correndo adiante, subiu a uma figueira brava para o ver; porque havia de passar por ali. E quando Jesus chegou àquele lugar, olhando para cima, viu-o e disse-lhe: Zaqueu, desce depressa, porque hoje me convém pousar em tua casa. E, apressando-se, desceu, e recebeu-o alegremente. E, vendo todos isto, murmuravam, dizendo que entrara para ser hóspede de um homem pecador. E, levantando-se Zaqueu, disse ao Senhor: Senhor, eis que eu dou aos pobres metade dos meus bens; e, se nalguma coisa tenho defraudado alguém, o restituo quadruplicado. E disse-lhe Jesus: Hoje veio a salvação a esta casa, pois também este é filho de Abraão. Porque o Filho do homem veio buscar e salvar o que se havia perdido.
} 
jardineiras. "Esses amarantos", diz o senhor de Montesquiou (ibid., 228), "significam em linguagem floral, etc." e ele cita graciosamente Molière e BoulayPaty**. Trazem peras. "Essas são peras-de-bom-cristão"19, diz o senhor de Montesquiou, "aquelas que o senhor Thibaudier envia à madame de Escarbagnas e que ela aceita dizendo: 'eis um bom cristão que é belíssimo'20". 0 dono da casa entra com calças cinzas que o senhor de Montesquiou declara balzaquianas. Você arrisca: "aquelas de Lucien de Rubempré". "De modo algum", protesta o senhor de Montesquiou, "aquelas de Pierre Grassou, que era 'avantajado', ou, melhor dizendo, aquelas de Sixte du Châtelet, que era pretensiosamente provinciano" ${ }^{21}$ (Caniços pensantes, p. 40)***. Uma convidada exibe a ponta de seu sapato e o senhor de Montesquiou percebe que se trata do mesmo gesto de madame Hulot diante de Crevel, uma exposição tão recatada que ele não a compreendeu ${ }^{22}$. Você vai ao Louvre e, diante de um Pisanello ${ }^{23}$, o senhor de Montesquiou lhe mostra, no fundo do retrato, flores que você talvez não teria notado. 0 que disse das flores? Que são uma generalidade ali, com a qual nossas confusas percepções são apenas obrigadas a se contentar. E o senhor de Montesquiou já lhe nomeou a aquilégia e fez notar com que verossimilhança ela é pintada. É assim que Ruskin, na representação floral mais vaga, mais simplificada de uma iluminura de manuscrito do século XIII,

\footnotetext{
**Confesso que Boulay-Paty foi incluído aqui por mim, após ler em Sainte-Beuve seus belos versos sobre o amaranto.†

† Alusão de Montesquiou à cena II do terceiro ato da peça Les femmes savantes (1672), de Molière (1622-1673). Cf. MOLIÈRE. OEuvres complètes. Paris: Gallimard, Bibliothèque de la Pléiade, vol. II, 2010, p. 580. Já Évariste Boulay-Paty (1804-1864) é poeta romântico francês. 0 poema ao qual Proust se refere é L'Amarante, parte da antologia Poésies de la dernière saison (1865): “Amarante, fleur éclatante / Comme un panache de guerrier, / Rivale, en ta rougeur constante, / Du vert feuillage du laurier" [Amaranto, flor brilhante / Feito penacho de guerreiro, / Rival, em seu rubor constante, / Da verde folhagem do loureiro]. Cf. BOULAY-PATY, Évariste. Poésies de la dernière saison. Paris: Ambroise Bray, 1865, p. 280.

${ }^{19}$ Nome popular atribuído à variedade de pera Williams. A fruta ganhou a nomenclatura de "bom cristão" quando o rei Luís XI (1423-1483), adoentado, chamou ao seu leito o peregrino Francisco de Paula (1416-1507). Ele lhe entregou então uma semente de sua terra natal, a Calábria, e pediu-lhe que, para se curar, plantasse-a e cultivasse-a com grande cuidado.

${ }^{20}$ Condessa de Escarbagnac e o senhor Thibaudier, personagens da peça La Comtesse d'Escarbagnac, de Molière. Cf. MOLIÈRE. Op. cit., p. 1019.

${ }^{21}$ Lucien de Rubempré, Pierre Grassou e o barão Sixte du Châtelet, personagens da Comédie humaine de Honoré de Balzac (1799-1850). Cf. BALZAC, Honoré de. La Comédie humaine. Paris: Gallimard, Bibliothèque de la Pléiade, vol. I-XII, 1976-1981.

***Aqui e ali, a propósito de Balzac, ver ainda mais curiosamente as Belezas profissionais, p. 298, 299 e 300 (César Birotteau) e 300 (A Solteirona).†

† Histoire de la grandeur et de la décadence de César Birotteau (1837) e La Vieille Fille (1836), romances de Balzac. Cf. BALZAC, Honoré de. Op. cit., vol. IV e VI.

${ }^{22}$ Cena de La Cousine Bette, primeiro episódio do romance Les Parents pauvres (1846), de Balzac. 0 narrador ironiza as dificuldades da baronesa Hulot em seduzir o rico Célestin Crevel: "elle ignorait totalement l'art d'avancer, au moment décisif, un joli pied en le faisant dépasser de quelques lignes une robe à demi soulevée pour ouvrir des horizons au désir!" [ela desconhecia totalmente a arte de exibir, no momento decisivo, um belo pé, fazendo-o ultrapassar em algumas linhas um vestido um pouco suspenso, para abrir os horizontes do desejo!]. Cf. BALZAC, Honoré de. Op. cit., vol. VII, p. 318. ${ }^{23}$ Antonio Pisanello (1395-1455), pintor da renascença italiana.
} 
nomeia imediatamente a rosa canina e a polygala alpina ${ }^{24}$, é assim que ele conseguia distinguir em uma tela de Collins um soberbo Alisma plantago $^{25}$ e, no Pastor mercenário de $\mathrm{Hunt}^{26}$, um não menos exato gerânio que o senhor de la Sizeranne ${ }^{27}$ (La peinture anglaise contemporaine, p. 262) nos diz ser, segundo o senhor Chesneau ${ }^{28}$, um gerânio Robertianum e que não poderia, com efeito, ser apelidado com maior felicidade ${ }^{29}$. Diante de um admirável Benozzo Gozzoli, Os anjos deixando Abraão ${ }^{30}$, Ruskin observa que o que há de muito belo é que haja um anjo de um lado e dois anjos do outro, uma vez que, com efeito, afirma ele: "recordem-se de que as Escrituras dizem que três anjos estiveram junto de Abraão, mas que apenas dois partiram em direção a Ló enquanto um terceiro rumou para outro sentido" ${ }^{\prime 2}$. É Ruskin sem dúvida quem escreve isso, mas ele, sem se dar conta, escrevia naquele momento como deveria falar cinquenta anos mais tarde (percebendo ainda menos a semelhança) o senhor de Montesquiou. Mas retornemos a este último, que abandonamos diante do retrato da princesa d'Este ${ }^{32}$. Nós o encontramos diante de um retrato de Bruyas e ele nota (Belezas profissionais, p. 209) "a transferência ao dedo indicador da mão esquerda de um anel de cavalaria aparentemente muito largo para o anelar"33. Assim, quando sabemos tudo ver, tudo distinguir e tudo nomear, já possuímos um privilégio inestimável na descrição do que quer que seja. Por todos os lados notaremos a

\footnotetext{
24 "in the more open ground, the vetch, and comfrey, and mezereon, and the small sapphire buds of the Polygala Alpina, and the wild strawberry, just a blossom or two, all showered amidst the golden softness of deep, warm, amber-coloured moss" [no campo mais aberto, a ervilhaca, e a consolda, e a dafne, e os pequenos botões cor de safira da Polygala Alpina, e os morangos silvestres, apenas uma ou duas flores, todos apresentados em meio à maciez dourada de um profundo, morno musgo cor de âmbar]. Cf. RUSKIN, John. The seven lamps of architecture. Londres: George Allen, vol. VIII, p. 223. ${ }^{25}$ COLLINS, Charles Allston. Convent thoughts. 1851. Óleo sobre tela, 84 x $59 \mathrm{~cm}$. Oxford, Ashmolean Museum.

${ }^{26}$ HUNT, William Holman. The Hireling Shepherd. 1851. Óleo sobre tela, 110,4 x 144,5 cm. Manchester, Manchester Art Gallery.

${ }^{27}$ O filósofo Robert de la Sizeranne (1866-1932), um dos primeiros leitores de John Ruskin na França, autor dos artigos que introduziram Proust, ainda jovem, à obra do crítico inglês.

${ }^{28}$ Ernest Chesneau (1833-1890), crítico de arte.

${ }^{29}$ Clarac e Sandre apontam para o trocadilho de Proust com a coincidência de nomes entre a planta Geranium robertianum e o filósofo Robert de la Sizeranne, que a descobre e cita a partir de uma leitura de Ernest Chesneau.

${ }^{30}$ Imagem que compõe o grande afresco do pintor renascentista Benozzo Gozzoli (1421-1497), Storie di Agar e di Abramo, exposto no Museo delle Sinopie, em Pisa. As reproduções que Ruskin desenhou se encontram arquivadas no Ashmolean Museum de Oxford.

${ }^{31}$ É o que diz Ruskin escrevendo a seu pai, no dia 15 de maio de 1845 , durante sua visita a Pisa: "It is a beautiful observance of the scriptural history that while three angels came to Abraham, only two come to Sodom at even" [É uma bela observação da história das Escrituras o fato de que, se três anjos vieram ao encontro de Abraão, apenas dois rumaram a Sodoma no anoitecer]. Cf. RUSKIN, John. The seven lamps of architecture. Londres: George Allen, vol. IV, p. xxx.

${ }^{32}$ Retrato da princesa Ginevra d'Este (ou de sua irmã gêmea, Lucia d'Este), executado por Pisanello entre 1435 e 1445. Cf. Pisanello. Ritratto di principessa estense. 1435-1445. Óleo sobre madeira, 42 $\times 29,6 \mathrm{~cm}$. Paris, Musée du Louvre.

${ }^{33} \mathrm{O}$ retrato do mecenas Alfred Bruyas (1821-1877) pelo pintor Eugène Delacroix (1798-1863). Cf. DELACROIX, Eugène. Portrait d'Alfred Bruyas. 1853. Óleo sobre tela, 0,93 x 0,74 cm. Montpellier, Musée Fabre.
} 
nuance exata: "um inapreensível tom de althea ${ }^{34 "}$ (Belezas profissionais, p. 130), "os rubros cravos de um Porbus não são aí ofuscados pelo veludo capuchinho de madame de Senones ${ }^{35 "}$ (Ibid., p. 205), "o vermelho e o negro de um Mefisto, o vermelho e o negro de um vaso etrusco, a mancha cinabre de uma boia de pesca, ou desse trapo rubro com a qual Corot pontilhou o verde grisalho de uma bela paisagem ${ }^{*} 36$ (toda essa última frase apenas para precisar a qualidade do vermelho na asa de uma borboleta, a Pyrameis atalanta). Quando a isso se soma o fato de sermos um impressionante escritor, conseguimos nos igualar à obra que descrevemos: "Pinturas e pasteis, possuo seis painéis de hortênsias jardinadas por $\mathrm{Helleu}^{37}$ e cujos corimbos glaucos ou louros se refletem em bandejas de prata como buquês de turquesas mortas". O que há, ao que parece, de mais delicioso, de mais inapreensível, de mais indescritível na arte do pintor se encontra aqui equiparado. O senhor de Montesquiou não nos diz se esses painéis lhe foram ofertados como presente por Helleu. Se sim, lhe aplicaremos de bom grado, modificando-a sutilmente e exaltando-a um pouco, a frase de Sainte-Beuve a propósito de Goncourt: "Feliz aquele que deseja retribuir sua magnificência com um louvor inestimável"38. E que sentimento de reflexo nesta frase: "o modelo cuja rósea cabeleira fez dourarem-se em seu reflexo tantos espelhos de cobre". Mas não há

\footnotetext{
${ }^{34} \mathrm{O}$ arbusto hibisco.

${ }^{35} \mathrm{O}$ retrato da viscondessa de Senonnes (1783-1828) pelo pintor Jean-Auguste-Dominique Ingres (1780-1867). Cf. INGRES, Jean-Auguste-Dominique. Portrait de madame de Senonnes. 1814. Óleo sobre tela, 106 x $84 \mathrm{~cm}$. Nantes, Musée des Beaux-Arts. Na versão original, que aqui preservamos, é importante reparar que Proust comete um pequeno equívoco na grafia do nome Senonnes.

*Comparem ainda (Altares privilegiados, p. 265 e 266): "as duas echarpes de vermelha caxemira das Índias, desse escuro vermelho de gerânio que despertava a admiração de Moreau, são também aquelas que adorava Ingres, que vestiram as madames Rivière e Devançay e com as quais Proud'hon envolveu sua Joséphine. Os vestidos são de uma doce escumilha listrada (talvez um barège) em algodão espesso, que o século de Luís XIV chamava "cor de cabelo" e que a cabeleira clareada de Maria Antonieta levou em seguida a ser chamado de cabelo da Rainha. Trata-se de um tipo de estopa diáfana. Um doloroso bracelete é entremeado com trança semelhante àquela que coroa a carpideira do Orfeu de Gustave Moreau". $\dagger$

† Robert de Montesquiou alude nesse excerto citado por Proust ao Portrait de madame Rivière (1805) e ao Portrait de madame Duvauçey (1807), executados por Ingres. Também menciona o Portrait de Joséphine de Beauharnais (1805), de Pierre-Paul Prud'hon (1758-1823), e a tela Orphée (1865), de Gustave Moreau (1826-1898). Cf. INGRES, Jean-Auguste-Dominique. Portrait de madame Rivière. 1805. Óleo sobre tela, 116,5 x 81,5 cm. Paris, Musée du Louvre; INGRES, Jean-AugusteDominique. Portrait de madame Duvauçey. 1807. Óleo sobre tela, 71 x $56 \mathrm{~cm}$. Chantilly, Musée Condé; PRUD'HON, Pierre-Paul. Portait de Joséphine de Beauharnais. 1805. Óleo sobre tela, $244 \times$ $179 \mathrm{~cm}$. Paris, Musée du Louvre; MOREAU, Gustave. Orphée. 1865. Óleo sobre madeira, $99.5 \times 155$ $\mathrm{cm}$. Paris, Musée d'Orsay.

${ }^{36}$ Alusão à tela La Pêche et la fenaison (environs de Ville-D'Avray), de Jean-Baptiste-Camille Corot (1796-1875). Cf. COROT, Jean-Baptiste-Camille. La Pêche et la fenaison (environs de Ville-D'Avray). 1865-1870. Óleo sobre tela, 39 x 54,3 cm. Coleção particular.

${ }^{37}$ Ver nota 7.

${ }^{38}$ Edmond de Goncourt (1822-1896), escritor francês. Segundo Clarac e Sandre, Proust estaria se referindo a uma passagem de Nouveaux Lundis, na qual Sainte-Beuve cita uma descrição elogiosa escrita por Goncourt a seu anfitrião durante uma viagem à Normandia: "Qui n'aimerait des amis qui savent payer par une telle page une quinzaine d'hospitalité dans un château de Normandie en hiver?" [Quem não adoraria amigos que sabem retribuir, com tal página, uns quinze dias de hospitalidade em um castelo da Normandia no inverno?]. Cf. SAINTE-BEUVE, Charles-Augustin. Nouveaux Lundis. Paris: Calmann Lévy, vol. X, 1883-1886, p. 414.
} 
uma frase que não mereça ser citada. Todas carregam curiosidades - naturais e artificiais -, belezas - uma intuição -, uma experiência. Talvez não haja nesse livro de 313 páginas uma só frase insignificante e esvaziada. 0 autor tem tanto a dizer que não perderia duas palavras para não dizer nada, e em sua pressa fecunda, ansioso por depositar seu germe, não possui a paciência ou a frivolidade de se ater aos detalhes biográficos**. Ele queima a primeira etapa e deixa preenchê-la aqueles que não irão mais adiante.

Sem dúvida, uma visão tão extraordinariamente minuciosa do detalhe característico e preciso exigia - e encontrou - um vocabulário infinitamente variado, fornecendo a cada minuto a palavra técnica, o termo exato, que é frequentemente aquele raro. $\mathrm{Na}$ realidade, quando hoje relemos com atenção certas peças que nos parecem as mais clássicas, vemos, ao observá-las de perto, de quanta precisão de detalhes, às vezes incômodos para nossa ignorância, é feita sua beleza, de longe tão vaga e tão geral. Abrimos a célebre peça: "no Arco do Triunfo" e somos interpelados por um ábaco, por um ático, uma cabeceira, uma aduela, etc $^{39}$. Abrimos 0 Capitão Fracasso, de Théophile Gautier ${ }^{40}$, e desde as primeiras páginas mais de vinte termos que nos são desconhecidos nos surpreendem. E podemos talvez argumentar que, para certos livros, essas palavras exatas são como os preciosos pregos que fixam imutavelmente a trama do estilo e lhe previnem essa flutuação que não resiste às afrontas do tempo. 0 que pareceu singular naquela época, não parece hoje mais que singularmente apropriado. Nosso autor exige o mesmo gênero de esforço. É certo que, às vezes, um termo pouco usual também nos imobiliza. A erudição do autor faz com que tudo evoque nele lembranças que nem todos nós organizamos tão cuidadosamente em nossas memórias. "Uma única roseira, com rosas de frente, de trás, de perfil (trata-se de um bordado), que lembra a roseira de Hildesheim, plantada por São Bernardo, o milagre de Santa Elisabete, o rosário de São Domingos ${ }^{41 " . ~-~ " E l a ~ q u i s ~(t r a t a-s e ~ d e ~}$

\footnotetext{
** "Certos espíritos se acomodam com esses fatos... eu os deixo seguir sua vocação. Exprimo apenas aquilo que me encanta. A aridez que me propõe a biografia, eu a repudio", etc. (Professionnelles beautés, p. 89).

${ }^{39}$ Alusão ao poema À l'Arc de triomphe, de Victor Hugo (1802-1885), parte da coletânea Les Voix intérieures. Todas essas palavras que Proust enumera podem ser encontradas em versos desse poema, à exceção da primeira, "abaque” [ábaco]: verso 441, “Quand ma pensée ainsi, vieillissant ton attique" [Quando meu pensamento, assim, envelhecendo seu ático]; verso 209, "De leur façade à leur chevet" [De suas fachadas a suas cabeceiras]; e verso 214, "Dans un claveau trop indigent" [Em uma aduela demasiado indigente]. Cf. HUGO, Victor. OEuvres poétiques. Paris: Gallimard, Bibliothèque de la Pléiade, tomo I, 1964, p. 936.

${ }^{40}$ Le Capitaine Fracasse, romance do escritor Théophile Gautier (1811-1872) publicado em 1863.

${ }^{41}$ Nesse excerto de Altares privilegiados, Montesquiou reúne uma série de referências em torno de um mesmo símbolo, a rosa. Primeiro, a roseira de Hildesheim, também conhecida como a roseira de mil anos, agarrada às paredes da Igreja de São Miguel, e que teria sido plantada por São Bernardo. Por sua vez, o milagre de Santa Elisabete ganha inúmeras versões a depender da hagiografia. Em todas, no entanto, Elisabete surge como uma mulher caridosa que, ao levar sob seu manto alimentos da própria casa, acaba surpreendida por seu marido, contrário a suas obras. Ele exige que ela mostre o que carrega escondido e, ao erguer seu manto, todo o alimento havia se transformado em um ramalhete de rosas. Por fim, no que diz respeito a São Domingos, Nossa Senhora teria lhe aparecido para revelar a devoção ao rosário como remédio às heresias.
} 
uma anfitriã literária) associar Petrônio a Hugo, Quasimodo a Trimalquião, Borlunt a Apício, quis reconciliar o mestre-cuca com o mestre-sineiro. Ela sonhava ser uma bas-bleu que seria um cordon-bleu, sonhava casar os ramos de salsa com os ramos de Clóris, juntar aos louros de Apolo o loureiro. E ela foi a Julie d'Étanges do potau-feu, a Sablière das fritadas e do fricot, a Geoffrin e a du Deffand dos fricassês... fazendo jorrar uma Hipocrene, um Refidim de boas palavras ${ }^{42 "}$. Somos levados por esse turbilhão aonde às vezes gostaríamos de nos ter aventurado apenas com seu dicionário. Mas, repito, ficamos na maior parte das vezes mais desconcertados ainda pelas palavras que emprega Théophile Gautier. No senhor de Montesquiou aliás, como nele, o termo raro é sempre um termo excelente pinçado dos melhores "círculos" literários dos séculos XVI, XVII ou XVIII, mas, nesse livro das Belezas profissionais, onde há, contudo, tantas coisas difíceis para se designar e diferenciar, não creio que haja metade das palavras raras contidas no primeiro volume do Capitão Fracasso.

Mais além, é de se notar que, se o senhor de Montesquiou sabe tudo de pintura, por outro lado, a partir do momento em que escreve, não é mais que um escritor. Vocês não encontrarão jamais em sua obra a menor dessas "velaturas", desses "impastos", de todos esses termos de ateliê que acabam como uma pequena mancha sobre as mais maravilhosas descrições da natureza dos Goncourt. E, no entanto, o senhor de Montesquiou não é jamais abstrato, algo que ocorre com bastante frequência com um outro crítico de arte, Fromentin ${ }^{43}$, nisso inferior a nosso ver. Sem dúvida, Fromentin permanecerá no fundo de seus livros de crítica de arte como uma das mais charmosas figuras que poderíamos amar, que devemos amar, já que inteiramente admirá-lo não o podemos sempre, e suas fragilidades, seus defeitos charmosos, o insucesso de seu nobre e melancólico esforço, do fundo das sombras que a indecisão de seu feitio tornou mais espessas sobre seus traços pouco distintos, parecem implorar e despertam com tanta naturalidade a simpatia

\footnotetext{
${ }^{42}$ Segundo Clarac e Sandre, a anfitriã do salão literário em questão é Lydie Euphrasie Héloïse Lemercier de Nerville (1825-1899). Mais conhecida como madame de Aubernon, essa salonista se tornou célebre por mediar os encontros entre escritores e intelectuais em sua casa com o auxílio de uma campainha e também por sempre apresentar mesas com enorme fartura de pratos e alimentos. Daí a razão de todos esses trocadilhos de Montesquiou, que associam termos do universo literário àquele da gastronomia. 0 Quasimodo do romance Notre-Dame de Paris, de Victor Hugo (18021885), e Trimalquião, personagem que esbanja um grande banquete no Satíricon de Petrônio (2766); Borlunt, cuja origem é incerta, e Marco Gávio Apício, cozinheiro romano, autor de De re coquinaria, um dos primeiros livros de gastronomia de que se tem notícia; mestre-cuca, um chefe de cozinha, e o mestre-sineiro, responsável pelos sinos de uma igreja; bas-bleu, termo pejorativo e machista que designava mulheres que organizavam salões literários no século XIX, e cordon-bleu, prato típico da culinária francesa; os ramos de salsa e Clóris, deusa da primavera na mitologia grega; o pé de louro e os louros da coroa do deus Apolo; Julie d'Étanges, personagem do romance Julie ou la Nouvelle Héloïse, de Jean-Jacques Rousseau (1712-1778), e o pot-au-feu, outro típico prato francês; Marguerite Hessein de La Sablière (1640-1693), Marie-Thérèse Rodet Geoffrin (1699-1777) e Marie de Vichy-Chamrond, marquesa du Deffand (1697-1780), todas aristocratas e salonistas, e a fritada, o fricot, o fricassê, mais pratos franceses; por fim, Hipocrene, fonte de água doce consagrada a Apolo, na encosta do Monte Hélicon, na Grécia, e Refidim, local onde Moisés golpeou uma rocha com seu cajado e dela fez surgir água.

${ }^{43} \mathrm{O}$ crítico e pintor francês Eugène Fromentin (1820-1876).
} 
das gerações. Mas será que é ignorá-lo e impedir de reconhecer-lhe todo o avanço sobre outros terrenos apenas confessar que ele soube raramente em seus livros, a despeito de todo seu luxo de explicações finas, de reflexões profundas, de toques técnicos, fazer-nos ver uma tela, como há pouco "víamos" esse pastel de Helleu, como, no mais, nos são magnificamente expostas as Duas irmãs de Chassériau ${ }^{44}$ ?

Esse espírito que se supera ao determinar o reflexo de uma nuance e a singularidade de um contorno se satisfaz com isso, no entanto, apenas de passagem e na medida com que é útil ao que pretende provar. Porque ele é, antes de mais nada, filosófico e não escreveu uma só página que tenha sido movimentada e emocionante senão para se dirigir a uma demonstração. As conclusões sempre novas e normalmente profundas às quais ele chega, se elas não parecem mais importantes aos espíritos superficiais, é porque, em lugar de exprimi-las sob uma forma abstrata, ele deseja atribuir-lhes uma aparência plástica e atraente. Mas não nos enganemos, e esse último traço lhe remata e concede a coroa. Não se trata apenas, como o chamava agradavelmente um grande pintor, do "único crítico de arte que jamais se conheceu na pintura", trata-se ainda de um verdadeiro filósofo da arte, aquele que concluía seu estudo sobre Ingres com esta página soberba, nova e definitiva:

“Ingres-Édipo, ei-lo fraco e forte, doce e arredio, sábio e inculto. Ele cria ao seu redor o ar rarefeito, a atmosfera de altitude e o irrespirável ambiente no qual o modelo e o espectador sentem se petrificar. Ouçam-no gritar: 'é belo enegrecer as pálpebras dos velhos... é belo descolorir as pálpebras das mulheres...'. Traduzam seu próprio rosto de olimpiano cabisbaixo habitado e interiormente ferido pelo aprisionamento, ali, de sua águia. Sobre seus lábios, um Quos ego dirigido àqueles que se abstém de nomear, mas que assim designa: os grandes maquinistas. Um artifício dos poemas orientais consiste em empregar o plural quando tratamos do amante, de modo a amplificá-lo, engrandecê-lo. Ingres faz o mesmo ao se referir ao inimigo: 'Eles desejam, eles nos opõem...'. Mas não é nem Rubens, nem Van Dyck, nem Rembrandt, nem Murillo, nem mesmo Géricault... é apenas um, o inominável ${ }^{45}$ ! O bem nomeado, segundo a lei de Balzac, não será ele, designado com esse nome de sonoridade fanhosa e áspera, beliscada e voraz, cuja rima é avarenta. Ingres, eis ainda um profeta: Moisés da arte contemplando de longe a terra prometida em cores e reflexos; Jonas repleto de imprecações e predições ruinosas. Um autocrata prodigioso descontente com a magnífica verdade que lhe fora outorgada, aquela de formular, e que lhe exige imperiosamente reger toda a arte. E, no entanto, eis o segredo de sua força e de sua beleza. É a forma estrita do soneto infligindo no

\footnotetext{
${ }^{44}$ Proust se refere à tela Les Deux Søurs, de autoria do pintor francês Théodore Chassériau (18191856). Cf. CHASSÉRIAU, Théodore. Les Deux Sczurs. 1843. Óleo sobre tela, $180 \times 135$ cm. Paris, Musée du Louvre.

${ }^{45}$ Montesquiou fala dos pintores Peter Paul Rubens (1577-1640), Antoon van Dyck (1599-1641), Rembrandt Harmenszoon van Rijn (1606-1669), Bartolomé Esteban Murillo (1617-1682) e Théodore Géricault (1791-1824). 0 "inominável” rival de Ingres (1780-1867) é Eugène Delacroix (1798-1863).
} 
sonho constrangido uma atitude mais rara. É a cultura japonesa alongando, dobrando suas ramificações de acordo com curvas mais requintadas. É a água transformada em feixes e jatos por uma poderosa hidráulica e que proporcionará essa bela semelhança com o grande Dominique ${ }^{46}$ : 'A luz é como a água, ela ocorre de bom grado malgrado sua posição, e se nivela instantaneamente'.

Ingres igualou-se ao criador não como um Pigmaleão, remetendo-se ao amor pelo empenho em dar vida a sua Galatea, mas como um Deucalião, que confia em seu orgulho de desejar humanizar as pedras ${ }^{47}$. Mas as pedras aguardam em vão em suas rijas atitudes; em suas frígidas veias, o sangue das cornalinas circula solitário e o violeta da morte se torna azul sobre seus lábios de ametistas. Punição por haver desejado existir sem a vida. Bíblico castigo por um crime mitológico. 0 outro, o inimigo, o rival inominado, ele realmente roubou-lhe a chama para vivificar sua criação toda ardente de fogo e de púrpura, de tecidos dourados, de bijuterias ardentes, de jubas de leões e cabeleiras de mulheres. A incandescente fogueira de Sardanápalo ${ }^{48}$, Ingres a vê e enrubesce; e o Incêndio do Burgo ${ }^{49}$, que aquele admirava, não lhe causa tanta inveja. Ora, sua musa, por lhe haver contemplado, se transforma em sal - que digo? - em marfim. E ele próprio, outro Prometeu, expia um estranho crime, eternamente acorrentado ao rochedo de sua Angélica ${ }^{50}$, e por ter roubado - o frio*"

\footnotetext{
${ }^{46} \mathrm{O}$ nome completo de Ingres é Jean-Auguste-Dominique Ingres.

${ }^{47}$ Duas referências mitológicas de Montesquiou. Primeiro, Pigmaleão, rei de Chipre que se isola para esculpir a estátua da mulher perfeita, Galatea, e, ao final, se apaixona por ela. Depois, Deucalião e sua mulher, Pirra - sobreviventes do grande dilúvio de Zeus que, orientados pelo oráculo da deusa Têmis, arremessaram pedras para trás e as transformaram em humanos.

${ }^{48}$ La Mort de Sardanapale, tela de Eugène Delacroix (1798-1863). Sardanápalo teria sido uma versão mitológica do rei Assurbanípal (690 a.C.-627 a.C.), da Assíria. Segundo a lenda, Sardanápalo, um rei consumido pela luxúria e pelos prazeres mundanos, vê a capital Nínive tomada por uma aliança inimiga. Sem escapatória, ele então ordena que seja incendiado em uma grande fogueira junto de seus cavalos, escravos, eunucos e amantes. Cf. DELACROIX, Eugène. La Mort de Sardanapale. 1827. Óleo sobre tela, $329 \times 496 \mathrm{~cm}$. Paris, Musée du Louvre.

${ }^{49}$ Incendio di borgo, afresco de Rafael Sanzio (1483-1520). Representa um milagre atribuído ao papa Leão IV (790-855), que, no ano de 847, teria logrado abafar um incêndio apenas com o sinal da cruz. Cf. SANZIO, Rafael. Incendio di borgo. 1514. Afresco, $670 \mathrm{~cm}$. Cidade do Vaticano, Musei Vaticani.

${ }^{50}$ Alusão à tela Rogério libertando Angélica, de Ingres. Na mitologia grega, Prometeu é acorrentado a um rochedo por roubar dos deuses o fogo. Já a Angélica do poema épico Orlando furioso, de Ludovico Ariosto (1474-1533), é sequestrada por piratas e presa a um rochedo para servir de alimento a bestas. É o cavaleiro africano Rogério quem a salva, montado em um hipogrifo. $C f$. INGRES, Jean-Auguste-Dominique. Roger délivrant Angélique. 1819. Óleo sobre tela, $147 \times 190 \mathrm{~cm}$. Paris, Musée du Louvre.

* Caniços pensantes, p. 49, 50 e 51.
} 


\section{Uma avó 51}

\section{(Le Figaro, 23 de julho de 1907)}

Há pessoas que vivem, por assim dizer, sem forças, bem como há pessoas que cantam sem voz. Essas são as mais interessantes; elas substituíram a matéria de que carecem pela inteligência e pelo sentimento. A avó do nosso caro colaborador e amigo ${ }^{52}$ Robert de Flers, madame de Rozière, sepultada hoje em Le Malzieu $^{53}$, não era mais que inteligência e sentimento. Consumida pela perpétua inquietude que é um grande amor que dura toda a vida (seu amor por seu neto), como pôde ela ser saudável! Mas ela tinha essa saúde particular dos seres superiores que não são sadios e à qual se atribui o nome de vitalidade. Tão frágil, tão leve, ela sempre flutuava sobre os mais assustadores picos de sua doença, e, no momento em que a imaginavam arrasada, a percebiam sempre, rapidamente, no topo, acompanhando de perto a barca que conduzia seu neto ao sucesso e à felicidade, não para que recaíssem sobre ela, mas para estar certa de que nada lhe faltaria, de que ele não precisaria um pouco mais dos seus cuidados de avó, o que ela, no fundo, tanto esperava. É preciso que a morte seja realmente muito forte para lhes haver separado!

\footnotetext{
${ }^{51} \mathrm{O}$ retrato fúnebre Une grand-mère foi publicado na seção La vie de Paris, do jornal Le Figaro, em 23 de julho de 1907. Trata-se de uma homenagem de Proust a madame de Rozière, avó de seu amigo de juventude, o dramaturgo Robert de Flers. Lê-se na correspondência do autor o quanto o episódio lhe comoveu. "Je peux à peine t'écrire les larmes m'aveuglant" (Mal consigo lhe escrever com as lágrimas me cegando os olhos), afirma Proust em carta dirigida a Flers tão logo soube da morte, através de uma nota da coluna social Le monde et la ville, assinada pelo cronista Ferrari no Figaro (cf. Corr., VII, p. 227). Aqui se encontram reunidos princípios que orientam uma certa visão proustiana da perda de uma avó. Tendo em vista a típica divisão que Proust traça entre a aparência superficial e a dinâmica espiritual de seus personagens, pode-se identificar, sem grandes dificuldades, uma senhora que, a despeito de sua fragilidade e leveza (qualidades físicas), revela inteligência elevada e admirável (virtudes espirituais). Quanto mais se aproxima da morte, maior é sua força intelectual, a tal ponto que, comparada ao Joubert de Chateaubriand, é quando tenta repousar que descansa menos. A decadência física acompanha, assim, aos olhos do narrador proustiano, o grau de elevação espiritual de um ser. E seus familiares, por sua vez, no intuito de preservar o ente amado, lhe omitem o declínio do corpo. Esses são traços que Proust recupera ao construir o episódio da morte de Bathilde, a avó do herói da Recherche, em Le côté de Guermantes. Como identificou Simonetta Boni, os manuscritos dessa passagem datam de um caderno de rascunhos de 1908, quase o mesmo contexto da publicação do retrato no Figaro (cf. BONI, S. La grand-mère et Albertine : figures wagnériennes. In Bulletin Marcel Proust, 2000, p. 103-127). Mas à coincidência cronológica se impõem outros elementos ainda mais relevantes. É num dos momentos mais drásticos de suas crises renais que Bathilde apresenta, na visão do narrador, "ses beaux yeux d'autrefois (peut-être encore plus surchargés d'intelligence qu'ils n'étaient avant sa maladie [...])" (seus belos olhos de antigamente (talvez ainda mais carregados de inteligência do que antes de sua doença [...]). Cf. C.G., p. 630). E, mesmo antes disso, a mãe do narrador também encobre o rosto de Bathilde com um lenço, "peut-être par respect, parce qu'elle ne croyait pas qu'il lui fût permis sans impiété de constater la trace de quelque affaiblissement intellectuel dans le visage vénéré" (talvez por respeito, porque ela não achava que lhe fosse permitido, sem ser impiedosa, constatar o traço de qualquer enfraquecimento intelectual no rosto venerado. Cf. C.G., p. 615).

${ }^{52} 0$ dramaturgo Robert de Flers foi articulista do Le Figaro e se tornou seu diretor no ano de 1921, pouco tempo após ser eleito para a cadeira número 5 da Academia Francesa de Letras, deixada por Pierre de Ségur (1853-1916).

${ }^{53}$ Comuna francesa no departamento de Lozère, região de Languedoc.
} 
Não foi sem preocupar-me com ela que eu, que vi suas lágrimas de avó suas lágrimas de menininha - cada vez que Robert de Flers apenas partia para uma viagem, pensava que, um dia, Robert se casaria. Ela dizia amiúde querer casá-lo, mas acredito que o fazia, sobretudo, para se endurecer. No fundo, ela temia esse marco fatal de seu casamento tanto mais quanto receara seu ingresso no colégio ou o adeus para o quartel. E só Deus sabe - porque somos corajosos quando ternos - o quanto ela sofreu nesses dois momentos! Eu lhe diria isso? Ao que me parecia, seu carinho por seu neto, quando Robert se casasse, não deveria ser uma fonte de tristezas para ninguém mais além dela: eu pensava em quem se tornaria sua neta... Um carinho tão ciumento não é sempre doce com aqueles com quem se deve dividir... A mulher que se casou com Robert de Flers ${ }^{54}$ logrou, com uma simplicidade divina, o milagre de fazer dessa união tão temida uma era de alegria sem igual para madame de Rozière, para ela mesma e para Robert de Flers. Todos os três não se desprenderam e nem se desentenderam uma única vez. Madame de Rozière costumava dizer que, por discrição, não continuaria a morar com eles e que iria viver em seu canto, mas acredito que nem ela, nem Robert, e nem ninguém pôde alguma vez seriamente acreditar que isso fosse possível. Apenas dentro de um caixão puderam levá-la embora.

Outra coisa não me parecera possível sem grandes dificuldades, o que, graças ao espírito e ao coração delicioso de Gaston de Caillavet ${ }^{55}$ e de sua esposa $^{56}$, ocorreu da maneira mais simples e mais feliz do mundo. A partir de um dado momento, Robert teve um colaborador. Um colaborador! Mas, honestamente, qual necessidade de um colaborador teria ele, seu neto, ele, mais talentoso por si só que todos os escritores que já passaram pela terra? No mais, isso não era importante; era bastante certo que, nas obras escritas em colaboração, tudo que houvesse de bom pertenceria a Robert e que se, por acaso, algo estivesse menos bom,

\footnotetext{
${ }^{54}$ Robert de Flers se casou em 1901 com Geneviève Sardou (1875-1958), filha de Victorien Sardou (1831-1908), mais célebre dramaturgo francês da segunda metade do século XIX. Ele passou a frequentar os Sardou aos treze anos, a partir de outubro de 1885, quando se tornou um dos melhores amigos de Pierre Sardou, seu futuro cunhado ( $c f$. HOUPPERMANS, S. (dir.). Marcel Proust Aujourd'hui. Amsterdam : n.5, 2007, p. 71).

${ }^{55} \mathrm{O}$ dramaturgo Gaston Arman de Caillavet (1869-1915), coautor de mais de uma dezena de peças ao lado de Flers, passou a fazer parte do círculo de amizades de Proust ainda quando aluno no Liceu Condorcet, em Paris. Proust também estabeleceu fortes laços com a mãe de Gaston, Léontine Arman de Caillavet (1844-1910). Foi ela quem apresentou tanto Proust quanto Robert de Flers a seu amante, o escritor Anatole France (1844-1924) (cf. BARILLET, P. Les seigneurs du rire. Paris : Fayard, 1999).

${ }^{56}$ Gaston Arman de Caillavet foi casado com a atriz Jeanne Pouquet (1874-1961), amiga de infância de Proust ( $c f$. BARILLET, P. op. cit.). A filha do casal, a atriz Simone de Caillavet (1894-1968), foi a segunda esposa do escritor André Maurois (1885-1967). Em carta dirigida ao duque de Guiche no ano de sua morte, Proust afirmou que Jeanne Pouquet havia sido "la deuxième grande passion de [son] adolescence" (a segunda grande paixão de sua adolescência. cf. Corr., XXI, p. 461). Por sua vez, Jeanne apresentou por muito tempo grande desconfiança em Proust, dada sua suposta ingerência na vida do casal. Chegou ela a escrever a Gaston de Caillavet: “J'ai toujours peur qu'il ne laisse échapper une phrase malheureuse devant le monde" (tenho medo que deixe escapar uma frase infeliz diante das pessoas. $C f$. SCHMIDT, M. Jeanne Pouquet. In BOUILLAGUET, A. et ROGERS, B. G. (dir.). Dictionnaire Marcel Proust. Paris : Honoré Champion, 2015, p. 789)
} 
pertenceria ao outro, ao audacioso... E vejam só! Nada foi "menos bom" e, no entanto, ela declarou que nem tudo pertencia a Robert. Eu não chegaria ao ponto de dizer que, nos triunfos incessantes que marcaram essa colaboração, ela acreditava que toda a glória deveria recair sobre Caillavet, mas ele seria o primeiro a não tolerá-la. E, no harmonioso êxito, ela equilibrava dons distintos que sabiam admiravelmente se unir. É que, antes de mais nada, ela era maravilhosamente inteligente e ainda é isso o que revela o mais justo. É inclusive por essa razão que, sem dúvida, a inteligência, uma fonte tão abundante de mal-estar, nos surge, ainda assim, como tão benevolente e tão nobre: é que realmente sentimos que apenas ela sabe honrar e servir à Justiça. "São dois poderosos deuses" 57 .

Ela não deixava seu leito ou seus aposentos mais que Joubert ${ }^{58}$, que Descartes ${ }^{59}$, que outras pessoas ainda que pensam ser necessário à saúde permanecer longamente em repouso, sem, para isso, possuir a delicadeza de espírito de um, nem o poder de espírito do outro. Não é por conta de madame de Rozière que digo isso. Chateaubriand dizia que Joubert permanecia constantemente estendido e de olhos fechados, mas que nunca se encontrava mais agitado e tanto se cansava como nesses momentos ${ }^{60}$. Pela mesma razão, Pascal ${ }^{61}$ não pôde jamais seguir os conselhos que Descartes lhe oferecia a esse respeito. Esse é o caso de muitos enfermos aos quais se recomenda o silêncio, mas - como a juventude ao neto de madame de Sévigné62 - seus pensamentos "fazem barulho". Era-lhe tão penoso tratar-se que talvez teria feito melhor se decidisse simplesmente pelo caminho bastante complicado de ser saudável ${ }^{63}$. Mas isso estava além de suas forças. Nos últimos anos, seus encantadores olhos cor de jacinto, ainda que mostrassem cada vez mais o que havia nela, deixaram de lhe

\footnotetext{
${ }^{57}$ Verso da tragédia Athalie, de Jean Racine (1639-1699): “J'ai mon Dieu que je sers, vous servirez le vôtre; / Ce sont deux puissants dieux" (Tenho meu Deus, ao qual sirvo, e vós servireis o vosso; / São dois poderosos deuses. $\mathrm{C} f$. RACINE, J. CEuvres complètes. Paris: Gallimard, Bibliothèque de la Pléiade, tomo I, 1920, p.1042).

${ }^{58}$ Joseph Joubert (1754-1824), moralista e ensaísta francês.

${ }^{59}$ O filósofo René Descartes (1596-1650).

${ }^{60}$ Proust alude a uma passagem das Mémoires d'outre-tombe de François-René de Chateaubriand (1768-1848) a propósito de Joseph Joubert: "Afin de retrouver des forces, Il se croyait souvent obligé de fermer les yeux et de ne point parler pendant des heures entières. Dieu sait quel bruit et quel mouvement se passaient intérieurement chez lui, pendant ce silence et ce repos qu'il s'ordonnait" (para recuperar as forças, [Joubert] pensava com frequência que deveria fechar os olhos e permanecer em silêncio por várias horas. Deus sabe o barulho e o movimento que passavam interiormente por ele durante esse silêncio e esse repouso aos quais se submetia. $C f$. CHATEAUBRIAND, François-René de. Mémoires d'outre-tombe. Paris : Gallimard, Bibliothèque de la Pléiade, tomo I, 1951, p. 450).

${ }^{61}$ O filósofo Blaise Pascal (1623-1662).

${ }^{62}$ Alusão de Proust a uma carta de madame de Sévigné (1626-1696) endereçada a sua filha, madame de Grignan (1646-1705), no dia 24 de janeiro de 1689, na qual relata que seu neto, o Marquês de Grignan (1671-1704), à época com 17 anos, havia confessado em um baile que não apreciava a leitura. Diz madame de Sévigné: "Sa jeunesse lui fait du bruit, Il n'entend pas" (sua juventude faz barulho, ele não escuta. $C f$. SÉVIGNÉ, Madame de. Correspondance. Paris : Gallimard, Bibliothèque de la Pléiade, tomo III, 1978, p. 482).

${ }^{63}$ Há aqui um trocadilho em torno da palavra "doente", presente na expressão francesa "rendre malade", cuja acepção original é de uma demanda de esforço excessivo, digno de pena.
} 
mostrar o que havia ao redor dela: estava quase cega. Ela o jurava, pelo menos. Mas eu sei bem que, se Robert apenas não se sentisse muito bem, ela era a primeira a se dar conta! E, como ela não precisava enxergar para além dele, sentia-se feliz. Ela sempre amou nele, para empregar a expressão de Malebranche. Ele era seu Deus ${ }^{64}$.

Ela sempre foi indulgente com seus amigos, e severa também, pois jamais os considerava dignos dele. Com nenhum outro além de mim ela foi mais indulgente. Ela tinha uma forma de me dizer: "Robert lhe ama como a um irmão" que significava ao mesmo tempo: "é bom mesmo que você tente merecê-lo" e "ainda assim você o merece só um pouquinho". No que diz respeito a mim, ela forçava sua cegueira até enxergar meu talento. Ela se dizia, sem dúvida, que qualquer um que houvesse convivido tanto com seu neto não poderia não ter criado laços de perfeita amizade. Amizades tão perfeitas como essa que unia Robert de Flers a sua avó jamais deveriam se esgotar. Como! Dois seres tão inteiramente correspondentes que nada presente em um não poderia encontrar no outro sua razão de ser, sua finalidade, sua satisfação, sua explicação, seu comentário terno, dois seres que pareciam a tradução de um e do outro, ainda que cada um deles fosse um original, esses dois seres não teriam apenas se encontrado por um instante, ao acaso, no infinito do tempo, no qual não serão mais nada um para o outro, nada mais particular do que são a bilhões de outros seres? Deve-se realmente acreditar nisso? Todas as letras desse livro espiritual e apaixonado que era madame de Rozière teriam subitamente se tornado caracteres sem nenhum significado, que não formam mais nenhuma palavra? Aqueles que, como eu, adquiriram logo cedo o hábito de amar ler nos livros e nos corações não poderão jamais acreditar de fato nisso...

Estou certo de que, há muito tempo, Robert e ela, sem jamais o dizerem, deviam pensar no dia em que se separariam. Estou certo também que ela teria adorado que ele não sofresse... Essa será a primeira satisfação que ele lhe recusará...

Quis, em nome dos amigos de Robert de Flers - os jovens amigos dela -, lhe dizer isso que não posso chamar de um último adeus, pois sinto que ainda me despedirei muitas outras vezes, e, além disso, para ser mais preciso, não dizemos jamais adeus aos seres que amamos porque jamais de fato nos separamos deles.

Nada dura, nem mesmo a morte! Madame de Rozière mal faleceu e logo volta a se dirigir a mim com bastante vivacidade para que eu não consiga deixar de falar dela. Se acham que o fiz em alguns momentos com um sorriso, que não pensem que, por essa razão, tive menos vontade de chorar. Ninguém me terá compreendido melhor que Robert. Ele teria agido como eu. Ele sabe que os seres que mais amamos, nós não pensamos jamais neles, no momento em que mais

${ }^{64} \mathrm{O}$ teólogo Nicolas Malebranche (1638-1715). Proust parafraseia a expressão “vision en Dieu”, um dos conceitos mais caros a sua teologia. 
choramos, sem lhes dirigir com paixão o mais terno sorriso de que somos capazes. Será isso para tentar enganá-los, acalmá-los, dizer-lhes que podem ficar tranquilos, que seremos corajosos, para fazê-los acreditarem que não estamos infelizes? Não será, aliás, esse sorriso apenas a forma mesma do interminável beijo que lhes damos no Invisível? 


\section{Gustave de Borda ${ }^{1}$}

\section{(Le Figaro, 26 de dezembro de 1907)}

O senhor Gustave de Borda, falecido na semana passada e, sobretudo, famoso e lendário pelo apelido de "Borda Espadada", passou de fato sua vida com o gládio empunhado, temido pelos maus, mas indulgente com os bons e piedoso com os desafortunados, como um cavaleiro do romanceiro ${ }^{2}$, de quem ele possuía o aspecto. Condecorado por sua bela conduta durante a guerra ${ }^{3}$, ele foi célebre por seus talentos de inigualável esgrimista e por seus incontáveis duelos. E o que menos sabíamos é que não lançava mão de sua extraordinária destreza com a espada senão para moderar os efeitos de sua força, da qual não abusou jamais.

Ele poderia ter sido o mais perigoso dos inimigos; mas, como era o melhor dos homens, foi sempre apenas o mais moderado, o mais justo, o mais humano, o mais cortês dos adversários. São os costumes, e não as opiniões, que dão origem às virtudes; a bravura criou pacíficos como Borda; o pacifismo não os produzirá. A aceitação e o exemplo de um tal homem lhe ensinaram a não temer a morte, a gozar ainda mais da vida. Sua simpatia, sua bondade eram deliciosas, porque sentíamos que não havia nada de medo, interesse e fragilidade, porque aquele era o dom voluntário e puro de uma alma verdadeiramente livre. De um espírito charmoso e ornamentado, ele possuía o gosto penetrante e natural pelas artes, sobretudo pela música, a qual apreciava com simplicidade, como convém a um bravo idoso. Stendhal, que participara da campanha da Rússia ${ }^{4}$, não preferia a

\footnotetext{
${ }^{1} 0$ retrato Gustave de Borda, uma homenagem a esse esgrimista escrita após sua morte, foi publicado na edição do Le Figaro de 26 de dezembro de 1907. Consta como assinatura apenas "D.", o que, segundo Pierre Clarac e Yves Sandre, seria a abreviação de "Dominique", um dos pseudônimos de Proust em seus artigos de jornal. Borda e o pintor Jean Béraud ( $c f$. nota 6) foram testemunhas de Proust quando o escritor desafiou o crítico Jean Lorrain para um duelo de armas. Lorrain, também homossexual, ironizou em um artigo do dia 3 de fevereiro de 1897 o convite feito por Proust a Alphonse Daudet para que prefaciasse seu Les plaisirs et les jours. 0 texto afirma que Daudet teria aceitado a proposta "porque não recusa nada a seu filho Lucien", com quem Proust sofria a suspeita de manter um relacionamento amoroso. Em outras palavras, uma insinuação de que Daudet seria o sogro de Proust. Essa provocação coincide com um momento bastante turbulento em seu círculo familiar. Seu pai reprova, mesmo antes de ter acesso a ela, uma série de oito imagens feitas pelo fotógrafo Otto com Marcel sentado entre Robert de Flers e Lucien Daudet, que o observa contemplativamente. 0 duelo com Lorrain ocorreu no bosque de Meudon, no Ermitage de Villebon. Foram disparadas duas balas, mas nenhum dos dois saiu ferido (cf. TADIÉ, Jean-Yves. Marcel Proust. Paris: Gallimard, vol. I, 1996, p. 497-503). Borda, que fora veterano da Guerra Franco-Prussiana, é descrito como uma figura paradoxal e complexa, cuja bravura lhe serve ao pacifismo e cuja força tão somente promove a parcimônia e a moderação. Esse tipo de construção da personalidade de um retratado, muito próximo do que se lê nos demais artigos desse gênero escritos por Proust, leva o crítico Jean-Yves Tadié a considerá-lo como exemplo da "arte do retrato proustiano", a qual, "sob a aparência, busca uma realidade que lhe seja contrária" (cf. Ibid., vol. II, p. 51).

${ }^{2}$ Conjunto de poemas corteses e de cavalaria produzidos, sobretudo, na Península Ibérica do século XV.

${ }^{3} \mathrm{Cf}$. nota 1

${ }^{4} \mathrm{O}$ escritor Stendhal participou da campanha de Napoleão Bonaparte na Rússia em 1812 e assistiu à ocupação de Moscou.
} 
música italiana a todas as outras? Esse maravilhoso duelista que era o Sr. de Borda foi também, com uma competência sem igual, com uma fineza e bondade raras, uma incomparável testemunha.

Foi preciso o cansaço de todos os últimos anos para impedi-lo de continuar a entrar nos terrenos como testemunha de seus amigos, quando havia passado da idade de neles estar como combatente. A última pessoa, se não falha nossa memória, que ajudou em um terreno, na qualidade de auxiliar, foi nosso colaborador, o senhor Marcel Proust, que sempre alimentou por ele um verdadeiro culto. 0 senhor Gustave de Borda alimentou por seus amigos tudo o que, em Paris, importa ao coração, às origens ou às ideias. Mas aquele que lhe foi o mais caro dentre todos, sem contar seu médico e amigo, o doutor Vivier ${ }^{5}$, foi o grande pintor Jean Béraud 6 . O Sr. de Borda sentia nesse maravilhoso artista uma natureza que, através de aspectos menos conhecidos do público, pela bravura e pelo coração, se avizinhava à sua. Ele reconhecia nele um de nossos últimos cavaleiros.

\footnotetext{
${ }^{5}$ Esgrimista célebre à época.

${ }^{6}$ Jean Béraud (1849-1935), pintor impressionista francês de quem Proust se aproximou por intermédio de Madeleine Lemaire.
} 


\section{Retrato do príncipe Léon Radziwill ${ }^{1}$}

\section{(Cahiers Marcel Proust, em 1927)}

I. Em seu físico, Léon Radziwill não é desses seres que - como os bustos "espirituosos" e enfadonhos de salão, sob os quais se destaca a roseta da Legião de Honra em mármore - oferecem a um passante, à primeira vista, um aspecto estupidamente delimitado e uma expressão a princípio apreensível. Como todas as coisas grandiosas e belas - como uma escultura gótica, como um Rodin -, ele é, ao mesmo tempo que infinitamente delicado, tão rude que apresenta mais o aspecto de um bloco ${ }^{2}$ que de uma estátua, e é à delicadeza, à compreensão daquele que o observa, esculpindo-o, que cumpre recuperar sua forma verdadeira, determinar sua beleza. "Qual é o seu nome?" perguntava um poeta a uma deusa que ele distinguia mal na penumbra. "Diga-me o seu", respondeu ela. "Aos estúpidos, sou a estupidez; aos inteligentes, a inteligência”. Um olhar estúpido a considerar traço por traço a figura de Loche $^{3}$ nela descobrirá facilmente a estupidez. 0 "nobre pudor" que colore a face desse Hipólito 4 liberto lhe parecerá o rubor vulgar de um homem inclinado apenas à vida material. Os olhos, tão expressivamente inexpressivos, como aqueles das estátuas gregas, pequenas escavações nas quais o mar, ao recuar, abandonou duas pequenas poças cor de pedras preciosas, esmeraldas ou safiras a depender da hora, tomariam a morna letargia de um

\footnotetext{
${ }^{1}$ O Portrait du Prince Léon Radziwill se mantém inédito até 1927, quando é incluso pela Nouvelle Revue Française na primeira edição dos Cahiers Marcel Proust. Trata-se de texto inacabado, em estágio de rascunho, o que salta aos olhos por suas deficiências coesivas (há repetição léxica em diversas passagens) ou, em última instância, pelas próprias indicações de Proust a esse respeito (trechos como "desenvolverei em outro momento" e "sinto frio demais para desenvolver, não sei mais o que escrevo"). A menção ao frio, por sinal, não surge ao acaso. Conforme Pierre Clarac e Yves Sandre nos informam, nos Essais et Articles editados pela coleção Bibliothèque de la Pléiade, esse retrato foi escrito numa noite de inverno entre os anos de 1903 e 1904, durante a estada de Proust no castelo do pai de Léon, o príncipe Constantin Radziwill, situado no município de Ermenonville. Em determinado momento, Proust é deixado a sós na sala de jantar e o sistema de calefação deixa de funcionar. Mas, aparte o que esse texto evoca de biográfico, sua relevância parece se inscrever, sobretudo, no âmbito das particulares formas proustianas de representação da realidade. Ao apresentar Léon Radziwill como ser complexo, por vezes mesmo paradoxal ("o corpo do gigante revelará delicadezas extremas”), Proust parece já indicar traços de sua noção dinâmica de busca de uma essência profunda, a percepção que encontramos amadurecida nos volumes de À la recherche du temps perdu. Além de sugerir que a exterioridade de um ser deve ser divorciada de sua interioridade caso se deseje apreender o que possui de mais definidor ("aqueles que sabem se posicionar detrás das coisas, no ponto nascente de onde vertem as linhas em toda sua significação gráfica e dimensão espiritual"), aqui o escritor reconhece que estamos, ainda por cima, sujeitos às variações do tempo e que nossas personalidades são fugidias. Trata-se, quanto ao físico e à psicologia da personagem, daquilo que Antonio Candido chamou de "visão poliédrica" ( $C f$. CANDIDO, Antonio. Realidade e realismo: via Proust. In CANDIDO, Antonio. Recortes. São Paulo: Companhia das Letras, 1993). E, mais além, do ponto de vista das inevitáveis transformações de personalidade no tempo, está-se diante do "mostrar-se de outra maneira", do "ser outro" a que se refere Jean-Yves Tadié ( $C f$. TADIÉ, Jean-Yves. Proust et le Roman. Paris: Gallimard, 1986).

${ }^{2}$ Pierre Clarac e Yves Sandre nos informam, na mesma edição dos Essais et Articles, que o príncipe Léon Radziwill era pessoa de grande estatura e corpulência, o que sustenta a opção de Proust por aproximá-lo, na dimensão do físico, à imagem de um "bloco" de pedra.

3 "Loche" era o apelido do príncipe Léon Radziwill.

${ }^{4}$ Originalmente Hipólito, filho de Teseu na tragédia Fedra, de Jean Racine (1639-1699).
} 
cretinismo enrijecido. A própria dicção, de uma languidez divertida e de uma falsa bonomia, aparentará como que empastada de tolice e ingenuidade. Mas, para aqueles que sabem se posicionar detrás das coisas, no ponto nascente de onde vertem as linhas em toda sua significação gráfica e dimensão espiritual, tudo nessa face respirará ora poder e delicadeza, a calma da natureza e as emoções da sensibilidade, o charme do natural e a profundidade da reflexão. E o próprio corpo do gigante revelará delicadezas extremas em atitudes e linhas que farão de uma saudação, de um gesto de deferência ou de entusiasmo algo pleno de graça e de significação moral. Assim é - duplo a depender do que parece a um imbecil ou a um artista -, no físico, Léon Radziwill. As mulheres, por um viés que, no Banquete ${ }^{5}$, parece haver profetizado Platão, se alinham, ainda que possuam bem mais a mentalidade dos imbecis, à opinião dos artistas. Porque o desejo é uma compreensão cega.

II. Intelectualmente. Padecemos de um mal que Renan classificou de morbus litterarius ${ }^{6}$. Ainda que fatal para cada um de nós, ele é cômodo a todos na medida em que permite aos mais imbecis distinguir de longe, no pavilhão de cultura que, mais ou menos orgulhosos, ostentam sobre seus mastros, as pessoas muito inteligentes, as pessoas medíocres, os idiotas. Ninguém duvida que Balzac ${ }^{7}$, que Stendhal ${ }^{8}$, que tantos outros não tenham sido alocados na última categoria. Por vezes, atribui-se a Loche a mesma honraria, provavelmente desmerecida, pois jamais escreverá $O$ cura de Tours, nem A cartuxa de Parma. Diremos a razão. Inclusive, mesmo aqueles mais dotados estão bem distantes de começar pela ingênua observação da natureza. É após um longo exílio voluntário em quimeras que experimentam - através da nostalgia - o amor do real. Loche, observador arguto da realidade medíocre aos vinte e cinco anos, observador da vida cotidiana, dos pequenos tipos e dos pequenos espíritos, observador das realidades que

\footnotetext{
${ }^{5}$ O Banquete, diálogo platônico composto por volta de 380 a.C.

${ }^{6}$ A expressão morbus litterarius (do latim, mal literário), foi empregada pelo filósofo francês Ernest Renan (1823-1892) por ocasião da resposta que proferiu, em 21 de fevereiro de 1889, contra o discurso de posse do romancista Jules Claretie (1840-1913) na Academia Francesa. Renan critica certa idealização da sociedade francesa do século XIX ao afirmar que a vida, em seu tempo, acabou substituída pela literatura. Proust, ao que parece, se vale dessa referência para justificar uma busca pela essência mais profunda de um indivíduo em detrimento de aparências imediatamente apreensíveis e fixas ("imbecis" distinguiriam pessoas pelos "pavilhões" que ostentam). Diz o filósofo em seu discurso: "A poesia é feita para nos despistar, para consolar a vida através do sonho, não para se sobrepor a ela. No tempo de Astreia [L'Astrée, longo romance de Honoré d'Urfé publicado entre 1607 e 1627], via-se burgueses do Quartier Saint-Antoine liquidarem seus estoques para se tornarem pastores e alimentar rebanhos imaginários. Os sonhos, agora, são menos inocentes. Morbus litterarius! O traço característico desse mal é que amamos menos as coisas que o efeito literário que elas produzem. Chega-se a ver o mundo como que por meio de uma ilusão teatral". Para a íntegra, em francês, do discurso de Renan: http://www.academie-francaise.fr/reponse-audiscours-de-reception-de-jules-claretie (acesso em 18 de janeiro de 2017).

${ }^{7}$ O romancista francês Honoré de Balzac (1799-1850), autor do romance Le Curé de Tours, parte da Comédie Humaine.

${ }^{8}$ Stendhal, pseudônimo do romancista francês Henri-Marie Beyle (1783-1842), autor de romances como Le Rouge et le Noir e La Chartreuse de Parme.
} 
pintou Chardin ${ }^{9}$ antes de Balzac, é à primeira vista um caso maravilhoso. Às orquídeas que não nos remontam a nada, ele prefere os deleites "bem franceses" das flores do jardim de um prebistério, o taraxaco tolo, a primavera que sabe seu valor, as bocas-de-leão que não forçamos a engolir isso. Não fosse tão tarde, não sentisse tanto frio na sala de jantar, não estivesse eu tão estafado, diria porque temo que essas qualidades deliciosas não se realizem. Loche, ao que me parece, carece de cultura a tal ponto que significa a indiferença diante da literatura e a indiferença diante da beleza. Enquanto tantos outros possuem a matéria, o corpo no qual encarnar uma obra, mas nenhum espírito para acomodar nela, eu o vejo rico de uma alma que busca eternamente um corpo no qual poderia se encarnar. Estou congelando. Desenvolverei em outro momento.

III. Moralmente. Ele participa da banalidade dos defeitos de seu tempo, do qual difere intelectualmente com sua originalidade tão interessante e tão intensa, promessa de um talento tão saboroso. Alma vadia, entregando-se ao primeiro que lhe aparece, ou, mais ainda, aos incapazes de desprendimento, repleto de nobres coisas, generoso, sensível, desgarrado de tudo que há de ordinário, do dinheiro, da celebridade, da mundanidade (com esta ressalva, de que ele detesta e despreza as pessoas chiques, mas desconfia delas, o que lhe elimina o soberano conforto de conduta que mesmo os mundanos possuem - sinto frio demais para desenvolver, não sei mais o que escrevo), capaz de fazer mil coisas por um amigo, à exceção de ser seu amigo, se essa palavra implica preferência, fidelidade, segurança, perseverança, etc. Por outro lado, certos hábitos ruins de linguagem lhe levam a ter os clássicos propósitos do invejoso e do ardiloso. "Eu, que amo profundamente Y..., que possuo extremo afeto por ele, posso dizer, uma vez que isso me dá uma pena enorme, que ele é incapaz de, etc...". Mas esse é, sobretudo, um defeito fraseológico. - De resto, defeito a se monitorar. Facilidade de soltar como que pérolas de frases, cujo sentido exato sua atenção não controla e que, por vezes, lhe dão um ar pérfido, por vezes, um ar imbecil. Certa vez, assim, ele me disse que o grande mérito de Ruskin $^{10}$ era tornar acessíveis e agradáveis a todos as ideias mais elevadas. É a inferioridade literária a maior insuficiência de cultura, senão humana ou psicológica, no instante em que foi levado a dizer isso, ou não se trata mais de um "falar para não dizer nada"? Tanta falta de vontade que mesmo a visão da realidade, a qual, contudo, não implica a ação, lhe é quase tão insustentável quanto o brilho do sol. Quando lhe falam da realidade, ele se entorpece rapidamente. Dentro de instantes, o olho azul atenua, o anestésico faz efeito. Nesse momento você pode dizer qualquer coisa de absolutamente chocante: ele não a perceberá mais, não se vê mais que uma face de olhar fixo. Se muito se insiste, em uma

\footnotetext{
${ }^{9}$ O pintor francês Jean Siméon Chardin (1699-1779).

${ }^{10} \mathrm{O}$ crítico de arte inglês John Ruskin (1819-1900), autor do fascínio de Proust, que, por sua vez, publicou na imprensa francesa uma série de artigos a propósito de sua obra e que traduziu dois de seus livros para o francês: Sésame et les Lys (Sesame and Lilies) e La Bible d'Amiens (Bible of Amiens). Neste, Proust, além de tradutor, também contribuiu com o célebre prefácio Sur la lecture (Sobre a leitura).
} 
convulsão suprema, ele vira de lado. Nesse momento, poder-se-ia lhe amputar uma perna que não sentiria nada. Eu, que o admiro infinitamente, através de um fenômeno nervoso bastante doloroso, a partir do momento em que ele assim se encontra, sinto-me ausente de mim mesmo, não posso mais nada dizer, torno-me estúpido. Desejei vencer esse encantamento e ele redobrou suas forças, como o esforço que fazemos para não perder uma mulher e que nos torna impotentes, ou o adormecimento que conduz à insônia. Após três ou quatro ocasiões, quando soava a campainha e anunciavam: "o príncipe Léon Radziwill", entediava-me pensando no estado doloroso em que me encontraria, e me entediava também em meu amorpróprio, sentindo que ele me achava tão bobo que um dos seres pelos quais mais adoraria ser estimado não teria jamais a mínima ideia de quem sou. Isso começou a matar o prazer de lhe ver. Mas, a partir do momento em que sua chegada se associou, assim, a um sentimento doloroso, a amizade foi abatida por uma morte precoce. 0 afeto é, do contrário, a associação de um nome a uma alegria. Então, esse estado, pela pressão de se repetir, tornou-se crônico, assim como uma doença cardíaca que, por se repetir com frequência, acaba por nos tornar cardiopatas. Primeira causa de destruição da amizade. Houve outras, como o sentimento, que me foi bastante doloroso no início, da impossibilidade de possuir a sua. A inteligência não é suficiente para se amar. Não por utilitarismo, mas por solidão moral e tristezas inconsoláveis, preciso de naturezas fixas com as quais possa estabelecer um pacto sólido e uma aliança durável. Os governos efêmeros e contraditórios que se sucedem sob o nome de Loche são desses com os quais não é possível se aliar, pois, a cada momento, é a uma nova pessoa que nos dirigimos, bem desculpável por não fazer valer os compromissos que seu predecessor, e não ela, firmou. Há ainda outras desculpas que poderia oferecer aqui para sua natural inconstância, mas já não mais consigo...

Marcel. 